\title{
A ATUAÇÃO DE LEBRET E DA \\ SAGMACS NO BRASIL (1947-1964). IDEIAS, PLANOS E CONTRIBUIÇÕES
}

\author{
Tese apresentada ao Programa de Pós- \\ Graduação em Arqutietura e Urbanismo do \\ Instituto de Arquitetura e Urbanismo da \\ Universidade de São Paulo, como requisito para \\ obtenção do título de doutor em Arquitetura e \\ Urbanismo.
}

PROF. DR. CARLOS ROBERTO MONTEIRO DE ANDRADE

Orientador

INSTITUTO DE ARQUITETURA E URBANISMO | IAU USP PROGRAMA DE PÓS-GRADUAÇÃO EM ARQUITETURA E URBANISMO

Apoio Financeiro

FAPESP - Proc. 2011/19.170-8

FUNDAÇÃO DE AMPARO À PESQUISA DO ESTADO DE SÃO PAULO

São Carlos - SP

2015 
Capa: Jonathan Bordignon (jonathaun@gmail.com)

Foto: Klaus Balzano

(disponível em shutterstock.com)

Revisão de Texto: Marisa Merli Antonio (marisarevisora@gmail.com)

AUTORIZO A REPRODUÇÃO TOTAL OU PARCIAL DESTE TRABALHO, POR QUALQUER MEIO CONVENCIONAL OU ELETRÔNICO, PARA FINS DE ESTUDO E PESQUISA, DESDE QUE CITADA A FONTE. EXCETUA-SE DESTA AUTORIZAÇÃO A REPRODUÇÃO DAS ENTREVISTAS APRESENTADAS EM ANEXO A ESTE TRABALHO, CABENDO SOLICITAÇÃO AOS SEUS AUTORES.

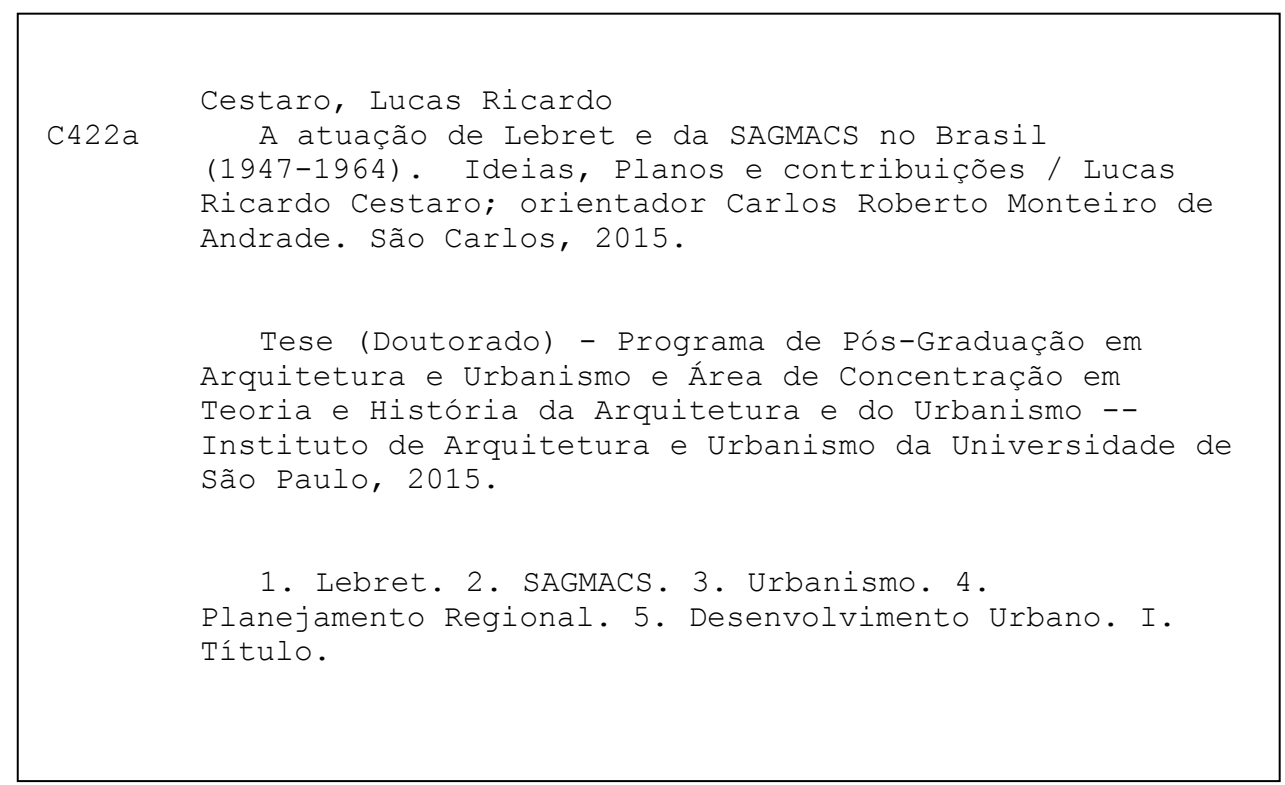




\section{FOLHA DE JULGAMENTO}

Candidato: Arquiteto e Urbanista LUCAS RICARDO CESTARO

Título da tese: "A atuação de Lebret e da SAGMACS no Brasil (1947-1964). Ideias, planos e contribuições"

Data da defesa: 16/11/2015

Comissão Julgadora:

Prof. Dr. Carlos Roberto Monteiro de Andrade (Orientador) Aspovado
(Instituto de Arquitetura e Urbanismo - USP)

Profa. Dra. Sarah Feldman

(Instituto de Arquitetura e Urbanismo - USP)

Prof. Dr. Tomas Antonio Moreira

(Instituto de Arquitetura e Urbanismo - USP)

Profa. Dra. Maria Adélia Aparecida de Souza

(Faculdade de Filosofia Letras e Ciências Humanas - USP)

Profa. Dra. Maria Cristina da Silva Leme

(Faculdade de Arquitetura e Urbanismo - USP) $\underline{\text { Resultado: }}$
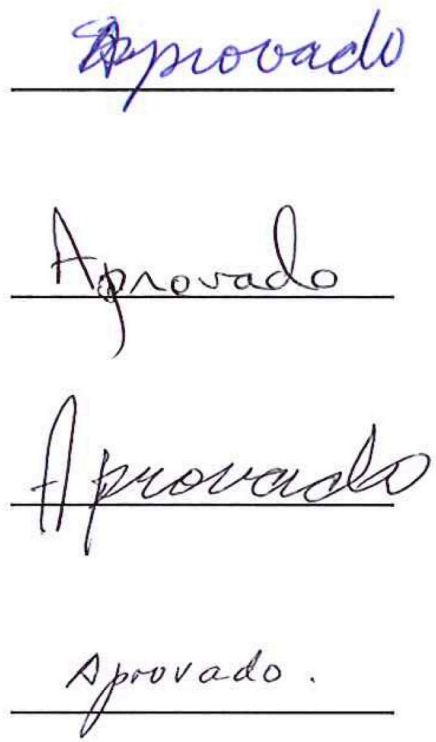

Diretor do Instituto de Arquitetura e Urbanismo - USP: Prof. Dr. Carlos Alberto Ferreira Martins 

Ao lan,

Para que seu anseio por crescer se manifeste em sede de aprender e conhecer para agir em prol de um mundo melhor.

Aos meus pais,

Primeiros a me apresentarem a cidade real. 



\section{AGRADECIMENTOS}

Preparar uma tese de doutorado exige tempo, dedicação, algumas renúncias e interrupções que as vezes duram anos. É um trabalho solitário, feito através da leitura e pesquisa de documentos, no silêncio dos Arquivos e Bibliotecas. Ainda que às vezes o ambiente seja impessoal e hostil, os objetos de pesquisa são sempre vivos, dinâmicos e mutantes. Pois, é neste universo que se pautam os temas, e também as ferramentas, das ciências humanas e sociais aplicadas.

O movimento e a interlocução são o que marcam as nossas trajetórias de vida! Sendo responsáveis por nos oferecer dúvidas e questões, nos levando aos nossos temas de interesse e objetos de pesquisa. Seria então impossível chegar até aqui sem o apoio e proximidade de algumas pessoas, que fizeram parte, e colaboraram direta ou indiretamente com a realização deste trabalho, as quais dirijo meus agradecimentos, desculpando-me previamente com os não nomeados que sentirem-se injustiçados. Lembro a eles que, ao tentarmos fazer história cometemos deslizes e esquecimentos, que felizmente podem ser revisados e reinterpretados a qualquer momento.

Assim, agradeço inicialmente ao Mancha, que nos incentivou a iniciar a pesquisa de doutorado e orientou este trabalho de forma cuidadosa e precisa, e com isso me proporcionou momentos de boas conversas, histórias e memórias. Desde sua orientação no mestrado, já são quase dez anos de convivência com o Prof. Dr. Carlos Roberto Monteiro de Andrade e sinto ainda ter muito a aprender com ele na forma com que incentiva o pesquisador e mais ainda com sua capacidade de articulação e elucidação dos fatos. Agradeço pela sua orientação, compromisso, liberdade e confiança que me foram dadas durante esta pesquisa.

À FAPESP - Fundação de Amparo à Pesquisa do Estado de São Paulo, que me concedeu bolsa de estudos durante parte do período em que me dediquei ao doutorado. Apoio indispensável para a realização deste trabalho, garantindo inclusive a possibilidade de visitação aos Arquivos na França, no Uruguai e aqui no Brasil, condição essencial para a elucidação dos fatos que nos dispusemos a investigar. Agradeço também por ter permitido que eu orientasse pesquisas de alunos para o Trabalho Final de Graduação, junto ao curso de Arquitetura e Urbanismo da Escola Superior de Tecnologia e Educação de Rio Claro, onde agradeço às professoras Monica Brunini Frandi Ferreira e Cláudia de 
Lima Nogueira, pela compreensão e apoio no que coube a diminuição de minha dedicação junto ao corpo docente.

Agradeço ao Prof. Natanael Macedo Jardim, que após o término da bolsa, me proporcionou retornar à Universidade Metodista de Piracicaba, onde, quando aluno do curso de graduação, surgiram as sementes que me instigaram a pesquisar a história da cidade e do urbanismo.

Agradeço a Profa. Assoc. Sarah Feldman pelas colaborações, observações e correções apontadas durante nosso Exame de Qualificação, mas também pela interlecução mantida desde nosso mestrado. E a Profa. Dra. Virgínia Pontual, que além de ter contribuído em nosso Exame de Qualificação, também se fez presente em outros momentos desta pesquisa, inclusive nos apoiando nas observações e indicações sobre pistas que mereciam ser investigadas e na indicação de contatos com os pesquisadores do Centro Latino Americano de Economia Humana - CLAEH. Cabendo agradecer a receptividade dada a nós pela Profa. Cecília Peres Mondino e a bibliotecária Rita, colaboradas do CLAEH.

Aos colegas do grupo de pesquisa Urbis pelos encontros, discussões de temas e o aprendizado que tenho tido com vocês. Ao George Dantas, amigo distante durante o doutorado, mas sempre presente como referência de conduta e ética na pesquisa. Às queridas amigas Fabíola Cordovil e Maristela Janjulio, companhias para todas as horas incluindo o inverno parisiense. À Michelle Ramos de Angelo pela interlocução de nossos temas de pesquisa e as dicas dadas sobre o Fonds Lebret em Fontainebleau.

Aos amigos de antes, de agora e de sempre lata Souza, Eliana Paes de Carvalho e Tatiane Pedro, pelo apoio e expectativa em torno deste trabalho. Aos que vieram durante as experiências profissionais no Poder Público, como a Regina Ferreira, Tatiane Rocha, Tatiane Monteiro, Eduardo Salgado, Silvia Morales e Paula Andreotti. E a Camila Moreno, sempre presente, colaboradora e participativa, seja em nossas atividades de docência, de pesquisa, mas também nas lutas e idas e vindas pela Washington Luís.

Agradeço de forma especial aos meus pais Armando e Maria Amélia, presentes e atentos para oferecer seu apoio, não só durante a realização desta pesquisa, mas em toda a minha vida. E minhas irmãs, Lilian que leu e discutiu alguns pontos deste trabalho e a Giovana que me instruiu à uma apresentação melhor. Por fim, agradeço a Deus, não por que estudei nesta pesquisa o religioso dominicano Lebret, mas porque é a força maior a nos permitir ver, entender e agir.

Obrigado! 


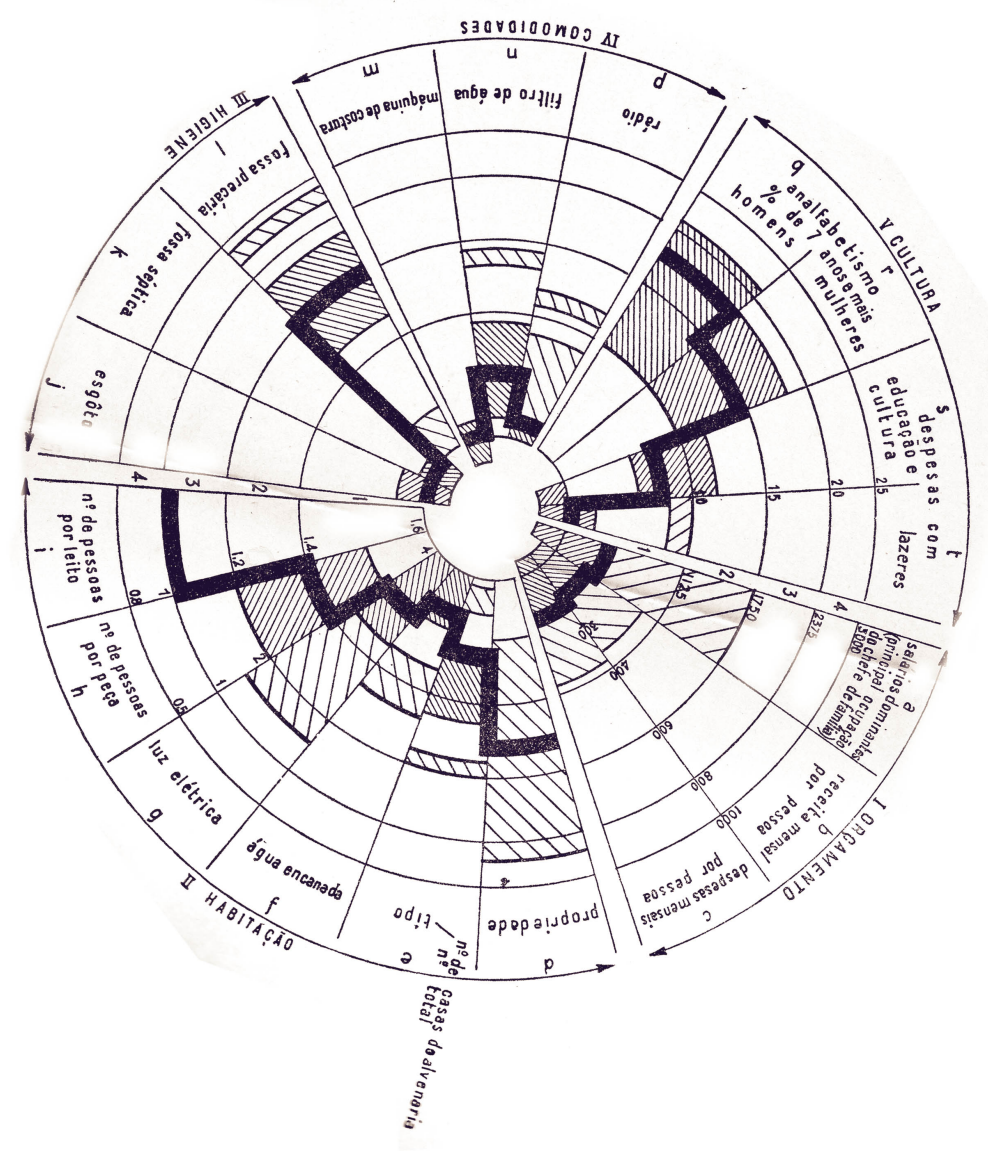


Diagrama da Margarida utilizado pela SAGMACS

Fonte: Estudo sobre o desenvolvimento e implantaçãoo de indústiras no Pernambuco e no Nordeste do Brasil - CODEPE 


\section{A Atuação de Lebret e da SAGMACS no Brasil (1947-1964). Ideias, planos e contribuições}

A atuação do Dominicano francês Louis Joseph Lebret no Brasil, e da Sociedade para Análises Gráficas e Mecanográficas Aplicadas aos Complexos Socias - SAGMACS, instituição fundada por ele, que atuou entre os anos de 1947 e 1964, foi o mote de nossa pesquisa de doutorado. Buscamos verificar se pode o ideário de Lebret e as concepções e propostas desenvolvidas pela SAGMACS serem consideradas como pertencentes ao campo do urbanismo e ao campo do planejamento urbano e regional. Assim, nesta tese investigamos o ideário lebretiano - no que concerne às instituições fundadas pelo religioso - e os procedimentos metodológicos utilizados por ele na SAGMACS, para entendermos sobre o que permeava, dentro deste ideário, o entendimento dos problemas e da questão urbana, a fim de se apontar as ideias e os estudos, os planos e as contribuições resultantes à formação do quadro do urbanismo e do planejamento regional no Brasil, neste período.

Palavras Chave: Lebret. SAGMACS. Urbanismo. Planejamento Regional. Desenvolvimento Urbano 

The work of Lebret and SAGMACS in Brazil (1947 to 1964). Ideas, plans and contributions

The performance of the French Dominican Louis Joseph Lebret in Brazil, and the Society for Graphical and Mecanográficas Analysis Applied to Socials Complexes - SAGMACS, created by him, here between 1947 and 1964 was the subject of our doctoral research. We tried to find out if the ideas of Lebret and the views and proposals developed by SAGMACS can be considered as part of the fields of urbanism and urban and regional planning. Thus, in this thesis, we investigate Lebret's ideas - concerning institutions founded by the religious - and the methodological procedures used by him in SAGMACS in order to understand what permeated within this ideology, understanding of the problems and the urban issue, in order to point out the ideas, studies, plans and contributions to the formation of urban planning framework and regional planning in Brazil, in that period.

Key words: Lebret. SAGMACS. Urbanism. Town and Country Planning. Urban Development 



\begin{tabular}{|c|c|}
\hline CAIC & Companhia Agrícola Industrial Colonizadora \\
\hline CEPAL & Comissão Econômica para a América Latina \\
\hline CEPEU & Centro de Estudos e Pesquisas Urbanísticas \\
\hline CEPUR & Centro de Pesquisas e Planejamento Urbano e Regional \\
\hline CIAM & Congresso Internancional de Arquitetura Moderna \\
\hline CIBPU & Comissão Interestadual da Bacia Paraná-Uruguai \\
\hline CLT & Consolidação das Leis Trabalhistas \\
\hline CNRS & Centre National de la Recherche Scientífica \\
\hline CODEPAR & Companhia de Desenvolvimento do Estado do Paraná \\
\hline CODEPE & Comissão de Desenvolvimento do Estado do Pernambuco \\
\hline CREDOC & Centre Regional de Documentatioin et de Conjoncture \\
\hline CSN & Companhia Siderúrgica Nacional \\
\hline DASP & Departamento Administrativo do Serviço Federal \\
\hline DATAR & Délégation à l'Aménagement du Territoire et à l'Action Régionale \\
\hline $\mathrm{EH}$ & Économie et Humanisme \\
\hline ELSP & Escola Livre de Sociologia e Política \\
\hline EUA & Estados Unidos da América \\
\hline \multirow[t]{2}{*}{ FESPSP } & Fundação Escola de Sociologia e Política de São Paulo \\
\hline & Atual nome da ELSP* \\
\hline FGV & Fundação Getúlio Vargas \\
\hline FIESP & Fedaração das Insdústrias do Estado de São Paulo \\
\hline IBAM & Instituto Brasileiro de Adminsitração Municipal \\
\hline IBGE & Instituto Brasileiro de Geografia e Estátística \\
\hline IMSAC & Institut Maseillais de statistique et d'analuse et de conjoncture \\
\hline IRFED & Institut de Recherche et Formation pour Économie et Développement \\
\hline JUC & Juventude Universitária Católica \\
\hline MRP & Movimento Republicano Popular \\
\hline MRU & Ministère de la Reconstruction et Urbanisme \\
\hline PAGE & Plano de Ação do Governo do Estado \\
\hline PCB & Partido Comunista do Brasil \\
\hline PDC & Partido Democrata Cristão \\
\hline
\end{tabular}




$\begin{array}{ll}\text { PR } & \text { Partido Republicano } \\ \text { PSB } & \text { Partido Socialista Brasileiro } \\ \text { PSD } & \text { Partido Social Democrata } \\ \text { PSP } & \text { Paritdo Social Popular } \\ \text { PTB } & \text { Partido Trabalhista Brasileiro } \\ \text { PTN } & \text { Partido Trabalhista Nacional } \\ \text { PUC } & \text { Pontíficia Universidade Católica } \\ \text { SAGMA } & \text { Societé pour l'applicatioin du graphisme et de la mécanographie à } \\ & \text { l'analyse } \\ \text { SAGMACS } & \text { Sociedade para Análises Gráficas e Mecanográficas Aplicadas aos } \\ \text { SENAI } & \text { Complexos Sociais } \\ \text { SERPHA } & \text { Serviço Nacional da Indústria } \\ \text { SESI } & \text { Serviço Especial de Reabilitação das Favelas e das Habitações } \\ \text { SFU } & \text { Insalubres } \\ \text { SUDENE } & \text { Serviço Social da Indústria } \\ \text { UDN } & \text { Société Française d'Urbanistes } \\ \text { UFPE } & \text { Superintendência de Desenvolvimento dos Estados do Nordeste } \\ \text { URSS } & \text { União Democrática Nacional } \\ \text { USIMINAS } & \text { Universidade Federal de Pernambuco } \\ \text { USP } & \text { União das Repúblicas Socialistas Soviéticas } \\ & \text { Usina Siderúrgica de Minas Gerais S/A } \\ & \text { Universidade de São Paulo }\end{array}$




\section{CAPÍTULO 1}

OS MÉTODOS E CONCEITOS ACERCA DO URBANISMO: A INCORPORAÇÃO DO TEMA NO ÉCONOMIE ET HUMANISME

Breve quadro de formação do urbanismo como disciplina na França

O uso da terminologia Urbanismo: uma questão de nomenclatura

Os métodos do urbanismo e o quadro de atribuições no meio técnico profissional

O Campo e a Cidade e a aplicação do Urbanismo como uma forma de desenvolvimento econômico e social

A consolidação do urbanismo francês e as ressonâncias na visão de mundo urbano em Lebret

\section{CAPÍTULO 2}

O IDEÁRIO URBANÍSTICO EM LEBRET E NA SAGMACS: DA CRÍTICA SOCIAL À INSTITUCIONALIZAÇÃO DO CENTRE D'ÉCONOMIE ET HUMANISME

O pensamento social do Dominicano Louis-Joseph Lebret: Trajetória e cronologia de formação

O contato social: A vida sacerdotal e o engajamento junto aos trabalhadores de Saint-Malo

A formação e fundação de um grupo para atuação comunitária e engajamento social: o Centre d'Économie et Humanisme

A incorporação da Questão Urbana pelo Économie et Humanisme

As imbricações de Lebret: Inserção e difusão do ideário lebretiano através do Économie et Humanisme

\section{CAPÍTULO 3}

\section{A FORMAÇÃO DA SAGMACS COMO INSTITUIÇÃO DE URBANISMO: FUNDAÇÃO E ATUAÇÃO DAS EQUIPES DE LEBRET NO BRASIL}

A difusão do método de Économie et Humanisme e do ideário lebretiano como forma de fortalecimento do grupo francês 
A visita de Lebret ao Brasil em 1947 e o engajamento social junto ao meio empresarial e acadêmico

A abertura da ELSP para Lebret explicar a "Economia Social"

A fundação da SAGMACS: principais atores envolvidos, áreas de interesse e os apoios para a criação de um grupo de Economia Humana no Brasil

Formação das equipes, cronologia, períodos e etapas na atuação da SAGMACS

\section{CAPÍTULO 4}

\section{OS TRABALHOS URBANÍSTICOS EMPREENDIDOS PELA SAGMACS E A CIRCULAÇÃO E APROPRIAÇÃO DAS IDEIAS DO GRUPO NO QUADRO DO URBANISMO NO BRASIL}

O Brasil pós-segunda Guerra Mundial

O quadro do urbanismo no Brasil nos anos 1950

O debate sobre a questão urbana e o planejamento urbano e regional nas equipes da SAGMACS

Um percurso em desenvolvimento para consolidação da SAGMACS como assistência técnica e de consultoria em planejamento urbano e regional

Os trabalhos desenvolvidos pela SAGMACS no campo do urbanismo e do planejamento regional

\section{CONCLUSÕES}

\section{A ATUAÇÃO DE LEBRET E DA SAGMACS: IDEIAS E CONTRIBUIÇÕES}

REFERÊNCIAS

Referências Bibliográficas 


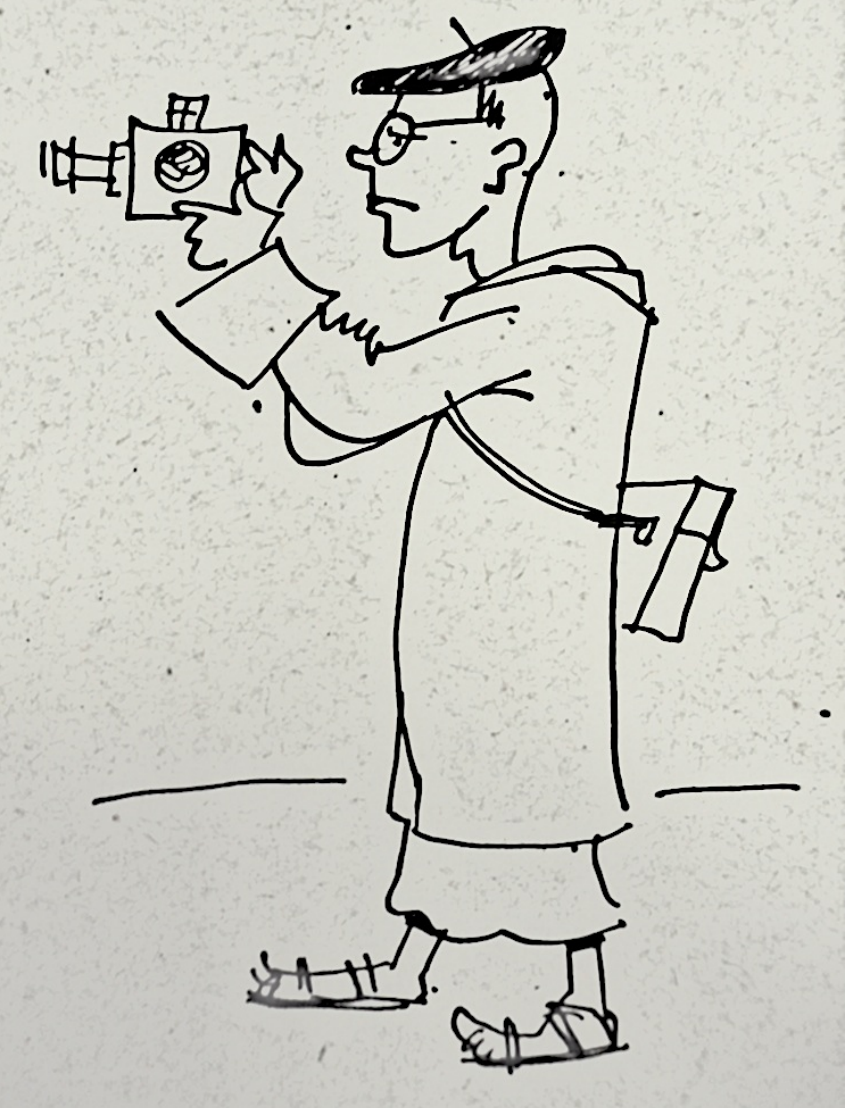


Caricatura de Lebret

Fonte: Fonds Lebret - Pasta AN45 AS105 
Dentro do quadro de pesquisas em ciências humanas, o trabalho do pesquisador que se propõe a investigar a história urbana e do urbanismo, segundo Lepetit (2001), consiste em contribuir com o incremento do debate e o incentivo às novas pesquisas sobre a temática. Isto porque, não há em história verdade absoluta e nem mesmo conclusões incontestáveis, sendo o estudo histórico um objeto sempre a retomar.

Nesta tese de doutorado estudamos os trabalhos desenvolvidos no campo do urbanismo e do planejamento urbano e regional pela Sociedade para Análises Gráficas e Mecanográficas Aplicadas aos Complexos Sociais - SAGMACS, instituição fundada ${ }^{1}$ pelo religioso francês Louis-Joseph Lebret, em julho de 1947, no Brasil, a qual funcionou até meados da década de 1960 e fazia parte da rede de organismos coordenados pelo Centre d'Économie et Humanisme, criado na França em 1941, pelo mesmo padre dominicano ${ }^{2}$.

Em nossa pesquisa, estudamos o percurso de atuação e os trabalhos desenvolvidos pela SAGMACS. Buscamos assim entender as aproximações de Lebret com o tema do urbanismo, de forma a responder se poderíamos atribuir ou não a Louis-Joseph Lebret, através de sua atuação na SAGMACS, a introdução de um método de trabalho para as questões inseridas no campo do urbanismo e do planejamento urbano e regional. Pois, ainda que Lebret não fosse um urbanista, a atuação do religioso tem sido estudada, entre os pesquisadores do tema no Brasil, dentro da história do urbanismo e do campo do planejamento urbano e regional.

Mesmo sem formação na área do urbanismo, Lebret coordenou no Brasil, através da SAGMACS, alguns trabalhos dentro deste campo profissional. De sua atuação junto à equipe da SAGMACS, destaca-se o trabalho elaborado para a Prefeitura de São Paulo

\footnotetext{
1 A SAGMACS foi uma instituição criada no Brasil, num período (final da década de 1940) que, segundo Feldman (2002 e 2009), favoreceu a formação de instituições de urbanismo e organismos voltados a pensar o planejamento urbano e regional no Brasil, o que abriu campo para que a década de 1950 fosse considerada como a da crença no planejamento regional no Brasil. Estas instituições de urbanismo foram criadas fora da administração pública e tinham como função fornecer assistência técnica aos municípios.

${ }^{2}$ O Centre d'Économie et Humanisme foi concebido durante a Segunda Guerra Mundial, nascendo em 1941 a partir do engajamento de Lebret, do economista François Perroux, dos empresários Rene Moreaux e Alexandre Dubois e dos padres Marie-Reginald Loew e Henri Desroche.
} 
em 1956 e finalizado em 1958, conhecido como "Estrutura Urbana da Aglomeração Paulistana: Estruturas atuais e estruturas racionais", coordenado por ele e com o apoio de outro dominicano, o Frei Benevenuto de Santa Cruz, diretor da SAGMACS, e dos Engenheiros Antônio Bezerra Baltar e Mário Laranjeira de Mendonça. Esta atuação demonstra seu interesse pelas questões da cidade e do urbanismo, em sua trajetória frente à coordenação de trabalhos neste campo.

Para responder à indagação colocada por nós sobre a criação de um método de trabalho no campo do urbanismo e do planejamento regional, por Lebret e pela SAGMACS, investigamos primeiro a inserção de suas ações dentro desta disciplina e campo profissional. Era preciso, antes, perceber e distinguir se o ideário de Lebret e as concepções propostas pela SAGMACS podiam ser considerados dentro deste campo, condição que prescinde a criação e aperfeiçoamento de uma metodologia de trabalho, bem como de procedimentos, desenvolvidos por determinado grupo ou personagem.

Para constituir nosso entendimento sobre o que seria o trabalho do urbanista, bem como a delimitação do campo disciplinar do urbanismo e do planejamento regional, é necessário situarmos as indicações quanto ao que cabe dentro deste campo. Ainda que as ações do urbanismo e do planejamento urbano e regional resultem em planos, estudos e ações sobre o território de uma cidade ou região ${ }^{3}$, independentemente de serem implantados ou não, a dúvida sobre a ação de Lebret persiste. E, conforme já apontado, o dominicano francês ficou conhecido no Brasil por atuar no campo do urbanismo e do planejamento regional através da SAGMACS, organismo identificado pelos pesquisadores em história do urbanismo e do planejamento urbano e regional como uma das instituições de urbanismo que atuaram no Brasil durante os anos 1950 e início dos 1960.

No Brasil, o quadro de pesquisas realizadas sobre a atuação da SAGMACS e do ideário lebretiano ganhou maior destaque a partir do trabalho apresentado por Celso Monteiro Lamparelli, no Seminário de História da Cidade e do Urbanismo, realizado em 1994, em Salvador-BA, onde o autor expôs a atuação do grupo em 1956, tomando como frente a

\footnotetext{
${ }^{3}$ Cabe aqui expor que, embora os relatórios produzidos pela SAGMACS fossem ricos na exposição de seus métodos, procedimentos e formas de obtenção de dados, resultando em apresentação de gráficos e diagramas que ficaram conhecidos como "margaridas", no que se refere às diretrizes e propostas os trabalhos não apresentavam grande informação em formas gráficas, utilizando-se de poucos mapas e planos. Este fato ressoa nesta tese, de forma que apresentamos poucas ilustrações e informações gráficas em nosso trabalho. É importante esclarecer que parte das peças gráficas produzidas pela SAGMACS, apontada nos índices dos relatórios de suas pesquisas, não se encontram mais disponíveis nos acervos que guardam estes documentos. Assim, no capítulo final desta tese, quando expomos sobre os trabalhos produzidos pela equipe de Lebret, as ilustrações não são os itens que garantiram nosso estudo sobre a atuação da SAGMACS, ficando o mesmo mais restrito aos relatórios elaborados e entregues aos contratantes.
} 
pesquisa "Estrutura Urbana da Aglomeração Paulistana: Estruturas atuais e estruturas racionais", grupo este do qual o autor fez parte. Além de Lamparelli, dentro o quadro de pesquisadores da área de história do urbanismo e do planejamento urbano e regional no Brasil, é importante dizer que os trabalhos de Maria Cristina da Silva Leme (1998, 1999, 2004 e 2012), Michelly Ramos de Angelo (2007, 2010, 2012 e 2013), Virginia Pontual (2011, 2012 e 2013), Elisangela de Almeida Chiquito (2012), Lícia do Prado Valladares (2005 e 2008), Dinalva Delorenzo Roldan (2012) e a nossa dissertação de mestrado (2009) vêm abordando aspectos sobre os trabalhos desenvolvidos pela SAGMACS e por Lebret em cidades brasileiras, os quais, a nosso ver, têm relevante importância para a historiografia do urbanismo. No entanto, não conseguiram ainda trazer uma abordagem elucidativa quanto à atuação do personagem Lebret, de forma que não se ocasionou uma interpretação aprofundada sobre seus métodos de trabalho e muito menos sobre sua relação com as práticas do urbanismo e do planejamento urbano regional.

A revisão bibliográfica durante nossa pesquisa revelou que o ideário lebretiano, termo indicado em nosso plano de pesquisa para o doutorado ${ }^{4}$, vem ganhando maior notoriedade e interesse por pesquisadores brasileiros da área de teoria e história do urbanismo e do planejamento urbano e regional, nesta década de 2010, ocorrendo, inclusive, dois colóquios internacionais sobre o assunto ${ }^{5}$. Constatamos, assim, um

\footnotetext{
${ }^{4}$ Entedemos por ideário o conjunto das principais ideias de um autor, ou de uma agremiação, grupo ou movimento. Assim, entendemos que buscar o entendimento sobre as ideias inseridas e difundidas dentro do pensamento de Lebret seria uma forma de perseguir sobre os aspectos da formação de um método de trabalho e das maneiras de difusão do mesmo, o que se daria através dos organismos e instituições fundados pelo dominicano francês, como a SAGMACS no Brasil.
}

${ }^{5}$ Em 2011 ocorreu em Recife, no Brasil, o Colóquio Internacional "Urbanismo e o Movimento Economia e Humanismo na América Latina", e em 2012 foi realizado em Caen, na França, o Colloque "Vers une Économie Humaine: Pensées critiques d'hier pour aujourd'hui". O Colóquio ocorrido em Recife, sob a coordenação de Virgínia Pontual e Maria Cristina da Silva Leme, reuniu pesquisadores, professores e intelectuais do Brasil, França, Argentina e Chile. Dentre os expositores, destacamos a participação de Denis Pelletier, Lícia Valladares e Yves Berthelot (presidente do Centre Lebret-IRFED), de Celso Lamparelli, Jacques Chonchol e Pierre Gervaiseau, que conviveram com Lebret e atuaram nos quadros das instituições vinculadas ao $\mathrm{EH}$. Destacamos ainda a participação do sociólogo Francisco de Oliveira, para quem a SAGMACS não teve papel relevante, devido à ascensão da CEPAL - Comissão Econômica para a América Latina, o que é também exposto em trabalho de Albertini (2006), ao afirmar que "La CEPAL de Prebish avec lequel il a des contacts réguliers ocupe le terrain". Já o Coloquio ocorrido em Caen, na França, voltou-se para a discussão do pensamento econômico humanista identificado entre os pensadores da metade do século XX, Henri Desroché, Lebret, Hénri Lefbvre, Emanuel Mounier e François Perroux, buscando possíveis saídas para a crise econômica vivida nesta segunda década do século XXI, sobretudo nos países europeus. Cabe ainda expor que no último Seminário de História da Cidade e do Urbanismo, ocorrido em setembro de 2014, em Brasília-DF, Carlos Roberto Monteiro de Andrade indagou: "pode o ideário de Lebret e as concepções e propostas da SAGMACS serem consideradas como pertencentes ao campo do urbanismo? Ou ao menos como pertencentes ao campo do planejamento urbano e regional?". A questão levantada por Andrade, que embasou a justificativa para a sessão "Pe. Lebret e a SAGMACS no Brasil: ideário, estudos e difusão", estabelece diálogo direto com a que colocamos como central para ser desvendada nesta tese de doutorado. Participaram da sessão de interlocução os grupos de pesquisa Urbis do IAU USP, coordenado por Andrade, orientador de nossa pesquisa de doutorado e o Grupo de Pesquisa em Conservação 
movimento contrário ao que sentimos durante nossa pesquisa de mestrado, realizada no período de 2006 a $2009^{6}$, quando nos aproximamos do tema sobre Lebret e a atuação da SAGMACS. Quando iniciamos nossa pesquisa sobre o assunto, em 2005, identificamos que poucos autores escreviam ou pesquisavam a respeito do que tinha sido a SAGMACS e a importância de Lebret para a formação do quadro do urbanismo no Brasil ${ }^{7}$.

Quanto ao ideário lebretiano, é importante dizer que, a princípio, vinculávamos as realizações do padre Lebret e do Économie et Humanisme colocando o dominicano como seu elemento de animação central. Porém, ao analisarmos a formação do movimento, bem como nos aprofundarmos no estudo sobre sua metodologia e formas de atuação, verificamos que, embora Lebret se constituísse numa figura central do grupo, não é possível afirmar que as ideias defendidas e difundidas pelo $\mathrm{EH}$ fossem somente as suas, uma vez que se trata de um organismo que contava com apoiadores, diretoria fixa e membros atuantes, de forma que seria melhor falar em ideário do Économie et Humanisme e não de Lebret $^{8}$.

Sobre o quadro de estudos e pesquisadores envolvidos com o tema relativo ao ideário do Économie et Humanisme e do padre Lebret, é importante esclarecer que entendemos haver uma distinção entre os autores brasileiros e os franceses. Enquanto no Brasil Lebret é objeto de estudo através da sua atuação na SAGMACS e na difusão das ideias do Centre d'Économie et Humanisme, vinculando-se aos pesquisadores da área de história do urbanismo e do planejamento urbano e regional, na França os trabalhos que abordam o ideário lebretiano apontam para aspectos da formação intelectual do

Integrada Urbana e Territorial da FAU UFPE, coordenado pela Profa. Dra. Virginia Pontual. XIII SHCU "Tempo e Escala das Cidades e do Urbanismo".

6 Durante nossa pesquisa de mestrado, estudamos um trabalho específico desenvolvido pela SAGMACS, sob coordenação de Lebret, a partir de contrato firmado pela Prefeitura de São Paulo. Como resultado, apresentamos nossa dissertação de mestrado "Urbanismo e Humanismo: A SAGMACS e o estudo da 'Estrutura Urbana da Aglomeração Paulistana'”, desenvolvido junto ao programa de pós-graduação em Arquitetura da Escola de Engenharia de São Carlos - EESC/USP, sob orientação do Prof. Dr. Carlos Roberto Monteiro de Andrade.

${ }^{7}$ Naquele período, identificamos que faziam abordagem mais direta sobre o ideário de Lebret e da SAGMACS os trabalhos apresentados por Celso Monteiro Lamparelli (1994 e 1995), que havia feito parte dos quadros da SAGMACS nos anos 1950 e 1960, Maria Cristina da Silva Leme (1998, 1999 e 2004) e Lícia do Prado Valladares (2005).

${ }^{8}$ Sobre este ideario do EH também é importante destacar que apesar da ativa participação de Lebret dentro dos organismos do grupo francês, o dominicano manteve atividades paralelas ao Centre d'Économie et Humanisme, alcançando destaque em ações junto a igreja católica, sobretudo a partir do Concílio Vaticano II, nas Nações Unidas em Nova York e na atividade docente na Universidade de Montreal no Canadá. Porém, este quadro de atividades desenvolvdas por Lebret fora do EH não consistia no nosso tema de pesquisa, uma vez que buscamos elucidar sobre as ideias, contribuições e os planos acerca da questão do urbanismo através de sua atuação junto a SAGMACS no Brasil. 
dominicano e pouco desvendam sobre as bases do urbanismo difundido nas instituições vinculadas a ele.

Dentre os autores franceses que tratam de Lebret e do Centre d'Économie et Humanisme, apontamos os trabalhos de Dennis Pelletier (1988, 1995 e 1996) ${ }^{9}$, Georges Celestin (1981), Hugue Puel (2004), Lydie Garreau (2007, 2011), Marcel Gonin (1981), Paul Borel (1982), Paul Houée (1997) e Gilberton $(2009)^{10}$, os quais não tratam da vinculação de Lebret à questão urbana ${ }^{11}$. Neste sentido, cabe excetuar o trabalho de Pelletier, que, além de tratar da biografia de Lebret e da formação do Économie et Humanisme, aponta sua vinculação com o planejamento urbano e regional através da atuação do dominicano junto a organismos da América do Sul, como seu engajamento junto à SAGMACS, no Brasil.

Entre os pesquisadores brasileiros, verificamos que, além de nossa dissertação de mestrado (2009), outros autores estudaram trabalhos desenvolvidos pela SAGMACS. Porém, assim como em nossa dissertação de mestrado analisamos o estudo da "Estrutura Urbana da Aglomeração Paulistana", desenvolvido pela SAGMACS para a Prefeitura de São Paulo entre 1956 e 1958, os demais autores também se debruçaram sobre trabalhos específicos da equipe, como Leme (1999), que apresenta o trabalho de

\footnotetext{
${ }^{9}$ Pelletier apresenta um levantamento das bases documentais a partir de um inventário realizado sobre a documentação dos arquivos da associação dos Amis du Père Lebret (1996, pp. 455-470). Além desta apresentação, o autor (1988) realiza um inventário sobre os documentos do Fonds Lebret. É importante mencionar ainda que Poulat e Bouteloupt (1983, pp. 468-472) escreveram artigo chamando a atenção para a abertura do acervo do antigo $\mathrm{EH}$ como novo campo de pesquisa para a história social. Estes levantamentos foram importantes para o desenvolvimento de nossa pesquisa de doutorado, pois nos permitiram recortar o material que nos interessava pesquisar na França para a busca no acervo de Lebret. O ponto de partida estabelecido para pesquisar eram os documentos que tratavam de aspectos da formação de um método de trabalho por parte do Économie et Humanisme, para que pudéssemos verificar a disseminação do mesmo e, sobretudo, por quais meios isso ocorria, procurando desvendar como esta repercussão havia extravasado o interesse unicamente de pessoas ligadas ao catolicismo e alcançado o meio técnico profissional, sobretudo no campo da economia, sociologia, geografia e do planejamento urbano e regional.

${ }^{10}$ Krystel Gilberton estudou a organização do acervo sobre a Association Économie et Humanisme junto aos Archives Municipales de Lyon, onde estão inseridos o Fonds Chronique sociale de France: Sécretariat social du sud-est, administration générale (1922-1937), Fonds Chronique sociale de France: Portrait du père Lebret (cliché anonyme aux Semianes sociales de France); Ville de Lyon: Direction de la communication externe. Além dos Arquivos de Lyon, o autor aponta também para a organização do acervo de documentos depositados nos Arquivos de Fontainebleau.

${ }^{11}$ Para se ter uma ideia da inserção de Lebret à margem do pensamento urbanístico francês, o filósofo Thierry Paquot, estudioso da cidade e do urbanismo, em compêndio organizado por ele e intitulado "Les faiseurs de Villes (1850-1950)", publicado em 2011, não menciona o padre Lebret e nem outros personagens que tiveram atuação junto a ele no Économie et Humanisme. O que mais o aproximaria do grupo seria a menção feita por Jean-Piere Frey a Gaston Bardet, que colaborou com Lebret na primeira década de funcionamento de EH (1941-1951). Assim, se podemos dizer que no Brasil a atuação de Lebret e da SAGMACS permaneceu como um tema marginal à historiografia do urbanismo, sendo exposto por Lamparelli (1994) somente trinta anos após o encerramento das atividades da equipe, também na França a atuação do padre dominicano e das instituições ligadas ao $\mathrm{EH}$, como a SAGMA, foi tratada como tema marginal.
} 
Lebret para a prefeitura paulistana, e Valladares (2005), que aborda as matrizes sociológicas no pensamento de Lebret e mostra o papel da SAGMACS na introdução de uma pesquisa empírica realizada junto às favelas do Rio de Janeiro, no final da década de 1950.

A tese de Angelo (2010), que resultou em publicação de livro (2013), aborda o papel do IRFED - Institut de Recherche et Formation pour Économie et Développement - na formação de um grupo de técnicos voltados à atuação junto ao planejamento urbano e regional no Brasil. Chiquito (2012), que estudou o trabalho da Comissão Interestadual da Bacia Paraná-Uruguai - CIBPU, menciona o vínculo de Lebret junto ao governador paulista Lucas Nogueira Garcez (1951-1955), que rendeu trabalhos à equipe da SAGMACS. A dissertação de Roldan (2012) busca entender a vinculação do grupo de Lebret com as questões do planejamento urbano e regional através das publicações da "Revue Économie et Humanisme", editada pelo EH francês. Sobre a atuação da SAGMACS no planejamento urbano de Belo Horizonte, Oliveira (2015) apresentou trabalho recente destacando a atuação da equipe na elaboração do Plano Diretor da cidade, no início dos anos 1960.

Pontual $(2011,2012,2013)$ trabalhou com a formação de uma rede de Économie et Humanisme na América Latina e estudou os vínculos entre Lebret e o engenheiro Antônio de Bezerra Baltar na formação de uma metodologia para a SAGMACS, e atualmente tem se dedicado a estudar sobre o urbanista francês Gaston Bardet, que teve um momento de aproximação com o grupo de Lebret na França, antes da segunda década de atuação do grupo, nos anos 1950.

É importante ainda mencionar trabalhos de autores brasileiros que estudam Lebret e o EH no campo da sociologia, da economia e da articulação política. Carneiro (1994) estudou a influência de Lebret no diagnóstico e planejamento das atividades econômicas no estado do Paraná. Coelho (2002) estudou as matrizes políticas e a atuação do Partido Democrata Cristão durante o governo de Ney Braga no Paraná. Bosi (2010 e 2012) tem estudado a história do movimento, as matrizes ideológicas e os desdobramentos das mesmas no trabalho de Lebret. Godoy (2014), em artigo recente, abordou o vínculo do dominicano com o estudo dos problemas de desenvolvimento dos estados do Nordeste.

Em nossa pesquisa, a atuação da SAGMACS e o engajamento de Lebret junto ao grupo constituem nossos principais objetos de estudo. Para alcançar este objetivo, delimitamos como corpus documental para o desenvolvimento desta tese as fontes que nos permitiram evidenciar os fios e os rastros, as relações, as aproximações e distanciamentos (GUINZBURG, 2012) alcançados através da pesquisa sobre os 
documentos consultados em Fontainebleau ${ }^{12}$, na França, que constituíram nossas fontes primárias, juntamente com os trabalhos elaborados pela SAGMACS no Brasil, estudados no capítulo final desta tese, além da revisão bibliográfica realizada a partir dos autores mencionados (brasileiros e franceses).

As fontes primárias utilizadas, pesquisadas no Fonds Lebret e em demais arquivos de documentação, foram os trabalhos desenvolvidos pela SAGMACS e os documentos escritos diretamente por Lebret e demais integrantes da rede de $\mathrm{EH}^{13}$, e serviram para respondermos à indagação, colocada como ponto de partida, sobre a criação de um método de trabalho no campo do urbanismo e do planejamento urbano e regional por Lebret a partir de sua atuação na SAGMACS, aspectos que foram analisados dentro da formação do quadro do urbanismo brasileiro.

Ainda que nosso objetivo consista em estudar as repercussões e inovações trazidas pela atuação de Lebret e da SAGMACS, nossa preocupação se insere também no estudo do campo do urbanismo e do planejamento urbano e regional no Brasil, durante as décadas de 1940, 1950 e 1960. Porém, como o recorte específico se faz sobre o que intitulamos de ideário lebretiano, foi preciso aprofundar na busca das informações sobre as fontes documentais que norteiam a formação do Économie et Humanisme, a disseminação das

\footnotetext{
${ }^{12}$ Em Fontainebleau se localiza o "Archives Nationales" da França, onde estão guardados os Fonds Louis-Joseph Lebret, Fonds Raymond Delprat e Fonds de la Féderation française des syndicats professionnels des pêches maritimes, cujos acervos são administrados pelo Centre Développement et Civilisations Lebret-IRFED, nome contemporâneo, alterado pela organização em 2007, para o antigo Centro d'Économie et Humanisme, fundado por Lebret em 1941. O acervo do Fonds Lebret foi formado pela associação Les Amis du Père Lebret, em 1982. Em 1986 foi encaminhado ao Centre d'Archives Contemporaines da França. A documentação que faz parte do acervo do Fonds Lebret está catalogada nas pastas identificadas como AN45 AS, dispostas em pastas variadas. Durante os períodos em que visitamos o arquivo acessamos os documentos das pastas AS31, AS32, AS34, AS35, AS36, AS44, AS45, AS46, AS47, AS48, AS49, AS50, AS51, AS52, AS53, AS57, AS58, AS59, AS60, AS61, AS62, AS63, AS64, AS65, AS66, AS67, AS68, AS70, AS90, AS105, AS144, AS145, AS146, AS149, AS160, AS174, AS182 e AS184.
}

13 Segundo o inventário apresentado por Pelletier (1988), o acervo sobre Lebret está dividido nos seguintes assuntos: itinerário e documentos pessoais de Lebret (pastas AS1 - 30, AS75 - 87, AS172 - 182), Économie et Humanisme (documentos sobre a organização interna, engajamento e escritos internos, dispostos nas pastas AS31 - 70, AS71 0 75, AS118 - 120, AS144, AS148, AS169 e AS181 - 194), a pesquisa no movimento Économie et Humanisme (pastas AS31, AS 33, AS34, 38 - 75, AS118 - 120, AS144, AS147 - 148, AS169 e AS182 - 194), o IRFED (pastas AS119 - 133), trabalhos do padre Lebret e sobre o padre Lebret (pastas AS79 - 84, AS89, AS 144 - 167 e AS144 - 171) e o EH e a igreja católica (pastas AS31 - 38, AS50, AS55, AS 58 e 59, AS 63, AS75, AS119 - 133, AS149 - 152 e AS172). Com o intuito de nos aprofundarmos sobre a formação e difusão de um método por Lebret e o grupo de $\mathrm{EH}$, realizamos a catalogação e leitura de documentos a partir de uma ordem cronológica, iniciando a pesquisa do material encontrado que tratava a respeito do início das atividades de exposição do Économie et Humanisme, ou seja, as Sessões de exposição feitas por Lebret e demais membros do grupo, que ocorriam em cidades francesas ao menos uma vez ao ano. Assim, verificamos que os documentos inseridos nas Pastas AN45 AS51 e AS105 apresentam o percurso de Lebret para a elaboração do I Congresso Internacional de Economia Humana, realizado em agosto de 1954, em São Paulo. Já a apostila e o roteiro de exposição das aulas ministradas por Lebret na Escola de Sociologia e Política, em 1947, estão dispostos na Pasta AN45 AS144. 
ideias do grupo, a visão sobre o mundo urbano que aflorava no cenário pós Segunda Guerra Mundial e a chegada de Lebret ao Terceiro Mundo, o que possibilitou sua inserção no Brasil através da visita realizada em $1947^{14}$.

Sobre a interpretação do ideário lebretiano e do $\mathrm{EH}$, é necessário entender e distinguir as ideias e ações de Lebret em relação às práticas empreendidas pela SAGMACS, já que o grupo fundado no Brasil, em 1947, atuou por quase vinte anos, tendo realizado trabalhos no campo do urbanismo e do planejamento regional. Também foi um organismo vinculado ao Centre d'Économie et Humanisme, fundado por Lebret na França, em 1941, com o apoio de outros padres, empresários e de intelectuais ligados ao meio católico, e fazia, portanto, parte da rede para disseminação das ideias do EH. O Centre d'Économie et Humanisme existiu até o ano de 2007, quando vinculou-se ao IRFED, fundando o Centre Lebret-IRFED.

Assim, para melhor situar a atuação de Lebret, também foi preciso estudar o movimento de Économie et Humanisme francês. Foi através dele que as ideias de Lebret sobre o desenvolvimento harmônico e para uma economia mais humana foram disseminadas mundo afora, principalmente nos países que, no início dos anos 1950, foram chamados de Terceiro Mundo ${ }^{15}$, numa referência às condições que os distanciavam das economias centrais e dos países desenvolvidos (envolvidos na disputa ideológica entre o capitalismo e o socialismo $)^{16}$. Ainda que estudar o movimento francês não fosse nosso objetivo de pesquisa, o estudo serviu-nos como um aporte teórico, pois o que oferecemos aqui é um esforço para desvendar vinculações e imbricações entre a SAGMACS e o Économie et Humanisme, uma vez que o mesmo se constituiu como um grupo central de estudos e

\footnotetext{
${ }^{14}$ Devido à complexidade de objetos em análise e a necessidade de reconstituição do percurso de Lebret na difusão dos métodos do Économie et Humanisme, e a fim de verificarmos a formação de equipes locais e a criação de instituições e demais órgãos que formaram a rede do movimento, dentro da qual se inseriu a SAGMACS no Brasil, foi preciso tomar contato com as fontes documentais primárias. Analisamos, assim, os ensaios, esboços de palestras e seminários, cartas e correspondências trocadas, respostas a convites recebidos por Lebret, além dos trabalhos empreendidos pelo grupo de EH no Brasil. Nesta pesquisa as fontes documentais, principalmente as primárias, foram objetos de nosso estudo a partir de consultas realizadas em Fontainebleau, na França, nos anos de 2012 e 2013, e visaram reconstituir o ideário lebretiano, e realizar o cruzamento destas informações com os aspectos históricos no campo da sociologia, política, economia e urbanismo no período pesquisado, as décadas de 1940, 1950 e 1960.

${ }^{15}$ A expressão "Terceiro Mundo" foi cunhada em 1952 pelo historiador e antropólogo francês Alfred Sauvy em artigo publicado na revista L'Observateur, para denominar os países localizados na América Latina e África, os quais, para ele, viviam em situação ainda precária, apesar de apresentarem amplas possibilidades de melhoria e desenvolvimento social.

16 Os países do Terceiro Mundo eram aqueles que, no contexto da Guerra Fria, pós-segunda Guerra Mundial, eram alvo da investida ideológica tanto dos países de economia capitalista, liderados pelos EUA, quanto socialistas, liderados pela URSS.
} 
pesquisas que resultou na fundação dos demais organismos e instituições a ele vinculados ${ }^{17}$.

Desta forma, esta tese se inicia buscando elucidar e conceituar o entendimento sobre o que seria o trabalho dentro do campo do urbanismo e do planejamento urbano e regional, apontando, no capítulo inicial, um percurso sobre o emprego das terminologias urbanismo, aménagement du territoire, engenharia social ${ }^{18}$ e planejamento urbano e regional. Junto a esta discussão situamos também a percepção sobre a questão do método. Se nos propomos a elucidar a formação ou não de uma metodologia de trabalho no campo do urbanismo e do planejamento regional, que tenha sido cunhada por Lebret através da SAGMACS, é necessário conceituarmos como os métodos e conceitos foram absorvidos pelos urbanistas.

O capítulo inicial expõe o que havia de diálogo entre as teorias, práticas, os métodos e conceitos acerca do urbanismo e do planejamento urbano e regional, sobretudo apresentando um quadro de formação em que se cunhou a terminologia urbanisme na França ${ }^{19}$. A partir deste debate, apresentamos nossa preocupação em situar as ações e práticas resultantes do urbanismo no contexto das décadas de 1940, 1950 e 1960, quando o mundo assistiu ao fim da Segunda Guerra e precisou pensar em ações para a reconstrução das cidades destruídas durante a mesma. Neste período, foi fértil o debate sobre o urbanismo e o planejamento de cidades, sendo possível notar a importância das ações dos Ministérios de Reconstrução Urbana criados pelos governos dos países da Europa.

\footnotetext{
17 Além da SAGMACS, criada por Lebret em 1947, no Brasil, também formavam a rede do Économie et Humanisme o CREDOC - Centre Regional de Documentation et de Conjoncture, o IMSAC - Institut Marseillais de Statistique et d'analyse et de conjoncture, a SAGMA - Societé pour l'application du graphisme et de la mécanographie à l'analyse, a Livraria mantida pelo grupo na cidade de Paris, entre outros organismos fundados em demais países da América Latina e, mais tarde, o IRFED, este último ainda em funcionamento.

18 Ao se referir à "engenharia social" como a parte sociológica do urbanismo, Gilberto Freyre faz menção à "sociologia praticada por homens como o padre Lebret", apontando que este método se dá "quando o sociólogo vai além desses limites e esboça sugestões de reforma social". (FREYRE, 1962, p. 61).

${ }^{19}$ Nosso objeto de pesquisa para elaboração desta tese foi constituído a partir do ideário lebretiano em seus desdobramentos no trabalho desenvolvido pela SAGMACS no campo do urbanismo e do planejamento regional. Para tanto, o primeiro capítulo da tese se debruça a elucidar os métodos do urbanismo a partir do quadro do urbanismo que se forjava na França e no Brasil. Na França porque é onde vivia o padre Lebret e foi fundado o Centre d'Économie et Humanisme, que atuou através da SAGMA - Société pour l'Application du Graphisme et de la Mecanographie à l'Analyse em trabalhos de reconstrução de cidades, contratados pelo Ministère de la Reconstruction et Urbanisme em 1946, e no Brasil, onde foi fundada a SAGMACS, onde a discussão sobre o urbanismo se dava através dos planos para as cidades que cresciam em torno do processo de industrialização.
} 
Sobre a criação destes órgãos, da mesma forma que os países europeus criaram os Ministérios da Reconstrução Urbana, no Brasil, que não sofreu bombardeios em suas cidades, como ocorreu na Europa, verificamos a criação de organismos e instituições voltadas à assistência técnica e ao planejamento regional. Estas instituições que, segundo Campos (2002) e Feldman (2002), foram criadas desde os anos 1920 e ganharam maior força a partir da década de 1940, consolidando-se nos anos 1950, relacionavam-se principalmente com a modernização do Estado brasileiro.

No segundo capítulo apresentamos a trajetória e a atuação de Lebret, discutindo as bases sociais de sua formação intelectual, que o despertaram para a crítica social. O seu diálogo com o marxismo culminou com a criação de uma estrutura de pensamento para a atuação na sociedade, alcançando, através do Économie et Humanisme, a formação de uma rede de instituições, da qual fazia parte a SAGMACS, no Brasil. Neste capítulo, além de estudarmos a trajetória de Louis-Joseph Lebret, aproveitamos para elucidar melhor a formação do EH, e assim desvendar como se deu a incorporação do tema do trabalho no campo do urbanismo e do planejamento regional pelo grupo de Lebret.

Assim, o segundo capítulo se inicia apontando os aspectos da formação intelectual de Lebret, seus anseios pelo desenvolvimento harmônico, seus escritos para divulgação dos pensamentos e ideias defendidas pelo Économie et Humanisme. Também aborda suas viagens por países além Europa, e como se deu a criação dos organismos que compõem a rede do grupo de economia humana, voltados a difundir os métodos de Lebret. Verificamos assim os percursos do grupo e também a proximidade entre as ideias de Lebret e a construção de uma doutrina social pela igreja católica. Para tanto, foi preciso contextualizar os aspectos sociais, políticos e econômicos, abordando com maior ênfase o período do pós-guerra nos anos 1940.

Ainda no segundo capítulo, buscamos elucidar melhor como ocorreu a disseminação das ideias de Lebret e do grupo $\mathrm{EH}$ no que tange à questão urbana e ao engajamento com os temas da cidade, do urbanismo e do planejamento urbano e regional, dentro dos ideais de desenvolvimento econômico e social, perseguidos por Lebret e os membros do Économie et Humanisme. Percebemos que este diálogo com a questão urbana, dentro do ideário lebretiano, ofereceu possibilidades e teve ressonância em outros países, como o Brasil, conforme apontam as fontes documentais analisadas como uma preocupação de Lebret e do EH sobre a formação de agentes que atuariam em instituições vinculadas ao grupo francês, como se deu com a SAGMACS, cuja formação estudamos no terceiro capítulo desta tese. 
No terceiro capítulo tratamos do objeto de estudo central de nossa pesquisa, analisando os desdobramentos do ideário lebretiano e a fundação da SAGMACS, em São Paulo, no ano de 1947, o que marca a vinculação e formalização do Brasil com o grupo francês de economia humana. Neste capítulo estudamos a instituição brasileira vinculada ao EH francês, dando ênfase aos trabalhos realizados no Brasil, onde a equipe atuou desenvolvendo estudos e trabalhos com foco na questão urbana e do planejamento regional. Tratamos aqui da cronologia de atuação da SAGMACS, ocorrida entre os anos de 1947 e 1964, período que envolveu profissionais das áreas de arquitetura, economia, engenharia, geografia, sociologia, forjando um quadro de atuação na área do planejamento urbano e regional, o que permitiu ao grupo se engajar em algumas cidades brasileiras e prestar serviços a organismos de Estado em algumas regiões do país, para o governo federal, alguns municípios e também para instituições privadas.

Pretendemos assim, neste capítulo, reconstituir as bases de formação da SAGMACS e a disseminação das ideias sobre economia humana em uma equipe no Brasil, bem como apontar para a forma como se deu a vinculação de Lebret com os brasileiros e os apoios recebidos para sua vinda, o que possibilitou a apresentação de suas ideias acerca do desenvolvimento econômico harmônico.

Visando elucidar o funcionamento da SAGMACS e sua inserção como instituição de urbanismo, apresentamos, no capítulo final, a composição das equipes, o percurso de formação e o debate sobre a questão urbana e regional dentro do grupo de EH no Brasil. Tratamos também de como se dava a captação de trabalhos pelos escritórios da equipe de Lebret no Brasil e estudamos os trabalhos mais importantes, tanto os que foram desenvolvidos no campo do urbanismo, os quais culminaram com alterações na organização da instituição, renderam reconhecimento e novos contratos, bem como aqueles que a consolidaram como instituição de assistência técnica no campo do urbanismo e do planejamento regional.

Iniciamos com o primeiro trabalho da equipe de economia humana no Brasil, a pesquisa da "Sondagem Preliminar a um estudo sobre habitação na cidade de São Paulo" (1947). Na sequência, estudamos o trabalho contratado pelo governo do Estado de São Paulo, pelo Comitê Interestadual da Bacia Paraná Uruguai, "Problemas de Desenvolvimento. Necessidades e Possibilidades do Estado de São Paulo" (1953-1956); o estudo elaborado a pedido da prefeitura de São Paulo em 1956, "Estrutura Urbana da Aglomeração Paulistana: Estruturas atuais e estruturas racionais"; o trabalho semelhante realizado para a prefeitura de Belo Horizonte, que rendeu a apresentação do "Plano 
Diretor de Belo Horizonte" (1963), e ainda o estudo sociológico "Aspectos Humanos da Favela Carioca" (1960).

Assim, o capítulo final situa a atuação da SAGMACS e do próprio Lebret no Brasil, possibilitando apurar as contribuições deixadas pelo grupo ao quadro do urbanismo brasileiro. Faz-se assim necessário verificar as ressonâncias, a disseminação e a apropriação das ideias do grupo frente ao que era vigente nas práticas do planejamento urbano e regional na década de 1960. Em relação à formação do quadro do urbanismo no Brasil e no campo do urbanismo e do planejamento regional, as ações empreendidas pela SAGMACS, bem como as ideias defendidas pelo grupo, não se deram de forma isolada, mas sim no contexto de um país que forjava o desenvolvimento urbano a partir da intensificação do processo de industrialização, sobretudo nas cidades localizadas na região sudeste, e do projeto em torno da construção de Brasília - a nova capital da República.

Situar as realizações e o debate em torno das ideias inseridas dentro da SAGMACS, no campo do urbanismo e do planejamento regional, disciplinas que ainda estavam em formação nos anos 1960, no Brasil, possibilitou-nos elucidar o incremento ou não de ferramentas dispostas pelo grupo de Lebret, a partir de seus trabalhos e contratos desenvolvidos nas décadas anteriores (1950 e 1960) e das preocupações e indagações que se faziam no âmbito do urbanismo e do planejamento urbano e regional de nossas cidades, dentro de um panorama de realizações frente às práticas do urbanismo no Brasil.

É importante expor ainda que este capítulo, além de discutir a circulação e apropriação das ideias do grupo de economia humana no Brasil, a partir da apresentação e análise dos trabalhos mencionados anteriormente, nos permitiu responder à questão principal desta tese: poderíamos ou não atribuir a Lebret, através de sua atuação na SAGMACS, a introdução de um método de trabalho no campo do urbanismo e do planejamento urbano e regional? Isto porque, seu percurso não teve início com a criação do escritório da SAGMACS em São Paulo, mas o mesmo já se fazia presente nas ideias debatidas pelos membros do Centre d'Économie et Humanisme na França, disseminadas mundo afora pelas ações de Lebret.

Dessa forma, nossa tese de doutorado irá destacar o papel reservado a Lebret e à SAGMACS em sua atuação, com ideias, contribuições e planos, dentro do quadro de formação do urbanismo no Brasil, durante os anos de 1950 e 1960, de modo a possibilitar a ampliação da compreensão do ideário lebretiano e, através de novos questionamentos, responder à indagação acima apresentada. 
CAPÍTULO 1

OS MÉTODOS E CONCEITOS ACERCA DO URBANISMO: A INCORPORAÇÃO DO TEMA NO ÉCONOMIE ET HUMANISME 

A hipótese colocada inicialmente nesta tese era de que Lebret, através de sua atuação junto à equipe da SAGMACS, formulou um método de trabalho no campo do urbanismo e do planejamento regional. Assim, neste capítulo inicial, buscaremos responder se o ideário lebretiano e as concepções e propostas da SAGMACS podem ser considerados como pertencentes ao campo do urbanismo. Ou ao menos como pertencentes ao campo do planejamento urbano e regional. Entendemos que estas indagações se colocam previamente à investigação da hipótese a ser confirmada.

Para respondermos às indagações que nortearam nossa pesquisa de doutorado, buscamos, neste capítulo, aprofundar sobre a formação dos métodos do urbanismo, investigando suas concepções, teorias e intervenções práticas. Assim, estudaremos o que se discutia acerca da questão urbana, sobretudo na França e no Brasil, na primeira metade do século XX. Este recorte se justifica porque, além da atuação da SAGMACS ser nosso objeto de investigação, as principais referências urbanísticas de Lebret e do Économie et Humanisme foram construídas a partir de autores franceses ${ }^{20}$.

As ações sobre o território e o interesse pelo desenvolvimento urbano e regional em Lebret não se iniciaram a partir de seu engajamento junto ao meio empresarial, religioso e político brasileiro. Desde a fundação do Centre d'Économie et Humanisme na França, em 1941, e sobretudo após o período de liberação, com o fim da Segunda Guerra mundial, a equipe formada por Lebret já apontava para os problemas das cidades e do campo e debatia o assunto, inclusive publicando textos sobre a questão do desenvolvimento urbano e regional na Revista ${ }^{21}$ editada pelo grupo francês.

\footnotetext{
${ }^{20}$ Até o período inicial do Centre d’Économie et Humanisme, nos anos 1940, é possível perceber que, além da influência de autores franceses, Lebret se apropriou também de fontes do urbanismo britânico e tinha conhecimento de trabalhos em desenvolvimento também na Alemanha e nos Estados Unidos. Já o vínculo com autores e urbanistas latinoamericanos se deu somente nos anos 1950, após suas incursões por países deste continente.

${ }^{21}$ A partir de 1942 o Centre d'Économie et Humanisme editou a "Revue Economie Humaine", que circulou até 2007, com o intuito de divulgar as ideias e ações do movimento fundado por Lebret. A revista publicava também resenhas sobre obras e textos de autores que escreviam sobre religião, economia, política, desenvolvimento social, trabalho e planejamento urbano e regional.
} 
Ainda assim, a atuação de Lebret e da SAGMACS na busca de solução para os problemas urbanos, que resultou em estudos, diagnósticos e algumas propostas para o desenvolvimento das cidades, causa dúvidas e motiva indagações que nortearam a formulação de nosso tema de investigação. Isto porque, o entendimento da atividade do urbanismo, que resulta em uma proposta de desenho ou ordenação para um território, poderia colocar em xeque as teorias e formulações acerca do que realizaram as equipes da SAGMACS e o padre Lebret no campo do urbanismo e do planejamento urbano e regional no Brasil.

Sobre o urbanismo enquanto práxis, entretanto, é importante lembrar que Le Corbusier reconhece que o urbanismo se faz através de ideias e não necessariamente de projetos executados, apontando, no contexto do pós Segunda Guerra na Europa, que "grandes urbanistas nos precederam, mas não usavam o lápis; manejavam a ideia", citando pensadores da virada do século XVIII para o XIX, como "Balzac, Fourier, Considérant, Proudhon" (1971, p. 14). Do mesmo modo Gaston Bardet, urbanista francês, opositor de Corbusier, define que "o urbanismo é antes de tudo uma ciência que se dedica ao conhecimento das coisas, que estuda metodicamente os fatos, que pesquisa as causas primeiras" (1990, p. 27). Isto nos permite colocar Lebret como atuante no campo do urbanismo e do planejamento urbano e regional. 


\subsection{Breve quadro de formação do urbanismo como disciplina na França}

Desvendar as chaves do urbanismo que influenciaram Lebret e as equipes da SAGMACS é tarefa recorrente em nossa tese de doutorado, uma vez que as ações do grupo não resultaram propriamente numa proposta de traçado ou plano urbanístico. Porém, o produto resultante do urbanismo não se dá unicamente em uma proposta de traçado, sendo o urbanismo apontado por Bardet e Le Corbusier como uma concepção de ideias, independentemente delas se materializarem na prancheta ou serem aplicadas num espaço físico.

Sabemos que o trabalho de Lebret junto ao Économie et Humanisme nasceu ligado à matriz de interpretação sociológica e econômica da realidade social, quando da fundação do grupo em 1941, e não a disciplina do urbanismo. Porém, não podemos desvincular as questões que emergiram sobre a cidade e os modos de vida urbana elencados no modo de produção econômica. No século XIX, com a ascensão do capitalismo industrial, a revolução industrial impôs um novo ritmo à produção econômica e a revolução liberal burguesa, empreendida pelos franceses no século XVIII, forjou uma nova forma de se apropriar do espaço urbano. Esta nova forma de apropriação, intrinsicamente ligada à matriz econômica, rendeu também a emergência de novos problemas e questões em uma sociedade que se deparava com altas taxas de crescimento populacional e assistia sua paisagem ser transformada rapidamente.

Quando discutimos a formação de uma "ciência da cidade", ou do urbanismo como disciplina, forjada no bojo da modernidade do século $\mathrm{XIX}^{22}$, verificamos em sua filiação a emergência da questão social trazida pelos aspectos econômicos decorridos do desenvolvimento do capitalismo industrial, apontando que "a revolução industrial e a demográfica tiveram início, por consequência, no mesmo período" (BAIROCH, 1974, p. 39). A ascensão do modelo de cidade instituído ao longo do século XIX, a partir da adesão ao ideário de modernidade e do capitalismo industrial, fez com que alguns estudiosos, políticos e literatos identificassem este momento como do surgimento da

\footnotetext{
${ }^{22}$ É importante atentarmos para as armadilhas do discurso modernista, pois este nos impõe a ideia de que o século XIX ocorreu como momento de uma ruptura social, política e econômica, e que todas as questões referentes à problematização das cidades começaram ali. O que estabelecemos como discussão da construção de uma ciência urbana, ao longo do século XIX, trata de um recorte temporal, no qual a abordagem sobre a cidade grande e moderna e sua problematização se aproxima dos trabalhos empreendidos dentro do ideário lebretiano. Porém, para Argan, a urbanística moderna tem sua origem já no período renascentista, que apontou para as cidades como um novo objeto social. Já para Piccinato e Calabi, o ponto de partida se deu durante o século XIX.
} 
cidade grande e moderna ${ }^{23}$, objeto inédito no campo da pesquisa social, uma vez que o desenvolvimento econômico e industrial permitiu que a cultura urbanística fosse invocada para solucionar os conflitos espaciais decorrentes deste período.

A cidade, que anteriormente se destacava como o lugar da troca de mercadorias, da sede do poder aristocrático, do clero e das manifestações artísticas e intelectuais, transformou-se durante o século XIX, passando a comportar também a sede da produção econômica e, consequentemente, do trabalho, sob o modelo do capitalismo industrial ${ }^{24}$. Tornando a "cidade o centro que irradia as influências da vida civilizadora moderna para os confins da terra, e o ponto que as controla", de forma que "os problemas persistentes da sociedade contemporânea tomam a sua forma mais aguda na cidade" (WIRTH, 1949, p. 604).

Com o advento da industrialização, formava-se uma nova paisagem urbana, construída ao longo do século XIX. Ao mesmo tempo em que o discurso dominante enaltecia a capacidade criadora do homem e a dominação da natureza através da mecanização da produção, uma multidão de trabalhadores e homens comuns trazia para a cidade grande e moderna o horror e as incertezas sobre os tempos modernos.

A partir deste cenário de transformação e da inserção da cidade como lugar da produção econômica industrial, surgiram novos atores como protagonistas e usuários do espaço urbano, com destaque para os trabalhos de Carlyle (1929), Chadwich (1842), Engels (1845), Thomas Hardy (1879), Le Play (1855), James Smith (1857), entre outros, que se deparavam com o que classificavam de ineditismo do conflito. Pois, "o estudo da cidade se apresenta como de suprema importância não só para a compreensão científica da própria cidade, mas também para a compreensão e acomodação da ordem social contemporânea”. (WIRTH, op. cit., p. 605).

O que se percebe é que estes autores enxergavam na cidade um rico campo analítico para as pesquisas sociais, pois as transformações dos espaços urbanos e do habitat do homem da cidade ocorriam num movimento que, segundo Williams, gerava ao mesmo tempo "labirintos e becos para a população pobre" e "dava origem às mansões urbanas,

\footnotetext{
${ }^{23}$ Segundo Hobsbawm, neste período "a grande cidade - quer dizer, um povoamento de mais de 200 mil incluindo um punhado de cidades metropolitanas de meio milhão de habitantes". Para o autor a cidade grande e moderna "não era exatamente um centro industrial, mas mais precisamente um centro de comércio, transporte, administração e uma multiplicidade de serviços que uma grande concentração de pessoas atraía." (1996, p. 294).

${ }^{24}$ Zuconi chama atenção para os riscos da visão totalizante sobre o crescimento das cidades no século XIX e o vínculo com a expansão industrial, apontando que "a história, ela nos aponta que a indústria é um dos fatores de desenvolvimento, mas não o único." (2009, p. 21).
} 
às praças e aos jardins elegantes" (1989, p. 204). Estas transformações se deram a partir de planos de melhoramentos, intervenções viárias e obras de infraestrutura, que impulsionaram não só o movimento de reformulação do espaço urbano, mas protagonizaram um trabalho de reforma social, impondo um conjunto de regras normatizadoras, sobretudo à classe trabalhadora e aos habitantes mais pobres. Além disso, podemos dizer que estas intervenções na paisagem fazem parte do campo de atuação do urbanismo, ou, como aponta Andrade, da "cultura urbanística", que "incluindo-se suas instituições, é uma criação particular no processo de criação geral da sociedade" (1992, p. 38).

Para se alcançar este objetivo de reforma social ${ }^{25}$, que impunha um comportamento e um estilo de vida ao habitante da cidade grande e moderna, era preciso reconhecer que a cidade do século XIX vivia uma crise urbana, gerada pelo ineditismo do conflito entre os diferentes atores da cidade. Além da cidade ter se tornado sede da atividade econômica industrial, a vinda de trabalhadores da indústria impunha que o espaço urbano fosse dividido entre capitalistas e operários, fato este que se configurou como uma das principais mudanças ocorridas no cenário social da cidade, abrindo campo para uma relação de antítese e conflito entre riqueza e pobreza ${ }^{26}$, conflito este que causava aos antigos moradores da cidade um sentimento de estranhamento. Para Hobsbawm, "dizer que a concentração de pessoas em cidades era o mais impressionante fenômeno do atual século era dizer o óbvio." O autor aponta que,

A cidade era sem dúvida o mais impressionante símbolo exterior do mundo industrial, exceção feita à estrada de ferro. A urbanização cresceu rapidamente

\footnotetext{
${ }^{25}$ Topalov observa que esta terminologia "reforma social" tem diferentes significados entre ingleses, norte americanos e franceses. Aponta que, na França, os reformadores foram um movimento que surgiu na III República, a partir de 1880, em contraponto ao movimento dos conservadores e revolucionários. Os reformadores seriam organizados pelos mais conservadores discípulos de Le Play, que por sua vez são combatidos pelos socialistas que dizem que seria necessária uma revolução. Para o autor, na Grã Bretanha e nos Estados Unidos, a noção de reformas é usada para descrever os movimentos que marcam o fim do século XIX e a passagem para o XX, apontando-se para as associações sociais, que se tornam organizações reformadoras que desenvolvem programas e cruzadas que ajudarão a moldar as políticas sociais do século XX. (1999, p. 14).

${ }^{26}$ O conceito de classe social e os estudos sobre a formação da sociedade de classes foram desenvolvidos por Karl Marx e Friedrich Engels na metade do século XIX, como resultado da expansão do projeto capitalista burguês, que introduziu um novo modo de produção econômica. Segundo Engels (2008, pp. 63-65), a indústria centraliza a propriedade em poucas mãos, exige enormes capitais, capazes de criar gigantescos estabelecimentos, arruinar a pequena burguesia artesã e colocar a seu serviço as forças naturais. Com o advento da industrialização vem a divisão social do trabalho, que fez surgir os primeiros proletários, criando uma sociedade dividida entre classes. Hobsbawm aponta esta divisão de classes sociais, sobretudo a partir do surgimento do proletariado urbano, e afirma que "as classes médias da Europa estavam assustadas e permaneceram assustadas com o povo", pois, "a democracia era vista como o prelúdio rápido e certeiro para o socialismo" (1996, p. 21).
} 
depois de 1850. Na primeira metade do século, somente a Inglaterra tinha tido uma taxa anual de urbanização superior a 0,20 pontos embora a Bélgica praticamente atingisse aquele nível. Mas entre 1850 e 1890 até a AustroHungria, Noruega e Irlanda urbanizavam-se naquele ritmo. (1996, p. 293).

Assim, é possível perceber que as transformações ocorridas na cidade grande e moderna ao longo do século $X I X$, que perduraram até o início do século $X X$, se deram em decorrência das transformações econômicas que levaram à constituição do urbanismo como disciplina. Neste contexto, a nosso ver, o urbanismo não está atrelado simplesmente a uma forma de ordenação territorial ou normatização do espaço urbano, atividade que poderia ser empreendida nas pranchetas de idealizadores, projetistas e engenheiros, mas colocada a serviço dos anseios econômicos e políticos presentes no período, no sentido de dar legitimidade ao novo modelo de produção econômica, o que causava certo estranhamento, por se tratar de um momento de transição e ascensão de um novo modus operandi. Segundo Zuconi, "à tendência objetiva de desenvolvimento acrescenta-se uma cultura do desenvolvimento a qual pretende adequar a estrutura da cidade às lógicas próprias do crescimento econômico". (2009, p. 28).

Este estranhamento dos novos tempos, ou modus operandi, dava-se em parte devido ao próprio projeto de modernização imposto pela matriz de economia capitalista industrial, que fazia com que a população procurasse as cidades, sede da indústria - símbolo do poder econômico do período. Esta nova realidade também revelava as contradições e relações de antítese presentes no contexto e no cenário da cidade do século XIX, de forma que,

Não era só uma questão de número de habitantes, pois, tais cidades haviam sido construídas para servir como lugares de trabalho: fisicamente, eram dominadas pelas fábricas e máquinas, os prédios enegrecidos pela fumaça e os rios enegrecidos pelos despejos industriais ao redor dos lugares de trabalho, de modo que a relação dominante estava sempre presente. (WILLIAMS, 1989, p. 297).

Com o aumento da população e da produção industrial surgiam também os problemas de falta de espaço e condições adequadas de atendimento, sobretudo da população mais pobre. As ruas eram tomadas por multidões, formadas pelos novos habitantes da cidade grande e moderna, pouco afeiçoados aos modos e comportamentos por ela exigidos. Esta condição de má adequação aos novos hábitos impunha a existência de um conflito do próprio sistema econômico, causando medo e desconforto àqueles que imaginavam deter o controle social. Nesse momento ocorreu uma série de mudanças no campo 
social, econômico e na organização espacial, de forma que as cidades passaram a ser alvo de um reordenamento a partir de métodos modernos de organização do território. Assim, "remodelada e equipada, a grande cidade capitalista poderia emergir como sede e símbolo do avanço modernizador" (CAMPOS, 2002, p. 26). Esta reorganização conferia novos aspectos às cidades, principalmente no que se referia à diferenciação entre os espaços públicos em relação aos lugares privados - implicando aos seus habitantes o aceite de novos hábitos de comportamento nos espaços comuns.

Para os planejadores de cidades, os pobres eram uma ameaça pública, suas concentrações potencialmente capazes de se desenvolver em distúrbios deveriam ser cortadas por avenidas e bulevares, que levariam os pobres dos bairros populosos a procurar habitações em lugares não especificados, mas presumidamente mais sanitarizados e certamente menos perigosos. Essa também era a política das estradas de ferro, que fazia suas linhas passarem pelo centro da cidade, de preferência pelo meio dos cortiços, onde os custos eram menores e os protestos negligenciáveis. Para os construtores e empreendedores, os pobres eram um mercado que não dava lucro. (HOBSBAWN, ibid., p. 295).

As transformações ocorridas nas cidades, durante o século XIX, visavam adaptá-las às exigências dos novos tempos, impostas pela economia capitalista industrial e o ideário da modernidade, pois "a classe dominante queria desfrutar das vantagens de um processo de transformação que ela própria estava promovendo e, ao mesmo tempo, controlar ou suprimir suas consequências indesejáveis, porém inevitáveis." (WILLIAMS, ibid., p. 204). $\mathrm{O}$ ineditismo do conflito impunha à cidade grande e moderna relações antagônicas. Ao mesmo tempo em que era preciso conter o avanço das multidões presentes nas ruas, também era preciso garantir à indústria a mão de obra da classe operária, formadora desta multidão anônima que se incorporava ao espaço urbano. Nesse contexto,

O medo e o fascínio orientam uma atitude exploratória que fará da cidade um observatório extenso, mas com limites delineados. A atividade exploratória se concentrava no levantamento do modo de vida dos homens pobres trabalhadores ou vagabundos, considerados equivalentes aos povos selvagens, e seus bairros definidos como terra incógnita. Os observadores políticos, médicos, reformadores sociais, sociedades estatísticas - assumem a postura de exploradores de culturas estrangeiras em busca de uma resposta sobre qual era a condição atual da sociedade. (BRESCIANI, ibid., p. 60).

As contradições do período podem ser percebidas nas relações de ambiguidades: o avanço da ciência e da técnica e ao mesmo tempo o avanço das epidemias; a ordem, simbolizada pelo tempo fabril, e a desordem, pela multidão caminhando 
desordenadamente pelas ruas da cidade; o crescimento da cidade e a ampliação dos custos para o enfrentamento de seus problemas, e, principalmente, o distanciamento entre ricos e pobres.

O caos e a desordem visível no período, resultando em crescentes epidemias, prejuízo à indústria, a falta de habilidade dos trabalhadores urbanos para as novas atividades da cidade e a perturbadora apropriação do espaço público pelos mais pobres levaram técnicos, intelectuais e políticos a se preocuparem com uma maneira de conter e remediar tais problemas, de forma a melhorar as condições de vida da população. Tal preocupação possibilitou a problematização da cidade e a disseminação do urbanismo como disciplina. Conforme Beguin, "o que caracterizava o começo do século XIX era um desenvolvimento sem precedentes dos meios técnicos que permitiram frear as doenças da insalubridade". (1991, p. 41).

Esta "problematização da cidade" acontece concomitantemente com a tentativa de constituir uma "ciência urbana" ou "ciência da cidade", fator que ganha maior importância no período moderno, quando alguns estudiosos atrelam a existência das cidades ao funcionamento da indústria, conferindo importância a elas, como fator de desdobramento ou reflexo do modo de produção capitalista. Ainda sobre esta constituição da "ciência urbana", é importante destacar que a cidade já se constituía como objeto e meio de organização social desde a antiguidade, o que rendeu trabalhos e estudos sobre autores que escreveram sobre a cidade anteriormente ao advento da industrialização ocorrida no século XIX. Porém, esta "problematização da cidade" dada ao longo do século XIX, trazia aspectos que incluíam o comportamento social dos novos habitantes dos centros urbanos, bem como buscavam entender a relação entre a pobreza e a classe burguesa com os espaços públicos, reflexo da sociedade de classes que se consolidava juntamente com o capitalismo industrial.

Era necessário enfrentar ou minimizar o desconforto causado pelos novos tempos, daí a ascensão das ferramentas de controle social que se vincularam ao urbanismo e que possibilitaram que os redutos da pobreza e os locais da moradia operária se tornassem lugares vigiados, controlados e dirigidos, abrindo campo para a época das reformas urbanas, da higienização da cidade, a implantação do saneamento básico e dos equipamentos sociais que deram lugar à arquitetura da cidade grande e moderna. François Beguin (ibid., p. 47) apresenta relatos publicados pelo "The Reports of the Society for Bettering the conditionandin creasing the comforts of the poor", em 1798, que afirmavam, sobre as condições de vida dos mais pobres em Londres, que "os hábitos morais, as condutas domésticas e o comportamento do conjunto dos pobres são 
influenciados por seu entorno imediato e, antes de qualquer coisa, pelo conforto e desconforto...".

Segundo Calabi (2012, p. 47), "diante de situações como o cólera e os protestos radicais do movimento dos trabalhadores, as classes médias ficam alarmadas a ponto de investigarem a natureza da sociedade urbana". Da mesma forma, Cohen (2013, p. 70) aponta que "as nascentes ciências sociais encontravam nas cidades um tema irresistível." Também para Cohen (2013, p.70),

Sociólogos como Max Weber e Georg Simmel, na Alemanha e Maurice Halbwachs, na França, bem como pesquisadores da Universidade de Chicago, lançaram os alicerces de um novo enfoque crítico para o estudo das relações sociais, apoiado em pesquisas sistemáticas e fatos verificáveis.

A complexidade dos aspectos urbanos das cidades, decorrentes das transformações ocorridas durante o século XIX, possibilitou a organização de várias pesquisas sobre as condições de vida, de trabalho e de habitação das classes populares urbanas. Em Londres, a primeira delas ocorreu em 1844, sob a coordenação de Chadwick, e revelou a relação entre insalubridade e más condições de habitação, dedicando-se a elucidar o custo do desconforto social e econômico. Frédéric Le Play também escreveu sobre as classes operárias parisienses em 1855, num trabalho intitulado "Les Ouvriers Européens: Études sur les Travaux, la Vie Domestique et La Condition Morale des Populations Ouvrières de l'Europe, Précédées d'um Exposé de La Méthode d'Observation".

\begin{abstract}
Algumas décadas depois, outras pesquisas - como a de Henry Mayhew (1862) sobre o trabalho precário e o desemprego, ou a depois realizada por Joseph Rowntree (1901) sobre a pobreza em relação ao ciclo familiar, feita a partir de um levantamento de toda a população de York, outras análises sobre Londres vão adquirindo o caráter de um levantamento sistemático e contribuem para organizar o problema da casa. Eles evidenciam, por um lado, a existência da questão dos slums e, por outro, a pressão de áreas em contínua expansão. Mas abordam também questões mais gerais que interessam à comunidade (horários de trabalho, condições nas fábricas, o fornecimento de serviços urbanos, como água, esgoto, iluminação, pavimentação). (CALABI, ibid., p. 48).
\end{abstract}

É importante dizer que as pesquisas realizadas nas diferentes cidades, durante o século XIX e início do XX, sobre as condições de vida da população mais pobre, traziam forte cunho moralista e higienista, o que expunha a maneira como as classes populares e as multidões das ruas eram vistas pelos olhos das camadas dominantes. Hardy enxergava Londres como "um monstro cujo corpo tinha 4 milhões de cabeças e 8 milhões de olhos", e, em 1879, escreveu: 
À medida que a multidão vai se tornando mais densa, ela perde o caráter de aglomerado de uma infinidade de unidades e transforma-se num todo orgânico, uma criatura negra, semelhante a um molusco, que nada tem em comum com a humanidade, que assume as formas das ruas nas quais se colocam e estendem horrendas excrescências e membros nos becos vizinhos; The early life of Thomas Hardy, Londres (1928, p. 129.)

Diante dessas preocupações, disciplinar o espaço da multidão e ao mesmo tempo contêla, e ainda minimizar a proximidade de convívio entre pobres e ricos tornam-se questões colocadas à cidade grande e moderna, ao longo do século XIX. Abre-se campo, então, para a implantação dos projetos de reordenamento dos espaços urbanos, visando à diferenciação entre o lugar do público e do privado e criando assim uma dicotomia entre o lugar do rico e do pobre. As ruas e praças - espaços voltados para a vida e convivência pública - passam por reformulação, de forma a disciplinar a presença das multidões e o uso desarticulado desses espaços; os edifícios privados também se tornam alvo de intervenções do urbanismo moderno. Da mesma forma, as edificações destinadas à moradia também necessitam passar por reformulações, de modo a se adequarem ao tempo e à cidade moderna, pois o habitat referia-se à vida íntima e privada da família e na sociedade moderna os meios de sociabilidade deveriam ser fortemente organizados e vigiados.

Estas transformações sociais e econômicas implantaram a arquitetura da cidade grande e moderna, que aparecia como um componente importante dos programas de higiene e salubridade. A classe dominante caracterizava os aspectos construtivos e os arranjos territoriais necessários ao bom funcionamento da cidade. Assim, o relato de Engels sobre a estrutura urbana criada em Manchester, na Inglaterra, em meados do século XIX, deixa claro que a disciplina do urbanismo era um desdobramento da economia vigente e se constituía a serviço deste modelo de produção econômico industrial. Ao relatar o desenho urbano de Manchester e o funcionamento da cidade, Engels aponta a preocupação do urbanista em traçar em sua prancheta uma solução que não criaria à classe dominante o desconforto de conviver com seus operários. Engels observa que:

Manchester é construída de um modo tão peculiar que podemos residir nela durante anos, ou entrar e sair diariamente dela, sem jamais ver um bairro operário ou até mesmo encontrar um operário - isso se nos limitarmos a cuidar de nossos negócios. A razão é que - seja por um acordo inconsciente e tácito, seja por uma consciente e expressa intenção - os bairros operários estão rigorosamente separados das partes da cidade reservadas à classe média [...] A alta burguesia habita vivendas de luxo, ajardinadas, mais longe, em Chorlton e Ardwick ou então nas colinas de Cheetham Hill, Brougthon e Pendleton, por 
onde corre o sadio ar do campo, em grandes e confortáveis casas [...] A média burguesia vive em ruas boas, mais próximas dos bairros operários, sobretudo em Chorlton e nas áreas mais baixas em Cheetham Hill. O curioso é que esses ricos representantes da aristocracia do dinheiro podem atravessar os bairros operários, utilizando o caminho mais curto para chegar aos seus escritórios no centro da cidade, sem se aperceber que estão cercados, por todos os lados, pela mais sórdida miséria. (2008, pp. 87-88).

Como podemos ver no exemplo apontado por Engels sobre a cidade de Manchester, o projeto da modernidade impõe o distanciamento entre as classes sociais, de forma que os mais pobres passam a ser vistos como classes perigosas. Na visão da burguesia o cenário urbano, transformado por novos espaços, edifícios públicos, ruas e praças, que tão bem serviam ao ideário imposto pela classe dominante, não era compreendido com a mesma naturalidade pela classe de trabalhadores urbanos, e então era preciso intervir para se evitar o confronto direto entre as classes. Esta intervenção, vinculada ao nascedouro do urbanismo moderno como disciplina, tem interação direta com os trabalhos de pesquisa sobre as condições de vida do morador desta cidade que se consolidava ao longo do século XIX.

Num tempo em que as atividades privadas deveriam restringir-se aos espaços íntimos, os estudos sobre a cidade grande e moderna, as condições de vida da população e a habitação operária ganham notoriedade. Da mesma forma que a cidade grande e moderna era desconhecida para as classes trabalhadoras, seu habitat também era algo ainda inexplorado e incompreendido pelas autoridades e intelectuais, de forma que ferramentas para sua análise e compreensão tornaram-se instrumentos necessários no apoio à tomada de decisão, buscando-se o conhecimento dos modos de vida da classe operária em suas residências para posteriormente se propor a remodelação e sua melhoria, visando obter o controle social sobre as mesmas. Neste sentido, Williams aponta que, embora o olhar distanciado do observador seja um elemento novo em busca de se entender a cidade grande e moderna, alguns aspectos se mantinham inalterados no entendimento das classes trabalhadoras.

O evidente medo da multidão, com a persistência da imagística do inumano e do monstruoso, representa uma continuação daquela reação à turba que já se evidenciava havia tantos séculos, e que foi tão intensificada pelo tremendo desenvolvimento da cidade. Mantendo-se a ideia de que a aglomeração excessiva da cidade como uma fonte de perigos sociais: desde a perda dos sentidos humanos comuns até o acúmulo de uma força poderosa, irracional e explosiva. (WILLIAMS, 1989, p. 293). 
Diante do eminente conflito entre as diferentes classes presentes nas novas feições da cidade grande e moderna, assistimos à ascensão das pesquisas urbanas sobre as condições e modos de vida da população e da habitação da classe operária. Estas pesquisas ofereceram subsídios e tiveram grande relevância na interferência das condições de vida e intervenções espaciais, propostas pelo urbanismo moderno. Os trabalhos de diagnósticos e pesquisas sociais foram incorporados, no final do século XIX e início do $X X$, aos trabalhos urbanísticos, o que não foi diferente no Brasil, onde o ideário do capitalismo industrial e a consolidação do modelo da cidade grande e moderna se deram de forma mais tardia do que nos países centrais.

Esta constituição da "ciência da cidade" ao longo do século XIX é apontada por Pereira (2014) como um marco que aproximou as "questões de territórios e cidades". Para a autora, "disciplinas antigas - como a arquitetura, a geografia, a história ou o direito uniam-se àquelas que se haviam constituído no bojo das 'revoluções' da era industrial como a economia, o urbanismo, a sociologia urbana, a ciência política, a economia política, a psicanálise" (2014, p. 9).

Assim, esta reconstituição do quadro no qual se formou a disciplina do urbanismo moderno, durante o século XIX, nos permite apontar para dois aspectos, sendo um deles já bastante abordado e discutido por diferentes autores. O primeiro aspecto seria a vinculação do urbanismo como uma disciplina que surge a partir do interesse das classes dominantes, assunto que o vincula diretamente ao modelo de produção econômica e, portanto, da matriz dominante sobre as relações sociais. Desta forma, as intervenções na cidade, sobretudo no ordenamento do espaço público e na criação de um padrão estético burguês, visam remediar os conflitos decorrentes da sociedade de classes surgida à luz do advento do capitalismo industrial e, ao mesmo tempo, consolidar a cidade como o espaço regido pelo homem burguês.

O segundo aspecto refere-se ao fato de que as obras de melhoramentos, bem como a inserção de uma estética burguesa, não foram concebidas de forma isolada na prancheta dos projetistas, técnicos e engenheiros, mas sim a partir dos diagnósticos construídos sobre os relatórios médicos, sanitários e dos filósofos e literatos, que permitiram ao urbanismo moderno ter acesso à classe trabalhadora e assim inserir-se em seu meio social urbano.

Este segundo aspecto ao qual nos referimos, e que é menos abordado pelos autores que estudam a formação do urbanismo moderno durante o século XIX, não se resume às realizações empreendidas pelas grandes obras de engenharia e pelo desenho dos espaços urbanos, nem ao ordenamento territorial para a cidade que resultou do 
capitalismo industrial. A nosso ver, esta abordagem com vistas a empreender mais do que uma reforma dos espaços públicos, também uma reforma social, foi o que garantiu o sucesso das realizações do urbanismo na segunda metade do século XIX em antigas capitais europeias, e no Brasil e Estados Unidos no início do século XX.

Seria então a partir desta matriz - da pesquisa social e dos diagnósticos urbanos - que se inseririam as ações empreendidas por Louis-Joseph Lebret em sua conceituação de mundo urbano, o qual se desenvolveria, sobretudo, a partir do fim da Segunda Guerra, na década de 1940, momento em que a cidade como objeto problematizado ou como campo de pesquisa já havia se constituído. Porém, a emergência da reconstrução das cidades europeias, destruídas pela guerra, e a desconcentração do capital econômico das antigas capitais europeias, que permitiu ampliar sua ação para novas fronteiras, como os países do Terceiro Mundo, vão impelir Lebret a buscar o entendimento para os novos problemas da cidade.

Dando continuidade ao desenvolvimento deste capítulo, buscaremos introduzir a disciplina do urbanismo e a "ciência da cidade" a partir da análise do que seriam seus métodos. É importante também situar que nossa incursão ao século XIX se deu como possibilidade de apontar para o pouco ineditismo das ações empreendidas por Lebret na sua interpretação de mundo urbano, tanto junto de seu grupo na França, através do Centre d'Économie et Humanisme, quanto de sua equipe na SAGMACS, que atuou no Brasil. Isto porque, desde a virada do século XVIII para o XIX se percebe espaço para estudos e diagnósticos sobre as cidades e as condições de vida de seus habitantes, trabalho que marcou a trajetória dos organismos fundados por Lebret, tanto na França, quanto no Brasil.

\subsection{O uso da terminologia Urbanismo: uma questão de nomenclatura}

Autores como Benévolo (1981 e 1993), Morbelli (1997), Zucconi (2009), entre outros, vinculam a história da construção da disciplina do urbanismo, ou da urbanística, à história da cidade, porque podemos entender a cidade como um objeto fruto da interdisciplinaridade. É neste espaço que se permite a constituição de uma "ciência da cidade", resultado da problematização da própria cidade, conforme apontamos 
anteriormente, e que se formula uma disciplina que já nasce atrelada aos diferentes saberes $^{27}$. É exatamente por ela permitir a problematização, atrair diferentes visões e interesses em linhas de pesquisas distintas que avançamos nos estudos sobre a disciplina do urbanismo, o que nos leva a situá-la como um objeto da interdisciplinaridade. Os estudos urbanos ocorrem em diferentes países e carregam entre si diferentes maneiras de interpretar, entender e abordar a cidade como um objeto de pesquisa, mas para nós reservam ao menos um objetivo comum: o de fazer "ciência urbana". A partir do século XIX,

Fundamentalmente se delineia um modo inédito de olhar a cidade: não é mais uma entidade paralisada, mas um organismo em movimento, cada vez comparável a outros sujeitos e in primis ao corpo humano. A cidade agora aparece como sendo uma figura que pode ser mediada, ampliada e principalmente modificada (ZUCCONI, ibid., p. 28).

Assim, a nova disciplina, forjada ao longo do século XIX, recebeu diferentes denominações ${ }^{28}$. Essas diferenças de nomenclatura rendem também abordagens distintas entre si, conforme apontado por alguns autores que afirmam haver em alguns casos maior pertinência do emprego e, a nosso ver, maior relação com o que estaria atrelado às pesquisas sociais e aos diagnósticos urbanos, que teriam sido utilizados por Lebret nas instituições em que atuou nas décadas de 1940, 1950 e 1960, tanto no Brasil quanto na França. A nomenclatura ${ }^{29}$ para esta "ciência da cidade" na França é denominada de "urbanisme", na Alemanha de "städtebau"30, nos países de língua

\footnotetext{
${ }^{27}$ Quando falamos em diferentes saberes, que envolvem a disciplina do urbanismo, referimo-nos àqueles que se vinculam ou se aproximam das questões de territórios e cidades, como a arquitetura, a geografia e a história, que já estavam constituídas quando, no século XIX, o advento da cidade grande e moderna permitiu a problematização da cidade. Assim, ao mesmo tempo em que o urbanismo como disciplina se constituía a partir da problematização da cidade, também se forjavam as disciplinas da economia, da sociologia e da ciência política.
}

${ }^{28}$ Segundo Bardet (1990, pp. 23-24), o termo "urbanisme" foi cunhado no Congresso de Londres, em 1910, onde se encontraram os pioneiros do urbanismo: o alemão Städtebau, Patrick Geddes, Louis Bonnier, Thomas Adam, Eugène Hénard, Ebenezer Howard, Raymond Unwin, Daniel Burnham, entre outros.

29 O uso do termo "urbanisme", utilizado pelos franceses, gerou polêmica entre um grupo de arquitetos que incluía Hannes Meyer, Giedion, Lurçat e Le Corbusier, durante o I CIAM Congresso Internacional de Arquitetura Moderna, realizado em 1928, o que explicita a dificuldade em se nomear a ciência ou arte urbana. Conforme Eric Mumford (2000, p. 25), o alemão Häring considerou o termo "urbanisme" incompreensível para o público em geral, mas Le Corbusier e Lurçat insistiram que a palavra fosse mantida no texto em francês. No texto em alemão constou "City and Regional Planning".

${ }^{30}$ Colins e Calabi apontam que Der Städtebau é o nome da primeira revista que se ocupa exclusivamente da disciplina do urbanismo. Fundada em janeiro de 1904 por Camillo Sitte e 
espanhola por "urbanismo", na Itália por "urbanismo" (que em francês corresponde a "urbanisation"), nos Estados Unidos "city planning" e na Inglaterra por "town and country planning". Desta forma,

O campo do urbanismo pode ser abordado sob muitos aspectos diferentes: a descrição das realizações, a crítica das práticas correntes com sugestões de reformas políticas ou administrativas e até a invenção de sociedades perfeitas habitando em cidades ideais, como faziam os utopistas do século XIX. (LACAZE, 1993, p. 7).

Como ciência, o urbanismo pretende descobrir a verdade das condições econômicas, sociais e físicas da cidade. Como arte, procura um comprometimento, seja econômico ou social, no estabelecimento de vias de comunicação, uso do solo, construção e das demais estruturas. (CALABI, 2012, p. XXI).

Para Claval, (2011, p. 3), "les hommes doivent comprendre le milieu dans lequel ils sont installés pour l'exploiter et l'aménager", revelando a curiosidade do homem em investigar o meio em que vive e colocando este fato como uma premissa para posterior organização do território.

Sobre o emprego da palavra "urbanisme" pelos franceses, Piccinato explica que o termo apareceu na França somente em 1910. Anteriormente a isso, até 1900, falava-se em "Art Urbain" e "Art Public", e, nos Estados Unidos, Peets expõe que até o início dos anos 1920 ainda se falava em "Civic Art", descrevendo a cidade como um trabalho de arte. Já no final da mesma década os norte-americanos teriam passado a usar o termo "City Planning", cujo significado não se alterou, predominando a ideia do urbanismo como arte de fazer cidade, portanto, uma obra de manifestação artística.

Sobre a criação do termo Urbanisme, difundido pelos franceses, Alfred Agache reivindica a autoria para si, expondo que a terminologia foi cunhada por ele em 1912, quando fundou a Sociedade Francesa dos Urbanistas, tecendo considerações sobre as dificuldades de classificação da ciência da cidade e da afirmação de um termo para ela.

Este vocábulo urbanismo, do qual fui o padrinho, em 1912, quando fundei a Sociedade Francesa dos Urbanistas, foi, durante algum tempo, como um barbarismo; posteriormente, porém, tendo sido adotado, adquiriu "foros de cidade". Em todo o caso, é agora universalmente empregado, sendo mais

Theodor Goecke e editada em Viena e Berlim, circulou pela Alemanha até 1942. Esta revista orienta a nomenclatura da nova disciplina na Alemanha. 
expressivo do que o vocábulo alemão Städtebau e o inglês Town-planning, por serem estes últimos mais aplicáveis às construções. (AGACHE, 1930).

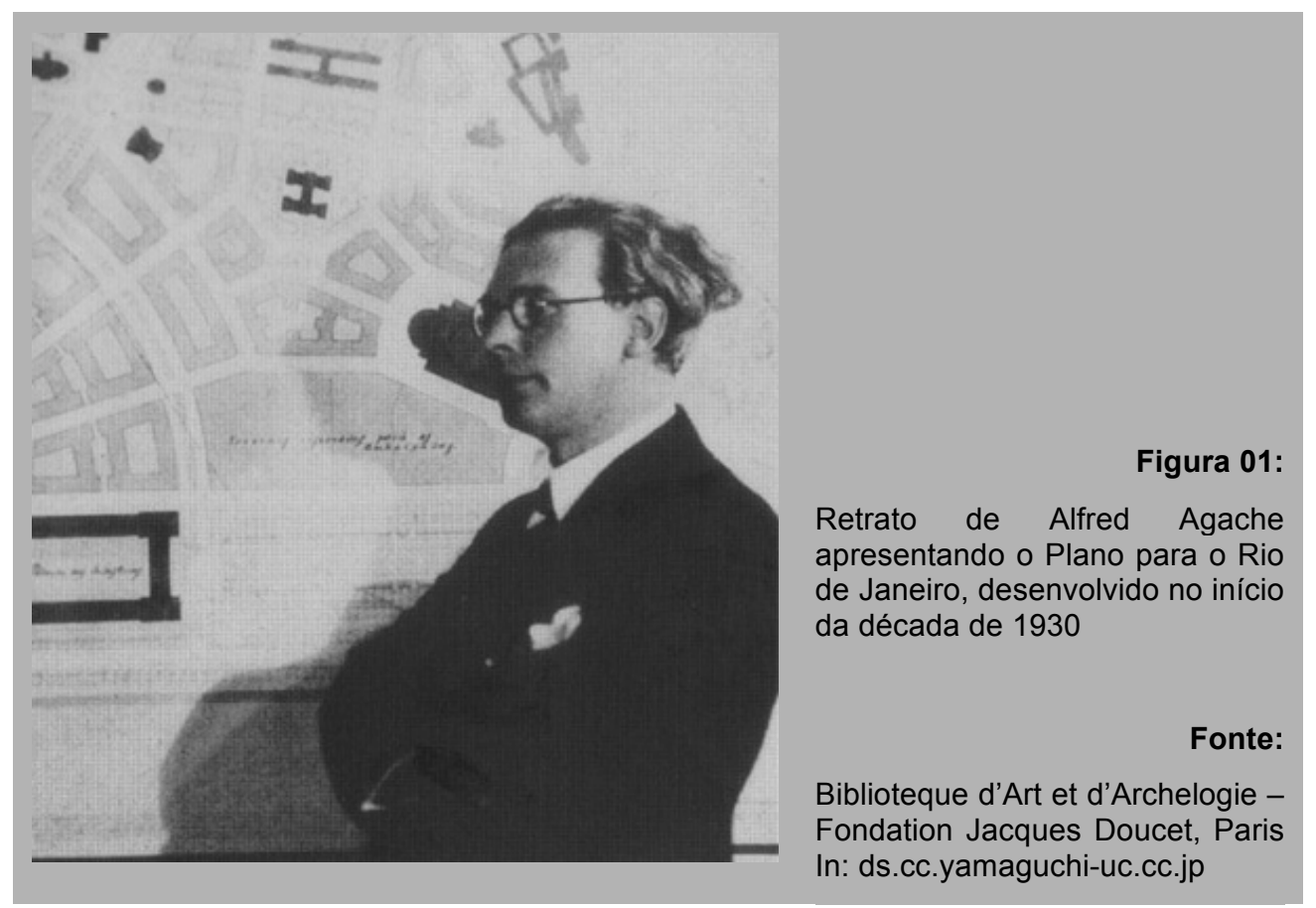

O urbanista francês Gaston Bardet (1990, p. 8) expõe que o nascedouro do urbanismo como disciplina está atrelado aos conhecimentos revelados por novas disciplinas - como a geopolítica e a estatística ${ }^{31}$ - que surgiram em decorrência da eclosão de novos problemas e a fim de disciplinar as massas populares, "que traziam problemas em grandes números devido a sua concentração em certos pontos do espaço". Assim, esta nova ciência - urbanisme - se preocuparia em organizar as massas sobre o solo urbano. Ainda segundo Bardet, "por volta de 1910, ela foi batizada na França de Urbanismo, o que quer dizer, etimologicamente, ciência do planejamento das cidades"32.

\footnotetext{
${ }^{31}$ Ebenstein, ao escrever sobre os métodos da ciência social e da filosofia, aponta que a estatística nasce na Itália em 1570, cujo papel seria de descrever o Estado, o que, para o autor, a tornaria precursora da ciência política. EBENSTEIN, William. "Ismos políticos contemporâneos: comunismo, fascismo, capitalismo, socialismo”. Caracas: Ariel, 1961

32 Sobre a terminologia urbanisme empregada pelos franceses e a definição sobre as atribuições da mesma, Bardet (1990, p. 8) ainda expõe que "no início, seus padrinhos não tiveram uma clara visão de sua missão territorial".
} 


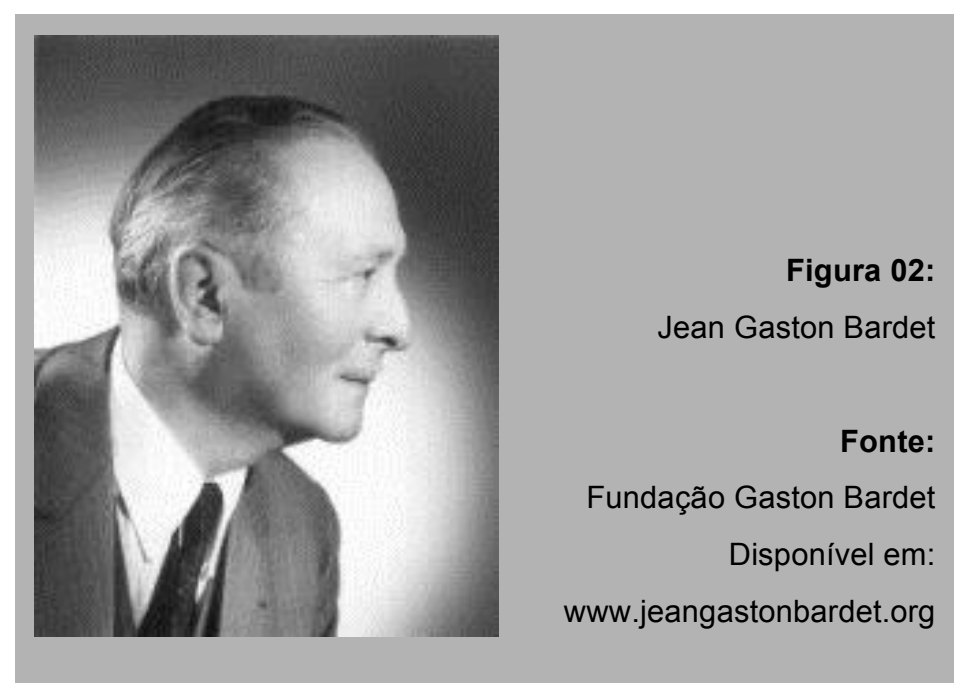

O arquiteto Léon Jaussely reconheceu, em 1920, a contribuição dos geógrafos na construção da ciência da cidade, afirmando que "les géographes sont les pères de cette Science" ${ }^{33}$ (apud TUCOULET, in CLAVAL, 2001, p. 98).

Estudamos neste capítulo a formação do quadro do urbanismo francês, a fim de desvendarmos as fontes que permearam e contribuíram com o ideário lebretiano. Sobre isto, Lavedan (1926, p. 1) diz que "o termo francês 'urbanisme' é o mais adequado e compreensivo, pois define o estudo geral das condições e das manifestações da existência e do desenvolvimento das cidades". E mais: "o termo se reporta a um exemplo de disciplinas variáveis que são solidárias entre elas: como história, geografia, sociologia, economia, direito e artes" (ibid., ibidem). Steinmann (1979, p. 25), por sua vez, define o termo francês "urbanisme" como "organização das funções da vida coletiva; entende-se tanto sobre aglomerações urbanas, quanto no campo". Também se pode apontar que "a urbanização não pode ser condicionada pelas pretensões de um esteticismo préexistente", destacando-se "que a ruptura com o passado, marcou o Movimento Moderno, manifestando-se no âmbito urbanístico enquanto desprezo pela cidade existente" (ANDRADE, 1992, p. 57).

\footnotetext{
33 Claval (2011, pp. 52-67) aponta para um quadro de formação da disciplina da geografia, vinculando a mesma como uma ciência humana, responsável pela compreensão da "topografia social" e dos "elementos de composição da paisagem", citando como pioneiros nesta concepção os geógrafos alemães Alexandre de Humboldt e Carl Ritter e atribui a Friedrich Ratzel o nascimento da geografia humana. Embora o autor aponte que "la conception que Ratzel se fait de la géograhie doit beaucoup à Humboldt et Ritter, qu'il a attentivement étudiés, mais elle est structurée par une vision darwinienne.", numa perspectiva "evolucionista", Claval atribui a Ratzel o fato de ter percebido "l'idée que le mouvement est une des característiques centrales du monde vivant, de l'homme en particulier, ce qui le conduit égalment à s'attacher aux faits de circulation, ou si l'on veut, aux rapport horizonatux que les sociétés développendt d'un point de la Terre à l'autre." Quanto à difusão da disciplina na França, a mesma coube a Vidal de La Blache.
} 
Para Lavedan, embora com a mesma finalidade, os diferentes termos empregados pelas escolas francesas, inglesas e alemãs não podem ser considerados sinônimos, pois "town-planning" ou "town and country planning" na Inglaterra e o alemão "städtebau" não integram as disciplinas solidárias entre si, tratando diretamente de ordenamento territorial e medidas de planejamento que se integram com a economia e a geografia, mas não levam em conta a mesma proporção que, para os franceses, tomam os estudos da sociologia, história e das artes ${ }^{34}$.

A nosso ver, existem nítidas diferenças entre ingleses, alemães e norte-americanos com relação aos franceses sobre as tentativas de construir uma ciência urbana. No caso do primeiro grupo, a ciência urbana está fortemente ligada à questão de uma técnica urbanística, que consiste em desdobramentos práticos, elaborando estudos que resultam em planos de intervenção ou melhoramentos. Já no segundo grupo, a ciência urbana vincula-se mais à teorização e emprego da história, sociologia, economia e geografia, resultando na elaboração de estudos, diagnósticos e apontamentos precisos sobre a cidade e os modos de vida de seus habitantes.

Assim, o que nos parece é que, enquanto os urbanistas franceses e os pesquisadores da cidade mais adeptos ao termo "urbanisme" conseguem enxergar a importância da cidade na história e levam em consideração os desdobramentos vividos em diferentes períodos e fases, os pesquisadores ingleses, alemães e norte-americanos ligam-se mais facilmente à ciência do ordenamento, aliando a ideia de cidade a um lugar do capital e reflexo do seu modo de produção, buscando assim amenizar os problemas originários em decorrência desta lógica organizativa, na busca de maior qualidade de vida para os habitantes das cidades, como apontamos na primeira parte deste capítulo. $\mathrm{Na}$ Declaração de La Saraz, extraída do I CIAM, em 1928, o termo foi assim definido:

Urbanismo é a organização das funções da vida coletiva; estende-se tanto sobre aglomerações urbanas, quanto no campo... A urbanização não pode ser condicionada pelas pretensões de um esteticismo pré-existente: sua essência é de ordem funcional. (MUMFORD, 2000, p. 25).

L'urbanisme est aussi un art par où se traduis en ten formules d'applications particulières les lois ou les règles établies. La généralité de l'urbanisme-science, son déterminisme latente, sont corrigés par tout ce que l'urbanisme-art peut impliquer de fantaisie, d'imprévu, d'individuel, Le savant et l'artiste peuvent se recommander de l'urbanisme; le premier y trouvera de quoi corriger une spirit trop

\footnotetext{
34 Sobre esta afirmação de Pierre Lavedan, é importante destacar que o autor é um estudioso francês, sendo perceptível que o mesmo traz consigo as características da tradição historiográfica de seu país.
} 
doctrinal et des formules générales trop abstraites et trop simplistes pour cadrer tous jours avec la matière vivant; le second y trouvera de quoi discipliner et asser vir heureusement à des fins sociales la beauté qu'ils ai tré aliser. L'urbanismeré unit deux pôles antithétiques de l'activité humaine. (LACROIX, 1932, p. 3). ${ }^{35}$

Sobre esta diferenciação entre urbanistas franceses e os técnicos dos demais países, é importante dizer que na França emprega-se, para se tratar do planejamento das cidades, o termo "aménagement du territoire" para discriminar a atividade de ordenamento territorial. Assim, o ordenamento territorial, que a nosso ver teria maior vínculo com a arte urbana, não é inexistente entre os urbanistas franceses, sendo mencionado inclusive por Bardet e pelo próprio Lebret ${ }^{36}$.

Porém, conforme exposto por Lavedan, a terminologia cunhada pelos franceses para distinguir a ciência da cidade, "urbanisme", nos possibilita mais uma vez vincular as ações empreendidas pelo padre dominicano no Centre d'Économie et Humanisme, para compreensão do território e das condições de vida dos habitantes, a um trabalho dentro do campo disciplinar do urbanismo, pois é preciso reconhecer que a cidade como lócus da prática do urbanismo não é uma paisagem estática e muito menos de calculabilidade.

Uma cidade não é um agrupamento de ruas e casas, essas são apenas carapaças, as conchas, de uma sociedade de pessoas. Uma cidade é uma obra de arte para a qual cooperaram gerações de habitantes, acomodando-se mais, ou menos, àquilo que existia antes delas. Justamente porque está em perpétua transformação, sob o efeito da sucessão infinitamente cambiante dos seres que a habitam, a fazem e a refazem, a cidade não se sujeita de maneira alguma a seu plano, a um esquema gráfico, nem mesmo ao conjunto dos vazios e cheios, não passam de manifestações exteriores da existência de um ser coletivo no qual a vida é entretecida pela substituição das gerações umas pelas outras. $\mathrm{O}$ que importa, antes de mais nada, é o conhecimento desse ser coletivo. (BARDET, ibid., p. 10).

\footnotetext{
${ }^{35} \mathrm{O}$ urbanismo é uma arte em que se traduzem leis ou regras de aplicações específicas e fórmulas estéticas. A generalidade do planejamento como ciência, o seu determinismo latente, são corrigidos pelo planejamento, pois - arte pode envolver fantasia, o indivíduo tem reações inesperadas, já o cientista pode recomendar o planejamento; o primeiro vai encontrar o espírito correto também doutrinal e fórmulas exageradamente abstratas e simplistas para sempre se encaixar com o espaço construído; o segundo vai encontrar algo para escravizar a disciplina e, felizmente, para alcançar a beleza social. Assim, o Urbanismo reúne dois polos antitéticos da atividade humana, o da arte e o da técnica. (Livre Tradução do autor).

${ }^{36}$ Numa exposição realizada em 1952, Lebret explica aos participantes que "Em aménagement, le problème de la population est un problème central. Cependant la notion statistique des population optima est dangerouse et don't être remplacée par la notion de rythme optimum d'accroisement." (LEBRET, 1952, documento consultado em Pasta AN45 AS48). Assim, Lebret expõe o conceito do que para Économie et Humanisme consistia o aménagement du territoire, observando-se a integração com a natureza e o respeito às condições físico territoriais "la répartition spatiale de la population doit être orientée en fonction des ressources naturelles."
} 
As exposições de Lavedan, Le Corbusier e Bardet, sobre o que seria o urbanismo, inserem a atuação da disciplina num campo de investigação sobre a cidade, o que nos permite incluir as ações de Lebret e dos participantes, tanto do Économie et Humanisme francês, quanto da SAGMACS no Brasil, dentro do campo disciplinar do urbanismo. É importante apontar que o grupo se apropria muito mais da terminologia "aménagement du territoire" para expor sobre seus procedimentos metodológicos e visão do mundo urbano, do que propriamente do termo "urbanisme", pois o termo aménagement se faz muito mais presente no ideário lebretiano, conforme pode-se constatar nas publicações da Revue Économie et Humanisme, nas exposições feitas por Lebret nas Semanas Sociais e nos trabalhos empreendidos pelos organismos vinculados ao grupo.

Assim, se podemos inserir as ações empreendidas por Lebret e os membros vinculados ao Économie et Humanisme no campo do urbanismo, pois a disciplina estaria vinculada também às matrizes de interpretação sociológica, econômica, da história e dos estudos da geografia, que permitiam maior aproximação com os aspectos físico-territoriais, poucos são os trabalhos vinculados ao aménagement du territoire, se considerarmos que estes deveriam resultar em uma práxis sobre a cidade, ou ainda nos apropriando da definição de arte urbana. Para melhor elucidarmos sobre o exposto e a questão levantada, na continuidade deste capítulo abordaremos sobre os métodos do urbanismo apontando para sua vinculação com o ideário lebretiano.

É importante dizer que sobre os métodos do urbanismo pudemos verificar que o emprego da própria terminologia - urbanismo - rende diferentes abordagens e desdobramentos de ações, ao ponto do próprio grupo vinculado a Lebret na França e no Brasil utilizarem aménagement du territoire, terminologia da qual outros autores franceses, sobretudo os ligados à geografia, preferiam se apropriar para ilustrar as ações sobre a organização territorial e o planejamento urbano e regional.

Assim, há que se expor que o emprego do termo planejamento urbano e regional para definição de ações de ordenamento e planejamento da ocupação do território não tem sua origem diretamente ligada à disciplina do urbanismo. Como disciplina, o planejamento urbano e regional foi forjado mais tarde, já no segundo quarto do século XX, fazendo parte do grupo de disciplinas vinculadas à "ciência urbana", porém, incorporando elementos da economia urbana, da ecologia e da visão regionalista, aspectos que se constituíram e se firmaram ao longo da segunda metade do século XIX, num reconhecimento de que a cidade seria um organismo em constante crescimento, 0 que contrastaria com as técnicas empregadas por urbanistas que pensaram a cidade 
barroca e do renascimento através de planos engessados que não levavam em consideração a pujança e possíveis metamorfoses da vida urbana. Para Cohen,

O velho procedimento de traçar ruas e parcelar o solo em loteamentos - dando prioridade ao projeto físico, sem que a destinação ou a densidade de ocupação dos lotes fossem definidas - foi substituído por uma abordagem complexa com regulamentação e pelo planejamento feito com base em dados estatísticos, sob supervisão pública dos estágios especializados de concepção e construção. (2013, p. 71).

Buscando reconhecer esta metamorfose da vida urbana, Marcel Poëte apontava, no início do século $X X$, que o urbanismo deveria ser uma ciência de observação. $O$ autor, considerado um dos pioneiros do urbanismo francês, apontava que a cidade como organismo vivo era dona de uma vida própria, que caminharia independentemente dos planos (ibid., 1929).

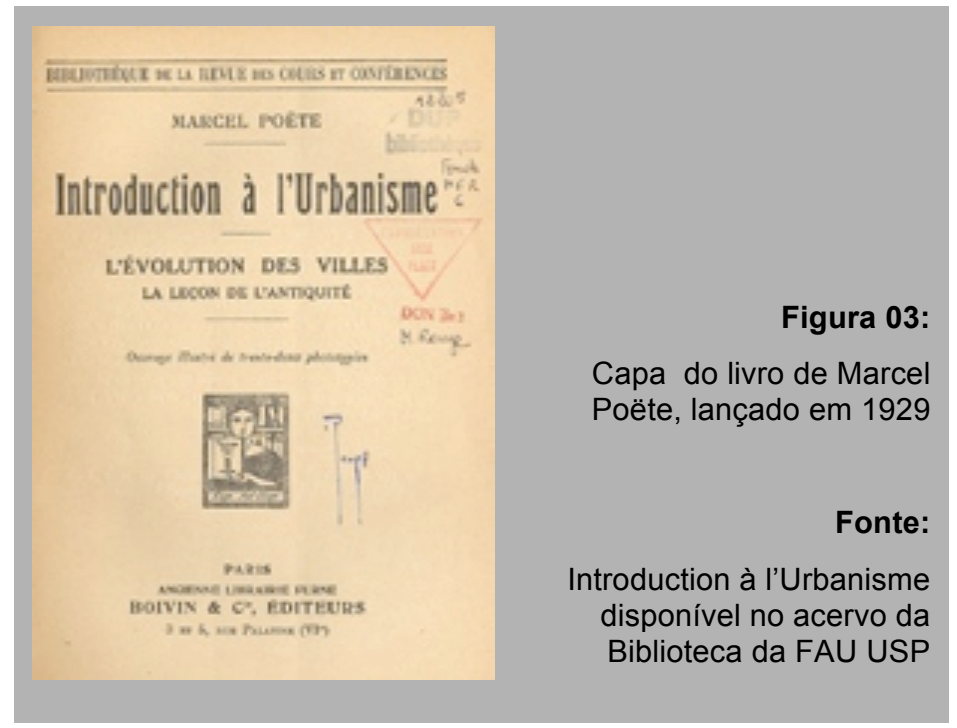

Conforme exposto neste item do primeiro capítulo, ao conceituar e definir melhor o emprego da palavra urbanismo, buscamos compreender se as ações empreendidas pelo Pe. Lebret, através do Économie et Humanisme e sobretudo da SAGMACS, poderiam se situar no campo do planejamento urbano e regional e na disciplina da urbanística. Embora o termo empregado pelo religioso francês em suas exposições e textos difundidos entre os adeptos do grupo fosse aménagement du territoire, podemos também situar suas ações dentro do "urbanisme", pois entre os franceses o emprego do 
termo para definir a "ciência da cidade" é bastante comum e não consiste somente em resultados práticos rascunhados na prancheta de desenhistas, técnicos e engenheiros, mas vincula-se também à interpretação da realidade social e da pesquisa sobre a cidade - ações presentes nos trabalhos empreendidos pelo grupo de Lebret.

\subsection{Os métodos do urbanismo e o quadro de atribuições no meio técnico profissional}

Como podemos perceber, o urbanismo como disciplina é composto de muitos aspectos e matérias para estudos e viabilização de planos e propostas. Porém, o que pudemos verificar, embora este aspecto não seja traduzido pela historiografia consagrada sobre o urbanismo, foi que, ao longo do século XIX tivemos uma melhor organização da urbanística moderna, reunindo diferentes saberes e possibilitando assim maneiras para intervenções físicas no espaço da cidade. A "Teoria Geral da Urbanização", escrita pelo espanhol Ildefonso Cerdá, em $1867^{37}$, forjava o "surgimento e consolidação do urbanismo como um campo disciplinar autônomo [...] entendido como fruto das inúmeras tentativas de se dar resposta à crise da cidade moderna" (ANDRADE, 1992, p. 36).

É fato que esta tentativa de constituir uma "ciência urbana" ganhou maior importância no período moderno, após a revolução industrial, devido a alguns estudiosos atrelarem a existência das cidades ao funcionamento da indústria, como um fator de desdobramento ou reflexo do modo de produção capitalista. Com as mudanças ocorridas no modelo econômico de produção e a ascensão de uma nova classe social, que impunha sua hegemonia, as transformações urbanísticas ocorridas nas cidades visavam impor a imagem de uma nova era e deixar claro o poder econômico burguês - os donos dos meios sociais de produção econômica e fiadores deste novo ideário urbano - frente às demais classes sociais, que disputavam o espaço na cidade grande e moderna. Assim, a imagem e o uso da cidade se relacionavam com a cultura dominante, de forma que na virada do século XIX para o XX assistimos a inúmeras intervenções em antigas capitais.

\footnotetext{
${ }^{37}$ Além de Cerdá é importante também expor que em 1880 o arquiteto alemão J. Stübben publicou a primeira edição do livro "Städtebau", sobre construção de cidades, um dos primeiros tratados de planejamento das cidades. Camillo Sitte publicou em 1889 o "Art de bâtir les villes". Enquanto institucionalização da prática do urbanismo a Suécia instituiu lei em 1874 obrigando que toda cidade do país deveria ter seu plano de extensão.
} 
Desta forma, podemos interpretar que, para se entender a cidade que emergia, seria preciso também conhecer os interesses da sua classe dominante.

Mesmo diante das transformações urbanas nas cidades, na virada do século XIX para o $X X$, empreendidas pela classe dominante, ainda é possível se perceber, nas primeiras décadas do século $\mathrm{XX}$, a forte herança das Belas Artes na formação dos urbanistas, que davam maior atenção ao desenho do que à análise do espaço urbano, dos atores presentes, ao programa de transformação concebido pela burguesia e muito menos à metodologia. De forma que, para Piccinato,

Por ser o urbanista filho da arquitetura, o que explica a ênfase no desenho e, portanto, escasso interesse nas motivações econômicas e sociais. Este fará do plano 'desenhado' um protagonista do desenvolvimento urbano. Se a cidade é antes de tudo um patrimônio de área edificável, um plano urbanístico não pode ser mais que um instrumento apto a administrar tal patrimônio e de adicionar valor. (1977, pp. 18-19).

Neste sentido, Bardet expõe que seria "necessário não confundir as grandes realizações da Arte Urbana, que resolveu magistralmente problemas que não eram nem da mesma escala, nem da mesma complexidade, nem da mesma substância que os nossos, com as soluções do Urbanismo." E prossegue apontando que "devemos abster-nos de apresentar o urbanismo [...] estudando apenas as formas geométricas ou a cobertura arquitetônica que a Arte Urbana sucessivamente empregou". (1990, p. 9).

Assim, mais do que transformações físicas no espaço da cidade e alterações no modo de vida de seus habitantes, estas intervenções renderam o incremento do debate acerca dos métodos do urbanismo e as possibilidades de implementação desta ciência no meio urbano. Podemos assim observar, nas primeiras décadas do século $X X$, a criação de uma série de associações e institutos voltados a discutir o urbanismo e os problemas das cidades.

Na França, do início do século XX, podemos constatar a existência de algumas dessas associações, que reuniam em torno de si profissionais e técnicos que atuavam em assuntos que diziam respeito à questão urbana. Destacamos entre elas a Association Générale des Higyénistes et des Téchiniciens Municipaux, a Société Française d'Urbanistes, o Conselho Municipal de Paris, a Section d'Hygiène Urbaine et Rurale do Musée Social, entre outras. Em 1913, a Société Française d'Urbanistes renunciou à menção que até então se fazia aos arquitetos e retirou do seu nome o título de SFAU, passando a ser SFU. Em 1919 foi fundado o Institut d'Urbanisme de l'Université de Paris e em 1922 a Revue Urbanisme. Já em 1928 ocorreu o I Congresso Internacional de 
Arquitetura Moderna - CIAM, que mostrava a tentativa dos arquitetos modernos de se reaproximarem das questões urbanas e se reafirmarem também como urbanistas.

Estas associações visavam, além de consolidar a disciplina que seria capaz de melhorar a cidade, também garantir as atribuições profissionais e reservar espaços para os profissionais que atuavam no campo disciplinar do urbanismo. Segundo Gaudin,

O mundo profissional, que progressivamente se estruturou quanto ao estudo e à implantação dos planos de ordenamento, extensão e embelezamento, parece à primeira vista feito de simples justaposições de competências prévias, as do geômetra para a qualidade dos documentos cadastrais, as do arquiteto na arte sanitarista e na composição do projeto, as do engenheiro para as redes de infraestrutura e para a higiene pública. Justaposições, mas também conflitos de intervenção e de interesses. (2014, p. 185).

Nos anos 1880, os franceses assistiram às intervenções do Barão Haussmann sobre a antiga Paris, que rendeu à capital francesa o título de capital do século XIX, e que desde os anos 1910 adotou o urbanisme como termo para definir a ciência da cidade. A partir daí "a concorrência de fato se mostra aguda no mercado do urbanismo e vai rapidamente alimentar os conflitos entre diferentes profissões." (GAUDIN, 1926, p. 185), pois, como vimos em Lavedan, o urbanismo para os franceses se constituiria para além da arte urbana e se afirmaria de forma generalista, dialogando também com as disciplinas da geografia, sociologia, direito e economia, além da engenharia e da arquitetura. Mas,

Ao contrário de outras matérias, o urbanismo não se deixa encerrar com facilidade numa lógica científica ou profissional interna cujo conhecimento poderia ser transmitido por um ensino de tipo universitário, que bastaria para justificar o fundamento de uma proposta de organização. (LACAZE, ibid., p. 8).

Sendo o urbanismo disseminado no meio técnico francês como uma ciência generalista, capaz de dialogar e unir as diferentes disciplinas e de "reunir para uma mesma cruzada todos que, sem distinção de formação, de profissão ou de opinião, desejavam difundir as ideias de urbanismo e de progresso social" (GAUDIN, op. cit., p. 186), era de se esperar que o movimento causasse dificuldades de relacionar os diferentes profissionais, por fazer a defesa de tantos interesses distintos, de diferentes formações técnicas e acadêmicas presentes nos grupos disciplinares dos quais eram oriundos. Esta situação causou uma disputa pelo reconhecimento político do urbanismo e pelo desenvolvimento de métodos novos de planificação para as cidades. 
Em meio a esta disputa pela delimitação do campo disciplinar e organização dos métodos, o urbanista francês Alfred Agache afirmou, em 1916, que o urbanismo seria ciência e arte, o que nos remete às ideias difundidas por Cerdá na Espanha, quarenta anos antes. Para Agache, o urbanismo "como ciência, persegue a aplicação dos conhecimentos sociais de hoje à economia das cidades do amanhã." (2014, p. 64). O autor também remeterá à ideia do urbanista como o regente da cidade, delegando a ele o papel de coordenar as ações sobre o território, desde a interpretação da realidade econômica e social, a elaboração de um diagnóstico e, por fim, a proposta de intervenção e melhoria do espaço urbano. Segundo Agache $^{38}$,

\begin{abstract}
O urbanismo - ou ciência das cidades - visa a pesquisa e a organização de todos os elementos que entram na composição de uma aglomeração urbana. Supõe análise e síntese, ou seja, de um lado, pesquisas monográficas, a escolha e a classificação dos elementos e dos grupos de elementos que constituem a cidade; de outro lado, a formação de uma doutrina reunindo as leis que a organização e mesmo a experiência fizeram descobrir e que permitem proceder a agenciamentos urbanos respondendo às necessidades mais modernas e antecipando mesmo em relação ao futuro próximo. (ibid., p. 64).
\end{abstract}

Contudo, o urbanismo é também uma arte; comporta uma parte de intuição, uma parte de invenção. Se assim não fosse, seria possível planejar as cidades usando fórmulas já estabelecidas para todo o sempre. [...] Os conselhos ou as sugestões que sanitaristas, economistas, engenheiros e arquitetos fornecem devem ser, de certo modo, transpostos pelo urbanista. É preciso que sejam traduzidos em beleza; (op. Cit., p. 65).

Para Bruant (2001), Agache define o urbanismo como uma ciência da sociologia aplicada, o que também é apontado por Gaudin (2014, p. 47) ao expor a afirmação do urbanista francês de que o urbanismo "persegue a aplicação dos conhecimentos sociais de hoje à economia das cidades do amanhã". Esta colocação de Agache, de que o urbanismo seria sociologia aplicada, nos remete a outro personagem francês que também atuou no campo das pesquisas sociais, no século XIX, o economista PierreFrederic Le Play ${ }^{39}$, que no início do século $X X$ tinha grande influência na sociologia

\footnotetext{
38 O texto original foi apresentado por Alfred Agache na Conferência para a exposição La Cité Reconstituée, em junho de 1916.

${ }^{39}$ O economista e estatístico Frédéric Le Play (1805-1882) teve grande influência na França no desenvolvimento da sociologia aplicada devido às metodologias que propôs para estudar determinados fenômenos sociais, como a família. Seus estudos influenciaram também o campo disciplinar do urbanismo e contribuíram com a formação de jovens franceses. Segundo Savoye, o pensamento leplaysiano se divide em três períodos: sobre as classes trabalhadoras, desenvolvido entre 1881 e 1888; as pesquisas sobre habitação (1890-1904); e a organização do espaço urbano (1905-1914).
} 
francesa. Para Savoye (2001), os discípulos de Le Play se dedicaram a difundir o pensamento leplaysiano sobre a discussão da organização do espaço urbano junto ao meio intelectual francês. O último período de difusão do pensamento leplaysiano teria ocorrido no início do século XX, entre os anos de 1905 e 1914, período em que se cunhava o termo "urbanisme" e se forjava as atribuições desta disciplina na França.

Este quadro sobre a classificação e enquadramento do que seria o urbanismo só confirma as palavras de Gaudin, citadas acima, sobre a acirrada concorrência e os conflitos entre as profissões. Gaudin também afirma que "os conflitos profissionais ligados às concorrências de mercados são os mais evidentes". Mas "as divergências são mais profundas talvez pela diferença de expectativas dos profissionais quanto à encomenda do urbanismo [...] que eles fazem das prioridades às quais deveria responder o ordenamento das cidades." (ibid., 187).

A amplitude desses conflitos e a multiplicidade das divergências não bastam, porém, para esconder a existência de uma forte comunidade de convicções em muitos daqueles que, na primeira metade do século $X X$, se engajam naquilo que, a seu ver, é um verdadeiro combate: a racionalização do crescimento urbano e da habitação operária por meio de planos previsionais. (ibid., ibidem, 191).

Partindo de uma concepção do urbanismo como simples prática que combina as contribuições de ciências, técnicas e talentos variados, a análise metodológica dos sistemas de decisão envolvidos permite precisar o campo de competência profissional do domínio, confirmar a existência de ferramentas intelectuais específicas e estudar as regras do uso correto das várias ferramentas. (LACAZE, ibid., p. 21).

Buscando melhor delimitação do campo profissional dentro do urbanismo, Léon Jaussely recupera, em 1919, o papel do dossiê das cidades, fazendo uma menção aos ingleses que chamavam tal ferramenta de Civic Development Survey, "que se refere não somente à distribuição cadastral da localidade, mas também a todas as circunstâncias e condições provenientes" (2014, p. 70) da circulação, do comércio, indústria e agricultura, da recreação e dos espaços públicos, higiene, instrução e administração da cidade. Pois, segundo Paul Claval, as cidades são fundamentalmente uma organização destinada a promover a interação social.

Assim, sendo a cidade um objeto da interdisciplinaridade, a "ciência da cidade" não poderia se constituir de forma diferente, sendo então o urbanismo um trabalho multidisciplinar, o que para Lacaze seria "uma condição essencial de um tratamento profissional dos problemas urbanos" (ibid., p. 120). Neste sentido, o autor aponta ainda 
que "o trabalho em equipe tem por objetivo permitir a elaboração de decisões num sistema complexo" (CLAVAL, ibid., p. 121), e, apontando para a concorrência entre os diferentes profissionais, afirma que "nenhum membro da equipe pode, portanto, contentar-se com encerrar-se nos métodos de otimização próprios do sistema de valores do qual é representante" (ibid., ibidem) ${ }^{40}$. Para o autor, seriam capazes de atuar dentro do campo do urbanismo os profissionais arquitetos e urbanistas, os engenheiros, economistas, geógrafos, sociólogos e ainda os administradores ou advogados.

Esse modo de trabalho supõe, portanto, um domínio real de seu próprio campo disciplinar, assim como a capacidade de encontrar soluções não estritamente ótimas com relação a uma gama de critérios única, mas mesmo assim aceitáveis desse ponto de vista porque permitem ir além na busca do ótimo baseado em múltiplos critérios. (ibid., p. 122).

Para o autor, na prática "o arquiteto urbanista seria antes de qualquer outro o responsável pela elaboração das propostas espaciais de organização." (ibid., ibidem), e mais, "sua contribuição é essencial desde a fase dos primeiros estudos para que traga sua competência e sua sensibilidade à análise das lógicas formais da paisagem natural ou urbanizada preexistente". O engenheiro traria suas "competências particulares em matéria de redes de infraestrutura e de transporte", cabendo a ele propor soluções e cuidar da execução técnica das propostas.

Ao economista caberia "estudar, antes de mais nada, os fatores de desenvolvimento e as dificuldades resultantes dos dados locais específicos." Já na fase das propostas estes profissionais poderiam elaborar uma "programação de realizações em função da executabilidade dos diferentes projetos." (ibid., p. 123). Ainda segundo o mesmo autor, "o geógrafo dispõe de métodos indispensáveis para conduzir num espirito de síntese as inúmeras investigações preliminares imprescindíveis."

\footnotetext{
${ }^{40}$ Para se verificar a ressonância e influência da visão dos franceses no campo do urbanismo sobre os urbanistas brasileiros, podemos apontar o curso ministrado por Antonio Bezerra Baltar, em 1957, na Escola de Belas Artes da Universidade da Bahia. Baltar aponta na introdução da "Conferência sobre Planejamento Urbano" que "a cena urbana que se desenrola nas cidades é observada do ponto de vista de diferentes espectadores. É objeto de estudo, por exemplo, do historiador, do etnógrafo, do sociólogo, do jurista, do geógrafo, do ecologista, do economista e financista, do demógrafo, do higienista, do arquiteto e do engenheiro, do urbanista, entre outros espectadores, cada um apreciando o espetáculo segundo o seu prisma próprio. [...] Assim, o arquiteto, o engenheiro o urbanista, os artistas, entre eles os literatos, encontram na cena urbana, observada nas perspectivas microscópica e macroscópica, problemas a estudar e a resolver tanto pelo prisma da especulação como pela aplicação prática" (BALTAR, 1957, pp. 13-14).
} 
O administrador ou jurista deve também ser associado muito cedo às reflexões. É importante de fato preparar o lançamento dos processos, bastante longos e complexos, que condicionam a passagem às realizações. Esses membros da equipe [...] têm, por suas funções permanentes junto aos poderes institucionais, uma boa capacidade de análise da situação política local e de intermediação para facilitar as inúmeras negociações sempre necessárias. (ibid., ibidem).

E por fim, Lacaze enumera as tarefas que caberiam aos sociólogos da equipe, que, para ele, desempenham dois papéis: a responsabilidade pela aplicação correta do princípio geral de controle dos métodos das ciências humanas e também a elaboração dos estudos preliminares "colocando em evidência os desafios e as estratégias particulares aos diversos grupos de habitantes envolvidos, assim como a organização das redes de poder e de influência com as quais vai ser necessário harmonizar-se". (ibid., ibidem).

Sobre as atribuições profissionais dos urbanistas, Lacaze observa que dentro de uma equipe interdisciplinar não se estabelecem a precedência de uma formação sobre a outra e reconhece a necessidade e capacidade que um teria em fortalecer o outro sobre a visão do todo urbano. Estas observações rompem de certo modo com os apontamentos mais presentes no início do século $\mathrm{XX}$, quando os diferentes profissionais estavam em busca de garantir seu espaço dentro da disciplina do urbanismo. Ainda que seja mantida a visão generalista do urbanismo como disciplina, presente desde as teorias desenvolvidas para explicar a "ciência da cidade", Lacaze deixa claro que há espaço para as diferentes formações e defende que o urbanismo é uma atividade para equipe interdisciplinar.

Para Wirth, "o problema central do sociólogo da cidade é descobrir as formas de ação e organização social que emergem tipicamente nas fixações relativamente permanentes e compactas de grande número de indivíduos heterógenos". (1949, p. 626). Revelando que caberia aos mesmos, atrelado ao campo do urbanismo, estudar as formas de organização da sociedade e seus desdobramentos sobre o espaço da cidade. De forma que:

O urbanismo como modelo característico de vida pode ser estudado empiricamente de acordo com três perspectivas: 1) Como estrutura física compreendendo uma base de população, uma tecnologia e uma ordem ecológica; 2) como um sistema de organização social envolvendo uma estrutura social característica, uma série de instituições sociais e um padrão típico de relações sociais, e 3) como um acervo de atitudes e ideias, e uma constelação de personalidades predendo-se em formas típicas de comportamento coletivo, sujeitas a mecansimos característicos de controle social. (ibid., p. 637). 
A observação de Lacaze se aproximaria da visão de mundo urbano da qual Lebret compartilha, ao adotar como método o trabalho em equipes multidisciplinares. É importante expor que o ideário lebretiano conseguiu, desde os anos 1930, ainda no período de amadurecimento do que viria a ser o Économie et Humanisme, no cerne do engajamento de Lebret com os sindicatos de Saint-Malo, envolver diferentes disciplinas e meios profissionais em prol de um objetivo comum. Há que se dizer que para alguns autores uma das chaves que tornaria o trabalho de Lebret inovador na questão urbana seria justamente o emprego de equipes muldisciplinares.

Neste contexto, temos mais uma vez a possibilidade de atribuir a Louis-Joseph Lebret sua inserção dentro do campo disciplinar do urbanismo. Porém, se por um lado suas teorias e práticas acerca da visão do mundo urbano o colocam em meio à "ciência da cidade", a abordagem e o engajamento de diferentes profissionais para se estudar a cidade e as condições de vida da população, no contexto dos anos 1940 e 1950, em pouco ou nada revelam o ineditismo do trabalho do dominicano francês, visto que para os franceses o urbanismo já nasce (considerando o exposto por Lavedan e Bardet, de que o emprego da palavra se daria somente em 1910) multidisciplinar e generalista. Assim, pudemos constatar, através da lista de participantes das sessões promovidas por Lebret na França, em 1943 e $1944^{41}$, a formação e as profissões exercidas por alguns dos participantes. E, conforme apontaremos no capítulo seguinte desta tese, verificamos que entre os participantes há profissionais com formação de assistentes sociais, engenheiros, advogados e arquitetos que se destacam em relação aos demais, o que apontaria para o engajamento do Économie et Humanisme às equipes multidisciplinares.

Há que se esclarecer, entretanto, que não é a atuação de Lebret e dos organismos que ele criou nos anos 1940, os quais contam com equipes multidisciplinares, que a nosso ver possibilitaria inserir os trabalhos empreendidos por ele dentro do campo disciplinar do urbanismo, mas sim as experiências construídas pela própria disciplina do urbanismo, sobretudo na França, anteriormente à criação do Économie et Humanisme, em 1941. Na França, desde os anos 1910 o urbanismo já era concebido como uma ciência catalizadora de diferentes saberes, que seria capaz de engajar profissionais das ciências sociais aplicadas, como o direito, a economia, geografia, serviço social e a administração;

\footnotetext{
${ }^{41}$ Estas informações foram obtidas através da consulta a documentos na Pasta AN45 AS44, onde constam a lista com os nomes dos participantes das Semanas Sociais, promovidas pelo Économie et Humanisme para dar formação e disseminar a metodologia do movimento aos adeptos do grupo. A lista traz o nome dos participantes e sua origem, mas não a formação profissional de todos. Retomamos a discussão sobre as Semanas Sociais promovidas pelo EH no capítulo 2 desta tese.
} 
das ciências humanas como a sociologia; das artes como os arquitetos e da tecnologia como os engenheiros. Já nas décadas de 1920 e 1930,

O urbanismo, então, já se apresentava como uma ciência baseada nas estatísticas, pesquisas e diagramas, tentando encontrar soluções para as contradições sociais. As análises são explicitamente compreendidas como uma metodologia para predispor os instrumentos de conhecimento, as previsões e o controle da distribuição da população e das atividades em um território que, no seu sentido mais específico, não é mais o urbano. (CALABI, ibid., pp. 193-194).

É importante ressaltar que estamos falando sobre a formação de quadros e delimitação do campo profissional acerca dos métodos do urbanismo em desenvolvimento na França. E sobre o urbanismo francês é importante pontuar que a atividade é vista como uma disciplina a ser aprimorada dentro do aparelho do Estado, o que se evidencia ainda mais em 1919 com a Lei Cornudet ${ }^{42}$, que dava o prazo de três anos para que os municípios franceses com mais de dez mil habitantes apresentassem um Plano Diretor. Calabi ainda aponta, sobre o papel central do Estado francês na condução das decisões acerca do urbanismo das cidades, que

Na França, a característica de destaque da organização é dada pelo planejador principal, que, em todos os níveis, é o Estado (representado pelo Ministère de l'Equipement et du Logement), capacitado até para a emissão de licenças de construção. (ibid., p. 337).

Este controle estatal da atividade de planejar, exercido pelo aparelho de Estado da França, teve início muito antes dos debates empreendidos na virada do século XIX para o XX, e nas primeiras décadas do século $X X$, que culminou com a nomeação da ciência da cidade como urbanismo pelos franceses. Zuconi aponta que,

Em 1800 é fundado, na França, um departamento central de estatística sob a direta dependência do Ministro do Interior; [...] O objetivo é, antes demais nada, aquele de realizar "estatísticas setoriais" de caráter corográfico, isto é, descrições gerais do quadro econômico e demográfico, cujos índices concorrem para definir as características e anomalias. (2009, pp. 73-74).

\footnotetext{
${ }^{42}$ A lei foi nomeada em homenagem a um de seus autores. Cornudet era membro do Musée Social e de outras associações higienistas, e se ocupou das questões de ordenamento territorial através de normas e leis desde 1913, junto com Bechmann, Siegfired e Risler. Segundo Calabi (2012, p. 262), era um moderado de grande prestígio que desempenhava papel importante em relação às associações dos proprietários.
} 
Este vínculo do urbanismo ao aparelho de Estado, presente na França, antes mesmo do surgimento do vocábulo que nomeou a nova disciplina, levanta para nós a hipótese de ter se dado aí a vinculação tão forte que Lebret buscou através dos organismos que fundou, a de atuar em parceria com órgãos estatais. Tanto na França quanto no Brasil, as instituições vinculadas ao Centre d'Économie et Humanisme desenvolveram trajetórias vinculadas ao Estado no que se refere ao desenvolvimento de trabalhos dentro do quadro do urbanismo. Seria assim, este vínculo entre Estado e Économie et Humanisme, uma herança da formação francesa do quadro de atuação do urbanismo.

Porém, se este vínculo dos organismos fundados por Lebret com o Estado se deve, em parte, ao Estado francês mostrar-se como principal planejador atuante no campo da urbanística, há que se considerar que, por outro lado, a apropriação dos métodos da estatística e dos levantamentos de cidade, estabelecidos pela disciplina do urbanismo e utilizados nos trabalhos empreendidos por Économie et Humanisme, não se deu unicamente pelos franceses, sendo visível também a contribuição dos ingleses através dos Surveys, Relatórios e Diagnósticos sobre as cidades, elaborados como etapa precedente às intervenções físicas.

\subsection{O Campo e Cidade e a aplicação do Urbanismo como uma forma de desenvolvimento econômico e social}

Dentro do quadro de discussão sobre os métodos do urbanismo, podemos verificar que a ciência da cidade está intimamente ligada a uma forma de se alcançar o desenvolvimento social e, sobretudo, econômico da antiga pólis. Assim, no período de consolidação do capitalismo industrial, que coincidiu com a ascensão da cidade grande e moderna, verificamos que houve também aumento da circulação de mercadorias, buscando-se ampliar o mercado consumidor. Dessa forma, podemos verificar uma conexão entre o campo e a cidade e com isso a formação de regiões e polos de desenvolvimento econômico, abrindo campo para o que ficou conhecido como aglomerações urbanas.

Neste sentido, o urbanista francês Gaston Bardet, proponente de métodos de trabalho para o urbanismo e com atuação destacada a partir dos anos 1940 no meio técnico profissional na França, faz uma série de apontamentos sobre as formas de compreensão e formação do contexto urbano regional, levando em consideração a cidade e o campo como atividades econômicas que se complementam e, assim, jamais uma poderia excluir 
a outra. O campo dependia da cidade para suprir uma série de demandas por matéria prima para a indústria crescente, a produção de alimentos para os habitantes urbanos, os serviços artesanais, entre tantos outros produtos encontrados no meio rural. No ano de "1934, no primeiro Congresso de Urbanismo de Bordeaux, foi que começaram as interrogações sobre as modalidades de um 'urbanismo rural'” (1990, p. 113), pois, na época, "acreditava-se que fossem de mesma natureza, ainda que de escalas diferentes, as pequenas cidades, os burgos e as aldeias". (op. Cit., ibidem).

Apesar de sua preocupação com o binômio campo e cidade e seus apontamentos sobre o que se debatia na França sobre o tema, para o próprio Bardet (ibid., p. 55) foi "Patrick Geddes o primeiro a estender para a região a survey, a investigação sobre o local", o que mostra a preocupação dos ingleses também com o desenvolvimento regional e não apenas com a cidade, de forma isolada. Neste sentido, Hobsbawm aponta, retornando ao século XIX, que talvez fosse esse um dos motivos para se ampliarem as preocupações com o desenvolvimento para além da cidade, trabalhando num contexto de integração regional, expondo que a noção de região se faz presente tanto pela morfologia das antigas cidades, quanto pela necessidade das mesmas expandirem seus territórios. Para Hobsbawn:

\begin{abstract}
As antigas cidades pré-industriais de maior reputação geralmente não atraíam as novas formas de produção, e, consequentemente, a nova região industrial típica tomava em geral a forma de pequenas vilas crescendo juntas, que se transformavam em pequenas cidades, que depois se desenvolviam em grandes cidades. [...] Poucos de seus habitantes estavam a uma distância do campo superior a uma caminhada. Até a década de 1870, as grandes cidades da Alemanha industrial do oeste, tais como Colônia e Düsseldorf, alimentavam-se com os mantimentos trazidos ao mercado semanal pelos camponeses das regiões circunvizinhas. (1996, pp. 293-294).
\end{abstract}

A integração entre o campo e a cidade e a formação da noção de região ${ }^{43}$ são trabalhadas pelo historiador francês Paul Meuriot, que em 1898 defendeu tese de Doutorado cujo título era "As aglomerações urbanas na Europa contemporânea". O autor apontava que, no final do século XIX, "nossos grandes centros urbanos tomam o aspecto que se fixa de agora em diante em nosso espírito, o de aglomeração", que seria definido por ele como algo que "se estende indefinidamente, sem limites precisos, com agrupamentos demográficos em 'perpétuo vir-a-ser'”. (2014, p. 52). E apontava ainda que

\footnotetext{
43 Sobre a terminologia "região", Bardet aponta que não se sabe ao certo quem foi o autor que cunhou tal expressão, e que a mesma apareceu aproximadamente por volta de 1895. Em 1898 foi criada a União Regionalista Bretã e em 1900 a Federação Regionalista Francesa, as quais adotaram o termo região e regionalismo.
} 
"a aglomeração urbana moderna nada mais é que um dinamismo contínuo pelo crescimento indefinido de sua população, pela extensão igualmente indefinida de sua área." (ibid., p. 56).

A exposição de Meuriot na virada do século XIX para o XX traz apontamentos que pareciam fazer coro à tônica dominante no período, de que não havia limites para o crescimento das cidades. Esta simplificação sobre o crescimento das cidades no início do século XX também permitia a naturalização do fenômeno da expansão territorial de forma a se alcançarem aglomerações urbanas.

A expansão das cidades era também um problema colocado para o urbanismo no início do século $X X$, visto que, com o advento da cidade grande e moderna e o surgimento das metrópoles, "o crescimento desmesurado das cidades escapara aos esquemas mentais e operativos que até então as controlavam." (ANDRADE, 1992, p. 36).

No final da década de 1910, Henri Prost abre o debate sobre o planejamento regional para Paris, reconhecendo a necessidade de uma organização geral da região parisiense. Esta preocupação abre espaço para o debate sobre os limites para o crescimento de uma cidade, seguindo a indagação de Jaussely "Quel est il limite de l'agglomération parisienne?". Mas somente em 1939 é que demais urbanistas se apropriam do discurso em prol da realização de um plano de organização geral para uma região.

La notion de limite ville-campagne sort de cette période profondément transfromée. La ruptura avec les conceptions traditionnelles est patente et permet une nouvelle compréhension de la ville, intégrant un rapport différent à la nature et ouvrant la voie à des pratiques urbanistiques novatrices. (VERDEIL, in BERDOULAY et CLAVAL, ibid., p. 211). ${ }^{44}$

Porém, ao mesmo tempo em que a discussão encabeçada por Prost avançava sobre a discussão dos limites da cidade e a necessidade de se estabelecer um plano que levava em consideração a aglomeração parisiense, distribuindo melhor as regiões, Verdeil concluía que o plano trouxe "encassants a représentation traditionnelle, statique et

\footnotetext{
${ }^{44} \mathrm{O}$ conceito de fronteira urbano-rural neste período sofre uma transformação profunda. A ruptura com modelos de interpretação tradicionais é óbvia e há uma nova compreensão da cidade, incluindo uma relação diferente com o campo e a natureza, abrindo caminho para práticas urbanas inovadoras. (Livre Tradução do autor).
} 
normative, ces débats rendent possible de concevoir d'autres usages adaptés et compatibles avec la croissance." ${ }^{45}$ (ibid., p. 215). De forma que, para o autor,

Ils impulsent une réflexion sur l'adaptation des périmètres administratifs à la réalité de l'urbanisation, accélérant la réflexion vers la notion de région. Du même coup, la ville et la campag ne son tliées dans une même problématique d'aménagement, ouvrant de nouveaux horizons aux a urbanistes. ${ }^{46}$ (ibid., ibidem).

Apesar das mudanças na visão sobre a expansão da cidade, forjada em debates ao longo dos anos 1930, até então o que se percebe é que predominava esta visão simplista de que a dinâmica do contínuo crescimento das cidades levaria as mesmas a se tornarem uma aglomeração urbana. A preocupação quanto ao tratamento deste fenômeno e as formas de melhorar a integração entre as cidades, criando um sistema de redes urbanas, não caminhava tão conjuntamente nos círculos de debates daqueles que pensavam sobre as atribuições do urbanismo. Somente em meados do século $X X$, tomando como cenário analítico a França, e, num contexto de maior, a concentração urbana, Bardet aponta que,

O estudo de todo projeto de planejamento nacional, deverá, estar baseado sobre três escalões territoriais: o micropaís ou panorama de ordem quase biológica; o país, unidade primordial de cultura, tradução da geologia agrícola; e enfim a região: forte unidade econômica e espiritual nascida da humanização do solo. (1990, p. 83).

Da mesma forma como trabalha com escalões de análise territorial e alcança assim subsídios para embasar uma ideia de planejamento nacional, levando em consideração a noção de região, Bardet também faz menção a escalas mais próximas dos habitantes da cidade. Estas escalas são chamadas pelo urbanista francês de patriarcal (que teria de cinco a quinze famílias, resultando cerca de 100 pessoas), doméstico (de cinquenta a cento e cinquenta famílias, que resultaria em cerca de 1.000 habitantes) e paroquial (com até mil e quinhentas famílias).

\footnotetext{
${ }^{45}$ Ao quebrar a representação tradicional, estática e normativa, esses debates tornaram possível projetar outros autores e adaptar o uso de suas ideias para o crescimento. (Livre Tradução do autor).

46 Eles incitaram a reflexão sobre a adaptação dos limites administrativos da realidade da urbanização, acelerando a reflexão sobre a noção de região. Percebe-se assim que, ao mesmo tempo, a cidade e o campo estão ligados nas mesmas questões de gestão, abrindo novos horizontes para os urbanistas. (Livre tradução do autor).
} 
Percebe-se aqui, novamente, a influência do economista Le Play, figura expressiva na segunda metade do século XIX no meio intelectual francês, e que influenciou a formação de urbanistas nas primeiras décadas do século $\mathrm{XX}$, conforme apontamos anteriormente. É nítida a influência lepleysiana em Bardet sobre a formação de um método de investigação a partir de um recorte estabelecido sobre uma amostragem populacional, pois Le Play trabalhou com a definição de escalões de análise partindo da estrutura familiar, a qual chamava de escala doméstica, definida por ele como o ponto inicial de qualquer pesquisa sobre condições de vida.

Buscando uma escala mais ampliada do que a célula doméstica trabalhada por Le Play, o geógrafo francês Pierre George $(1952)^{47}$ aponta para uma divisão de população urbana no mundo a partir da classificação em grupos que correspondem ao tamanho das cidades. O geógrafo propõe, assim, no período do pós Segunda Guerra, uma divisão em cidades com mais de 100.000 habitantes, cidades de mais de 20.000 habitantes e cidades de cinco mil habitantes, tomando como base o padrão das aglomerações francesas.

Porém, temos que expor que, no mesmo período em que Bardet, Prost e George trabalhavam conceitos de região na França, também nos Estados Unidos, sobretudo a partir dos estudos da ecologia urbana e, posteriormente, da sociologia urbana, tais conceitos eram formados no meio intelectual, contribuindo assim para o incremento de uma visão regionalista sobre o território urbano e possibilitando a abertura para o planejamento urbano e regional como um campo de atuação profissional que havia sido forjado com a contribuição da disciplina do urbanismo.

Segundo Goitia (1992, p. 209), "Walter Firey, que estudou os processos ecológicos na cidade de Boston, com o objetivo de experimentar a validade das teorias mais conhecidas sobre o assunto, divide-as em três grandes grupos", classificando os estudos sobre o desenvolvimento regional e a distribuição espacial das aglomerações em estudos que se apoiam em esquemas descritivos ideais. Esta classificação, segundo o autor, foi iniciada por Ernest Burgess nos anos 1930 e divulgada por Robert Park no livro "The City" (1935), e seus resultados se apresentam em esquemas de: teoria das zonas concêntricas e teoria dos setores de círculos, as quais sofreram críticas de outros estudiosos norte-americanos.

\footnotetext{
${ }^{47}$ GEORGE, Pierre. La Ville. Paris: Presses Univeritaires de France, 1952.
} 
Com a intenção de procurar superar as anomalias que a teoria das zonas concêntricas revelava, Homer Hoyt desenvolveu a teoria setorial. Segundo esta, a cidade expande-se também de maneira circular, a partir de um centro que é o centro comercial e de negócios. Porém, em vez de o representar com anéis, Hoyt figura-o com setores de círculo, correspondendo a cada setor distritos especialmente caracterizados sob o ponto de vista social. (GOITIA, ibid., p. 216).

Além da teoria setorial de Hoyt e das teorias das zonas concêntricas e dos setores de círculos, Firey também aponta para as teorias metodológicas racionalistas que, segundo Goitia (ibid., p. 219), "procuram explicar as forças que condicionam a adaptação da sociedade ao espaço físico, através de motivos estritamente econômicos."

Há que se observarem as diferenças morfológicas entre as cidades norte-americanas e europeias,pois as cidades europeias carregavam o peso de seu passado histórico, enquanto os Estados Unidos formavam uma rede de cidades desenraizadas deste apelo. Mesmo tendo sofrido os efeitos do desenvolvimento do capitalismo industrial, assim como a Europa, suas cidades acabavam de ser implantadas. Assim, haverá diferenças entre o entendimento sobre os significados do subúrbio, das zonas periféricas e dos centros econômicos para os norte-americanos e para os europeus. Nos Estados Unidos "a palavra subúrbio equivale a zona residencial, respeitável, tranquila, calma, quando não opulenta e senhorial", enquanto que "na Europa, na maior parte dos casos, é sinônimo de pobreza e miséria." (ibid., p. 213).

Sobre estas diferenciações e na busca de desenvolver padrões de análise para a intervenção nas aglomerações urbanas, Bardet aponta que,

Sejam quais forem os regimes políticos ou econômicos, caímos sempre sobre as mesmas estimativas, no que diz respeito aos volumes ideais dos grupos sociais: cinco mil habitantes para o bairro, de 30 a 60 mil para a cidade, seja na URSS, nos Estados Unidos, na Inglaterra ou Alemanha, França ou Itália. (ibid., pp. 75-76).

E tecendo considerações sobre as formas de interpretação e compreensão do território, utilizando os exemplos franceses, afirma que "o limite das regiões naturais varia segundo a escala na qual trabalha aquele que as observa". (ibidem, p. 82). E conclui dizendo que as divisões regionais na França se confundem com regiões econômicas do país, apontando para uma ação que culminaria no desenvolvimento de um plano nacional para a França. Tira como diretriz que "em vez de continuar a congestionar os centros já demasiadamente populosos, como que espetados sobre ferrovias, trata-se de 
esparramar a atividade produtora sobre toda a extensão das correntes de trocas ${ }^{48 . "}$ (ibidem, p. 86).

Sobre a formação de regiões, Goblet (1942, apud BARDET, 1990, p. 88) salienta que é "preciso acentuar a personalidade de cada região afirmando sua economia local e adaptando as técnicas novas às produções tradicionais." O autor reconhece assim que o plano de desenvolvimento de um aglomerado tem que levar em consideração as condições locais, os arranjos produtivos e, sobretudo, a cultura popular daqueles que nela vivem. Assim, Bardet salienta que,

Todos os argumentos de urbanismo, mais ou menos atados uns aos outros, só poderão viver se estiverem integrados organicamente nas duas dezenas de regiões francesas. É preciso não concebê-los numericamente como agrupamentos de equipamento, mas como verdadeiras comunidades que estruturam a diversa e complexa nação francesa. (ibid., p. 89).

Essa alma comunitária poderá jorrar se a aglomeração dos habitantes se desenvolver em volta dos edifícios comuns: lugares para a educação, a aprendizagem, o culto, a cultura e os lazeres, realizados em primeiro lugar, se o desenvolvimento tiver lugar por meio da federação de escalões reunidos em volta de seus respectivos polos, e ligados entre si em seus pontos de contato; se substituir a pontuação das casas de campo isoladas por pequenos ramalhetes de casas; enfim, se o alvará dessas comunidades for justo. (ibidem, p. 93).

Desta forma, se o que assistimos no meio técnico francês, no início do século $X X$, foi a delimitação do campo profissional dentro do campo disciplinar do urbanismo, terminologia que havia sido forjada pelos franceses na primeira década do século, a partir da década de 1950, no contexto do pós-guerra percebemos que a implantação de um tratamento regional para os problemas da cidade se consolidou, após os debates ocorridos nas duas últimas décadas, iniciado no final dos anos 1920 sobre a questão regional e dos aglomerados urbanos. Este debate perpassou fronteiras do mundo todo, mas na França, segundo Calabi,

Em 1963, insere-se a criação da DATAR - Délégation à l'Aménagement du Territoire et à l'Actioin Régionale, que tem a responsabilidade de coordenar o conjunto de funções que permitem a articulação em sistemas do território. As delegações regionais são nomeadas para a organização das estruturas territoriais e para as políticas dos novos assentamentos. Em 1964, as

\footnotetext{
${ }^{48}$ Por "correntes de trocas" o autor explica que esta seria uma espécie de curso que pode medir de 20 a 50 quilômetros de largura, sendo mais comum seu desenvolvimento ocorrer sobre um vale. (op. Cit., p. 86).
} 
comissões para desenvolvimento econômico regional têm o papel de articular a ação de desenvolvimento nos diversos setores. (ibid., p. 313).

Neste sentido, é importante salientar que a ascensão do debate sobre a questão regional e o tratamento dos aglomerados urbanos ocorreu em período de ebulição do Centre d'Économie et Humanisme, fundado em 1941, o que explicaria, em certa medida, os trabalhos empreendidos por Lebret no campo do urbanismo e do aménagement du territoire apresentarem preocupação em fornecer diretrizes que levavam em conta o aglomerado urbano e o desenvolvimento regional. Esta constatação nos leva a verificar, mais uma vez, o vínculo de Lebret e do Économie et Humanisme com o campo disciplinar do urbanismo e do planejamento urbano e regional. Porém, esta vinculação da equipe de Lebret com o urbanismo não renderia a elaboração de um método de trabalho urbano, uma vez que o que se percebe é a apropriação dos conceitos e aperfeiçoamento de métodos que já vigoravam nos anos 1940 e 1950 e eram empregados, inclusive, em outras instituições atuantes na França e em demais partes do mundo, como nos EUA e na Inglaterra.

\subsection{A consolidação do urbanismo francês e as ressonâncias na visão de mundo urbano em Lebret}

Segundo Lamas, a escola francesa teve papel preponderante pelo debate teórico, realizações de planos e pela irradiação internacional. Exportou saber e formação, e seus urbanistas trabalharam na organização de muitas cidades pelo mundo, conferindo-lhes determinada homogeneidade cultural, técnica e distributiva. (2010, p. 260). Para Quintella, "a escola francesa possui papel de destaque e de referência primordial, tanto do ponto de vista da produção bibliográfica, quanto da criação e da execução de planos urbanísticos" (2014), além de destacar ainda a "criação de instituições, legislações e promoção de eventos."

Segundo Leme e Lamparelli (2001, p. 676) "esta influência pode ser percebida na leitura de documentos, artigos publicados nas revistas especializadas, livros, planos e projetos urbanos." Mas também por contato pessoal direto através da participação em congressos e conferências internacionais, reproduzindo "as ideias e as polêmicas" e os modelos elaborados pelos urbanistas franceses. 
Como vimos no debate sobre a formação do campo disciplinar do urbanismo na França, a escola francesa de urbanismo "est pragmatique" (CLAVAL, 2001, p. 248), pois "aqueles que a criaram tiveram a preocupação de atacar os males reais da cidade: é a razão pela qual eles fazem tão fortemente apelo à enquete social". Dessa forma, "o urbanismo francês não procura revolucionar a cidade, mas torná-la mais humana e mais harmoniosa" (QUINTELLA, ibid.).

Além desta influência da escola francesa do urbanismo, as afirmações do norte americano Wirth (1949) nos levam a verificar também coincidências entre a concepção do método do urbanismo difundido na França, com o que se pregava na sociologia urbana e rural dos Estados Unidos, que buscam estabelecer entendimento e uma definição sociológica da cidade, entendendo "o urbanismo como modo de vida" (op. Cit., p. 621). Observando ainda que o urbanismo não se trata de uma questão física. Tecendo crítica àqueles que definem a atividade como resultado de um estudo ou proposta para determinada área ou da confecção de um plano de cidade.

Enquanto identificarmos o urbanismo com a unidade física da cidade, encarando-o apenas como rigidamente delimitado em espaço, e procedermos como se os atributos urbanos cessassem de repenete de manifestar-se além de uma linha divisória arbitrária, é provável que não alcancemos uma concepção adequada do urbanismo como modo de vida. (ibid., ibidem).

Percebe-se, então, que o campo do urbanismo e do aménagement du territoire, difundido no meio profissional francês durante a primeira metade do século $X X$, além de estabelecer diálogo multidisciplinar, indo além da questão formalista e dos planos desenvolvidos na prancheta, abriu-se para discutir a questão social da cidade de forma a propor soluções que a tornassem mais humana. Este aspecto torna os trabalhos de Lebret e da SAGMACS próximos a esta concepção metodológica, , presente no meio técnico francês no início do século $X X$ e também difundido pela sociologia norte americana a partir da década de 1920.

De forma que, na França, o Économie et Humanisme, fundado em 1941, por Lebret entre outros intelectuais católicos, tentará fornecer respostas à crise da cidade do pós-guerra, de forma que, na França, o Économie et Humanisme tentará fornecer respostas à crise da cidade do pós-guerra, tendo, inclusive, firmado contrato com o Ministère de La Reconstruction et de l'Urbanisme, durante a gestão de Raoul Dautry.

Para Quintella, a exemplo das preocupações estabelecidas por Lebret quanto à cidade, 
O urbanismo francês da primeira metade do século XX primava, assim, por uma compreensão da complexidade do contexto existente como embasamento projetual. Isso faz com que não seja possível considerá-lo como uma mera continuação da arte urbana histórica barroca e neoclássica, e nem mesmo do legado haussmaniano. (ibid., ibidem).

Isto porque, "os urbanistas franceses faziam do estudo do contexto histórico, econômico, social e morfológico existente, a 'enquete', o princípio de base para o desenvolvimento de seus planos", sendo "preciso ter-se em conta a preocupação social e o senso pragmático característico de suas realizações." (ibid., ibidem). Embora já tendo visto que a preocupação social está atrelada ao campo do urbanismo e fez parte do movimento de reforma social empreendido na passagem do século XIX para o XX, ainda assim Andrade destaca que,

Pelo menos três das principais temáticas urbanísticas de então são, ainda hoje, objetos de discussões, propostas e políticas públicas no seio do urbanismo; são eles: a questão da habitação da classe trabalhadora, ou habitação social; a questão da expansão das cidades e a da renovação das áreas centrais. (ibid., p. 39).

Nesse sentido, é inegável a contribuição de Le Play na formação da metodologia que incluiu as práticas das pesquisas e enquetes sociais no campo do urbanismo, tanto na França quanto no Centre d'Économie et Humanisme. Além de Le Play, é preciso também expor a contribuição de Patrick Geddes, como aponta Ghorra-Gobin:

A suite de Le Play et de Geddes, on réalise à quel point l'enquête sociale est un instrument fondamental de la production des connaissances reflétant au mieux la réalité sociale avec Geddes, et comment elle devient un enjeu fondamental dans cette quête d'une identité au niveau local. (2001, p. 234). ${ }^{49}$

Após expormos como se deu a consolidação e a conceituação do urbanismo como disciplina, no meio francês, local onde as atividades de Lebret e dos organismos ligados a rede de $\mathrm{EH}$ foram iniciadas, no capítulo a seguir abordaremos como o tema do urbanismo e do planejamento regional, além da preocupação com a cidade e a organização do território, entraram como área de interesse junto ao Centre d'Économie et Humanisme, criado na França em 1941, o qual se desdobrou na instituição brasileira

\footnotetext{
49 Através de Le Play e Geddes, percebemos como a investigação social é um instrumento fundamental de produção de conhecimento, que reflete melhor a realidade social, e como ele se torna fundamental nesta busca de identidade local. (Livre tradução do autor).
} 
SAGMACS, filiada ao grupo, que foi criado por Lebret em sua primeira estada no Brasil, em 1947.

Neste sentido é importante expor sobre a influência dos métodos do urbanismo francês no grupo de Lebret e sobretudo na equipe de SAGMACS, que Leme e Lamparelli apontam para "a noção de ressonância, significando tratar-se de um terreno de trocas de experiências em que todos os profissionais envolvidos modificam-se através destes contatos" (ibid., p. 677). Sendo assim possível dizer, que tanto no caso de Lebret quanto da SAGMACS a absorção do quadro de ideias e referências não teria se dado de forma a se apropriar de fonte única e nem de conceitos puros. Tanto que percebe-se que assim como para os urbanistas franceses do início do século $X X$, os sociólogos norte americanos também tratam a cidade e as disciplinas ligadas ao campo do urbanismo como uma questão social.

Verificando os métodos e conceitos acerca do urbanismo, conforme apontando ao longo deste capítulo, podemos afirmar que Lebret e a SAGMACS atuaram no campo do urbanismo e do planejamento regional. Cabe a nós então verificar quanto a formação de um método por Lebret, através de sua atuação na SAGMACS. De forma que, se por um lado há em Lebret e no Centre d'Économie et Humanisme uma possibilidade para a criação de um método de trabalho no campo do urbanismo, também devemos investigar até que ponto o que se deu na atuação dentro do ideário lebretiano não foi somente um aperfeiçoamento ou aprimoramento dos métodos já colocados e difundidos no meio técnico francês. Levando-se em conta também a possibilidade de ressonância dentro do ideário lebretiano de referências não francesas, como a da sociologia norte americana e também de trabalhos ligados a urbanística inglesa $\mathrm{e}$ as enquetes e surveys desenvolvidas por Geddes, o sociólogo francês Chombart de Lauwe e o economista Le Play.

Assim, "na formação do urbanismo no Brasil, como disciplina e como campo de trabalho profissional, constata-se a importante influência das concepções urbanísticas internacionais." (ibidem, p. 676). Verificaremos o papel e a contribuição do Dominicano francês sobre a formação do quadro do urbanismo no Brasil, através de sua inserção junto a SAGMACS, a partir de 1947.

Porém, anteriormente a sua vinda ao Brasil, estudaremos no capítulo seguinte, conforme já exposto o como Lebret e o Économie et Humanisme passaram a vincular-se junto a questão urbana e ter alguma atuação dentro do campo do planejamento urbano e regional, a fim de verificarmos sobre a formação de um método de trabalho para o enfrentamento dos problemas impostos pelo modo de vida urbano. 

CAPÍTULO 2

O IDEÁRIO URBANÍSTICO EM LEBRET E NA SAGMACS:

DA CRÍTICA SOCIAL À INSTITUCIONALIZAÇÃO DO CENTRE D'ÉCONOMIE ET HUMANISME 

Neste capítulo abordamos os aspectos que norteiam "os fios e os rastros que evidenciam as tramas, as relações, as aproximações e distanciamentos" (GINZBURG, 2012) de Lebret quanto à institucionalização de um organismo para atuação na sociedade através de diagnósticos sociais e econômicos, em diretrizes para a política habitacional e reconstrução das cidades francesas que haviam sido bombardeadas pela guerra. No caso brasileiro, esta institucionalização do ideário lebretiano se desdobrou em uma atuação do órgão no campo do planejamento urbano e regional, durante as décadas de 1950 e 1960.

Para evidenciar tais fatos, visamos neste capítulo situar a trajetória pessoal e intelectual do religioso dominicano francês, a qual resultou numa formação que o despertou para a crítica social e culminou com a criação do Centre d'Économie et Humanisme na França, que se desdobrou formando uma rede de instituições voltadas ao desenvolvimento harmônico, dentre as quais destacamos a SAGMACS no Brasil, fundada em 1947.

A trajetória de Louis-Joseph Lebret inclui sua passagem pelas Escolas de formação dos Dominicanos - o Noviciado d'Angers, na França, e o Convento de Rijckolt, na Holanda, bem como o Convento de Saint-Malo Paramé, onde ele iniciou suas atividades como sacerdote. Buscamos com este percurso mostrar como se deu a articulação de seus anseios pelo desenvolvimento harmônico, a reforma social e o engajamento de lideranças para reivindicar tais aspectos, que culminaram com seus escritos para divulgação dos pensamentos e ideias defendidas pelo Centre d'Économie et Humanisme, difundidas em suas viagens por países além Europa, e com a criação dos organismos que compõem a rede do Économie et Humanisme.

É importante lembrar que a difusão das ideias defendidas e difundidas por Lebret ocorreu num contexto social, político e econômico singular, num mundo que buscava se reconstruir após a Segunda Guerra, dividido entre a economia capitalista, liderada pelos EUA, e o socialismo, liderado pela URSS. 
Este quadro traz desdobramentos que merecem ser melhor elucidados, visto que a atuação de Lebret não se restringiu à França e demais países europeus, mas se estendeu também a países da África, Ásia e os sul-americanos, como o Brasil, cuja atuação se deu através da criação da SAGMACS ${ }^{50}$. Por isso, este capítulo se desenvolve também na contextualização dos aspectos sociais, políticos e econômicos do período, a fim de verificarmos as vinculações e o percurso do grupo fundado pelo Dominicano francês, o comportamento da igreja católica frente à construção de uma doutrina social a partir da Encíclica "Rerum Novarum", escrita pelo Papa Leão XIII, em 1891"1 , e o combate ao comunismo pela Encíclica "Divinis Redemptoris”, escrita por Pio XI em 1937.

Por fim, analisamos, dentro do quadro de formação do Centre d'Économie et Humanisme e da definição de seus procedimentos metodológicos, como ocorreu a institucionalização e a inserção do tema do urbanismo e do planejamento urbano e regional nos organismos do grupo, e como ocorreu no Brasil, através da atuação da equipe coordenada por ele na SAGMACS.

\footnotetext{
${ }^{50}$ Referimo-nos à SAGMACS como organismo que possibilitou a Lebret atuar no Brasil, durante cerca de quinze anos. Porém, é importante expor que a atuação de Lebret no Brasil não se deu somente no âmbito da SAGMACS e que sua primeira vinda, que culminou com a criação do órgão, ocorreu de forma a possibilitar a inserção do pensamento social de Lebret junto ao quadro de pensadores econômicos, através de curso oferecido sobre Economia Humana na Escola de Sociologia e Política - ELSP, a convite de seu diretor, Prof. Cyro Berlinck.

51 Para Poulat (1998, p. 137), a "Rerum Novarum" é o primeiro documento de grande amplitude e autoridade consagrado, pela igreja católica, para discutir a questão social e a condição do trabalhador.
} 


\subsection{O pensamento social do Dominicano Louis-Joseph Lebret:}

\section{Trajetória e cronologia de formação}

Louis-Marie-Nicolas Lebret é o segundo filho do casamento de Pierre Lebret e Yvonne Bedel. Nasceu em 26 de junho de 1897, em Le-Minihic-sur-Rance, sul da Bretanha, na França. Com apenas dois anos Lebret perdeu a mãe, falecida ainda jovem, deixando órfãos ele e Pierre, seu irmão mais velho, então com sete anos. Viúvo, Pierre Lebret casou-se com Anne-Marie Poitevin, que se tornou a responsável pela educação dos irmãos Lebret.

A proximidade do vilarejo de Le-Minihic com o mar rendeu a Lebret o contato, desde a infância, com duas atividades profissionais: a pesca e a marinha. A Marinha francesa era onde seu pai, Pierre Lebret, atuava como carpinteiro, carreira que foi seguida por seu irmão e que também rendeu trabalho a Louis Lebret, que chegou ao posto de vicealmirante em $1922^{52}$, após ter servido como Oficial Adjunto em Beirute, durante a Primeira Guerra.

Nascido numa família católica, de hábitos modestos, mas com condição um pouco superior em relação à média das famílias costeiras, seus estudos básicos foram iniciados em instituição vinculada à congregação dos padres Jesuítas de Saint-Malo. Em 1914, obteve o título de bacharel em Matemática e ingressou na École Navale à Saint-Brieuc, não concluindo o curso devido a seu ingresso, em 1915, na Marinha Nacional Francesa, onde Lebret deu sequência a sua formação na École de Marine de Rochefort. Apesar de seu ingresso na Marinha, a vocação religiosa já aparecia em meio ao ambiente católico familiar, tendo Lebret, durante o ensino médio, manifestado preferência pelo clero mais próximo da esquerda secular ${ }^{53}$.

Segundo Houée (1997), mais do que a vocação religiosa, o contato de Lebret desde a infância com o catolicismo the rendeu a possibilidade de entender melhor as divisões existentes na sociedade em que vivia, pois as disputas existentes dentro da igreja

\footnotetext{
52 Lebret atuou na Marinha Francesa entre 1915 e 1922, quando solicitou demissão para ingressar no Noviciado de Angers, tendo sido sua demissão publicada no Jornal Oficial em 3 de março de 1923, quando cessaram suas funções junto ao Estado francês. As informações sobre o período em que Lebret atuou na Marinha, bem como da publicação de sua baixa, podem ser consultadas na Pasta AN45 AS5.

53 Tanto Houée (1997) quanto Pelletier (1996) afirmam, em suas obras, que Lebret havia manifestado seu interesse pelo ingresso na vida religiosa desde a adolescência, tendo, aos dezessete anos, tomado a decisão de ingressar num seminário. Porém, o cumprimento desta decisão precisou aguardar oito anos, pois em 1917 seu superior na Marinha não aceitou a solicitação feita por Lebret, tendo ele que manter-se trabalhando na corporação.
} 
católica, entre as posições defendidas por uma direita clerical conservadora e a esquerda secular e progressista, Ihe permitiram superar os conceitos que o instigaram a compreender melhor a sociedade daquele período.

Dès son enfance, L. Lebret apprend à dépasser les oppositions droite cléricale et conservatrice, gauche laïque et progressiste pour mieux saisir la société dans laquelle il vit. II restaura marqué para les inventaires de 1905 et les violentes oppositions qu'elles suscitent. (HOUÉE, ibid., p. 16). ${ }^{54}$

Porém, não somente os conflitos existentes no interior da igreja católica permitiram a Lebret perceber as disparidades sociais e diferenças entre as condições dos homens. Desde sua infância Lebret convivia próximo de pessoas ligadas à atividade pesqueira do sul da França, pessoas estas que eram mais pobres e enfrentavam maior dificuldade econômica do que os oficiais da Marinha, que tinham condição social pouco melhor, como a de sua família. Atuando na Marinha Lebret depara-se com uma nova dualidade, percebendo que os pescadores de Saint-Malo trabalhavam sob condições ainda precárias, distantes do ideário da modernidade e da modernização de seus instrumentos de trabalho, diferentemente da tecnologia presente na Marinha, que recebia vultosos recursos financeiros do Estado francês para possibilitar sua participação na guerra.

Inserido neste contexto de disparidades e em meio a uma guerra entre nações, as noções de desigualdade e divergências foram aprofundadas e melhor entendidas por Lebret, que perto dos vinte anos mantinha-se próximo da ação da igreja católica, frequentando atividades que, em 1917, se intensificaram a partir da reaproximação com os jesuítas ${ }^{55}$, o que tornou sua inclinação à vida religiosa cada vez mais forte.

É importante observar que o engajamento religioso de Lebret não estava vinculado à alienação da religião cristã, manifestada em Marx e Feuerbach, mas, segundo Bosi (2010, p. 143), estaria ligado ao exposto por Kant sobre o catolicismo, a "necessidade de levar até o limite o propósito de agir livre, reta e conscientemente em relação a si próprio e ao semelhante", entendendo assim a mensagem exposta no Evangelho de Cristo

\footnotetext{
${ }^{54}$ Desde a infância Lebret aprende a superar as oposições da direita clerical e conservadora frente a uma esquerda secular e progressista para entender melhor a sociedade em que vive. Ele se lembra dos inventários de 1905 e da violenta oposição que se sucede na igreja. (Livre tradução do autor)

${ }^{55}$ A Companhia de Jesus também teve influência sobre Lebret, que além de ter feito seus estudos básicos em colégio católico chefiado pelos jesuítas, segundo Lydie Garreau (2011, p. 22), a decisão de ingressar nos estudos religiosos junto aos Dominicanos ocorreu após ele ter participado de um retiro religioso em Lalhé, no Libano, com padres jesuítas.
} 
"como resultante de um movimento produzido no âmbito da razão prática". Esta preocupação de transformar os ensinamentos religiosos em resultados práticos é perceptível nos anseios de Lebret, uma vez que, desde a juventude, já manifestava aversão ao clero mais conservador.

Segundo Pelletier (1996, p. 16), Lebret se questionava quanto a "quel ordre choisir? Franciscains, Capucins, Jésuites, Dominicains?". Tendo já manifestado inclinação aos sacerdotes ligados à esquerda secular, outra de suas preocupações era também quanto à possibilidade de ação, de modo que não interessava a ele uma ordem que estivesse mais ocupada em trabalhos internos da igreja e orações, mas sim em atuar numa ação mais temporal. Assim, em 31 de março de 1923, Lebret ingressou no Noviciado de Angers, numa província da ordem dos Dominicanos ${ }^{56}$ de Lyon, pertencente à Bretanha.

Em 1923 Lebret já estava com vinte e cinco anos, havia acumulado experiência trabalhando na Marinha e trazia consigo algumas inquietações quanto às disparidades sociais no mundo. Esta experiência de vida, obtida, sobretudo, trabalhando na Marinha, o tornava diferente dos demais rapazes que estudavam em seminários, pois, além de mais velho, Lebret não se limitava a estudar as questões teológicas e nem se voltava às orações privadas. O religioso se interessava pelas ações temporais, ou seja, o jovem sacerdote se preocupava em conhecer e interagir com as dificuldades existentes na sociedade, sendo perceptível sua solidariedade para com os homens.

Assim, sua passagem pela Marinha Francesa teve grande importância em sua formação pessoal e intelectual, pois os anos dedicados à corporação, a passagem pela guerra, as experiências vividas em outras regiões da França e também no Líbano e Oriente Médio renderam a Lebret uma ampliação de sua visão de mundo para além das atividades dos pescadores e dos marinheiros da Bretanha. Este percurso, durante os anos da guerra em que passou na Marinha, permitiu-lhe conhecer a riqueza e a cultura de outras civilizações e se sensibilizar ainda mais com o desenvolvimento social e econômico dos homens.

Além disso, ele pôde se aprimorar no desenvolvimento de atividades que foram reconhecidas por seus superiores como qualidades do oficial, as quais, segundo Garreau (2011, p. 22), apontavam para a ordem, a autoridade, a eficiência e o senso de iniciativa, características que também foram levadas por Lebret para o Noviciado de Angers.

\footnotetext{
${ }^{56}$ A escolha de Lebret pela ordem dos Dominicanos, conhecida como Ordem dos Pregadores, nos parece acertada se considerarmos a informação de Hugue Puel (2004, p. 69) de que, desde o século XIX, os Dominicanos já tinham como fundamento a reconciliação da igreja católica com o mundo moderno, aspirando à liberdade, o diálogo com os Estados e com um regime político aberto à opinião pública e aos partidos políticos, em contraposição à velha igreja ligada às monarquias da idade clássica e aos Estados reacionários provenientes do Congresso de Viena, realizado em 1815.
} 
O percurso de formação religiosa junto aos dominicanos consistia de um ciclo de duração de sete anos, dividido em duas etapas: uma voltada aos estudos da filosofia e ciências humanas e outra aos estudos de teologia, voltados ao estudo da teologia de São Tomás de Aquino e ao aprofundamento dos estudos das escrituras e passagens bíblicas, dos padres da igreja católica e da história do cristianismo.

A primeira fase de formação religiosa aconteceu a partir de 1923, quando Lebret ingressou no Noviciado de Angers e ali permaneceu por dois anos. Em 1925, partiu para os estudos de filosofia e teologia realizados na cidade de Rijckolt, na Holanda, onde permaneceu até 1929 , quando foi ordenado padre ${ }^{57}$, adotando o nome de Louis-Joseph Lebret.

Durante o período de formação religiosa, dois professores marcaram sua trajetória de forma mais enfática: os padres Augier e Sertilanges. Augier era responsável pela coordenação dos estudos e mestre dos noviços, iniciou Lebret na leitura teológica de São Paulo e no trabalho de Santo Agostinho. Já o Pe. Sertillanges engajou Lebret num trabalho de interpretação crítica do pensamento moderno no mundo. Sertillanges ${ }^{58}$ baseava seus estudos a partir das correntes do pensamento moderno, abrindo campo para Lebret estudar os filósofos asiáticos, gregos, árabes e judeus, além das correntes doutrinárias do século XVIII, com os filósofos Descartes, Malebranche, Spinoza, Leibniz, Hobbes, Loke, Montesquieu, Rousseau, Kant, Hegel e o pensamento do século XIX, através de Marx e Freud.

O estudo sobre o pensamento moderno levou Lebret, juntamente com o Pe. Chenu ${ }^{59}$, no decorrer de sua formação sacerdotal, a trabalhar num estudo para integrar a ciência

\footnotetext{
${ }^{57}$ É comum fazer referência ao Dominicano como "Padre Lebret", porém o correto seria Frei Lebret, visto que, dentro da estrutura hierárquica da igreja católica, os sacerdotes que se ordenam e permanecem numa Ordem Religiosa, como a dos Dominicanos, tem como título de tratamento a palavra frade e não padre. Cabe o título de padre aos religiosos seculares que fazem seus estudos nos Seminários Diocesanos e permanecem à frente de comunidades pertencentes às Dioceses da região.

${ }^{58}$ Segundo informado pelos autores Garreau (2011, p. 23), Houée (2007, p. 16-18) e Puel (2004).

59 Marie-Domenique Chenu (1895-1990) foi ordenado frei dominicano em 1920 e atuava como professor e orientador no Convento de La Saulchoir. Participou da formação do Centre Économie et Humanisme junto com Lebret e teve importante participação junto à igreja católica, sendo considerado um dos teólogos do século XX. Presidiu a Societé Thomiste devido sua especialidade na teologia de São Tomas de Aquino. Além da teologia de São Tomás, Chenu também era um dos católicos especializados em história medieval. Em 1942 publicou o livro "École de Théologie", que foi suspenso pela Congregação do Santo Ofício do Vaticano, sob a acusação de que Chenu havia utilizado o método histórico em teologia, o que lhe rendeu uma proibição de atuar como professor em escolas e universidades católicas. Segundo Fillipo Rizzi, do Observatório Romano (edição de 11/02/2010), sua importância intelectual foi reconhecida por historiadores como Giuseppe Alberigo, Jacques Le Goff e o padre Louis-Jacques Bataillon e suas ideias foram reabilitadas com o advento
} 
moderna à visão de São Tomás de Aquino. Assim, Lebret inicia um diálogo entre ciência e religião, pensamento moderno e pensamento social, e constrói bases teóricas para tentar identificar mais tarde as contrariedades entre os anseios dos cristãos e as ações da cúpula do catolicismo.

Com o fim dos estudos de formação junto aos dominicanos e após ser ordenado, em 1929, Lebret parte para o Convento de Saint-Malo-Paramé ${ }^{60}$, conhecido como Saint-Anne des Grèves, em Saint-Malo, onde dá início a sua carreira dedicada ao sacerdócio. Porém, mais do que o início de sua carreira sacerdotal, foi ali, em Saint-Malo, que o padre dominicano Louis-Joseph Lebret deu início ao trabalho de engajamento social que o tornou uma referência nos estudos sobre os níveis de vida ${ }^{61}$, dando continuidade ao seu objetivo de não se fechar num convento, mas dar, através do evangelho e da ação da igreja, uma motivação temporal que fosse capaz de responder aos anseios de seus fiéis. Para Bosi,

A sua carreira não seria, porém, a do pregador para a qual o preparara o seminário holandês [...] Ordenado, Louis-Joseph voltou às praias de sua sofrida Bretanha, atraído pelo convívio fraterno com os pescadores de SaintMalo, então empenhados em uma luta desigual com a indústria pesqueira japonesa, bem mais poderosa e rentável do que os seus barcos e suas redes. [...] Nascia o Movimento de Saint-Malo, que defendendo um setor marginal da classe trabalhadora, se pautava por um programa de ação corporativo, idealmente comunitário, então afastado do sindicalismo de

do Vaticano II, convocado pelo papa João XXIII, onde, assim como Lebret, Chenu participou como perito.

${ }^{60}$ Dentro do objetivo de nossa pesquisa, que visa também elucidar a visão de um mundo urbano pelo ideário lebretiano, é importante mencionar que a Ordem dos Pregadores, à qual se vinculam os frades dominicanos, impõe aos mesmos a condição de viverem em comunidades, conhecidas como conventos dispostos junto às cidades, onde os sacerdotes podem se vincular mais diretamente com os moradores do local e assim ter uma atuação direta na vida social e religiosa deste local. Evita-se assim conferir aos dominicanos o status de liderança da igreja naquela localidade, uma vez que esta condição teria que ser forçosamente dividida com outros religiosos dominicanos lotados naquele convento.

${ }^{61}$ Fazemos esta deferência a Lebret devido ao mesmo ter sido reconhecido pela Organização das Nações Unidas como especialista no assunto e ter desempenhado junto à mesma trabalho numa comissão de especialistas instituída pelo Secretário Geral, para elaboração de uma pesquisa sobre a situação e as tendências econômicas no mundo. Os trabalhos desta comissão foram concluídos com a publicação do relatório "Measures For the Economic Development of Underdeveloped Countries", em 1951. Fazia parte das atribuições da comissão construir conceitos e sistematizar dados voltados à elevação do padrão de vida internacional, bem como buscar a padronização e metodologia de coleta de dados sobre os níveis de desenvolvimento humano e de qualidade de vida, juntamente com outros seis especialistas. Além de Lebret, participaram desta comissão: o economista chileno Alberto Baltra Cortez, o indiano Dhananjay Ramchandra Gadgil, diretor do Instituto de Política e Economia de Gokhale, o libanês George Hakim, o norte americano Theodore Schultz, professor do Departamento de Economia da Universidade de Chicago, e o britânico Arthur Lewis, professor de Economia Política da Universidade de Manchester. 
classe que se reunia em torno da Confederação Geral dos Trabalhadores. (2010, p. 260).

Na exposição feita em Marseille ${ }^{62}$ Lebret lembra que, quando ordenado frei, em 1929, com 32 anos, estava frágil, com a saúde debilitada e inapto ao trabalho. Seus superiores o mandaram para uma temporada em Saint-Malo para que ele descansasse e se reabilitasse. Este quadro de fragilidade de sua saúde é definido pelo próprio religioso como o mesmo problema da juventude católica cristã que se agitava e provocava os padres para uma ação espiritual e ao mesmo tempo temporal da fé.

Esta identificação de Lebret com os problemas da juventude católica ocorre porque, no início de sua carreira como sacerdote dominicano, o contexto sócio político encontrado por ele em Saint-Malo apontava para a necessidade de reconciliação entre a igreja católica e o mundo moderno. O distanciamento desta instituição da realidade social e econômica, em detrimento da fé, já não bastava mais para atrair as massas de fiéis e garantir a predominância do catolicismo mundo afora, e Lebret pôde constatar isto ao perceber o desinteresse dos pescadores bretões pelo cristianismo e o consequente afastamento da igreja católica. Ao mesmo tempo em que se distanciavam da igreja, alguns pescadores mostravam-se simpáticos ao engajamento aos sindicatos de trabalhadores, organizações vistas com preocupação pela cúpula do catolicismo devido à matriz de orientação marxista.

Neste contexto, é importante situar que, após o fim da primeira guerra mundial, o socialismo ascendeu sob a Rússia criando a União das Repúblicas Socialistas Soviéticas, as quais conseguiram forjar, em curto espaço de tempo, o desenvolvimento das atividades de produção industrial num país que era predominantemente agrário. Com o avanço das atividades de produção industrial, o domínio da planificação econômica pelo Estado e o controle do mesmo em relação à formação intelectual da classe trabalhadora contribuíram para que surgisse um contraponto à economia capitalista, culminando com a difusão das ideias soviéticas em outros países do mundo, o que favoreceu o incremento das organizações sindicais.

Ao mesmo tempo em que o contraponto ao capitalismo servia à expansão dos sindicatos de trabalhadores, o engajamento da classe trabalhadora e a difusão das ideias socialistas tornavam-se temidas pela igreja católica, pois, além da cúria romana enxergar

\footnotetext{
62 Estas informações são apontadas em “L'Origine d'Économie et Humanisme”, texto escrito por Lebret por ocasião da exposição feito por ele para a Semana Social em Marseille, em 1944. Documento consultado na Pasta AN45 AS44.
} 
um viés anticapitalista nos sindicatos, a URSS havia extinguido o catolicismo como religião oficial da antiga Rússia, o que serviu para tensionar ainda mais as relações entre o Vaticano e o governo soviético, tornando o socialismo uma corrente a ser combatida pela igreja católica.

Une partie importante du clergé et des dirigeants des mouvements chrétiens préconise un anticommunisme haineux et ridicule, incapables qu'ils sont de réfléchir aux problèmes posés par l'existence du communisme, ils luttent contre un matérialisme d'un certain type, par alliance avec un matérialisme d'un autre type." $O$ que para Lebret "c'est un paradoxe, comme la lutte pour la justice, par alliance avec l'injustice. (GARREAU, 2011, p. 33). ${ }^{63}$

Assim, já no início de sua vida sacerdotal Lebret depara-se novamente com uma situação de dualidade, relação esta imposta ao nosso personagem desde sua infância, tanto no campo religioso, quanto econômico e social. Naquele momento, a dualidade se dava em relação ao anseio dos cristãos por respostas para a crise social e econômica que os afligia, ao mesmo tempo em que a igreja católica procurava manter-se distante deste embate e seguir com uma linha de orientação espiritual, numa ação que Lebret chamava de intramuros. Para Lebret, a igreja deveria se posicionar frente os problemas do mundo contemporâneo, pois,

II s'emploie à convaincre, par le témoignage d'amour plus que par la raison, que le christianisme est seul capable d'assurer le bonheur de tout homme, l'avancée de l'humanité, bien plus sûrement que les mirages du communisme, les illusions du capitalisme, les puissances des nations totalitaires. (HOUÉE, 1997, p. 19) ${ }^{64}$

Esta atuação intramuros da igreja católica refletia, inclusive, em seus colegas dominicanos Cathelineau e Serrand, que, diante da perda de fiéis e da crise econômica vivida pelos pescadores bretões, diziam que pouco havia a se fazer para reverter tal quadro. Neste ponto não havia concordância entre o jovem padre Lebret e os antigos dominicanos de Saint-Malo, o que levou Lebret a criticar a estratégia da Diocese, que

\footnotetext{
${ }^{63}$ Uma parte importante do clero e líderes cristãos defende o ódio ridículo e o anti-comunismo, eles são incapazes de pensar sobre os problemas colocados pela existência de movimentos comunistas, eles lutam contra um materialismo de um certo tipo, com uma aliança com o materialismo de outro tipo. Este é um paradoxo, lutam pela justiça, fazendo aliança com a injustiça. (Livre tradução do autor).

${ }^{64}$ Ele está trabalhando para convencer o testemunho do amor mais do que a razão, de que só o cristianismo é capaz de garantir a felicidade de todos os homens, o progresso da humanidade, muito mais seguramente do que as miragens de comunismo as ilusões do capitalismo, as forças de nações totalitárias. (Livre tradução do autor).
} 
não se adaptava à nova conjuntura econômica e social e se mostrava mais preocupada em dar sequência às cerimonias grandiosas, com templos repletos de ornamentos, impondo a força do catolicismo através de uma igreja rica e para os ricos, mantendo assim os padres distantes das verdadeiras causas da evasão de fiéis.

Para Lebret, conforme Garreau (2011, pp. 33), a igreja estava muito mais próxima do "parti de la bourgeoisie, du patronat, des riches, du gouvernement, d'un parti de l'anticommunisme", enquanto para as massas trabalhadoras "le clergé, dans son ensemble, est socialement et politiquement de droite ou du centre conservateur",o que o levou a afirmar que,

L'ignorance des structures, des conditions de vie, des courants idéologiques, de la conjoncture économique mondiale et locale, l'ignorance de la psychologie et de la sociologie, sont autant de fermenteurs à l'humanité réelle. (GARREAU, 1997, p. 28). ${ }^{65}$

Desse modo, percebendo o pouco espaço para colaborar com mudanças nas formas de atuação do clero junto à comunidade católica de Saint-Malo, e com a saúde fragilizada, o que Ihe rendia a prescrição para descansar, Lebret se juntou ao padre Thomas Suavet ${ }^{66}$, dominicano jovem, membro da Secretaria Marítima, que tinha maior abertura com os pescadores bretões. Além disso, Suavet tinha também mais flexibilidade de ideias e mostrava-se tão preocupado quanto Lebret com o processo de descrença dos mais pobres em relação à igreja católica.

Participando do congresso da juventude em Rennes, em 1929, Lebret e Suavet se depararam com uma possibilidade de sedução dos leigos pela religião católica, verificando a possibilidade de unificação da espiritualidade da religião como vida e da técnica através da pesquisa sobre o meio, resumida na fórmula "ver, julgar e agir" ${ }^{n}$, que

\footnotetext{
${ }^{65}$ A ignorância sobre as estruturas, as condições de vida, as correntes ideológicas, a conjuntura econômica mundial e local, a ignorância sobre a psicologia e a sociologia são igualmente fermentadores da real humanidade. (Livre tradução do autor).

66 Joseph-Thomas Suavet (1908-1975) foi frei dominicano, engajou-se em movimentos de trabalhadores e da juventude católica na França. Ainda na juventude, no início de seu ministério sacerdotal, estabeleceu vínculos com Lebret na Bretanha e atuou junto dele ao longo da década de 1930, no trabalho de apoio à modernização das atividades pesqueiras de Saint-Malo. Nos anos 1940, colaborou com a formação do Centre Économie et Humanisme e, após a morte de Lebret, foi um dos fundadores da associação Les Amies du Pére Lebret.

67 "Ver, Julgar e Agir" refere-se a um método indutivo utilizado pela igreja católica desde 1961, para reforçar sua doutrina social, quando o papa João XXIII publicou a Encíclica "Mater et Magistra", por sugestão do Monsenhor Cardijn,em comemoração aos cinquenta anos da publicação da "Rerum Novarum". Na "Mater et Magistra", João XXIII (1961) afirma que "para levar a realizações concretas
} 
o dominicano adaptaria ao mundo marítimo para dar início à interpretação dos modos de vida e dos problemas que afligiam os pescadores da Bretanha e assim tentar reverter o abandono da igreja católica.

Neste contexto de oposição entre as forças da cúpula católica e os fiéis simpáticos ao movimento sindical, de contraposição entre os sistemas econômicos capitalista e socialista, e uma igreja que parecia incapaz de atualizar-se em relação aos anseios do mundo moderno, teve início não só a carreira sacerdotal de Lebret, mas também, e a nosso ver com maior importância, as atividades de investigação e pesquisa no meio social. A princípio esta atividade teve sua origem junto às classes trabalhadoras da costa marítima francesa, num movimento chamado por Houée, Pelletier e Suavet de movimento de Saint-Malo, que se apropriou do método indutivo: ver, julgar e agir. Assim,

Se, por um lado, a militância de Lebret o aproximava de uma visão tradicionalista da vida dos pescadores bretões, juntando patrões e empregados segundo princípios corporativos do catolicismo social ${ }^{68}$, por outro lado, a experiência direta da concorrência capitalista, que favorecia a empresa internacional em detrimento do trabalhador da região, abria-lhe a mente para compreender que 0 nível da luta deveria ser mais alto. (BOSI, ibid., 261).

os princípios e as diretrizes sociais passariam ordinariamente por três fases", sendo, "três momentos que habitualmente se exprimem com as palavras seguintes: ver, julgar e agir", explicando que consistia em "ver" o estudo da situação concreta, em "julgar", uma avaliação e apreciação desta situação à luz dos princípios cristãos e o "agir" como determinação do que poderia ser feito para aplicar os princípios e as diretrizes a uma ação prática. O conceito de "ver, julgar e agir" foi originalmente cunhado pelo religioso belga Josef-Léon Cardijn, um dos fundadores da Ação Católica em 1920, que na década de 1910 foi capelão dos sindicatos cristãos e exerceu liderança entre os jovens da chamada Juventude Sindicalista, que abriu campo para a formação na década seguinte da Juventude Operária Cristã. O monsenhor Cardijn participou do Concílio Vaticano II, foi tornado cardeal arcebispo pelo papa Paulo VI em 1965 e faleceu em 1967. No ano de 2015, a Confederação Nacional dos Bispos do Brasil - CNBB deu ampla divulgação a este método por ocasião da realização da Campanha da Fraternidade, que teve como tema "Fraternidade, igreja e sociedade" e como lema "eu vim para servir", visando discutir os problemas da conjuntura política, econômica e social do período. Devido a publicação, em 1952, pelo Économie et Humanisme de "Princípios para a ação" sob autoria de Lebret, em que se faz apontamento a este método indutivo, é comum o vínculo da criação de "ver, julgar e agir" ao Pe. Lebret e não ao Monsenhor Cardjin, pois, a edição circulou em várias línguas e distintos países, anteriormente a "Mater et Magistra".

18 Segundo Santos (2006, pp. 1-3), o catolicismo social a que Bosi se refere foi criado durante o século XIX diante das transformações impostas pelo avanço do liberalismo econômico. Neste período a igreja católica perde prestígio e também poder diante dos avanços da economia capitalista, do declínio das monarquias e da ascensão do Estado liberal. Há uma total transformação da sociedade e uma nova divisão entre classes sociais, destacando-se a situação da classe trabalhadora. A condição de vida da classe trabalhadora passa a ser motivo de preocupação de alguns intelectuais, culminando com a publicação do Manifesto Comunista, escrito por Marx, em 1848. Parte do clero também se mostra apreensiva com os novos conflitos sociais e preocupada com a questão social, dando origem assim ao que ficou conhecido como catolicismo social e que, mais tarde, foi debatido pela igreja católica visando à criação de uma doutrina social da igreja. 
Veremos a seguir como estas preocupações resultaram numa tentativa de Lebret, juntamente com Suavet, realizar uma ação mais temporal do que espiritual no mundo, usandor sua formação religiosa e intelectual, que lhe rendiam algum prestígio e liderança entre a população de Saint-Malo, para se engajar num trabalho de investigação da realidade social e busca de melhorias das condições de trabalho dos pescadores.

\subsection{O contato social:}

A vida sacerdotal e o engajamento junto aos trabalhadores de Saint-Malo

De acordo com Garreau (1997, p. 25), a primeira pesquisa feita por Lebret foi realizada em 1930, na costa francesa, anteriormente à criação do Économie et Humanisme. A mesma ocorreu de forma improvisada, não seguindo nenhum rigor científico, limitada a uma análise hipotética que buscava compreender a complexa situação vivida pelos pescadores de Saint-Malo e, sobretudo, as razões pelas quais estes se mostravam descrentes e abandonavam a igreja católica, demonstrando descontentamento com sua doutrina. Neste sentido, é importante destacar que o real motivo que levou o jovem sacerdote dominicano a preparar esta primeira pesquisa, na década de 1930, não era a preocupação com a situação econômica da população costeira, mas sim com o fato desta população deixar de frequentar a igreja católica e se afastar da religião.

Este primeiro contato social e a realização da pesquisa com os trabalhadores de SaintMalo, que marcaram o início do trabalho de investigação de Lebret, são descritos por ele próprio no roteiro preparado para expor as origens do Centre Économie et Humanisme, na sessão de Marseille, em 1944. O documento intitulado 'L'Origene d'Économie et Humanisme" 69 narra o início da vida sacerdotal de Lebret e o percurso feito por ele para desvendar as raízes dos problemas vividos pelos pescadores da Bretanha, num trabalho que durou cerca de vinte meses.

Assim, entre 1929 e 1931, Lebret percorreu a costa da França, da fronteira com a Bélgica até a fronteira espanhola, e visitou cerca de 250 cidades. Pelos lugares que passou realizou uma pesquisa que retornava uma folha de impressões que the rendeu um estudo

\footnotetext{
${ }^{69}$ Documento consultado na Pasta AN45 AS44.
} 
sobre o contato do meio com a literatura, sobre os problemas econômicos da marinha e da pesca e da marinha de transporte. Isso resultou num dossiê dividido parte a parte de forma que ele formulou questões para entrevistar pessoas independentemente de suas competências.

Cette première enquête a été pour moi extrêmement instructive. En mêmes temps que je enquêtais, je constituais la ou je le pouvais de sections de J.M.C. [...] Je constituais des dossiers non seulement port par port mais encore question pour question. Et j'interrogeais touts le personnalités qui me semblaient avoir quelque compétence. ${ }^{70}$

Em 1931, no Congresso Internacional do Apostolado da Oração, Lebret expôs os resultados desta pesquisa, abordando aspectos da situação material, moral e espiritual das áreas marítimas francesas. A descrição de Lebret sobre o problema foi feita com a apresentação de dados estatísticos, números das importações e preços praticados pelos produtos importados e peloo pescado nacional. Assim, Lebret relata a crise econômica que se agravava durante a década de 1930 entre os moradores da região costeira.

Les années 1930 en France ont été des annés de décadence avec la crise économique et l'incapacité de résister à la montée du nazisme en Allemagne, mais ce furente des années d'intense activité intellectuelle comme le montre bien l'ouvrage de Jean-Louis Loubert Del Bayle sur ce qu'il appelle "lés non conformistes des années trente". Comme Maritain et Mounier, Lebret fut un nom conformiste de ces années, même si leurs messages portent bien au-delà et rayonnent encore au XXI siècle. (PUEL, 2004, p. 73) ${ }^{71}$

Em novembro de 1930, Lebret ajudou na realização de um primeiro congresso social bretão, que reuniu cerca de 300 pessoas, todas ligadas às atividades marítimas, para pesquisar de maneira minuciosa as causas da queda dos lucros dos pescadores da Bretanha. Somente três anos depois e com muito empenho de pesquisa é que se

\footnotetext{
70 “L'Origine d'Économie et Humanisme" escrito por Lebret. Documento consultado na Pasta AN45 AS44, aponta que: o primeiro inquérito foi para mim muito informativo. Ao mesmo tempo em que eu estava investigando, eu constituía as seções do JMC [...] E constituía não apenas registros porta a porta, mas pergunta por pergunta. Eu questionei as totalidades e personalidades que pareciam ter alguma competência. (Livre tradução do autor).

71 A década de 1930 na França representou os anos de declínio, com a crise econômica e a incapacidade de resistir à ascensão do nazismo na Alemanha, mas foi de intensa atividade intelectual, conforme o trabalho de Jean-Louis Loubert Del Bayle sobre o que ele chama de "tiras antiéticas dos anos 30". Como Maritain e Mounier, Lebret era um não conformista, mesmo até o século XXI suas mensagens estão muito além daquele tempo. (Livre tradução do autor).
} 
conseguiu chegar a uma resposta, de que a falta de energia havia levado os pescadores a esta situação desesperadora. E então eles formaram uma associação cooperativa, que uniu os sindicatos cristãos, sindicatos neutros e sindicatos comunistas. Segundo Bosi, "o Movimento de Saint-Malo adotou a estratégia de alianças com as associações de pescadores espalhadas pelos portos do Atlântico e da Mancha" (2010, p. 261) e disso resultou a formação da Associação Marítima Cristã, que visava também o reconhecimento da profissão de pescador pelo governo francês. A Associação Marítima Cristã,

\begin{abstract}
Passou a ser o seu primeiro campo de observação e ação social. Nascia o Movimento de Saint-Malo, que, defendendo um setor marginal da classe trabalhadora, se pautava por um programa de ação corporativo, idealmente comunitário $^{72}$, então afastado do sindicalismo de classe que se reunia em torno da Confederação Geral dos Trabalhadores. (ibid., p. 260).
\end{abstract}

O tempo todo Lebret acompanhou a luta e o empenho destes pescadores na formação desta cooperativa e, em 1933, intermediou uma conversa deles com o prefeito de Quimper, que foi quem fez contato com o governo francês em Paris. Além deste apoio à formação de uma cooperativa de pescadores, Lebret colaborou durante o governo de Vichy com a normatização da profissão de pescador na França, regulamentada por decreto lei em 1938 e, mais tarde, por lei ${ }^{73}$. Desta forma o padre dominicano havia passado progressivamente de um plano de ação espiritual para um plano de ação temporal, percebendo que as instituições já não davam conta de enfrentar os problemas presentes no mundo, buscando uma maneira de fazer o contraponto aos valores vigentes, difundidos pela modernidade, de forma a não se aliar nem com o socialismo e

\footnotetext{
72 O ideal comunitário em EH estaria ligado a uma estratégia de polos de crescimento e desenvolvimento econômico, defendidos por Perroux (1955). Numa definição dada por Perroux e Friedman (1975, p. 30), polos de desenvolvimento são áreas de atividades econômicas concentradas e altamente independentes, que exercem uma influência decisiva no caráter e no ritmo de desenvolvimento econômico do sistema, ou subsistema em questão. Perroux desdobrou o conceito de polo de crescimento e desenvolvimento atrelando-o a uma região-chave, que se apresenta como centro de inovação no espaço que domina. Assim, "os pólos de crescimento estão ligados ao fenômeno da urbanização, pois um pólo não é necessariamente uma cidade." (FRIEDMAN, 1975, p. 34). Cabe ainda expor que nos EUA o ideal comunitário é trabalhado pela sociologia rural e entendido como estratégia de desenvolvimento local.
}

${ }^{73}$ A contribuição de Lebret para a regulamentação da profissão de pescador na França culiminou com a promulgação do Decreto Lei de 23 de março de 1938, emitido pelo Front Populaire. Em 13 de maio de 1941 a profissão foi regulamentada por Lei. As informações sobre o engajamento de Lebret para a promulgação destas leis é apontada por André Chomel (1981) em "Cahiers Les Amies du Pére Lebret", $n^{0} .1$. 
nem com o capitalismo ${ }^{74}$, pois, para ele, ambos os modelos eram perversos aos trabalhadores e insuficientes para alcançar o desenvolvimento econômico e social.

Devido à incompreensão dos problemas sociais do mundo atual, que não se restringia à igreja católica, as críticas de Lebret àquele período extrapolaram a estrutura da igreja conservadora, de modo a incluir o Estado, os empresários e suas organizações de classe e os sindicatos de trabalhadores, além de outras instituições, indiscriminadamente, públicas ou privadas, apontando que todas estas estruturas não estavam preparadas para dar respostas ao mundo naquele momento, pois simplesmente não conheciam as especificidades dos problemas. Para Lebret, todos descartavam a necessidade de interpretação da realidade e, além disso, não dispunham de qualificação para utilizar-se das ciências modernas para a elaboração deste diagnóstico.

Assim, durante o trabalho em Saint-Malo, na década de 1930, é possível notar a aproximação de Lebret com as teorias de Marx, que lhe davam condições para empreender uma atividade de interpretação do mundo moderno e capitalista, e, consequentemente, de sua realidade social. A leitura de cunho marxista não era uma novidade para Lebret, pois, durante seus estudos no seminário, o Pe. Sertillanges já havia introduzido a questão através de uma imersão aos filósofos modernos. Assim "a leitura atenta do Capital the daria argumentos para denunciar a exploração sistêmica, o pesadelo do desemprego e a degradação da vida da classe operária que as suas pesquisas empíricas traziam continuamente à luz." (ibid., p. 264).

A aproximação do dominicano com o marxismo, somada às continuas críticas que Lebret fazia sobre o distanciamento da igreja católica da realidade social, o tornaram uma voz incômoda à cúpula do catolicismo. Ao mesmo tempo, este anseio de interpretação da realidade social fora da estrutura do catolicismo o aproximou dos estudos de economia que o permitiram aliar-se a intelectuais ligados a universidades e centros de estudos, como os economistas François Perroux e Raymond Delprat e o empresário Alexandre Dubois.

É importante observar aqui que este primeiro contato de Lebret com a realidade social dos pescadores da Bretanha confirmou seu processo de amadurecimento intelectual e permitiu a ele apropriar-se, ou então, aproximar-se de alguns conceitos que culminaram

\footnotetext{
74 Alfredo Bosi atribui a Lebret a pecha de anticapitalista e aponta que ele chegaria cedo à conclusão de que o capitalismo não respeita limites na sua expansão (2010, p. 261), porém, o autor não explicita fontes que possibilitariam classificar o dominicano como um anticapitalista, de forma que os textos escritos por ele trazem críticas ao capitalismo, mas também ao socialismo. Suas ações junto ao movimento de Saint-Malo vincularam-se muito mais em dissuadir a força dos sindicatos ligados aos partidos socialistas e comunistas do que propriamente a declarar-se como anticapitalista.
} 
com a elaboração de um método de pesquisa que, mais tarde, levou à criação de uma instituição voltada à interpretação da realidade social, bem como de um grupo de ação comunitária que, para Albertini (2006, p. 22), "est au centre des réflexions de la première époque d'Économie et Humanisme".

A nosso ver, a aproximação com a leitura de cunho marxista ${ }^{75}$ o fez romper com sua formação original de engenheiro - obtida durante sua passagem pela Marinha Francesa, e de filósofo - alcançada no Seminário, conduzindo-o ao estudo das teorias econômicas, com o intuito de interpretar as condições de vida da população e os problemas que a afetavam e impediam o seu desenvolvimento econômico. Isto o levou ao anseio de construir na França uma terceira via, alternativa tanto ao capitalismo quanto ao socialismo, possibilitando assim a correção das distorções presentes em ambos. Este anseio pela terceira via foi chamado por Lebret de Economia Humana. Vale dizer que "o padre Lebret vinha, por sua vez, de um projeto humanístico, de fundo religioso, para muitos utópicos, de promover a formação de comunidades solidárias no seio de uma estrutura adversa" (BOSI, ibid., p. 259).

Para agir em prol da construção de uma terceira via, não era possível restringir sua ação à igreja católica, e por isso, utilizando seu conhecimento intelectual, o prestígio obtido em Saint-Malo como frei dominicano e a influência entre personalidades e intelectuais franceses, Lebret deu início ao trabalho de formação do Économie et Humanisme, que consistia num trabalho - a princípio - de compreensão das causas dos problemas sociais e econômicos do período, de forma a buscar uma possível solução para estes a partir do que havia de bom, tanto no capitalismo, quanto no socialismo, buscando o apoio de François Perroux, Raymond Delprat, Gustave Thibon, Jean-Marie Gatheron, René Moreaux e Alexandre Dubois. Esta preocupação de Lebret de buscar, tanto no capitalismo quanto no socialismo, alternativas possíveis à construção de uma terceira via, nos leva a não inserirmos o dominicano no campo dos anticapitalistas.

Ao mesmo tempo, é importante situar que a fundação do Centre d'Économie et Humanisme, em 1941, consistiu também numa ruptura de Lebret com o regime de Vichy, período em que se intensificou o corporativismo de Estado, o que distanciava o governo das associações de classe e de categorias profissionais, além da exigência de submissão das corporações e intervenção direta na composição das suas diretorias.

\footnotetext{
${ }^{75}$ Lebret aponta em “L'Origine d'Économie et Humanisme” que o primeiro nome pensado para o Économie et Humanisme, em 1937, por ele e Suavet, foi Centro de Estudos sobre o Marxismo, porém, ambos buscavam um nome de maior impacto e, em 1941, chegaram ao nome de Centre Économie et Humanisme.
} 
Além da ideia contrária às associações de classe, o governo de Vichy preocupava Lebret devido a sua aproximação com os líderes do nazismo alemão e fascismo italiano, em plena Segunda Guerra Mundial. Ainda assim, é preciso destacar que Lebret não foi o tempo todo contrário ao regime de Vichy, estando bem próximo do mesmo durante o início do governo. Foi durante o Regime da Revolução Nacional, presidido pelo marechal Pétain, que o dominicano conseguiu força para emplacar a regulamentação da profissão dos pescadores franceses e até fez parte da École des cadres d'Uriage, instituição criada em 1940 pelo governo de Vichy, com o intuito de formar intelectualmente uma elite dentro de um quadro de dirigentes no governo de revolução nacional.

Porém, mais do que a aproximação de Lebret das teorias marxistas, o que contribuíu para a criação do Économie et Humanisme, em 1941, é importante observar que o dominicano também incorporava ao seu vocabulário algumas terminologias e empregava conceitos que vinham de autores da sociologia. Referimo-nos aqui à utilização das palavras: Desenvolvimento - que era facilmente encontrada nos textos de Marx, porém, havia impregnado o discurso de economistas e sociólogos, sobretudo os que estudavam as economias periféricas; Comunidade - que já era empregada cinquenta anos antes da fundação do $\mathrm{EH}$, pelo economista francês Friedrich Le Play, numa tentativa de definição de escalões de análise. Além de Le Play, cabe ressaltar que a questão do desenvolvimento comunitário e do estudo das comunidades era fortemente debatida pelos estudiosos vinculados à sociologia rural nos EUA, fundada por Thomas Lynn Smith, que, diferentemente dos franceses, criaram uma disciplina específica dentro das ciências sociais para o estudo do meio rural e outra para o meio urbano; por fim, destacamos a palavra Engajamento - que nos anos 1960 passou a ser utilizada pela igreja católica, numa tentativa de aproximação dos fiéis leigos da estrutura clerical organizada. Nas décadas de 1930 e 1940 é notório o emprego do termo entre os estudiosos do movimento sindical e também nos jornais editados pelos próprios sindicatos.

O destaque dado aos termos empregados por Lebret, ou que no mínimo permearam o ideário lebretiano, como pode ser observado nos documentos que relatam a disseminação do método do Économie et Humanisme, é importante para situar o percurso de formação intelectual e das matrizes sociais do dominicano. Além disso, esta elucidação sobre os termos empregados nos permite também verificar sua aproximação de fontes documentais e autores que não foram tão explicitados pela pesquisa realizada a partir dos títulos presentes na biblioteca que pertenceu à SAGMACS ${ }^{76}$.

\footnotetext{
${ }^{76}$ Durante nossa pesquisa de mestrado realizamos um levantamento do acervo que pertenceu à SAGMACS e foi adquirido pela Faculdade de Arquitetura e Urbanismo da USP em 1973. Buscamos,
} 
Este percurso nos permite afirmar que, mais do que o vínculo de Lebret com Le Play e os métodos de Marx para a interpretação da realidade social, há também uma abertura para o que estudava a escola da sociologia norte-americana, onde a noção de comunidade vinculava-se diretamente aos estudos do meio rural do país e também à cadeira de ecologia urbana, criada pela Escola de Chicago no início do século XX e que também empregava o termo. Neste momento é importante dizer que, para o sociólogo José Arthur Rios, que trabalhou com o padre Lebret, ele,

Era um padre, não era um cientista travestido de padre. Ele converteu-se tarde, ele foi comandante de navio mercante na França, procurou os Dominicanos, fez seus estudos já adulto, se engajou em movimentos operários, ele sabia distinguir o que era comunista do que não era, distinguir o que era doutrina da igreja, o que era marxismo, ele sabia distinguir isso tudo perfeitamente, o que não era tão simples para os demais padres. E muitos não conseguiam fazer esta distinção. Então quando alguém começava a fazer a defesa do trabalhador já taxavam de comunista. [...] O Economia e Humanismo falava em comunidade e daí a confusão, pois falar em comunidade já era ser visto como comunista. [...] Então isso tudo é anterior e havia uma grande confusão, mas para o Lebret sempre houve uma linha muito nítida de não confundir ciência com doutrina católica. Os livros dele são de um economista. Agora, ele era um padre! ${ }^{77}$

Neste sentido, Radicliffe Brown (1946, p. 159) afirma que "estudar estruturas sociais não é exatamente dizer que estudamos relações sociais", pois "uma relação social só existe como parte de uma vasta rede de relações sociais, envolvendo muitas outras pessoas". Pois, conforme Maurice Duverger (in EBENSTEIN:1965, pp. 19), "para investigar los princípios de una organización ideal, hay que estudiar necessariamente el funcionamento de la organización social existente". Assim, "no estudo da estrutura social, a realidade concreta de que cuidamos é o conjunto de relações realmente existentes" (BROWN, ibid.). Conforme Lucien Febvre (1946, p. 28), em ciências sociais "não estamos tratando com um agente ativo: o ambiente, e um passivo: o homem".

\footnotetext{
através desta atividade, verificar sobre os autores utilizados pela equipe de Lebret e desta forma verificar as filiações da SAGMACS e de Lebret com a sociologia, a economia, filosofia, a influência da geografia e os autores inseridos no campo do urbanismo e do planejamento urbano e regional.

${ }^{77}$ A afirmação foi feita pelo sociólogo José Arthur Rios, em entrevista concedida ao autor em 28 de março de 2014. Rios foi membro do EH e atuou na equipe da SAGMACS, no Rio de Janeiro. Deixou os quadros da equipe no início dos anos 1960, devido seu engajamento como Secretário de Bem Estar Social do governo de Carlos Lacerda. Além de seu engajamento com Lacerda, Rios também manifestou descontentamento com a equipe de São Paulo e revelou discordância com a maneira como alguns atuavam, considerada por ele muito à esquerda, o que motivou seu desligamento da SAGMACS.
} 


\subsection{A formação e fundação de um grupo para atuação comunitária e engajamento social: \\ O Centre d'Économie et Humanisme}

O engajamento de Lebret no trabalho de pesquisa sobre as condições de vida dos pescadores da Bretanha não o distanciou da igreja católica, porém, ampliou seu leque de conhecimento e informação e também seu horizonte de atuação, que ficou maior do que a atuação limitada e conservadora da igreja. A descrença na religião e o afastamento dos fiéis da igreja católica motivaram Lebret, no início de sua carreira sacerdotal, a empenhar-se em conhecer as causas deste problema, colocando-se dentro do meio social dos pescadores de Saint-Malo, e os resultados obtidos moveram o dominicano a ampliar sua linha de atuação, ambicionando por uma transformação da economia de forma a colocar o homem no centro do desenvolvimento econômico, político e social.

Ao contrário do que pregava a cúpula da igreja católica, sobre afastar fé e religião das ciências modernas, e, consequentemente, da realidade social do mundo, Lebret propunha maior ação frente aos entraves do desenvolvimento econômico na França e nos demais países europeus. Percebendo que não era possível dar continuidade a esta separação, que, para ele, contribuía para o aumento das tensões sociais entre trabalhadores e empresários, Lebret buscou uma maneira de agir. Assim, em 1938, engajado nos estudos das teorias marxistas, a ponto de pensar juntamente com o padre Suavet na formação de um Centro de Estudos sobre Marx, Lebret aprimorou a ideia de fundar o Centre de Économie et Humanisme, que seria um organismo autônomo em relação à igreja católica e que tentaria conciliar as teorias de interpretação da realidade social com uma base de desenvolvimento econômico que colocaria o homem como principal elemento das transformações da sociedade, apontando para uma economia das necessidades.

Esta reconciliação entre ciência e religião poderia ser realizada fora do ambiente católico, embora o trabalho de Lebret sobre a pesquisa social e interpretação da realidade dos pescadores de Saint-Malo já tivesse sido baseado em sua experiência acadêmica, com métodos que conhecia graças às ciências modernas - como a sociologia, a economia e a filosofia - com as quais teve contato durante sua formação religiosa nos conventos e seminários da Ordem dos Pregadores.

Porém, este despertar de Lebret para a formação de um organismo de estudo e interpretação da realidade social ocorreu concomitantemente com o avanço do nazismo 
de Hitler e do fascismo de Mussolini, que culminaram com a eclosão da segunda Guerra Mundial, o que impôs a Lebret e aos demais apoiadores da ideia de criação do Économie et Humanisme cuidados que impediram o avanço imediato da formação do organismo, que só se constituiu de forma oficial em 1941. Assim "Economia e Humanismo foi fundada como uma associação sediada no convento dominicano de Marseille" (PONTUAL in FARIA, 2014, pp. 168). Em 1943 se instalou em Ecully (Rhône) e em 1945 no convento de La Tourette ${ }^{78}$.

Neste sentido, é importante dizer que no início da década de 1940, quando Lebret funda o Économie et Humanisme na França, o mundo vive um período tumultuado em termos de disseminação de ideias e ideologias, sobretudo pelo avanço do nazismo e do fascismo. "A via reacionária fora tornada pelos regimes fascistas hegemônica em razão da corrida bélica da Alemanha nazista." Já a

\begin{abstract}
Alternativa oposta, seguida pela União Soviética sob o regime estalinista e em processo de expansão para a Ásia e a Europa do Leste, era temida pelos que idealizavam uma terceira via, ou seja, os socialistas democráticos ou cristãos de esquerda orientados por valores de liberdade política e cultural. (BOSI, ibid., p. 263).
\end{abstract}

Em paralelo ao campo ideológico, o capitalismo atuava pela manutenção da guerra que permitia o desenvolvimento industrial em países periféricos à Europa, como o Brasil. Assim, já no início dos anos 1940, período que antecede os anos finais da Segunda Guerra, é possível perceber a existência de grupos e organismos que se debruçavam a estudar e elaborar planos para a reconstrução, sobretudo da Europa, no contexto do pósguerra $^{79}$.

Com o fim da Segunda Guerra mundial, em 1945, ocorreu uma melhor delimitação dos campos ideológicos e políticos e assim abriu-se espaço para oposições entre as frentes que haviam derrotado as forças nazistas de Hitler, impondo-se as hegemonias políticas,

\footnotetext{
${ }^{78}$ Este percurso de instalações da sede do Économie et Humanisme nos permite verificar que o descolamento do movimento em relação à igreja católica, pregado por Lebret, não se dá de forma direta, visto que os locais que sediaram este grupo eram conventos da Ordem dos Dominicanos. Mais tarde, com o grupo mais consolidado, após o fim da segunda guerra, outros núcleos de difusão do EH são formados, como a SAGMA e a Livraria, o que permite ao grupo de Lebret maior autonomia em relação à igreja.

${ }^{79}$ Neste sentido o próprio Économie et Humanisme produz documentos voltados a pensar cenários para o mundo no contexto do pós-guerra, a exemplo do trabalho "Regarde sur la conjocture mondiale", que, partindo do estudo do período entre guerras, visa projetar algumas possibilidades para o mundo no contexto pós-segunda guerra, considerando a vitória dos países aliados. Documento obtido junto à pasta AN45 AS45.
} 
sociais e econômicas, separadas pela defesa do capitalismo pelos norte-americanos, de um lado, e pelo avanço do socialismo com os soviéticos, de outro.

Neste cenário de competição pelo pensamento hegemônico e domínio da economia pelas potencias mundiais emergentes da segunda guerra, e apesar do engajamento de Lebret na leitura marxista, a teoria da luta de classes era rejeitada por ele, que dizia que esta divisão não contribuía com uma cultura de paz e harmonia entre os homens, uma vez que visava à aniquilação da classe dominante em detrimento de mais liberdade para a classe trabalhadora, que passaria a administrar o processo histórico. Assim, nos anos 1940, Lebret adotou em seu discurso e incorporou ao Économie et Humanisme a dinâmica do bem comum, ao invés de luta de classes, a qual foi atualizada, mais tarde, para desenvolvimento harmônico.

Esta noção da dinâmica do bem comum, apropriada por Lebret e difundida pelo $\mathrm{EH}$, a nosso ver também foi extraída da Encíclica "Rerum Novarum", escrita pelo papa Leão XIII, em 1891, numa crítica às ideias socialistas ${ }^{80}$. Para Leão XIII, segundo o que ele chamou de concórdia de classes,

\begin{abstract}
O homem deve aceitar com paciência a sua condição: é impossível que na sociedade civil todos sejam elevados ao mesmo nível. É, sem dúvida, isto o que desejam os Socialistas; mas contra a natureza todos os esforços são vãos. Foi ela, realmente, que estabeleceu entre os homens diferenças tão multíplices como profundas; diferenças de inteligência, de talento, de habilidade, de saúde, de força; diferenças necessárias, de onde nasce espontaneamente a desigualdade das condições. Esta desigualdade, por outro lado, reverte em proveito de todos, tanto da sociedade como dos indivíduos; porque a vida social requer um organismo muito variado e funções muito diversas, e o que leva precisamente os homens a partilharem estas funções é, principalmente, a diferença das suas respectivas condições. $^{81}$
\end{abstract}

A "Rerum Novarum" insistia em combater o conceito marxista de luta de classes, afirmando que "o erro capital na questão presente é crer que as duas classes são inimigas natas uma da outra, como se a natureza tivesse armado os ricos e os pobres para se combaterem mutuamente num duelo obstinado." Conclui que ambas as classes

\footnotetext{
80 Ao analisar a carta encíclica "Rerum Novarum" Poulat (1998, p. 137) aponta que, embora a mesma tenha sido o primeiro documento da autoridade católica a discutir a questão social e a condição do trabalhador, no final do século XIX, sua escrita ocorreu de forma tardia e em resposta ao Manifesto Comunista de 1848, renovando a posição colocada por Pio IX na "Syllabus" de 1864. A "Rerum Novarum" também vinha como resposta a Comuna de Paris em 1871 e ao prefácio de Engels à terceira edição alemã do Manifesto Comunista.

81 Trecho extraído da carta Encíclica Rerum Novarum, escrita pelo Papa Leão XIII em 1891, documento considerado como marco fundador da doutrina social da igreja católica.
} 
tinham "imperiosa necessidade uma da outra, pois: não pode haver capital sem trabalho, nem trabalho sem capital." (LEÃO XIII, 1891). Assim,

\begin{abstract}
L'Église romaine reconnaît à tout homme le droit, et même le devoir, de se déterminer en conscience - au for intime de la conscience dont Dieu seul est juge -, mais non à sa conscience de prétendre fair ela loi et de se régler sur ses décrets. II y a ainsi une progressivité du libéralisme catholique: l'Église s'abstienne d'intervenir dans I avie publique qui n'est pas son affaire et laisse les hommes en décider comme ils le pensent qu'elle s'abstienne d'intervenir dans $\mathrm{m}$ avie personnelle et familiae qui ne la regarde pas; qu'elle cesse de s'interposer entre les hommes et Dieu dans leur vie religieuse. (POULAT, 1998, pp. 138-139). ${ }^{82}$
\end{abstract}

Em nossa dissertação de mestrado (2009) apontamos que Lebret fez uso e manteve-se fiel à doutrina social do catolicismo, guiado pelas diretrizes ditadas pela "Rerum Novarum". Porém, substituiu as críticas rancorosas de Leão XIII aos socialistas, no final do século XIX, suavizando o discurso contrário a estes e absorvendo elementos críticos dos defensores do capitalismo e do desenvolvimento econômico a qualquer custo, passando a pregar o desenvolvimento harmônico, na tentativa de unir trabalhadores e empresários, apoiando-se num trabalho de conciliação entre os homens e as diferentes classes sociais, da mesma forma que tentava conciliar os aspectos positivos do capitalismo e do socialismo na elaboração de uma terceira via.

Assim, o grupo do Économie et Humanisme, dirigido por Lebret, é concebido de forma a ser um organismo crítico do liberalismo econômico, passando a pregar maior regulação, afirmando que crescimento e desenvolvimento não são sinônimos, e que mais importante do que crescer economicamente a qualquer custo era desenvolver a sociedade, perpassando áreas além da economia, como as questões sociais através do desenvolvimento de programas e ações para a saúde, a educação e a cultura, "a partir de um cruzamento (nada ortodoxo e nada acadêmico) entre a ética tomista do bem comum e a reconstituição crítico-estrutural que Marx fizera do sistema capitalista" (BOSI, ibid., p. 264).

Este perfil de conciliação presente na figura humana do padre Lebret, a nosso ver, devese ao antagonismo da sua convivência com as teorias marxistas, que criticavam o

\footnotetext{
${ }^{82}$ A Igreja Romana reconhece a cada homem o direito, até mesmo o dever de determinar sua consciência - a consciência íntima de que só Deus é o juiz - mas não sua consciência fugindo da lei e seus decretos. Existe, portanto, uma escalada do liberalismo católico: a Igreja se abstém de intervir na vida pública, que não é o seu caso, e deixa os homens decidirem como eles pensam e abstém-se de intervir em sua vida pessoal e familiar; ela deixa de ficar entre o homem e Deus em sua vida religiosa. (Livre tradução do autor).
} 
capitalismo, e o seu vínculo de sacerdote, obediente à igreja católica, o que o tornava um crítico do socialismo, já que em 1937, a carta Encíclica "Divini Redemptoris", escrita por Pio XI, reafirmava a hostilidade da igreja em relação ao comunismo e às teorias marxistas. Ainda assim, Pelletier (1996, p. 115) aponta que existia uma conexão de Lebret com Marx, de forma que "une analyse (celle Marx) et une experiénce (celle du père Lebret) se rencontrent dans une même indignation devant le système capitaliste". Segundo Puel,

L'économie humaine n'est ni pour le marxisme, ni contre le marxisme ni au-delà du marxisme. Elle part de la réalité économique que Marx, parmi tous les économistes, a le mieux cernée dans toutes ses dimensions et ele applique à cette réalité une méthode originale: l'enquête socio-économique impliquant les acteurs concernes dans son processos, c'est-à-dire dans la collecte des données, l'analyse des structures, la découverte des mesures à prendre pour passer d'une situation inhumaine ou mais humaine à une situation plus humaine. (2004, p. 72). ${ }^{83}$

Desse modo, o Économie et Humanisme reconhecia o marxismo como um método científico para a interpretação socioeconômica e seus desdobramentos, o que é entendido por Pelletier como a tentativa de reencontro da tradição católica com as ciências humanas, a exemplo do que Lebret havia realizado com os pescadores da Bretanha, salientando que "L'économie humaine doit être une discipline de synthèse, le point de rencontré de toutes les sciences de l'homme et de la société" (1996, p. 42). Esta afirmação de Pelletier é confirmada também por Rios ao expor que Lebret tinha clareza sobre suas obrigações religiosas e ao mesmo tempo conseguia distinguir ciência de religião, não empregando erroneamente a teoria marxista, mas tendo absoluta clareza de que a mesma se tratava de um método científico.

Já para Bosi (2010, p. 265), a afinidade de Lebret com Marx é ainda maior, pois "a ortodoxia the aparece como uma forma de cumplicidade com a exploração capitalista, o que é a própria denúncia da ideologia burguesa." Ainda assim, o autor destaca a supressão, ou filtragem, de expressões marxistas como "acumulação capitalista", "mais valia" e "valor trabalho", que, conforme já expusemos, ganham nova roupagem no

\footnotetext{
${ }^{83}$ A economia humana não é nem pelo marxismo nem contra o marxismo ou além do marxismo. Ela é baseada na realidade econômica que Marx, de todos os economistas, foi quem melhor definiu em todas as suas dimensões e aplicou dentro desta realidade um método original: o levantamento socioeconômico envolvendo as partes interessadas em seus processos em questão, ou seja, na coleta de dados, análise de estruturas, a descoberta de meios de se transformar uma situação desumana em uma situação humana. (Livre tradução do autor).
} 
discurso em defesa de uma economia humana, que consistia numa economia a partir das necessidades do homem. De forma que,

\begin{abstract}
O valor da mercadoria teria, de todo modo, a ver com necessidades objetivas dos grupos humanos, e Economia e Humanismo seria em primeiro lugar, um reconhecimento e uma taxinomia dessas necessidades. O valor supremo é o bem comum, ideal atingido quando as necessidades das populações locais tiverem sido satisfeitas sem permitir que os gastos supérfluos e ostentatórios das classes altas aprofundem os males da concentração de renda, situação iníqua por excelência. (ibid., p. 265).
\end{abstract}

Assim, em 1941, com sede em Marseille, foi fundado o Centre Économie et Humanisme, conforme Estatuto ${ }^{84}$ que foi depositado na Prefeitura de Bouche du Rhone, em 24 de setembro deste ano, sendo oficializado pela municipalidade em 10 de outubro. Com a formalização do grupo, René Moreaux, formado em economia, amigo de Lebret desde a Marinha, com experiência de pesquisa à frente da "Revista da Marinha Mercante" e tendo apoiado Lebret e Suavet no movimento de Saint-Malo, onde contribuiu para a reforma dos pescadores e formação da cooperativa dos mesmos, foi escolhido como primeiro presidente. A vice-presidência coube a François Perroux, economista e professor da Faculdade de Direito de Paris, autor da teoria sobre o desenvolvimento harmônico e um dos principais intelectuais a contribuir com a formação econômica de Lebret. Segundo Pelletier (1996, p. 34), foi o principal intelectual a introduzir na França o trabalho da escola marginal vienense, rompendo com a tradição "Durkheiniana" na sociologia francesa.

Além dos economistas Perroux e Moreaux, a ata de fundação do grupo apresenta o nome de mais cinquenta participantes, divididos em: membros titulares, personalidades escolhidas pelo movimento, personalidades escolhidas por indicação de superiores ou semelhantes, teólogos, teólogos responsáveis por trabalhos e teólogo convidado ${ }^{85}$. Cabe esclarecer que entre os religiosos apontados, os teólogos responsáveis por trabalhos e o Padre Candeau, teólogo convidado, somavam vinte pessoas dentro do grupo, de forma que os leigos, embora a maioria ligada à igreja católica, eram numericamente superiores

\footnotetext{
${ }^{84}$ O Estatuto do Centre Économie et Humanisme faz parte da documentação consultada junto à Pasta AN45 AS35.

${ }^{85} \mathrm{O}$ artigo $3^{\circ}$ do Estatuto do movimento aponta que os membros da associação se compõem de duas categorias distintas: os membros titulares, limitados a um máximo de vinte pessoas, as quais formariam a diretoria da associação, e os membros aderentes. Quanto aos membros titulares há ainda a distinção entre os membros titulares do conselho de direção e os membros titulares nomeados por teólogos católicos que seriam indicados por autoridades eclesiásticas. Documento consultado na Pasta AN45 AS35.
} 
aos padres no EH. Na composição da primeira diretoria coube ao empresário Alexandre Dubois o comando da tesouraria e aos padres Lebret e Suavet o controle da secretaria geral e da secretaria adjunta ${ }^{86}$.

Assim, além do padre Lebret, o Centre d'Économie et Humanisme contava com a participação dos religiosos Marie-Fabien Moss, Marie-Réginald Loew, Alain-Zacharie Serrand, Bouche, Henri Desroches, Thomas Suavet, Joseph-Marie Perein, Tonneau, Labodrdette, Hynacinthe Paissac, Chenu, Lajeunie, Norbert Malley, Raymond Martin, Noël Bouille, Benoît Allo, Thomas Allegre, Grandin e Candau.

Entre os membros titulares foram indicados os nomes de Ernest Lamort, Paul Colin, André Laulhere e sua esposa, Gérard Marcy, Léon Bonnasse, Jean Courbier, Jean Quenau, A. Piettre e dos que compunham a diretoria: Gustave Thibon, Jean-Marie Gatheron e Alexandre Dubois. Além dos membros titulares também foram apontados os nomes de mais dezoito personalidades: Alexandre Chaseaux, François Picard, Paul Bacaon, Bourais ou Esperet, André Villette, Louis Naillod, Lucien Rozf, Bourriere, Raymond Delprat, Jacques User, Jacques Merand, Yves Chareton, Francie Roret, M. Dubruel, M. Levi, Alice de Montmirail, Claude Vo-Thank-Loc e René Fantapie.

Segundo o Estatuto da Associação Économie et Humanisme, a mesma foi constituída para estudar através de "enquêtes et tous autres moyens d'investigation appropriés" as realidades humanas, econômicas e sociais do contexto atual; provocar, por meio de seus membros, o olhar do trabalho científico para se alcançar a elaboração de uma doutrina econômica, espiritualista, colocando a economia a serviço do homem; e suscitar o senso dos diversos profissionais ou de certas categorias econômicas, das técnicas e dos profissionais capazes de determinar as condições concretas do Bem Comum na sua profissão ou na sua região de trabalho, de forma a propiciar a participação de esforços públicos e privados na reorganização econômica e profissional ${ }^{87}$.

A exposição de motivos para a constituição da associação fundada por Lebret, transcrita no Estatuto de criação do grupo, deixa clara a intenção do Économie et Humanisme em se tornar uma instituição voltada ao pensamento de uma doutrina econômica e social, o que expõe a ambição dos seus membros de se tornarem uma referência no engajamento social frente às demais tarefas a serem assumidas junto a organismos da sociedade, como as esferas de governo. A instituição criada por Lebret é, portanto, um

\footnotetext{
${ }^{86}$ Conforme documento consultado na Pasta AN45 AS35.

87 Conforme apontado nos parágrafos $1^{0}, 2^{0}$ e $3^{0}$ Artigo $1^{0}$ do Estatuto, cujo Documento foi consultado junto à Pasta AN45 AS35.
} 
organismo voltado a pensar novas formas de desenvolvimento econômico e social, que vislumbra impor-se não só como um contraponto às instituições dominantes, mas como um conciliador e mediador destas relações, buscando contribuir para o avanço do que era pregado na Europa pela democracia cristã e pelos sociais democratas, a busca de uma terceira via em relação ao capitalismo e ao socialismo.

A primeira diretoria de EH redigiu o ato de fundação chamado de "Manifeste d'Économie et Humanisme", publicado somente em 1942, no primeiro número da Revue Économie et Humanisme, também criada pelo grupo. O Manifesto apontava que a instituição caminhava em busca da esperança de uma ordem social cristã, capaz de conciliar o ideal comunitário e a organização corporativa dos profissionais. O rigor ideológico contido no manifesto, pregando uma cultura de paz e tecendo duras críticas ao liberalismo econômico, constituiu, para Pelletier e Puel, uma virada política um tanto modesta, porém um tormento teórico capaz de municiar a intelectualidade francesa contrária ao regime de Vichy.

Neste primeiro momento, sob a presidência de Moreaux, a principal tarefa do grupo, além da estruturação do método de trabalho, foi a difusão do ideário lebretiano ${ }^{88}$, através da edição da "Revue Économie et Humanisme", com tiragem bimestral. Seu conteúdo trazia artigos e ensaios sobre economia e críticas políticas ao regime de Vichy, além de análises sociológicas sobre ações do empresariado e do Estado francês. Cabe apontar também a interface da revista com o ideário urbano, conforme aponta Roldan (2012, p. 57), com o primeiro número trazendo uma resenha de Loew sobre o "Problème d'urbanisme", trabalho do urbanista francês Gaston Bardet.

\footnotetext{
${ }^{88}$ Conforme já apontamos, a indicação do ideário lebretiano foi um termo indicado por nós no plano de pesquisa para nosso doutorado, cabendo aqui expor que distinguimos "ideário" de "ideologia", pois, segundo Lukács "nem mesmo uma difusão social mais ampla é capaz de transformar um complexo de pensamentos diretamente em ideologia. Para que isso ocorra é necessária uma função social bem determinada, que Marx descreve distinguindo com precisão os abalos materiais das condições econômicas das produções e 'formas jurídicas, políticas, religiosas, artísticas ou filosóficas, ou seja, as formas ideológicas que permitem aos homens conceber esse conflito e combate-lo'" (Lukács, 1981, p. 445).
} 


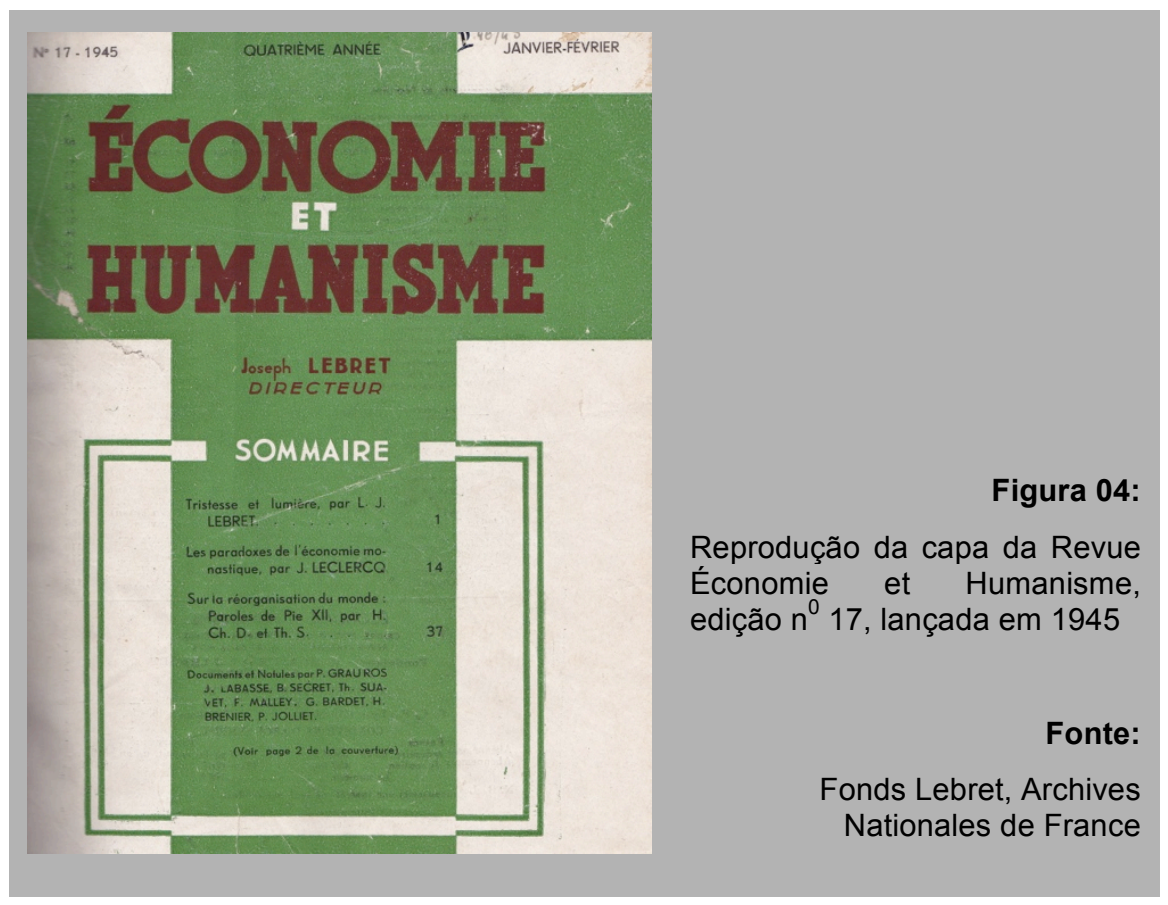

Além da forma de organização do $\mathrm{EH}$ e das áreas de interesse do movimento, o estatuto do grupo ${ }^{89}$ aponta, em seu parágrafo $2^{\circ}$, que mais do que pesquisar a realidade social e econômica dos homens, a maior ambição do grupo é provocar seus membros através do trabalho científico para suscitar a elaboração de uma nova doutrina econômica, de forma a impor "l'économie au service de l'homme". Assim, conforme Bosi já apontou, Roldan também toca no vínculo entre as matrizes marxista e tomista em Lebret,

\begin{abstract}
A economia humana procura se exprimir não somente como doutrina social da igreja católica, mas também em termos de teoria econômica. E neste ponto parecem se encontrar as duas correntes de pensamento: uma matriz marxista e outra tomista.

Sendo que para a autora "da matriz de Marx retém-se a noção de mais-valia através da análise da relação valor-trabalho em que o valor da mercadoria é medido socialmente pelo tempo de trabalho e a exploração residiria justamente neste ponto, na medida mesma em que o trabalhador gera um sobretrabalho que é capturado pelo dono da fábrica. Já a matriz tomista parte da teoria do preço justo colocando o foco nas relações de troca do comércio sob um viés ético da justiça das trocas, não se atendo às relações que se estabelecem na produção." (2012, p. 35).
\end{abstract}

Em meio a estas teorias econômicas, anseios e expectativas é que a organização da metodologia de trabalho do Économie et Humanisme foi desenvolvida por Lebret, que

${ }^{89}$ Documento obtido na Pasta AN45 AS35. 
contou com o apoio de Désroches, Suavet e André Laulhere, os quais participaram de discussões sobre a ordem comunitária e os escalões de análise, apontando a família como um primeiro grupo comunitário dentro destes escalões de pesquisa empírica, e também que a análise deveria ser feita de baixo para cima, entre os mais próximos ${ }^{90}$. Porém, é importante dizer que neste período inicial do EH a elaboração do método de trabalho do grupo consistia, de forma mais enfática, a encontrar maneiras de proceder com a interpretação da realidade social e econômica ${ }^{91}$, não havendo uma abordagem direta da questão urbana e da vida nas cidades.

Percebe-se então que o método introduzido por Lebret no $\mathrm{EH}$ teve como norma o empirismo, trabalho interpretado como pouco científico pelos intelectuais franceses das áreas de filosofia e sociologia. Mas, para Pelletier, Lebret opôs-se à maneira tradicional de fazer análises econômicas e sociais, sendo que

Cette méthode, hypothético-déductive, suppose d'abstraire de la complexité du réel un certain nombre de phénomènes économiques, et de leur appliquer un raisonnement économique d'ordre logique à partir d'hypothèses restrictives préalables. (ibid., pp. 123-124). ${ }^{92}$

Desta forma, contrariando a tendência dos economistas tradicionais, Lebret buscou, através do Économie et Humanisme, uma maneira de analisar a realidade social, de forma a deduzi-la e explicá-la concretamente, diferenciando o "homo aeconomicus" dos valores econômicos, abrindo espaço para uma economia das necessidades humanas e criando uma hierarquia destas necessidades. Segundo Pelletier, "les refus de la méthode hypothétique joue face à la tradition des économistes libbéraux un rôle analogue à celui

\footnotetext{
${ }^{90}$ A base de pesquisa a partir da "célula doméstica" é apontada na metodologia de trabalho de Le Play, desde os anos 1880 na França, sendo perceptível a ressonância das ideias para outros períodos, incluindo o Économie et Humanisme. Nos EUA, Donald Pierson (1946) afirma também que "uma das organizações sociais mais universais e fundamentais é, obviamente a família" numa referência de que os estudos sobre a comunidade e a organização social deveriam partir do núcleo doméstico-familiar.

91 Mais uma vez percebemos aproximações de Lebret com a sociologia norte americana, pois Gordon Brown e James Barrett definem o que seria interpretação da realidade social e econômica a partir da organização social e da estrutura social dentro das ciências sociais, apontando que "a estrutura social se refere à colocação e posição de indivíduos e de grupos dentro do sistema de relações de obrigações", que seriam estabelecidas pela "organização social que refere-se aos sistemas de relações de obrigação que existem entre os grupos que constituem uma sociedade" (1946, p. 174).

92 Este método hipotético-dedutivo envolve abstrair a complexidade de uma série de fenômenos econômicos reais, e aplicar um raciocínio económico lógico de hipóteses restritivas anteriores. (Livre tradução do autor).
} 
de l'utopie communautaire face à l'individualisme des cociétés industrielles" (PELLETIER, ibid., p. 124). Assim, se há alguma contradição entre Lebret e os economistas tradicionais, não notamos contraponto entre Lebret e o que praticavam os sociólogos da época em suas definições sobre a análise da realidade social, o que tornaria possível inserir o trabalho interpretativo do padre dominicano dentro do campo das ciências sociais e não da economia.

O método desenvolvido por Lebret foi publicado em 1944 sob o título "Méthode d'enquête" ${ }^{\text {"93 }}$, apontando para maneiras de interpretação da realidade social e econômica e apresentando o método de trabalho que $\mathrm{O} \mathrm{EH}$ introduziu em seus estudos para compreender a vida em comunidade, a realidade social destas comunidades e constituir uma economia das necessidades. O método trazia referências às disciplinas de economia, estatística, sociologia e geografia, apontando para a necessidade do pesquisador ir a campo buscar suas referências e conhecer a realidade social.

Nesta primeira versão do manual que detalha o método desenvolvido por Lebret através do Économie et Humanisme, a questão urbana é apontada como um pano de fundo, porém, notamos avanços do grupo em relação à preocupação com as cidades e os modos de morar, sobretudo no pós-guerra, quando Lebret redigiu um trabalho sobre um plano emergencial para a reconstrução das cidades francesas que haviam sido atacadas pela guerra e parcialmente destruídas.

Percebe-se então que Lebret impõe aos pesquisadores a necessidade de impregnaremse da realidade, não se limitando apenas aos métodos tradicionais e aos números obtidos através da estatística, o que, para Pelletier, "se révèle à son tour décevante, car ele impose à sélection de critères quantifiables au risque de perdre de vue eles éléments qualitatifs du modo de vie" (ibid., p. 134).

Desta forma é possível afirmar que o trabalho de Lebret, como pesquisador, propunha inovação frente às pesquisas científicas, pois rompia com tradições clássicas da economia e da estatística, mas não da sociologia. Numa mesma ação ele integrava a economia e a estatística aos demais campos do saber, como a sociologia, abrindo espaço para o trabalho interdisciplinar. Assim, à medida que o Économie et Humanisme se firmava como instituição e disseminava suas ideias, estes avanços no método interpretativo eram incorporados às enquetes e estudos realizados e difundiam-se por

\footnotetext{
${ }^{93}$ No mesmo ano a Révue Économie et Humanisme publica o artigo "La méthode d'économie et humanisme" assinado por Lebret e Desroches. REH, Ecully, v. 3, n. 12, pp. 121-134, Mar-Avr, 1944 e v. 3, n. 13-14, pp. 225-258, Mai-Jul, 1944.
} 
demais países, fato possibilitado também pela liberação da circulação dos cidadãos ocorrida em 1944, após o fim da segunda guerra.

O momento da liberação da circulação coincide com o período em que o Économie et Humanisme já se apresentava de forma mais consolidada na França, já havia realizado alguns encontros, chamados de Semanas Sociais, onde novos adeptos se juntavam ao grupo de Lebret. Para Bosi,

Com o fim da guerra, em plena euforia da Libertação, seria de esperar que o padre Lebret, já apartado de sua breve e frustrante relação com as autoridades da França ocupada, se aproximasse de uma das principais correntes políticas do pós-guerra, o Movimento Republicano Popular, MRP, que apresentava um programa autodenominado "democrata cristão". (2010, p. 269).

Neste contexto em que as ideologias e as forças hegemônicas ascendiam no pós-guerra, o Centre d'Économie et Humanisme também se firmava e mostrava condições de expandir suas atividades, bem como difundir suas ideias. Daí a aproximação de Lebret com o MRP, o que, a nosso ver, se deu pela visão estratégica do padre numa tentativa de emplacar o grupo e vislumbrar a possibilidade de influenciar nas decisões de governo, ainda que,

\footnotetext{
O foco mesmo de suas inquietações, a iniquidade que feria a divisão de classes na França e repartia o mundo em povos ricos e povos pobres, não era manifestamente a questão prioritária dos democratas cristãos que estavam então chegando ao poder na França, na Itália, na Holanda, na Alemanha e na Bélgica. (ibid., ibidem).
}

Para alcançar este objetivo de influenciar o governo que se iniciava, como já estava previsto no estatuto de fundação do grupo, teve início a criação do que podemos chamar de rede de $\mathrm{EH}$, visando angariar novos adeptos, capitalizar recursos para o funcionamento do grupo e difundir o que o grupo chamou de Economia Humana e Desenvolvimento Harmônico. Esta aproximação com o MRP rendeu alguns contratos ao grupo de Lebret junto ao Ministère de la Reconstruction et Urbanisme, que tinha como seu titular o Ministro Raoul Dautry. Em 1946 foram realizados quatro estudos sobre as condições de habitação, contratados pelo Ministère de la Reconstruction et Urbaine para quatro cidades francesas - Lyon, Marseille, Nantes e Saint-Etienne, que envolveram técnicos ligados ao Économie et Humanisme. 
Assim, além da "Revue Économie et Humanisme", em circulação desde 1942, o EH lança a livraria do grupo, em 1947, com sede em Paris, atuando como editora e publicando exemplares de obras escritas por Lebret, Desroches e outros membros da associação. Além dos trabalhos de membros do grupo, também era feita a publicação de escritos de personalidades que tinham alguma vinculação com o Économie et Humanisme, como o urbanista Gaston Bardet, que teve pulicado pelo EH a obra "Mission de I'Urbanisme", em $1949^{94}$. Cabe também mencionar que a contratação de pesquisas a Lebret, pelo Ministère de la Reconstruction et Urbanisme, culminou com a criação de laboratórios de pesquisa locais, constituídos em forma de associações, permitindo assim um crescimento da área de atuação do Centre d'Économie et Humanismee e a ascensão de novos nomes na linha de frente do grupo, como Jacques Gauducheau, à frente da equipe de Nantes (CREDOC - Centre Regional de Documentation et de Conjoncture); Jacques Loew no IMSAC (Institut Marseillais de statistique et d'analyse et de conjoncture) e Jean Queneau $^{95}$, em Saint-Étienne com a SAGMA (Societé pour l'application du graphisme et de la mécanographie à l'analyse).

A criação do CREDOC, do IMSAC e da SAGMA, em 1945, por outros membros do grupo do $\mathrm{EH}$, foi um importante marco na disseminação das ideias da equipe, sobretudo no engajamento de técnicos em um trabalho de aménagement du territoire, além do estabelecimento de um elo de ligação com o Ministère de la Reconstruction et Urbanisme da França. Já o ano de 1947 marcou profundamente o processo de expansão das atividades de Lebret e seu grupo, expansão esta possibilitada pela viagem realizada por ele a países da América Latina, onde permaneceu por quase seis meses, tendo em São Paulo, no Brasil, ministrado o curso de pós-graduação em Economia Humana na Escola de Sociologia e Política - ELSP, e fundado a SAGMACS, instituindo de forma oficializada a cooperação institucional de intelectuais e técnicos brasileiros com o Économie et Humanisme francês.

Segundo Pontual (2014, p. 174), "no dia 5 de abril de 1947, Lebret chegou ao Rio de Janeiro, tendo sido recebido pelos padres Dupuy e Jophly. Dois dias depois, efetivou-se

\footnotetext{
94 Sobre a aproximação entre Lebret e Bardet, é importante dizer que, embora documentos evidenciem a troca de correspondências entre ambos somente a partir de 1946, Roldan (2012, pp. 59-65) afirma que as ideias do urbanista francês já se faziam presentes no grupo através da Revista do Économie et Humanisme, desde sua primeira edição em 1943, através de resenha assinada por Loew sobre o livro "Problème d'Urbanisme" de Gaston Bardet. A sequência de cartas trocadas entre ambos foi consultada junto à documentação da Pasta AN45 AS70.

95 Jean Queneau era um empresário, com formação em engenharia e foi um dos dirigentes do $\mathrm{EH}$ no final dos anos 1960. Segundo Roldan (2012, p. 81), Queneau "frequentou La Toureette, participou da construção do método de $E H$, coordenou as publicações dos 'Guide pratique de l'enqête sociale' e teve forte atuação na SAGMA."
} 
um encontro com Alceu Amoroso Lima" que o apresentou "às elites da democracia cristã". Já em São Paulo, Lebret chegou no dia 9 de abril, sendo recebido pelo padre Romeu Dale e, na sequência, por Cyro Berlinck, Diretor da ELSP, que abriu a instituição para que o padre proferisse um curso de pós-graduação sobre a economia humana.

A partir de então se efetivam as primeiras ações de Lebret que marcaram a sua atuação no Brasil: o curso Introdução à Economia Humana, a fundação da SAGMACS e os estudos voltados para a habitação e o planejamento urbano e regional realizados em diversos estados brasileiros. Ao lado dessas ações, foram feitas articulações com a Juventude Operária Católica (JOC) e a Juventude Universitária Católica (JUC), ambas integrantes da Ação Católica Brasileira (ACB), assim como movimentos de cunho eminentemente religioso, especialmente no Rio de Janeiro e em São Paulo. (ibid., pp. 175-176).

Antes de falarmos da criação da SAGMACS e do vínculo estabelecido por Lebret no Brasil, bem como de que forma ocorreu esta abertura para a vinda do dominicano em 1947, daremos continuidade, neste capítulo, à exploração das matrizes que enredam o pensamento e o ideário lebretiano no que tange aos métodos desenvolvidos pelo Économie et Humanisme e também à incorporação da questão urbana pelo grupo francês, nos idos da década de 1940.

\subsection{A incorporação da questão urbana pelo Économie et Humanisme}

Conforme já apontado, a questão urbana não foi um objeto inserido de imediato junto ao Centre d'Économie et Humanisme. Sua incorporação foi se dando de forma gradativa e passou a ser mais nítida a partir de 1945, tanto porque o tema foi exposto nas Sessões do $\mathrm{EH}$, quanto pelo fato do grupo de Lebret ter se aproximado do Ministère de la Reconstruction et Urbanisme da França, o que Ihe rendeu alguns trabalhos que tiveram sua contratação formalizada para que organismos do $\mathrm{EH}$ orientassem o ministério na formulação de um programa de construção de novas habitações nas cidades que haviam sido arrasadas durante a Segunda Guerra. 
Na Sessão de La Tourette, em 1945, Jean Marie Gatheron expôs aos participantes "La

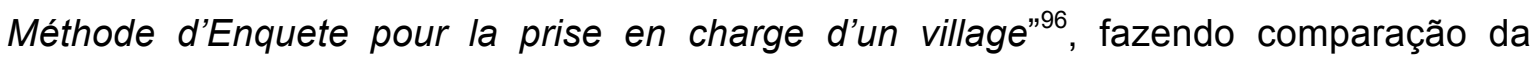
organização familiar com uma cidade, e dizendo que, pelo fato das famílias terem migrado para os centros urbanos, a cidade transformou-se também no local da economia e da agregação de valores culturais, sociais e políticos, passando a ser o cenário principal das relações humanas. O autor afirma que no grupo familiar é que se percebe a economia de forma racional, pois ali é que se verifica que toda a produção econômica se pauta a partir das necessidades de um segmento social.

Les complexes économiques doivent être étudiés d'abord en partant de la famille - c'est-à-dire de la cellule fondamentale de vie. De la famille, vous êtes passés tout naturellement à la cité. Les deux éléments sociaux: la vie de la famille est la vie de la cité sont reliés par l'étude de l'habitat qui est précisément un des éléments qui conditionnent le niveau d'existence de la famille. ${ }^{97}$

Sobre a incorporação do tema da cidade pelo grupo, antes da exposição de Gatheron, em Nantes, na sessão ocorrida em abril do mesmo ano, Lebret fez seis exposições, sendo a maioria delas voltada para a apresentação da origem e das linhas mestras do Économie et Humanisme. A exposição de 22 de abril abordou assuntos sobre a economia urbana, numa palestra intitulada "La Distribuition géographique nationnelle des centres de production et d'habitat', discorrendo sobre a localização das cidades industriais e dos habitantes na França, abordando alguns pontos do planejamento urbano e regional à luz da planificação econômica.

Verificamos, então, que a terminologia cidade surge nas Sessões do EH de 1945, com as exposições de Gatheron e Lebret, mesmo ano em que o grupo se aproxima do Ministère de la Reconstruction et Urbanisme, criado pelo governo francês para realizar ações sobre as cidades que haviam sido arrasadas pela guerra, terminada há pouco. A partir de então, a cidade e a questão urbana são incorporadas em outros discursos e textos do frei dominicano, para as sessões dos anos seguintes. Porém, é importante dizer que o binômio campo e cidade são expostos pelo Économie et Humanisme como organismos que se complementam e que não poderiam ser tratados separadamente sob o ponto de

\footnotetext{
96 Roteiro de Exposição de Jean Marie Gatheron para a Sessão de La Tourette em setembro de 1945. Documento consultado na Pasta AN45 AS45.

97 Os complexos econômicos devem ser estudados, em primeiro lugar, a partir da família - isto é, a unidade fundamental da vida. Família, que veio muito naturalmente para a cidade. Os dois fatores sociais: vida em família e vida da cidade são ligados aos estudos do habitat, que é precisamente um dos elementos que determinam o padrão de vida da família. (Livre tradução do autor).
} 
vista do desenvolvimento econômico, para não comprometer a produção de riqueza no mundo e nem impedir o avanço das atividades industriais sobre a cidade.

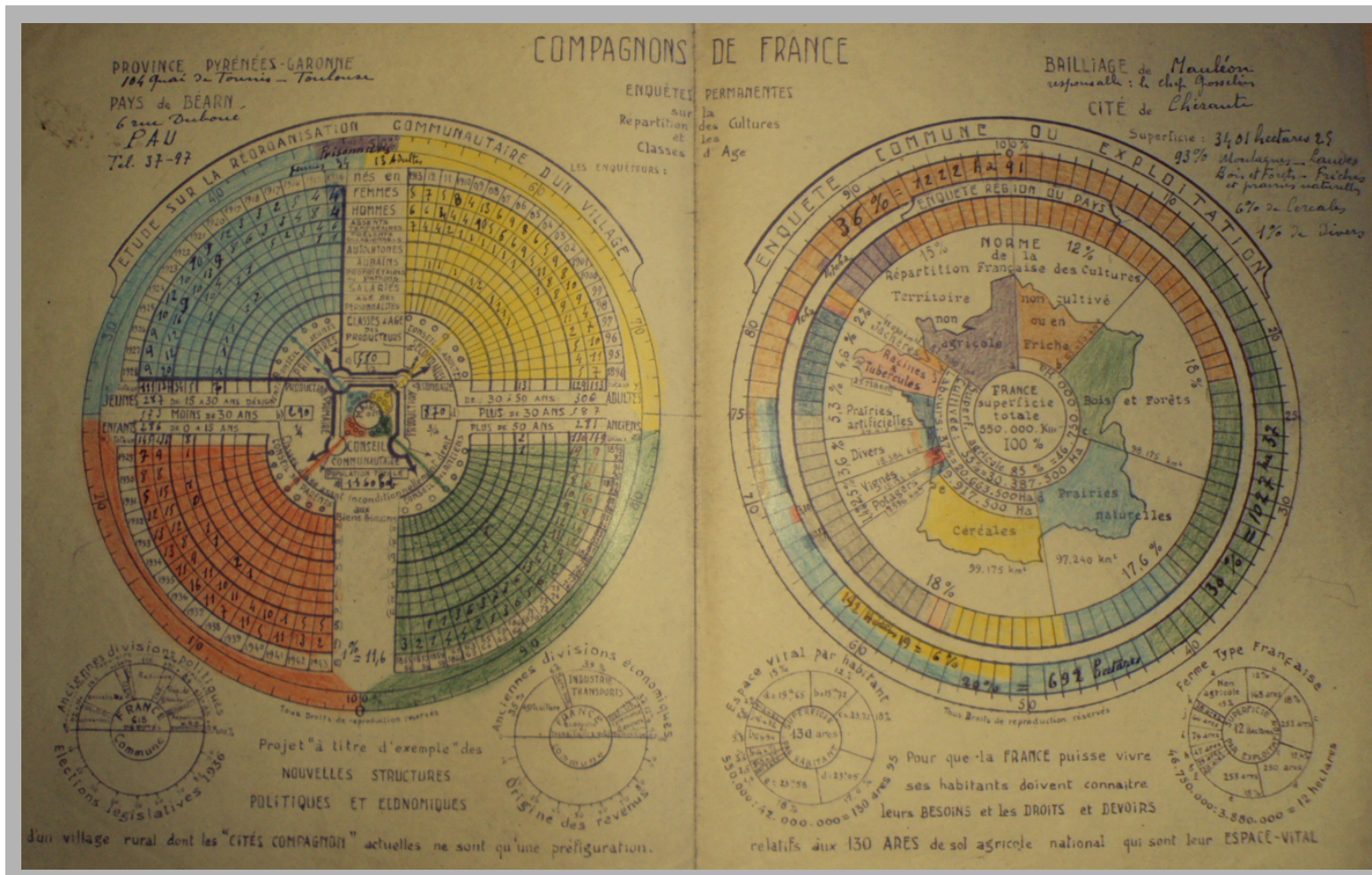

Figura 05:

Reprodução de diagrama constante no "Rapport sur les affaires économiques" da Comission des economistes du Tarn, apresentado em 1946.

Fonte:

Fonds Lebret, Archives Nationales de France, Pasta AN45 AS58

Esta impressão, obtida a partir da análise dos documentos referentes aos temas abordados nas Sessões promovidas pelo $\mathrm{EH}$, coincide com as observações de Roldan sobre as publicações relativas ao tema em outro meio de atuação e divulgação do grupo: a "Revue Économie et Humanisme". A autora afirma que é "a partir de 1945 que a discussão acerca do urbano toma corpo dentro da revista. Ela se dá em duas frentes (complementares): uma se coloca em debate com modelos urbanos ou teorias urbanísticas; e outra se debruça sobre o problema da habitação." (2012, p. 65).

Em 1945, Lebret escreve o editorial da revista intitulado "Tour de France" onde procura reconhecer uma complexidade política, econômica e social nova 
naquele momento e propor as diretrizes para a reconstrução francesa. Nele, Lebret revela seu olhar sobre as cidades francesas [...] reconhece a dimensão da destruição processada nas cidades e a disparidade dos meios socialmente disponíveis para a auto-reconstrução com a expansão da miséria, da insalubridade e da superlotação habitacional. Diante de tal fato, apela por um plano de reconstrução do conjunto da França. E para tal, seria necessário detectar metodicamente os problemas encontrados a partir de análises minuciosas das cidades francesas, o que exigiria colocar em ação seu método de pesquisa empírica. (ibid., p. 79).

Em relação à incorporação da questão urbana pelo grupo e à apropriação dos estudos sobre os problemas da cidade, é preciso mencionar a aproximação de Lebret com o urbanista francês Gaston Bardet ${ }^{98}$. Em 1946, ambos iniciam uma troca de correspondências que se estende até $1951^{99}$, quando Bardet se distancia do Économie et Humanisme criticando "la marxisation" do movimento devido à presença das teorias de Marx, consideradas por ele como anticristãs. A carta de Bardet a Lebret, assinada em 3 de fevereiro de 1950, mostra o urbanista francês mais temente às normas impostas por Pio XII quanto à condenação do marxismo, do que o próprio padre Lebret, que devia obediência ao papa.

A julgar pela publicidade dada aos artigos e livros escritos por Bardet na Revue Économie et Humanisme, e o período de proximidade entre Lebret e o urbanista, é possível perceber que o trabalho de Bardet rende ao Économie et Humanisme uma melhor compreensão da questão urbana, sendo evidente a apropriação, pelo grupo, de algumas das ideias defendidas pelo urbanista, como a relação entre o campo e a cidade, de forma a exercerem atividades complementares. Tanto que a publicação 'L'Enquête Rurale: L'Analyse de la Commune et du Canton" é publicada pelo grupo em $1951^{100}$, tendo Bardet entre os autores que colaboraram com o trabalho, enquanto que "L'Enquête Urbaine: L'Analyse du Quartier et de la Ville" é publicada somente em 1955, e sem o nome de Gaston Bardet.

Porém, se Bardet é figura recorrente nas publicações da Revue mantida pelo grupo de Lebret, o mesmo não ocorre em relação à abertura do Économie et Humanisme e à

\footnotetext{
${ }^{98}$ A pasta AN45 AS 44 apresenta uma exposição de Gaston Bardet sobre a instalação do Comitê de Estudos sobre o Território, em maio de 1944.

${ }^{99}$ Levantamos a sequência de correspondências trocadas entre Lebret e Bardet, conforme consulta aos documentos inseridos na Pasta AN45 AS53. De acordo com as correspondências, a sequência foi iniciada por Gaston Bardet com carta datada de 03/02/1946, 02/10/1946, 31/01/1948, $18 / 05 / 1950,11 / 10 / 1950,03 / 11 / 1950,03 / 02 / 1951$ e $08 / 05 / 1951$. As cartas de Lebret em respostas a Bardet datam de: 15/11/1946, 14/12/1946, 18/02/1948, 22/05/1950 e 03/11/1950.
}

100 Conforme documentos consultados na Pasta AN45 AS144. 
participação do urbanista nos eventos realizados para a disseminação do método e filiação de novos membros ao grupo, como as Semanas Sociais, onde os temas da questão urbana e rural, o estudo sobre a cidade e o desenvolvimento regional incidem a partir de 1945.

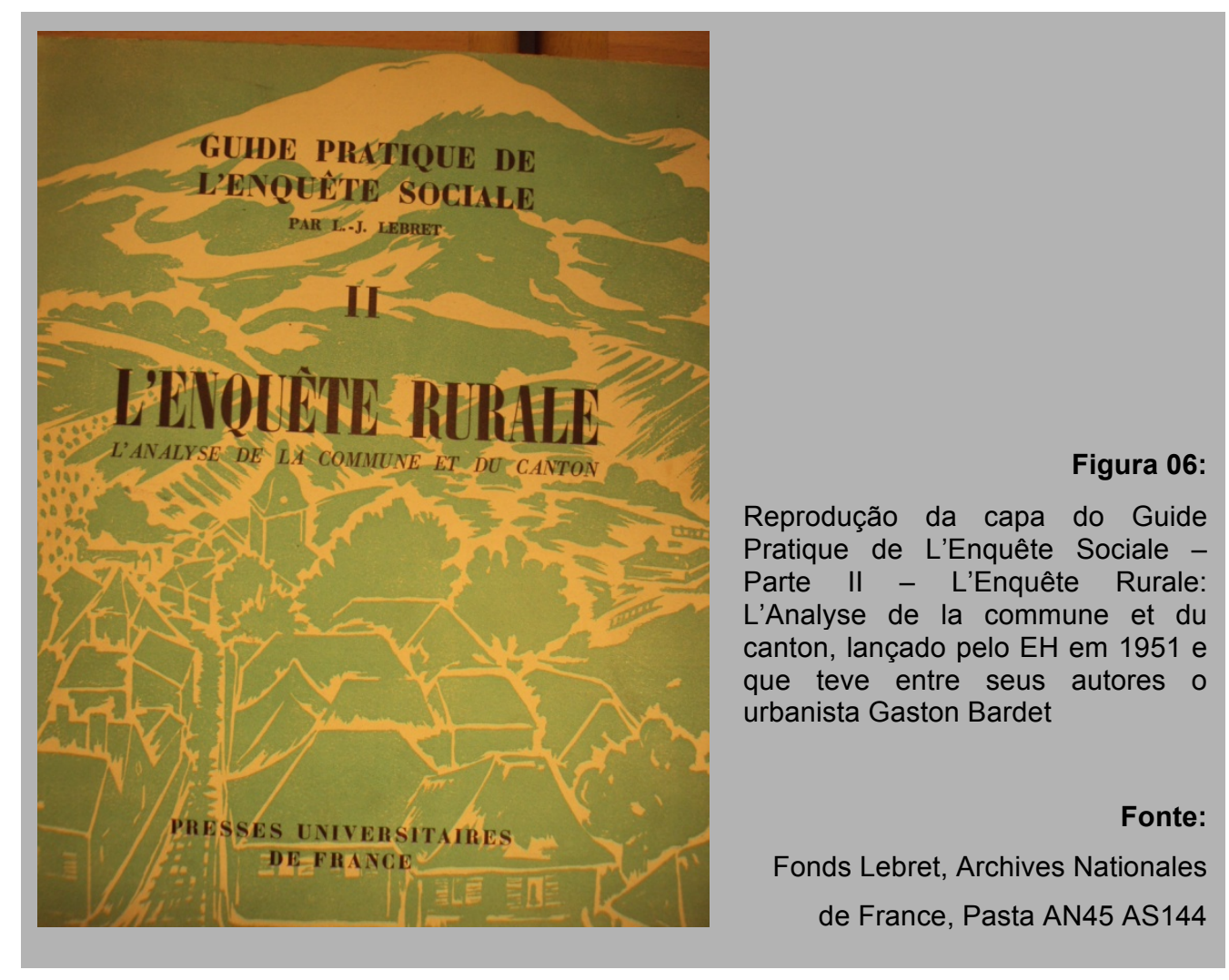

Independentemente da participação de Bardet junto ao grupo de Lebret, nos anos 1940, é fato que o urbanista francês já era considerado, neste período, uma importante referência nos estudos sobre a cidade e nas teorias de desenvolvimento e planejamento dos espaços urbanos. O relatório de atividades apresentado pelo próprio Économie et Humanisme, em 1951, num balanço sobre os dez primeiros anos do grupo, aponta, conforme já expusemos, que o $\mathrm{EH}$ passou por um período de formulação de hipóteses que durou cerca de cinco anos, e certamente utilizou de muitas fontes e referências até que se considerasse consistente e maduro para a apresentação e difusão de um método.

Conforme nosso percurso na leitura dos documentos consultados nos Archives Nationales de France, verificamos que em 1946 Lebret e demais participantes do Économie et Humanisme apontavam para um método que consistia numa análise global a fim de conhecer as condições de vida das pessoas e as necessidades dos grupos sociais. Somente nos anos 1950, o grupo introduziu palestras e cursos de formação 
sobre os problemas da cidade em suas semanas sociais, eventos estes que não contaram com a participação de Gaston Bardet ${ }^{101}$.

Nas Semanas Sociais promovidas pelo Économie et Humanisme, a temática da cidade e a problematização da questão urbana começam a incidir de forma mais direta em 1949, em La Tourette, quando Robert Caillot (membro do Bureau Lyonnais d'Analyse et de Conjoncture) expõe aos participantes "Une enquête sur la distribution dans une grande ville" e o padre Suavet expõe os resultados obtidos pela equipe de Saint-Etienne ${ }^{102}$, que havia realizado trabalho em 1946 para o Ministère de la Reconstruction et Urbanisme, numa pesquisa sobre as condições habitacionais, que visava o fornecimento de dados que balizassem a construção de um programa habitacional no pós-guerra.

Assim, no início dos anos 1950 abre-se espaço dentro do Movimento para se falar em aménagement du territoire, terminologia que, conforme já apontamos no capítulo anterior, pode ser traduzida como ordenação do território, sendo empregada nos trabalhos desenvolvidos no campo do urbanismo na França, inclusive por Bardet. A expressão é traduzida por Lebret ${ }^{103}$ como o aprimoramento da terra a partir dos aspectos de ordenação e melhoria das condições do solo, do subsolo e da energia, necessários para o desenvolvimento humano, o que Bardet chamava de topografia social.

Ainda sobre o interesse do grupo de Lebret pela questão urbana, há que se considerar que antes mesmo do cenário do pós-guerra, em que as cidades precisavam ser reconstruídas, o tema já era discutido dentro das ciências sociais. Conforme Louis Wirth, "a cidade é o centro que irradia as influências da vida civilizada moderna para os confins da terra, e o ponto que as controla", de forma que "os problemas persistentes na sociedade contemporânea tomam a sua forma mais aguda na cidade." E conclui que "o estudo da cidade tem se apresentado como de suprema importância não só para a compreensão e acomodação da ordem social contemporânea em alguns de seus aspectos mais amplos". (1946, p. 604).

\footnotetext{
101 Em carta assinada em 3 de fevereiro de 1951 Bardet responde a Lebret declinando do convite para participar como expositor da Semana de Formação dos Engenheiros, que ocorreria naquele ano. Documento consultado na Pasta AN45 AS70.

102 Ambos os documentos foram consultados na pasta AN45 AS46. Cabe situar que o trabalho realizado pela equipe de Saint-Etienne em 1946, foi um dos quatro estudos contratados pelo Ministère de la Reconstruction et Urbanisme de forma a envolver técnicos ligados ao Économie et Humanisme. Da mesma forma o Bureau Lyonnais d'Analyse et de Conjoncture era um dos organismos criados por EH no período para cumprir contrato com órgãos do governo francês.

103 Conforme exposição na Session Internationale de Aménagement du Territoire, realizada em La Tourette em 1952. Documento consultado na Pasta AN45 AS48.
} 
No momento em que o Économie et Humanisme era criado, na década de 1940, a questão urbana já havia se consolidado de forma que já não era possível mais ignorá-la como um organismo social e diretamente relacionado com a política e os meios sociais de produção, independentemente da disputa ideológica pautada pelos soviéticos, defensores do socialismo, e dos norte-americanos, defensores do capitalismo. Assim, se a precariedade presente nas vilas dos pescadores da Bretanha levou Lebret a engajar-se num trabalho de interpretação da realidade social, que culminou com a criação do $\mathrm{EH}$, nos anos 1940 foi a vida nas cidades e, consequentemente, os problemas nela existentes, que permitiram ao grupo avançar e aprimorar suas ideias a ponto de disseminá-las em países periféricos, sobretudo na década de 1950.

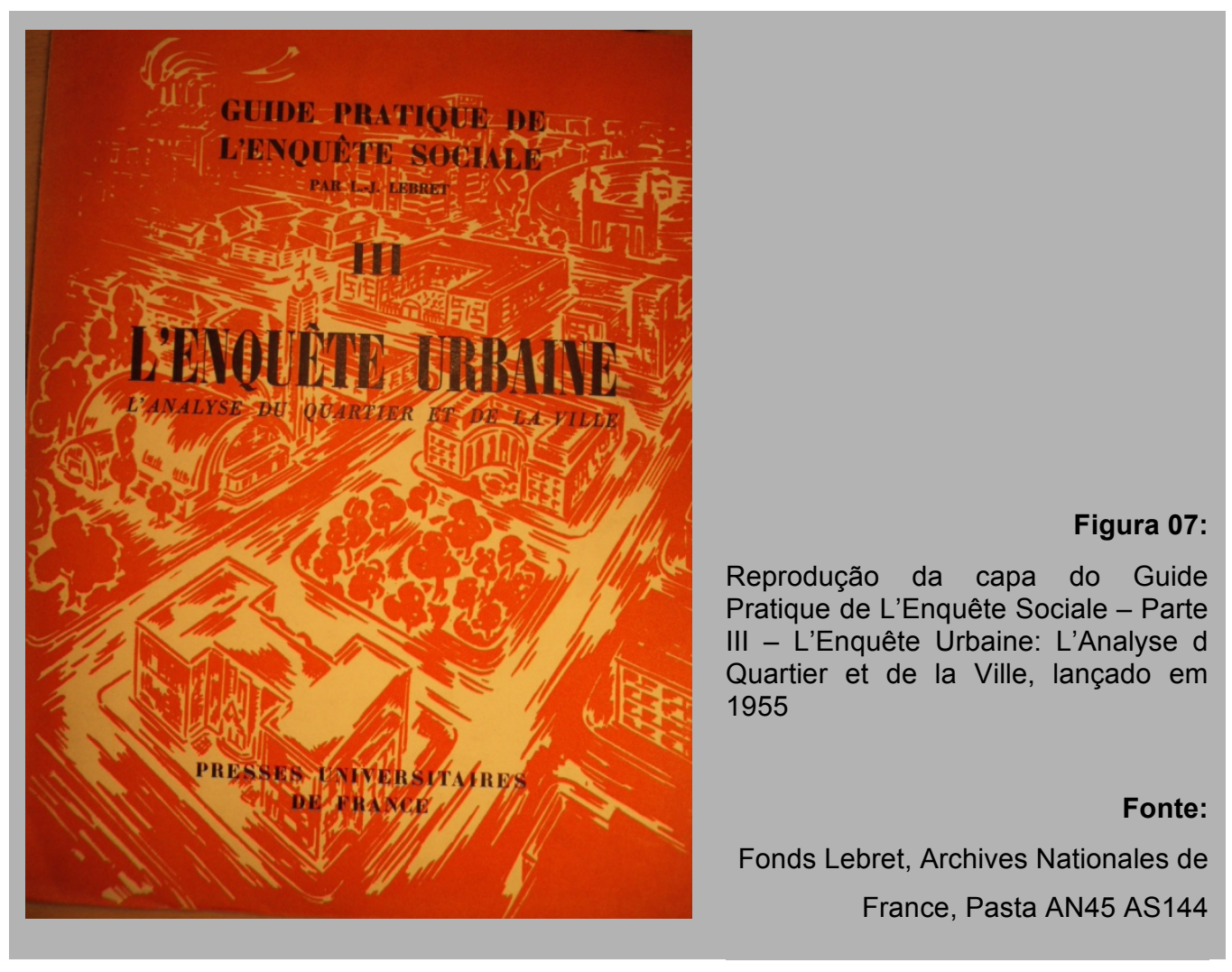




\subsection{As imbricações de Lebret $^{104}$ : \\ Inserção e difusão das ideias do Économie et Humanisme}

De acordo com documentos consultados sobre a história da formação do Centre d'Économie et Humanisme, num ensaio preparado por Lebret para a Sessão de Marseille ${ }^{105}$, em 1944, as preocupações do grupo com o tema da cidade e a questão urbana não eram expostos. Entretanto, o mesmo faz menção à preocupação econômica e à formação da organização dos trabalhadores, em torno de suas aspirações e proteção quanto aos resultados obtidos com a venda de seus produtos, ou da exploração de sua mão de obra, que num vocabulário marxista seria traduzido como "mais valia" - expondo o apoio de Lebret ao Movimento de Saint-Malo.

Assim, verificamos que, embora as preocupações com os estudos da cidade não fossem tão evidentes nos textos de Lebret preparados para suas exposições nas Sessões do $\mathrm{EH}$, até 1945, a questão urbana havia se apresentado como campo de trabalho para pesquisa já no início da década, quando o dominicano passou pela École des Cadres d'Uriage ${ }^{106}$.

Neste sentido, é importante mencionar a aproximação ocorrida entre Lebret e o sociólogo Chombart De Lauwe ${ }^{107}$, no início dos anos 1940, por ocasião da atuação do mesmo na École National des Cadres d'Uriage. Angelo (2010, p. 54) destaca que "ambos tiveram pontos em comum, como a ligação com o método de pesquisa de Le Play. [...] A ideia da 'cidade vista do alto', o que permitiu a Lebret ter uma visão geral do conjunto urbano que estudou".

\footnotetext{
104 Empregamos o termo "imbricações" pois o significado do mesmo quer dizer "entrelaçamento", "superposição" ou "sobreposição", que aparentemente é a palavra que melhor indica a atuação de Lebret, que ao mesmo tempo consegue coordenar trabalhos na SAGMACS, seguir no corpo diretivo do Économie et Humanisme, bem como ter uma atuação paralela a isso tudo. Assim, entendemos que as questões trabalhadas por Lebret, pelo EH e pela SAGMACS, imbricam-se, ainda que possam ser organismos e instituições separadas em si.

105 Documento consultado na Pasta AN45 AS44.

${ }^{106}$ A École des cadres d'Uriage foi uma instituição francesa criada sob o regime de Vichy em 1940. Funcionou somente até 1942, com o intuito de formar intelectualmente uma elite dentro de um quadro de revolução nacional.

107 Segundo Angelo "Paul-Henry Chombart de Lauwe foi um sociólogo francês conhecido como um dos precursors da sociologia urbana na França, fazendo estudos de psicologia e etnografia para suas pesquisas urbanas." (2010, p. 53). Publicou vários livros ao longo de sua vida, cabendo a nós destacar aqueles com tematica voltada à questão urbana, como: "Familles et Habitacion" (1958), "Des hommes et des villes" (1965) e "La Fin des villes: mythes ou réalité?" (1982).
} 
Chombart De Lauwe se destaca entre os intelectuais franceses por seus trabalhos de sociologia urbana cunhados nos anos 1940 e 1950. Outra hipótese levantada por Angelo (ibid.) é de que De Lauwe seria o responsável por aproximar os estudos da Escola de Chicago ao ideário lebretiano, anos mais tarde, pois foi ele "quem introduziu a Escola de Chicago na França", afirmando que "possivelmente foi uma das pontes na transferência de algumas ideias para o grupo EH".

Sobre o trabalho de Lebret anteriormente a 1945, verificamos que o mesmo apresentou à École d'Uriage, em 1941, um projeto para introduzir o estudo sobre a cidade, intitulado "La Cité: Projet d'un programme d'enquête et d'un programme d'action"108. Logo no início do texto, Lebret aponta que a ação se exercerá sobre a cidade, apontando que "notre premier travail sera donc de comprendre la ville dans laquelle nous vivons d'en étudier les traditions, l'histoire, les possibilités, leur ôle dans le pays", sendo:

Nécessaire de délimiter pour chaque groupe un champ d'action et un programme de travail précis. Nous ne voullons pas entreprendre seuls cette mise au point; c'est porquoi nous faisons appel aujourd'hui à la collaboration des spécialistes pour construire un plan détaillé. ${ }^{109}$

Desse modo, percebemos que a questão urbana já figurava entre as preocupações de Lebret, desde sua passagem pela École d'Uriage, antes mesmo da fundação do Économie et Humanisme. Entretanto, no Movimento o assunto passou por um período de hibernação, até que o EH se consolidou como um grupo de pesquisa sobre a economia e as aspirações para o desenvolvimento harmônico. Mais tarde, próximo a 1945, nas pesquisas sobre as condições de vida, é possível perceber a preocupação de Lebret e dos membros do grupo com a consolidação do Movimento e a difusão de suas ideias nos anos de atuação inicial.

Em 1943 o Économie et Humanisme realizou a Session de Formation d'Enquêteurs ${ }^{110}$, em Saint-Étienne, com duração de três dias e exposições de Lebret, R. Fantapie, P. Suavet e P. Martin. Lebret realizou somente uma palestra, mas coube a ele expor sobre o método de Économie et Humanisme, numa palestra intitulada "Exposé sur le méthode

\footnotetext{
${ }^{108}$ Documento consultado na Pasta AN45 AS67.

${ }^{109}$ Necessário definir para cada grupo um escopo e um programa de trabalho detalhado. Nós não só iremos realizar este desenvolvimento; É por isso que chamamos hoje a colaboração de especialistas para construir um plano detalhado. (Livre tradução do autor).

${ }^{110}$ Os documentos disponíveis referentes às Sessões realizadas pelo Économie et Humanisme em 1943 e 1944 foram consultados junto à Pasta AN45 AS44.
} 
d'Économie Humaine"111. Durante a exposição ele apontou que o $\mathrm{EH}$ prioriza o trabalho em equipe, e que uma equipe central deve se aproximar da elite para se constituir em mais comunidades de trabalho. O discurso sobre o método era composto por perspectivas históricas e perspectivas metodológicas, fazendo menção a Descartes, porém, demarcando que não se pretendia fazer uma analogia com o mesmo.

No capítulo a seguir apresentaremos melhor as diretrizes expostas pelo EH quanto à metodologia de trabalho do grupo. Porém, preliminarmente, apontamos que a exposição de Lebret divide-se em quatro ideias mestras do movimento, esclarecendo que a ação espiritual e a ação temporal ${ }^{112}$ devem ter um mesmo objetivo, pois, na busca de resultados, ambas se confundem em uma só. Podemos dizer que esta mesma unificação, entre ação espiritual e ação temporal, se dá na forma do discurso adotado por Lebret, uma vez que, como sacerdote da igreja católica, traz em suas exposições uma série de apelos à ação espiritual, à misericórdia e à busca da fé, ao mesmo tempo em que consegue conciliar a "homilia sacerdotal" com teorias e aspectos científicos.

Assim, Lebret aponta que para se alcançarem resultados práticos o grupo estabelece que é preciso transcender as experiências concretas de cada profissional, para que seja possível entender a complexidade do sistema como um todo. Com um olhar científico, Lebret também aponta que é preciso distanciar-se da noção do mal moderno (a proletarização, concentração econômica, queda da produção industrial, êxodo e o desequilíbrio entre indústria e artesanato), pois é necessário entender esta questão complexa e a leitura com ceticismo e aversão não garantiria a correta interpretação do momento.

Outras seis regras são estabelecidas como básicas nas exposições de Lebret sobre o método de $\mathrm{EH}$, conforme veremos no capítulo seguinte desta tese. A regra da misericórdia, exposta de uma maneira bastante clerical, consistia no reconhecimento da miséria humana como uma manifestação universal, ou seja, miséria definida como questões de cunho moral, econômico e de saúde, cabendo ao movimento reagir com o coração diante da mesma.

\footnotetext{
111 Documento consultado na Pasta AN45 AS44. Discurso do padre Lebret, com 27 páginas, com o título: "La Méthode d'Economie et Humanisme", utilizado na Sessão de Formação realizada em dezembro de 1943 em Saint-Étienne e em 1944 na Sessão de Marseille.

112 É importante entender a distinção feita por Lebret sobre ação espiritual, que visava alimentar a fé das pessoas através de orações e pregações religiosas, da ação temporal, que visava integrar uma ação pastoral às necessidades do homem, sobretudo, na comunidade local.
} 
Além da regra da misericórdia, o documento colocava como regras, também, a regra dos complexos, a regra do apoio popular, a regra do objeto, a regra da equipe e a regra do superior. O entendimento do que seriam estas regras e a forma de aplicação das mesmas serão analisados por nós no capítulo seguinte desta tese, quando discutiremos a difusão do método e a ampliação do campo de atuação do Économie et Humanisme, que incluiu a incursão de Lebret ao Brasil, em 1947.

Em 1951, numa carta de Lebret endereçada ao Monsenhor Guerry ${ }^{113}$, o dominicano reafirma que o objetivo do Économie et Humanisme era essencialmente o estudo da realidade social sobre todos os seus aspectos, apontando três deles:

1 - A fim de trazer aos ativistas cristãos um método preciso de análise dos fatos sociais e da cultura econômica e social necessária a sua ação;

2 - A fim de elaborar um espaço de economias materialistas, uma economia humana como disciplina de síntese das diversas ciências sociais;

3 - E, por fim, em vias de enfrentar os problemas da moral social e espiritual dos militantes com conhecimento preciso das estruturas atuais, das forças $e$ das ideologias presentes.

Tanto na carta de 1951 quanto nas exposições de Lebret, nas sessões de 1943 e 1944, a questão urbana não é abordada de forma específica, mas os anseios expostos pelo EH quanto à definição de um método de trabalho vão muito além dos problemas que as cidades enfrentavam no contexto do final da segunda guerra. O movimento extrapola esta questão ao induzir o expectador a engajar-se numa proposta de leitura e interpretação da sociedade contemporânea, o que não era tarefa simples.

Visando compreender a difusão deste método, analisamos a lista com o nome dos participantes destas sessões ${ }^{114}$, procurando elucidar quantos eram, qual era a origem e a formação profissional destas pessoas convidadas por Lebret a se tornarem adeptos do Économie et Humanisme. Verificamos então que pouco mais de cento e trinta pessoas participaram do evento promovido pelo grupo. A lista com o nome dos participantes não traz a formação e ocupação de todos, mas algumas profissões se destacam, como os assistentes sociais, professores, engenheiros, empresários, advogados e arquitetos. Dificilmente também se percebe a repetição de uma informação, pois, se a lista traz à

\footnotetext{
${ }^{113}$ Carta de Lebret ao Monsenhor Guerry, assinada em 7 de junho de 1951. Documento consultado na pasta AN45 AS32.

${ }^{114}$ Documento consultado na Pasta AN45 AS44.
} 
frente do nome do participante a instituição à qual o mesmo está ligado, não aponta sua profissão ou área de formação.

\begin{tabular}{|c|c|c|}
\hline $\begin{array}{l}\text { Particif-ant for } \\
\text { ABTEIIIE }\end{array}$ & michel & MSI I2, rue Bel Air \\
\hline ABRIBAT & Fedousy & $\begin{array}{l}\text { Centre Inseignement } 9, \text { Bd Nontricher } \\
\text { Jénager }\end{array}$ \\
\hline AGOSTINI & E & 44, rue Grignan \\
\hline ALIEST d & Monique & 6, rue J. Autran \\
\hline xATLEX & suzanne & $\begin{array}{l}\text { 1, Place Delille } \\
\text { Sède (Hérault) }\end{array}$ \\
\hline & Oherites? & Secrétariat Jeunesse \\
\hline ARNAUD & Pierre & Compagnon $23, \mathrm{Bd}$ Banon \\
\hline ARNAUD & Francis & 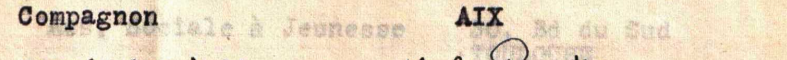 \\
\hline ARWOULD & Pierre & $\begin{array}{l}\text { Secrétaire à la ire. Rue Paradio. } \\
\text { préfecture }\end{array}$ \\
\hline AUROY & PTI & 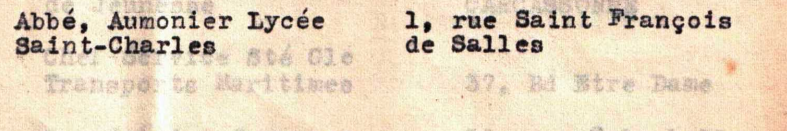 \\
\hline BARRAUD & Clotilde & $\begin{array}{l}\text { Conseillère du travail I30 Chemin de la } \\
\text { Assistante Sociale } \\
\text { Chantiers et Ateliers } \\
\text { de Provence }\end{array}$ \\
\hline BATAIILAARD & Charles & 67, rue de la Loubière \\
\hline $\begin{array}{l}\text { BAUCHISRON DT } \\
\text { BOISSOUDY }\end{array}$ & Clotilde & $\begin{array}{l}\text { Conseillère du travail } \\
\text { attachée à la jeunesse I52, Bd wichelet }\end{array}$ \\
\hline BENCY de & Solange & $\begin{array}{l}\text { Directrice due Centre } \\
\text { Provençal Inseignement } 63 \text {, rue Saint Jacques } \\
\text { Ménager }\end{array}$ \\
\hline XBTERNIER & Georges & $\begin{array}{l}\text { Ancien secrétaire de la } \\
\text { S.D.N. }\end{array}$ \\
\hline BLANQQUART & Lbuise & Assistante Sociale 4 , rue Chalucet TOULON \\
\hline BONHOMATE & R. & Secrétariat Jeunesse I8, A. Léon GAMBETTA \\
\hline BONHOעaIE & A.I. & 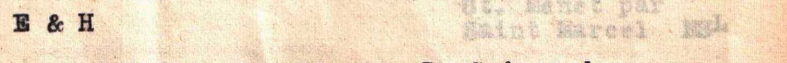 \\
\hline BONIFAY & Pierre & $\begin{array}{lc}\text { Propriétaire exploitant } & \text { La Seignardone } \\
\text { secrét. District corp. } & \text { Aux Royantes } \\
\text { paysanne } & \text { AUBAGNE }\end{array}$ \\
\hline 60098 & Resent & 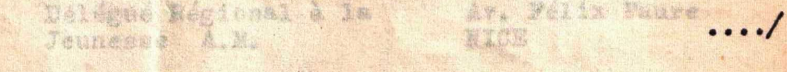 \\
\hline
\end{tabular}

Figura 08:

Lista com os nomes e endereços dos participantes inscritos para a Sessão do EH em 1944 - a lista completa tem 8 páginas datilografadas

Fonte:

Fonds Lebret, Archives Nationales de France, Pasta AN45 AS44 

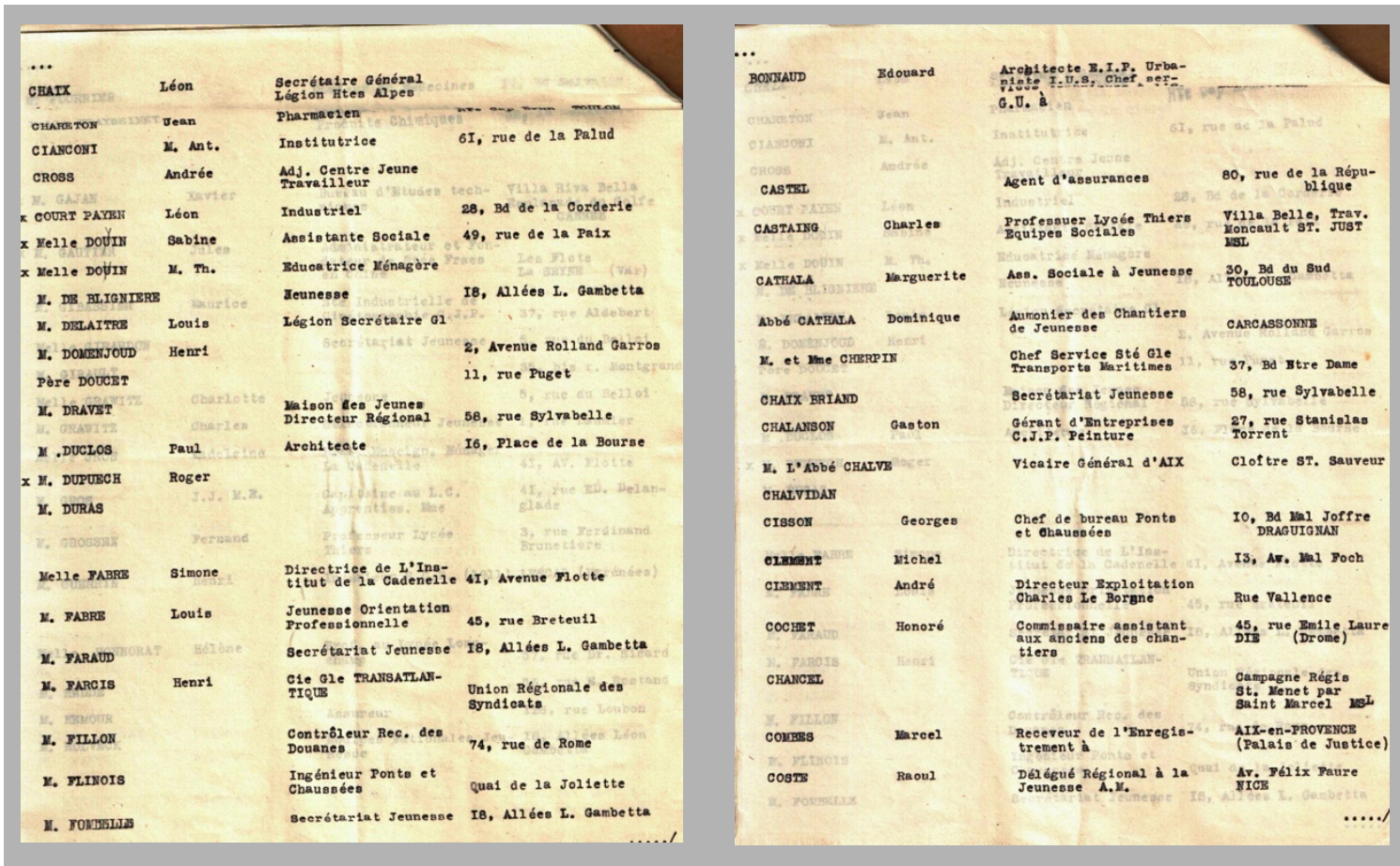

Figura $09-\mathbf{A}$

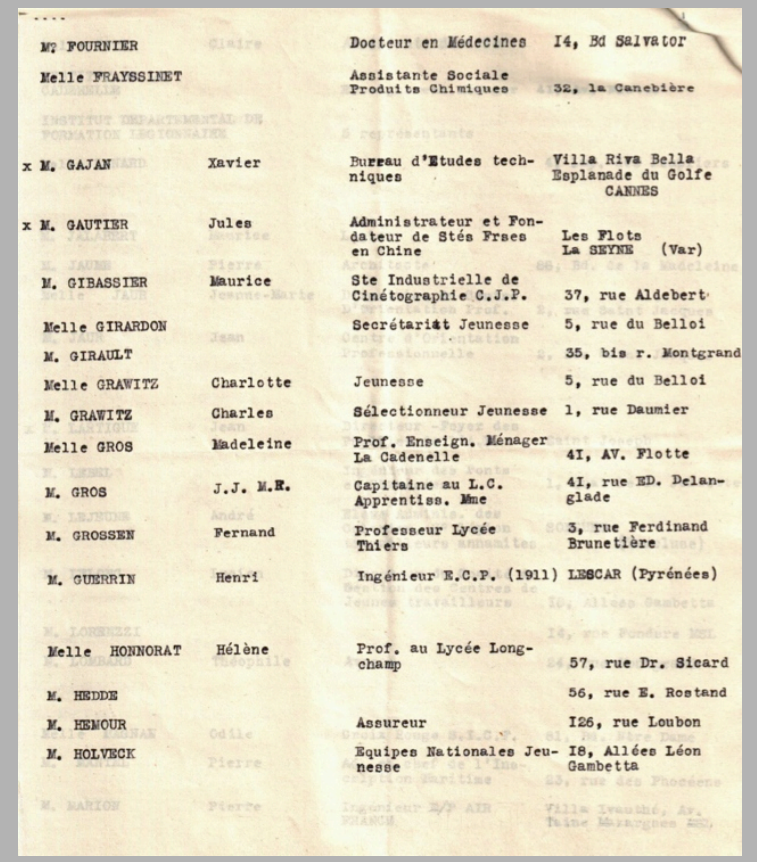

\begin{tabular}{|c|c|c|c|}
\hline \multicolumn{4}{|l|}{$\cdots$} \\
\hline עelle TCHs & cratre & Aosiotante Boolase. & \\
\hline $\begin{array}{l}\text { INSTITUT DB LA } \\
\text { CADSNOSLIS }\end{array}$ & 4.96 & Bnveignement Yénager & 4I, Ar. Motte \\
\hline \multicolumn{2}{|c|}{ 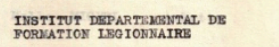 } & 5 représentants & cherits ofen 72 \\
\hline Nene Istakd & Jeanne & 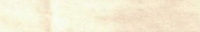 & 4, Imp. des Peupliers \\
\hline wee vionate & & 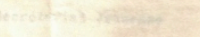 & 25: \\
\hline X. JNLABERT & Meuriee & Lég1on & \\
\hline 1. JAUUS & Pierre & Arch1 tecte & 88, Bd. de $2 \mathrm{a}$ \\
\hline Nelle JAUR & Jeanne-Marie & $\begin{array}{l}\text { Directrice du Centre } \\
\text { D'orientation Prof. }\end{array}$ & 2, rue saint Jacques \\
\hline 1.. JAUR That: & Jean & $\begin{array}{l}\text { Centre d Orientation } \\
\text { Profesolonelle }\end{array}$ & 2, rue saint Jacques \\
\hline 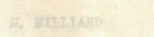 & monot & 6 & 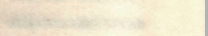 \\
\hline$x$ y. IARTIOTS & Jean & $\begin{array}{l}\text { Directeur - - poyer des } \\
\text { Puplileo de 1. A.P. }\end{array}$ & saint Jooeph \\
\hline v. IBHest & sempanstad & $\begin{array}{l}\text { Ingénieur des Ponts } \\
\text { et chanuesées }\end{array}$ & 1, qual de la Joliet \\
\hline 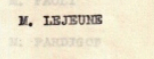 & André & 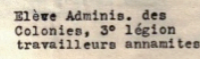 & songuss f(vaucluse) \\
\hline w. Trsoso & Iucien & $\begin{array}{l}\text { Directeur du Coritté de } \\
\text { Destion deb centres de } \\
\text { Jeunes travalileurs }\end{array}$ & I8, N116es Gambetta \\
\hline x. LORanzzI & & & 14, rue Pondère vSI \\
\hline v. LOVBARED & Théoph11e & Avocat & 24, rue Nontgrand \\
\hline . xamols & 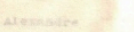 & & \\
\hline Nezle ZaATAK & odile & Croix Rouge s.r.c.p. & 81, Bd. Wtre Dame \\
\hline 1. xarmat & Pierre & $\begin{array}{l}\text { Ad. en cher de } 1 \text { 'Ina- } \\
\text { cription haritive }\end{array}$ & 23, rue deo Phocéeng \\
\hline ע. YARTOS & Pierre & 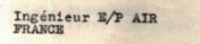 & $\begin{array}{l}\text { Vil1a Irauthé, Av. } \\
\text { Taine }\end{array}$ \\
\hline
\end{tabular}

Páginas 2, 3, 4 e 5 da Lista de Participantes da Sessão de 1944

Fonte:

Fonds Lebret, Archives Nationales de France, Pasta AN45 AS44 

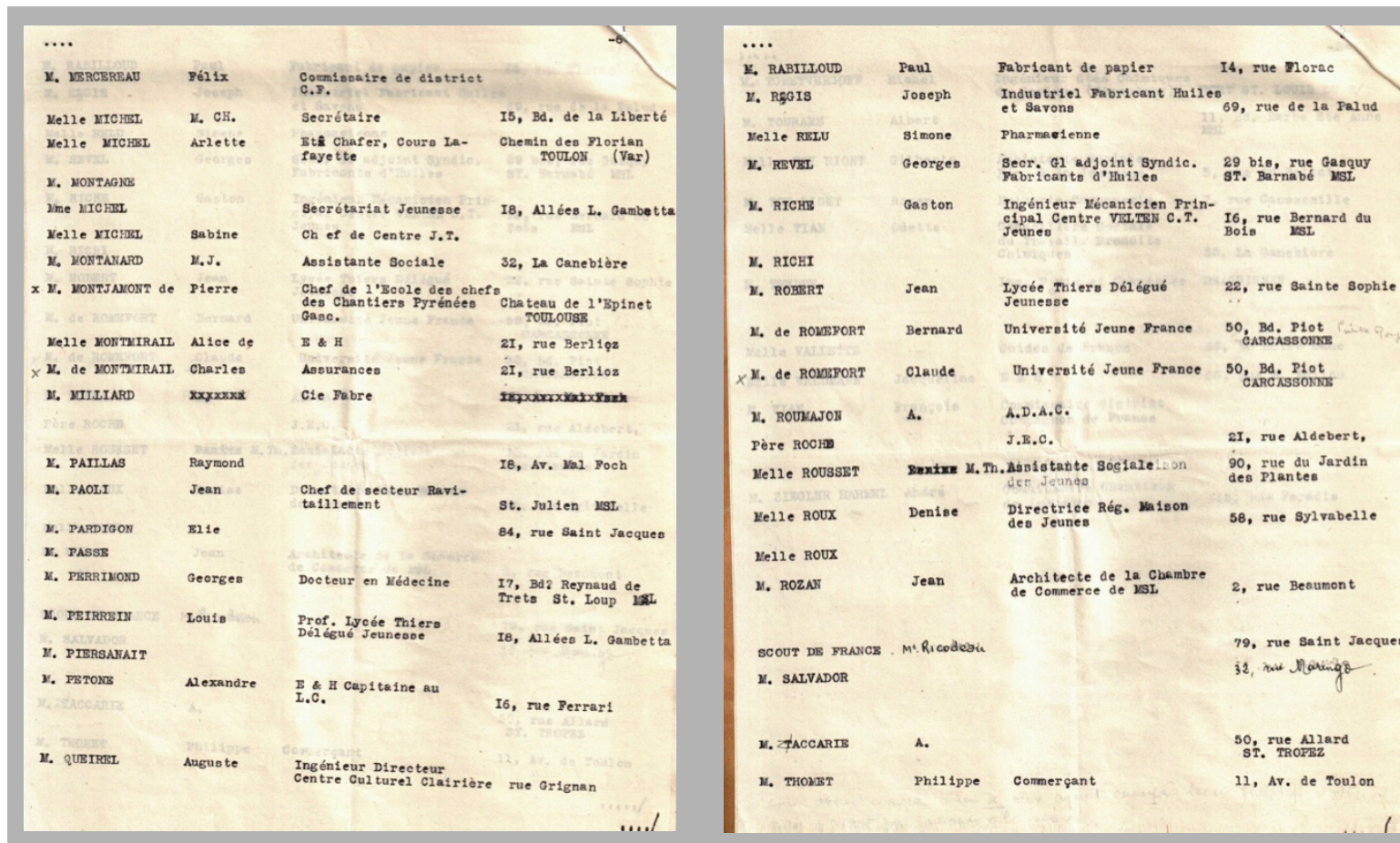

Figura 10 - A

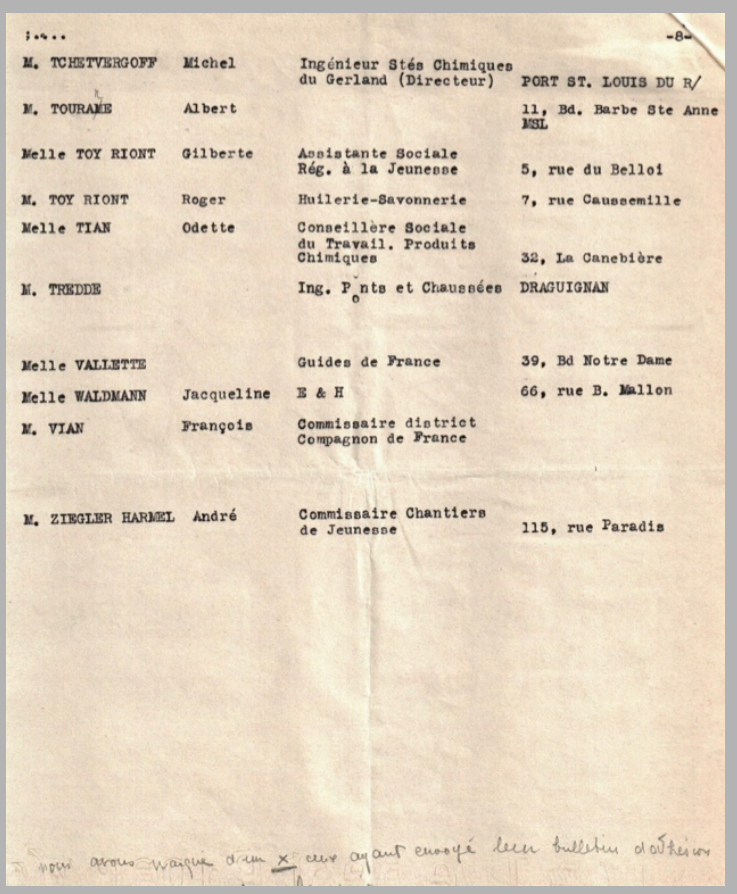

Páginas 6,7 e 8 da Lista de Participantes da Sessão de 1944

Fonte:

Fonds Lebret, Archives Nationales de France, Pasta 
Entre os 137 participantes, somente cinco faziam parte do grupo de Lebret: A. M. Bohomme, Alice Montmiral, Alexandre Petone, Jacqueline Waldmann e o Padre Roche, que era ligado ao movimento da Jeunesse Étudiant Crétienne - JEC. Também participaram quatro arquitetos: Edouard Bonnaud, Jean Rozan, Paul Duclos e Pierre Jaume; nove engenheiros: Auguste Queirel, Filnois, Gaston Riche, Georges Cison, Henri Guerrin, Lebel, Michel Tchetvergoff, Pierre Marion e Tredde; doze professores e instrutores, dez assistentes sociais, dois médicos e dois farmacêuticos. Sete participantes eram empresários, comerciantes ou industriais, enfim, pessoas ligadas aos meios de produção.

De posse da lista de participantes das sessões de 1943 e 1944, apesar das lacunas no preenchimento, pudemos verificar que desde os anos iniciais do movimento a preocupação com a diversidade de profissionais era latente em Lebret. Porém, assim como percebemos que a questão urbana não foi abordada em sua exposição, também não consideramos relevante, em número, a participação dos engenheiros e arquitetos, se comparados aos profissionais da área do ensino e da assistência social, o que mostra a tentativa de Lebret abordar pessoas que, de certo modo, tinham maior inserção entre os grupos sociais e jovens.

Esta impressão obtida por nós através da leitura destes documentos também é apontada pelo próprio Économie et Humanisme, que, em relatório de trabalho publicado pelo grupo em 1951, apresenta uma análise dos primeiros dez anos de atuação do grupo. O relatório ${ }^{115}$ aponta a existência de três fases do Centre d'Économie et Humanisme, sendo a primeira delas chamada de "formulação de hipóteses" e tendo ocorrido entre os anos de 1941 a 1945, o que demonstra o reconhecimento do próprio grupo de que se tratava de um momento ainda de formação das ideias do $\mathrm{EH}$, para posteriormente, nas próximas etapas, se dar a disseminação das mesmas.

As outras duas etapas são apontadas como ocorrendo no ano de 1946, período iniciado com o fim da Segunda Guerra e que permitiu ao Movimento e ao próprio Lebret circularem livremente pela França e demais países da Europa. A terceira fase constitui o período iniciado também em 1946, com a abertura de grupos e atividades ligadas ao Économie et Humanisme, como a criação da SAGMA, em 1945, e a abertura da Livraria em Paris, em 1947. Além da abertura de novas frentes de trabalho vinculadas ao grupo, esta fase também é marcada pelas viagens iniciadas por Lebret por países fora do

\footnotetext{
${ }^{115}$ Documento consultado na Pasta AN45 AS146.
} 
continente europeu, como a realizada ao Brasil ${ }^{116}$, Argentina, Chile, Colômbia, México e Uruguai, em $1947^{117}$. É nesta última fase indicada pelo relatório de 1951 que, a nosso ver, consolida-se dentro do grupo a preocupação com o urbanismo e o planejamento urbano e regional.

\footnotetext{
${ }^{116}$ Lebret visitou o Brasil pela primeira vez em 1947. Na ocasião ministrou a convite da Escola de Sociologia e Política de São Paulo o curso de Introdução Geral a Economia Humana a personalidades políticas e empresários paulistanos. A vinda ao Brasil também serviu para estreitar os laços com os Dominicanos latino-americanos e conhecer a situação de países como a Argentina, Chile, México, Paraguai, Uruguai e Brasil. As exposições e matérias abordadas por Lebret no curso da ELSP estão dispostas na Pasta AN45 AS144 e serão comentadas por este autor no capítulo seguinte desta tese.

${ }^{117} \mathrm{Na}$ Pasta AN45 AS69 constam anotações pessoais de Lebret em seus diários. Apesar da grafia é possível verificar o percurso de viagem estabelecido por ele em 1947.
} 

CAPÍTULO 3

A FORMAÇÃO DA SAGMACS COMO INSTITUIÇÃO DE URBANISMO:

FUNDAÇÃO E ATUAÇÃO DAS EQUIPES DE LEBRET NO BRASIL 

Conforme exposto no capítulo anterior, a vinculação de Lebret e do Centre d'Économie et Humanisme com a questão urbana passou a ser mais evidenciada a partir da criação da SAGMA, em 1945, e com a aproximação do grupo com o Ministère de la Reconstruction et Urbanisme da França. O MRU foi criado visando acelerar o processo de reconstrução das cidades francesas que haviam sido arrasadas pela Segunda Guerra, que acabara de terminar. A exemplo desta iniciativa do governo francês, outros países da Europa também criaram organismos semelhantes, o que aponta para um processo de expansão do interesse dos Estados pela questão urbana e consequente institucionalização destes organismos de apoio à cidade ${ }^{118}$.

Com a criação da SAGMA como um dos órgãos do Économie et Humanisme, a questão urbana foi incorporada em definitivo pelo grupo de Lebret, abrindo campo para a atuação de $\mathrm{EH}$ em novas frentes, como os trabalhos de pesquisa sobre as condições de habitação em cidades francesas, experiência esta replicada em sua primeira visita à cidade de São Paulo, em 1947. Assim, neste capítulo, buscamos elucidar as bases de disseminação das ideias que circularam por algumas cidades e países, como no caso brasileiro, onde se deu a criação da SAGMACS, em 1947, de forma a identificar e apontar os motivos que levaram Lebret e o EH a aportarem no Brasil neste mesmo ano.

Lembramos que o foco de nossa pesquisa é o trabalho de Lebret no Brasil, onde a SAGMACS atuou sob sua coordenação, entre 1947 e $1964^{119}$, e foi tratada desde sua criação como instituição voltada ao trabalho urbano, uma vez que a mesma se vincula à segunda etapa de atuação do $\mathrm{EH}$, quando o interesse pelo mundo urbano já fazia parte do ideário lebretiano. Além disso, trataremos neste capítulo da cronologia de atuação da SAGMACS, instituição que permitiu o envolvimento de inúmeros profissionais das áreas

\footnotetext{
118 Além da França, também foram criados organismos semelhantes junto aos governos da Grã Bretanha, Alemanha e Itália, países que receberam o apoio dos Estados Unidos através do Plano Marshall, que investiu US\$ 17 bilhões na reconstrução das cidades que sofreram ataques e bombardeios durante a segunda guerra.

119 Lebret participou ativamente do processo de criação da SAGMACS em São Paulo, em julho de 1947, e mesmo após seu retorno para a França manteve vínculo com a instituição, tomando a frente na coordenação de trabalhos desenvolvidos pela equipe brasileira. Porém, na década de 1960, a SAGMACS se transformou numa cooperativa de técnicos e Lebret deixou de fazer parte da equipe, mantendo contato a distância e através do Économie et Humanisme.
} 
de arquitetura, economia, engenharia, geografia e sociologia. Pretendemos, assim, reconstituir as bases de formação da equipe do $\mathrm{EH}$ no Brasil, apresentando as composições de diretoria, alterações no modelo de administração do grupo, o investimento na formação de novos agentes e as maneiras como se dava a captação de trabalhos pelos escritórios da SAGMACS.

Por fim, através do detalhamento cronológico das fases de funcionamento da SAGMACS, durante o período em que atuou, destacamos a elaboração de diferentes trabalhos desenvolvidos. Tais trabalhos vinculam-se ao campo técnico profissional do trabalho urbano e apontam para as diferentes fases de concepção e engajamento dos técnicos da equipe coordenada por Lebret no Brasil. Desta forma, alguns destes trabalhos serão destacados para que seus métodos sejam analisados por nós no capítulo a seguir. 


\subsection{A difusão do método de Économie et Humanisme e do ideário lebretiano como forma de fortalecimento do grupo francês}

O Centre d'Économie et Humanisme foi fundado na França em 1941, com o mundo ainda vivendo sob a ameaça do avanço do nazismo de Hitler e do fascismo de Benito Mussolini, dentro do contexto e ocorrência da Segunda Guerra Mundial. No período em que o EH foi fundado, a França estava invadida pelas tropas nazistas (1943) e, mesmo assim, Lebret não se intimidou e seguiu com seu trabalho frente ao grupo, que neste primeiro momento de atuação limitou-se à criação e aprimoramento de um método empírico-analítico para a interpretação dos problemas presentes na sociedade moderna.

Neste primeiro momento de atuação do grupo, que, para nós, se inicia com a fundação em 1941 e encerra-se em 1945, com o fim da segunda Grande Guerra, é possível verificar o percurso de tentativa na formação de um método por Lebret, cujas linhas mestras norteariam a atuação das pesquisas e a disseminação das ideias do EH. A discussão sobre o trabalho no campo do urbanismo, bem como o aprimoramento de um método para isso, somente teria início a partir de 1945, conforme apontado no capítulo anterior $^{120}$.

Se, por um lado, as tropas de Hitler sobre o território francês não impediam o trabalho de Lebret visando aprimorar um método de pesquisa no Économie et Humanisme, o impedimento da livre circulação pelos países em guerra limitava os avanços do grupo, pois impedia que os franceses pudessem circular livremente pelos demais países europeus, de forma que os mesmos viam-se obrigados a atuar apenas nas cidades francesas, mais precisamente em Lyon e Marseille. Com o fim da Segunda Guerra, em 1945, e com a assinatura do Armistício, a liberação de circulação entre os territórios vizinhos tornou-se possível e com isso Lebret iniciou algumas viagens por outros países da Europa, como a Bélgica e a Holanda, abrindo assim campo para além das cidades francesas.

\footnotetext{
${ }^{120}$ Quanto a esta periodização é importante destacar que em documento de 1952 sobre relatório da atuação do EH há apontamento para três fases de atuação do grupo, sendo que a primeira delas é chamada por "Período de formulação de hipóteses" e abrange também o momento de aprofundamento de uma metodologia voltada para o trabalho no campo do urbanismo, pois segundo o relatório consultado junto a Pasta AN45 AS146, esta primeira fase percorre os anos de 1940 a 1949, primeira década de atuação do grupo e por se tratar de um período de formulação de método, adentra sobre a segunda e terceira fases. A segunda fase é iniciada em 1946, quando o EH amplia suas atividades através da formação de novos organismos vinculados ao grupo, como a SAGMA e a terceira em 1947, que consiste no período em que o grupo estende atividades para além do território da França. Ainda sobre a periodização da atuação do grupo cabe ainda mencionar a divisão proposta por Pelletier que aponta para um primeiro período sob a influência e proximidade com o Regime de Vichy e a Resistência, que para ele se encerraria em 1944.
} 
Próximo ao fim da guerra, o método desenvolvido pelo Centre d'Économie et Humanisme estava definido e havia sido exposto em 1944 por Lebret na Sessão de Marseille, promovida pelo grupo como forma de disseminação das ideias do dominicano. $O$ documento em que se firma o método do $\mathrm{EH}$ é intitulado de "Méthode d'Économie et Humanisme"121 e foi exposto por Lebret e Henri Desroches, ambos religiosos dominicanos $^{122}$, destacando-se que o método foi composto sob perspectivas históricas e perspectivas metodológicas. Sobre a regra do pensamento da ação, mencionou-se o filósofo René Descartes, embora fosse afirmado ali que não se pretendia realizar uma analogia a Descartes, mas sim imitar seu método de forma mais simples.

Este documento não é propriamente uma carta, apostila ou manifesto do grupo, mas sim um ensaio datilografado com o discurso de Lebret para divulgação das ideias do Économie et Humansime. Nele são expostas quatro ideias iniciais que, segundo Lebret, deveriam fazer parte do discurso dos membros de $\mathrm{EH}$ e ser defendidas e disseminadas pelos mesmos, independentemente de onde estivessem. Conforme a exposição de Lebret e Desroches, os membros do Économie et Humanisme deveriam se engajar na defesa de quatro ideias que são impostas como a doutrina do grupo. Estas ideias são:

1) Que a ação espiritual e a ação temporal num certo ponto se confundem e devem, portanto, caminhar conjuntamente;

2) Que era preciso que o pesquisador se limpasse da experiência concreta que ele trazia sobre cada setor, e da visão que tinha sobre os conflitos que existiam entre as técnicas novas, técnicas de produção, técnicas de troca, com as estruturas antigas;

3) Eliminar o que ele identificava como aspectos do mal moderno: proletarização, concentração, queda da produção, êxodo rural, desequilíbrio entre indústria e artesanato;

4) Reorganizar os quadros profissionais num plano internacional, superando o antagonismo da classe para instaurar um sindicalismo que tenha participação efetiva na reorganização da profissão.

E pregava ainda:

\footnotetext{
${ }^{121}$ O Documento original foi consultado junto a pasta AN45 AS44.

122 Henri Desroches rompe com a igreja católica em 1949 e consequentemente se distancia do Économie et Humanisme a partir de 1950, devido a publicação de "Signification du Marxisme", de sua autoria, que cria à ele problemas com o Papa Pio XII que recomenda a proibição da obra. Em 1951 Desroches ingressa no corpo de pesquisadores do Centre Nationale de Recherche Sociale CNRS na França.
} 
Enfin reforme des structures qui doit dépasser à la fois le social proprement dit et l'intervention plus ou moins artificielle de l'Etat. Un dernier échelon enfin: cette intervention s'élargit pour s'en prendre aux Mystiques elles mêmes qui conditionnent un certain ordre de structures, mystiques capitalistes, mystiques communistes ou autres. ${ }^{123}$ (LEBRET, 1944).

Tais apontamentos revelam planos ambiciosos de Lebret e do Économie et Humanisme e mostram que sua ação não pretendia restringir-se somente ao território francês, mas expandir-se mundo afora, num trabalho que envolveria sindicatos, governos, universidades, o meio empresarial e a própria igreja católica, e culminaria com uma reforma das instituições, preparando-as para um contexto de desenvolvimento harmônico. Para Lebret, o mundo estava dividido em duas classes: a elite e os trabalhadores, dentre os quais havia os miseráveis. Esta visão de mundo o aproxima novamente do pensamento de Marx e da sociedade de classes. Porém, mais do que a influência de Marx sobre o pensamento de Lebret, Pelletier (1996, p. 125) aponta que fizeram parte da teia de referências para a formulação do método "hipotético-analítico" utilizado pelo EH o pensamento de Tomas de Aquino, a tradição de Aristóteles e de Le Play. "Le refus de la méthode hypothétique joue face à la tradition des économistes libéraux un rôle analogue à celui de l'utopie communautaire face à l'individualisme des sociétés industrielles." ${ }^{124}$ (PELLETIER, ibid., p. 124).

Lebret aponta, em sua exposição, que as regras do método que foram extraídas do pensamento para o funcionamento do Économie et Humanismo são as mesmas regras de ação e "regras da vida". Sendo assim, Lebret expõe que o método desenvolvido pelo EH traz como primeira tarefa a ser feita"a construção de um método de pesquisa, um método de pensar, um método de ação e um modo de vida que culminaria em regras elementares para o método do $\mathrm{EH}$, dividido em seis pontos". Os pontos apontados como regras por Lebret consistiam em: regra da misericórdia, regra dos complexos, regra do apoio popular, regra do objeto, regra da equipe e a regra do superior;

\footnotetext{
${ }^{123}$ Enfim, a reforma das estruturas que devem ultrapassar tanto a ação do Estado social e mais ou menos a artificialidade do real. Finalmente, um último passo: esta intervenção se expande para atacar as místicas próprias que determinam uma ordem de estruturas capitalistas, místicas, comunistas e ainda outras formas. (Livre tradução do autor).

${ }^{124} \mathrm{~A}$ recusa do método hipotético projeta junto à tradição dos economistas liberais um papel semelhante ao da utopia comunitária face ao individualismo das sociedades industriais. (Livre tradução do autor).
} 
Lebret explicava o que estaria embutido em cada uma delas. A regra da Misericórdia tinha o objetivo de reconhecer que existe a miséria humana e que ela é universal, devendo o EH ser uma reação do coração diante da miséria. Sobre miséria cita temas tirados de dados estatísticos, baseados na ampliação dos índices de mortalidade, da prostituição, das doenças venéreas, das deficiências em crianças, o aumento do número de crianças abandonadas, a delinquência infantil, a tuberculose, o alcoolismo, as carências do habitat, os acidentes de trabalho, o desequilíbrio orçamentário, a degradação da vida familiar e o aumento de clientela nos hospitais e nos sanatórios.

Para Lebret, a regra da misericórdia dentro do $\mathrm{EH}$ é importante, pois a mesma não é a condescendência, nem um sentimento artificial. A misericórdia leva à justiça. A misericórdia tem que ser florescente, tem que agir sobre a vida do homem, tem que atuar para que todos os homens tenham direito de fazer de sua vida um direito inalienável, um direito para ele e para o outro. É uma questão de justiça.

A regra dos complexos explicava que, por complexos, o Économie et Humanisme entendia as estruturas da sociedade, dividindo-as em estruturas horizontais e verticais, e que "o interesse do método era o de abordar um interesse pedagógico, de forma a estudar o funcionamento do mundo moderno, a engrenagem humana e, a partir de estudos abstratos e livres, caminhar em passos médios para estudar a partir de um complexo concreto",sempre levando em consideração aquilo que é afeito às atividades humanas e à sociedade, como fatores biológicos e mecânicos, fenômenos psíquicos e físicos.

Au schéma hypothèse-déduction est ici opposé un schéma postulat-enquêteinduction qui débouche directement sur la réforme des structures économiques, sans s'autoriser de détour par la formulation abstraite de modèles économiques. La méthode d'Économie et Humanisme relève à la fois d'un très strict empirisme et d'une volonté normative préalable à l'observation même du réel. ${ }^{125}$ (PELLETIER, ibid. , p. 125).

A regra do apoio popular visava à obtenção de reconhecimento ao trabalho do grupo, bem como alcançar o apoio de um setor específico e de parte da sociedade. Para tanto,

\footnotetext{
${ }^{125} \mathrm{O}$ esquema hipotético-dedutivo é contestado por um esquema de pesquisa de indução postulado que leva diretamente à reforma das estruturas económicas, sem permitir desvio pela formulação abstrata de modelos econômicos. Assim, o método do Economie et Humanisme é tanto um empirismo muito rigoroso e um compromisso normativo anterior à mesma observação da realidade. (Livre tradução do autor).
} 
Lebret aponta que era preciso que os membros do Économie et Humanisme fizessem duas coisas: vivenciar e dominar ${ }^{126}$.

Dentro da regra do apoio popular é apontado ainda que a transparência dos trabalhos é fundamental para se obter apoio, pois os dados que foram extraídos de um setor rendem produtos que podem ser apresentados aos mesmos. Como forma de apresentação, Lebret apontava que os diagramas são formas facilitadoras para mostrar os resultados das enquetes e permitem em uma única página apontar os resultados de certo número de entrevistas, sendo que os diagramas podem ser personalizados e apresentados por temas de interesse.

$\mathrm{Na}$ descrição da regra da equipe, Lebret apontava que "a arquitetura de Economia e Humanismo é uma arquitetura de equipes", e trazia diretrizes para o funcionamento desta equipe, bem como para a captação de trabalho pelo Centre d'Économie et Humanisme, dizendo que a equipe central do $\mathrm{EH}$ deve se aproximar da elite para se constituir em mais comunidades de trabalho.

Para nós, entender a questão da captação de trabalho e inserção do Économie et Humanisme junto às comunidades é uma questão importante na compreensão do funcionamento do ideário lebretiano. $O$ documento que descreve o método desenvolvido pelo grupo e apresentado por Lebret na Sessão de Marseille, em 1944, traz alguns destes apontamentos, afirmando que:

Primitivement nous étions à l'équipe centrale un certain nombre de gens qui constituaient un personnel de direction, un autre constituant un personnel d'executants. De plus en plus nous essayons de nous constituer en communauté intégrale, les uns et les autres partageant le même ideal, ce qui suppose à la fois une politique de rémuneration et aussi une politique pédagogique qui a fait notre préoccupation de l'anné dernière et de cette anné commencente. ${ }^{127}$ (LEBRET, ibid., p. 23).

\footnotetext{
126 Traduzimos do documento original a palavra "maître" como dominação e entendemos que por isso Lebret buscava utilizar dos métodos usados por algumas congregações religiosas, como a dos padres Jesuítas, considerados mestres na arte de dominação e promoção da aculturação de um povo. Notemos que antes da dominação o documento aponta para a necessidade de que os membros vivenciassem determinadas situações a fim de compreender sobre elas para, posteriormente, tirar proveito das informações obtidas através da vivência daquela situação, e chegar de fato à dominação.

${ }^{127}$ Primeiramente instala-se na equipe central certo número de pessoas que constituirão o pessoal de direção da equipe; num outro momento se constitui o pessoal de execução e de mais a mais vai se formando uma comunidade integral, com pessoas que compartilham dos mesmos ideais, até que seja possível praticar uma política de renumeração e também uma política pedagógica, que foi a nossa preocupação no último ano e neste ano que começa. (Livre tradução do autor).
} 
Lebret expõe que a arquitetura do EH é então constituída por alguns serviços e organismos: o diretor, a assembléia geral e o conselho de direção. Subordinadas às equipes ficam os serviços de edição, de exploração dos diagramas, de documentação e informação, e, por fim, pretende-se formar uma escola, que será a principal arma, o principal instrumento, que será ao mesmo tempo uma célula de vida humana e também um laboratório de experiência para mostrar que é possível haver um tipo de vida comunitária.

Por fim, é exposta a regra do superior, apontando que o discurso do EH tem como ponto de partida a extensão da ação espiritual para uma ação temporal, que teria como ponto de chegada uma ação no tempo, pautada pela espiritualidade. Como medidas diretas do grupo, são apontadas duas ações: a oposição à sociedade contemporânea e a contribuição constante para a construção de um mundo humanista cristão. Lebret destaca ainda que era preciso seguir as regras de forma engajada, pois as mesmas culminariam em um estilo de vida que poderia se institucionalizar, e, com isso, atrair mais adeptos, suscitando uma mesma utopia de temperamentos dos chefes, dos responsáveis e dos militantes.

O documento aponta, em sua última página, que "para resumir este mecanismo complexo que é o método de Economia e Humanismo deve-se dizer que o EH é um método de estudo, um método de ação, movido pela fé. Mas é acima de tudo um ato de caridade. Como é um ato caridade, o EH tem grande dimensão para atuar em todo o mundo de hoje, elevando a dimensão científica, política e, enfim, institucional.”

Além de Lebret, que tinha o cargo de Secretário Geral do grupo, vale dizer que, em 1944, quando o "Méthode d'Économie et Humanisme" foi apresentado na Sessão de Marseille para cerca de cem participantes ${ }^{128}$, o Économie et Humanisme era dirigido por René Moreaux, presidente do grupo, e contava ainda com o economista François Perroux na vice presidência, o Padre Loew como Secretário Geral Adjunto de Lebret e o empresário Alexandre Dubois como Tesoureiro, composição que atravessou a primeira fase da equipe $^{129}$. Tal observação é importante, pois é capaz de situar o Centre d'Économie et Humanisme para além do trabalho de Lebret e expor que o mesmo se tratava de um organismo de pensamento social para além do catolicismo.

\footnotetext{
${ }^{128}$ Conforme lista de participantes consultada junto à Pasta AN45 AS44.

${ }^{129}$ Conforme documento consultado junto à Pasta AN45 AS35.
} 
Com o fim da Segunda Guerra, em 1945, o Économie et Humanisme apresenta um relatório sobre a conjuntura mundial intitulado "Regarde sur la Conjoncture Mondiale"130. O documento traz algumas considerações sobre o cenário encontrado no mundo ao final da Segunda Guerra, tecendo críticas ao fato de que o fim da Primeira Guerra havia trazido uma nova conjuntura que ainda não estava diagnosticada e que isto certamente prejudicaria a análise do período atual. Propõe, então, um programa de estudos para a compreensão do momento.

O Relatório traz uma análise do período entre guerras, com algumas projeções para o pós-guerra, já apontando para a divisão dos países em economia capitalista e socialista e a ascensão das duas grandes potências representantes de cada uma delas, os Estados Unidos, à frente do imperialismo, e a União das Repúblicas Socialistas Soviéticas, coordenando os avanços do socialismo.

Percebe-se que o objetivo da análise consistia em examinar as possibilidades de inserção da doutrina social da igreja católica nos novos problemas encontrados a partir das novas estruturas surgidas no período pós primeira guerra, quando então houve a consolidação do ideário de modernidade iniciado lá atrás, consolidando-se o capitalismo industrial e a divisão da sociedade em duas classes: dos trabalhadores e dos empresários.

Já ao final da Segunda Guerra Mundial, em 1945, para o Économie et Humanisme, mais do que a divisão entre as classes, nota-se um mundo dividido geograficamente e por sistema econômico: capitalismo liderado pelos EUA e socialismo liderado pela URSS,que poucos anos depois chegaram ao ponto de dividir a capital alemã em uma parte oriental, sob o governo da URSS, e outra ocidental, sob o efeito do capitalismo financiado pelos norte-americanos.

No documento são apresentados 13 tópicos e alguns apontamentos para a atuação no cenário encontrado, através de um programa de pesquisas onde se apontava para estudos sobre a conjuntura política, conjuntura econômica, conjuntura humana, ideologias vigentes, filosofias e místicas, e linhas mestras para uma solução. Este último tópico aponta para três itens a serem estudados sobre a ação do Économie et Humanisme:

1) Filosofia fundamental de uma economia humana;

2) Linhas mestras de uma economia planificada;

${ }^{130}$ Documento consultado na Pasta AN45 AS45. 
3) Primazia do espírito sobre a economia;

Dentro do programa de estudos proposto, ao final do relatório o mesmo é dividido em cinco pontos de pesquisa, incluindo-se o que visava apresentar as linhas mestras para a solução dos problemas estudados nos quatro primeiros pontos. O primeiro deles é voltado para a compreensão da conjuntura política, buscando-se entender as modificações da estrutura política do mundo e a mudança de conceito e definições sobre nação e soberania de Estado; estudar as tendências gerais das mudanças na estrutura interna dos Estados e buscar a distinção entre a comunidade política e a comunidade totalitária; e, por fim, compreender sobre a evolução da dependência entre os países, as relações internacionais e segurança dos mesmos.

O segundo ponto proposto para o estudo é voltado para a conjuntura econômica e se divide em quatro subitens, sendo: a evolução dos centros e dos blocos de produção econômica; a evolução das necessidades e do consumo; a evolução das trocas e intercâmbios internacionais; a evolução das estruturas financeiras e bancárias.

O terceiro ponto do programa de estudos é voltado à compreensão da conjuntura humana e apresenta cinco subitens. No primeiro deles propõe-se a entender as consequências sociais da guerra. No segundo a modificação da conjuntura humana, considerando-se, sobretudo, os povos anglo-europeus. O terceiro subitem se dedica a estudar os problemas demográficos encontrados na reconstrução das cidades. No quarto subitem são estudados os planos sociais e no último as posições do Économie et Humanisme, buscando-se tecer criticas e diretrizes para uma solução.

O quarto ponto traz a preocupação com as ideologias, filosofias e místicas presentes no mundo pós-guerra e divide o estudo em cinco itens, tendo sido o último deles acrescentado posteriormente ao documento datilografado, uma vez que está grafado a caneta. Os itens a serem estudados aqui são: as reações dos trabalhadores, as reações nacionalistas, outras formas de reação e as reações psicológicas mais presentes (grafados a caneta).

Tanto a metodologia apresentada por Lebret quanto a análise da conjuntura do pósguerra são aspectos retomados por Lebret no curso ministrado por ele no Brasil em 1947. Em 1946, Lebret é convidado pelo Frei Romeu Dale e pelo professor Cyro Berlink a visitar o Brasil e enxerga na oportunidade um novo campo para a disseminação das ideias do Centre d'Économie et Humanisme.

A nosso ver, a vinda de Lebret ao Brasil marca o início de uma nova fase para o $\mathrm{EH}$, quando o movimento lança mão de trabalhos junto a países situados na periferia do 
mundo. Lebret se estabelece no Brasil no período de abril a agosto de 1947, quando ministra um curso sobre a Economia Humana na Escola Livre de Sociologia e Política. Além do Brasil, Lebret visitaria também outros países da América Latina, como o Uruguai (numa visita entre os dias 23 de junho e 2 de julho de 1947), a Argentina (de 3 a 6 de julho) e o Chile (de 7 a 16 de julho).

\subsection{A visita de Lebret ao Brasil em 1947 e o engajamento social junto ao meio empresarial e acadêmico}

Conforme apontamos, os planos do Économie et Humanisme eram ambiciosos e para serem alcançados precisariam extrapolar para além do território francês. Neste sentido, parece-nos que caberia a Lebret a responsabilidade de introduzir o método do $\mathrm{EH}$ nos demais países do mundo. Porém, o ponto de questionamento entre os pesquisadores, sobre a difusão do ideário lebretiano e as ações da SAGMACS, é: por que o interesse do dominicano pelo Brasil? E por que ocorreu no Brasil a criação de um primeiro organismo vinculado ao $\mathrm{EH}$ fora da França?

É fato que o contexto econômico e político brasileiro, no período do pós-guerra, apresentava uma realidade favorável ao país que despontava devido ao processo de industrialização, crescimento das cidades e concentração de investimentos públicos voltados ao desenvolvimento econômico do país, que na época era governado pelo presidente Emilio Gaspar Dutra, eleito como sucessor de Getúlio Vargas em 1945, pelo Partido Social Democrata - PSD e com o apoio do PTB de Vargas ${ }^{131}$.

Coincidentemente com os aspectos positivos da economia, o contexto pós Segunda Guerra no Brasil também trazia avanços quanto à redemocratização do país, que tornou o quadro político social mais complexo do que nos países europeus, arrasados pela guerra $^{132}$. Tanto o Brasil quanto os países latino-americanos não haviam assumido

\footnotetext{
${ }^{131}$ Estudamos o quadro do desenvolvimento econômico e contexto político brasileiro no pós-guerra no capítulo 4 desta tese.

132 Quanto à complexidade do quadro político brasileiro, referimo-nos à composição dos partidos políticos e aos alinhamentos ideológicos à época, como, por exemplo, a existência de pensadores mais progressistas e também mais conservadores dentro da própria esquerda, podendo-se notar a existência, dentro das forças à esquerda, de liberais conservadores, democratas cristãos, e também do próprio PCB - Partido Comunista do Brasil, liderado por Luís Carlos Prestes. Da mesma
} 
posicionamento tão marcante frente à guerra, não tendo se alinhado nem com os países do Eixo e nem com os países Aliados, o que garantiu maior segurança da população e do território nacional durante o período de batalhas ${ }^{133}$.

Neste período, a atividade industrial brasileira desenvolveu-se de maneira expressiva, em decorrência da destruição do parque industrial europeu, que fora alvos de bombardeios. Havia necessidade de produção de materiais e fornecimento de equipamentos para os países que estavam envolvidos nas batalhas. O governo brasileiro, que já debatia desde os anos 1930 o incentivo à industrialização, devido ao aumento do mercado consumidor interno, no período da guerra, percebendo as demandas externas por produtos manufaturados, soube aproveitar este momento e investir nas áreas de ponta, para que a indústria se desenvolvesse e gerasse importantes conquistas à nação brasileira. Este desenvolvimento fez o Brasil ampliar significativamente seu saldo na balança comercial, pois as exportações de produtos manufaturados para a Europa nunca haviam sido feitas em tão grande quantidade ${ }^{134}$. Graças a este contexto econômico beneficiado pela guerra, o Brasil vivia um processo de transição de um país agrário e rural para um país que começava a ser urbano.

Em nossa dissertação de mestrado (2009) apontamos que tínhamos no Brasil, neste período do pós-guerra, a combinação de bons números na economia e a reconstrução de um novo tempo com a reabertura das vias democráticas, pós-ditadura Vargas, o que

forma que o PCB, a União Democrática Nacional também tinha em sua origem lideranças políticas tanto progressistas, alinhadas à esquerda, como o economista Caio Prado Junior, e também conservadores à direita, como o jornalista Carlos Lacerda. Inicialmente a ideia da UDN era de reunir todos os que se opunham a Vargas e ao Estado Novo, e com a nova constituição o partido tomou rumo à direita. De certo modo, este quadro ainda ressoava a eleição de 1945, quando foi eleito o novo presidente da República e os parlamentares para a Câmara e o Senado, que se reuniriam conjuntamente como o Congresso Constituinte para elaborar e aprovar a Constituição de 1946. Nesta eleição Getúlio Vargas foi um dos grandes vencedores, não só por ter tido papel decisivo na vitória de Dutra, mas por ter contado com a legislação eleitoral a seu favor, de forma que "concorreu ao mesmo tempo ao Senado em cinco Estados e a deputado federal em nove. Elegeu-se senador pelo Rio Grande do Sul e por São Paulo e deputado em sete Estados" (FAUSTO, 2004, p. 399). Vargas optou por tomar posse como Senador pelo Rio Grande do Sul, mas os votos obtidos nos demais estados garantiu ao PSD a maioria absoluta dos lugares, tanto na Câmara como no Senado. A UDN, opositora de Vargas e Dutra, era o segundo partido com maior número de representantes e o PCB surgia como o quarto partido mais votado do país, tendo sido seu candidato a presidente Yedo Fiuza, o terceiro colocado, com cerca de $10 \%$ dos votos.

${ }^{133}$ Enquanto foi possível, o governo brasileiro, comandado por Vargas, tentou manter uma relação de neutralidade durante a Segunda Guerra, porém, em fevereiro de 1942 tomou posição favorável aos países aliados, permitindo que os Estados Unidos instalassem no Rio Grande do Norte uma base aérea. Em 1944 o Brasil enviou 25.000 soldados da Força Expedicionária para combater os Países do Eixo na Itália.

${ }^{134}$ Veremos no capítulo seguinte que este movimento de ampliação do saldo da balança comercial brasileira não se deu exclusivamente devido à exportação de produtos, mas sim, devido à dificuldade imposta pela Guerra para a importação dos mesmos, o que obrigou o Brasil a fabricar tais produtos a fim de atender à demanda pelo consumo interno do país. 
gerava um clima de otimismo, mas também de preocupação entre a elite empresarial e os trabalhadores brasileiros. Também rendia uma complexidade do quadro político, institucional e econômico para além da disputa ideológica entre comunistas e capitalistas, e o alinhamento do Brasil com as novas e emergentes potências mundiais, a URSS de um lado e os EUA de outro.

A maior concentração industrial se localizava em São Paulo, que apresentava acelerados índices de crescimento populacional e urbanização. Embora o poder político central fosse sediado no Rio de Janeiro, com a pujança econômica alcançada graças às dificuldades das indústrias das economias centrais durante o período da guerra, foi na cidade de São Paulo que a elite empresarial do país se consolidou nos anos 1940. Esta mesma elite empresarial, que se mostrava extremamente entusiasmada com o crescimento econômico brasileiro, sentia também ausência de um programa de governo e um projeto de país e não reconhecia no presidente Dutra a capacidade para elaborar e conduzir um plano desses para o Brasil.

Sobre este quadro de satisfação econômica e incerteza política, Valladares (2005, p. 79) nos aponta que "naquele momento, cristãos e elites anticomunistas buscavam um projeto político para uma sociedade em plena reconstrução." Esta situação abria campo para a constituição de ideias para além dos centros empresariais, mas que propiciassem a adoção de um discurso de conciliação social dos industriais com os trabalhadores, a fim de se afastarem as ambições socialistas presentes em alguns meios sindicais e em parte do clero católico alinhado a uma esquerda progressista. Para Lebret, tratava-se de um terreno fértil, pois seu discurso propondo uma alternativa humanista e solidária para solucionar problemas sociais, segundo Valladares, "tanto seduziu os jovens católicos brasileiros, quanto uma grande parte da elite envolvida na busca de uma via ao mesmo tempo anti-imperialista e anticomunista que permitisse impulsionar as mudanças sociais $e$ o desenvolvimento econômico" (ibid., ibidem).

Ao contextualizar a visão de Valladares sobre o campo aberto para Lebret vir ao Brasil em 1947, é importante situar que antes mesmo de sua vinda ao país o dominicano já contava com vias de abertura às suas ideias através da "influência espiritual sobre a juventude católica, especialmente a JUC - Juventude Universitária Católica” (ibid., p. 80). Isto mostra que o vínculo entre o dominicano francês e o Brasil não se deu de forma tão simplória e despretensiosa, pois, além da JUC, a Faculdade de Arquitetura e Urbanismo da USP assinava a "Revue Économie et Humanisme" editada pelo grupo de Lebret, contando com exemplares publicados desde a terceira edição da revista, no ano de 1942, à disposição dos estudantes na biblioteca. 
Além de Valladares, Angelo (2010) e Roldin (2012) estudaram os motivos da vinda de Lebret para o Brasil em 1947 e trazem alguns apontamentos para além dos sugeridos por Pelletier (1996) sobre a questão financeira que envolvia o grupo e apontava a necessidade de ampliação de suas frentes de trabalho a fim de se equilibrar o orçamento do EH. Para Angelo, "desde a criação do EH e o fim da guerra, (Lebret) tinha a intenção de buscar novas frentes de atuação para além do território francês, onde fosse possível aprofundar o método de pesquisa e divulgar o pensamento de seu grupo", apontando que "a abertura para a vinda de Lebret ao Brasil veio do diretor da ELSP" (LEBRET, ibid., p. $59)$.

Segundo Valladares (2005), a Escola Livre de Sociologia e Política - ELSP foi fundada em São Paulo, em 1933, pela elite empresarial paulistana, e baseava-se num modelo de universidade mais próximo daquele defendido pelos norte- americanos, centrado na pesquisa empírica e com o objetivo de formar quadros para a administração pública do aparelho do Estado. Para Angelo, a ELSP "se aproximava mais do empirismo de Lebret e menos da sociologia teórica valorizada pela USP", afirmando ainda que "a ELSP tinha o interesse nas ideias do avançado catolicismo social que Lebret pregava" (ibid., p. 69). Desta forma "Lebret vai encontrar espaço para dar início a sua carreira no exterior" (ibid., p. 70).

Angelo mapeou a forma com que se deu a vinda de Lebret ao Brasil e aponta, em sua tese de doutorado (2010), que o primeiro contato teve início em 1941, através do frei dominicano brasileiro Romeu Dale, que frequentou o Convento de Saint Maximin na França e, mais tarde, trabalhou com Lebret em Marseille. ${ }^{135}$ "Dale também se mostrava interessado em constituir um Centro de $\mathrm{EH}$ no Brasil e na América Latina quando retornasse ao Brasil" (ibid., p. 59). Porém, segundo a autora, Dale retornou ao Brasil em 1942 e só retomou contatos com Lebret em 1946, "quando o frei intermediu o contato entre o diretor da ELSP, Cyro Berlinck, e Lebret" (ibid., p. 60), confirmando assim a abertura dada pela instituição paulista ao dominicano francês, conforme apontado por Valladares.

Entre a aceitação de Lebret, em junho de 1946, até a sua vinda, em abril de 1947, existe o relato em inúmeras correspondências sobre a organização da viagem, do curso e de todas as burocracias que os envolviam, inclusive o pedido

\footnotetext{
135 Angelo aponta esta trama de relação entre Lebret e o frei brasileiro, Romeu Dale, através de pesquisa sobre as cartas trocadas entre ambos, que constam do Fonds Lebret, na Pasta AN45 AS102, conforme informado pela autora nas páginas 59 de sua tese e que culminou com o convite do Diretor da ELSP, Prof. Cyro Berlink, para que Lebret viesse ao Brasil pela primeira vez em 1947.
} 
de visto para que Lebret entrasse no Brasil como professor-visitante da ELSP, onde desenvolveria atividades científicas e didáticas. (ANGELO, p. 60).

Assim, num movimento de expansão do Économie et Humanisme e de tentativa de legitimação do método junto ao meio intelectual francês, seguir para o Brasil para ministrar um curso em nível de pós-graduação junto a uma instituição de ensino superior parecia abrir para Lebret a chance de conquistar um espaço junto ao meio universitário e acadêmico, ainda que não o francês, mas que estava em voga desde o início dos trabalhos da equipe do $\mathrm{EH}$.

Neste sentido, tanto Valladares quanto Angelo apontam que, desde a França, Lebret buscava uma forma de ter o método cunhado por ele junto ao Centre d'Économie et Humanisme reconhecido no meio intelectual e acadêmico francês. Com este reconhecimento seria possível ao Économie et Humanisme conquistar o custeio das suas pesquisas através de orçamento e verbas advindas do Centre National de la Recherche Scientífica - $\mathrm{CNRS}^{136}$, organismo público voltado ao fomento do desenvolvimento da pesquisa científica na França, atualmente vinculado ao Ministère de l'Éducation Nationale, de l'Enseignement Supérieur e de la Recherche.

Porém, a resistência era grande, pois, segundo Valladares (ibid., p. 81), Lebret "não pertencia ao meio acadêmico francês e nem compartilhava da tradição sociológica"; também não era "nem sociólogo e nem antropólogo de formação". O "seu investimento nas ciências sociais remetia a uma trajetória cultural e profissional bem diversa da trajetória acadêmica francesa: ao invés da tradição durkheimiana, seguiu a prática sociológica herdada de Le Play". E assim, para a autora, da mesma forma que na França, "aos olhos da elitista USP, o trabalho realizado pelo Économie et Humanisme, quase ignorado no Brasil, não correspondia à sociologia canônica exportada pela França."

Sendo assim, o padre Lebret vai então encontrar o seu lugar no Brasil em uma graduação em Ciências Sociais da ELSP, com duração de quatro meses, o equivalente a um semestre letivo. Foi neste período que ele aproveitou para estreitar seus contatos no Brasil, bem como aperfeiçoar seu conhecimento sobre o terceiro mundo. Além dos padres dominicanos, Lebret estreitou seus laços com importantes lideranças empresariais e intelectuais, como os engenheiros Prof. Lucas Nogueira Garcez e Prof. Luiz Cintra do Prado, ambos da Escola Politécnica da USP; o Prof. Luiz Anhaia Mello, da Faculdade de Arquitetura e Urbanismo da USP; o sociólogo norte-americano Frank

\footnotetext{
${ }^{136}$ Segundo Albertini (2006), em 1954 Lebret tornou-se assistente do CNRS e assim seguiu até sua morte, em 1966.
} 
Goldman; o empresário Olívio Gomes, o Desembargador João Batista de Arruda Sampaio, além de jovens com aspirações políticas como Wladimir Toledo Piza, André Franco Montoro, Carlos Alberto Alves de Carvalho Pinto e Darcy Passos ${ }^{137}$, e ainda com seus contatos no meio religioso através da Fraternidade Leiga dos Dominicanos.

Segundo Lamparelli $(2007)^{138}$, a estada de Lebret foi custeada pela Federação das Indústrias do Estado de São Paulo - FIESP, órgão de representação dos interesses da elite industrial paulista, capaz de exercer significativa influência no governo federal. Este vínculo de Lebret com a FIESP, para Valladares, explicaria o "interesse de personalidades da elite industrial na busca de um novo modelo socioeconômico." Isto porque, "tais personalidades, convencidas da utilidade do planejamento, almejavam um certo progressismo, interessadas no enfoque inovador de um catolicismo social baseado em princípios científicos". (ibid., ibidem).

Porém, as ideias difundidas por Lebret em seu curso eram consideradas por algumas lideranças empresariais avançadas demais e muito simpáticas à planificação da economia, o que era visto como ferramenta utilizada pelos países de economia socialista, sendo, portanto, nocivas aos interesses econômicos individuais, presentes no ideário da classe empresarial paulistana, encontrando resistência inclusive em setores da igreja católica que consideravam Lebret subversivo à ordem social vigente. A escola de sociologia era

voltada para uma sociologia mais empírica e mais aplicada do que a sociologia teórica valorizada pela USP. [...] Uma grande diferença marcava as duas instituições em que um estudante nos anos 1940 poderia adquirir uma formação em ciências sociais, na cidade de São Paulo: a Faculdade de Filosofia, Ciências e Letras da USP, na qual predominava um ensino generalista e essencialmente teórico, e a ELSP, que visava à formação de profissionais da pesquisa dotados de competências administrativas. (ibid., ibidem).

\footnotetext{
${ }^{137}$ É importante observar que entre os nomes citados, Lucas Nogueira Garcez foi governador do Estado de São Paulo entre os anos de 1951 e 1955; Carvalho Pinto governou o Estado entre 31/01/1959 e 31/01/1963 e assumiu o Ministério da Fazenda do governo de João Goulart entre 21/06/1963 e 19/12/1963; Franco Montoro foi deputado federal por dois mandatos antes da ascensão da ditadura militar e tornou-se o primeiro governador de São Paulo eleito pelo voto direto em 1982, com o enfraquecimento do regime militar. Destacamos ainda que o Promotor Público Darcy Passos teve três mandatos como Deputado Federal e que Wladimir Toledo Piza foi vereador e prefeito da cidade de São Paulo. Além disso, cabe menção ao Prof. Luiz Anhaia Mello, que havia ocupado o cargo de Prefeito de São Paulo no ano de 1931.

${ }^{138}$ A informação foi dada por Celso Lamparelli em entrevista concedida em 11/06/2007 para este autor e é repetida por Lícia Valladares, citando a mesma fonte. Porém, Angelo mostra em sua tese de doutorado que na carta de Ciro Berlink para Romeu Dale, em 12 de abril de 1946, "A Escola ofereceria um contrato de um ano, fazendo as despesas de viagem ida e volta e um honorário mensal a se combinar, o que seria em torno de 48.000 a 60.000 cruzeiros por ano."
} 
Em carta de Romeu Dale para Lebret, em 1946, o frei dominicano brasileiro destaca que a Escola de Sociologia começava a ter influência sobre a jovem geração intelectual, expondo que o dominicano francês deveria aproveitar o convite feito pelo diretor da mesma para vir ao Brasil. Dale finaliza a carta expondo ainda que "esta será a ocasião de organizar um grupo de Economia e Humanismo no Brasil". ${ }^{139}$

Durante os anos 1940 a ELSP contratou uma série de professores estrangeiros, alguns como visitantes e outros para compor o quadro fixo da Escola, como foi o caso de Donald Pierson (norte-americano), assim como de Herbert Baldus e Emílio Willems (alemães). (ROLDIN, 2012, p. 100).

É então essa Escola Livre de Sociologia e Política de São Paulo, ligada à valorização das pesquisas de campo, que acolhe o Padre Lebret em 1947, para ministrar ali, durante quatro meses, um Curso de Introdução Geral à Economia Humana. (VALLADARES, ibid., p. 82).

A disciplina oferecida por Lebret na área de economia inseria-se dentro do programa de pós-graduação.

Breuil destaca que a primeira estadia de Lebret no Brasil foi determinante para o seu encaminhamento intelectual, até porque era a primeira vez que Lebret saía do campo das pesquisas europeias para confrontar diferentes problemas, como o do subdesenvolvimento. (BREUIL, 2006, apud ANGELO, ibid., p. 67).

Segundo Lamparelli (2007), a situação de Lebret no Brasil se agravou quando o presidente Dutra, juntamente com o Congresso Nacional, obtendo o aval do Supremo Tribunal Federal, cassou o registro de legalidade ${ }^{140}$ do Partido Comunista Brasileiro - o $\mathrm{PCB}^{141}$. Mesmo sem haver empatia entre Lebret e o Partidão, e vice-versa, o dominicano

139 Conforme apontamentos feitos por Angelo através da carta de Dale para Lebret datada de 28/04/1946, consultada junto ao Fonds Lebret, pasta AN45 AS102.

${ }^{140}$ A cassação do registro de legalidade do PCB ocorreu em maio de 1947, por decisão do Supremo Tribunal Federal, que decidiu cassar o registro do partido a partir de denúncias apresentadas por deputados do PTB, que temiam pela hegemonia dos Estados Unidos e o equilíbrio europeu que eram ameaçados pelo avanço dos soviéticos na ocupação dos países do leste europeu. Segundo Fausto "a decisão controvertida, tomada por apenas um voto de diferença (três a dois), baseou-se em texto da Constituição. Ele vedava a existência de qualquer partido político cujo programa ou ação contrariassem o regime democrático" (2004, p. 402).

141 Segundo Pelletier (1996, p. 161), o PCB era uma jóia no jogo político brasileiro em 1947. Seu candidato a presidente, Yedo Fiuza, obteve $10 \%$ dos votos em 1945 e mais de $20 \%$ deles nas maiores cidades, como o Rio de Janeiro e São Paulo. Para o autor : "Le 7 mai, l'interdictioin du parti marqua clairement les limites de l'experiénce démocratique." No mesmo sentido Fausto aponta 
francês criticou o governo brasileiro dizendo que um país que cassa o registro de um partido político não pode ser considerado um Estado Democrático de Direito e muito menos um país democrático. Estas palavras de Lebret levaram o governo federal, juntamente com a cúpula da igreja católica brasileira, sobretudo os mais conservadores, que já se mostravam preocupados com os posicionamentos do padre, a negociar o retorno de Lebret à França, alcançando o apoio do Vaticano, que ordenou o imediato retorno dele ao seu país de origem e a proibição de retornar ao Brasil e aos demais países da América Latina.

Se as ideias de Lebret assustavam o meio empresarial liberal e os padres conservadores, que atribuíam a ele ser avançado demais, o PCB, por sua vez, também não simpatizava com as ideias de Lebret, pois elas se opunham ao conceito de luta de classes, pregando o desenvolvimento harmônico, o que, para Luís Carlos Prestes, líder do Partidão, era impossível de ocorrer sem uma justa distribuição de renda. A seu ver, isto só seria alcançado em caso de vitória da classe trabalhadora sobre o capital, com a mesma tomando os meios sociais de produção econômica e o controle do Estado, abrindo campo para o que Marx definia como a ditadura do proletariado.

Desse modo, Lebret não encontra espaço para transitar entre os extremos políticos do país e, assim como suas ideias de desenvolvimento harmônico, começa a buscar formas de alcançar a conciliação dos diferentes interesses, tanto da elite empresarial, simpática às ideias progressistas, quanto dos políticos e lideranças vinculadas a partidos de centro esquerda. A Democracia Cristã, que na época conseguia reunir liberais conservadores e simpatizantes do socialismo, era o espaço ao qual Lebret se vinculava com maior empatia aqui no Brasil. Porém, esta corrente política, que inclusive havia contribuído para a eleição do presidente da República, não foi capaz de impedir seu retorno para a França, sob ordem do Vaticano.

A proibição imposta pelo Vaticano a Lebret se estendeu aos demais países da América Latina, pois no mesmo ano ele havia visitado o Chile, a Argentina, a Colômbia e o Uruguai, e também disseminado seus pensamentos progressistas sobre democracia e desenvolvimento econômico, desagradando algumas lideranças católicas, favoráveis a uma igreja mais tradicionalista, voltada exclusivamente à doutrina cristã e fechada para a realidade social e os problemas da população católica no mundo e, principalmente, nos países sul americanos.

que "o PCB surgia em 1946 como o quarto partido do país. Elegera dezessete deputados e um senador e alcançara a maioria na Câmara de Vereadores do Distrito Federal. Em São Paulo, os comunistas obtiveram o terceiro lugar no total de votos nas eleições estaduais de 1947, superando a UDN." (ibid., p. 402). 
Por ocasião de seu retorno à França, no final do ano de 1947, a ordem recebida na carta de Roma era para que Lebret se reportasse ao papa Pio XII, relatando os problemas ocorridos durante sua estada no terceiro mundo. Esperava-se a repreensão da igreja católica a ele. Porém, Lamparelli (2007) relata que, devido a problemas de agenda, coube ao Núncio Apostólico em Paris receber o dominicano para a reprimenda. Em 1947, o cargo de Núncio Apostólico era exercido pelo Cardeal Arcebispo Angelo Roncalli, que em 1958 tornou-se o papa João XXIII.

Em novembro de 1947, o encontro de Lebret com Roncalli foi muito cordial, conforme ele mesmo relatou em seu diário.O Cardeal representante do papa advertiu Lebret de que não havia na cúpula da igreja católica consenso sobre o uso do termo "humanismo", sendo que alguns ainda vinculavam esta palavra ao período do iluminismo, quando filósofos e pensadores puseram a doutrina da igreja católica sob suspeição. Roncalli conclui que o emprego do termo por Lebret poderia assim ser confundido com outras aspirações e recomenda a Lebret maior cuidado em seu trabalho e em suas aspirações sociais, sugerindo que o mesmo encaminhasse de imediato uma carta ao papa Pio XII, expondo as ideias defendidas por ele através do Économie et Humanisme. ${ }^{142}$

De acordo com a sequência de cartas trocadas entre Lebret e o Vaticano, pudemos observar que, após a reprimenda de Roncalli, o Économie et Humanisme passou a ter no Cardeal italiano um aliado. Roncalli não somente encaminhou carta ao papa relatando a conversa que teve com o dominicano e expondo os objetivos de Lebret junto ao $\mathrm{EH}$, como também,segundo carta assinada pelo Cardeal Montini, em 12 de dezembro de 1947, "o Núncio Apostólico na França transmitiu ao santo padre a última coleção da revista 'Economie et Humanisme'”.

Embora não exercesse de forma oficial o cargo de Secretário de Estado do Vaticano, o Cardeal Montini ${ }^{143}$ fazia parte do Departamento de Estado da Santa Sé e respondia, no período, como um dos principais assessores do papa Pio XII. Na carta de dezembro de 1947, expôs ao padre Lebret o tom de aprovação do santo padre às ações do Économie et Humanisme, o que rendeu ao grupo um período de trégua com a igreja católica, porém, não permitiu o retorno imediato de Lebret ao Brasil. Montini afirma que:

\footnotetext{
142 A primeira carta de Lebret endereçada ao Papa Pio XII data de 29 de outubro de 1947 e foi consultada por nós junto à Pasta AN45 AS34. Nela Lebret encaminha um breve relato com a descrição dos objetivos do Centre d'Économie et Humanisme e histórico de trabalho do mesmo.

${ }^{143}$ O Cardeal Giovanni Battista Enrico Montini trabalhou no Departamento de Estado do Vaticano desde a juventude e era considerado um dos colaboradores mais próximos do papa Pio XII, que o nomeou Cardeal Arcebispo de Milão em 1954. Em 1963 foi eleito papa Paulo VI em substituição a João XXIII, morto naquele ano.
} 
J'apprécie beaucoup les belles initiatives de votre mouvement et serai heureux de pouvois ainsi me documenter plus amplement sur ses idées et sur ses réalisations. Je ne doute pas qu'il ne soit appelé à apporter à la grande ouvre de la reconstruction de la société sur des bases vraiment humaines et chretiennes des éléments bien prêcieus, et c'est de bon couer que je prie Dieu de vous aider dans votre tâche. ${ }^{144}$

Mesmo assim, após o seu retorno à França, o dominicano finalmente conquistava o apoio da cúria romana para seguir com seu trabalho à frente do Centre d'Économie et Humanisme, pelo intermédio de Roncalli e Montini. Porém, conforme já expusemos, o apoio do Vaticano não rendia o respaldo do trabalho desenvolvido por Lebret entre o meio acadêmico e intelectual francês, mas permitia a Lebret que seguisse engajado à frente do movimento e buscasse, assim, ampliarsua atuaçãonos territórios de ação do $\mathrm{EH}$.

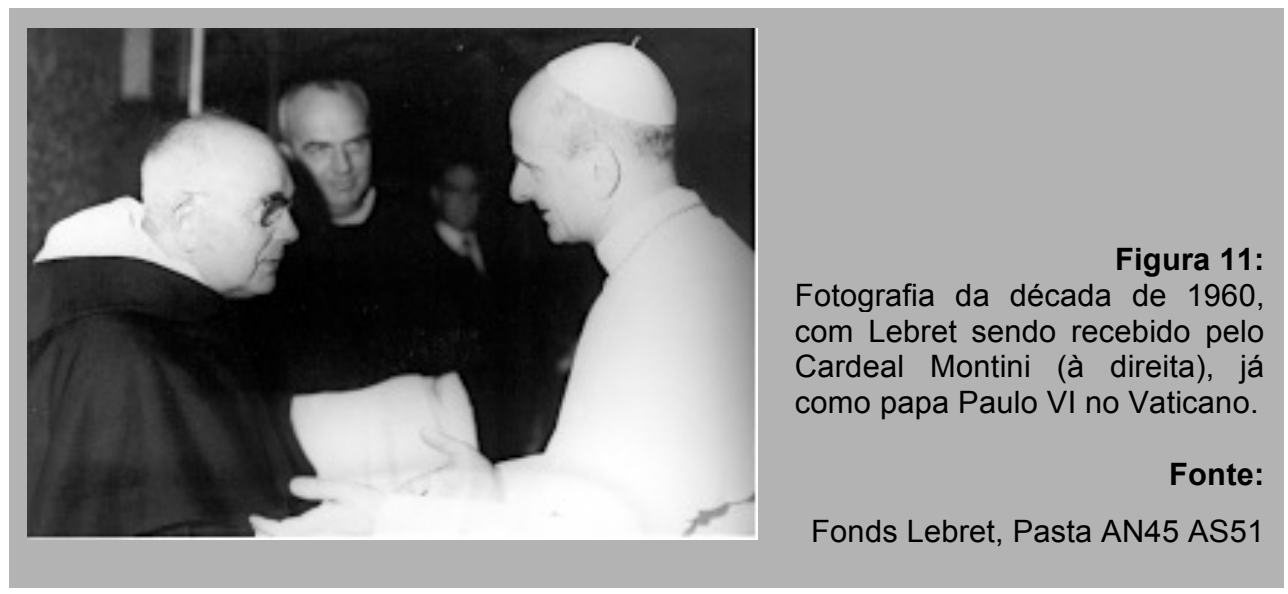

No Brasil, onde Lebret, durante sua primeira estada, não havia despertado o interesse da ala conservadora da igreja católica pelos trabalhos do Économie et Humanisme e entre o meio empresarial mais simpático a uma matriz econômica liberal ganhara a pecha de esquerdista e simpático ao socialismo, o dominicano havia, no entanto, conquistado o

\footnotetext{
${ }^{144}$ Carta assinada por Montini em resposta ao padre Lebret, datada de 12/12/1947. O documento foi consultado junto à Pasta AN45 AS34. Livre tradução do autor: Eu aprecio as grandes iniciativas de seu movimento e fico feliz por ver mais plenamente suas idéias e realizações. Eu não duvido que este movimento foi chamado para fazer o grande trabalho de reconstrução da sociedade em bases verdadeiramente humanas e principios cristãos de bem, e isso é bom para o coração, peço a Deus para ajudá-lo em sua tarefa.
} 
apoio e a simpatia de algumas lideranças políticas moderadas, mas com trânsito em setores da direita, como o Prof. Lucas Nogueira Garcez. Conquistara também o apoio de lideranças religiosas como do Cardeal Arcebispo do Rio de Janeiro D. Hélder Câmara, de alguns empresários católicos com certa influência na FIESP e, a nosso ver, o mais importante, através de seu curso na ELSP havia alcançado o respaldo de uma instituição junto ao meio intelectual e acadêmico de São Paulo.

Segundo Angelo e Valladares, este respaldo buscado por Lebret através de uma instituição acadêmica foi outro ponto que favoreceu a vinda de Lebret ao Brasil em 1947. Comentando sobre os intelectuais franceses "que vieram na missão francesa fundar a USP.", Angelo aponta que "o Brasil foi uma 'nova via' para esses intelectuais" que iniciaram "suas carreiras acadêmicas no Brasil e posteriormente foram reconhecidos pela comunidade científica francesa”. (ibid., p. 64). ${ }^{145}$

Neste contexto, é importante retroagirmos à década de 1930, quando o sistema universitário se configurava não só em São Paulo, mas em todo o país, e passava por reformulação da política educacional imposta pelo governo de Getúlio Vargas. Assim, "no plano do ensino superior, o governo procurou criar condições para o surgimento de verdadeiras universidades, dedicadas ao ensino e à pesquisa" (FAUSTO, 2004, p. 337). "O governo baixou o Estatuto das Universidades Brasileiras [...] procurando estabelecer as bases do sistema universitário" (ibid., p. 338).

Sob este processo de reorganização e institucionalização do ensino superior e da pesquisa científica, no início dos anos 1930 a cidade de São Paulo, que já contava com a Universidade Presbiteriana Mackenzie, assistia à criação da Universidade de São Paulo em 1934 e da Escola Livre de Sociologia e Política em 1933. Em 1946 foi criada a Pontifícia Universidade Católica - PUC, que já atuava na década de 1930 oferecendo formação universitária com cursos de graduação nas áreas de Filosofia, Direito e Economia.

Segundo Angelo, a criação da USP seguiu um modelo de orientação humanista e matriz universitária francesa, ou seja, "teórica, generalista e voltada à formação docente" (ibid., p. 69), sendo que "essas características eram contrastantes em relação ao modelo seguido pela ELSP."

\footnotetext{
145 Sobre a presença de estrangeiros e da missão francesa que contribuiu com a criação da Universidade de São Paulo na década de 1930, é importante lembrar que o próprio economista François Perroux, um dos fundadores do Centre d'Économie et Humanisme junto com Lebret, esteve no Brasil em 1936 para auxiliar na criação do curso de Economia.
} 
A Escola, fundada em 1933 pela elite de São Paulo, oferecia outra matriz, de orientação norte-americana, centrada na pesquisa empírica e com finalidades intervencionistas, inclusive sendo este o requisito básico para a qualificação do sociólogo. (ibid., ibidem).

Mesmo tendo a ESLP matriz de orientação norte-americana, Lebret aceitou o convite para visitar o Brasil, seguindo assim os passos que outros intelectuais franceses haviam feito anos antes, e, ao retornarem ao seu país de origem, conquistado o espaço dentro do meio intelectual e acadêmico francês. Na década de 1930, além de François Perroux, visitaram o Brasil, embuídos com o projeto de criação da USP, o geógrafo Pierre Monbeig, o filósofo Claude Lévi-Strauss e o historiador Fernand Braudel.

A estada de Lebret como professor visitante junto à ELSP não lhe rendeu prestígio junto a alguns intelectuais e sequer alcançou reconhecimento junto à Faculdade de Filosofia da USP, que manteve a posição de classificar o trabalho de Lebret como antiacadêmico. No entanto, possibilitou, através de seu contato com alunos da ELSP, demais professores e religiosos, disseminar no Brasil os métodos do Économie et Humanisme e, sobretudo, criar em São Paulo um organismo vinculado ao grupo francês, a SAGMACS, cuja formação e cronologia de atuação será analisada na sequência deste capítulo, após a apresentação do conteúdo abordado e tratado por Lebret em sua disciplina no curso de pós-graduação da ELSP.

Além disso, para Albertini, foi graças a sua visita ao Brasil que Lebret "perçoit les problèmes posés par le pays en voie de développement et les considere comme plus importants que ceux que l'Europe affonte". (2006, p. 21). Isto demonstra a importância da estada de Lebret no Brasil e em demais países sul americanos para a própria formação do religioso, no sentido de entender os problemas do mundo e principalmente a economia do Terceiro Mundo em relação às economias centrais.

\subsection{A abertura da ELSP para Lebret explicar a "Economia Social"}

Conforme vimos, Lebret encontrou na Escola Livre de Sociologia e Política a abertura de espaço junto ao meio acadêmico e intelectual paulistano. O convite feito pelo Prof. Cyro Berlink, diretor da ELSP, intermediado pelo frei Romeu Dale, foi visto por Lebret como a forma de alcançar prestígio acadêmico para o método e as ideias defendidas pelo Centre 
d'Économie et Humanisme. Dessa forma, o dominicano não tinha porque recusar a oferta para visitar o Brasil ${ }^{146}$ no contexto pós Segunda Guerra e alcançar o acolhimento junto a uma instituição de ensino superior. Segundo Roldan,

As posições de Lebret vão ao encontro do projeto da ELSP que é (naquele período) igualmente crítico ao liberalismo econômico (e ao Estado autoritário) e reivindica uma "intervenção estatal" nas questões sociais (como no caso da habitação social no pós-guerra), tendo como perspectiva as pesquisas empíricas como subsídio para a política pública. (ibid., p. 100).

Buscando aproveitar ao máximo a oportunidade alcançada junto à ELSP para difundir, no meio intelectual brasileiro, seu pensamento e as ações de seu grupo na França, Lebret se dedica, antes de sua chegada, à organização do material de orientação para o curso sobre a Economia Social ${ }^{147}$, que depois passou a ser chamado de "Introdução à Economia Humana". O curso seria ministrado por um período de três meses, dentro do calendário semestral da instituição, e foi dividido em quatro grandes temas, expostos por Lebret em 36 aulas.

Segundo informações da FESPSP ${ }^{148}$, matricularam-se para o curso ministrado por Lebret um total de 53 alunos $^{149}$, destacando-se o alto número de alunos especiais, 41 , o que demonstra o interesse da sociedade e juventude paulistana por conhecer melhor as ideias do Pe. Lebret, mas aponta também para o prestígio da própria ELSP no período. A lista de alunos matriculados traz os nomes de doze alunos regulares, que já cursavam o programa de pós-graduação em Ciências Sociais da ELSP, sendo: P. A. Amaral, O. Baptista Filho, I. Dale, C. Escobar Filho, O. F. Leme, W. J. Loewenberg, E. H. M. Lopes, Z. B. Luna, M. C. Mariante, O. Roldão, M. M. Rosa e J. Scantimburgo.

\footnotetext{
${ }^{146}$ Além da abertura dada pela ELSP, que contribuiu para a primeira vinda de Lebret ao Brasil, é importante mencionar também a importância que os dominicanos brasileiros sediados em São Paulo, além de Romeu Dale, tiveram na facilitação dos trâmites para a visita do fundador do $\mathrm{EH}$. O Convento dos Dominicanos de São Paulo era supervisionado pelos dominicanos de Toulouse e vinculado aos franceses. A Ordem dos Dominicanos dividia a supervisão dos conventos dominicanos espalhados pelo mundo entre os italianos e franceses e naquele período os frades brasileiros ligados a Fraternidade de Santo Domingo vinculavam-se aos dominicanos franceses.

147 Nos documentos consultados junto ao Fonds Lebret verificamos que o nome originalmente pensado pela direção da ELSP para o curso que seria ministrado por Lebret na instituição era sobre a "Economia Social", porém, após a definição do conteúdo e organização do programa, passou a ser chamado de "Introdução à Economia Humana".

${ }^{148}$ Atual nome da antiga Escola Livre de Sociologia e Política.

${ }^{149}$ Conforme informação da Seção de Alunos constante do Anuário de 1948 da ELSP.
} 
Entre os alunos especiais constam os nomes de: N. Abrão, D. B. Almeida, A. Assis, L. N. Assumpção, M. A. Barbosa, O. Bernardini, E. Bridi, A. Calvo, A. J. Caropreso, F. V. Carvalho, S. Casheil, E. Chaves, H. S. D’Avila, J. M. Donozetti, J. P. Ferreira, O. C. Ferreira, G. C. Franco, J. M. Freitas, H. T. Junqueira, O. S. Melanson, F. R. Mello Jr., N. Nazo, J. Penteado, S. M. Pompeia, A. C. Prado, F. Ramos, V. M. Rangel, L. C. G. Reis, A. Sampaio, M. M. Sampaio, J. J. B. Turpin, C. C. F. Vampré, L. C. M. Vasconcellos; e dos sete religiosos: Frei A. M. A. Costa, Frei H. T. B. Lagenest, Frei L. M. Neves, Frei E. Puppi, Frei G. M. Saab, Frei B. Santa Cruz e o Pe. E. C. Gusso.

O programa do curso "Estudos Post-Graduados de Economia Social", montado por Lebret, distribuiu os temas abordados em 14 subtemas, que foram ministrados nas 36 aulas, ocorridas às segundas e sextas-feiras, no período matutino, durante os meses de abril e junho. Há também uma apostila produzida por Lebret, em francês, disposta em quatro volumes que alcançam mais de 400 páginas, onde ele expõe a divisão do curso em três partes. Esta apostila, consultada nos arquivos de Lebret na França, apresenta na sua primeira parte o tema: "Appel d'une Économie Humaine", e na segunda parte "Lignes d'orientation d'une Économie Humaine". A última parte se dedica às "Perspectives d'une Économie Humaine" e é exposta de forma a concluir o curso de Lebret junto à ELSP.

A apostila produzida por Lebret traz a distribuição dos temas e subtemas das 36 aulas que seriam ministradas na ELSP. Porém, o programa apresentado no início de suas atividades junto aos alunos matriculados traz algumas alterações em relação aos títulos que constavam na apostila, fato que nos parece ter ocorrido numa tentativa de simplificação e facilitação da compreensão dos temas. Apresentamos a seguir a sequência dos subtemas abordados nas aulas, de acordo com o programa disponibilizado pela ELSP ${ }^{150}$.

1. Fracasso Humano no mundo moderno.

2. Crítica da economia política.

3. -7 . A reação marxista (5 aulas).

8. A reação nazista.

9. Os ensaios corporativistas.

10. - 12. A planificação soviética (3 aulas).

\footnotetext{
${ }^{150}$ O programa foi obtido junto ao Anuário de 1948 da ELSP. A apresentação do programa completo disponibilizado pela ELSP é citado como "Anexo 1" da nossa dissertação de mestrado (2009). Em nossa estada na França, durante nossa pesquisa de doutorado, verificamos o documento também junto ao Fonds Lebret, em Fontainebleau, na Pasta AN45 AS155 e na Pasta AN45 AS144, onde estão depositados os volumes da apostila de preparação do curso elaborado por Lebret.
} 
13. - 15. Bases e exigências da economia humana (3 aulas).

16. Lugar da economia humana entre as ciências.

17. As unidades territoriais em economia humana.

18 - 22. A análise em economia humana (5 aulas).

23. Conjuntura Humana e Conjuntura Econômica.

24. - 28. Elementos dum "sistema" em economia humana (5 aulas).

29. A economia humana e a política.

30. A economia humana e a espiritualidade cristã.

31. - 35. Passagem da economia atual à economia humana (5 aulas).

36. Necessidades de um movimento espiritual.

$\mathrm{Na}$ apostila produzida por Lebret para subsidiar os assuntos e conteúdos que seriam tratados no curso de pós-graduação da ELSP, constatamos outra divisão dos temas, conforme pode ser visto no índice apresentado para a primeira parte, no primeiro volume da apostila e no sumário sobre a segunda parte, disposto no terceiro volume da mesma, conforme apresentamos a seguir ${ }^{151}$ :

1 ère Partie - Appel d'une Économie Humaine

I. Echec humain du monde moderno

II. Critique de l'économie politique

III. La préparation du marxisme

IV. "Le Capital" de Marx

V. Synthèse des positions de Marx-Engels

VI. Regard d'ensemble sur le marxisme

VII. Le national-socialisme

VIII. Le sessais corporatifs et corporatistes

IX. Les structures soviétiques

$X$. Le léninisme

${ }^{151}$ Documento consultado na Pasta AN45 AS144. 
2 ème Partie - Lignes d'Orientation d'une Économie Humaine

XI. Le drame d'un siècle

XII. Aspiration à L'Économie Humaine - Définition et place de l'Économie Humaine

XIII. Postulats de l'Économie Humaine

XIV. Les précurseurs de l'Économie Humaine
a. Les méthodes d'analyses et de synthèse
b. Les catholiques d'avant-garde au début du XIXe siécle
c. La vision de P. Kropotkine

XV. Les précurseurs de l'Économie Humaine dans l'Église

Lebret inicia suas aulas em 14 de abril de 1947, dedicando-se à exposição do programa do curso e à elaboração de uma análise da conjuntura mundial, tratada por ele como o "fracasso do homem no mundo moderno". De forma esquemática, Lebret aponta para o que ele chamava de místicas presentes no mundo moderno, mas que podemos traduzir como as crenças e matrizes norteadoras do ideário humano naquele período pós-guerra. Para ele, as místicas do mundo moderno estariam vinculadas às crenças sobre a liberdade na ciência, o progresso técnico, o lucro e o trabalho e produtividade. Estes dois últimos - lucro e trabalho e produtividade, seriam os responsáveis por desdobrar-se em problemas como a falta de investimentos, falta de crédito e o aumento da inflação.

Par une contradiction insurmontable les mystiques qui animent l'humanité, mystique de la connaissance et mystique du progrès, forcent l'homme à soupirer après toujours plus de savoir, toujours plus de facilites et finalement à un gigantesque effort de production, domine jusqu'ici par la passion du gain, par l'avidité du profit ${ }^{152}$. (LEBRET, 1947: $1^{\mathrm{e}}$ partie).

La guerre endémique du monde moderne n'est pas simplement la guerre de nations en armes, mais la tension permanente et croissante entre des forces antagonistes, qui peut aussi bien se manifester par une opposition constante au plan des échanges entre les groupes et entre les peuples ${ }^{153}$. (ibid., ibidem).

\footnotetext{
152 Há uma contradição insanável entre as místicas que conduzem a humanidade, a mística do conhecimento e do progresso, forçando o homem a ansiar mais e mais conhecimento, mais e mais facilidades e, finalmente, há um esforço de produção gigante, dominado pela paixão de ganhar, pela ganância de obter lucro. (Livre tradução do autor).

${ }^{153}$ A Guerra endêmica do mundo moderno não é apenas a guerra das nações com armas, mas a tensão permanente e crescente entre forças opostas, que pode ser manifestada por constante oposição ao plano de intercâmbio entre os grupos e entre os povos. (Livre tradução do autor).
} 
Lebret aponta que na última guerra foram gastos cerca de seiscentos e sessenta e seis milhões de dólares pelos países protagonistas da Segunda Guerra, como a Alemanha, Itália, Japão, Estados Unidos, Grã Bretanha e URSS, mostrando assim uma contradição entre estes gastos e o baixo investimento no desenvolvimento econômico e atendimento dos anseios da classe trabalhadora por melhores condições de vida. Chama isto de "uma nova barbárie", apontando que "L'homme a montré jusqu'à quel point il est capable de donner libre cours à ses instincts barbares." 154 (ibid, ibidem).

Le monde moderne marque bien son déséquilibre en multipliant dispensaires, asiles, préventorias. II veut sauver les faibles, mais dans la guerre il sacrifice les forts par milliers. II est sensible à l'extrême, mais Gestapo et Guépéou sont capables des pires crimes.

\section{$[\ldots]$}

II se préoccupe de l'urbanisation des grandes cités, mais il ne sait pas retenier les ruraux à la campagne. La grande ville, cependant, est toujours malfaisante pour l'immense majorité de ses occupants. ${ }^{155}$ (ibid., ibidem).

Até então a exposição feita por Lebret aos alunos da ELSP em pouco diferia de suas exposições nas Semanas Sociais promovidas pelo Économie et Humanisme, na França. Nas Semanas Sociais, Lebret iniciava a exposição sobre o trabalho do $\mathrm{EH}$ a partir de uma visão crítica sobre o mundo moderno. Sua filiação de matriz marxista para a interpretação da realidade social e econômica do período torna-se clara quando, na segunda aula do curso, Lebret indica a leitura de "O Capital", de Marx, para seus alunos, aconselhando "a todos que lessem a obra completa, prevenindo que sem essa leitura seria difícil a compreensão de suas conferências" (ANGELO, ibid., p. 70). Esta recomendação marca o início das aulas dedicadas a estudar os pensamentos econômicos vigentes e as ideias dos economistas e pensadores econômicos do período, considerados por Lebret como os responsáveis pelas desordens do mundo.

Après avoir considéré l'échec humain, nous aurions à examiner ce qu'ont fait les intellectuels dont la mission était de sonder le malaise du monde et d'y remédier.

\footnotetext{
${ }^{154}$ O homem mostrou o quanto ele é capaz de dar livre curso aos seus instintos bárbaros. (Livre tradução do autor).

155 O mundo moderno é muito marcado por seu desequilíbrio, multiplicando clínicas, asilos, previdências. Ele quer salvar os fracos, mas na guerra sacrifica os milhares mais fortes. É sensível ao extremo, mas Gestapo e Guépéou são capazes dos piores crimes. [...] Ele está preocupado com a urbanização das grandes cidades, mas ele não sabe respeitar o campo rural. A grande cidade, no entanto, é sempre prejudicial para a grande maioria dos seus habitantes. (Livre tradução do autor).
} 
Ces intellectuels défaillants ont été les philosophes, les sociologues, les économistes, les politiques, les théologiens. Nous bornerons notre examen aux économistes, qui sont peut-être les responsables les plus directs du désordre universe $^{156}$. (LEBRET, ibid., Vol. I).

Assim, Lebret se dedica à exposição da aula que ele intitula como "Crítica à economia política" e aponta que a mesma se divide em 3 abstrações teóricas: a economia axiomática, a economia matemática e o marginalismo, explicando no que consiste cada uma delas. Para ele, a economia axiomática faz uma certa observação da realidade econômica, através das leis e dos princípios da matéria, considerando o todo sem recorrer ao emprego sistemático de fórmulas matemáticas. É voltada para pesquisar os princípios da beneficência, da livre concorrência e da lei da oferta e da procura. A economia matemática busca analisar mais precisamente o fato econômico e considera todas as suas dimensões através de fórmulas. Visa, assim, determinar fórmulas para as funções e variáveis diversas, empregando o domínio da física e, com isso, segundo Lebret, se esquece que o domínio humano é indeterminável.

Já a economia marginal é exposta por Lebret de forma menos crítica, podendo-se perceber maior simpatia do dominicano por esta escola empregada pelos norteamericanos e vienenses. Para ele, a economia marginal representa um dos esforços mais interessantes da Economia Política, pois ela faz uma análise mais precisa da oferta e da procura e se utiliza de fórmulas, como a derivada e a representação gráfica, para discutir seus métodos e resultados.

Como um dos objetivos de Lebret ao ministrar estas aulas na ELSP era o de difundir o método da Economia Humana, então, apesar de um pouco mais simpático ao marginalismo, a apresentação de Lebret é feita de forma a criticar a Economia Política em suas três abstrações teóricas. Para ele, nenhuma delas era centrada no homem, ao contrário das linhas mestras que configuravam a atuação teórica do Centre d'Économie et Humanisme. Fica nítida, aqui, a intenção de Lebret em recrutar adeptos para seu grupo e expandir o domínio do EH para o Brasil.

A definição do que seria a Economia Humana só é feita por Lebret na segunda parte do curso, a partir da vigésima quarta aula, quando o padre se propõe a discutir o tema "Lignes d'Orientation d'une Économie Humaine". Segundo Lebret, diferentemente da

\footnotetext{
${ }^{156}$ Depois de considerarmos o fracasso humano, teríamos de olhar para o fracasso dos intelectuais que tinham a missão de sondar o desconforto do mundo e propor formas para resolvê-los. Esses intelectuais falharam, foram filósofos, sociólogos, economistas, políticos, teólogos. Nós restringiremos nossa avaliação aos economistas, que têm, talvez, a responsabilidade mais direta do distúrbio universal. (Livre tradução do autor).
} 
economia política, a economia humana "vincula-se à política tout court, vista como estratégia e tática para transformação das estruturas". (ANGELO, ibid., p. 74). E buscando respaldo acadêmico, aponta se tratar de "uma ciência humana, da ciência de um homem social e dos melhores quadros da vida humana e da economia humanista que a coordenação de todas as ciências deveria executar."

Ainda na sequência da primeira parte do curso, são ministradas cinco aulas baseadas nos estudos de Karl Marx. As aulas são intituladas de "A reação marxista". As aulas sobre Marx ganham nitidamente maior peso dentro do curso, se considerarmos que na apostila preparada por Lebret as mesmas são tratadas como seminário e distribuídas em quatro partes: Introdução a Marx, Formação de Marx, Influência de Hegel em Marx e o retorno da doutrina de Hegel. Lebret apresenta Marx como um pensador e grande revolucionário. Mas, sabendo das desconfianças existentes entre os mais conservadores em relação à obra de Marx, tenta justificar sua escolha apontando que:

Pour comprendre la situation du monde moderne, il faut commencer par étudier les philosophes et les grands révolutionnaires, en allant directement aux grands maîtres, sans se perdre dans des études de moindre valeur. [...] Ce que je vous apporte, c'est seulement un plan pour l'orientation de vos recherches personnelles. II m'a fallu 20 ans pour analyser et comprendre peu à peu les structures du monde. II vous faudra sans doute bien des annés d'observation et d'expérience avant que vous puissiez portes sur le monde un regard objectif ${ }^{157}$. (ibid., ibidem).

Continuando a tecer críticas sobre o mundo moderno e a economia política, ciente do descontentamento da classe operária com as condições de vida, bem como das dificuldades do empresariado em sensibilizar-se com estas condições, Lebret faz um apelo aos estudantes que o assistiam questionando: "est-ce que des hommes ne vont pas reagir est-ce que l'homme depouillé du meilleur de soi-même va accpeter son sort?" 158 (ibid., ibidem).

Segundo Angelo (2010, p. 73), os estudos de Marx, Engels e Lenin, no curso ministrado por Lebret, geraram a desconfiança da igreja católica, e "esta preocupação fica clara ao

\footnotetext{
157 Para compreender a situação do mundo moderno, temos que começar por estudar os grandes filósofos e revolucionários, indo diretamente para os grandes mestres, sem se perder em estudos de menor valor. [...] O que eu trago para vocês é só um plano para a direção de sua própria investigação. Levei 20 anos para analisar e compreender gradualmente as estruturas do mundo. Vão levar, provavelmente, muitos anos de observação e experiência antes que vocês possam abrir as portas para o mundo com um olhar objetivo. (Livre tradução do autor).

${ }^{158}$ Os homens não vão reagir? Irão aceitar seu próprio fracasso? O próprio homem vai aceitar o seu destino? (Livre tradução do autor).
} 
lermos o seu diário no dia 6 de abril de 1947." Antes de iniciar o curso na ELSP, Lebret "relata sobre as reuniões no Convento do Rio de Janeiro, onde parecia ser preciso escolher entre comunismo e capitalismo. [...] os jesuítas (eram) muito conservadores (e) os dominicanos eram facilmente acusados de comunistas", e acrescenta que para o Économie et Humanisme "era necessário construir entre os dois (capitalismo e socialismo) sem rejeitar o que o marxismo tem de válido". Mesmo assim, na visão dos mais conservadores,

Lebret incitava seu público a conhecer as obras de Marx, tendo algumas de suas afirmações "ampla repercussão nos meios católicos, pois aquele sacerdote refutou, com a sua inegável experiência e conhecimento dos problemas, a argumentação da ala reacionária da igreja (católica)". (ibid., ibidem). ${ }^{159}$

O dominicano busca então apresentar o marxismo como um método científico de análise econômica e, para tanto, sistematiza o pensamento do filósofo alemão, apresentando em sua apostila uma tabela sobre as ideias de Marx, conforme apresentamos a seguir.

\begin{tabular}{|c|c|c|c|}
\hline & Contra & Para & \multirow{2}{*}{ Pela Promoção Final } \\
\hline & Uma fase de divisão & Uma fase de integração & \\
\hline & 1. A divisão em classes & $\begin{array}{l}\text { Unidade de uma } \\
\text { sociedade sem classes }\end{array}$ & A luta de classes \\
\hline $\begin{array}{l}\text { A alienação } \\
\text { na família }\end{array}$ & $\begin{array}{l}\text { 2. A divisão de sexo e a } \\
\text { família jogando contra a } \\
\text { pessoa (o homem) }\end{array}$ & A união livre & $\begin{array}{l}\text { Um novo tipo familiar } \\
\text { baseado na superação da } \\
\text { propriedade capitalista }\end{array}$ \\
\hline \multirow{2}{*}{$\begin{array}{l}\text { As } \\
\text { alienações }\end{array}$} & \multirow[t]{2}{*}{$\begin{array}{l}\text { 3. A divisão do capital e } \\
\text { do trabalho }\end{array}$} & $\begin{array}{l}\text { A unificação do capital e } \\
\text { do trabalho baseado: }\end{array}$ & \multirow[b]{2}{*}{$\begin{array}{l}\text { A expropriação da } \\
\text { propriedade } \\
\text { instrumentos de produção } \\
\text { social }\end{array}$} \\
\hline & & $\begin{array}{lr}\mathrm{Na} \text { posse comum da } \\
\text { propriedade } & \text { dos } \\
\text { instrumentos } & \text { de } \\
\text { produção social } & \end{array}$ & \\
\hline Econômicas & $\begin{array}{l}\text { 4. A divisão do trabalho } \\
\text { no geral }\end{array}$ & $\begin{array}{l}\text { A liquidação do trabalho } \\
\text { desigual }\end{array}$ & $\begin{array}{l}\text { Para o progresso mecânico } \\
\text { e uma nova organização do } \\
\text { trabalho }\end{array}$ \\
\hline
\end{tabular}

${ }^{159}$ O texto entre aspas foi extraído do artigo "Marx foi um gênio, e os comunistas querem o bem da humanidade". Publicado no Jornal do Povo em Belo Horizonte, no dia 15 de agosto de 1947. A menção é feita por Angelo. 


\begin{tabular}{|c|c|c|c|}
\hline & $\begin{array}{l}\text { 5. A divisão do trabalho } \\
\text { em industrial e agrícola } \\
\text { e consequentemente a } \\
\text { divisão da cidade e do } \\
\text { campo }\end{array}$ & $\begin{array}{l}\text { A combinação do } \\
\text { trabalho industrial e } \\
\text { agrícola e a superação } \\
\text { da dicotomia entre o } \\
\text { campo e a cidade }\end{array}$ & $\begin{array}{l}\text { A alternância das } \\
\text { atividades, a mecanização } \\
\text { rural e a descentralização } \\
\text { industrial }\end{array}$ \\
\hline & $\begin{array}{l}\text { 6. A divisão entre } \\
\text { trabalho intelectual e } \\
\text { manual }\end{array}$ & $\begin{array}{l}\text { A combinação da } \\
\text { educação e da produção }\end{array}$ & Uma nova pedagogia \\
\hline & $\begin{array}{l}\text { 7. A divisão dos homens } \\
\text { e a concorrência entre } \\
\text { eles }\end{array}$ & $\begin{array}{l}\text { A organização unificada } \\
\text { da produção }\end{array}$ & O planejamento \\
\hline Política & $\begin{array}{l}\text { 8. A divisão do homem } \\
\text { entre ele mesmo e sua } \\
\text { consciência política }\end{array}$ & $\begin{array}{l}\text { A unidade de uma } \\
\text { existência concreta e de } \\
\text { sua consciência política } \\
\text { que se exprima num } \\
\text { desaparecimento do } \\
\text { Estado }\end{array}$ & A ditadura do proletariado \\
\hline Religiosa & $\begin{array}{l}\text { 9. A divisão do homem } \\
\text { entre ele mesmo e sua } \\
\text { consciência religiosa }\end{array}$ & $\begin{array}{l}\text { A unidade de sua } \\
\text { existência social e de } \\
\text { sua consciência } \\
\text { expressa num ateísmo }\end{array}$ & $\begin{array}{ll}\text { A disparidade das } \\
\text { contradições sociais, a } \\
\text { propaganda racionalista e } \\
\text { os casos antirreligiosos }\end{array}$ \\
\hline
\end{tabular}

Da mesma maneira utilizada para resumir as principais ideias de Marx, a apostila aponta uma tabela sistematizada por Lebret sobre as ideias e diretrizes do nazismo, assunto abordado na oitava aula do curso, conforme apresentaremos a seguir. Antes, é importante dizer que, enquanto a exposição de Lebret sobre o pensamento de Marx rendeu artigos de jornais, críticas de setores da igreja católica e certa apreensão no meio empresarial, além de se atribuir a Lebret simpatia do EH pelo marxismo, a exposição sobre a "reação nazista" não rendeu tamanha repercussão.

\begin{tabular}{|l|l|l|}
\hline Contra & Para & Pela Promoção \\
\hline 1. O capital internacional & O povo alemão & $\begin{array}{l}\text { a) um responsável } \\
\text { b) autoritário } \\
\text { c) fundação do Estado Racista } \\
\text { d) Emprego de meios necessários para o } \\
\text { triunfo da ideia: }\end{array}$ \\
$\begin{array}{ll}\text { 2. O comunismo russo e } \\
\text { internacional } \\
\text { - a organização } \\
- \text { a propaganda }\end{array}$ \\
$\begin{array}{ll}\text { 3. A justiça } \\
\text { 4. A democracia } \\
\text { 5. deterioração do } \\
\text { sangue alemão }\end{array}$ & A Humanidade \\
\hline
\end{tabular}


A primeira parte do curso é encerrada com três aulas voltadas à discussão do planejamento pela URSS e uma aula específica sobre o pensamento de Lenin, líder da revolução soviética. Lebret expõe que o "leninismo" é o marxismo da época imperialista e da revolução do proletariado, e seria para ele, numa visão teórica, a tática estratégica da ditadura do proletariado. Explica para seus alunos que,

Le léninisme est fondé sur la perspective dialectique de l'opposition bourgeoisieprolétariat. La victtoire du prolétariat est dans le mouvment de l'histoire. Comme ele libérera l'homme tout ensemble de sa triple lliénation au profit des capitalistes, de l'Etat est du divin, ele est l'objectif suprême ${ }^{160}$. (LEBRET, ibid., ibidem).

Após esta primeira parte, dedicada a expor uma análise da conjuntura presente no mundo moderno, e, sobretudo, no contexto do pós-guerra, além da passagem pelas correntes de pensamento econômico identificadas como anticapitalistas, Lebret inicia a segunda parte de seu curso. Nela, o dominicano buscará apresentar a Economia Humana como um contraponto à Economia Política, expondo que a principal diferença entre ambas estaria no fato de a "ciência" defendida por Lebret colocar o homem como o centro das decisões e não como um dado econômico, como é tratado na visão mais tradicional da economia política. Para Angelo, "Lebret sintetizou sua teoria definindo o seu lugar como doutrina, sistema de estratégia e tática de transformação e distribuição a serviço do homem" (ibid., p. 74).

Lebret apresentou, além dos postulados e conceitos da Economia Humana, os seus precursores, e nesse ponto expôs a influência direta de Fréderic Le Play: "Ainda no século XIX, cristãos sociais, marxistas, anarquistas; bem antes de nós, socialistas sinceros, comunistas e corporativistas, viam a necessidade da economia humana sem serem capazes de estabelecê-la. A aspiração fundamental dos homens generosos de nossa geração era a economia humana". Lebret considerava como precursores da economia humana "os inventores do método de análise científica, dos fatos sociais, certos católicos da primeira metade do século XIX, e vários teóricos anarquistas". No primeiro grupo, dos inventores do método de análise científica, Lebret destacou Le Play e sua escola, a escola estatística e os conjunturistas. No segundo grupo, os

\footnotetext{
160 O "Leninismo" é baseado na perspectiva dialética da oposição burguesia X proletariado. A vitória do proletariado está no movimento da história. Como ela libertará o homem de sua tripla alienação imposta pelos capitalistas, de que o Estado é o divino, é o objetivo supremo. (Livre tradução do autor).
} 
teóricos posteriores; e, por último, os libertários, como Pierre Kropotkine. (ibid., ibidem).

Nas primeiras aulas da segunda parte do curso, Lebret questiona os estudantes sobre como seria possível implementar uma economia humana, num momento em que o homem se voltou para si mesmo, arraigado em valores do materialismo, do individualismo e do consumismo. Para Lebret, neste contexto, a educação econômica e cultural do homem do campo era ainda mais difícil do que a dos trabalhadores urbanos. Isso tudo fazia parte do que ele chamava de alienação por completo, ou seja, onde não havia cultura alguma, nenhuma iniciativa, e, portanto, nenhuma possibilidade de desenvolvimento.

A resposta para a questão formulada por Lebret só chega na última parte do curso, voltada à exposição do que é chamado de transição para uma economia humana. Assim, o que se percebe na segunda parte do curso é um aprofundamento dos assuntos discutidos nas primeiras aulas, quando Lebret tece sua impressão sobre a conjuntura mundial.

Nesta segunda parte, Lebret busca mostrar certo pioneirismo do Centre d'Économie et Humanisme na formulação de um método de análise e na organização do que ele intitula de uma nova "ciência", que seria a economia humana, em concorrência direta com a economia política. Ainda que buscasse seu lugar como formulador pioneiro desta economia humana, a exposição do método deixa clara sua filiação aos métodos da estatística e da economia doméstica desenvolvida por Le Play na virada do século XIX para o XX, na França, e também de sua simpatia às ideias de Marx e Engels, filósofos alemães que teceram um contraponto teórico ao capitalismo.

Na parte final do curso, Lebret tenta traduzir como seria a atuação da economia humana, apontando que ela parte das postulações do bem humano, entendidas como maneiras de salvaguardar o homem utilizando os métodos da observação, experimentação e indução, para que as pessoas estudadas sejam inseridas no contexto do local, e, posteriormente, num espectro mais amplo, na conjuntura econômica mundial. Seis princípios são apontados por Lebret para o funcionamento de uma economia humana, iniciando-se com o respeito à natureza humana. O segundo princípio é a busca pelo mínimo e necessário à vida. A seguir vêm a solidariedade, a cooperação, o equilíbrio do homem, onde são feitos apontamentos sobre o cuidado com a saúde das famílias, e, por fim, o progresso.

Os princípios ou postulações expostos por Lebret apontam sempre para a ideia de se alcançar uma terceira via, onde seria possível se construir um desenvolvimento 
harmônico, buscando-se a conciliação entre as ideias do capitalismo e do socialismo. Sobre um dos pontos mais caros ao socialismo, Lebret expõe sua contrariedade, refutando o propósito de Marx e dos soviéticos de acabar com a propriedade privada. Ao mesmo tempo, porém, defende que o homem deveria viver com um mínimo, tendo somente uma propriedade voltada para suas necessidades, pois, sem esta propriedade não haveria condições do homem alcançar o desenvolvimento.

Dans toute la mesure du possible l'homme doit disposer du minimum de biens de consommation qui lui permettra de vivre en homme c'est à dire de conserver et d'améliorer sa vie et de donner la vie. Ce minimum comporte les biens absolument indispensables sans vie l'on meurt et les biens sans lesquels on n'accède pas à la vie digne. On peut les appeler biens essentiels en les distinguant en biens de stricte subsistance et en bien de dignité. ${ }^{161}$ (LEBRET, ibid., Vol. III).

Se a visão de Lebret sobre a propriedade privada o distancia das ideias socialistas, sua posição contrária ao consumo e à acumulação, presente no liberalismo econômico, também o afasta da matriz capitalista. Na sequência de sua exposição, Lebret menciona o princípio da solidariedade, apontando que os homens deveriam ter cuidado, sobretudo, com aqueles que mais necessitavam de ajuda, como os inválidos, pessoas com deficiências, crianças e idosos.

Assim, o que é possível perceber nestes apontamentos de Lebret sobre o que seria a Economia Humana é uma pregação religiosa fortemente identificada com a Encíclica "Rerum Novarun", de 1891, a qual, segundo a Santa Sé, foi responsável pela instituição da doutrina social da igreja católica. Porém, conforme já apontamos em nossa dissertação de mestrado (CESTARO, 2009, p. 107), a nosso ver a "Rerum Novarum", escrita pelo Papa Leão XIII, não é um documento que prega a transformação social, e muito menos condena o capitalismo, mas faz, sim, o reconhecimento da sociedade de classes e dos contrastes presentes nela, apontando também para a necessidade de se fazer caridade para com os mais pobres.

$\mathrm{Na}$ "Rerum Novarum", Leão XIII apontava que "o homem deve aceitar com paciência a sua condição", afirmando ser "impossível que na sociedade civil todos sejam elevados ao mesmo nível." E buscando combater a luta de classes, afirmava que "o erro capital na

\footnotetext{
${ }^{161} \mathrm{Na}$ medida do possível, o homem deve ter o mínimo de bens de consumo que lhe permitam viver como um homem que é para manter e melhorar a sua vida e dar a vida. Esse mínimo tem a propriedade absolutamente essencial para a vida e morte, pois sem esta propriedade ele não tem acesso à vida digna. Podemos chamá-los de bens essenciais e distingui-los em produtos estritamente de subsistência e de dignidade. (Livre tradução do autor).
} 
questão presente é crer que as duas classes são inimigas natas uma da outra, como se a natureza tivesse armado os ricos e os pobres para se combaterem mutuamente num duelo obstinado" e ainda que "elas têm imperiosa necessidade uma da outra: não pode haver capital sem trabalho, nem trabalho sem capital". (LEÃO XIII, 1881).

É importante dizer que a encíclica "Rerum Novarum" não foi um documento citado por Lebret durante o curso da ELSP. Porém, a inflexão que fizemos a 1891, mencionando esta encíclica papal, visa mostrar o quanto o dominicano era seguidor da igreja católica e obediente às ordens do Vaticano.

Esta constatação nos leva a refletir sobre a repercussão obtida por Lebret através do curso ministrado em São Paulo, quando,mesmo buscando a conciliação entre as ideias presentes na economia política naquele período e a defesa de uma economia humana, de forma a resultar num desenvolvimento harmônico, usando para isto um tom conciliador, as ideias de Lebret, no Brasil, foram mal interpretadas, evidenciando que, entre nós, não havia pensadores tão avançados e capazes de distinguir a pregação religiosa feita por Lebret.

Ainda assim, mesmo neste contexto conservador, e sob a desconfiança da igreja católica, Lebret teve a oportunidade de difundir suas ideias para além do curso ministrado na Escola Livre de Sociologia e Política. Visitou outras cidades, como o Rio de Janeiro, Belo Horizonte e Porto Alegre, e nelas ministrou palestras sobre a Economia Humana.

Em São Paulo, porém, foi onde o dominicano francês se alojou por tempo maior e teve o apoio do Convento dos Dominicanos e da ELSP para garantir sua estada no Brasil, além do interesse pela criação de um organismo vinculado ao Centre d'Économie et Humanisme na França.. Além do apoio da ELSP, dos próprios dominicanos e dos nomes ligados ao meio empresarial paulista e à Escola Politécnica da USP, cabe também mencionar o apoio do Partido Democrata Cristão como um dos fatores que favoreceram a criação da Sociedade para Análises Gráficas e Mecanográficas Aplicadas aos Complexos Sociais - SAGMACS, em São Paulo, no ano de 1947, que se estruturou sob a direção do Prof. Luiz Cintra do Prado, mesmo após o retorno de Lebret à França.

Segundo Roldan, após ser criada,

A SAGMACS funcionou como um escritório de planejamento urbano de caráter interdisciplinar reunindo religiosos, intelectuais, políticos, arquitetos, economistas, geógrafos e sociólogos, e que ao longo dos anos 1950 e 1960, foi responsável por estudos, projetos e programas de planejamento de desenvolvimento urbano e regional. $(2012,122)$. 
É importante perceber aqui que, mesmo diante deste quadro de contrariedade e temor às ideias de Lebret, as contradições vigentes tanto no cenário político quanto empresarial e religioso permitiram instituir a cooperação formal de brasileiros com o Économie et Humanisme francês, criando para tanto um órgão vinculado ao padre Lebret, cujo modo de criação e funcionamento é nosso objeto de estudo na continuidade deste capítulo.

\subsection{A fundação da SAGMACS:}

Principais atores envolvidos, áreas de interesse e os apoios para a criação de um grupo de Economia Humana no Brasil

A Sociedade para Análises Gráficas e Mecanográficas Aplicadas aos Complexos Sociais - SAGMACS nasceu em julho de 1947, vinculada ao Centre d'Économie et Humanisme, organismo fundado por Lebret, François Perroux e empresários católicos, na França. Alcançou notoriedade em países da América Latina através dos adeptos da Democracia Cristã, dos jovens da Juventude Universitária Católica - JUC e da Fraternidade Leiga dos Dominicanos de São Paulo, além dos que assistiram as aulas ministradas por Lebret no curso da ELSP, no contexto pós-segunda guerra mundial, período em que os Estados Unidos e a União Soviética se consolidavam potências econômicas e militares, e a Europa tentava se reerguer.

Para tanto, houve uma movimentação de organismos internacionais, sediados em países europeus, na tentativa de ampliar sua interlocução com os países localizados na América do Sul e África, os quais, a partir dos anos 1950, ficaram conhecidos como países de Terceiro Mundo. A preocupação com a questão econômica exposta aqui não se refere somente à polarização entre as duas grandes potências mundiais emergidas da Segunda Guerra - EUA e URSS, mas também à necessidade dos países europeus recuperarem seu domínio econômico, político e cultural sobre os demais países do mundo. Com os problemas emergidos durante a segunda guerra e a urgente necessidade de reconstrução das cidades e das indústrias arrasadas durante os combates, a economia europeia mostrava-se em declínio, de forma que era preciso buscar formas de superar esta crise para além do continente europeu e também para além das duas grandes 
potências mundiais.

Neste sentido, Pelletier (1996) aponta que a fundação da SAGMACS em São Paulo teria se dado como forma de expansão do domínio cultural e econômico francês, a fim de contrapor-se à expansão imperialista norte-americana sobre o continente sul americano. Teria assim ocorrido como forma de expansão do domínio capitalista sobre o que na época era considerada a periferia do mundo. Porém, a nosso ver, outros aspectos nortearam a criação da SAGMACS em São Paulo, além da expansão do capital e da expansão territorial da ação do Économie et Humanisme.

Para Albertini, após a visita de Lebret ao Brasil e aos demais "países em vias de desenvolvimento", como o Senegal, o Vietnam, Libano, Colômbia e Chile, os mesmos "lui confient l'analyse de leur situation économique et sociale et leurs projets de developpment." Assim, "Lebret va élaborer une dynamique concrète et systémique du développement et être une des grandes voix qui feront percevoir l'urgence des problèmes des pays en voie de développement." (2006, p. 20). ${ }^{162}$

A fundação da SAGMACS ocorreu em São Paulo, no ano de 1947, momento em que Lebret visitava pela primeira vez o Brasil, Chile, Argentina, Colômbia e Uruguai, países que nos anos 1950 ficaram conhecidos como de terceiro mundo. Na França o Économie et Humanisme consistia em estudar os malefícios do capitalismo e do socialismo em busca da proposição de uma terceira via, chamada por Perroux de Desenvolvimento Harmônico.

$\mathrm{Na}$ vinda de Lebret para o Brasil já havia a intenção de fundar em São Paulo um grupo vinculado ao $\mathrm{EH}$ francês, conforme exposto por Angelo em carta do frei Romeu Dale, recebida por Lebret. Assim, conforme já apontamos, Lebret conseguiu o apoio de personalidades importantes como dos professores Luiz Cintra do Prado e Lucas Nogueira Garcez, além do Frei Benevenuto de Santa Cruz, na defesa do ideário pregado pelo Économie et Humanisme, o que culminou com a criação de um organismo de estudos e pesquisas aplicadas aos complexos sociais, chamado de SAGMACS. Esta iniciativa colocou o Brasil na rota do movimento Économie et Humanisme, instituindo-se a cooperação técnica entre o meio intelectual católico e e empresariado paulista, e o vínculo do ideário lebretiano entre o Brasil e a França, mais precisamente entre os

\footnotetext{
${ }^{162}$ Confiam a ele a análise de sua situação econômica e social e seus projetos de desenvolvimento (Livre tradução do autor)

Lebret desenvolverá uma concreta e dinâmica sistemática de desenvolvimento e será uma das grandes vozes que perceberão a urgência dos problemas dos países em desenvolvimento. (Livre tradução do autor).
} 
membros ligados ao padre Lebret em Lyon e a SAGMACS em São Paulo.

No período de fundação da SAGMACS, a cidade de São Paulo figurava como principal sede da produção industrial do país, absorvendo intenso crescimento populacional, o que Ihe permitiu superar a população do Rio de Janeiro e se tornar a maior cidade do país na década de 1950. Devido às condições econômicas, Lebret enxergava em São Paulo e no Brasil o campo fértil para a expansão do Économie et Humanisme na América Latina, tentando empregar seus métodos de análise para desvendar os problemas do subdesenvolvimento e abrir espaço para um modelo de economia mais harmônica.

Enquanto em sua origem na França o Centre d'Économie et Humanisme, fundado por Lebret, contava com a participação de profissionais das áreas de economia, filosofia e sociologia, que estudavam os malefícios do capitalismo e do socialismo e propunham uma terceira via, no Brasil a SAGMACS configurou-se como um organismo voltado para a pesquisa urbana e o planejamento territorial, não tendo descartado a temática do desenvolvimento econômico. A nosso ver, esta faceta se deve ao fato de Lebret não ter sido bem aceito pela Faculdade de Filosofia da Universidade de São Paulo, pois ali seus métodos eram vistos como antiacadêmicos e pouco científicos. Entretanto, conquistou simpatia na Faculdade de Arquitetura e Urbanismo e na Escola Politécnica, de onde saiu o primeiro diretor da equipe de Lebret no Brasil, o que abriu espaço para um engajamento maior dos engenheiros e arquitetos à equipe da SAGMACS, levando Lebret a realizar um trabalho voltado para as questões urbanas.

Através dos discursos e exposições de Lebret em palestras e cursos, notamos que uma de suas principais preocupações era com a formação de quadros, por isso buscava sempre vincular-se a setores da elite a fim de encontrar jovens com futuro político promissor e também estudantes e professores universitários. Desse modo, os adeptos de Lebret entre a juventude católica, principalmente a chamada JUC - Juventude Universitária Católica, passaram a estudar os problemas e as potencialidades de cada Estado. Estes estudos foram amplamente discutidos no Congresso da JUC, que Lebret organizou em São Paulo no ano de 1954, como atividade preparatória para o I Congresso Internacional do Économie et Humanisme.

Com tudo isso, Lebret conseguiu despertar, em sua primeira estada no Brasil, os universitários e futuros profissionais para a necessidade de agir e contribuir com o desenvolvimento regional, formando lideranças e fomentando o debate sobre as condições de vida do homem. E assim a SAGMACS atuava desde sua fundação, no levantamento de questões urbanísticas e das condições de vida dos habitantes, buscando conhecer, de forma empírica, os problemas da cidade, relacionando-os aos 
complexos sociais.

As ideias de desenvolvimento harmônico difundidas por Lebret através do Économie et Humanisme o qualificaram como uma autoridade na área do desenvolvimento econômico, e por isso causaram grande interesse entre o meio empresarial paulista, especialmente entre os adeptos das ideias de Roberto Simonsen e da FIESP. Estes empresários buscavam uma maneira de alavancar o Brasil como grande potência mundial e líder do continente sul americano. Ao mesmo tempo, Lebret também enxergava no Brasil e em demais países do chamado terceiro mundo tal possiblidade, porém, apontava para a necessidade de não repetir os mesmos erros que os avanços do capitalismo vinham causando na Europa.

Dessa forma, a SAGMACS surge como possibilidade do Économie et Humanisme implantar uma espécie de laboratório no terceiro mundo, para difundir e testar as ideias defendidas acerca do desenvolvimento harmônico.

No início da SAGMACS a parceria de Lebret com a elite industrial paulistana foi tão rendosa que levou o grupo a ter sua primeira sede, instalada no Jockey Club de São Paulo, com espaços reservados aos diretores da equipe, que já começavam a estruturar trabalhos para possíveis parceiros e investidores. Além disso, é importante notar que, neste primeiro momento, a SAGMACS era subsidiada pelo Jockey, ainda que a maioria dos dirigentes e frequentadores deste clube estivessem muito mais identificados com uma doutrina econômica capitalista, mais monetarista do que progressista.

Subventionnée au début par le Jockey-Club de São Paulo, la SAGMACS avait été conçue comme un laboratoire d'enquêtes sociales où les dominicains n'apparaissaient pas officiellement. Son bureau comptait cinq laïcs: Luis Cintra do Prado, ancien directeur de l'École polytechnique de São Paulo, qui avait été l'assistant de Lebret dans son enquête; le docteur de Freitas, directeur de I'hôpital de São Paulo; un ingénieur pauliste, Lucas Garces; le docteur Montoro, jeune professeur à la Faculté de Droit et secrétaire général de l'Action catholique pauliste; Mlle Pinheiro enfin, ancienne militante du parti communiste brésilien passée à l'Action catholique. Ils furent assistés jusqu'à la fin de 1949 par un directeur technique envoyé par La Tourette, auquel succéda alors Santa Cruz. ${ }^{163}$ (PELLETIER, ibid., p. 298).

\footnotetext{
${ }^{163}$ Financiada inicialmente pelo Jockey Clube, em São Paulo, a SAGMACS foi concebida como um laboratório para pesquisas sociais, onde os dominicanos não aparecem oficialmente. Seu escritório tinha cinco leigos: Luis Cintra do Prado, ex-diretor da Escola Politécnica de São Paulo, que havia sido assistente de Lebret na sua investigação; Dr. Freitas, diretor do Hospital São Paulo; um engenheiro paulista Lucas Garces; Dr. Montoro, um jovem professor da Faculdade de Direito e secretário geral da Ação Católica Paulista; Senhorita Pinheiro, ex-militante do Partido Comunista do Brasil que seguiu para a Ação Católica. Eles foram atendidos até o final de 1949 por um diretor técnico que foi enviado a La Tourette, e foi substituído depois por Santa Cruz. (Livre tradução do autor).
} 
Já em 1947, tão logo se deu a fundação da SAGMACS, Lebret realizou seu primeiro trabalho com foco na questão urbana, o qual ocorreu no Brasil, a partir da pesquisa sobre as diferenças da estrutura residencial entre uma cidade industrial sul-americana e as cidades industriais francesas. A pesquisa chamada de "Lo Logement de la Population de São Paulo", publicada pela Revista do Arquivo Municipal, em 1951, sob o título de "Sondagem Preliminar a estudo sobre Habitação em São Paulo", coordenada por Lebret e Raymond Delprat, será apresentada e analisada no próximo capítulo deste trabalho. Esta pesquisa marca a fase fundadora dos trabalhos da SAGMACS no Brasil e revela o caráter da pesquisa empírica utilizada por Lebret e sua equipe, sendo importante salientar que, neste período, os principais membros da equipe eram ligados às áreas de economia e sociologia.

Segundo Valladares (2005, p. 80), Nogueira Garcez foi a figura chave para que Lebret conseguisse penetrar neste meio empresarial e político paulistano, que teria rendido esta parceria com o Jóckey Club. Garcez ocupou posto chave na composição da primeira diretoria da SAGMACS, porém, coube ao Prof. Luiz Cintra do Prado o cargo de primeiro Diretor Presidente da equipe.

\subsection{Formação das equipes, cronologia, períodos e etapas na atuação da SAGMACS}

Sobre esta periodização das distintas fases vividas pela SAGMACS, até então, destacam-se os trabalhos de Leme e Lamparelli (2001) e do francês Pelletier (1996). Ambos apontam para as formas de organização da equipe e do engajamento dos mesmos em temas diferentes de trabalho. Leme e Lamparelli (op. Cit., pp. 678-679) definem os anos de 1947 até 1954, quando Lebret se aproxima do engenheiro pernambucano Antônio Bezerra Baltar, como a primeira fase de atuação da SAGMACS.

Para os autores, esta primeira fase de atuação é marcada pela realização de trabalhos no Rio de Janeiro, Recife e São Paulo, a partir dos contatos com Garcez, Rios e Baltar. Os mesmos apontam para a aproximação de Lebret com Josué de Castro, que o tornou consultor da Comissão de Bem Estar Social, cabendo ao padre francês a "ajuda para instalar uma pesquisa sobre o nível de vida em 34 cidades brasileiras." (ibid., p. 679). Este trabalho resulta num relatório intitulado "A pesquisa brasileira de padrões de vida" e 
publicado pelo SESI em 1954. Segundo os autores, "o questionário é elaborado segundo o modelo Economia e Humanismo e Josué de Castro encarrega o padre Lebret de redigir um capítulo de interpretação que será adicionado ao relatório" (ibid., ibidem).

De certo modo, a periodização proposta por Leme e Lamparelli segue a matriz proposta por Pelletier (idid.), que aponta os anos de 1952 e 1954 como os de consolidação do vínculo entre a SAGMACS e o poder público, tanto através da aproximação e prestação de serviços para o governo federal, presidido por Vargas ${ }^{164}$, quanto para o governo de Garcez, no estado de São Paulo.

Além disso, destacam-se também os trabalhos empreendidos para os estados do Paraná ${ }^{165}$ e de Pernambuco, sendo que neste último Lebret estudou sobre as condições para o desenvolvimento e industrialização, num trabalho que contou com a participação de Baltar e do frei Benevenuto de Santa Cruz, para a Comissão de Desenvolvimento Econômico de Pernambuco. Para Pelletier, este trabalho marca o início da transição para uma segunda fase da atuação da SAGMACS.

Aqui podemos observar que, se levado em consideração somente este trabalho para o estado do Pernambuco, a transição colocada por Pelletier não se dá simplesmente por razões de interesse e coordenação internas da equipe da SAGMACS, mas sim, em função de uma conjuntura política e econômica, quando o governo de Vargas demonstra maior interesse em modernizar os estados do Nordeste do país.

Le Pernambouc, avec sa capitale Recife, est l'État leader de la région du Nordeste, dont les conditions de sécheresse ainsi que l'histoire ont fait la région la plus pauvre du Brésil. Une equipe Économie et Humanisme a été fondée à Recife sous l'impulsion de Santa Cruz, et [...] Antonio Bezerra Baltar, en a pris la tête. Là, Économie et Humanisme-Brésil beneficie de l'appui de l'archevêque de Recife, ainsi que du mouvement d'intérêt qui commence à se manifester à travers tout le Bréil dans les années cinquante pour le maldéveloppement du Nordeste. Une politique de rééquilibrage regional en faveur des régions déshéritées est en effet lancée par Vargas, avec la fondation de la

\footnotetext{
${ }^{164}$ Segundo Pelletier (op. Cit., pp. 305-307), neste período a SAGMACS atuou em quatro pesquisas para o governo federal. Porém, é possível verificar que o levantamento do autor levou em consideração não necessariamente a contratação direta da SAGMACS pelo poder público, mas sim o engajamento de alguns membros vinculados à instituição, em trabalhos e contratos redigidos pelo governo de Vargas. Apuramos tratar dos seguintes trabalhos: a campanha nacional de educação rural, coordenada por Rios, em 1952; a direção do mesmo sociólogo à frente da Seção de Pesquisas do Serviço Especial de Saúde Pública, em 1954; o trabalho de Lebret como consultor da Comissão de Bem Estar Social, presidida por Josué de Castro, em 1954; e a organização "A pesquisa brasileira de padrões de vida", coordenada por Lebret.

165 "Pesquisa sobre os níveis de vida das zonas rurais do Estado do Paraná", contratado pela Fundação de Assistência ao Trabalhador Rural, em novembro de 1953.
} 
Banco do Nordeste en $1952^{166}$. (PELLETIER, 1996, p. 308).

No entanto, é possível perceber que, ainda que Leme e Lamparelli sigam a mesma periodização de Pelletier, para o autor francês esta distinção de períodos não é tratada somente levando-se em consideração os trabalhos realizados pela SAGMACS. Esta transição, que Pelletier aponta como a segunda fase de atuação da equipe do Économie et Humanisme, no Brasil, se consolida mesmo com a realização da primeira conferência internacional do grupo francês, realizada na cidade de São Paulo, no Brasil, em $1954^{167}$, “Organisée à l'initiative de Lucas Garcez, financée par l'État de São Paulo dans le cadre des célébrations commémorant le quatrième centenaire de la fondation de sa capitale." (ibid, p. 311).

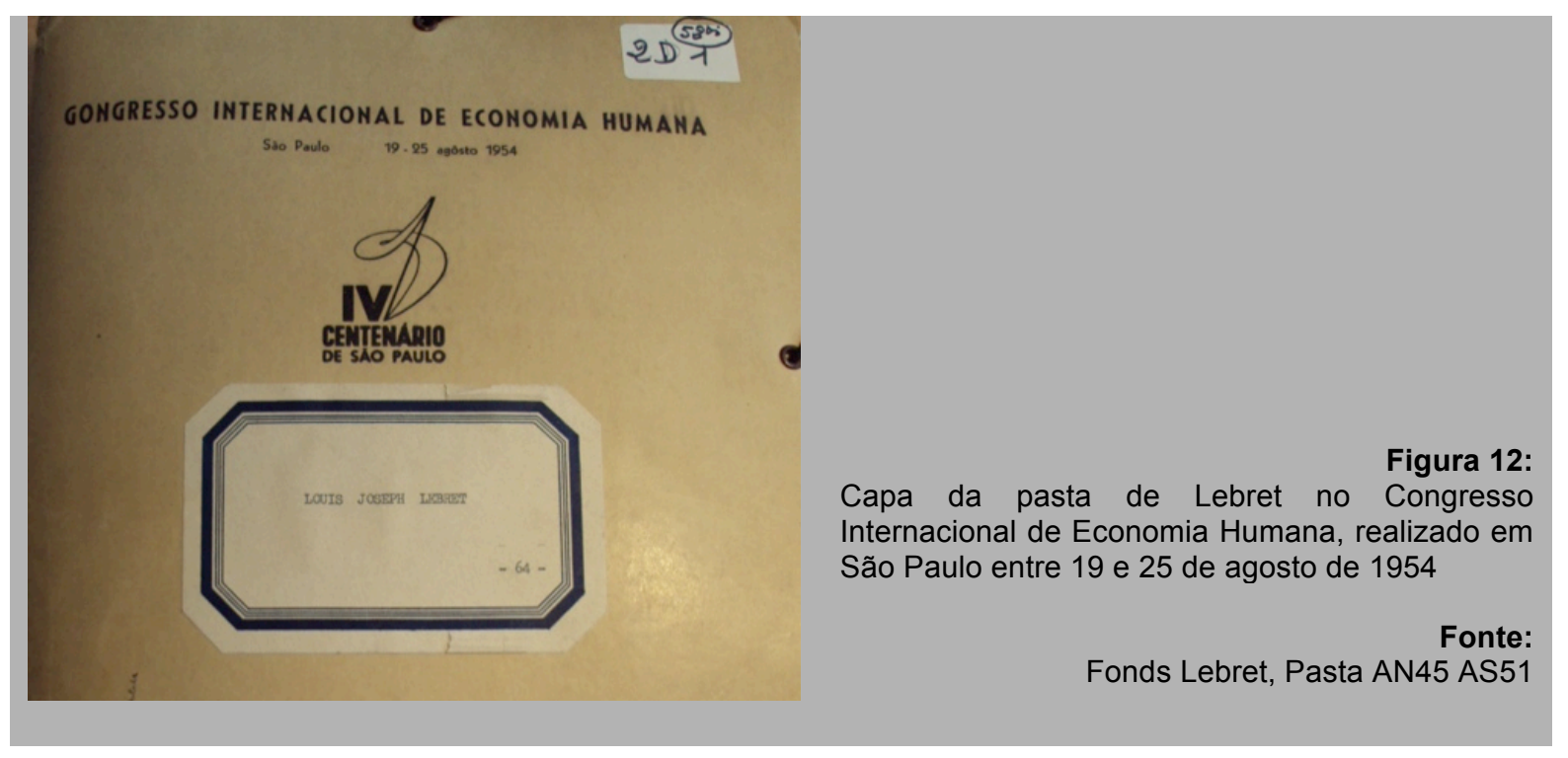

166 Pernambuco, com sua capital Recife, é o estado líder da região Nordeste, com as condições de seca e da história fizeram a região mais pobre do Brasil. A equipe de EH foi fundada em Recife, sob a liderança de Santa Cruz, e [...] Antônio Bezerra Baltar, que mais tarde assumiu a liderança. Lá, o Economia e Humanismo-Brasil beneficiou-se do apoio do Arcebispo de Recife, bem como do interesse e da circulação que começa a se manifestar em todo o Brasil nos anos cinquenta para o fraco desenvolvimento do Nordeste. Uma política de reequilíbrio regional para áreas carentes é lançada por Vargas, com a fundação do Banco do Nordeste em 1952. (Livre tradução do autor).

167 A primeira Conferência Internacional do Économie et Humanisme foi marcada para acontecer entre 18 e 25 de agosto, porém, não chegou a ser finalizada, devido à morte do presidente Getúlio Vargas, em 24 de agosto. 


\section{CONGRESSO INTERNACIONAL DE ECONOMIA HUMANA}

Patrocinado pela Comissão do IV Centenário da Cidade de São Paulo

de 18 a 25 de agôsto de 1954

\section{$P R O G R A M A$}

Dia 18 Quarta-Feira

9,00 horas: Inscrição

Local: Instituto de Educação Caetano de Campos - Praça da República.

15,00 horas: Reunião Preparatória, reservada aos Congressistas inscritos.

Local: Hotel Esplanada - Praça Ramos de Azevedo.

20.30 horas: Sessão Solene de Instalação do Congresso, presidida por Sua Excia. o Snr. Governador do Estado, Professor Dr. Lucas Nogueira Garcez.

Local: Instituto de Educação Caetano de Campos - Praça da República.

Dia 19 Quinta-Feir

9,00 horas: Reunião Plenária.

Local: Instituto de Educação Caetano de Campos, onde serã̃o realizadas todas as sessões plenárias.

14,30 hora:: Visita dos Congressistas ao Exmo. Snr. Governador do Estado.

16,00 horas: Reunião Plenária.

19,00 horas: Recep̧̧̃o oferecida pelo Sr. Consul-Geral da França.

Dia 20 Sexta-Feir

9,00 horas: Reunião Plenária.

16,00 horas: Reunião Plenária.

Dia 21 Sábado

8,00 horas: Visita ao Instituto Agronômico de Campinas e à fazenda Holambra.

Dia 22 Dominge

9,00 horas: Visita à uma fazenda no Vale do Paraiba.

Dia 23 Segunda-Feira

9,00 horas: Sessão Plenária.

14,00 horas: Visita ao Parque Ibirapuera.

16,00 horas: Sessão Plenária.

Dia 24 Terça-Feira

9,00 horas: Sessão Plenária.

16,00 horas: Sessão Plenária.

Dis 25 Quarta-Feirn

9,00 horas: Sessäo Plenária.

16.00 horan: Sessío Plenária.

19,00 horas: Sessio de Encerramento.

Local: Instituto de Bducaşăo Caetano de Campos.

Figura 13:

Programação do Congresso Internacional de Economia Humana, realizado em São Paulo entre 19 e 25 de agosto de 1954 


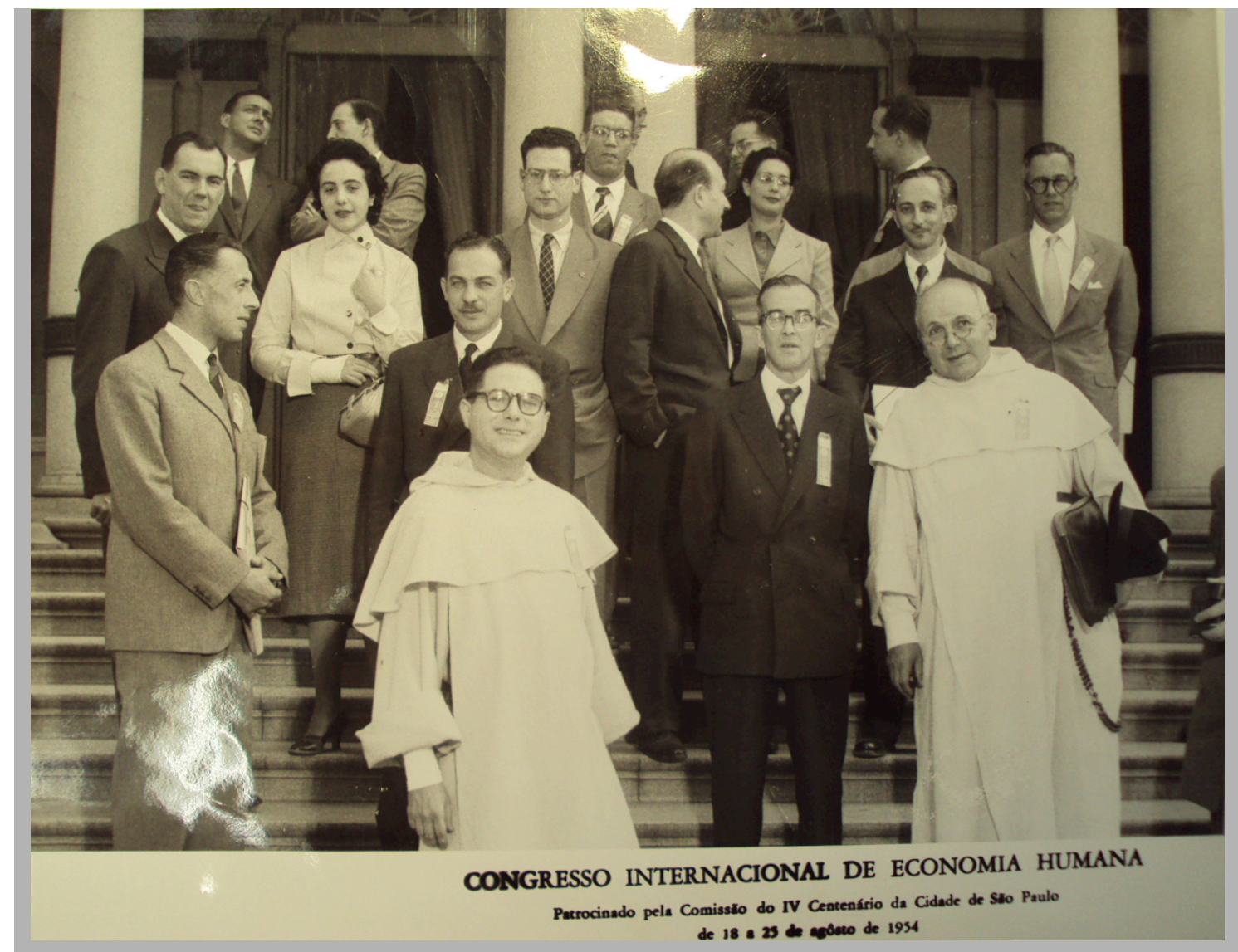

Figura 14:

Participantes do Congresso Internacional de EH em São Paulo. A frente os freis Benevenuto de Santa Cruz (esq.) e Louis Joseph Lebret (dir.).

Fonte:

Fonds Lebret, Pasta AN45 AS51

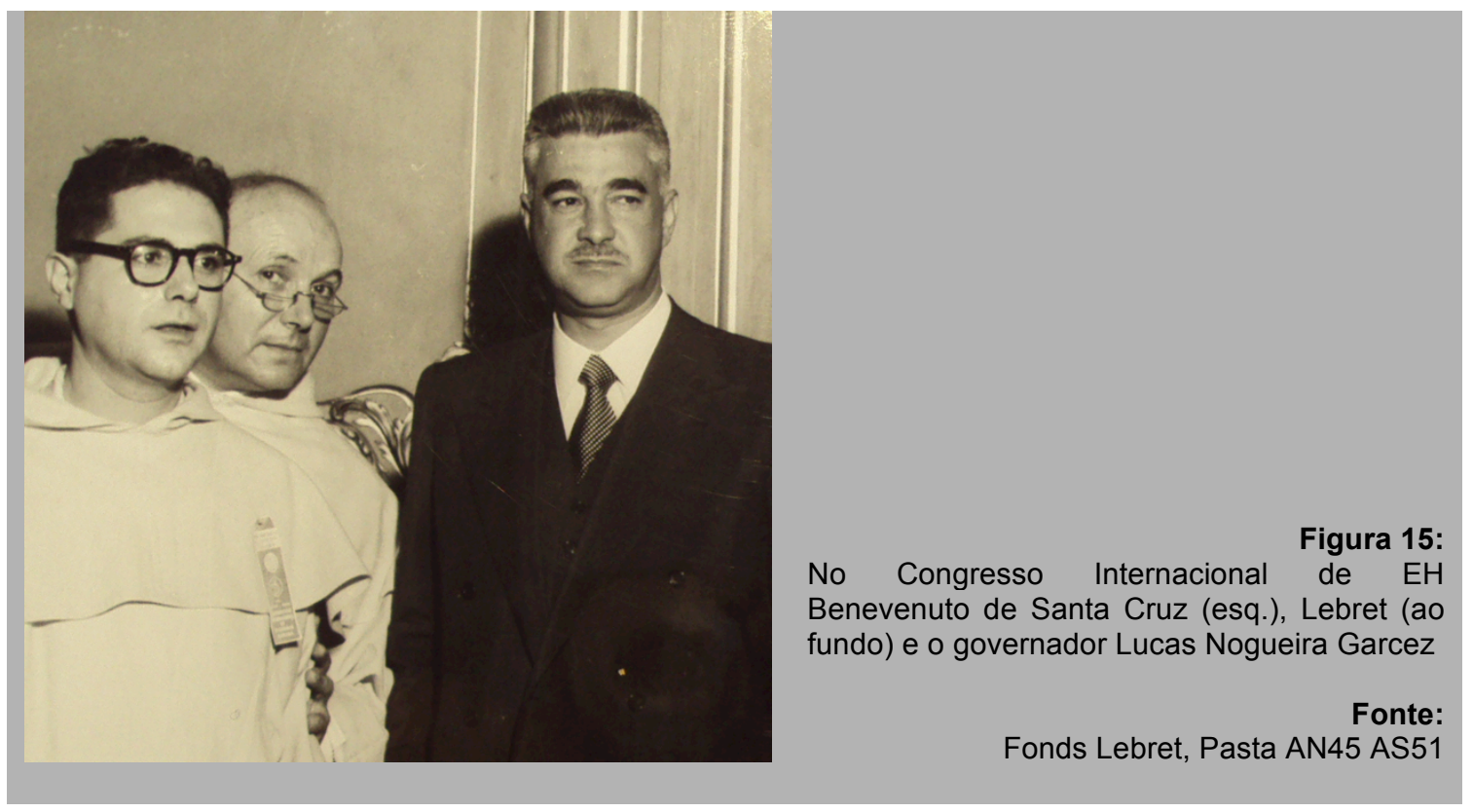


Para o autor, este movimento ilustra a imagem da abertura dada pelo EH à internacionalização do grupo, desde os debates dos anos 1940, e aponta para a vinda de personalidades de outras partes do mundo para participarem do evento no Brasil, destacando como expositores o italiano Georgio Sebregondi, o norte americano Robert Faulhaber, o chileno Jaques Chonchol. Entre os franceses, além de Lebret, também participaram o geógrafo Pierre Mombeig e Alfred Sauvy. Além destes expositores, destacamos a participação dos brasileiros: Eduardo Bastos, Alceu Amoroso Lima e José Francisco Camargo.

\begin{abstract}
Cette manifestation motre la place désormais occupée par l'Amérique latine dans l'élaboration de l'économie humaine: outre la mouvance brésilienne tout entière mobilisée, des participants sont vênus d'Uruguay du Chili et de Colombie. La conférence est suivie de deux journées de reencontre entre les représentants de ces divers noyaux, avant que le père Lebret n'accomplisse durant les semaines suivantes un périple qui le mène du Chili au Pérou puis en Colombie. Un programme d'action interaméricain est dressé, qui renoue avec les projets politiques d'Économie et Humanisme. ${ }^{168}$ (ibid., pp. 311-312).
\end{abstract}

Entendemos assim que a atenção de Pelletier sobre as distintas fases da SAGMACS, volta-se para os vínculos da equipe de Lebret no Brasil com o Centre d'Économie et Humanisme na França. A tentativa do autor é demonstrar as formas de funcionamento do grupo e a importância que o Brasil e demais países da América Latina tiveram para o Économie et Humanisme em sua matriz, na França.

A periodização que propusemos para entender as fases de atuação da SAGMACS levou em consideração os trabalhos de Leme e Lamparelli, bem como de Pelletier. Porém, nossa proposta se deu visando entender tais períodos a partir da análise do envolvimento da equipe em trabalhos realizados pelos mesmos. Para tanto, não levamos em consideração, como fez Pelletier, os trabalhos realizados por membros que integravam as equipes da SAGMACS, mas sim aqueles que foram contratados para serem realizados sob a coordenação da instituição.

Neste sentido, entendemos que as fases de atuação da equipe podem ser vistas de outra maneira, inserindo-se, inclusive, uma terceira fase de atuação da SAGMACS, que para

\footnotetext{
168 Este evento mostra o lugar ocupado pela América Latina no desenvolvimento da economia humana, nos anos 1950: além de todo o movimento brasileiro, o encontro mobilizou a participação de pessoas vindas do Uruguai, do Chile e da Colômbia. A conferência é seguida e coordenada por Lebret em dois dias de encontro entre os representantes desses vários núcleos, então o mesmo realiza nas próximas semanas uma viagem que vai do Chile para o Peru e a Colômbia. Uma agenda Interamericana é elaborada, a qual revive os projetos políticos de Economia e Humanismo. (Livre tradução do autor).
} 
nós se deu quando os membros do grupo alteraram o contrato social e constituíram uma Cooperativa de Técnicos.

A partir da leitura e análise destes trabalhos e também com o cruzamento das informações obtidas em relatórios e balanços elaborados pelo Économie et Humanisme, conseguimos contemporizar uma datação sobre três fases distintas na atuação da SAGMACS no Brasil. A primeira fase ocorrendo entre 1947 e 1952, quando se deu a estruturação da instituição e a mesma funcionou junto ao Jóquei Clube de São Paulo, tendo em sua linha de frente os engenheiros Lucas Nogueira Garcez e Luiz Cintra do Prado. Nesta primeira fase a questão urbana e regional ainda não se apresentava como principal preocupação da equipe, que empreendia trabalhos de consultoria e apoio a empresários e industriais, bem como realizava ensaios e análises sociológicas sobre as condições de vida dos empregados de algumas indústrias e comunidades determinadas.

A segunda fase da SAGMACS inicia-se a partir de 1952, com a segunda vinda do padre Lebret ao Brasil, quando a instituição é contratada pelo governador Lucas Nogueira Garcez para atuar junto ao Comitê Interestadual da Bacia Paraná-Uruguai - CIBPU ${ }^{169}$, realizando o estudo "Problemas de Desenvolvimento: Estudo das necessidades e possibilidades do Estado de São Paulo". É nesta fase que o desenvolvimento urbano e regional figura presente na equipe de Lebret, que passa a empreender trabalhos e estudos voltados ao desenvolvimento das cidades, como o "Plano Diretor para a cidade de Ourinhos", realizado em 1954, e o estudo sobre os "Polos para o Desenvolvimento do Estado de Pernambuco", que aproximou o padre Lebret do engenheiro pernambucano Antônio Bezerra Baltar, que atuou na coordenação do estudo da "Estrutura Urbana da Aglomeração Paulistana”, realizado para a Prefeitura de São Paulo em 1957.

A terceira e última fase de atuação da SAGMACS inicia-se no final dos anos 1950, após a realização dos trabalhos para a Aglomeração Paulistana, estudado por nós em nossa dissertação de mestrado, e a Aglomeração de Belo Horizonte, que resultou na minuta para a lei do Plano Diretor em 1961. Esta última fase consistiu num distanciamento de Lebret em relação aos trabalhos empreendidos e a alteração do estatuto da instituição, que passou a ser uma Cooperativa de Técnicos, contando com a participação maciça de arquitetos e engenheiros, e, em menor quantidade, de economistas, geógrafos e sociólogos.

\footnotetext{
169 Sobre a CIBPU, consultar os trabalhos de Chiquito (2012) e Gardin (2009). CHIQUITO, Elisangela de Almeida. A Comissão Interestadual da Bacia Paraná-Uruguai: do planejamento de vales aos polos de desenvolvimento. Tese de Doutorado. São Carlos, SP: EESC-USP, 2011. GARDIN, Cleonice. CIBPU: a Comissão Interestadual da Bacia Paraná-Uruguai no planejamento regional brasileiro. Dourados, MS: Editora da UPGD, 2009.
} 
Segundo Leme e Lamparelli, a mudança na forma de atuação da SAGMACS deve-se também ao fato de "uma parte da equipe de São Paulo se deslocar para ser incorporada ao Grupo de Planejamento do Governador Carvalho Pinto que iniciava sua gestão" em 1960. (ibid, p. 685). Para os autores, esta seria uma terceira fase de atuação do grupo, havendo ainda uma quarta fase, a fase final que, para eles, se deu após o fim do governo de Carvalho Pinto.

Porém, conforme já apontamos, a nosso ver esta quarta fase não se distingue do que classificamos de terceira fase, iniciada em 1958, após a realização do estudo para a Prefeitura de São Paulo e início do trabalho para a Prefeitura de Belo Horizonte. O ponto chave aqui parece-nos a alteração no contrato social, que transformou a SAGMACS numa cooperativa de técnicos.

Esta última fase se encerrou a partir do golpe de 1964, quando se instalou o regime militar no Brasil. A SAGMACS manteve por algum período o escritório de São Paulo, localizado na Praça da Bandeira, porém, teve seus contratos reduzidos e com o endurecimento do regime, em 1968, viu-se obrigada a desmontar sua sede, esvaziando sua biblioteca.

Em março de 1964 havia cerca de onze contratos ou em andamento ou em vias de serem assinados. O golpe de primeiro de abril tornou-os inviáveis. Caíram os onze. Era uma equipe muito grande nas três dimensões do engajamento técnico-profissional, administrativo e político que perdiam um ponto de apoio e de coesão.

$[\ldots]$

O pessoal que estava no governo sai todo, é perseguido e muitos saem do país, os deputados e políticos são cassados, a equipe técnica se vê sem nenhum trabalho, há um completo esvaziamento do escritório. (LEME e LAMPARELLI, ibid, p. 686).

É importante dizer também que esta fase de término da SAGMACS coincide com a morte de Lebret. O dominicano faleceu em Paris, no ano de 1966, acometido por um câncer no intestino. Assim, segundo Lamparelli, após o golpe militar "há uma debandada geral e uma procura de novas formas de trabalho e sobrevivência, alguns entram na clandestinidade, outros saem do país e os que permaneceram se dispersaram." (op. Cit., ibid). 

CAPÍTULO 4

OS TRABALHOS URBANÍSTICOS EMPREENDIDOS PELA SAGMACS E A CIRCULAÇÃO E APROPRIAÇÃO DAS IDEIAS DO GRUPO NO QUADRO DO URBANISMO NO BRASIL 

Este capítulo analisa os trabalhos empreendidos pela SAGMACS no campo do urbanismo e do planejamento regional, apontando os aspectos relacionados aos procedimentos metodológicos empregados pela equipe coordenada por Lebret no Brasil. Analisando os referidos trabalhos, buscamos compreender o que era prática na SAGMACS e como isso refletia em inovação no campo do urbanismo e do planejamento urbano e regional durante os anos 1950 e 1960, e ainda elencar quais as contribuições do grupo deixadas ao quadro do urbanismo no Brasil. Para tanto, seguimos uma linha de investigação das filiações presentes no ideário que permeava a equipe da SAGMACS, conforme expusemos nos capítulos anteriores desta tese, verificando também as ressonâncias, possíveis permanências, a apropriação das ideias pelo grupo e se houve alguma ruptura na trajetória desta instituição.

Esta investigação somente foi possível devido à descrição dos métodos utilizados pela equipe na elaboração dos trabalhos consistir numa das características dos relatórios entregues aos contratantes, prática esta não utilizada em trabalhos desenvolvidos por outros profissionais, equipes ou demais instituições de urbanismo no período. Neste sentido, faz-se necessário conhecer o contexto histórico, político e social vigente nas décadas de 1950 e 1960, pois, na formação do quadro do urbanismo no Brasil as ações empreendidas pela SAGMACS, bem como as ideias defendidas pelo grupo de Lebret, não se deram de forma isolada, mas sim dentro de um contexto em que o país forjava o desenvolvimento urbano a partir da intensificação do processo de industrialização, sobretudo nas cidades localizadas na região sudeste ${ }^{170}$.

Coincidentemente com este quadro e com a formação da SAGMACS, em 1947, a década de 1950 é considerada pela historiografia do urbanismo brasileiro como a década da crença no planejamento urbano e regional, o que abriu campo para o trabalho não só da

\footnotetext{
${ }^{170}$ É preciso mencionar também os esforços empreendidos e as tentativas do governo federal, a partir dos anos 1950, para fomentar o desenvolvimento dos estados do Nordeste brasileiro. Tais esforços culminaram com a criação do Banco do Nordeste e da SUDENE - Superintendência de Desenvolvimento dos Estados do Nordeste.
} 
equipe de Lebret, mas também de outros órgãos, que aqui encontraram terreno fértil para implementar suas propostas.

Porém, para entender o contexto encontrado por Lebret ao chegar no Brasil em 1947, quando foi fundada a SAGMACS, é preciso retroagir ao período iniciado em 1930, antes da eclosão da Segunda Guerra, década em que ocorreram profundas transformações também na organização do Estado brasileiro, enquanto estrutura de poder e organização burocrática, ações estas voltadas a fomentar o desenvolvimento econômico no país. 


\subsection{O Brasil pós-segunda Guerra Mundial}

No terceiro capítulo desta tese, introduzimos a questão dos motivos que teriam levado Lebret a visitar o Brasil em 1947, visita esta que marcou um período importante da trajetória do religioso. O primeiro desses motivos foi a porta aberta pela Escola Livre de Sociologia e Política - ELSP, espaço que permitiu que Lebret ministrasse o curso sobre Economia Humana. O segundo foi a própria criação da SAGMACS, em São Paulo, em julho de 1947.

Além disso, verificamos que o avanço da indústria nacional, alavancada pelo aumento da produção e exportação de produtos para países europeus, que, devido à guerra, tinham dificuldades para produzir, fazia com que o país, sobretudo o estado de São Paulo, que era a principal sede da indústria nacional, vivenciasse um momento fértil para a discussão das ideias sobre desenvolvimento econômico e o planejamento deste desenvolvimento ${ }^{171}$, não só pela questão econômica, mas por toda a mudança sofrida numa tentativa de modernização do Estado brasileiro, durante a era Vargas (1930-1945).

Sem dúvida, este cenário era um terreno fértil para que Lebret disseminasse suas ideias sobre a Economia Humana e o Desenvolvimento Harmônico. Porém, há que se expor ainda que, da mesma forma que o Brasil era um campo aberto para Lebret e o Centre d'Économie et Humanisme discutir as ideias sobre o desenvolvimento econômico, o cenário também propiciava abertura para outros pensadores, analistas e críticos dos modelos vigentes.

Segundo lanni (1996, p. 25), após a Revolução de 1930, que levou Vargas ao poder, "alteraram-se as funções e a própria estrutura do Estado brasileiro". E,

Devido à derrota, ainda que parcial, das oligarquias dominantes até então, pelas novas classes sociais urbanas, a Revolução exprimiu as rupturas estruturais a partir das quais se tornou possível reelaborar as relações entre o Estado e a Sociedade. Assim, [...] o que caracteriza os anos posteriores à Revolução de 1930 é o fato de que ela cria

\footnotetext{
171 Segundo lanni, "nos anos de 1930 a 1945, o governo brasileiro adotou uma série de medidas econômicas e realizou inovações institucionais que assinalaram, de modo bastante claro, uma fase nova nas relações entre o Estado e o sistema político econômico" (1996, p. 26). Porém, "as medidas econômico-financeiras adotadas, as reformas político-administrativas realizadas e a própria reestruturação do aparelho estatal não foram o resultado de um plano preestabelecido." (ibid., ibidem).
} 
condições para o desenvolvimento do Estado burguês, como um sistema que engloba instituições políticas e econômicas, bem como padrões e valores sociais e culturais de tipo propriamente burguês. (ibid., ibidem).

Para Oliveira (2003, p. 35), "a Revolução de 1930 marca o fim de um ciclo e o início de outro na economia brasileira: o fim da hegemonia agrário-exportadora e o início da predominância da estrutura produtiva de base urbano-industrial." De forma iniciam-se na década de 1930, significativas mudanças na estrutura social, política e econômica do Brasil, que se tornam mais visíveis a partir dos anos 1940.

A população brasileira crescia e, em uma década, o Brasil havia saltado de 30.635 .000 habitantes em 1930 para 41,2 milhões, conforme o Censo de 1940, segundo o qual $31,3 \%$ dos brasileiros viviam em cidades. Foi somente a partir deste senso de 1940 que o IBGE passou a contar a população de forma dividida entre urbana e rural, motivo pelo qual não é possível mostrar o crescimento da população das cidades, havendo somente uma distribuição da proporcionalidade dos habitantes que viviam em cidades com mais de 20.000 habitantes, divididos pelas regiões do país.

Segundo os dados do IBGE, a população brasileira em 1940 era predominantemente jovem, ou seja, $54 \%$ dela era formada por jovens de menos de vinte anos, o que indicava que o Brasil passaria por um processo de intenso crescimento populacional nas próximas décadas, motivo que ocasionaria problemas como a inserção desta população em postos de trabalho e o acesso aos serviços públicos ${ }^{172}$.

Com o fim do Estado Novo, a questão econômica não era o único pilar que preocupava e incrementava as discussões sobre o Brasil. Havia também a preocupação com os rumos da política e a ausência de um projeto de país pelo governo de Dutra. Percebia-se a ausência de novas lideranças capazes de impor um fim ao prestígio político de Getúlio Vargas. Porém, o contexto encontrado no Brasil, pós-segunda Guerra Mundial, era de um extremo otimismo, motivado pelo saldo da balança comercial ${ }^{173}$, puxado pelas

\footnotetext{
172 Considerando-se a distribuição por região, em 1940 a população brasileira se dividia em $32,1 \%$ nos estados do Nordeste, $26,2 \%$ no Centro-Sul (que incluía também os estados de São Paulo e Paraná), $18,1 \%$ no Leste (formado pelos estados de Minas Gerais e Espírito Santo), $10,9 \%$ nos estados do Sul (Santa Catarina e Rio Grande do Sul) e apenas $3,5 \%$ da população vivia nos estados do Norte.

${ }^{173}$ Segundo Prado Junior, é importante expor que este saldo positivo da balança comercial não se dá exclusivamente pelo aumento das exportações de produtos brasileiros, mas sim "em conseqüência do aumento da exportação e declínio das importações" desaparecendo assim "o desequilíbrio crônico da balança de pagamentos exteriores" (1988, p. 303). "A economia brasileira encontrava assim, graças às circunstâncias excepcionais da guerra, um novo equilíbrio provisório". (ibid., p. 304).
} 
exportações de produtos manufaturados para a Europa e pelo crescimento do mercado consumidor interno.

Além do saldo na balança comercial, motivado pelas exportações e pelo aumento do mercado consumidor interno, o debate sobre a modernização e o desenvolvimento econômico do país também era motivado pela implantação da indústria siderúrgica, incentivada pela criação da empresa estatal Companhia Siderúrgica Nacional - CSN, em 1941, e a implantação da Usina de Volta Redonda. Nesse momento, todas as vertentes ideológicas reconheciam a necessidade de ampliação e diversificação da produção de aço no país, e sobre isto Fausto aponta que:

A expansão dos serviços de transporte e a instalação de uma indústria pesada dependiam da solução do problema. Além disso, as importações de aço representavam um peso cada vez maior para um balanço de pagamentos continuamente desfavorável. (2004, p. 371).

Nesse contexto, segundo lanni (ibid., p. 57), o Estado Novo procura meios de proteger os interesses nacionais e incentivar o domínio brasileiro sobre as jazidas minerais, bem como das águas e energia hidráulica. Ainda que as mesmas pudessem ser de propriedade privada, seus proprietários dependiam da autorização federal, na forma da Lei, conforme a constituição de 1937, que dizia que "as autorizações ou concessões serão conferidas exclusivamente a brasileiros ou a empresas organizadas no Brasil".

Deve-se também a este contexto político e econômico, de abertura para o debate sobre as ideias de desenvolvimento econômico, a aproximação inicial de Lebret com os setores mais conservadores, pois, segundo Leme e Lamparelli (2001, p. 676), "é no meio político anti Getúlio, católico, conservador, aproximando-se até com o integralismo, que são feitos os primeiros contatos" de Lebret no Brasil.

Assim, faz-se necessário apresentarmos um quadro sobre o Brasil encontrado por Lebret no contexto pós-segunda Guerra Mundial, que era também o período pós-era Vargas, em que ocorria a migração da matriz de economia agrária, desenvolvida no meio rural, para a matriz de produção industrial ${ }^{174}$, com a predominância da população moradora no meio urbano.

\footnotetext{
174 Sobre a transição da matriz econômica é importante perceber que se trata de um processo que não ocorreu em curto espaço de tempo, mas sim foi iniciado na década de 1930, após a crise econômica de 1929. Para se ter uma ideia deste processo, Fausto aponta que "em 1920, a agricultura detinha $79 \%$ do valor da produção total e a indústria, 21\%. Em 1940, as proporções
} 
Sobre esta migração da matriz econômica de agrária para industrial, Prado Junior (1988) destaca que a mesma não ocorreu como um produto nacional, mas sim como reflexo de uma ação imperialista dos países desenvolvidos e economias centrais, iniciada ainda no século XIX, a partir da abertura dos portos em 1808. Para o autor, contudo, somente "depois da II Guerra que o fato alcança vulto considerável" (PRADO JUNIOR, op. Cit., p. 274), podendo-se constatar que o

\begin{abstract}
Estabelecimento de empresas subsidiárias de grandes trustes internacionais no Brasil se torna a principal via de penetração do imperialismo e de suas operações na economia do nosso país, assumindo papel relevante e de primeiro plano no conjunto da vida econômica brasileira. (ibid., ibidem).
\end{abstract}

Após a $1^{a}$. Guerra Mundial, "os grandes trustes industriais resolvem descentralizar sua produção, disseminando suas unidades pelo mundo e localizando-as nos pontos estratégicos dos mercados e das fontes de matérias-primas". Assim, "o Brasil recebe uma quota desta distribuição e se industrializa" mais rapidamente. (op. Cit., p. 279). Porém, mantém a lógica dominante do caráter fundamental da economia do país desde os primeiros tempos de colonização, ou seja, a de produzir gêneros destinados ao comércio exterior.

Esta realidade começa a se alterar a partir da década de 1930, às vésperas da eclosão da Segunda Guerra, quando, devido à crise internacional iniciada nos Estados Unidos em 1929, o Brasil viu seu mercado consumidor internacional reduzir de forma considerável. Assim, a forma de garantir o desenvolvimento da indústria era com a formação de um mercado consumidor interno. Segundo Fausto (2004, p. 370), "a partir de novembro de 1937, o Estado embarcou com maior decisão em uma política de substituir importações pela produção interna e de estabelecer uma indústria de base", de forma que já havia um fortalecimento da economia brasileira ainda antes da eclosão da guerra.

Foi também por causa deste movimento de formação de um mercado consumidor interno que, segundo Prado Junior, deu-se "o grande crescimento das aglomerações urbanas em

correspondiam a $57 \%$ e $43 \%$ respectivamente" (2004, p. 392). Oliveira aponta que, a predominância da "da estrutura produtiva de base urbano-industrial" só se concretizará "em termos da participação da indústria na renda interna senão em 1956, quando pela primeira vez a renda do setor industrial superará a da agricultura." (ibid., p. 35). 
virtude do progresso industrial, e que se constituem em núcleos de elevado nível econômico e grande potencial de consumo." (ibid., p. 291).

Os defensores dessa perspectiva ganharam força, tanto pelos problemas críticos do balanço de pagamentos, que vinham desde 1930, como pelos riscos crescentes de uma guerra mundial, que imporia, como realmente impôs, grandes restrições às importações. (FAUSTO, ibid., p. 370).

A II Guerra Mundial (1939-1945) trouxe grandes modificações na evolução de todos os povos. Ela assinalou uma acentuada deflexão na marcha dos acontecimentos humanos e os encaminhou por novos rumos que, embora já preparados e em gestação em fase anterior, somente então se precisam de forma nítida e decisiva. [...] O Brasil se fazia de novo alvo de forte demanda internacional de gêneros alimentares e matérias primas exigidos agora pelas necessidades da luta em que se empenhavam as grandes potências. (PRADO JÚNIOR, ibid., pp. 301-302).

Privado do abastecimento externo no que diz respeito a um sem número de manufaturas, o mercado interno tem de recorrer à produção nacional, o que abre amplas perspectivas para as atividades industriais do país. Repetia-se o que já ocorrera por ocasião da I Guerra Mundial (1914-1918). E desta vez em escala muito maior, de um lado porque a redução dos fornecimentos exteriores é muito maior [...] porque as necessidades do mercado nacional se tinham tornado maiores. (op. Cit., p. 302).

Assim, os desdobramentos da política econômica de $\operatorname{Vargas}^{175}$, nos anos 1930 , somados à complexidade de abastecimento dos países em guerra, são percebidos no contexto pós-guerra a partir de 1945, coincidindo com a chegada de Lebret ao Brasil, em 1947, ainda que "esse momentâneo equilíbrio e artificial prosperidade começam a declinar na

\footnotetext{
175 A política econômica de Getúlio Vargas durante o Estado Novo baseou-se na decisão de substituir importações pela produção interna e de estabelecer uma indústria nacional de base. Em 1937 através de decreto-lei Vargas determinava que "só poderiam funcionar no país bancos e companhias de seguros cujos acionistas fossem brasileiros. Concedia-se às empresas estrangeiras um prazo, a ser fixado por lei, para que se transformassem em nacionais." (FAUSTO, ibid., p. 370). Apesar desta tentativa de incentivo à nacionalização da base industrial e econômica do país, percebe-se que durante o período, tanto os grupos econômicos privados brasileiros, quanto o presidente Vargas, buscavam uma associação com o capital estrangeiro visando uma forma de financiar tal política.
} 
medida em que desaparecem as circunstâncias extraordinárias que os tinham provocado" (PRADO JUNIOR, ibid., p. 304).

Estas mudanças ocorridas no país nas décadas de 1930 e 1940 combinavam com as ambições do Économie et Humanisme de formar quadros para o desenvolvimento do Brasil. Era preciso formar quadros para a atuação econômica e também para a administração pública, uma vez que, durante o Estado Novo, a estrutura da administração pública passou a ser vista como um agente de modernização do próprio país ${ }^{176}$. "Assim, assiste-se à emergência e à ampliação das funções do Estado, num período que perdura até os anos Kubitschek." (OLIVEIRA, 2003, p. 40).

O Estado Novo procurou reformular a administração pública, transformando-a em um agente de modernização. Buscou-se criar uma elite burocrática, desvinculada da política partidária e que se identificasse com os princípios do regime. [...] essa elite deveria introduzir critérios de eficiência, economia e racionalidade. (FAUSTO, ibid., p. 378).

A principal instituição responsável pela reforma da administração pública foi o Departamento Administrativo do Serviço Público - DASP, previsto na Carta de 1937 e criado por um decreto-lei de julho de 1938, como órgão ligado à presidência da República. [...] Esse critério abriu oportunidades para profissionais de classe média. (ibid., ibidem).

Sobre esta reestruturação da administração pública durante o Estado Novo, lanni expõe que este processo deixa clara a relação e "o modo pelo qual o Estado e a Economia se relacionam" exprimindo "relações e influências recíprocas entre o poder político e o poder econômico" (1996, p. 16). Para o autor,

\footnotetext{
${ }^{176}$ Conforme dados do DASP (1957), extraídos de lanni (op. Cit., p. 35), desde os anos 1930 foram criados os seguintes órgãos federais, na tentativa de modernizar a máquina pública e fomentar 0 desenvolvimento do Estado brasileiro: Ministério do Trabalho, Indústria e Comércio (1931); Conselho Nacional do Café e Instituto do Cacau da Bahia em 1932; 1933: Departamento Nacional do Café e o Instituto de Açúcar e Álcool; 1934: Conselho Federal do Comércio Exterior, Instituto Nacional de Estatística, Código de Minas, Código de Águas, Plano Geral de Viação Nacional e o Instituto de Biologia Animal; 1937: Conselho Brasileiro de Geografia, Conselho Técnico de Economia e Finanças; 1938: Conselho Nacional de Petróleo, Instituto Nacional do Mate, Instituto Brasileiro de Geografia e Estatística (IBGE) e o próprio DASP - Departamento Administrativo do Serviço Federal; 1940: Comissão de Defesa da Economia Nacional, Instituto Nacional do Sal, Fábrica Nacional de Motores; 1941: Companhia Siderúrgica Nacional e Instituto Nacional do Pinho; 1942: Serviço Nacional de Aprendizagem Industrial (SENAI); 1943: Coordenação de Mobilização Econômica, Companhia Nacional de Álcalis, Fundação Brasil Central, Usina Siderúrgica de Volta Redonda, criação da CLT - Consolidação das Leis do Trabalho e do SESI - Serviço Social da Indústria;
} 
Algumas das políticas econômicas (dentre aquelas adotadas ao longo dos anos 1930-1970) parecem revelar a ambição de grupos e classes sociais no sentido de criar um sistema econômico configurado como capitalismo nacional. Isto é, um sistema em condições de preservar e manipular com autonomia os centros de decisão fundamentais, quanto a objetivos e relações econômicos internos e externos. (ibid., ibidem).

No campo do urbanismo o ideário modernizador se manifesta através da concepção do planejamento como função staff, a ser exercido por um grupo de técnicos que estejam fora da rotina administrativa; e o planejador com visão administrativa geral, como manager, e não como especialista. [...] introduz-se uma concepção de planejamento que parte de soluções técnicas e racionais, divorciadas dos conflitos sociais, o que denota uma visão tecnocrática para resolução dos problemas urbanos. (FELDMAN, 2002, p. 03).

Porém, segundo Quinto Junior (2008, p. 51), ao se analisarem as políticas públicas voltadas ao meio urbano da época e "como de fato funcionava a questão dentro do desenho institucional do Estado brasileiro, constatamos a total desarticulação entre o governo federal e as administrações municipais".

Retornando à década de 1940 e ao contexto pós-guerra, momento em que Lebret chegou ao Brasil pela primeira vez, é importante observar que, apesar de todas as alterações ocorridas mundo afora devido à eclosão da segunda Guerra Mundial, terminada em 1945, o Brasil encontrado por Lebret em 1947 não era resultado somente do saldo deste período, mas sim de ações iniciadas desde os anos 1930, sob a era Vargas.

Este contexto de industrialização, tentativa de modernização do Estado e crescimento das aglomerações urbanas, sobretudo na região centro-sul, colocava o Brasil em situação semelhante ao que Lebret havia enfrentado após sua ordenação sacerdotal, durante sua atuação em Saint-Malo, na década de 1930, quando, na Bretanha, ocorria a precarização do trabalho artesanal dos pescadores em detrimento da modernização do capitalismo e da industrialização da atividade pesqueira na França.

De certo modo, apesar de sua aproximação com o meio anti-Getúlio, Lebret encontra no Brasil tentativas de ações, por parte do Estado, de outorgar a proteção do interesse nacional e a formação de um país que se desenvolvesse através de uma indústria 
nacional de base, que fosse capaz de alimentar o seu mercado consumidor interno e, assim, zerar o déficit com a balança comercial.

Apesar do protecionismo e da inserção de um nacional desenvolvimentismo por Vargas, ainda assim percebemos que as diretrizes da política econômica do Estado Novo, (Constituição de 1937) mantêm-se no bojo da orientação liberal ${ }^{177}$, garantindo ao Estado a possibilidade de atuação do poder público em qualquer esfera da economia e, principalmente, prevendo a intervenção do Estado no domínio econômico para suprir as deficiências da iniciativa individual, conforme apontando no artigo 135 da mesma constituição, que "a intervenção do domínio econômico poderá ser mediata e imediata, revestindo a forma de controle, do estímulo ou da gestão direta."

Desta forma, para Leme e Lamparelli, "o final do governo Vargas, em 1945, tem consequências importantes na politização do meio do urbanismo no Brasil." (ibid., p. 675), devido ao crescimento populacional e ao inchaço das aglomerações urbanas, além da própria reforma empreendida pelo Estado, que buscava ampliar as possibilidades de intervenção e participação do Poder Público no planejamento das ações, tanto na área econômica e na política de incentivo à indústria, quanto no ordenamento do território. São criados então, dentro dos quadros das administrações municipais, sobretudo em algumas capitais, os Departamentos de Urbanismo e Departamentos de Municipalidades.

Veremos a seguir que o quadro do urbanismo no Brasil, no período do pós-guerra, também passou por mudanças em detrimento dos ajustes sofridos pelo país na década anterior. É neste contexto que a SAGMACS, fundada por Lebret, surgirá em 1947, inserindo-se como uma instituição de urbanismo, a exemplo de demais grupos, conforme apontamos na sequência deste capítulo, que se organizaram para oferecer os trabalhos de assistência técnica ao Poder Público, trazendo aos anos 1950 um novo momento para a formação do quadro do urbanismo no Brasil.

\footnotetext{
177 Segundo lanni (ibid., p. 56), cabe ressalva à Constituição de 1934, quando "adotaram-se os princípios nacionalistas e intervencionistas, em contraposição à orientação liberal das constituições anteriores" (1891 e 1926). No campo do urbanismo, Fernandes (2012, pp. 54-55) destaca que, "essa mesma constituição reconhece ao Estado o direito de tributar a propriedade urbana em função da valorização advinda de obras públicas", bem como estabelece um limite para o direito de propriedade, entendendo que esta "não é um direito, mas uma função social". Já "na Constituição do Estado Novo, de 1937," esses elementos jurídicos - "o princípio da submissão do direito de propriedade aos limites do interesse social ou coletivo e o direito de tributar a contribuição de melhoria" são retirados da lei, mostrando um recuo e a submissão à matriz liberal.
} 


\subsection{O quadro do urbanismo no Brasil nos anos 1950}

A SAGMACS foi fundada por Lebret em 1947, na cidade de São Paulo, com o apoio de Lucas Nogueira Garcez, Luiz Cintra do Prado e do frei Benevenuto de Santa Cruz. Mais tarde, já na década de 1950, contou com o apoio do engenheiro Antônio Bezerra Baltar e do sociólogo José Arthur Rios, que atuavam, respectivamente, em Recife e no Rio de Janeiro. A aproximação de Lebret com Baltar e Rios contribuiu para que a SAGMACS formasse equipes para além da cidade de São Paulo. Porém, o início de seus trabalhos deu-se primeiramente subvencionado pelo Jóquei Clube de São Paulo, inclusive tendo sua sede mantida em espaço nas dependências desta instituição.

Como já expusemos anteriormente, os primeiros trabalhos desenvolvidos pela equipe aconteceram no final da década de $1940^{178}$. Porém, foi nos anos 1950 que a SAGMACS alcançou sua consolidação como instituição voltada para a assistência técnica e assessoramento de órgãos públicos e também do setor privado ${ }^{179}$, atuando dentro do campo do urbanismo e do planejamento urbano e regional ${ }^{180}$. Desta forma, podemos dizer que a inserção da SAGMACS ocorreu durante a década de 1950, período apontado por Feldman como "a década da crença no planejamento urbano e regional". Segundo esta autora ${ }^{181}$,

A década de 1950 pode ser considerada o momento de maior crença no planejamento regional e nas possibilidades do planejamento como atribuição privilegiada do Estado, no Brasil. É o momento de um

\footnotetext{
178 Referimo-nos aos primeiros trabalhos empreendidos pela equipe da SAGMACS já em 1947, sob a coordenação de Lebret, como o estudo "Sondagem preliminar a um estudo sobre habitação na cidade de São Paulo" e o trabalho sobre "o problema do menor", que não chegou a ser concluído.

${ }^{179} \mathrm{Na}$ década de 1960 a SAGMACS desenvolve alguns trabalhos para o setor privado, destacando o contrato estabelecido com a Companhia Ferro e Aço de Vitória, com a USIMINAS e os estudos para implantação de loteamentos nas cidades de São Vicente, São Paulo e Ubatuba, desenvolvidos por encomenda de uma incorporadora imobiliária paulista à equipe.

${ }^{180}$ É importante expor que em 1952, antes ainda de destacar-se como instituição atuante no campo do planejamento urbano e regional, Lebret coordenou, após a eleição de Lucas Garcez para o governo do Estado de São Paulo, um estudo sobre as possibilidades de desenvolvimento do Estado, que resultou num plano de trabalho para o novo governador e marcou o retorno do religioso francês ao Brasil.

${ }^{181}$ Para a autora o que se denomina como crença no planejamento regional seria "a convicção de que o controle público é possível, a convicção de que as grandes cidades podem ser renovadas, reorganizadas, redistribuídas, e que tornar eficiente a organização territorial é um caminho para superar as desigualdades regionais." (FELDMAN, 2009, p. 03).
} 
otimismo modernizador, que se insere no quadro do chamado nacional desenvolvimentismo e se expressa também no Plano de Metas, na criação da SUDENE, na mudança da capital para Brasília. (2009, p. 01).

Este processo de institucionalização do quadro do urbanismo no Brasil também teve sua origem anterior à chegada de Lebret, em 1947. Ainda que o debate acerca da questão urbana no Brasil tenha se dado de forma tardia, quando comparado com os demais países capitalistas, foi a partir da "rápida industrialização que ocorreu nos anos de 1920 a 1930" que se iniciou o processo de "grandes mudanças nas estruturas intra-urbanas das aglomerações brasileiras" (QUINTO JUNIOR., ibid., p. 50).

Para Campos (2002, p. 193), este debate sobre a institucionalização de um quadro do urbanismo no Brasil surgiu juntamente com o anseio pela modernização do país, que tomou corpo desde as primeiras décadas do século $X X$ e se intensificou após o fim da Primeira Guerra ${ }^{182}$. Para o autor, "a primeira metade do século $X X$, no Brasil, foi marcada pela intensificação do debate social e cultural em torno da formação da nacionalidade". Assim, nos anos 1920,

Entre os instrumentos técnicos arregimentados para a modernização do país emergia a disciplina recém-instituída do urbanismo - articulando a transformação dos centros decisórios, importadores e exportadores, com destaque para a modernização dos portos, a remodelação das áreas centrais, o saneamento e a criação de bairros residenciais destinados aos estratos dominantes.

$[\ldots]$

A introdução do urbanismo como disciplina no Brasil era muitas vezes acompanhada pelo questionamento da urbanização em si mesma. Além de sua acepção estrita como ciência e arte de construir e remodelar cidades, o termo 'urbanismo' também podia indicar uma postura ideológica que considerava como desejáveis e positivas a urbanização, a grande cidade e a vida urbana em geral - opondo-se ao ruralismo, ao agrarismo e a outras correntes de pensamento que viam com maus olhos as cidades. (ibid., p. 194).

\footnotetext{
182 Podemos ainda lembrar de ações dentro do campo do urbanismo ocorridas antes do período mencionado por Campos, tomando como exemplo as intervenções na cidade do Rio de Janeiro, ainda no século XIX, a vinda de arquitetos estrangeiros para São Paulo na última década do XIX e o debate acerca do projeto para o Vale do Anhangabaú, que adentrou a primeira década do XX, 0 projeto de Araão Reis para a cidade de Belo Horizonte, nova capital do estado de Minas Gerais, inaugurada em 1893, as obras de engenharia sanitária planejadas por Saturnino Brito para o Estado de São Paulo, bem como o trabalho de Prestes Maia e Ulhoa Cintra na confecção de planos para a Prefeitura de São Paulo, entre outros planos e projetos desenvolvidos para as demais cidades do país e por demais engenheiros e arquitetos.
} 


\begin{abstract}
A formação do campo do urbanismo no Brasil, enquanto espaço intelectual e espaço prático que se dedica a conhecer, conceber, estruturar e gerir os processos de crescimento das cidades, implementado por um corpo de profissionais dotado de competência técnica, estética e política, é [...] um processo que se constrói [...] e se consolida a partir dos anos 1920 e 1930. (FERNANDES, 2012, p. 47).
\end{abstract}

Sobre este quadro de formação, Quinto Jr. menciona que, no Brasil, os primeiros cursos especializados em urbanismo surgiram no final dos anos 1940, citando "a importância da criação do curso de Arquitetura e Urbanismo na USP em 1948 e a posição do professor Anhaia Mello, que colocaria o curso de Urbanismo junto com o curso de graduação em Arquitetura." (ibid., p. 54) ${ }^{183}$. Feldman (2004, p. 51) aponta ainda que, em 1947, foi criada a Faculdade de Arquitetura Mackenzie, separando assim o ensino de arquitetura da Escola de Engenharia da mesma instituição. Além dos cursos em São Paulo, segundo Feldman (2012, p. 26), desde a

\begin{abstract}
Década de 1930 o ensino de urbanismo se dissemina, e engenheiros e arquitetos se qualificam e se legitimam para atuar como experts. A Escola Nacional de Belas Artes - ENBA, no Rio de Janeiro, implanta a cadeira de urbanismo - arquitetura paisagística no curso de Arquitetura (1931); seguindo o programa da ENBA, a disciplina começa a ser lecionada na Escola de Belas Artes do Recife (1936). Além disso, em 1930, nos moldes da seção de Arquitetura da ENBA cria-se, em Belo Horizonte, a Escola de Arquitetura. [...] A partir do final dos anos 1940, surgem cursos de pós-graduação e de especialização em urbanismo em Porto Alegre e Belo Horizonte.
\end{abstract}

Frente a este cenário de institucionalização do quadro do urbanismo no Brasil, Leme e Lamparelli (ibid., p. 676) observam que "na formação do urbanismo no Brasil, como disciplina e como campo profissional, constata-se a importante influência das concepções urbanísticas internacionais", nas quais se inseria a ação de Lebret nos anos 1950.

Quanto à presença e influência estrangeira no quadro de formação do urbanismo no

\footnotetext{
183 Sobre os cursos de urbanismo que surgem neste período, Feldman (2004, p. 50) aponta que "desde os anos de 1920, o rompimento da formação unificada de engenheiros, arquitetos e urbanistas vinha sendo reivindicado em duas frentes." Apontando que o diretor da Escola de Engenharia da Universidade Mackenzie, Christiano Stockler das Neves "preconizava a discriminação das atividades a serem desempenhadas por engenheiros civis e por arquitetos e se posicionava contra o título de engenheiro-arquiteto". Na USP, Anhaia Mello também "defendia a formação especializada do urbanista".
} 
Brasil, destacamos neste período (1930-1950), além de Lebret, a importância do arquiteto francês Alfred Agache, que atuou no Rio de Janeiro, na década de 1930, e em Curitiba, no início dos anos 1940. O arquiteto modernista Le Corbusier também visitou o Brasil e demais países sul americanos na década de 1930 e teceu planos para as cidades do Rio de Janeiro e São Paulo, e o norte-americano Robert Moses apresentou o "Plano de Melhoramentos para a cidade de São Paulo", em 1951. Tivemos ainda a visita do urbanista francês Gaston Bardet, que em sua primeira vinda, em 1948, ministrou curso de formação na ELSP ${ }^{184}$, e no início dos anos 1950 se instalou em Belo Horizonte, e o geógrafo norte-americano Preston James que, nos anos 1940, estudou o processo de urbanização brasileiro a fim de fazer comparação com as cidades americanas e da Europa, além do geógrafo francês Pierre Mombeig que ministrou aulas na USP.

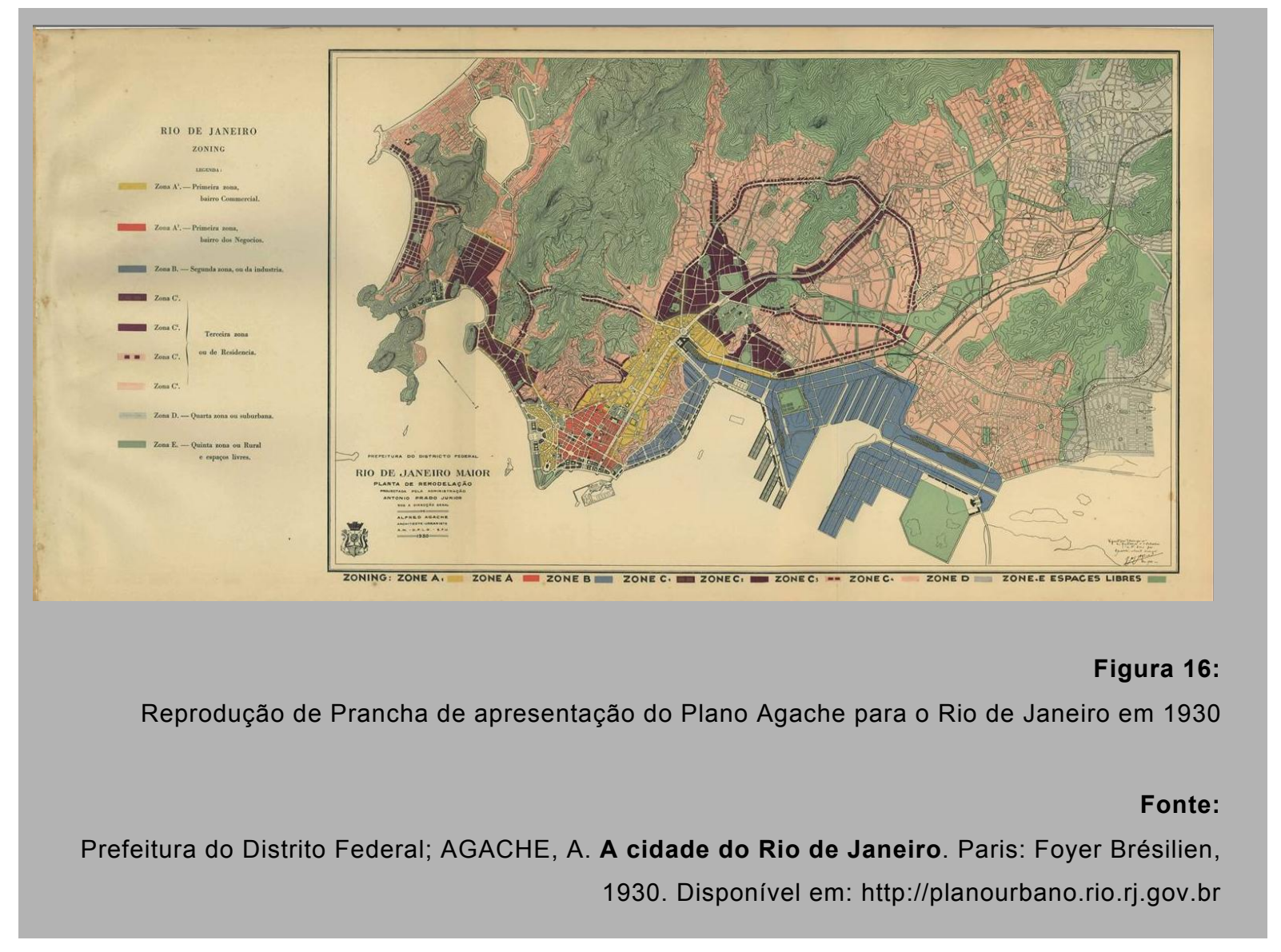

\footnotetext{
${ }^{184}$ Quanto à presença de Bardet no Brasil, é importante destacar que sua primeira estada se deu em 1948, para ministrar um curso junto à Escola de Sociologia e Política, um ano após a primeira vinda de Lebret. Neste período Bardet era próximo do Économie ET Humanisme e colaborava com artigos para a revista editada pelo grupo. Segundo Pontual (2014), além do curso Bardet ministrou conferências na cidade de São Paulo, entre os dias 16 e 20 de agosto, sobre os temas: "I) Sociologia e Urbanismo; II) Escola Comunitária; III) A organização natural e regional da França; IV) A nova estrutura rural; V) Simbiose".
} 


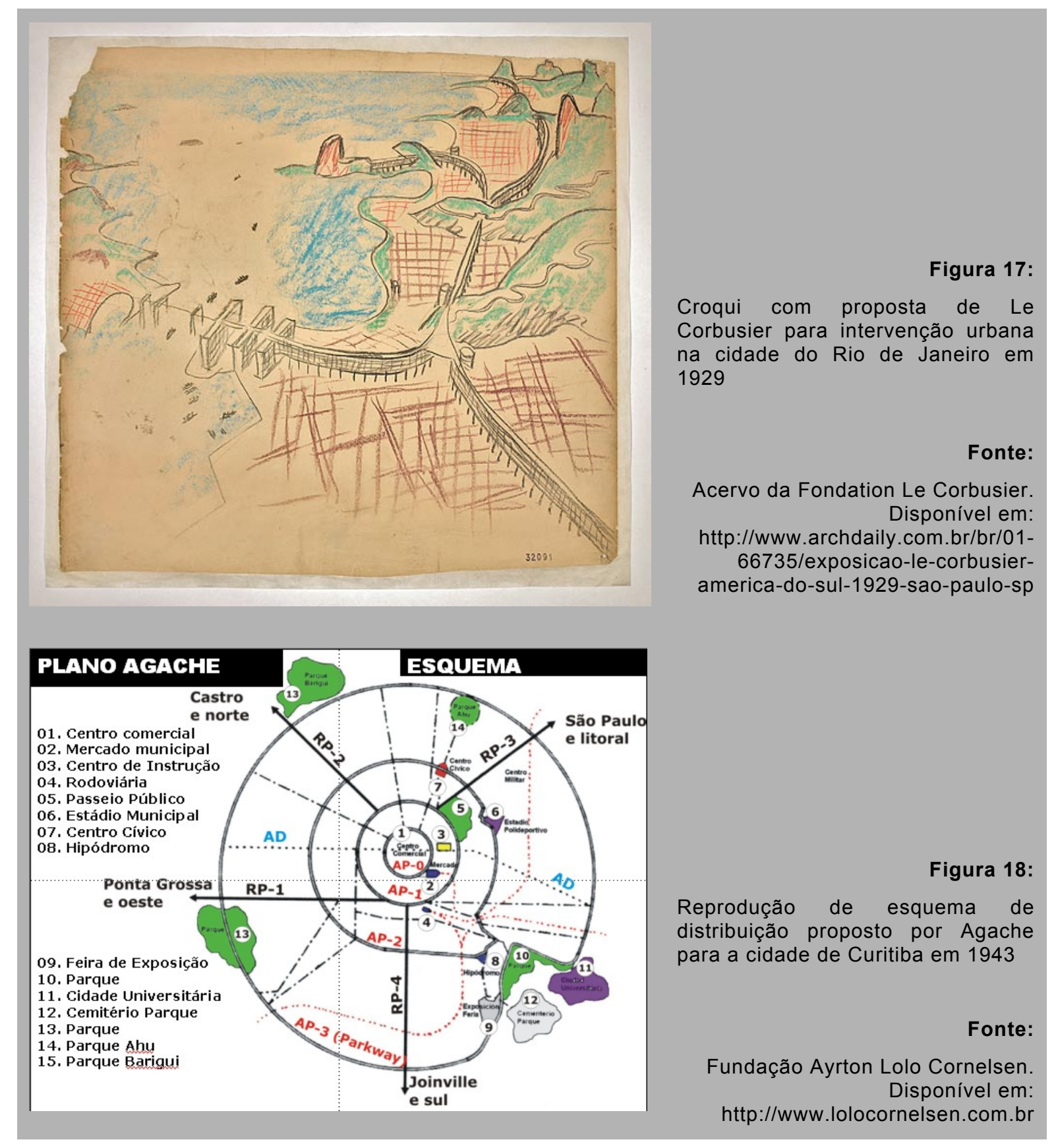

Ao se analisarem as instituições de urbanismo criadas no Brasil entre os anos 1930 e os anos 1960, podemos observar que esse período se caracteriza por movimentos de naturezas diversas que tem em comum a proposição de novas abordagens de gestão municipal. No campo do urbanismo é o período de institucionalização do planejamento. (FELDMAN, 2002, p. 02). 
Para Feldman, podemos dividir as ações "no âmbito da estruturação de órgãos nas administrações municipais" em dois momentos e "dois tipos de instituições, onde se destaca a presença de urbanistas envolvidos com o projeto de modernização do serviço público empreendido por Vargas". Esta distinção de momentos explica-se devido ao quadro político institucional do Brasil, pois, de 1930 a 1945, sob a Era Vargas, há distinção entre os períodos que vão de 1930 a 1937 (quando Vargas exerce a presidência da República como chefe provisório do poder - 1930 a 1934, e depois eleito indiretamente em 1934), entre 1937 e 1945 (período em que Vargas exerce o poder como ditador) e após 1945, quando o país se redemocratiza, buscando apoiar as ações de planejamento urbano e regional,

\begin{abstract}
A partir dos anos 1930, ao nível dos governos estaduais, são criados órgãos de assistência aos municípios que inicialmente, têm como mira o controle e a assistência financeira às cidades do interior, mas que acabam por assumir e propor estruturas e mecanismos de controle urbanístico para estas. Junto aos governos municipais criam-se as comissões consultivas para elaboração e execução de planos para as cidades.
\end{abstract}

$[\ldots]$

As comissões consultivas dão origem, em algumas capitais, aos Departamentos de Urbanismo, que institucionalizam um espaço de atuação exclusiva do urbanismo [...] e se consolidam na função de assistência técnica.

$[\ldots]$

Criam-se instituições fora da administração pública que também desenvolvem trabalhos de assistência aos municípios que, por caminhos diversos, retomam a idéia de colaboração com as administrações das cidades do interior. (ibid., ibidem).

Durante o mesmo período em que Lebret fundou a SAGAMCS, foram fundados também o CEPEU - Centro de Estudos e Pesquisas Urbanísticas, criado por Luiz Anhaia Mello como órgão vinculado à Faculdade de Arquitetura e Urbanismo da USP (em 1955); o IBAM - Instituto Brasileiro de Administração Municipal (1952) e a Fundação Getúlio Vargas (1944), ambos no Rio de Janeiro, e o CEPUR - Centro de Pesquisas em Planejamento Urbano e Regional, criado pelo engenheiro Antônio Bezerra Baltar dentro da Universidade do Recife (1955). Assim, 
Ao longo dos anos 1940 e 1950 órgãos nas administrações municipais começam a se estruturar nas capitais e nas cidades do interior na perspectiva de introduzir um processo de planejamento, planos diretores começam a ser elaborados por escritórios de arquitetura e por instituições de urbanismo que atuam no campo da assistência técnica. (ibid., 2009, p. 04).

Podemos citar como exemplo destas mudanças e organização deste quadro institucional a organização da Secretaria de Obras Públicas da Prefeitura de São Paulo, em 1947, que criou os Departamentos de Urbanismo, de Arquitetura e de Obras Públicas ${ }^{185}$. Feldman chama a atenção para o fato da Secretaria de Obras Públicas de São Paulo distinguir, através dos seus diferentes departamentos, as especialidades nas quais os profissionais deveriam atuar.

Demarca-se, dessa forma, um campo para projetos de edifícios, reservado aos arquitetos, um campo para obras públicas e construção, para os engenheiros, e um campo de elaboração de planos, para urbanistas.

\section{$[\ldots]$}

A reorganização do Departamento de Obras Públicas, ao separar arquitetos, engenheiros e urbanistas, aponta para a demarcação de um território de urbanistas - nem arquitetos, nem engenheiros. (2004, pp. 52-55).

Além da reestruturação da Secretaria de Obras Públicas da Prefeitura de São Paulo, podemos também mencionar, na esfera dos governos estaduais, os Departamentos de Assistência aos Municípios, os quais, apesar de terem sido criados com o intuito de dar suporte e controlar o orçamento dos estados sobre os municípios, também acabaram por incorporar, na década de 1950, "funções de assistência técnica e específica do campo do urbanismo". (ibid., 2002, p. 5).

Em 1955, Departamentos das Municipalidades (ou Departamentos de Assistência aos Municípios) estavam ativos no Pará, Rio Grande do Norte, Pernambuco, Sergipe, Bahia, Espírito Santo, Rio de Janeiro, Paraná, Rio Grande do Sul, Minas Gerais e São Paulo. [...] Os Departamentos das Municipalidades constituem o embrião de um conjunto de assistência técnica aos municípios que se estruturam a

\footnotetext{
${ }^{185}$ A Secretaria de Obras Públicas foi criada pelo Decreto Lei 431/1947 por Christiano Stockler das Neves em 1947, quando o mesmo ocupou o cargo de prefeito de São Paulo (março a agosto).
} 
partir do final da década de 1940, principalmente fora das administrações, como a SAGMACS, CEPEU, CEPUR e IBAM. (ibid., ibidem).

Assim, nos anos 1950, o quadro do urbanismo no Brasil mostrava-se ainda em formação, porém acenando para novas questões a serem debatidas. Ocupavam espaço nos debates acerca do planejamento urbano e regional tanto a questão da criação de órgãos e instituições voltados à assistência técnica e assessoramento de prefeituras e demais órgãos públicos, como o caso da SAGMACS fundada por Lebret, quanto a própria atribuição profissional dos arquitetos urbanistas e dos profissionais urbanistas. Nesse momento, segundo Feldman (2012, p. 27), "os urbanistas se confrontam com mudanças estruturais das cidades, e a formação de conhecimento sobre a realidade urbanoindustrial ocorre tanto no campo do urbanismo como em outros campos profissionais, como a sociologia e a geografia."

Percebemos assim que, no Brasil dos anos 1950, recupera-se a discussão feita por nós, no capítulo inicial desta tese, quanto à conceituação do que seria o urbanismo e o trabalho no campo da urbanística, bem como a quem caberia coordenar tais ações. A partir da distinção das especialidades, descrita acima, "os urbanistas se inserem, portanto, no processo de formação de uma elite burocrática, desvinculada da política que persegue os critérios de eficiência, economia e racionalidade" (ibid., 2002, p. 5).

Porém, cabe aqui a ressalva de que, diferentemente de Anhaia Mello e Baltar, Lebret não tinha formação nem em engenharia e nem em arquitetura, e mesmo assim, sobretudo a partir de 1952, colocou a SAGMACS para atuar neste campo profissional do urbanismo e do planejamento urbano e regional. Neste mesmo período (1952) também não se nota a presença de arquitetos nos quadros da equipe de Lebret no Brasil, mas sim de engenheiros, como Mário Laranjeira de Mendonça e Luiz Cintra do Prado, primeiro diretor da SAGMACS. Além destes engenheiros, também apontamos para a presença de profissionais com formação fora da área da arquitetura e engenharia, como do médico e diretor da Escola Paulista de Medicina, Dr. José Maria de Freitas, do médico psiquiatra Dr. Oscar Rezende Lima, de Estanislau Maiorano e do advogado André Franco Montoro, secretário geral da Ação Católica.

Podemos dizer que a não vinculação da SAGMACS com o campo do urbanismo, no início de seus trabalhos no Brasil, se deu em decorrência da própria condição políticoeconômica do país, que, naquele momento, mostrava-se preocupado em garantir o desenvolvimento da indústria nacional, bem como manter-se menos dependente da 
importação de produtos industrializados dos países de economia central.

Levando-se em consideração os apontamentos de Feldman e Quinto Jr. sobre a institucionalização do quadro do urbanismo no Brasil, ao final dos anos 1940, e do movimento do governo brasileiro, bem como de demais órgãos, como universidades, instituições de urbanismo e de assistências técnicas, ainda que se verifique a ascensão de instrumentos de ordenamento territorial como o Plano Diretor e as comissões de planos para as cidades, é possível dizer que a maior preocupação no período era de discutir o desenvolvimento econômico e social do país.

Neste sentido, "o conjunto das atividades governamentais nesses anos revela que o poder público foi levado a criar mais algumas condições infra-estruturais e institucionais para a aceleração do desenvolvimento industrial do país." (IANNI, ibid., p. 126). E assim, como "não só criaram-se órgãos destinados a favorecer o desenvolvimento econômico, mas também realizaram-se estudos técnico-científicos sobre os problemas econômicos brasileiros" (op. Cit., ibidem), havia campo para que a SAGMACS desenvolvesse suas atividades e trabalhasse pesquisando tais aspectos, antes de inserir-se no campo do urbanismo, o que se deu de forma mais efetiva a partir de 1952.

\begin{abstract}
Ampliou-se a discussão a propósito do planejamento econômico e da adoção de políticas econômicas planificadas por parte do governo e dos setores governamentais. [...] A problemática da planificação econômica estatal passou a ser discutida também no Congresso Nacional, nas universidades, em livros, em artigos de jornais, revistas e em reuniões promovidas por partidos políticos. (op. Cit., ibidem).
\end{abstract}

Os debates sobre os problemas do crescimento das cidades e das aglomerações urbanas começaram a ocorrer nos anos 1950, como uma extensão dos problemas discutidos no seio da questão do desenvolvimento econômico do Brasil,e assim as instituições de urbanismo ganharam peso para imbricar-se neste campo. Porém, ao contrário das outras instituições que tinham nascido vinculadas ao campo do urbanismo, como o CEPEU e o CEPUR, a SAGMACS fora fundada como um organismo da rede de Économie et Humanisme, cuja matriz de fundação na França, em 1941, era a discussão do desenvolvimento econômico harmônico e de uma terceira via, conforme já apontado nesta tese.

Desse modo, podemos entender que esta vinculação da SAGMACS com o Centre d'Économie et Humanisme proporcionou ao padre Lebret e à equipe formada por ele no 
Brasil melhor trânsito entre aqueles que se preocupavam com o desenvolvimento brasileiro neste período.

Este vínculo rendeu alianças da SAGMACS tanto com setores progressistas quanto conservadores. Dentre os setores progressistas, a SAGMACS aliou-se com o engenheiro Baltar, em Pernambuco, que militava no PSB, tinha proximidade com Miguel Arraes e atuou na CEPAL - Comissão Econômica para a América Latina, e com o médico Josué de Castro, consultor da Comissão de Bem Estar Social. Ao mesmo tempo aliou-se com o sociólogo José Arthur Rios no Rio de Janeiro, que coordenou a campanha nacional de educação rural e na década de 1960 foi secretário do governo Carlos Lacerda, e com Lucas Nogueira Garcez em São Paulo, que foi eleito governador pelo PSP com apoio de Adhemar de Barros e, após 1964, filiou-se à Arena, partido que deu sustentação à ditadura militar. Segundo Oliveira (2015, pp. 347-348):

Ao longo da década de 1950, a SAGMACS consolidou um foco de atenção e de atração sobre elites políticas brasileiras. A instituição fez acordos políticos bastante diversificados: no Rio de Janeiro, a aliança foi forjada com o apoio de udenistas e católicos, tendo como figura central Carlos Lacerda e Dom Hélder Câmara; em São Paulo, recebeu apoio do governador Lucas Garcez, que tinha bases políticas no ademarismo e no trabalhismo, e do petebista Wladimir Toledo Pizza na prefeitura de São Paulo; em Belo Horizonte, recebeu apoio de Celso Melo Azevedo do Partido Democrata Cristão (PDC) e, depois, pelo trabalhista Amintas de Barros; em Recife, o principal articulador foi Miguel Arraes, do Partido Socialista Brasileiro (PSB) ${ }^{186}$.

No meio religioso católico Lebret se beneficiou do apoio do Arcebispo do Rio de Janeiro, D. Hélder Câmara, liderança da igreja católica, que, embora tenha sido um jovem integralista, era considerado um bispo progressista e defensor da causa dos mais pobres, próximo da Fundação Leão XIII (órgão vinculado à Secretaria de Assistência Social do estado do Rio) e foi fundador da Cruzada de São Sebastião, que visava um trabalho pastoral e de apoio às necessidades temporais da população moradora das favelas cariocas.

Assim, "as pesquisas da SAGMACS se situam no ponto de encontro político entre o

\footnotetext{
186 Sobre esta permeabilidade da SAGMACS e de Lebret junto aos meios políticos, é importante mencionar que, nos anos 1960, o grupo se aproximou de Ney Braga, governador do Paraná, eleito pelo PDC. A SAGMACS foi contratada pelo governador para empreender um plano de desenvolvimento para o estado, que culminou com um estudo para a reorganização de toda a máquina administrativa do governo paranaense.
} 
governo federal e os poderes regionais e se inscrevem na lógica geral do desenvolvimentismo e de intervenção dos poderes públicos na gestão econômica do país." (LEME e LAMPARELLI, ibid., p. 680). Diante desta possibilidade de articulação com os poderes locais e regionais e com o governo federal, a SAGMACS se inserirá no campo do urbanismo e do planejamento urbano e regional a partir do trabalho junto à Comissão Interestadual da Bacia Paraná Uruguai, criada em 1951 por Getúlio Vargas.

\subsection{O debate sobre a questão urbana e o planejamento urbano e regional nas equipes da SAGMACS}

A vinculação da SAGMACS com o temário do urbano e do desenvolvimento regional, para nós, se deu no início dos anos $1950^{187}$. No período que definimos como sua fase inicial (1947-1952), conforme exposto no capítulo anterior, a equipe atuou em estudos na área de sociologia e economia, prestando serviços a empresários, industriais e organizações de apoio ao desenvolvimento econômico no Estado de São Paulo. Alguns de seus membros atuaram também em trabalhos e comissões instituídas pelo governo federal. Já em sua fase final, nos anos 1960, a SAGMACS desenvolveu um trabalho de organização e reforma da administração para o Estado do Paraná, teve a participação de membros do grupo no governo de Carvalho Pinto, no Estado de São Paulo, entre outras ações voltadas a cumprir o objeto contratado.

Assim, podemos dizer que, embora o debate sobre a questão urbana e o planejamento urbano e regional estivesse presente desde os anos iniciais da SAGMACS, foi a partir de 1953, período que consideramos como início da segunda fase de atuação do grupo, que tais práticas se consolidaram ${ }^{188}$. Em 1953, a SAGMACS foi contratada pelo governador Lucas Garcez para realização de um plano de eletrificação do Estado de São Paulo ${ }^{189}$,

\footnotetext{
${ }^{187}$ Adotamos como ponto de partida da SAGMACS para o desenvolvimento no campo do urbanismo e do planejamento urbano e regional o trabalho iniciado para o governador Lucas Garcez à frente da Comissão Interestadual da Bacia Paraná Uruguai, que culminou com a realização do trabalho "Necessidades e Possibilidades do Estado de São Paulo", apresentado em 1954.

188 Conforme exposto no capítulo anterior, Leme e Lamparelli (2001) apontam o momento da entrega deste trabalho, em 1954, como ponto que delimita o início do que, para os autores, seria a segunda fase de atuação da equipe de Lebret no Brasil.

${ }^{189}$ Este trabalho foi elaborado na sequência do relatório confeccionado por Lebret em 1952, a pedido de Lucas Nogueira Garcez, que havia sido eleito governador do Estado. O relatório serviu
} 
bem como para elaborar o diagnóstico sobre os "Problemas de Desenvolvimento, Necessidades e Possibilidades do Estado de São Paulo", trabalho este realizado dentro do escopo de ação da Comissão Interestadual da Bacia Paraná-Uruguai.

Conforme apontamos em nossa dissertação de mestrado (2009), o estudo dos "Problemas de Desenvolvimento, Necessidades e Possibilidades do Estado de São Paulo" foi coordenado por Lebret e pela primeira vez a SAGMACS formou uma equipe ampla, com profissionais das áreas da economia, sociologia e arquitetura, abrindo espaço para o trabalho interdisciplinar dentro do grupo ${ }^{190}$.

Contratado para coordenar o estudo, Lebret viajou e conheceu todo o território paulista $^{191}$, e verificou de perto as condições de vida da população e suas necessidades básicas, percebendo as mudanças em relação às condições que estava acostumado a verificar no primeiro mundo, mas também constatando a diversidade de paisagem, economia e meios culturais que marcavam as diferenças entre a capital paulista, que figurava como a principal sede da indústria no período, e as cidades do interior do estado.

É importante dizer que buscamos aqui demonstrar como ocorreu esta vinculação da SAGMACS com o tema do urbanismo e do planejamento urbano e regional, e, desta forma, faz-se necessário expormos que, já em 1947, tão logo ocorreu a fundação da instituição em São Paulo, o primeiro trabalho realizado por Lebret vinculava-se à questão urbana, tratando de um levantamento sobre as condições de moradia da cidade de São Paulo.

A pesquisa "Le Logement de La Population de São Paulo" foi publicada pela Revista do Arquivo Municipal em 1951, sob o título de "Sondagem Preliminar a um estudo sobre Habitação em São Paulo", e visava observar as diferenças da estrutura residencial existentes entre uma cidade industrial sul-americana e as cidades industriais

como um plano de governo para o recém-eleito governador e apontava como um dos principais problemas que poderiam impedir o avanço do desenvolvimento de São Paulo a limitação da geração de energia elétrica, essencial para o incremento das atividades industriais.

190 Em nossa dissertação de mestrado apontamos que "o estudo interestadual da Bacia ParanáUruguai envolveu cerca de quarenta e cinco pessoas, entre engenheiros, economistas, arquitetos e sociólogos. A coordenação do estudo ficou a cargo de Alain Birou, Benevenuto de Santa Cruz, Louis-Joseph Lebret, Luiz Carlos Goelzer e Raymond Delprat.” (CESTARO, 2009, p. 128). O apontamento dos nomes que compuseram a equipe participante deste estudo é apresentada neste trabalho no item 4.4 .

${ }^{191}$ Em correspondência enviada por Benevenuto de Santa Cruz ao padre Lebret, em abril de 1952 , é apontado um cronograma de visitas e uma sugestão de agenda que Lebret deveria seguir durante sua estada de três meses no Brasil. Documento consultado na Pasta AN45 AS51. 
francesas $^{192}$.

A "Sondagem Preliminar a um estudo sobre Habitação em São Paulo" marca a fase fundadora dos trabalhos da SAGMACS no Brasil e revela o caráter da pesquisa empírica, método utilizado por Lebret e sua equipe na França, que consistia em colocar o pesquisador diretamente com o objeto a ser pesquisado. Este trabalho foi realizado sob o patrocínio do Serviço Social da Indústria.

Em um relatório ${ }^{193}$ do Économie et Humanisme sobre trabalhos em realização pelas equipes do grupo, nos anos de 1948 e 1949, há menção à equipe da SAGMACS, atuante no Brasil, e sobre os trabalhos que estavam em curso naquele momento, incluindo-se a pesquisa sobre a condição habitacional na cidade de São Paulo. Além deste trabalho, o relatório menciona também que, no mesmo período, o grupo brasileiro pesquisava e produzia relatórios sobre "as condições das crianças abandonadas na cidade e no estado de São Paulo", sobre o "pensamento social dos estudantes universitários paulistanos e suas condições de vida", sobre "a condição dos trabalhadores" e "sobre os problemas de nutrição na infância".

À exceção da "Sondagem Preliminar", os demais trabalhos em desenvolvimento nos anos iniciais da SAGMACS mostram que o grupo de Lebret no Brasil não se vinculava diretamente ao tratamento da questão urbana em sua fase inicial. Porém, mostravam a preocupação com temas sociais - que estavam inseridos nos aspectos da cultura das cidades, mas não na discussão do planejamento urbano e regional - como o problema das crianças abandonadas, a desnutrição infantil e também dos aspectos culturais, como as condições de vida dos estudantes universitários da cidade de São Paulo.

É importante também mencionar que, apesar da direção do Engenheiro Luiz Cintra do Prado e da presença de Garcez nos quadros iniciais da SAGMACS, havia também a participação de médicos, advogados e sociólogos, o que, para nós, distanciaria inicialmente a equipe de uma abordagem sobre os problemas da cidade em escala

\footnotetext{
192 Importante expor que no caso do Centre d'Économie et Humanisme na França, os primeiros trabalhos vinculados ao campo do urbanismo e do aménagement du territoire se deram através de estudos sobre a questão da habitação em cidades francesas, ocorridos no contexto de reconstrução das cidades destruídas pela Guerra. Estes aspectos foram apresentados por nós, no capítulo 2 desta tese, quando tratamos da aproximação do $\mathrm{EH}$ com $\mathrm{O}$ Ministère de La Reconstruction et Urbanisme e o desdobramento do grupo em demais instituições vinculadas, como a SAGMA - Societé pour l'application du graphisme et de la mécanographie à l'analyse, o CREDOC - Centre Regional de Documentation et de Conjoncture e o IMSAC - Institut Marseillais de statistique et d'analyse et de conjoncture.

193 Conforme consulta na Pasta AN45 AS36 "Compte-rendu d'activitédes equipes EH pendant l'exercice 1948-49, em que se mencionam os trabalhos em desenvolvimento nas cidades de Maubeuge, Romans, Saint-Etienne, Nantes e Lyon na França e trabalhos em desenvolvimento na Suíça e no Brasil.
} 
urbana e regional.

Ainda assim, o relatório do EH aponta que a SAGMACS foi constituída "mais plutôt d'un centre SAGMA", o que demonstra o interesse em se vincular a questão urbana aos trabalhos empreendidos pela equipe, uma vez que, conforme exposto no segundo capítulo desta tese, a SAGMA foi constituída na França por Jean Queaneu para dedicarse aos estudos do problema habitacional e elaborar diretrizes para uma política de reconstrução das cidades. O mesmo relatório aponta ainda para o que é chamado de "problème trés délicat" sob o ponto de vista técnico, o fato de que "Le groupe est constitué em société civile à finalité commerciale", afirmando:

Que les chrétiens du Brésil n'ont pas le sens social. Les milieux d'action catholique sont très inefficaces: l'action catholique n'a commencé qu'il y a 4 ou 5 ans, et dans une perspective très cléricale. On ne peut pas envisager un majorité du laïcat. Le décalage psychologique entre l'Europe et le Sud-Amérique est immense. II semble que rien ne puisse être fait au Brésil d'ici dix ans ; le travail le plus important à confier au Père de Santa-Cruz serait la pénétration du clergé et de l'épiscopat. ${ }^{194}$ $(\mathrm{EH}, 1949)$.

Os apontamentos da equipe central do EH mostram certa decepção com o grupo em formação no Brasil, neste período inicial de vinculação com Lebret. Porém, fazem ressalva a um grupo em formação no Recife, apontando que o mesmo "caminha bem, constituído por assistentes sociais, universitários, médicos, arquitetos e 4 ou 5 engenheiros" (livre tradução do autor), e que deveria se manter na "clandestinidade" para não despertar o interesse da igreja local ${ }^{195}$.

\footnotetext{
${ }^{194}$ O problema é que os cristãos no Brasil não se importam e não têm senso social. Os círculos da Ação Católica são muito ineficientes: a Ação Católica começou há apenas 4 ou 5 anos, e numa perspectiva muito clerical. Nós não podemos contar com uma maioria dos leigos. A diferença psicológica entre a Europa e a América do Sul é imensa. Parece que nada pode ser feito no Brasil em menos de dez anos; o trabalho mais importante a ser confiado ao Frei Benevenuto de Santa Cruz seria a penetração do EH no clero e do episcopado. (Livre tradução do autor).

195 Como o relatório não aponta para nomes vinculados às equipes no Brasil, não é possível precisar sobre a presença de Baltar como sendo um dos engenheiros mencionados anteriormente a década de 1950. As informações dispostas entre os estudiosos do tema SAGMACS apontam para a vinculação de Baltar ao grupo de Lebret a partir de sua segunda estada no Brasil, em 1953. Conforme documentos pesquisados junto à pasta AN45 AS64, é possível verificar que a troca de correspondências entre ambos se inicia em abril de 1953. Da mesma forma, o frei Benevenuto de Santa Cruz, com quem Lebret manteve contato desde sua primeira vinda ao Brasil, menciona em carta datada de 1952 e endereçada ao francês sobre a possibilidade de um encontro do dominicano com o engenheiro pernambucano se dar por ocasião de sua segunda estada no Brasil. Sobre este vínculo com Baltar, é ainda importante mencionar que seu nome passa a constar de trabalhos
} 
Podemos então perceber que as ações iniciais da SAGMACS são vistas sob desconfiança pelo Centre d'Économie et Humanisme, que mostra-se preocupado com a dependência dos cristãos leigos em relação ao clero e o baixo senso dos mesmos em relação às questões sociais, como o combate à miséria e ao subdesenvolvimento. Por isso, é possível verificar que, nesta primeira fase, o grupo não atuou propriamente como uma instituição, conforme apontamos no capítulo anterior, embora houvesse sim o engajamento de alguns membros em trabalhos de grande monta junto a Comissões instituídas pelo Poder Público, tanto no nível dos estados, quanto do governo central ${ }^{196}$.

Assim, a "Sondagem Preliminar" pode ser entendida como um trabalho realizado sob excepcionalidade, contando inclusive com a coordenação direta de Lebret. Este primeiro estudo realizado pela SAGMACS foi feito durante os meses de Abril, Maio e Junho de 1947, contou com uma equipe de 40 pesquisadores e com Oscar Rezende Lima e Estanislau Roberto Maiorano, que atuaram sob a coordenação do dominicano. A pesquisa definiu como metodologia o levantamento de um número de 1.257 inquéritos divididos proporcionalmente de acordo com a população de cada distrito da cidade ${ }^{197}$.

Diferentemente de outros levantamentos realizados sobre a situação habitacional do paulistano, a "Sondagem Preliminar" tinha caráter quantitativo, ao mesmo tempo em que classificava diferentes tipos de modalidade e condições de moradia e compreendia também a análise sobre quem eram os habitantes e onde as diferentes classes e tipologias habitacionais se localizavam na cidade de São Paulo. Apesar de não ter utilizado métodos científicos reconhecidos, o trabalho de Lebret, segundo Leme (2004, p. 112), teve relevância no tratamento da questão habitacional, assim como da questão social e econômica urbana, possibilitando "a percepção da diversidade socioeconômica na composição dos bairros da cidade e a compreensão da existência da periferia e de sua relação dialética com o centro", o que, para a autora, teve "um enorme impacto na formulação do pensamento urbanístico em São Paulo" (ibid.).

realizados pela SAGMACS a partir de 1954, no que chamamos de segundo período de atuação da equipe.

\footnotetext{
${ }^{196}$ Referimo-nos aos trabalhos que contaram com a participação de membros da equipe, como a campanha nacional de educação rural, coordenada por Rios, em 1952; a direção do mesmo sociólogo à frente da Seção de Pesquisas do Serviço Especial de Saúde Pública, em 1954; o trabalho de Lebret como consultor da Comissão de Bem Estar Social, presidida por Josué de Castro, em 1954; e a organização "A pesquisa brasileira de padrões de vida", coordenada por Lebret.

197 O número de inquéritos levantados em cada distrito da cidade foi estimado em função dos dados obtidos através do Censo de 1940, realizado pelo IBGE. Em 1947, estes dados já não eram tão representativos, devido ao distanciamento temporal e ao rápido crescimento ocorrido nesta década. Isto motivou Lebret a preferir chamar sua pesquisa de "Sondagem Preliminar" a fim de se evitar distorções.
} 
Ainda que tenhamos apontado no capítulo anterior, e reiterado aqui, que a consolidação da SAGMACS como instituição de urbanismo se deu em sua segunda fase (a partir de 1952), verificamos que este primeiro trabalho desenvolvido sob a coordenação de Lebret, em São Paulo, já trazia a equipe para o campo do urbanismo e demonstrava a preocupação da mesma com os problemas da cidade. Tal aspecto já era desenvolvido pelo Économie et Humanisme, na França, que já em 1944 dera início ao debate sobre a questão urbana e do aménagement du territoire, através de exposições feitas por Lebret nas Semanas Sociais promovidas pelo grupo, conforme apontamos no segundo capítulo desta tese.

Desta forma, podemos confirmar que há grande proximidade entre a SAGMACS e o Centre d'Économie et Humanisme, pois, na França, o EH também iniciou a década de 1950 discutindo os métodos para o trabalho no campo do urbanismo, o que culminou com a publicação dos manuais escritos para orientação das equipes vinculadas ao grupo, independentemente de sua localização no mundo.

A sequência de publicações dos manuais pelo Économie et Humanisme demonstra o peso dos autores franceses na definição dos métodos, mas também a consolidação da equipe de Lebret no Brasil junto à equipe central do $E H$, a partir de 1955 , pois as publicações ocorridas na sequência trazem a participação de membros da SAGMACS entre os autores. A nosso ver, isso demonstra consonância com a periodização que estabelecemos sobre as fases de atuação da SAGMACS, podendo apontar que sua inserção no campo do urbanismo se deu a partir de 1953. Desse modo, podemos entender que o trabalho "Sondagem Preliminar", mesmo tratando de um aspecto dentro deste campo, pode ser considerado como uma ação deslocada dos temas dos trabalhos desenvolvidos pelos membros do grupo até 1952.

Ainda sobre a vinculação da equipe da SAGMACS com o grupo de Lebret na França, podemos citar que, em 1951, o Économie et Humanisme publicou, através da Prèsses Universitaires du France, o manual “L'Enquête Rurale: L'Analyse de la Commune et du Canton", que traz, entre seus autores, o urbanista Gaston Bardet, que não compunha o quadro de autores da “L'Enqûete Urbaine: L'Analyse du Quartier et de La Ville”, publicado pela mesma editora em 1955. O manual para a pesquisa urbana foi escrito por Lebret e Renné Bride, com a colaboração de H. Hollard, M. Michoud, M. Perrot, R. Caillot, Raymond Delprat, F. Lerouge e Michel Quoist.

Já a "L’Enqûete envue de L’Aménagement Régional", publicada em 1958, conta com a colaboração dos brasileiros Eduardo Bastos e Benevenuto de Santa Cruz. O manual foi escrito por Lebret, Jean Marie Albertini, R. Caillot, Georges Célestin, Raymond Delprat e 
contou também com o apoio de André Chomel.

A publicação deste último manual coincide com o término do contrato da SAGMACS com a Prefeitura de São Paulo, para realização do estudo da "Estrutura Urbana da Aglomeração Paulistana", trabalho realizado entre os anos de 1956 e 1957, sob a coordenação de Lebret e do engenheiro Antônio Bezerra Baltar. Assim, a preparação desta publicação pelo Économie et Humanisme ocorreu conjuntamente com o desenvolvimento do trabalho da SAGMACS para compreensão dos problemas e da estrutura da aglomeração paulistana, que consistiu num trabalho no âmbito do planejamento urbano e regional.

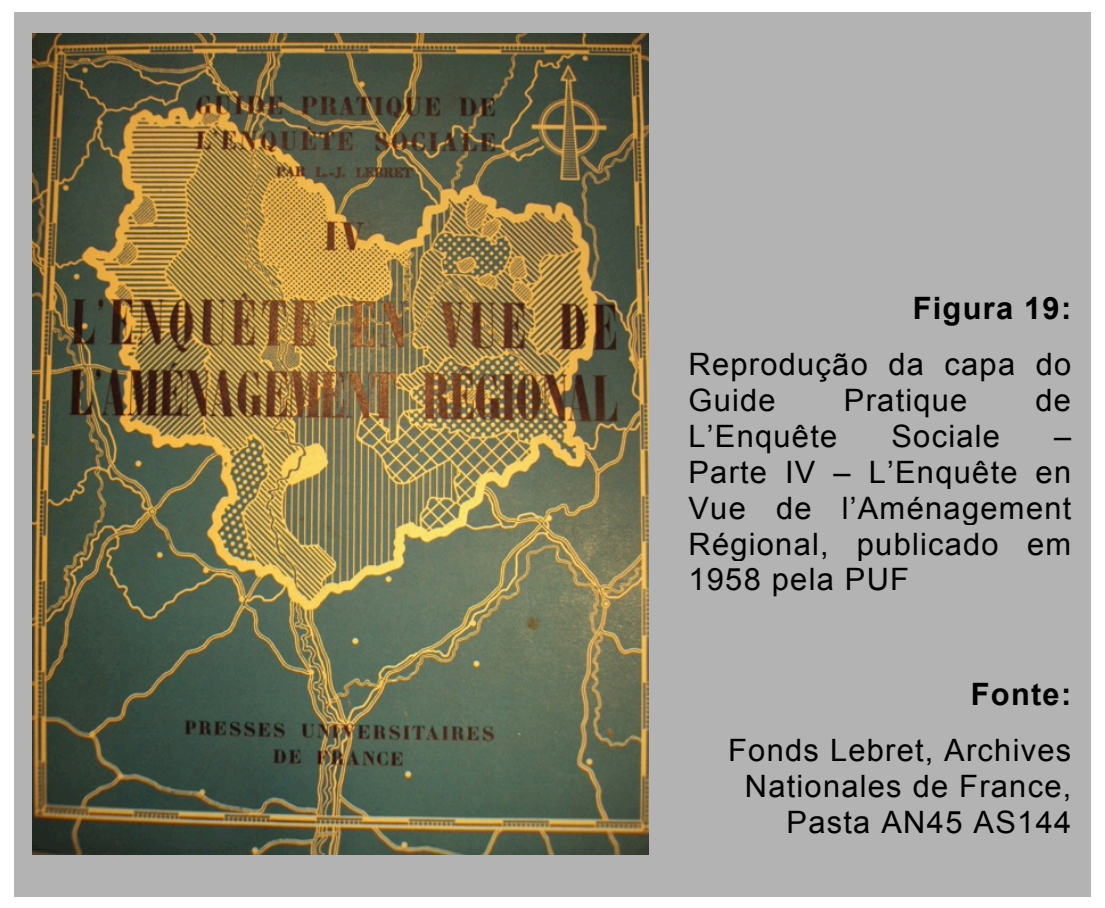

Se o vínculo da SAGMACS com a questão urbana, durante a realização da pesquisa "Sondagem Preliminar a um estudo sobre habitação em São Paulo", em 1947, foi uma exceção ao que a equipe desenvolveu nos primeiros anos de sua atuação, a partir de 1952, com a segunda vinda de Lebret ao Brasil, os trabalhos no âmbito do planejamento urbano e regional se destacaram, sobretudo a partir da contratação da pesquisa "Problemas de Desenvolvimento: necessidades e possibilidades do estado de São Paulo", realizada para a Comissão Interestadual da Bacia Paraná-Uruguai, a pedido do governador Lucas Nogueira Garcez.

Num aspecto mais amplo sobre a montagem das equipes da SAGMACS, podemos dizer que este trabalho ocorreu num período em que o grupo crescia e contava com diferentes 
frentes de apoio. Além do governador Garcez, também gozava de bom trânsito entre os setores mais progressistas da igreja católica, como o Arcebispo do Rio de Janeiro D. Hélder Câmara; André Montoro, da Ação Católica, e Plínio de Arruda Sampaio, da Juventude Universitária Católica. No meio jurídico paulista, tinha o apoio do Desembargador João Batista de Arruda Sampaio, pai do então presidente da JUC. Porém, a nosso ver, foi de Recife que veio o maior reforço no campo da formação técnica das equipes, o engenheiro e professor Antônio Bezerra Baltar ${ }^{198}$, que colaborou com o trabalho realizado para o governo paulista.

A aproximação de Lebret com o engenheiro Baltar permitiu à SAGMACS uma ampliação física de sua área de atuação, que até então era limitada ao Rio de Janeiro e São Paulo. No Rio, o dominicano contava com o apoio de Josué de Castro e de José Arthur Rios, que tinham trânsito junto ao governo de Vargas e também no estado da Guanabara. No estado de São Paulo, a permeabilidade de Lebret se dava por seu vínculo com setores empresariais e o meio intelectual, sobretudo da Escola Politécnica da USP e da Escola Livre de Sociologia e Política.

Com o vínculo estabelecido com Baltar, e em parceria, ambos desenvolveram um estudo para o desenvolvimento do Estado do Pernambuco, aliando economia com fatores sociais e urbanísticos. Isso permitiu a Lebret a formação de uma equipe da SAGMACS na cidade do Recife. O trabalho "Estudo sobre o desenvolvimento e implantação de Indústrias no Pernambuco e no Nordeste do Brasil" foi encomendado pela Comissão de Desenvolvimento do Estado do Pernambuco - CODEPE, e finalizado em $1955^{199}$.

Dentro deste quadro de formação das equipes da SAGMACS, temos ainda que inserir o apoio dado pelo professor Luiz Anhaia Mello, diretor da Faculdade de Arquitetura e Urbanismo da USP. No momento da contratação da SAGMACS pela Prefeitura, em 1956, Mello fazia parte da Comissão do Plano Diretor, uma comissão especial, dirigida pelo engenheiro da prefeitura Carlos Lodi - então Chefe do Departamento de Urbanismo. Diante da dificuldade da Prefeitura aprovar junto à Câmara de Vereadores uma lei que permitisse a subvenção à SAGMACS para realização do estudo da "Estrutura Urbana da Aglomeração Paulistana", Anhaia Mello redigiu uma carta em apoio à contratação de

\footnotetext{
198 Em 1951, Antônio Bezerra Baltar tornou-se professor titular da cadeira de urbanismo e arquitetura paisagística na Escola de Belas Artes da Universidade do Recife, defendendo a tese "Diretrizes de um Plano Regional para o Recife".

199 Embora faça parte dos trabalhos desenvolvidos pela SAGMACS, o relatório resultante da pesquisa contratada pela CODEPE não consta junto ao antigo acervo da equipe, depositada na biblioteca do Programa de Pós-Graduação da Faculdade de Arquitetura e Urbanismo da USP. O trabalho foi consultado junto à pasta AN45 AS105 e também na Biblioteca Central da EESC-USP.
} 
Lebret, apontando "sua reconhecida experiência na área do urbanismo"200

Assim, a partir de 1953, com o trabalho para o governo de São Paulo, o grupo passa a contar com a presença de estudantes de arquitetura e recém-formados pela FAU-USP, dirigida por Anhaia Mello. Entre os nomes de estudantes de arquitetura que compuseram esta equipe, destacamos Clementina de Ambrosis, Domingos de Azevedo Neto, Joaquim Guedes, Liliana Marsicano Guedes e Miguel Zangaro, que atuaram inicialmente como desenhistas da SAGMACS.

Desta forma, com o quadro de referências e personalidades que influenciaram a formação técnica das equipes da SAGMACS, bem como permitiram a mesma encampar a questão urbana e inserir-se junto ao quadro do urbanismo e do planejamento urbano e regional no Brasil, nos anos 1950, trataremos, ao final deste capítulo, dos trabalhos desenvolvidos pelo grupo. Iniciaremos com o primeiro deles, a "Sondagem Preliminar", passando pelo trabalho que, a nosso ver, marcou o ingresso da SAGMACS no quadro do planejamento urbano e regional, o estudo dos "Problemas de desenvolvimento, necessidades e possibilidades do estado de São Paulo", concluído em 1955. Apresentaremos o estudo da "Estrutura Urbana da Aglomeração Paulistana", (1958); o "Plano Diretor de Belo Horizonte", desenvolvido na sequência do estudo da "Estrutura Urbana de Belo Horizonte" e concluído em 1963, além de outros planos para demais municípios e o estudo "Aspectos Humanos da Favela Carioca", apresentado em 1960.

A escolha destes trabalhos se deu não somente devido à filiação dos mesmos ao campo do planejamento urbano e regional, mas também pelo fato dos mesmos terem rendido à SAGMACS alterações em sua estrutura interna, bem como marcado a distinção de fases de atuação do grupo.

Ao analisarmos o estudo da "Sondagem Preliminar", verificamos tratar-se de um trabalho ainda inicial, realizado na primeira fase de atuação da equipe. Os trabalhos desenvolvidos para o estado de São Paulo e a prefeitura da capital se vinculam ao segundo período da equipe e demonstram o crescimento da estrutura da SAGMACS para o cumprimento de tais contratos. Ainda que a pesquisa "Aspectos Humanos da Favela Carioca" tenha sido realizada entre os anos de 1958 e 1959, inserimos a mesma na última fase de atuação da equipe, devido ao fato do relatório das favelas ter sido contratado por um organismo privado, o que marca a última fase de atuação da equipe, quando a mesma passa a ter contratos com instituições privadas. Por fim, o "Relatório do

\footnotetext{
200 Conforme documento consultado na Biblioteca da Câmara Municipal de São Paulo, junto ao processo de contratação da SAGMACS pela Prefeitura. Processo 8.038 de 1956.
} 
Plano Diretor de Belo Horizonte", realizado entre 1960 e 1963, é estudado por tratar-se de um trabalho finalizado pela equipe, diferentemente dos trabalhos realizados para São Paulo, que foram apenas entregues aos contratantes, mas que não foram efetivados ou tiveram desdobramentos em continuidade de contratos ${ }^{201}$.

Antes de abordar diretamente estes trabalhos desenvolvidos pela SAGMACS, faremos uma apresentação do percurso de formação do grupo, refletindo sobre o amadurecimento dos mesmos frente à questão urbana e do planejamento regional, bem como sobre a consolidação da instituição como órgão de prestação de serviços e consultoria voltado ao planejamento.

\subsection{Um percurso em desenvolvimento para consolidação da SAGMACS como Assistência Técnica e de consultoria em planejamento urbano e regional}

A SAGMACS atuou entre os anos de 1947 e 1964. Em quase vinte anos de atuação da equipe, alguns trabalhos se destacaram devido à complexidade e abrangência do objeto de estudo. Podemos destacar, entre os principais trabalhos desenvolvidos pelo grupo, principalmente dentro do campo do planejamento urbano e regional, no sentido de ter suscitado novas questões e aberto oportunidades de atuação para a equipe: o estudo da "Estrutura Urbana da Aglomeração Paulistana: Estruturas Atuais e Estruturas Racionais", contratado pela Prefeitura em 1956 e entregue em 1958; o estudo dos "Problemas de Desenvolvimento: Necessidades e Possibilidades do Estado de São Paulo", desenvolvido dentro das atividades da CIBPU, entre os anos de 1953 a 1955, e o estudo sobre os "Aspectos Humanos da Favela Carioca", apresentado em 1960, além de planos diretores $^{202}$, estudos sobre problemas de desenvolvimento de cidades e regiões ${ }^{203}$, relatórios técnicos ${ }^{204}$ e propostas para novos loteamentos ${ }^{205}$.

\footnotetext{
201 É importante esclarecer que Lebret expõe que o estudo da "Estrutura Urbana da Aglomeração Paulistana" é contratado por Toledo Piza em continuidade ao trabalho realizado para a CIBPU, entregue em 1955. Porém, tratamos a "Aglomeração Paulistana" de forma diferente do "Plano Diretor de Belo Horizonte", pois este último se deu em continuidade ao estudo da "Estrutura Urbana de Belo Horizonte", entregue em 1959 para a prefeitura. A entrega do trabalho para a prefeitura de São Paulo deveria vir em sequência, mas não foi efetivada pelas administrações que sucederam Piza.

202 A SAGMACS desenvolveu em 1954, sob supervisão de Baltar, a proposta para o Plano Diretor de Ourinhos, no Estado de São Paulo. Segundo Trindade (2014), o estudo contou com a
} 
Como pode se observar, mesmo após o ano de 1952, quando apontamos como início da segunda fase de atuação da equipe de Lebret no Brasil, o escopo de trabalhos prestados pela SAGMACS continuou amplo e não se restringiu ao campo do urbanismo e do planejamento urbano e regional. Entre os contratos firmados, a SAGMACS seguiu prestando serviços a órgãos estatais, como o Serviço Social Rural do governo federal; aos governos dos estados de São Paulo e do Paraná, a algumas prefeituras e também a contratantes privados, como o Jornal Estado de São Paulo, financiador do estudo sobre a favela carioca; à Cia. Ferro e Aço de Vitória, que contratou trabalho para o desenvolvimento de um estudo sobre moradia operária, e à USIMINAS, que solicitou um estudo sobre os problemas socioeconômicos de Ipatinga.

Ainda antes de iniciar o que chamamos de segunda fase de atuação da equipe, logo após a fundação da SAGMACS, Lebret coordenou um primeiro trabalho com vistas a conhecer a realidade social e os aspectos urbanos da cidade de São Paulo, através de uma pesquisa sobre as condições de moradia dos paulistanos. A pesquisa "Sondagem Preliminar a um estudo sobre Habitação em São Paulo" foi objeto de estudo de Leme (2004) e tratado também na dissertação de mestrado de Roldan (2012). Esta pesquisa, conforme já apontamos, trata-se de uma exceção frente aos demais trabalhos que os membros da SAGMACS realizaram até 1952, pois, até então, não havia maior vinculação da equipe com a questão urbana e o planejamento regional, embora houvesse um entendimento dos membros de que os problemas sociais e econômicos em decorrência do subdesenvolvimento se agravavam no espaço da cidade.

participação dos estudantes de arquitetura da FAU- USP, Clementina de Ambrósis e Domingos Teodoro de Azevedo Neto, que seguiram para Recife, onde receberam um "treinamento" de Baltar. Além do Plano Diretor para Ourinhos, a SAGMACS desenvolveu também trabalhos semelhantes para as cidades de Sorocaba, Barretos e Belo Horizonte, em 1963.

203 Constam do escopo de trabalhos desenvolvidos pela SAGMACS a pesquisa regional voltada para o Nordeste, contratada pelo Serviço Social Rural em 1959, o estudo para o desenvolvimento do Estado da Guanabara (1960), "Prospecto dos Problemas de Desenvolvimento de Ubatuba, SP" (1963), o estudo sobre as "Comunidades Territoriais do Paraná" (1963). Whitaker Ferreira (2007) aponta também para o "Projeto para a região do Araguaia".

204 Como o trabalho desenvolvido para o governo do Estado do Paraná durante a gestão do democrata cristão Ney Braga, o "Relatório sobre os problemas da Saúde Pública no Paraná" (1961), o "Relatório sobre o serviço de Água e Esgoto: Análise da situação dos sistemas nas redes de municípios do interior de São Paulo" (1963), o relatório sobre o serviço de "Energia Elétrica no Estado de São Paulo" (1964) e o estudo para um "Programa de Educação Fundamental", desenvolvido por Lamparelli, em 1963, dentro do PAGE.

205 "Estudo para implantação de um loteamento no município de São Paulo" (1962), "Estudo para implantação de um loteamento no município de São Vicente" (1962), "Estudo para a revisão agrária de São Paulo", realizado em 1962, que consistia numa proposta para viabilizar um loteamento urbano na Fazenda Jacilândia, no interior de São Paulo. 
Também mencionamos que a SAGMACS alcançou prestígio e foi reconhecida como instituição atuante dentro do campo do planejamento urbano e regional, sobretudo a partir da participação da equipe nos trabalhos desenvolvidos para o governo de São Paulo, entre 1953 e 1955, e da pesquisa para a prefeitura, sobre a "Aglomeração Paulistana", contratada por Toledo Piza em 1956 e concluída em 1958.

É importante mencionar que, após o término do estudo para a prefeitura de São Paulo, em 1958, Carlos Alberto Carvalho Pinto, então Secretário da Fazenda do governo de Jânio Quadros, foi eleito governador do estado, numa aliança que envolvia o Partido Democrata Cristão, a UDN, PTN, PR e o PSB. Com a posse de Carvalho Pinto, em 1959, alguns membros da SAGMACS se distanciaram da equipe para exercerem papel junto ao grupo de planejamento do governo estadual - o PAGE ${ }^{206}$, coordenado pelo advogado e ex-presidente da JUC, Plínio de Arruda Sampaio.

Quanto à participação de membros da SAGMACS no PAGE, Lamparelli expõe que "nos primeiros meses de 1959 [...] uma parte da equipe de São Paulo é deslocada para ser incorporada ao Grupo de Planejamento do Governador Carvalho Pinto, que iniciava sua gestão." (LEME e LAMPARELLI, ibid., p. 685). Numa comparação em relação aos trabalhos realizados até então pela SAGMACS, no âmbito do planejamento urbano e regional, o autor expõe que:

Se a pesquisa de São Paulo foi um mergulho nos pouco conhecidos problemas urbanos, o Plano de Ação também foi um período de descoberta das questões de desenvolvimento do Estado e do aparelho e prática da sua administração, sob os princípios que devem comandar o desempenho de um verdadeiro staff da cúpula decisória, pois acreditávamos que planejamento deveria ser instrumento e prática de todos os setores e níveis. Aquela concepção mais globalizante de desenvolvimento integral, harmônico, partindo da população, vai, de repente, se diluir e se fracionar numa concepção de Estado que divide tudo em setores. Assim, os técnicos da SAGMACS que foram trabalhar

\footnotetext{
206 O PAGE - Plano de Ação do Governo do Estado, foi estudado por Alves, em sua tese de doutorado defendida em 2008 e na dissertação de mestrado de Cordido, defendida em 2007. Segundo Cordido, Buzzar e Simoni (2009, p. 2), "o PAGE foi um instrumento de planejamento territorial inovador na experiência brasileira de políticas públicas. [...] foi fundamentado com 0 intuito de promover e incentivar o desenvolvimento das 'regiões atrasadas' do interior do estado." A autora aponta ainda para a existência de um vínculo com Lebret na metodologia aplicada pela equipe, dizendo que o plano "foi incrementado com as bases humanísticas dos fundamentos ideológicos cristãos, influenciadas estas pelo pensamento e trabalho de pesquisa do padre Lebret". Para Lamparelli, que participou da equipe técnica do plano, esta "foi uma das experiências mais significativas" (LEME E LAMPARELLI, ibid, p. 685). Além de Lamparelli, a equipe técnica do PAGE contava com a participação de outros membros da SAGMACS, sendo: Domingos Theodoro de Azevedo Neto, Francisco Whitaker Ferreira e Mário Laranjeira de Mendonça.
} 
no Plano de Ação acabam tendo que escolher um setor de atuação e uma especialidade. (ibid., ibidem).

Apesar do destaque de Lamparelli sobre a visão estanque do Estado, Cordido, Buzzar e Simoni (2009, p. 5) apontam que "o PAGE agrega um dos primeiros planejamentos orçamentários e, sobretudo, abrange e unifica vários setores da administração pública".

Nesse período a SAGMACS esteve com poucas atividades e só vai multiplicar seus trabalhos no final de 1962, num crescendo de novas posições características, novos contratos e compromissos durante os anos de 1963 e 1964 até ser atingida pelos efeitos do golpe militar que iria inviabilizar sua continuidade. (LEME E LAMPARELLI, ibid., p. 686).

Apesar do incremento de contratos assumidos nos últimos anos de atuação da SAGAMCS, conforme apontado por Lamparelli, nos anos de 1963 e 1964, também é importante mencionar que a experiência obtida pelos técnicos junto aos quadros do governo de Carvalho Pinto possibilitou uma nova agenda dentro do governo do Estado do Paraná. Com a eleição de Ney Braga ${ }^{207}$, que assumiu o governo paranaense em 1961, a SAGMACS desenvolveu trabalhos para o Estado do Paraná, visando responder aos anseios da modernização da máquina administrativa daquele estado ${ }^{208}$.

É importante entender que, apesar de se tratar de mais um trabalho para um órgão público, há diferenças entre os resultados alcançados pelo PAGE de Carvalho Pinto, em São Paulo, e os estudos apresentados pela SAGMACS ao governador Ney Braga, no Paraná.

Estas diferenças devem-se em parte ao fato de como os trabalhos foram desenvolvidos. Enquanto o governo do Paraná contratou a SAGMACS para desenvolver estudos no

\footnotetext{
207 O governador Ney Amintas de Barros Braga filiou-se ao PSD e conquistou, em 1958, uma cadeira de deputado federal. Sua vida política teve início no Partido Social Popular, de Ademar de Barros, tornando-se o primeiro prefeito eleito pelo voto direto na cidade de Curitiba, em 1953, após ter atuado no governo do estado como membro do Conselho Regional de Desportos. Em 1960 candidatou-se ao governo do Estado e elegeu-se pelo PSD, assumindo o governo em 1961, onde permaneceu até 1964, destacando-se pela implantação do "Plano de Desenvolvimento Econômico do Paraná", trabalho realizado pela SAGMACS, que culminou com a criação da CODEPAR Companhia de Desenvolvimento do Estado do Paraná.

${ }^{208}$ Sobre o governo de Ney Braga, consultar os trabalhos de COELHO (2002) e DOUSTDAR (2010). COELHO, Sandro Anselmo. O Partido Democrata Cristão (1945-1965): Dilemas e inconsistências da Terceira Via Brasileira. Dissertação de Mestrado. Curitiba, PR: Setor de Ciências Humanas, UFPR, 2002. DOUSTDAR, Neda Mohtadi. O Paranismo atualizado: a democracia cristã e o planejamento no governo Ney Braga. Tese de Doutorado. Curitiba, PR: Setor de Ciências Humanas, Letras e Arte da UFPR, 2010.
} 
âmbito de modernização da máquina administrativa, durante o governo de Carvalho Pinto, Lamparelli, Whitaker, Domingos Theodoro de Avezedo Neto e Mário Laranjeira de Mendonça se afastaram da SAGMACS para ocupar posições dentro da equipe técnica do governo de São Paulo. Portanto, ainda que se verifique influência dos métodos da SAGMACS e das preocupações de Lebret quanto ao desenvolvimento harmônico no PAGE, o mesmo não consistiu num trabalho desenvolvido pela instituição, tendo apenas contado com membros que influenciaram em sua metodologia.

Porém, tanto no trabalho para o PAGE, quanto para o governo paranaense, é importante destacar que as ações culminaram com uma tentativa de estabelecer uma nova regionalização territorial do estado. Esta preocupação reforça o vínculo da SAGMACS com as ações voltadas ao planejamento urbano e regional.

Para a "modernização" do Estado, o PAGE teve que fixar objetivos, estabelecer escalas de prioridades e prazos de execução, sendo que os pontos iniciais dessas metas advinham das análises dos programas estabelecidos pelas Secretarias, das projeções econômicas do Estado e das possibilidades financeiras de sua execução para o período de quatro anos. (CORDIDO, BUZZAR e SIMONI, 2009, p. 6).

Para aplicação dessas iniciativas em São Paulo, o PAGE considerou seus diferentes estágios de desenvolvimento como "disparidades regionais". [...] Assim, para uma atuação mais "precisa", foi elaborada uma nova divisão territorial do Estado, baseada na área de influência dos polos regionais de atração, cujos fatores eram demográficos, econômicos e sociais, e tinha a seguinte divisão, num total de onze regiões. (ibid., pp. 6-7).

O PAGE propunha dividir regionalmente o estado de São Paulo, conforme mapa a seguir, em onze regiões, que se uniam em torno das seguintes cidades: 1a) a capital paulista e as cidades do ABC; 1b) Bragança Paulista, Guarujá, Itu, Jundiaí, Mogi das Cruzes, Santos e São Vicente; 2) Cruzeiro, Guaratinguetá, Jacareí, Lorena, São José dos Campos e Taubaté; 3) Americana, Araras, Campinas, Limeira, Piracicaba, Rio Claro e São João da Boa Vista; 4) Araraquara, Franca, Jaboticabal e Ribeirão Preto; 5) Barretos, Catanduva e São José do Rio Preto; 6) Andradina, Araçatuba e Lins; 7) Assis, Presidente Prudente e Tupã; 8) Avaré, Bauru, Botucatu, Jaú, Marília e Ourinhos; 9) Itapetininga, Sorocaba e Tatuí; 10 Registro. 


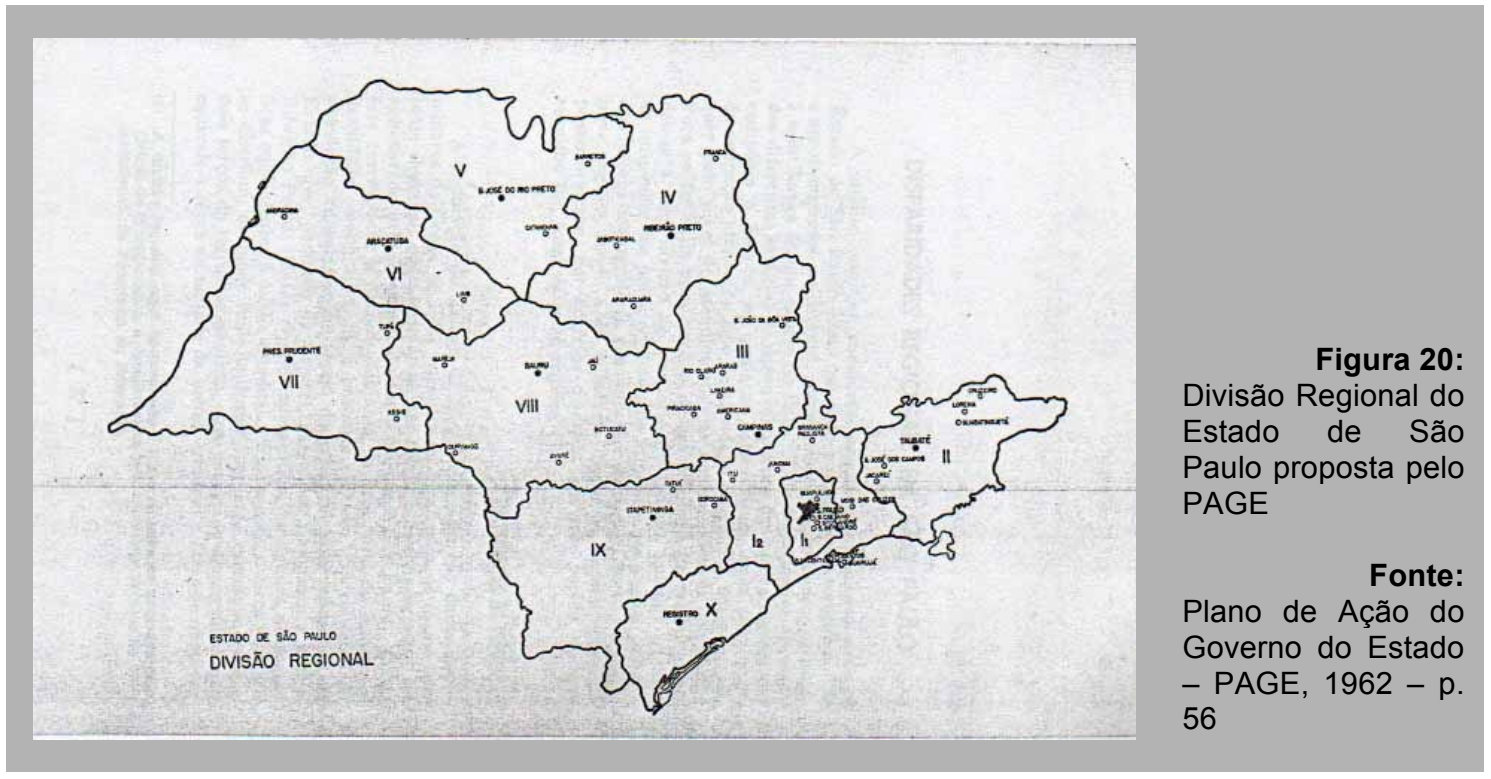

A exemplo do PAGE, a SAGMACS também propôs para o governo do Paraná uma nova distribuição territorial, que tinha como objetivo estabelecer maior proximidade entre o Estado e os cidadãos que dependiam dos serviços públicos. Esta setorização foi estabelecida no "Plano de Desenvolvimento do Paraná" e dividia o estado em sete regiões, sendo: Curitiba, Ponta Grossa, União da Vitória, Guarapava, Jacarezinho, Londrina e Maringá.

\begin{tabular}{|c|c|c|c|c|c|c|c|c|c|c|c|}
\hline \multirow{3}{*}{ REGIOES } & \multirow{3}{*}{$\begin{array}{l}\text { POIOS } \\
\text { REGIOIAIS }\end{array}$} & \multirow{3}{*}{$\begin{array}{l}\text { Ne DE } \\
\text { MUNICI } \\
\text { PIOS }\end{array}$} & \multirow{3}{*}{$\begin{array}{l}\text { AREA (MII } \\
\text { IHARESE } \\
\text { DE KMM }\end{array}$} & QUADRO & "A" & \multicolumn{6}{|c|}{ 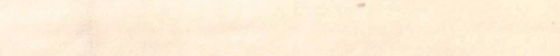 } \\
\hline & & & & \multirow[b]{2}{*}{ Total } & \multirow[b]{2}{*}{ Rural } & \multicolumn{4}{|c|}{$\frac{\text { POPULAGRO (MILHARES DE }}{1960}$} & \multicolumn{2}{|c|}{$\frac{\text { HABITANTES ) }}{1970}$} \\
\hline & & & & & & Total & Urbanal & Rural & Total & Urbana & Rural \\
\hline I & Curitiba & 33 & 25,9 & 29 & 12 & 747,6 & 439,9 & 307,7 & $1.327,7$ & $1.027,7$ & 299,4 \\
\hline II & Ponta Grossa & 18 & 31,6 & 12 & 8 & 384,9 & 121,4 & 263,5 & 637,6 & 189,6 & 448,0 \\
\hline III & ข. Vitoria & 24 & 22,8 & 15 & 13 & 337,8 & 38,5 & 299,3 & 834,8 & 91,2 & 743,6 \\
\hline IV & Guarapuava & 5 & 21,9 & 9 & 8 & 189,0 & 20,3 & 168,7 & 584,1 & 49,5 & 534,6 \\
\hline$v$ & Cascavé1 & 14 & 23,7 & 6 & 5 & 135,7 & 25,6 & 110,1 & 615,6 & 117,8 & 497,8 \\
\hline vI & Jacarèzinho & 36 & 14,3 & 36 & 29 & 521,6 & 105,7 & 415,9 & 740,5 & 188,7 & 551,8 \\
\hline VII & Iondrina & 48 & 18,7 & 50 & 39 & 941,2 & 216,6 & 724,6 & $1.465,5$ & 467,3 & 998,2 \\
\hline VIII & Maringa & 36 & 13,6 & 40 & 32 & 551,3 & 218,3 & 433,0 & $1.070,7$ & 326,3 & 744,4 \\
\hline$I X$ & Campo Mourão & 29 & $26,5 x$ & 18 & 16 & 468,5 & 46,2 & 422,3 & $1.272,6$ & 168,51 & $.104,1$ \\
\hline
\end{tabular}

(1) Considerou-se urbana a populagão de nucleos de mais de 2.000 habitantes

Figura 21: Tabela com a divisão dos Pólos de desenvolvimento regionais do Paraná, com as seguinte. áreas e população de abrangência e projeção populacional para a década

Fonte: SAGMACS, Plano de Desenvolvimento do Paraná, p. 43 
Dentro do contrato para a realização do "Plano de Desenvolvimento do Paraná", implementado por Ney Braga, nos anos 1960, a SAGMACS também atuou nos estudos sobre a Saúde Pública, o Serviço de Água e Esgoto do Paraná, as Comunidades Territoriais, que tratava do problema da terra no estado, e apresentou ainda um estudo para a reorganização do Serviço Público do Estado ${ }^{209}$.

Devido a esta complexidade de estudos, análises e propostas, trouxemos para esta tese a atuação da equipe junto ao governo do Estado do Paraná, pois os trabalhos desenvolvidos ali mostram a visão abrangente que figurava dentro da equipe, bem como a capacidade da mesma de trabalhar de forma multidisciplinar. Embora este seja um dos últimos trabalhos de vulto desenvolvidos pela SAGMACS, o mesmo parece, para nós, coroar a atuação do grupo do Économie et Humanisme no Brasil, pois, além das preocupações demonstradas e da efetivação das propostas por parte do governador Ney Braga, ao se comparar com os demais trabalhos desenvolvidos, trata-se aqui de um trabalho finalizado ${ }^{210}$ pelos membros da equipe da SAGMACS.

Este aspecto pode ser melhor entendido ao se analisar o estudo da "Estrutura Urbana da Aglomeração Paulistana", desenvolvido para a prefeitura de São Paulo, cujo contrato não foi inteiramente cumprido pelo grupo, e, tão pouco se efetivaram as diretrizes e os apontamentos feitos por Lebret e Baltar, que norteariam o desenvolvimento da cidade de São Paulo nas próximas décadas ${ }^{211}$.

\footnotetext{
209 Segundo Doustdar (2010, p. 183), o "Plano de Desenvolvimento do Paraná" foi coordenado por Antônio Almicar de Oliveira Lima, Antônio Cláudio Moreira Lima e Moreira, Celso Monteiro Lamparelli, Francisco Whitaker Ferreira e o Frei Benevenuto de Santa Cruz. A elaboração do plano contou ainda com os seguintes membros na equipe técnica: Antônio Carlos Bernardo, João Yunes, João Alfredo Alberti, João Carlos Seixas, LeodegarJost, Lúcio Félix Frederico Kovarick, Luiz Lorenzo Rivera, Maria Adélia de Souza, Myriam Vallias de Oliveira Lima, Pedro Calil Padis, Reynaldo Dias de Moraes e Silva, Saulo Vassimon e Vicenzo Bochicchio. Doustdar indica ainda os nomes de César Muniz Filho, Haroldo do Amaral e Sérgio Fleishfresser como técnicos vinculados ao governo do Paraná, que tiveram participação junto à equipe da SAGMACS.
}

210 Por trabalho finalizado entendemos tratar-se daqueles que apresentaram algum resultado no âmbito da SAGMACS oferecer uma proposta que pudesse ser efetivada e tenha sido em parte implementada pelo contratante. Assim, difere-se do escopo de trabalhos desenvolvidos pela SAGMACS os contratos com o governo do Paraná, onde a equipe atuou por cerca de dois anos e ofereceu ao governador uma proposta de modernização administrativa para a máquina pública do Estado, a reorganização da regionalização em função da instituição de polos de desenvolvimento e ainda propostas para melhoria das condições de abastecimento de água nas diferentes regiões do Estado. Diferentemente deste trabalho, o estudo sobre a "Aglomeração Paulistana", desenvolvido para a Prefeitura de São Paulo, embora tenha possibilitado um momento de crescimento do grupo, não culminou com uma proposta para a cidade, oferecendo somente diretrizes que sequer foram seguidas pelos prefeitos que sucederam Toledo Piza. O mesmo ocorreu com o estudo das "Necessidades e possibilidades de desenvolvimento para o estado de São Paulo", que, embora abrangente, não foi efetivado pelo governador do Estado.

211 Das cinco partes previstas na contratação do estudo, a terceira, destinada à "Análise Sociológica" não foi concluída e sequer entregue ao município de São Paulo, conforme pode-se 
Não incluímos aqui nesta consideração a mesma observação sobre o estudo da "Estrutura Urbana de Belo Horizonte", pois, apesar dele ter se desdobrado na elaboração do Relatório para o Plano Diretor da cidade, o mesmo não contava com um prospecto de trabalho tão amplo quanto ocorreu no estudo para a "Aglomeração Paulistana", que, assim como o trabalho realizado para o governo do Paraná, levou em consideração aspectos do orçamento público municipal, da reestruturação da máquina administrativa e dos aspectos físico-territoriais.

O Relatório do Plano Diretor de Belo Horizonte apresentou ao prefeito Amintas de Barros um projeto de lei com as disposições para regular a expansão urbana da cidade, os processos para aprovação e implantação de novos loteamentos, a regulamentação do uso, da ocupação e do aproveitamento dos edifícios e terrenos, uma proposta para melhoria do sistema viário, diretrizes para o tratamento das áreas verdes e ainda um estudo para tributação a partir da licença de localização, ou seja, a instituição de uma nova planta genérica de valores. O Plano estabelecia também os índices de aproveitamento e taxas de ocupação do solo urbano.

No caso da pesquisa sobre a "Estrutura Urbana da Aglomeração Paulistana", tais aspectos não foram tratados, devido à não continuidade dos trabalhos pela equipe. $A$ SAGMACS indica neste relatório que, após a análise feita pelo grupo, a Prefeitura deveria dar continuidade aos estudos voltando-se para a elaboração de um Plano Diretor para a cidade, o que foi apresentado no final da gestão de Ademar de Barros, em 1961, sem a participação da SAGMACS.

A fim de demonstrar o crescimento e desenvolvimento da SAGMACS, bem como a diversidade de trabalhos desenvolvidos pelas equipes vinculadas à instituição, apontamos a seguir o quadro dos trabalhos realizados, com a composição das equipes e os contratantes dos trabalhos ${ }^{212}$. E, em continuidade a este capítulo, apresentaremos, conforme exposto no subtítulo anterior, nossa análise sobre aqueles que definimos como tendo sido os principais trabalhos desenvolvidos pela equipe no campo do urbanismo e

verificar junto aos exemplares que fazem parte do EUAP, depositados na Biblioteca da PósGraduação da FAU- USP.

212 Excetuam-se da lista de trabalhos apontados, aqueles cujos relatórios não foram encontrados junto à Biblioteca da Pós-Graduação da Faculdade de Arquitetura e Urbanismo da USP, que adquiriu o acervo da SAGMACS em 1973, nem no Fonds Lebret nos Archives Nationales de France, tendo sido possível apurar a existência de alguns desses trabalhos, bem como a relação da equipe atuante, através de menção de autores que estudaram o tema. Sobre a sistematização dos nomes que compõem as equipes formadas para desenvolvimento dos trabalhos, é importante apontar que a partir dos anos 1960, no que intitulamos de terceira fase de atuação do grupo, a indicação das equipes passaram a ser mais concisas, trazendo menores detalhes e discriminando somente a equipe de coordenação com o corpo técnico, no qual passou a ser inserido também os nomes dos desenhistas e estagiários. 
do planejamento urbano e regional.

\begin{tabular}{|c|c|c|}
\hline Título do Trabalho: & \multicolumn{2}{|c|}{$\begin{array}{l}\text { SONDAGEM PRELIMINAR A UM ESTUDO SOBRE HABITAÇÃO } \\
\text { NA CIDADE DE SÃO PAULO }\end{array}$} \\
\hline Ano de Realização: & \multicolumn{2}{|l|}{1947} \\
\hline Contratante: & \multicolumn{2}{|c|}{ SESI - Serviço Social da Indústria } \\
\hline \multirow[t]{2}{*}{ Equipe Participante: } & Direção: & Louis-Joseph Lebret \\
\hline & Coordenação Técnica: & $\begin{array}{l}\text { Oscar Rezende Lima } \\
\text { Estanislau Roberto Maiorano }\end{array}$ \\
\hline
\end{tabular}

\begin{tabular}{|l|l|}
\hline Título do Trabalho: & $\begin{array}{l}\text { CONDIÇÕES DE VIDA DOS TRABALHADORES DO JÓCKEY } \\
\text { CLUBE DE SÃO PAULO* }\end{array}$ \\
\hline Ano de Realização: & 1947 \\
\hline${ }^{*}$ Trabalho não publicado \\
\hline
\end{tabular}

\begin{tabular}{|l|l|}
\hline Título do Trabalho: & $\begin{array}{l}\text { CONDIÇÕES DAS CRIANÇAS ABANDONADAS NA CIDADE E } \\
\text { NO ESTADO DE SÃO PAULO* }\end{array}$ \\
\hline Ano de Realização: & $1947-1948$ \\
\hline * Trabalho não publicado \\
\hline
\end{tabular}

\begin{tabular}{|c|c|c|}
\hline Título do Trabalho: & \multicolumn{2}{|c|}{$\begin{array}{l}\text { PROBLEMAS DE } \text { DESENVOLVIMENTO: ESTUDO } \\
\text { NECESSIDADES E POSSIBILIDADES DO ESTADO DE SÃO } \\
\text { PAULO }\end{array}$} \\
\hline Ano de Realização: & \multicolumn{2}{|l|}{ 1953-1955 } \\
\hline Contratante: & \multicolumn{2}{|c|}{$\begin{array}{l}\text { Governo do Estado de São Paulo } \\
\text { Comissão Interestadual da Bacia Paraná-Uruguai }\end{array}$} \\
\hline Governador: & \multicolumn{2}{|l|}{ Lucas Nogueira Garcez } \\
\hline \multirow[t]{5}{*}{ Equipe Participante: } & Direção: & Antônio Delorenzo Neto \\
\hline & Coordenação Técnica: & $\begin{array}{l}\text { Antônio Bezerra Baltar } \\
\text { Benevenuto de Santa Cruz } \\
\text { Darcy Passos } \\
\text { Eduardo Bastos } \\
\text { Louis Joseph Lebret } \\
\text { Raymond Delprat }\end{array}$ \\
\hline & Colaboradores Diretos: & $\begin{array}{l}\text { Chiara de Ambrosis } \\
\text { Gilles Lapouge }\end{array}$ \\
\hline & Pesquisadores: & $\begin{array}{l}\text { Casimiro dos Reis Filho } \\
\text { Cristóvão de Andrade Franco } \\
\text { Frank Perry Goldmann } \\
\text { Geraldo Semenzato } \\
\text { Kaoro Onaga } \\
\text { Maria Aparecida Teani } \\
\text { Maria Beatriz de Mello Mattos } \\
\text { Maria Edy de Andrade Ferreira } \\
\text { Otto Marques da Silva }\end{array}$ \\
\hline & Desenhistas: & $\begin{array}{l}\text { Clementina de Ambrosis } \\
\text { Domingos T. de Azevedo Netto } \\
\text { Joaquim Guedes } \\
\text { Liliana Marsicano Guedes } \\
\text { Miguel Zangaro }\end{array}$ \\
\hline
\end{tabular}




\begin{tabular}{|c|c|c|}
\hline Título do Trabalho: & \multicolumn{2}{|c|}{ PLANO DIRETOR DE OURINHOS } \\
\hline Ano de Realização: & \multicolumn{2}{|l|}{ 1953-1954 } \\
\hline Contratante: & \multicolumn{2}{|c|}{ Prefeitura Municipal de Ourinhos/SP } \\
\hline Prefeito: & \multicolumn{2}{|c|}{ Domingos Carmelingo Carló } \\
\hline \multirow[t]{3}{*}{ Equipe Participante: } & Direção: & Louis-Joseph Lebret \\
\hline & Coordenação Técnica: & Antonio de Bezerra Baltar \\
\hline & Equipe Técnica: & $\begin{array}{l}\text { Antonio Delorenzo Neto } \\
\text { Benevenuto de Santa Cruz } \\
\text { Clementina De Ambrósis } \\
\text { Domingos T. de Azevedo Netto }\end{array}$ \\
\hline
\end{tabular}

\begin{tabular}{|l|l|}
\hline Título do Trabalho: & $\begin{array}{l}\text { ESTUDO SOBRE O DESENVOLVIMENTO E IMPLANTAÇÃO DE } \\
\text { INDÚSTRIAS NO PERNAMBUCO E NO NORDESTE DO BRASIL }\end{array}$ \\
\hline Ano de Realização: & $1954-1955$ \\
\hline Contratante: & CODEPE \\
\hline Governador: & Etelvino Lins de Albuquerque \\
\hline $\begin{array}{l}\text { *Não consta a composição da equipe no exemplar consultado, disponivel junto a Biblioteca Central da } \\
\text { EESC USP e da Biblioteca da Pós-Graduação da FAU USP }\end{array}$ \\
\hline
\end{tabular}

\begin{tabular}{|c|c|c|}
\hline Título do Trabalho: & \multicolumn{2}{|c|}{$\begin{array}{l}\text { PROBLEMAS DE DESENVOLVIMENTO, NECESSIDADES E } \\
\text { POSSIBILIDADE DOS ESTADOS DO RIO GRANDE DO SUL, } \\
\text { SANTA CATARINA E PARANÁ }\end{array}$} \\
\hline Ano de Realização: & \multicolumn{2}{|l|}{1958} \\
\hline Contratante: & \multicolumn{2}{|c|}{ Comissão Interestadual da Bacia Paraná Uruguai - CIBPU } \\
\hline \multirow[t]{5}{*}{ Equipe Participante: } & Direção: & Louis-Joseph Lebret \\
\hline & Coordenação Técnica: & $\begin{array}{l}\text { Alain Birou } \\
\text { Benevenuto de Santa Cruz } \\
\text { Eduardo Bastos } \\
\text { Luiz Carlos M. Goelzer } \\
\text { Raymond Delprat }\end{array}$ \\
\hline & Diretores de Pesquisa: & $\begin{array}{l}\text { Luiz Carlos Goelzer - RS } \\
\text { Benevenuto de Santa Cruz - RS/SC } \\
\text { Eduardo Bastos - PR }\end{array}$ \\
\hline & Equipe de Estudos Especiais: & $\begin{array}{l}\text { Paulo Gonçalves } \\
\text { José do Patrocínio Motta } \\
\text { Antonio Saint Pastous } \\
\text { Michel de Planta } \\
\text { José Arthur Rios } \\
\text { Benevenuto de Santa Cruz }\end{array}$ \\
\hline & Pesquisadores: & $\begin{array}{l}\text { Edison Quintana } \\
\text { Eduardo Roman } \\
\text { Jacob Elloy Runrath } \\
\text { José Antonio Giusti Bueno } \\
\text { José Antonio Moraes de Oliveira } \\
\text { José Júlio Vilela } \\
\text { Luiz Andrade } \\
\text { Milton Teixeira } \\
\text { Seno Antônio Cornely } \\
\text { Telmo Sebastião Bueno } \\
\text { Domingos de Azevedo Neto } \\
\text { Jacob Souza Filho } \\
\text { João Paulo Rodrigues } \\
\text { José Sobierajski }\end{array}$ \\
\hline
\end{tabular}




\begin{tabular}{|l|l|l|}
\hline \multirow{5}{*}{} & $\begin{array}{l}\text { Luiz Andrade } \\
\text { Manoel Cabral Pinho } \\
\text { Paulo Mendes Rodrigues } \\
\text { Cristóvão Andrade Franco } \\
\text { Osmar Nascimento }\end{array}$ \\
\cline { 2 - 3 } & Desenhistas: & Clementina De Ambrosis \\
& Francisco de Assis \\
Maria Candida Pedrosa de Campo & Aloysio de Carvalho \\
& Paulo Cordeiro \\
& Christa Hahlohm \\
& Paulo Apício Macedo \\
\hline
\end{tabular}

\begin{tabular}{|c|c|c|}
\hline $\begin{array}{ll}\text { Título } & \text { do } \\
\text { Trabalho: } & \end{array}$ & \multicolumn{2}{|c|}{$\begin{array}{lccc}\text { ESTRUTURA } & \text { URBANA } & \text { DA } & \text { AGLOMERAÇÃO } \\
\text { PAULISTANA: } \\
\text { ESTRUTURAS ATUAIS E ESTRUTURAS RACIONAIS }\end{array}$} \\
\hline $\begin{array}{l}\text { Ano } \\
\text { Realização: }\end{array}$ & \multicolumn{2}{|l|}{$1956-1958$} \\
\hline Contratante: & \multicolumn{2}{|c|}{ Prefeitura Municipal de São Paulo } \\
\hline Prefeito: & \multicolumn{2}{|l|}{ Wladimir Toledo Piza } \\
\hline \multirow[t]{3}{*}{$\begin{array}{lr}\text { Equipe } & \\
\text { Participante } & \text { da } \\
\text { Direção } & \text { dos } \\
\text { trabalhos } & \text { e } \\
\text { coordenação } & \\
\text { geral: } & \end{array}$} & Direção: & $\begin{array}{l}\text { Antônio Delorenzo Neto - Presidente } \\
\text { José Gomes de Moraes Netto - Gerente } \\
\text { Benevenuto de Santa Cruz - Técnico } \\
\text { João B. de Arruda Sampaio - Adjunto } \\
\text { Domingos de Azevedo Neto - Adjunto } \\
\text { Antonio Bezerra Baltar - Adjunto } \\
\text { José Arthur Rios - Adjunto }\end{array}$ \\
\hline & Coordenação Técnica: & $\begin{array}{l}\text { Louis-Joseph Lebret } \\
\text { Antônio Bezerra Baltar }\end{array}$ \\
\hline & $\begin{array}{l}\text { Coordenadores de } \\
\text { Equipe: }\end{array}$ & $\begin{array}{l}\text { Mario Laranjeira de Mendonça } \\
\text { Frank Goldman } \\
\text { Raymond Delprat } \\
\text { Antonio Bezerra Baltar } \\
\text { Antonio Delorenzo Neto }\end{array}$ \\
\hline \multirow[t]{2}{*}{$\begin{array}{l}\text { Equipe A - Análise } \\
\text { Básica }\end{array}$} & Membros da Equipe: & $\begin{array}{l}\text { Mario Laranjeira de Mendonça } \\
\text { Carlos Eduardo Alves Lima } \\
\text { Manuel Valente Barbas } \\
\text { Hélio Hell Caiaffa } \\
\text { Celso Monteiro Lamparelli }\end{array}$ \\
\hline & Pesquisadores: & $\begin{array}{l}\text { José Gustavo de Arruda Botelho } \\
\text { Mario Azevedo Rison Bongonha } \\
\text { Reynaldo Rudge Carlini } \\
\text { Alahyr Ferreira Cruz } \\
\text { Maury Demange } \\
\text { Otavio Escobar } \\
\text { José Joaquim Ferreira } \\
\text { Mariano Silveira Gomes } \\
\text { José da Silva Guedes } \\
\text { Antonio Carlos Queiroz Guimarães } \\
\text { Paulo Irineu } \\
\text { Carlos Alberto Lima de Faria } \\
\text { Antonio Carlos de Macedo } \\
\text { Gil Augusto Machado } \\
\text { Marco Antonio França Matrobuono } \\
\text { Mario Nariotto } \\
\text { Nelson Megamine } \\
\text { José Crispin Noronha }\end{array}$ \\
\hline
\end{tabular}




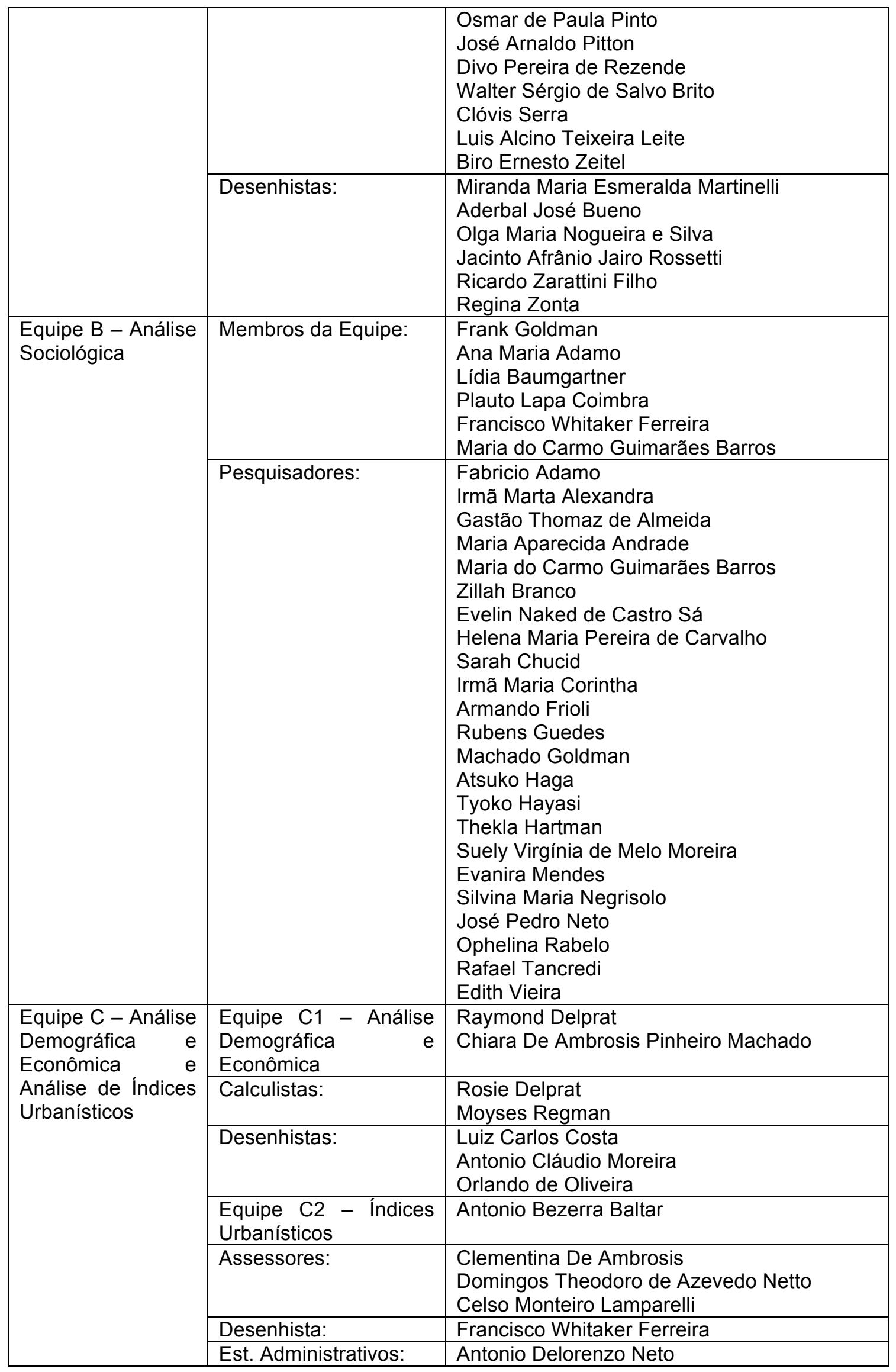




\begin{tabular}{|c|c|c|}
\hline Título do Trabalho: & \multicolumn{2}{|c|}{ ESTRUTURA URBANA DE BELO HORIZONTE } \\
\hline Ano de Realização: & \multicolumn{2}{|l|}{ 1958-1959 } \\
\hline Contratante: & \multicolumn{2}{|c|}{ Prefeitura Municipal de Belo Horizonte } \\
\hline Prefeito: & \multicolumn{2}{|c|}{ Celso Mello de Azevedo } \\
\hline \multirow[t]{3}{*}{ Equipe Participante: } & Direção: & Benevenuto de Santa Cruz \\
\hline & Coordenação Técnica: & $\begin{array}{l}\text { Annibal Villela } \\
\text { Antonio Bezerra Baltar } \\
\text { Antonio Delorenzo Neto } \\
\text { Celso Lamparelli } \\
\text { Francisco Whitaker Ferreira }\end{array}$ \\
\hline & Desenhistas: & $\begin{array}{l}\text { Hilton Prates } \\
\text { Haroldo Taborda Galliac } \\
\text { Paulo Faria Matos } \\
\text { Paulo lazzetti Filho } \\
\text { Raimundo Costa Braga } \\
\text { Roberto Yazigi }\end{array}$ \\
\hline \multirow{2}{*}{$\begin{array}{lr}\text { Equipe I } & \text { Estudos } \\
\text { Econômicos } & \text { e } \\
\text { Demográficos } & \end{array}$} & Coordenador: & Annibal Villela \\
\hline & Pesquisadores: & $\begin{array}{l}\text { Fernando Correia Dias } \\
\text { Margarida Luiza Ribeiro } \\
\text { Pedro Galery } \\
\text { Silviano Cançado Azevedo }\end{array}$ \\
\hline \multirow{2}{*}{$\begin{array}{l}\text { Equipe II - Pesquisa } \\
\text { das estruturas básicas }\end{array}$} & Coordenador: & Francisco Whitaker Ferreira \\
\hline & Pesquisadores*: & $\begin{array}{l}\text { Archanjo Gabriel Medeiros Cruz } \\
\text { Afonso dos Santos } \\
\text { Hiroshi Watanabe Queiroz } \\
\text { Jayme Hilário de Souza } \\
\text { Jurema Rosalva Vieira } \\
\text { Laercio Rodrigues de Moraes } \\
\text { Maria Aparecida Ferreira de Aguiar } \\
\text { Maria Immacolata Lama } \\
\text { Noemi Firmato de Almeida } \\
\text { Pajehu Marra } \\
\text { Talmo Pompeu Araújo } \\
\text { Tarcísio Wanderley } \\
\text { Vicente Figueiredo de Sampaio } \\
\text { Welber da Silva Braga }\end{array}$ \\
\hline $\begin{array}{l}\text { Equipe III - Estudos de } \\
\text { Urbanismo }\end{array}$ & Coordenadores: & $\begin{array}{l}\text { Antonio Bezerra Baltar } \\
\text { Celso Lamparelli }\end{array}$ \\
\hline \multirow[t]{2}{*}{$\begin{array}{l}\text { Equipe IV - Estudos } \\
\text { Sociológicos }\end{array}$} & Coordenadores: & $\begin{array}{l}\text { Benevenuto de Santa Cruz } \\
\text { Jurema Rosalva Vieira }\end{array}$ \\
\hline & Pesquisadores**: & $\begin{array}{l}\text { Maria Aparecida de Queiroz } \\
\text { Maria Aparecida de Aguiar } \\
\text { Mauro Santayana } \\
\text { Noemi de Almeida }\end{array}$ \\
\hline $\begin{array}{l}\text { Equipe V }- \text { Estudos } \\
\text { sobre problemas } \\
\text { administrativos }\end{array}$ & Coordenador: & Antonio Delorenzo Neto \\
\hline \multirow[t]{2}{*}{$\begin{array}{l}\text { Equipe VI - Anexo } \\
\text { sobre o Abastecimento }\end{array}$} & Coordenadores: & $\begin{array}{l}\text { Fernando Correia Dias } \\
\text { Margarida Luiza Ribeiro } \\
\text { Pedro Galery } \\
\text { Silviano Cançado Azevedo }\end{array}$ \\
\hline & Pesquisadores: & $\begin{array}{l}\text { José Carlos Vieira } \\
\text { Jurema Vieira } \\
\text { Maria Immacolata Lama } \\
\text { Vicente de Sampaio } \\
\end{array}$ \\
\hline
\end{tabular}




\begin{tabular}{|c|c|c|}
\hline Título do Trabalho: & \multirow{3}{*}{\multicolumn{2}{|c|}{$\begin{array}{l}\text { SÓCIO-ECONÔMICO } \\
\text { 1958-1960 } \\
\text { Jornal O Estado de São Paulo }\end{array}$}} \\
\hline Ano de Realização: & & \\
\hline Contratante: & & \\
\hline \multirow[t]{5}{*}{ Equipe Participante: } & Direção: & José Arthur Rios \\
\hline & Orientação: & Louis-Joseph Lebret \\
\hline & Coordenação Técnica: & $\begin{array}{l}\text { Carlos Alberto de Medina } \\
\text { Ailza Barbosa de Araújo } \\
\text { Hélio Modesto }\end{array}$ \\
\hline & Pesquisadores: & $\begin{array}{l}\text { Antonio Assimos } \\
\text { Aryvalde Ferreira da Silva } \\
\text { Carlos Moraes } \\
\text { Elias Pessoa de Carvalho } \\
\text { Helio Moulin } \\
\text { Hebe Vainier } \\
\text { Ilka Leite } \\
\text { José Mirama Moreira } \\
\text { José Maria Lopes } \\
\text { José Sampaio } \\
\text { Laerte Marques Lima } \\
\text { Luiz Alvear Palermo } \\
\text { Maria do Carmo Pereira } \\
\text { Milton Santos } \\
\text { Nilda Moreira de Deus } \\
\text { Regina Maria Novais de Almeida }\end{array}$ \\
\hline & Desenhos: & Maria Cândida Pedrosa de Campos \\
\hline
\end{tabular}

\begin{tabular}{|l|l|l|}
\hline Título do Trabalho: & \multicolumn{2}{|l|}{ PESQUISA REGIONAL VOLTADA PARA O NORDESTE } \\
\hline Ano de Realização: & 1959 \\
\hline Contratante: & Serviço Social Rural do governo federal \\
\hline Equipe Participante: & Direção: & José Arthur Rios \\
\cline { 2 - 3 } & Pesquisadores: & $\begin{array}{l}\text { Luiz Carlos Medina } \\
\text { Hans Alfred Rappel } \\
\text { José Maria Lopes }\end{array}$ \\
\hline
\end{tabular}

\begin{tabular}{|l|l|l|}
\hline Título do Trabalho: & $\begin{array}{l}\text { RELATÓRIO SOBRE IPATINGA E SEUS PROBLEMAS SÓCIO- } \\
\text { ECONÔMICOS }\end{array}$ \\
\hline Ano de Realização: & 1961 \\
\hline Contratante: & Usina Siderúrgica de Minas Gerais S/A - USIMINAS \\
\hline Equipe Participante: & Direção: & Benevenuto de Santa Cruz \\
\cline { 2 - 3 } & Pesquisadores: & $\begin{array}{l}\text { Flávio Villaça } \\
\text { Francisco Whitaker Ferreira } \\
\text { Luiz Carlos Costa } \\
\text { Margarida Luiza Ribeiro } \\
\text { Silviano Cançado de Azevedo }\end{array}$ \\
\hline
\end{tabular}




\begin{tabular}{|l|l|l|}
\hline Título do Trabalho: & \multicolumn{2}{|l|}{$\begin{array}{l}\text { REVISÃO AGRÁRIA DO ESTADO DE SÃO PAULO: ESTUDO } \\
\text { PARA UM PLANO DE LOTEAMENTO DA FAZENDA } \\
\text { JACILÂNDIA }\end{array}$} \\
\hline Ano de Realização: & $1961-1962$ \\
\hline Contratante: & CAIC - Governo do Estado de São Paulo \\
\hline Governador: & Carlos Alberto Carvalho Pinto \\
\hline Equipe Participante: & Direção: & Benevenuto de Santa Cruz \\
\cline { 2 - 3 } & Pesquisadores: & $\begin{array}{l}\text { Francisco Whitaker Ferreira } \\
\text { Leopoldo Garcia Brandão } \\
\text { Margarida Luiza Ribeiro } \\
\text { Milton Antonio Moyses }\end{array}$ \\
\hline & & $\begin{array}{l}\text { Paulo Yazzetti } \\
\text { Roberto Yasigi }\end{array}$ \\
\hline
\end{tabular}

\begin{tabular}{|l|l|}
\hline Título do Trabalho: & $\begin{array}{l}\text { PROGRAMA DE MECANIZAÇÃO AGRÍCOLA DO ESTADO DO } \\
\text { MATO GROSSO }\end{array}$ \\
\hline Ano de Realização: & 1962 \\
\hline Contratante: & Armazéns Gerais do Estado do Mato Grosso \\
\hline Governador: & Fernando Correia da Costa \\
\hline Equipe Participante: & $\begin{array}{l}\text { Antônio Cláudio Moreira Lima e Moreira } \\
\text { Francisco Whitaker Ferreira } \\
\text { Maria Adélia Aparecida de Souza } \\
\text { Pedro Calil Padis }\end{array}$ \\
\hline
\end{tabular}

\begin{tabular}{|l|l|}
\hline Título do Trabalho: & PROJETO ARAGUAIA \\
\hline Ano de Realização: & $1962-1963$ \\
\hline Equipe Participante: & $\begin{array}{l}\text { Antônio Cláudio Moreira Lima e Moreira } \\
\text { Francisco Whitaker Ferreira } \\
\text { Maria Adélia Aparecida de Souza } \\
\text { Reynaldo Dias de Moraes e Silva }\end{array}$ \\
\hline
\end{tabular}

\begin{tabular}{|c|c|c|}
\hline Título do Trabalho: & \multicolumn{2}{|c|}{$\begin{array}{l}\text { RELATÓRIO SOBRE O PROBLEMA DE ÁGUA E ESGOTOS: } \\
\text { ANÁLISE DA SITUAÇÃO DOS SISTEMAS NAS SEDES DE } \\
\text { MUNICÍPIOS DO INTERIOR DE SÃO PAULO }\end{array}$} \\
\hline Ano de Realização: & \multicolumn{2}{|l|}{$1962-1963$} \\
\hline Contratante: & \multicolumn{2}{|c|}{ Governo do Estado de São Paulo } \\
\hline Governador: & \multicolumn{2}{|c|}{ Carlos Alberto Carvalho Pinto } \\
\hline \multirow[t]{5}{*}{ Equipe Participante: } & Direção: & Benevenuto de Santa Cruz \\
\hline & Coordenação Técnica: & $\begin{array}{l}\text { Domingos de Azevedo Neto } \\
\text { Nelson Luiz Rodrigues Nucci }\end{array}$ \\
\hline & Equipe de Engenharia: & $\begin{array}{l}\text { Antonio de Felice } \\
\text { Mariano H. Aranha Domingues } \\
\text { Peter Greiner } \\
\text { Roberto Hamilton Salveadeu Cruz } \\
\text { Takudy Tanaka } \\
\text { Tsuneo Kimate }\end{array}$ \\
\hline & Equipe de Urbanismo: & $\begin{array}{l}\text { Flávio Villaça } \\
\text { Paulo lazzetti Filho } \\
\text { Roberto Yasigi }\end{array}$ \\
\hline & Equipe de Estatística: & $\begin{array}{l}\text { César Ubaldo Câmara } \\
\text { Miriam Vallias de Silva Alves }\end{array}$ \\
\hline
\end{tabular}




\begin{tabular}{|l|l|l|}
\hline & & Selda Vale da Costa \\
\cline { 2 - 3 } & Equipe Médica: & $\begin{array}{l}\text { Odilon Mello Franco Filho } \\
\text { Arnaldo Begossi }\end{array}$ \\
\cline { 2 - 3 } & Desenhistas: & Celio Abrusio \\
& Edison Eloy de Souza \\
& Munir Buarraj \\
& Paulo Rocha Queiroz \\
& Roberto Yasigi \\
& Ruy Arini \\
& Shigueiro Kudo \\
& Tetsuo Uemo \\
\hline
\end{tabular}

\begin{tabular}{|l|l|l|}
\hline Título do Trabalho: & \multicolumn{2}{|l|}{ PLANO DIRETOR DE BARRETOS } \\
\hline Ano de Realização: & 1963 & \multicolumn{2}{|l|}{} \\
\hline Contratante: & Prefeitura Municipal de Barretos \\
\hline Prefeito: & Cristiano Carvalho & Antonio Delorenzo Neto \\
\hline Equipe Participante: & Direção: & Nelson Luiz Rodrigues Nucci \\
\cline { 2 - 3 } & Coordenação Técnica: & Clementina De Ambrósis \\
\cline { 2 - 3 } & Equipe Técnica: & Flávio Villaça \\
& & Francisco Whitaker Ferreira \\
& & Glauco Glacobbe \\
& & Silvio Breno de Souza \\
& & Maria Adélia A. de Souza \\
& & Paulo lazetti Filho \\
& & Pedro Calil Padis \\
& \\
& & Roberto Yazigi \\
\hline
\end{tabular}

\begin{tabular}{|l|l|l|}
\hline Título do Trabalho: & PLANO DIRETOR DE SOROCABA \\
\hline Ano de Realização: & 1963 \\
\hline Contratante: & Prefeitura Municipal de Sorocaba \\
\hline Prefeito: & Artidoro Mascarenhas \\
\hline Equipe Participante: & Direção: & Benevenuto de Santa Cruz \\
\cline { 2 - 3 } & Equipe Técnica: & $\begin{array}{l}\text { Antonio Carlos Bernardo } \\
\text { Antonio Cláudio Moreira Lima } \\
\text { Francisco Whitaker Ferreira } \\
\end{array}$ \\
& & $\begin{array}{l}\text { Maria Adélia A. de Souza } \\
\text { Pedro Calil Padis } \\
\text { Saulo Vassimon }\end{array}$ \\
\hline
\end{tabular}

\begin{tabular}{|l|l|l|}
\hline Título do Trabalho: & \multicolumn{2}{|l|}{ PLANO DIRETOR DE BELO HORIZONTE } \\
\hline Ano de Realização: & 1963 & \multicolumn{2}{|l|}{} \\
\hline Contratante: & Prefeitura Municipal de Belo Horizonte \\
\hline Prefeito: & Amintas de Barros & Frei Benevenuto de Santa Cruz \\
\hline Equipe Participante: & Direção: & Antonio de Bezerra Baltar \\
\cline { 2 - 3 } & Coordenação Técnica: & Celso Monteiro Lamparelli \\
\cline { 2 - 3 } & Equipe Técnica: & Cláudio Soares de Azevedo \\
& & Clementina de Ambrósis \\
& & Domingos T. de Azevedo Neto \\
& & Francisco Whitaker Ferreira \\
& & Flávio Villaça \\
& & Glauco Giacobbe \\
\hline
\end{tabular}




\begin{tabular}{|l|l|l|}
\hline & & $\begin{array}{l}\text { Paulo lazzetti Filho } \\
\text { Roberto Yazigi } \\
\text { Silvio Breno de Souza Santos } \\
\text { Yoneco Tako } \\
\text { Witold Zmitrowicz }\end{array}$ \\
\hline & Secretária: & Déa Canotilho \\
\hline
\end{tabular}

\begin{tabular}{|l|l|}
\hline Título do Trabalho: & $\begin{array}{l}\text { ESTUDO PARA IMPLANTAÇÃO DE UM LOTEAMENTO EM SÃO } \\
\text { VICENTE/SP }\end{array}$ \\
\hline Ano de Realização: & 1963 \\
\hline Equipe Técnica: & $\begin{array}{l}\text { Clementina De Ambrósis } \\
\end{array}$ \\
& Flávio Villaça \\
& Lúcio Kowarick \\
& Luiz Carlos Costa \\
& Miriam Valias de Oliveira Lima \\
& Silvio Breno de Souza Santos \\
\hline
\end{tabular}

\begin{tabular}{|l|l|}
\hline Título do Trabalho: & $\begin{array}{l}\text { ESTUDO PARA UMA POLÍTICA HABITACIONAL PARA A CIA. } \\
\text { FERRO E AÇO DE VITÓRIA/ES }\end{array}$ \\
\hline Ano de Realização: & 1963 \\
\hline Contratante: & Cia. Ferro e Aço de Vitória \\
\hline Equipe Técnica: & $\begin{array}{l}\text { Clementina De Ambrósis } \\
\text { Flávio Villaça } \\
\text { Francisco Whitaker Ferreira } \\
\text { Lúcio Kowarick } \\
\text { Luiz Carlos Costa } \\
\text { Miriam Valias de Oliveira Lima } \\
\text { Silvio Breno de Souza Santos }\end{array}$ \\
\hline Desenhos e Cálculos: & $\begin{array}{l}\text { André Franco Montoro Filho } \\
\text { Paulo Queirós } \\
\text { Rui Arini } \\
\text { Vicenzo Bochicchio }\end{array}$ \\
\hline
\end{tabular}

\begin{tabular}{|c|c|}
\hline Título do Trabalho: & $\begin{array}{l}\text { RELATÓRIOS PARA O PLANO DE DESENVOLVIMENTO DO } \\
\text { PARANÁ }\end{array}$ \\
\hline Ano de Realização: & 1963 \\
\hline Contratante: & Governo do Estado do Paraná \\
\hline Governador: & Ney Braga \\
\hline Coordenação: & $\begin{array}{l}\text { Antônio Almicar de Oliveira Lima } \\
\text { Antônio Cláudio Moreira Lima e Moreira } \\
\text { Celso Monteiro Lamparelli } \\
\text { Francisco Whitaker Ferreira } \\
\text { Frei Benenvenuto de Santa Cruz }\end{array}$ \\
\hline Equipe Técnica: & $\begin{array}{l}\text { Antônio Carlos Bernardo } \\
\text { João Yunes } \\
\text { João Alfredo Alberti } \\
\text { João Carlos Seixas } \\
\text { Leodgar Jost } \\
\text { Lúcio Kovarick } \\
\text { Luiz Lorenzo Rivera } \\
\text { Maria Adélia A. de Souza }\end{array}$ \\
\hline
\end{tabular}




\begin{tabular}{|l|l|}
\hline & Miriam Vallias de Oliveira Lima \\
& Pedro Calil Padis \\
& Reynaldo Dias de Moraes e Silva \\
& Saulo Vassimon \\
Vicenzo Bochicchio
\end{tabular}

\begin{tabular}{|c|c|}
\hline Título do Trabalho: & $\begin{array}{l}\text { PROSPECÇÃO DOS PROBLEMAS DE DESENVOLVIMENTO DE } \\
\text { UBATUBA }\end{array}$ \\
\hline Ano de Realização: & 1964 \\
\hline Contratante: & Prefeitura Municipal de Ubatuba \\
\hline Prefeito: & Francisco Matarazzo Sobrinho \\
\hline Equipe Técnica: & $\begin{array}{l}\text { Antonio Amilcar de Oliveira Lima } \\
\text { Antonio Cláudio Moreira Lima e Moreira } \\
\text { Clementina de Ambrosis } \\
\text { Frei Benevenuto de Santa Cruz } \\
\text { João Yunes } \\
\text { José Carlos Seixas } \\
\text { Luiz Carlos Costa } \\
\text { Maria Luiza Bresser da Silveira }\end{array}$ \\
\hline
\end{tabular}

\subsection{Os trabalhos desenvolvidos pela SAGMACS no campo do urbanismo e do planejamento regional}

Até então temos demonstrado, neste capítulo, como se deu o engajamento da SAGMACS com o campo do urbanismo e do planejamento regional. Para tanto, apresentamos a cronologia de trabalhos e a formação das equipes e destacamos alguns dos mais significativos. Para finalizar este capítulo analisaremos alguns dos trabalhos, conforme já apontado, que a SAGMACS desenvolveu durante sua atuação entre os anos de 1947 e 1964. Escolhemos para esta análise debruçarmos sobre os trabalhos que, além de se vincularem ao campo do urbanismo e do planejamento regional, também significaram pontos de inflexão para a organização da própria SAGMACS, trazendo à mesma o reconhecimento e notoriedade quanto às suas realizações.

Assim, tratamos primeiramente do estudo realizado na cidade de São Paulo em 1947, sobre as condições de habitação dos paulistanos, elaborado sob a coordenação direta do religioso dominicano. Na sequência, seguimos para os trabalhos que marcam a segunda fase de atuação da equipe: "Problemas de Desenvolvimento. Necessidades e Possibilidades do Estado de São Paulo", realizado a pedido do governador Lucas Garcez 
e entregue em 1955, e o estudo da "Estrutura Urbana da Aglomeração Paulistana", realizado para a prefeitura de São Paulo entre 1956 e 1958. Por fim, analisamos dois trabalhos que classificamos como pertencentes à última fase de atuação da equipe do Économie et Humanismeno no Brasil: o estudo dos "Aspectos Humanos da Favela Carioca", coordenado por Rios e publicado em 1960, e o Relatório com a minuta de lei para o Plano Diretor de Belo Horizonte, entregue em 1963 ao prefeito Amintas de Barros.

A "Sondagem Preliminar a um estudo sobre habitação em São Paulo" ${ }^{213}$ foi o primeiro trabalho desenvolvido pela equipe da SAGMACS, e foi elaborado sob a coordenação de Lebret no Brasil. A pesquisa foi realizada na cidade de São Paulo entre os meses de abril, maio e junho, e contou com uma equipe de cerca de quarenta participantes. Este trabalho é importante por tratar-se do marco inicial da atuação da SAGMACS no Brasil, el, apesar da periodização apontada por nós, que coloca o ano de 1952 como o início do engajamento da equipe de Lebret no campo do urbanismo e do planejamento regional, também pode ser inserido dentro do campo disciplinar do urbanismo.

A pesquisa realizada em 1947 resultou num amplo relatório que trazia o diagnóstico sobre as condições de moradia dos habitantes de São Paulo. Classificava as tipologias de uso das mesmas e tecia uma análise sobre as condições sociais e econômicas dos seus moradores. Além disso, analisava tais aspectos estabelecendo um escalão de análise a partir de uma distribuição por bairros e distritos, de forma que possibilitava a diferenciação das tipologias em conformidade com as classes sociais da população.

O estudo se divide em XI capítulos: I. Sondagem; II. Resultados gerais; III. Resultados por zonas; IV. Localização das categorias extremas; V. Estudo dos tipos de habitação; VI. Estudo das habitações segundo seu número de peças; VII. Estudo da superfície das habitações; VIII. Ensaio de localização das classes sociais e tipos de moradia; IX. Estudos dos defeitos da habitação. X. Nacionalidade dos ocupantes. XI. Comparação com a França. (LEBRET, 1951, p. 8).

A "Sondagem Preliminar" classificava as modalidades habitacionais paulistanas em sete categorias: Sub-casebre (habitação miserável, insatisfatória sob todos os aspectos); casebre (habitação insatisfatória, que não podia ser melhorada, cabendo sua substituição

\footnotetext{
213 Lebret expõe numa nota introdutória ao estudo explicando que adotou título "Sondagem preliminar" por considerar que a pesquisa tratava de um levantamento prévio e também pela limitação do número de amostras e a qualificação dos pesquisadores, ainda com pouca formação para o desenvolvimento de uma pesquisa empírica.
} 
ou remoção do local); semi-casebre (semelhante à anterior, porém, com um ou mais cômodos que os casebres); habitação insatisfatória; habitação satisfatória; habitação confortável; e habitação luxuosa ou muito confortável. O estudo considerava também as diferentes regiões da cidade de São Paulo, buscando fazer uma classificação em: Zona Central, Zona Residencial e Zona de Arrabalde, explicando que as mesmas " levam em consideração principalmente as analogias de densidade e parecem que correspondem melhor à estrutura real da cidade". (SAGMACS, 1947, p. 16).

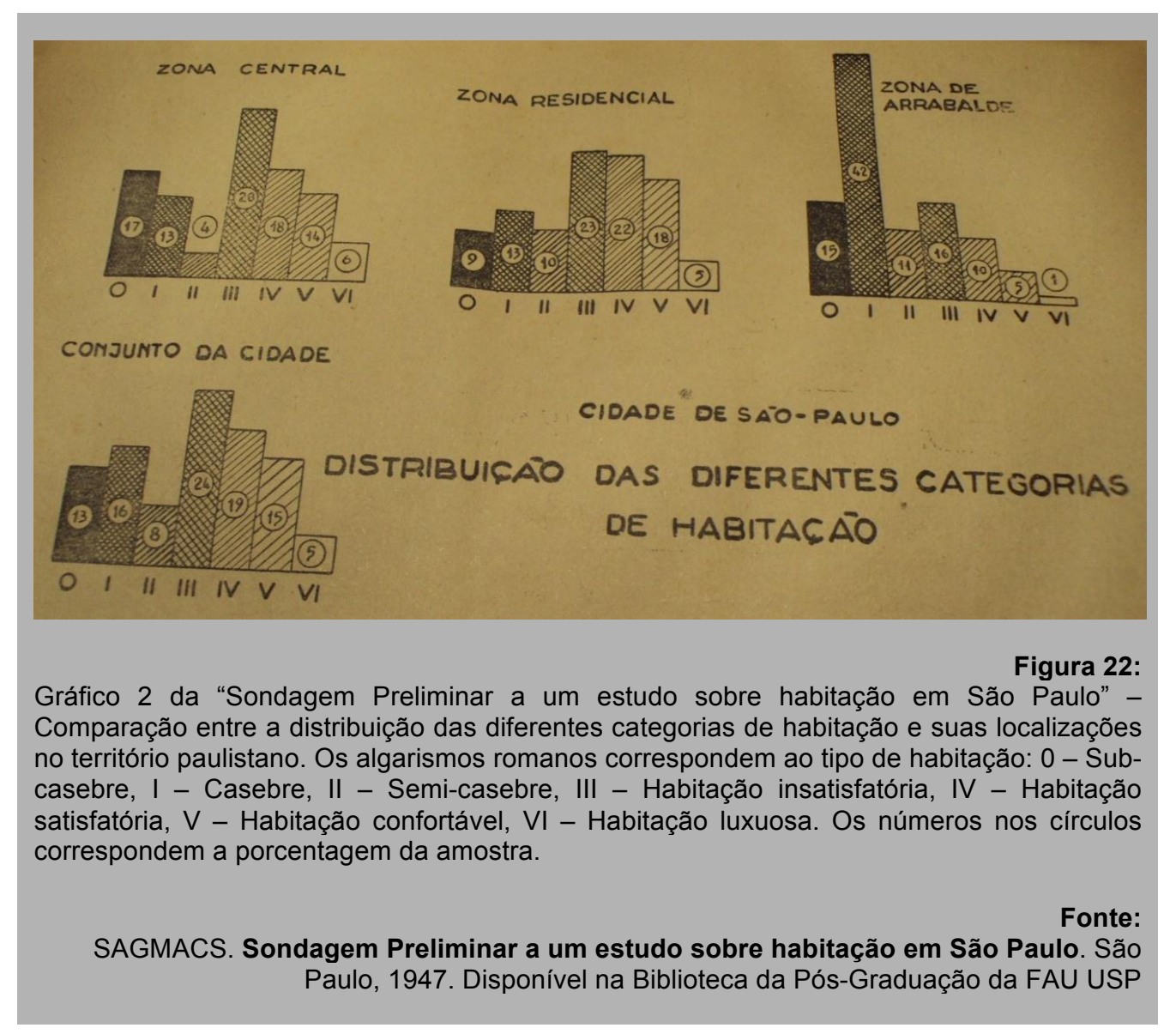

Porém, é importante apontar que esta distribuição em três zonas: central, residencial e arrabalde, não levou em consideração o conjunto da cidade de São Paulo. A distribuição serviu para estabelecer a distinção entre os distritos pesquisados, divididos em região oeste, noroeste, leste, nordeste e sul. O relatório definiu como zona central de cada distrito aquelas que tinham como características de usos principais do solo as atividades administrativas e comerciais. As zonas residenciais eram as que tinham as habitações como uso predominante do solo, e as zonas arrabaldes os setores mal organizados de infraestrutura urbana, em relação às outras duas zonas, com características ainda rurais, com casas pequenas, em mau estado, mal construídas e sem condições de conforto. 


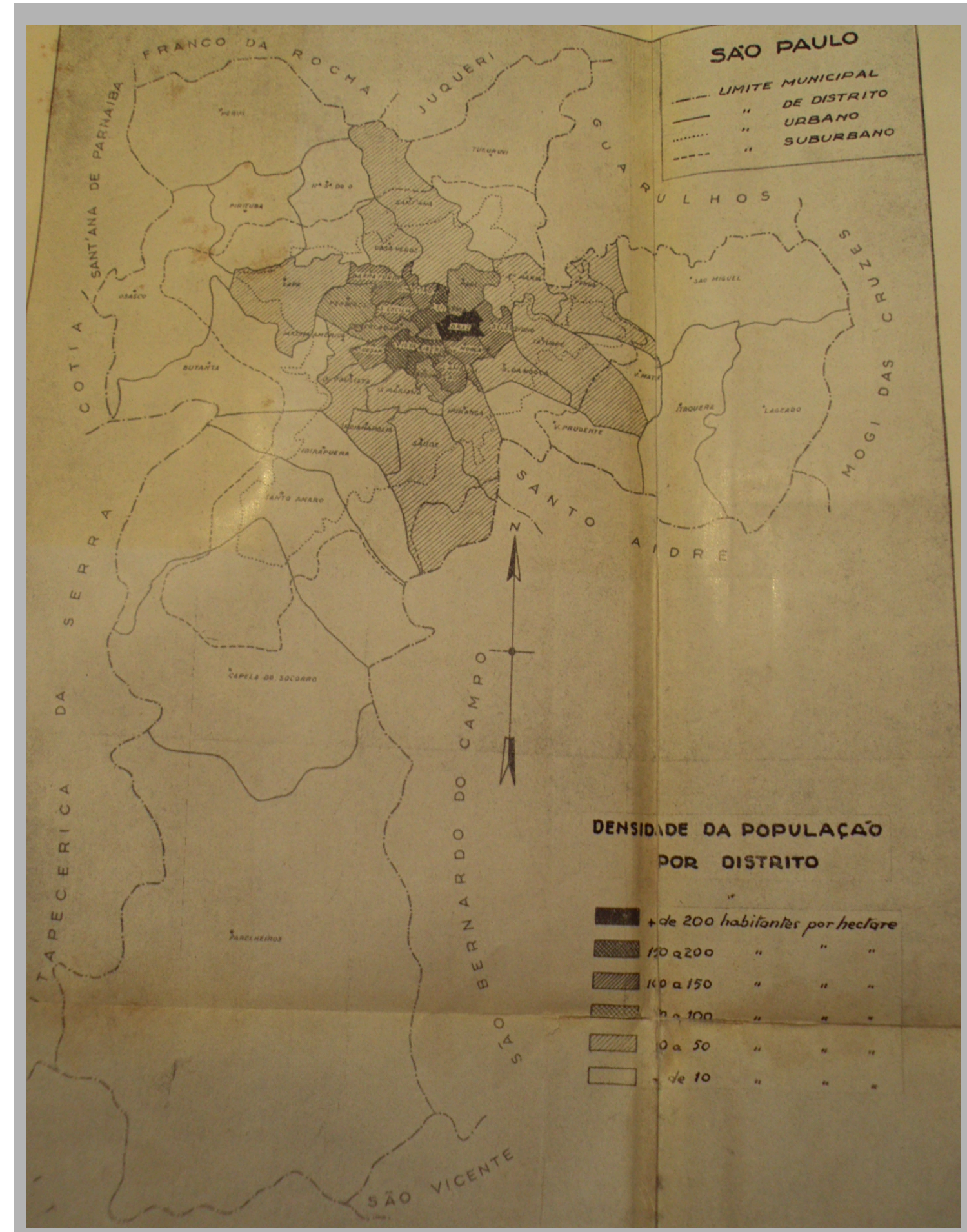

Figura 23:

Mapa da cidade de São Paulo com a divisão dos distritos pesquisados e a densidade populacional de cada um deles.

Fonte:

SAGMACS. Sondagem Preliminar a um estudo sobre habitação em São Paulo. São Paulo, 1947. Disponível na Biblioteca da Pós-Graduação da FAU USP 
Assim, foram classificados por Lebret como pertencentes à zona central os bairros da Bela Vista, Consolação, Santa Cecília, Bom Retiro, Barra Funda, Pari e Santa Ifigênia, que, segundo o relatório, se inseriam na Região Oeste de São Paulo. Os bairros da Liberdade, Sé, Brás, Cambuci, Moóca, Belenzinho e o Alto da Moóca, na Região Leste. Faziam parte da zona residencial os bairros da Nossa Senhora do Ó, Lapa, Perdizes, Butantã, Jardim América, Cerqueira César e Jardim Paulista, na região oeste. Na região sul, os bairros da Vila Mariana, Aclimação, Saúde, Ipiranga, Vila Maria, Penha, Vila Matilde, Vila Prudente e Tatuapé, e na região nordeste os bairros da Casa Verde, Santana e Tucuruvi.

Nas zonas arrabaldes estavam os bairros da região noroeste: Perus, Pirituba, Osasco e parte do Butantã; o Ipiranga, parte da Saúde, Indianópolis, Ibirapuera, Santo Amaro e Capela do Socorro na região sul, e na região leste os bairros de Lageado e São Miguel. A distribuição dos distritos analisados consta do mapa apresentado no Relatório publicado em 1947.

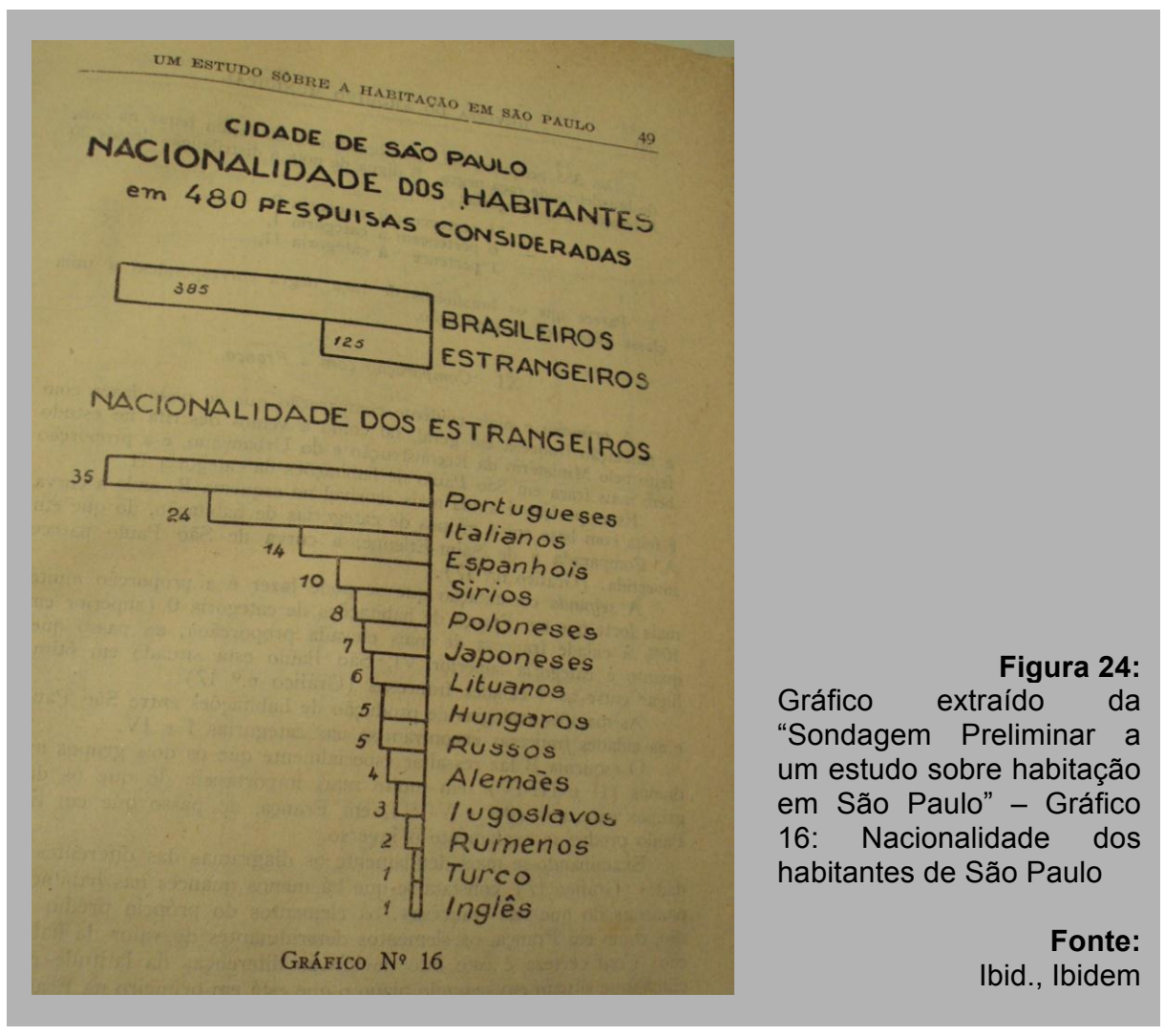




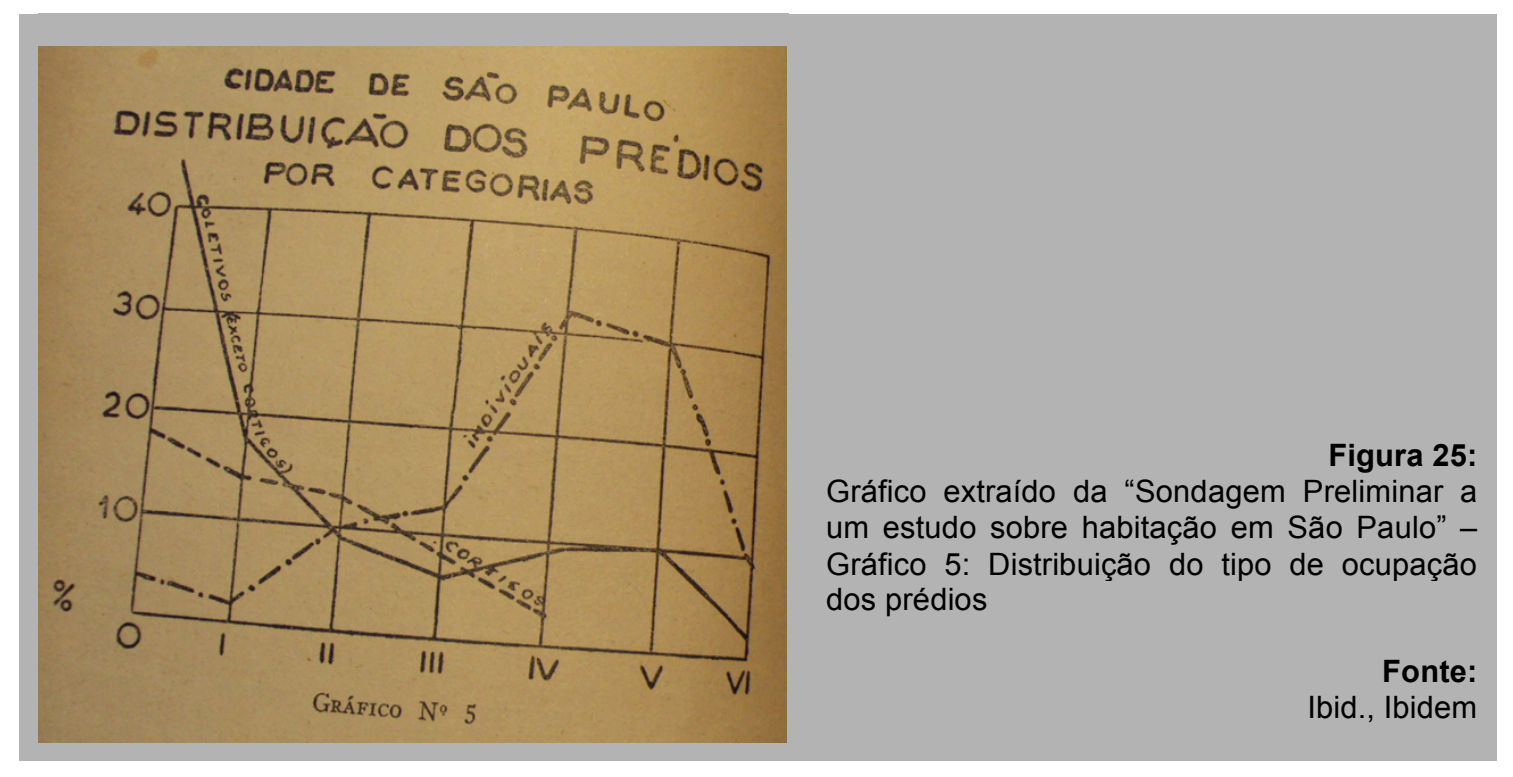

É importante dizer que, no início dos anos 1940, outro trabalho foi realizado por um estrangeiro, a fim de estudar as condições de moradia dos paulistanos. O geógrafo norteamericano Preston James realizou, durante esta década, um amplo trabalho de diagnóstico sobre a América Latina, visando identificar as matrizes do seu desenvolvimento econômico, as características físico-territoriais e os aspectos da cultura. No momento de sua publicação, em 1950, James dedicou um capítulo inteiro à cidade de São Paulo.

Devido à proximidade de datas da realização dos dois trabalhos e à presença estrangeira na coordenação de ambos, é possível estabelecer um comparativo entre os estudos de Lebret e de James. A nosso ver, ainda que tenha sido uma "Sondagem Preliminar", a pesquisa da SAGMACS revela-se como um trabalho mais completo sobre as condições de moradia na cidade de São Paulo do que a pesquisa de James, pois Lebret trazia análises a partir dos levantamentos feitos sobre a população que habitava as moradias e as diferentes zonas da cidade, a nacionalidade desses habitantes, as condições de trabalho, a escolaridade, e ainda tentava estabelecer um comparativo com pesquisas semelhantes realizadas na França, tanto as realizadas a pedido do MRU, quanto o estudo do sociólogo Chombart de Lauwe sobre a cidade de Lyon, em 1943. 


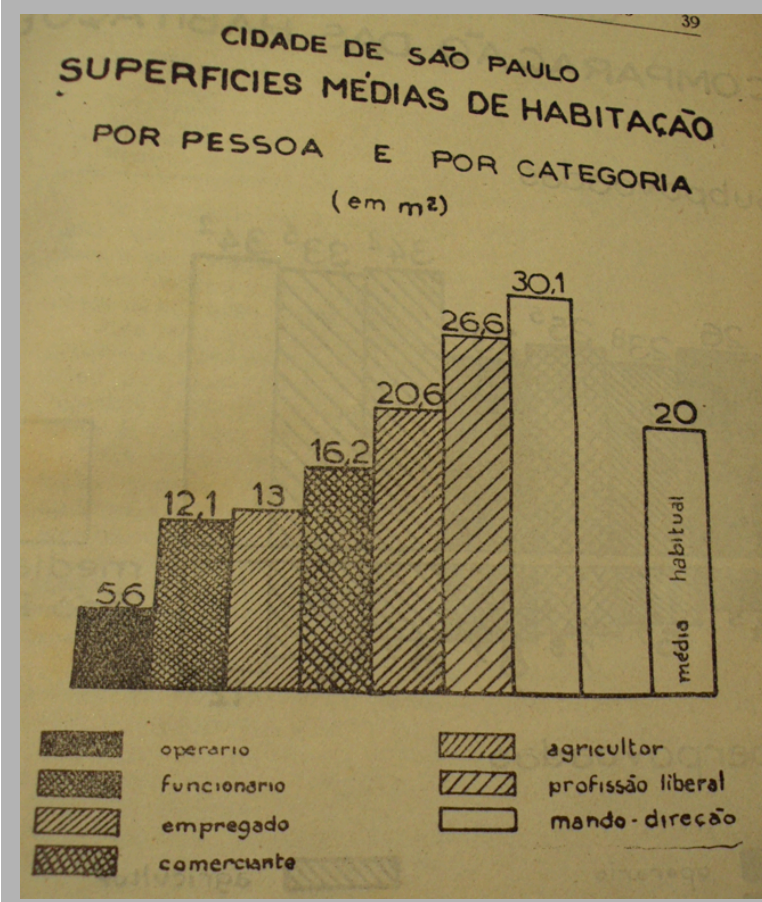

Figura 26:

Gráfico extraído da "Sondagem Preliminar a um estudo sobre habitação em São Paulo" Gráfico 10: Levantamento da quantidade de $\mathrm{m}^{2}$ por habitante de uma unidade de acordo com a ocupação econômica do chefe de família

Fonte:

SAGMACS, ibid.

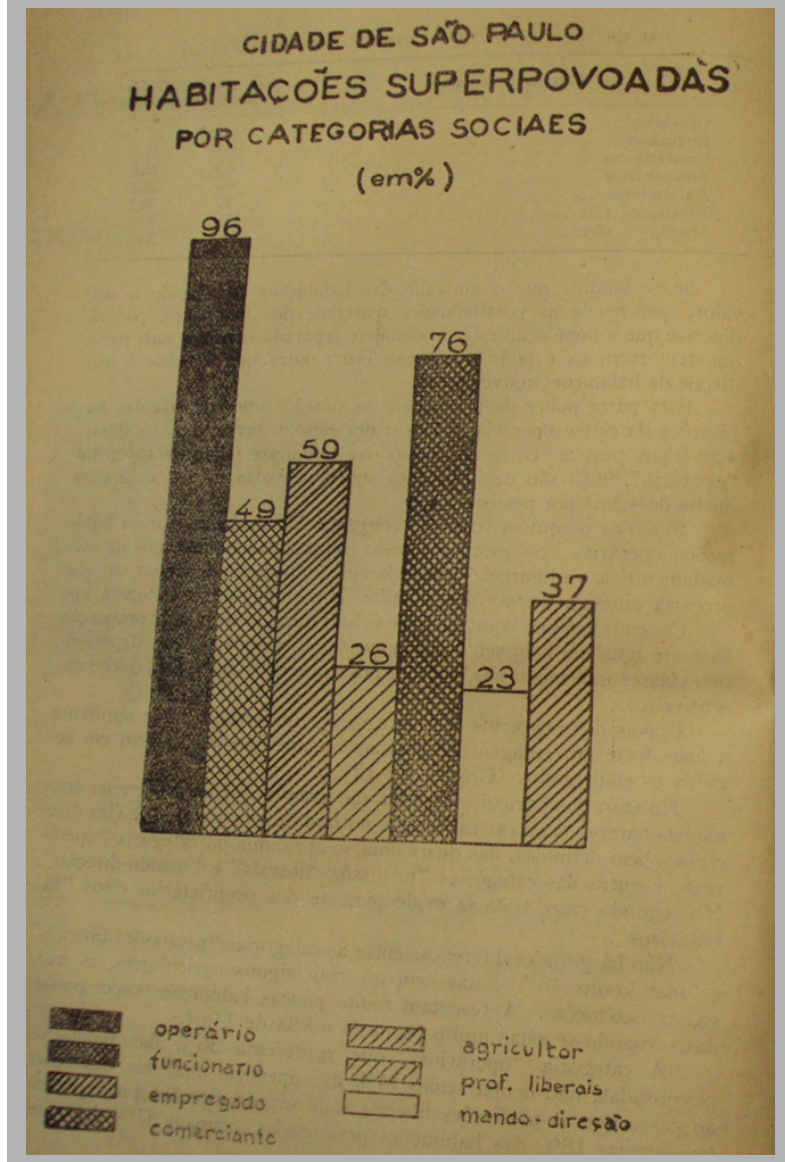

Figura 27:

Gráfico extraído da "Sondagem Preliminar a um estudo sobre habitação em São Paulo" Gráfico 12: Percentual de habitações "super povoadas" por ocupação econômica do chefe de família

Fonte:

SAGMACS, ibid. 
Demonstrando que o problema da habitação é, antes de ser uma questão de urbanismo, uma questão social, o relatório aponta para a relação entre o tamanho dos edifícios residenciais e o custo comercial do imóvel, dizendo que,

Se se admitir que o tamanho das habitações está ligado a seu valor, que revela as possibilidades materiais dos habitantes, poderá dizer-se que a população está nitidamente separada em dois: uma parte que tem recursos e pode instalar-se bem; outra que é pobre e não dispõe de habitações convenientes.

Esta parte pobre da população, na porção superpovoada das habitações da classe operária, vive em um espaço terrivelmente exíguo: $4,5 \mathrm{~m}^{2}$ por pessoa. E, no conjunto das pesquisas feitas na categoria "operário", $96 \%$ são de habitações super-habitadas, isto é, com uma média de $4,5 \mathrm{~m}^{2}$ por pessoa.

$36 \%$ das pesquisas feitas no conjunto da cidade estudaram habitações operárias. Se estas pesquisas representarem, mesmo aproximadamente, a configuração social da cidade, poder-se-á avaliar em que precária situação encontra-se a cifra importante de lares operários. (SAGMACS, 1951, p. 41).

Assim, a "Sondagem Preliminar" situa, ao final dos anos 1940, um quadro sobre as condições habitacionais da cidade de São Paulo, já apontando para problemas que transpareciam as dificuldades de acesso da população aos bens de consumo de primeira necessidade, o que poderia ser entendido como parte do subdesenvolvimento econômico. Desta forma, pode-se verificar que o relatório elaborado pela SAGMACS busca situar questões para além da área do urbanismo, ao mesmo tempo em que atrela este campo de atuação a uma matriz social, econômica e política.

Após a conclusão da "Sondagem Preliminar", Lebret deixa o Brasil e retorna à França, sob as exigências impostas pelo Vaticano, conforme apontamos no terceiro capítulo desta tese. A equipe da SAGMACS segue trabalhando vinculada à sede do Jóquei Clube de São Paulo e seus membros se engajam em trabalhos e comissões de órgãos estatais do governo federal. Em 1951, toma posse no governo do Estado de São Paulo o engenheiro Lucas Nogueira Garcez, que havia participado da fundação da SAGMACS, e sua eleição, em 1950, possibilita um novo retorno de Lebret ao Brasil e, mais do que isso, resulta no período que atribuímos como sendo a segunda fase de atuação da SAGMACS. 
Garcez era engenheiro, professor da Escola Politécnica da USP, responsável pela disciplina de Hidráulica e Saneamento, e no início dos anos 1940 havia sido superintendente da construção da Usina Hidrelétrica de Avanhandava e da Fábrica Nacional de Motores. Seu conhecimento na área de hidráulica e saneamento o levou a uma de suas principais preocupações quando assumiu o governo de São Paulo: a insuficiência de infraestrutura e abastecimento de energia para suprir as demandas impostas e garantir o desenvolvimento econômico. Ciente do crescimento populacional alcançado na última década e do desenvolvimento da indústria naquela região, percebeu que a energia gerada não daria conta do desenvolvimento almejado pela elite empresarial paulista.

Em abril de 1951, Garcez envia uma carta a Lebret ${ }^{214}$ convidando-o a viajar para São Paulo e assessorá-lo na elaboração de seu plano de governo. Naquele momento, além de Lebret indicar outros compromissos que o impossibilitavam de visitar o Brasil, também era preciso revogar a proibição de retorno do padre, o que não se constituía num entrave junto à Santa Sé, visto que, após a reprimenda dada pelo Cardeal Roncale, em 1947, o dominicano havia estreitado laços com o Cardeal Montini, que atuava na Secretaria de Estado do Vaticano. Porém, era preciso vencer a resistência a Lebret no Brasil, tanto no meio católico conservador, quanto no meio político e empresarial. Assim, Garcez articula com o Cardeal Arcebispo de São Paulo, Dom Carlos Mota, a permissão para Lebret retornar ao país.

Da França, Lebret encaminha ao governador de São Paulo orientação para o plano de governo de Garcez, o qual é transformado pela equipe do governador no Plano Quadrienal e apresentado à Assembleia Legislativa do Estado. Para a elaboração do mesmo, Garcez contou, em sua equipe, com um integrante da SAGMACS, o frei Benevenuto de Santa Cruz, que foi colocado como assessor especial do governador para responsabilizar-se pelo Plano Quadrienal.

Sobre o Plano Quadrienal, segundo Chiquito (2012, p. 154), Lebret propõe ao governador um plano que deveria extrapolar os limites físico-territoriais do estado e dar tratamento no âmbito do planejamento regional, olhando para além dos problemas de São Paulo, para aquilo que era comum aos demais estados e regiões do país. Assim, em setembro de 1951 tomou corpo a criação da Comissão Interestadual da Bacia Paraná Uruguai -

${ }^{214}$ Conforme documento consultado na Pasta AN45 AS51. 
CIBPU, instituição composta pelos estados de Goiás, Mato Grosso, Minas Gerais, Paraná, Rio Grande do Sul, Santa Catarina e São Paulo ${ }^{215}$.

Com a CIBPU criada e, a principio, contando com o apoio de Vargas para o seu funcionamento, Garcez "se dirige a Lebret para convidá-lo para realizar o primeiro estudo" a ser realizado pela comissão (ibid, pp. 157-158). A correspondência do Palácio do governo ao dominicano é datada de 4 de janeiro de 1952, convidando "para que Lebret dirigisse uma pesquisa utilizando os métodos do Economia e Humanismo, sobre os problemas econômicos e sociais da região da Bacia Paraná-Uruguai” (op. Cit, p. 158).

Poucos dias depois, Lebret confirma, através de carta ${ }^{216}$ endereçada a Maria Izabel Gomes, secretária do Governador Garcez, sua vinda ao Brasil, a qual se efetiva somente no mês de junho. Numa correspondência escrita por Benevenuto em 22 de abril, o frei aponta a agenda de atividades que seriam realizadas por Lebret durante sua estada no Brasil, com chegada a partir de primeiro de junho. Destacamos que uma das primeiras atividades de Lebret ao desembarcar em São Paulo foi uma reunião com o governador, realizada em 2 de junho.

Benevenuto aponta uma agenda de três meses de atividades para Lebret. O primeiro mês seria dedicado a sua estada em São Paulo, com atividades que incluíam uma viagem de exploração, realizada entre 5 e 13 de junho, preparação das enquetes e um curso de formação para os pesquisadores, realizado entre os dias 21 e 30 . Somente em agosto é que a agenda retomaria as atividades de Lebret voltadas à interpretação das enquetes $^{217}$.

Assim, em 1952 a SAGMACS inicia o trabalho contratado pelo governo de São Paulo, inserindo-se no campo do planejamento regional. Enquanto para nós o estudo realizado pode ser considerado um marco na organização da equipe brasileira do Économie et

\footnotetext{
${ }^{215}$ A CIBPU foi instituída a princípio com o apoio do governo federal que pretendia transformá-la numa autarquia. Porém, não houve consenso entre os governadores dos estados envolvidos e o presidente Getúlio Vargas, sendo que no ano de 1953 a instituição da Comissão foi vetada pelo governo federal. Mesmo assim, os governadores deram continuidade a criação do órgão e inclusive criaram rubricas orçamentárias para a manutenção e funcionamento da mesma. Conforme já apontado, a criação e o funcionamento da CIBPU foram estudados por Chiquito (2012) e Gardin (2002) que fizeram um estudo aprofundado da comissão, relatando o seu contexto de fundação e como ela passou a ter como responsável o governador Garcez, que obteve a presidência em todas as administrações de 1951 a 1955.

${ }^{216}$ Conforme documento consultado na Pasta AN45 AS51.

217 Segundo a carta de Benevenuto, consultada junto a documentação inserida na Pasta AN45 AS51, além das atividades em São Paulo, Lebret viajaria para o Rio de Janeiro, onde permaneceu por quinze dias, trabalhando com Josué de Castro na Comissão de Bem Estar Social, seguiu para a cidade de Poços de Caldas onde permaneceu por seis noites e retornou ao local para um descanso em companhia de um amigo no período de 7 a 15 de agosto.
} 
Humanisme, para Chiquito, ao analisar o quadro do urbanismo e do planejamento regional no Brasil, através de demais estudos técnicos produzidos tanto por órgãos públicos, quanto por equipes de assistências técnicas, o trabalho coordenado por Lebret "pode ser considerado um marco" para a instituição das ações de planejamento e desenvolvimento regional.

Em primeiro lugar por ser inédito e, em segundo lugar, por ser abrangente, representando um esforço de compreensão e interpretação da realidade brasileira até então praticamente desconhecida pelo Estado e da possibilidade de comparação desta com outras regiões do mundo. (CHIQUITO, ibid., p. 162).

O estudo contratado demandou dois anos de trabalho e exigiu da SAGMACS a formação de uma equipe em torno da realização do mesmo. Até então, a SAGMACS se projetava apenas através da atuação de alguns de seus membros, que se engajavam e atuavam em trabalhos técnicos e comissões especiais instituídas por organismos públicos. Anteriormente, no início deste capítulo, mencionamos a forma de trabalho que pautava a SAGMACS até a contratação por Garcez e apontamos que, a nosso ver, até então não havia um movimento de grupo, mas sim o engajamento de um ou outro membro que se inseria nos trabalhos e possibilitava a contratação de outros membros da equipe.

Devido à complexidade desse trabalho e à institucionalização da contratação junto ao aparelho de Estado, a SAGMACS se viu em condições de encampar uma equipe grandiosa de pesquisadores, que contou com profissionais de variadas áreas do conhecimento, como economistas, engenheiros, geógrafos e sociólogos. Foi neste momento de realização do estudo "Necessidades e Possibilidades do Estado de São Paulo" que os arquitetos, ainda que atuando como estagiários e desenhistas, passaram a ter contato com a equipe de Lebret.

A metodologia para a realização da pesquisa seguiu o trabalho de levantamento empírico e contato global utilizado pelo Économie et Humanisme e impôs, inclusive ao padre Lebret, a necessidade de ir a campo, conhecer a realidade das cidades do interior paulista, numa atividade chamada por ele de "viagem de exploração", que, segundo Angelo (2010, p. 163), culminou com um "relatório realizado entre 1 de junho e 31 de agosto de 1952 por Benevenuto e Lebret, intitulado 'Conclusions provisoires du Voyage d'étude'". 
Em fevereiro de 1954, Lebret apresenta no Palácio dos Campos Elíseos os resultados preliminares do estudo "Necessidades e Possibilidades do Estado de São Paulo" com uma longa e minuciosa exposição a respeito dos métodos e princípios de pesquisa de Economia e Humanismo. O vicepresidente da CIBPU, Álvaro de Souza Lima destaca 'a importância do trabalho apresentado pela instituição, a objetividade das conclusões alcançadas, o cabedal precioso de dados e informações coligidas e, principalmente, os fecundos métodos de análise desenvolvidos por Economia e Humanismo' ressaltando ainda que tais métodos foram 'pela primeira vez empregados no extenso e complexo campo dos problemas econômicos de uma área superior a de vários países da Europa. (CHIQUITO, ibid., p. 162).

Se, na primeira estada de Lebret no Brasil e aos demais países da América do Sul, em 1947, o dominicano francês percebera disparidades econômicas e sociais em relação ao que ele conhecia como primeiro mundo, durante sua visita exploratória às cidades do interior paulista, realizada em junho de 1952, e posteriormente às cidades dos estados do Rio Grande do Sul, Santa Catarina, Paraná, Minas Gerais, Mato Grosso e Rio de Janeiro, Lebret foi capaz de perceber as disparidades regionais dentro de um mesmo estado da nação (São Paulo) e das diferentes regiões do país.

Para Angelo (ibid., p. 166), "Lebret trouxe a novidade de pensar o desenvolvimento, porém, com características mais humanistas, e não somente econômicas." Já para Gardin (2009), o trabalho de Lebret estaria mais próximo do trabalho realizado pela Comissão do Vale do São Francisco, ou seja, uma experiência de planejamento voltada para o desenvolvimento de bacias hidrográficas, que tomavam como referência o modelo de planejamento norte-americano do Vale do Rio Tennesee. Ainda assim, a autora "destaca o pioneirismo da Instituição de Lebret, lembrando que ele estabeleceu as bases gerais para o planejamento territorial do estado de São Paulo a partir daquele momento." (apud ANGELO, op. Cit., ibidem.). Já Chiquito destaca que,

No estudo podem-se identificar as concepções de desenvolvimento presentes e a aplicação dos métodos na avaliação dos níveis de vida da região e sua importância para a formulação da "Contribuição à Teoria do Desenvolvimento" por Lebret. O estudo se baseava na construção de elementos para a valorização, o desenvolvimento, a organização e o aproveitamento do território. A análise foi realizada através da identificação das "necessidades" e "possibilidades". As "necessidades" foram divididas em essenciais (bens imprescindíveis, bens primários), de facilidade (relacionadas ao grau de conforto e à tecnologia 
desenvolvida, setor secundário), e de superação (permitiam um alto grau de civilização cultural e espiritual. (ibid., p. 164).

Quando o trabalho expõe sobre a identificação das necessidades e das possibilidades, fica clara a utilização da metodologia definida pelo "Méthode d'Énquête" do Économie et Humanisme, que hierarquizava as necessidades e demandas dos homens em bens essenciais, aquilo que seria imprescindível à vida humana, onde se incluíam os bens primários, e em necessidades de facilidade e de superação. As necessidades de superação consideravam a possibilidade de implementação para as sociedades que tivessem atingido um alto desenvolvimento social e econômico e as de facilidade eram aquelas que permitiam algum nível de conforto, e poderiam ser utilizadas após a superação do subdesenvolvimento.

Assim, a conclusão do trabalho para o governo de São Paulo e a CIBPU insere Lebret e a SAGMACS também no campo do urbanismo, quando a equipe propõe uma nova distribuição regional do Estado, utilizando-se da implantação de polos de desenvolvimento regional, conceito que havia sido introduzido por François Perroux.

Como o trabalho "Problemas de Desenvolvimento. Necessidades e Possibilidades do estado de São Paulo" havia sido contratado através da CIBPU, que extrapolava os limites físico-territoriais do estado, a SAGMACS conseguiu, na sequência da realização deste trabalho, a contratação para desenvolver estudos semelhantes sobre os estados do Paraná, Rio Grande do Sul e Santa Catarina. Estes trabalhos foram desenvolvidos pela equipe da SAGMACS entre os anos de 1955 e 1957 e empregaram a mesma metodologia utilizada no estudo para São Paulo. A publicação ocorreu em 1958, sob patrocínio da Comissão Interestadual, apontando para a implantação de polos de desenvolvimento regional.

Podemos então dizer que, a partir da realização do estudo das "Necessidades e Possibilidades do estado de São Paulo", a SAGMACS se inseriu em definitivo no campo do planejamento regional no Brasil, pois, além de trabalhos semelhantes realizados para os estados do sul do país, sob contrato estabelecido pela CIBPU, em 1954 Lebret se engajou, em Pernambuco, em um estudo para o desenvolvimento da indústria naquele estado, contratado pela CODEPE, que contou com a parceria do engenheiro Baltar.

Nesta segunda fase de atuação da SAGMACS, a instituição passou a contar com uma ampla equipe em seu corpo técnico. A formação de cada equipe variava de acordo com o escopo dos trabalhos que eram encomendados a ela, de forma que, segundo Lamparelli (2007) e Whitaker Ferreira (2007), havia, além da diretoria, um núcleo fixo de 
pesquisadores formado por arquitetos, engenheiros, economistas, geógrafos e sociólogos. Os demais pesquisadores, desenhistas e assistentes, eram contratados para desempenharem tarefas junto a trabalhos específicos, como ocorreu durante a contratação do estudo da "Estrutura Urbana da Aglomeração Paulistana: estruturas atuais e estruturas racionais" pela prefeitura de São Paulo, em 1956.

O estudo realizado para a prefeitura de São Paulo no final da década de 1950 foi o que mais demandou mão de obra. De acordo com as equipes apresentadas nos relatórios dos trabalhos realizados, o estudo sobre a "Aglomeração Paulistana" empregou cerca de oitenta participantes, entre advogados, arquitetos, economistas, engenheiros, geógrafos e sociólogos. Havia também os pesquisadores de campo, os desenhistas, assistentes e secretárias para apoio do trabalho que, segundo Lebret (1958, Parte I, p. 2), foi realizado como um desdobramento do "Necessidades e Possibilidades do estado de São Paulo". De forma que,

\footnotetext{
Em agosto de 1956, o então prefeito de São Paulo, Dr. Wladimir Piza convidara 'SAGMACS', a continuar, na aglomeração paulistana, os estudos efetuados de 1952 a 1954, para a Comissão Interestadual da Bacia Paraná-Uruguai, sobre as necessidades e possibilidades de desenvolvimento do Estado de São Paulo. (ibid., ibidem, p. 13).
}

A nota prévia ao relatório aponta ainda que "o trabalho pedido é da alçada das disciplinas 'ordenação racional do espaço' e 'desenvolvimento'” (op. Cit., ibidem), mostrando assim sua filiação ao campo do planejamento urbano e regional. O relatório apresentado à Prefeitura de São Paulo foi dividido em cinco partes, dispostas em dois volumes. O volume inicial apresenta a primeira e a segunda parte do relatório, voltadas a apresentar as perspectivas históricas, demográficas e econômicas da Aglomeração Paulistana (Parte I), e a estrutura urbana de São Paulo (Parte II). No segundo volume são apresentadas a quarta parte, voltada à análise urbanística, e a quinta parte, apontando as conclusões e sugestões.

A terceira parte do estudo, destinada à análise dos aspectos sociológicos da aglomeração, não consta de nenhum dos volumes impressos, pois o trabalho não foi concluído. No índice do relatório publicado (op. Cit., p. 4) não se indicam capítulos, nem 
seções ou apêndices pertinentes ao trabalho que era coordenado pelo norte-mericano Frank Goldman ${ }^{218}$.

Sobre este trabalho, destacamos como um dos pontos de inovação o emprego de uma classificação conforme a localização e hierarquização das cidades próximas a São Paulo, e os escalões de análise, que seguiram a metodologia empregada pelo Économie et Humanisme, mas um tanto mais aperfeiçoada pela SAGMACS. A SAGMACS apresentou para a análise uma divisão regional em cinco escalões: o município de São Paulo; a Aglomeração Paulistana, que incorporava, além da capital paulista, as cidades de Santo André, São Bernardo do Campo, Guarulhos e São Caetano; a Great São Paulo, que envolvia os municípios próximos à capital e com alguma dependência direta de São Paulo; a Greater São Paulo, que incorporou as cidades industriais do interior e o literal do estado de São Paulo, numa clara continuidade ao estudo desenvolvido para a CIBPU; e a Greatest São Paulo, que compreendia todo o território paulista.

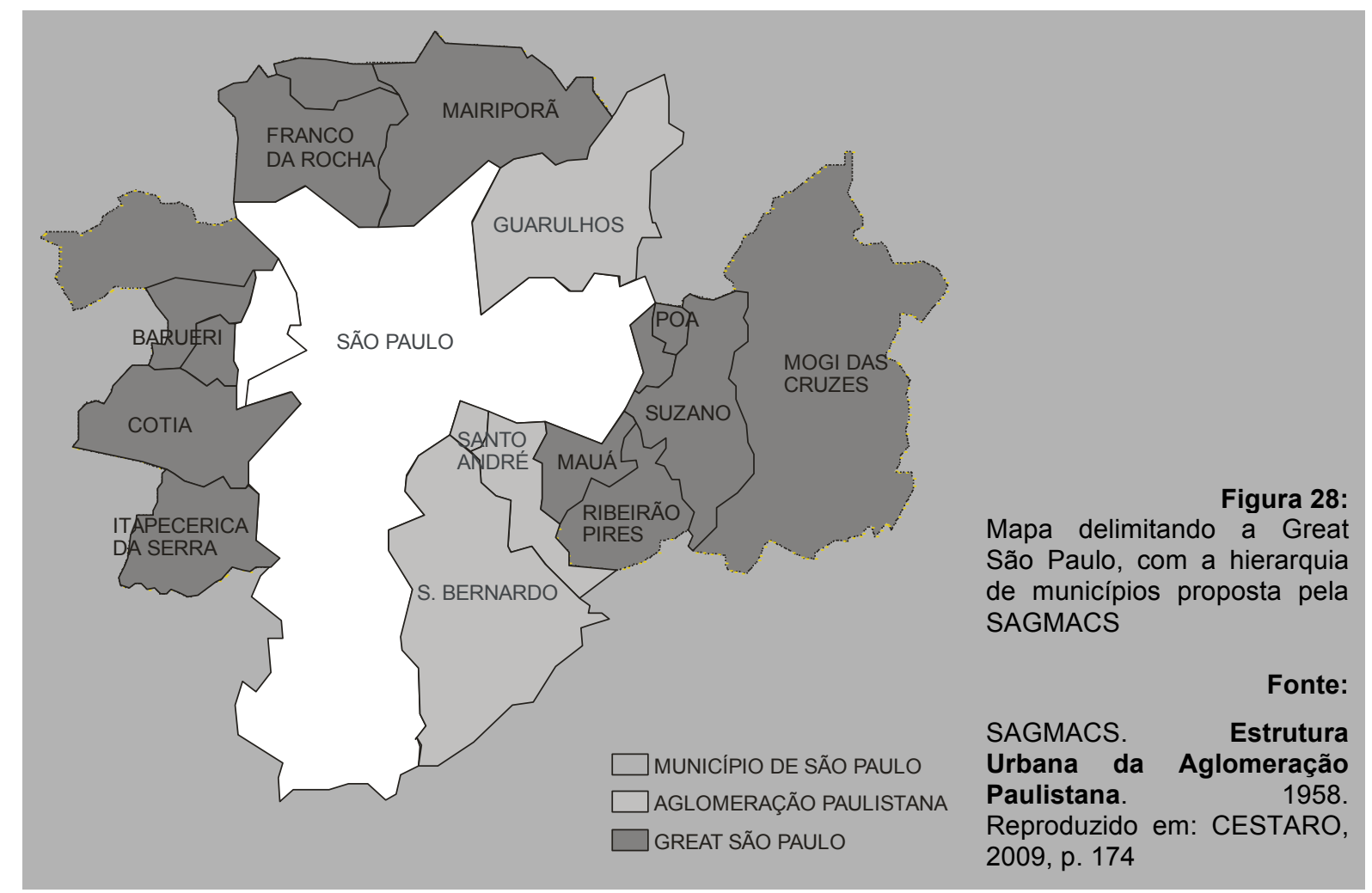

\footnotetext{
${ }^{218}$ Sobre o estudo da "Aglomeração Paulistana" consultar os capítulos 4 e 5 de nossa dissertação de mestrado "Urbanismo e Humanismo: A SAGMACS e o estudo da 'Estrutura Urbana da Aglomeração Paulistana'” (2009).
} 
Como a pesquisa foi contratada pela Prefeitura de São Paulo, o estudo realizado pela SAGMACS não se dedicou a analisar todos os municípios da Great São Paulo, mas, expandindo os limites físico-territoriais da capital paulista, também teceu análise sobre as cidades inseridas dentro do que a equipe classificou como aglomeração. Assim, os municípios de São Paulo, Santo André, São Bernardo do Campo, São Caetano do Sul e Guarulhos foram divididos em escalões de análises elementares, ou seja, unidades ou áreas da cidade inseridas em um bairro, que contavam com o mínimo para suprir as necessidades de consumo e oferta de serviços à população local, sendo considerada como equipamentos mínimos a existência de comércio de gêneros alimentícios, escola primária, farmácia, bares e ponto de parada de ônibus.

Num segundo escalão de análise, as unidades elementares formavam as unidades complexas, que tinham um diâmetro de cerca de $3 \mathrm{Km}$, que deviam oferecer aos habitantes desta área ao menos uma loja de roupas e artigos domésticos, cinema, médico, dentista e clube recreativo, formando assim um polo regional da cidade. Da mesma forma que as unidades complexas eram formadas pelas unidades elementares, as mesmas formavam as unidades completas. As unidades completas eram uma espécie de sub-cidade ou sub-centro, apresentando quase auto-suficiência em relação ao centro da cidade de São Paulo, dispondo de grande diversidade de comércio, equipamentos escolares, de saúde e administrativos.

Conforme apontamos em nossa dissertação de mestrado (2009, p. 175), a Aglomeração Paulistana foi então dividida em 364 unidades elementares, sendo 307 no município de São Paulo, 23 em Santo André, 17 em São Bernardo do Campo, 12 em São Caetano e 5 em Guarulhos. Como resultado desta divisão em três graus de unidades, e apoiando-se no critério de divisão em zonas fisiográficas, utilizadas pelo IBGE, a SAGMACS constatou haver três regiões para a cidade de São Paulo: Central, Região de Transição (em torno da região central e em direção à periferia) e Externa (periferia). 


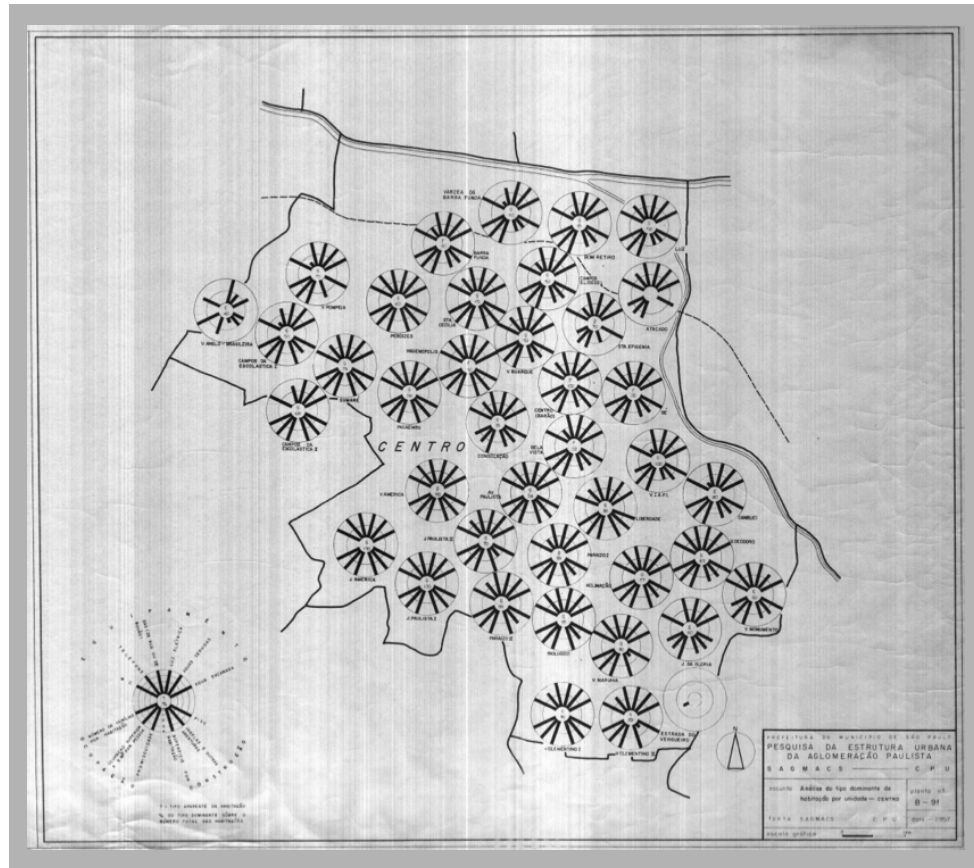

Reprodução da Planta B 9F do EUAP. Mapa delimitando a unidade complexa formada pelas 40 unidades elementares que compunham o Centro de São Paulo. Cada uma das unidades elementares é representada aqui por uma "margarida" que dispõe de informação sobre as tipologias predominantes de habitação.

Fonte: SAGMACS. Estrutura Urbana da Aglomeração Paulistana. 1958. Planta B 9F - Tipologias Habitacionais Predominantes.

Disponibilizada pelo Setor Audiovisual da Biblioteca da FAU USP. 


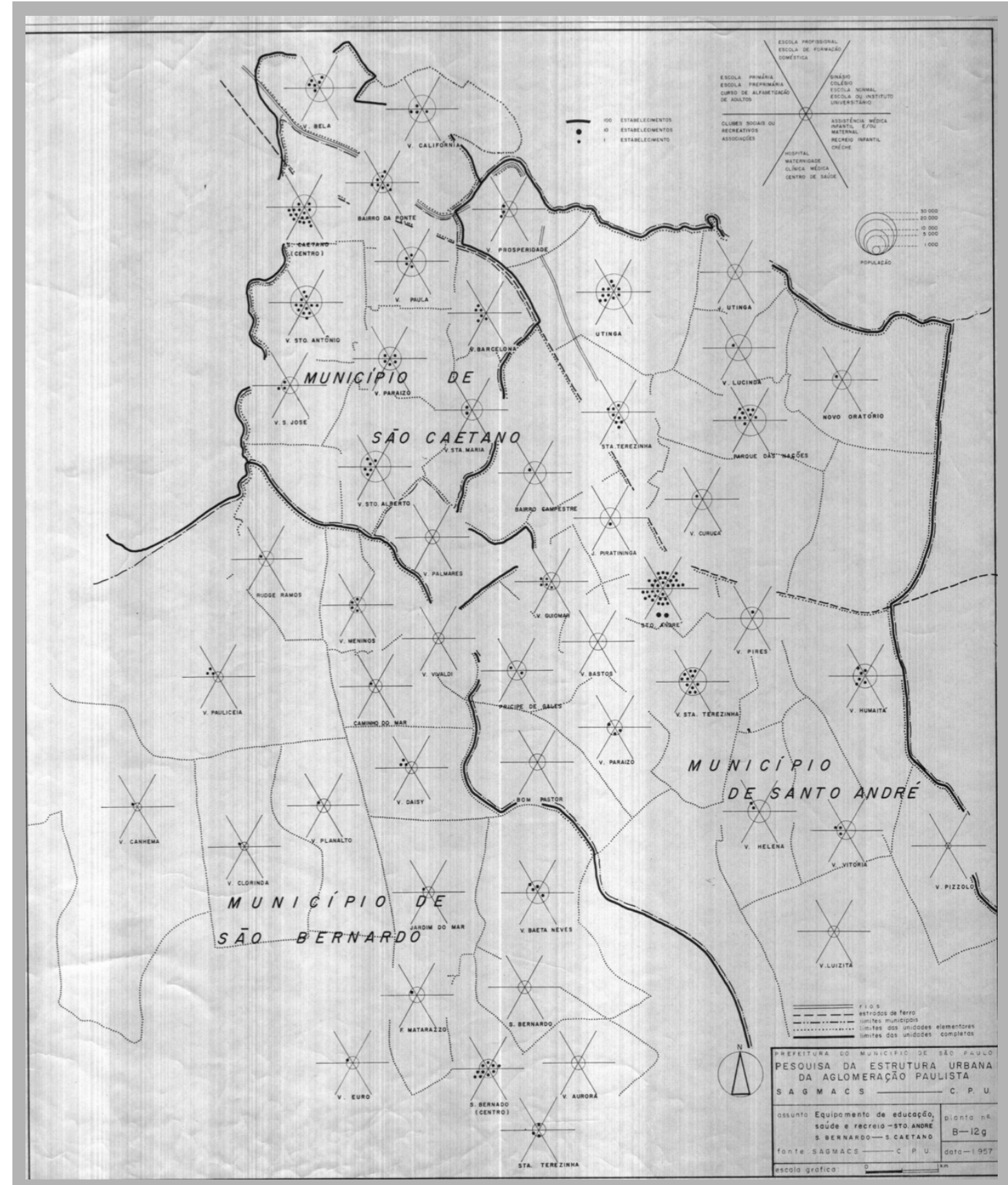

Figura 30:

Reprodução da Planta B 12 G do EUAP. Mapa com as unidades complexas de Santo André, São Bernardo e São Caetano, com as informações sobre a oferta de equipamentos e serviços públicos de saúde e educação em gráficos para cada uma das unidades elementares que compunham a unidade complexa.

Fonte:

SAGMACS. Estrutura Urbana da Aglomeração Paulistana. 1958. Disponibilizado pelo Setor Audiovisual da Biblioteca da FAU USP 


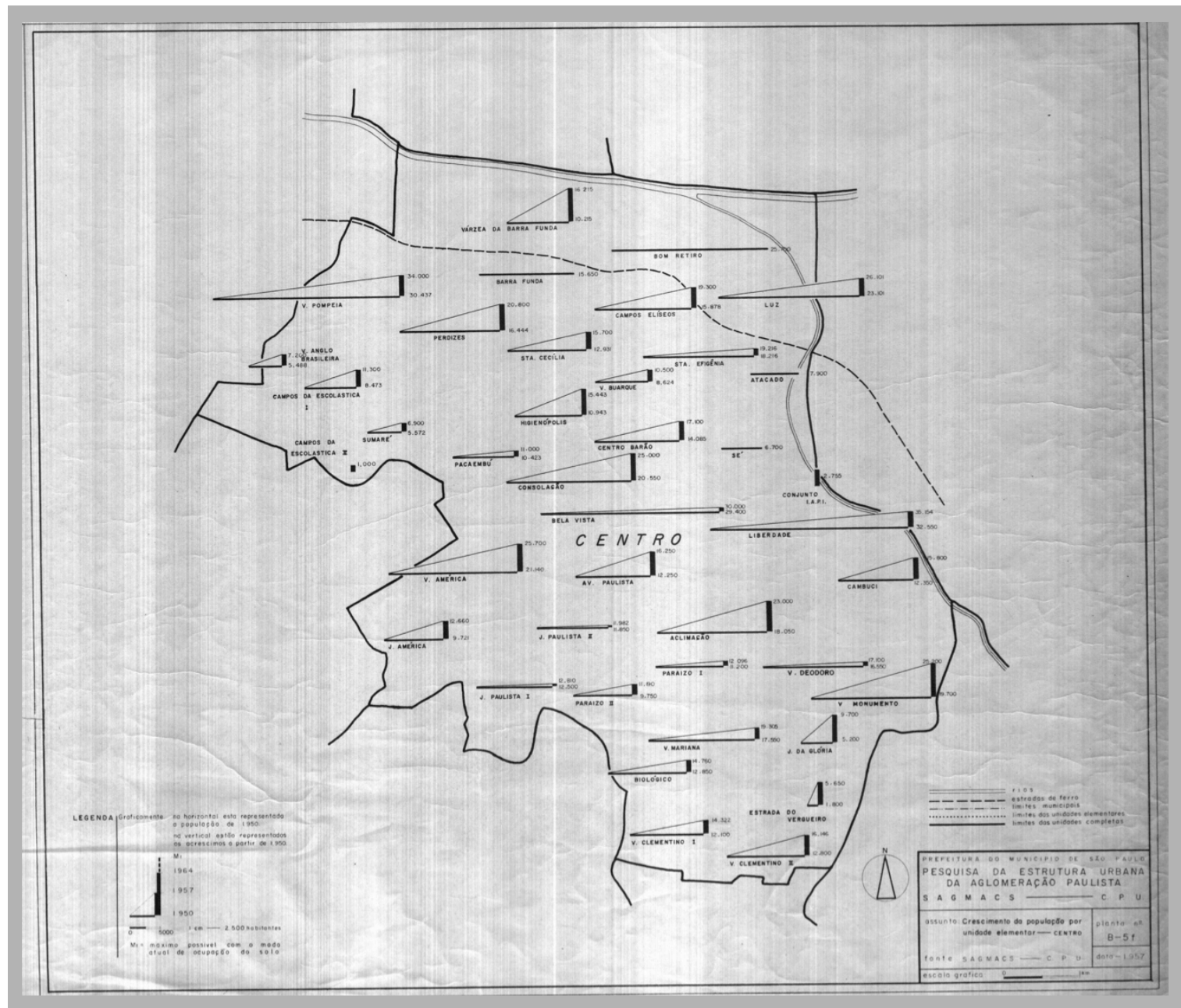

Figura 31:

Reprodução da Planta B 5F do EUAP com os apontamentos do crescimento populacional da última década em cada uma das unidades elementares da unidade complexa do centro.

Fonte:

SAGMACS. Estrutura Urbana da Aglomeração Paulistana. 1958. Disponibilizado pelo Setor Audiovisual da Biblioteca da FAU USP

Buscando apontar soluções que poderiam representar melhorias no futuro da cidade e equilíbrio entre as regiões, a SAGMACS, após ter levantado as bases para a expansão populacional, através de pesquisa junto aos números do IBGE e do Departamento de Estatística do Estado, verificou que os municípios da aglomeração (Santo André, São Bernardo, São Caetano e Guarulhos), no período de 1940 a 1950, apresentavam uma taxa de crescimento de $9,6 \%$ ao ano, devido ao fluxo migratório de pessoas que deixavam cidades no interior e as zonas rurais da capital rumo aos centros urbanos, atraídas, sobretudo, pela disponibilidade de trabalho na indústria.

Deste modo, o estudo da "Aglomeração Paulistana" tece três hipóteses que nortearam os trabalhos da equipe de pesquisa urbanística da SAGMACS. Estas hipóteses levaram em 
consideração os cenários de crescimento populacional e expansão econômica, além de uma possível desaceleração da economia ou recessão. Estas hipóteses constituíram cenários para o planejamento dos próximos quarenta anos da cidade, transcendendo os limites físico-territoriais da capital paulista, revelando assim uma abertura para a discussão da questão metropolitana e do planejamento regional. Dentre as três hipóteses ${ }^{219}$ trabalhadas, a SAGMACS optou pela terceira delas. Esta hipótese admitia que os índices de crescimento seriam reduzidos a partir de 1975, chegando a uma população em torno de 10 a 12 milhões de habitantes no ano 2000.

$\mathrm{Na}$ segunda parte do estudo, o relatório apresenta a estrutura urbana de São Paulo, levando-se também em consideração as cidades da aglomeração paulistana. Seguindo a metodologia incorporada pela SAGMACS, que visava medir as condições de vida da população, os pesquisadores da equipe atuaram no campo, levantando os dados a partir da célula doméstica, medindo assim as condições de moradia e de sua inserção no meio urbano. Dessa forma, "a interpretação detalhada dos níveis de vida exigiria o estabelecimento de uma tipologia precisa em função das camadas sociais, da idade, da densidade e da localização da unidade." (SAGMACS, ibid., p. 65). Como resultado da coleta em campo, é possível verificar a distribuição das classes de unidades estabelecidas, segundo nota média dos níveis de vida, que definiam as condições da população em: "situação péssima" (0,0 a 1,3$)$; "situação má" (1,4 a 2,4); e "situação satisfatória” (2,5 a 4,0).

A partir deste levantamento, também foi possível avaliar a renda dos habitantes, dividindo a população em: "Alta burguesia", formada por proprietários rurais tradicionais, grandes industriais e comerciantes; "médias superiores", formada por proprietários rurais, industriais e comerciantes, profissionais liberais, funcionários e empregados de alto nível (formação superior); "médias inferiores", composta por pequenos industriais, artesãos importantes, comerciantes médios, funcionários e empregados médios; "classes populares urbanas", formadas por pequenos artesãos, pequenos comerciantes, empregados e funcionários, operários qualificados e trabalhadores braçais; "populares rurais", formada por agricultores trabalhadores agrícolas; e "população marginalizada".

\footnotetext{
${ }^{219}$ A primeira hipótese adotava a possibilidade de um crescimento geométrico de $5,25 \%$ ao ano para a Aglomeração Paulistana, apontando que São Paulo alcançaria no ano 2000 uma população superior a 31 milhões de pessoas. A segunda hipótese previa um maior equilíbrio entre a população da aglomeração e do estado. Este cenário previa a possibilidade de São Paulo alcançar um terço da população do Estado, o que era visto como possível, mas sendo provável sua superação devido ao crescimento da última década. Levando-se em consideração esta hipótese, a cidade de São Paulo atingiria, no ano de 1975, uma população de 5.630 .000 habitantes e em 2000 de 10 milhões e meio de pessoas. (SAGMACS, 1958, Parte I, pp. 75-76).
} 
Ainda levando-se em consideração a célula doméstica, o relatório apresenta, em complementação à pesquisa sobre a predominância de rendas, uma análise das tipologias habitacionais predominantes nas unidades complexas. As tipologias eram classificadas como: a) Favelas - casas feitas com material precário com chão de terra batida; b) Habitação coletiva precária (cortiço) - definidas quando tendo o equipamento sanitário utilizado em comum por mais que uma família; c) casa de tijolos precária com área inferior a $30 \mathrm{~m}^{2}$, sem divisões internas ou com divisões precárias; d) Habitação coletiva regular; e) casa de tijolos popular com área construída entre 30 e $60 \mathrm{~m}^{2}$, sem forro; f) apartamento confortável, com todos os equipamentos - possuindo eletricidade, água corrente, chuveiro, esgoto, wc; g) casa média a luxo, com as mesmas condições do apartamento confortável, mas com área superior a $60 \mathrm{~m}^{2}$.

Sobre a existência dos equipamentos e serviços básicos, o relatório faz uma divisão em equipamentos básicos gerais (via principal, mercados e feiras, limpeza de rua, telefone, correios e telégrafos, transporte coletivo, estádios e clubes, campos de futebol e parques e jardins) e equipamentos básicos de rua (pavimentação asfáltica, guias e sarjetas, iluminação pública e rede de água e luz), em cada uma das unidades complexas. 0 relatório classifica a condição destes equipamentos em: a) Inexistente; b) Apenas iniciados; c) Pouco desenvolvido; d) Desenvolvido regularmente; e) Pouco satisfatório; f) Bons; e g) Excelentes ou satisfatórios.

A quarta parte do relatório analisa a urbanística paulistana, verificando a situação urbana existente, as condições para o desenvolvimento do urbanismo, sua legislação, seu plano de obras e ações concretas a fim de melhorar as condições de vida dos habitantes. Nesta parte do relatório, a pesquisa compreende análise somente sobre o município de São Paulo.

Apesar de alguns aspectos propositivos, como sugestões feitas com respeito a soluções que poderiam ser adotadas para alguns dos problemas de planejamento, a SAGMACS deixa claro que "não nos cabe, evidentemente, neste trabalho, organizar o plano urbanístico de São Paulo, tarefa para a qual, entretanto, a pesquisa realizada deverá fornecer os dados básicos indispensáveis." (ibid., ibidem, Parte IV, p. 97).

Em nossa dissertação de mestrado apontamos que (2009, pp. 195-196), para obter os índices urbanísticos de São Paulo, "o relatório aponta algumas vinculações com procedimentos metodológicos e diretrizes urbanísticas de autores ingleses e norteamericanos", destacando que os britânicos empregam a maneira correta de observação de índices, chamada de net-ratioofsepace, "em que se leva em consideração a ocupação do terreno, utilização do espaço e dimensão construída em altura" (SAGMACS, ibid., 
ibidem, p. 22). A partir deste levantamento, o relatório aponta para anomalias de legislação existentes com destaque para as inadaptações às novas condições metropolitanas.

$\mathrm{Na}$ página 88 da Parte IV do Relatório, a SAGMACS apresenta o levantamento das condições urbanísticas das unidades levantadas, destacando uma ficha para cada uma delas, com as seguintes informações: nome do bairro; número de quadras levantadas sem população/ocupação do solo; número de quadras levantadas com população; área total levantada; população residente; população empregada; usos dos terrenos, divididos em: área dos lotes vagos, área dos lotes ocupado,; área destinada dos lotes residenciais, área de recreação, área de circulação, área estimada de outros usos. Apresenta ainda os "coeficientes técnicos": índice de ocupação, número médio de pavimentos e índice de utilização (aproveitamento).

Buscando resolver os problemas de ordem urbanística encontrados, a SAGMACS apresentou um levantamento preliminar de custos para suprir a demanda por infraestrutura e equipamentos básicos mínimos com os recursos existentes no período. Segundo o relatório, para suprir esta carência seria necessário um investimento de 80 bilhões de cruzeiros, que correspondia a cerca de $8 \%$ do PIB brasileiro no período e 16 vezes o orçamento do município de São Paulo no ano de 1957.

\begin{abstract}
Essa anomalia se deve à desmesurada expansão periférica da zona dita urbana com a inclusão de loteamentos inteiramente desprovidos de equipamento básico, enquanto zonas residenciais mais próximas do centro e, portanto, caracterizadas por um custo de serviços públicos muito mais econômicos, foram mantidas com índices de ocupação por unidade de área total urbanizada atualmente verificada - da ordem de 70 habitantes por hectare - o que é totalmente impraticável, se o município decidir-se promover a implantação e a manutenção de um equipamento básico satisfatório. O mesmo poderia ser dito dos municípios do ABC e Guarulhos. (ibid., ibidem, p. 59).
\end{abstract}

A conclusão da quarta parte apresenta, além de sugestões para a constituição de "Normas Técnicas para o dimensionamento das unidades dos diferentes escalões" ( $p$. 97 ), as "Etapas para o dimensionamento das unidades completas ou secundárias" ( $p$. 101), traçando diretrizes para o planejamento futuro da cidade, pensando em uma cidade que, no ano 2000, alcançaria 12 milhões de habitantes, em uma área de $600 \mathrm{~km}^{2}$. Cada unidade elementar teria como padrão um raio de 800 metros, superfície de cerca de 20 
hectares e população de 20.000 a 40.000 habitantes. Combatendo a segregação socioespacial, cada unidade elementar deveria conter áreas residenciais de diferentes padrões econômicos, devendo as mesmas se estruturarem em proximidade das áreas de polarização, como os sub-centros de comércio, criando-se uma cidade humanizada com estrutura poli-nuclear e orgânica ${ }^{220}$.

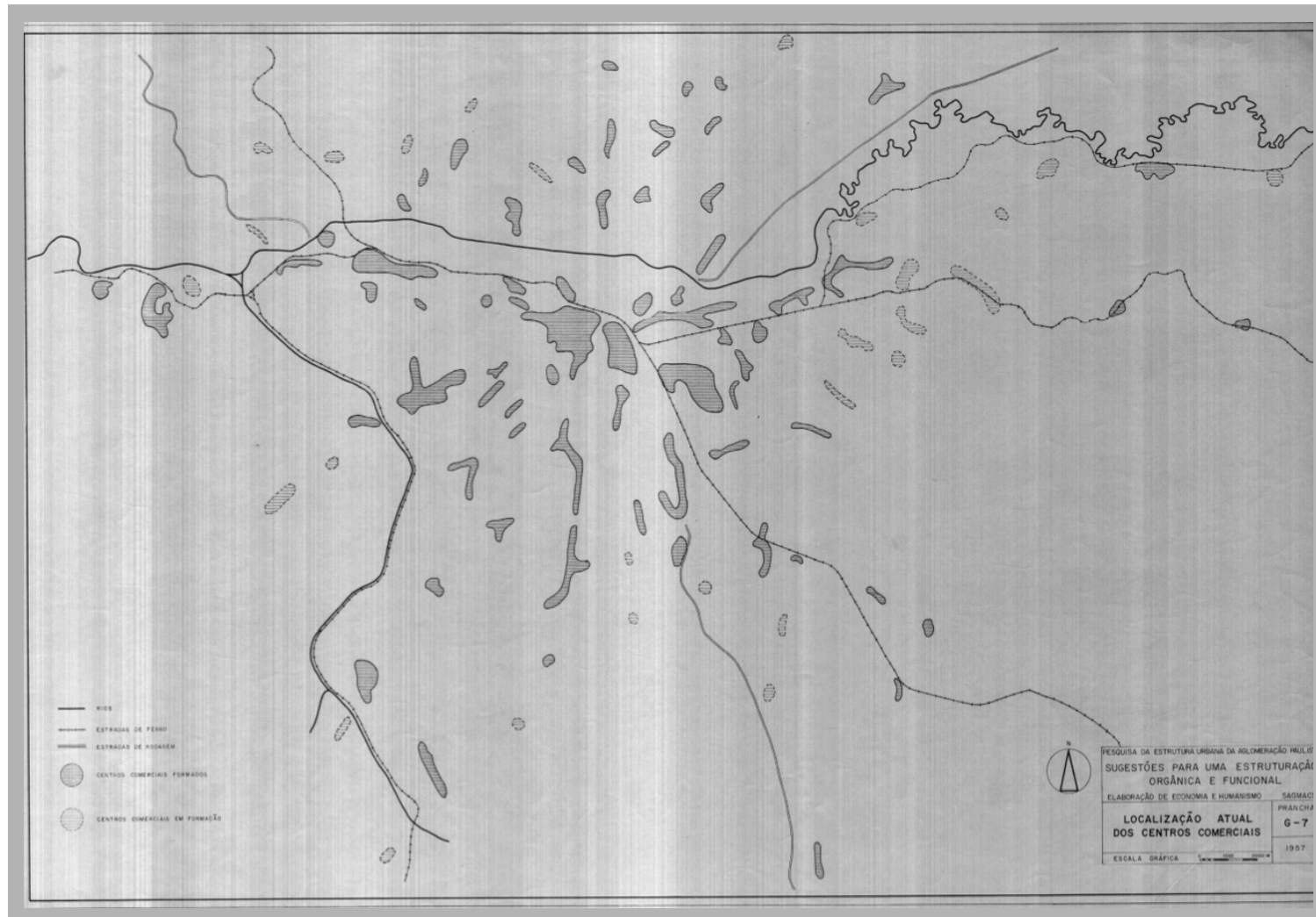

Figura 32: Reprodução da Planta G7 do EUAP com as manchas de localização dos centros comerciais na Aglomeração Paulistana em 1957.

Fonte:

SAGMACS. Estrutura Urbana da Aglomeração Paulistana. 1958 Disponibilizado pelo Setor Audiovisual da Biblioteca da FAU USP

$\mathrm{Na}$ quinta parte do relatório - "conclusões e sugestões", as diretrizes apresentadas pela SAGMACS são elaboradas para uma cidade com capacidade para uma população que atingiria, no máximo, 12 milhões de habitantes, numa área efetiva de $600 \mathrm{~km}^{2}$.

${ }^{220}$ O relatório tece em sua última parte uma crítica aos trabalhos de planejamento anteriormente pensados para São Paulo, apontando que a base estruturada pelos planos elaborados era de uma "cidade caracteristicamente mononucleada organizada em função de um único centro" (op. Cit., Parte V, p. 9). 
Apontando as diretrizes para o futuro da cidade, o estudo traça perfis e faz considerações sugerindo diretrizes para serem adotadas em cada uma das unidades elementares, de forma a descongestionar o centro da cidade e contribuir com uma cidade poli-nucleada, ou seja, multipolar. Sugere ainda que o centro de serviços já fixado, bem como as ligações com os loteamentos que constituem a zona residencial da unidade, sejam descongestionados, pensando no incentivo a novas centralidades.

Contrastando com o ambiente de concentração econômica e disparidade entre o centro polarizado e a periferia desassistida, exposto pelo estudo da "Estrutura Urbana da Aglomeração Paulistana", no mesmo período de realização do mesmo a equipe da SAGMACS no Rio de Janeiro foi contratada para realizar uma pesquisa sobre as condições de vida nas favelas cariocas.

O estudo "Aspectos Humanos da Favela Carioca" foi realizado no final dos anos 1950, pela equipe da SAGMACS, ligada ao escritório do Rio de Janeiro, que era chefiado pelo Prof. José Arthur Rios e tinha forte ligação com a Fundação Leão XIII, instituição vinculada à igreja católica, que contava com a participação do bispo D. Helder Câmara. Este estudo foi publicado em 1960 nos jornais O Estado de São Paulo e A Tribuna da Imprensa, em suplementos especiais que levavam o nome do trabalho realizado pela SAGMACS.

A pesquisa durou quase três anos (1957-1959) e consistia num trabalho aprofundado, que fosse capaz de fornecer dados concretos e novos sobre esta forma de ocupação e a precarização da cidade. A pesquisa recorreu à observação, combinada com uma análise secundária de dados, e utilizou os dados estatísticos disponíveis nos organismos oficiais, cabendo à equipe uma revisão aprofundada dos mesmos. Num primeiro momento, foram conduzidos 16 estudos de caso, apresentados na "parte geral" do relatório; em seguida a investigação, através da observação direta concentrada primeiramente em duas favelas Parque Proletário da Gávea e Barreira do Vasco, e, posteriormente, ampliando-se para um total de sete favelas. Essa segunda etapa é apresentada na "parte específica" do relatório. Assim, a metodologia apontava para uma pesquisa construída sobre estudos de casos aprofundados e não a partir de uma amostra representativa da população. 


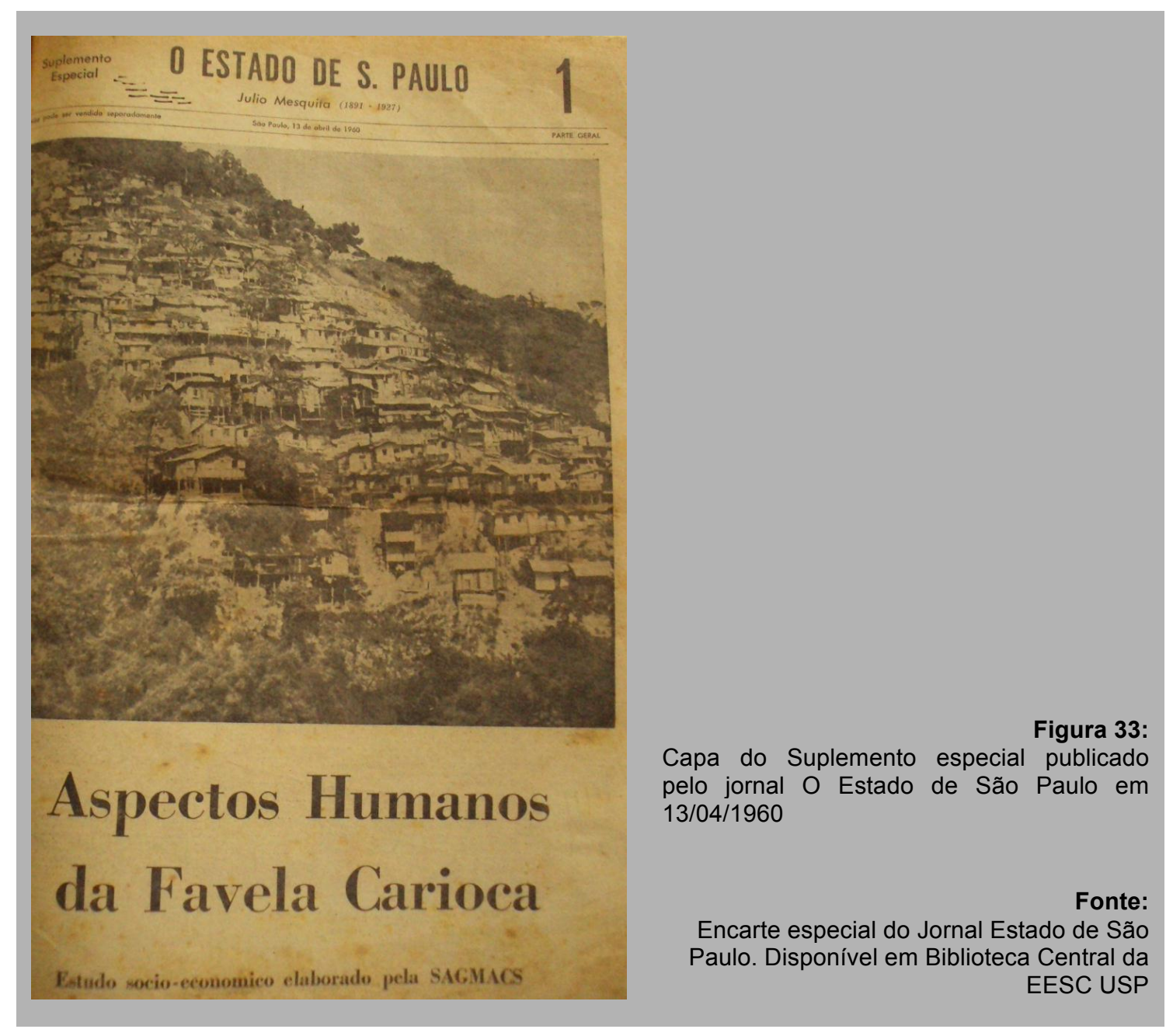

A representação gráfica e visual ganhou importância nesse estudo, ao contrário da "Sondagem" realizada dez anos antes em São Paulo, pois no mesmo nota-se a presença de muitos gráficos elucidativos e quase nenhum mapa ou imagem dos objetos investigados. A nosso ver, a presença de gráficos, croquis e esquemas, com sugestões de ocupação de espaços destas favelas, é um ponto que mostra o distanciamento da SAGMACS em relação a sua fase inicial e deixa claro o incremento do trabalho dos arquitetos urbanistas, que ganham maior peso do que nos anos iniciais da equipe. Isto porque, ao contrário do primeiro trabalho da SAGMACS realizado em São Paulo, em 1947, na pesquisa "Aspectos humanos da favela carioca" os pesquisadores realizaram planos e esboços dos espaços ocupados pelas favelas, o que permitiu situá-las a partir de fotos aéreas e com a ajuda dos esclarecimentos trazidos pelos geógrafos. 


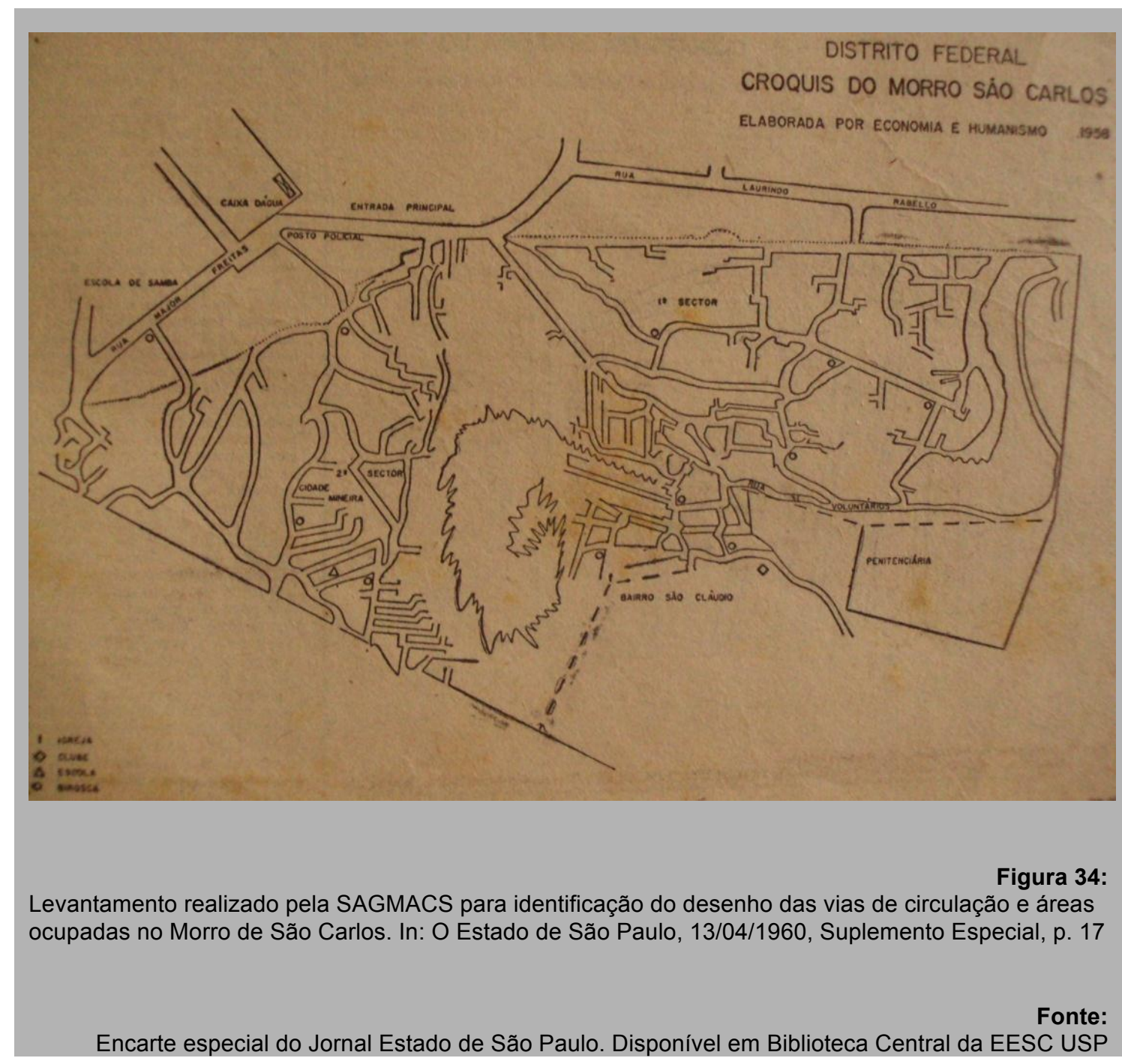

A apresentação do trabalho foi feita em duas publicações dos jornais citados, uma chamada de Parte Geral e outra de Parte Específica. A parte geral se dividia em três partes: a primeira, em que se apontavam os aspectos gerais, a metodologia empregada e a análise demográfica sobre as favelas cariocas. A segunda parte do estudo apresentava um histórico sobre a caracterização e a origem das favelas, a implantação e os problemas de conjunto, seguindo-se com capítulos em que se apontavam os aspectos levantados empiricamente, como: o barraco, o nível sanitário, a aplicação de medicina popular, a instrução dos moradores da favela, as formas de solidariedade entre os moradores, a recreação, a vida religiosa, a delinquência e a vida na favela. Na terceira e última parte do estudo era apresentado um capítulo específico intitulado de "As Soluções", e um outro de conclusões. 


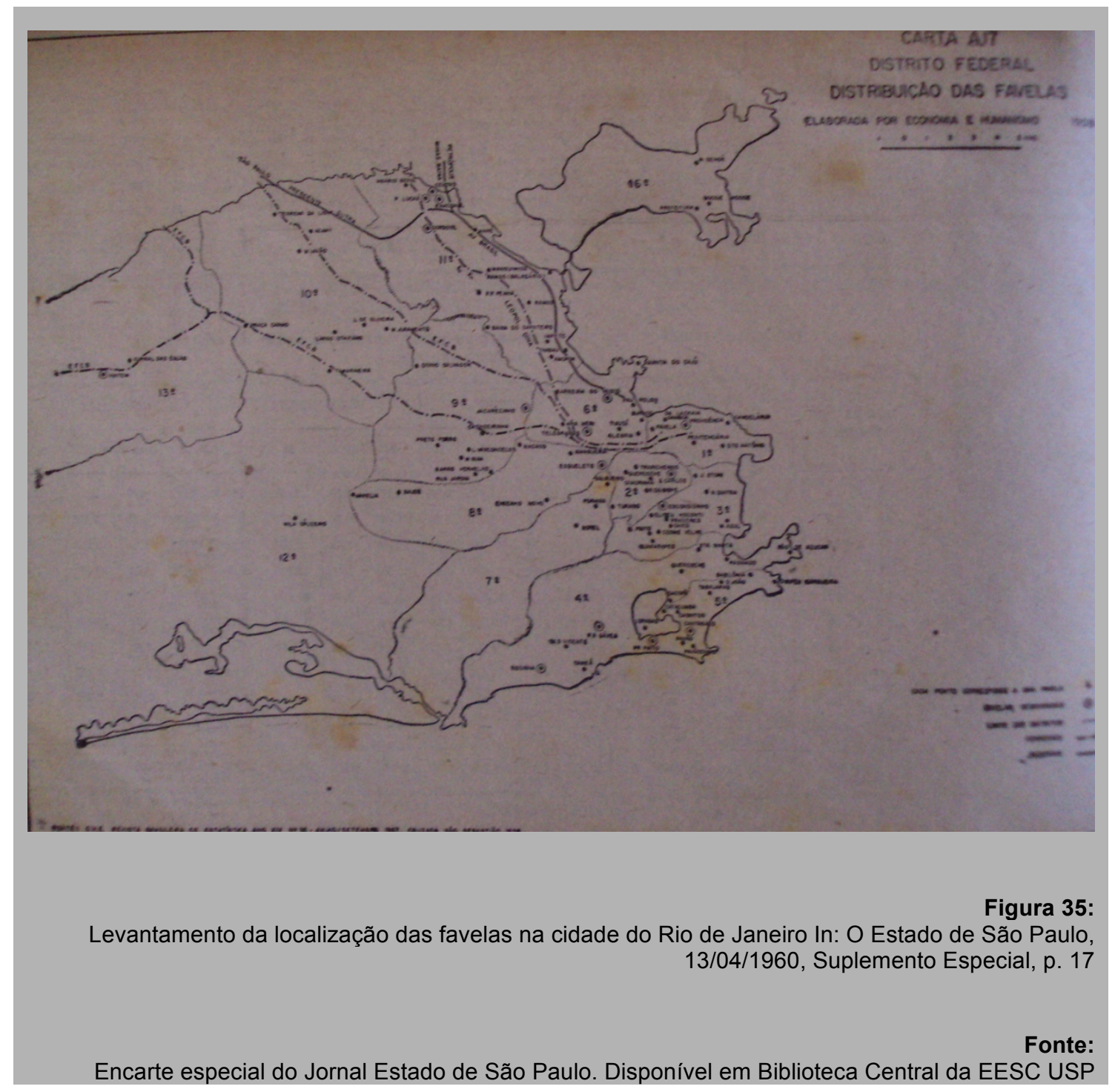

No suplemento que trazia a Parte Específica, apontava-se para outras três partes. A primeira, sobre Família, Educação e Delinquência nas Favelas, apresentava três capítulos sobre os temas tratados, mostrando dados estatísticos, as impressões dos pesquisadores e fotos ilustrativas. A segunda parte: Os processos da demagogia na Favela, trazia os aspectos da vida política e da participação dos eleitores moradores da favela nos processos eleitorais, apontando-se para a presença de lideranças, de militantes engajados e também de ações populistas feitas por alguns candidatos e pessoas ligadas a partidos políticos, que visavam os votos da população favelada. $A$ terceira parte: A Urbanização do Distrito Federal e sua repercussão sobre o problema das favelas, trazia a análise do histórico de urbanização do Rio de Janeiro e dos planos 
implementados que visavam ao desenvolvimento urbano e ao provimento de moradias para a população, apontando que havia poucas ações oficiais de tratamento para resolver a questão das favelas cariocas. O estudo termina apontando soluções, a curto e médio prazos, para os problemas levantados.

A equipe de pesquisa foi orientada pelo Pe. Lebret, dirigida tecnicamente pelo Prof. José Arthur Rios, que, após o fim deste trabalho, recebeu convite para dirigir o SERPHA (Serviço Especial de Reabilitação das Favelas e das Habitações Insalubres), organismo governamental criado no Rio quatro anos antes para gerir o problema das favelas, o que revela que o estudo feito pela SAGMACS ganhou notoriedade e reconhecimento do poder público. Além de Rios e Lebret, o estudo teve como coordenadores os sociólogos Carlos Alberto Medina e Ailza Barbosa de Araujo e o arquiteto Hélio Modesto. A equipe de pesquisadores era formada por cerca de 15 pessoas, e os desenhos couberam a Maria Cândida Pedrosa de Campos.

Segundo Valladares (2005, pp. 103-105), a nova perspectiva política introduzida por Arthur Rios concretizou-se através de um decreto de 1961, que pedia às favelas que se organizassem em associações de moradores, para permitir um diálogo melhor com as instâncias de administração e as agências de serviços, levando a um acordo formal assinado entre associações e o SERPHA, com a finalidade de contra-atacar as práticas clientelistas anteriores. Porém, suas ações à frente do SERPHA foram bastante discutidas, tendo o órgão sido considerado como manipulador e criticado por sua aliança com a direita, destinada a controlar a população das favelas com o auxílio da máquina do Estado. De fato, Carlos Lacerda tinha dividido a cidade em 23 regiões administrativas, integrando as favelas às mesmas, de modo a transformá-las em campos de clientela eleitoral.

Os apontamentos de Valladares (2005) sobre o "Aspectos Humanos da Favela Carioca" revelam que este trabalho elaborado pela SAGMACS teve repercussão bem mais significativa do que a "Sondagem" realizada para São Paulo. A nosso ver, isso se deve ao fato do trabalho da equipe carioca ter trazido alguns apontamentos de forma a tentar solucionar o problema da favela na cidade do Rio de Janeiro. Porém, percebe-se, nos seus aspectos metodológicos, a manutenção da matriz fundadora da SAGMACS, que tinha como principal meio de pesquisa o levantamento empírico, que inseria o pesquisador diretamente com seu objeto de estudo e a busca pelos dados estatísticos.

Lembramos que, no mesmo período em que o escritório da SAGMACS no Rio de Janeiro realizava esta pesquisa, a equipe de São Paulo participava do estudo da "Estrutura Urbana da Aglomeração Paulistana", conforme apontamos há pouco. Esta coincidência 
de datas apenas confirma a consolidação do trabalho da SAGMACS como importante instituição de pesquisa e consultoria no campo do urbanismo e do planejamento urbano e regional, superando-se a fase inicial da pesquisa sociológica e incorporando estes aspectos do urbanismo. Verifica-se também que, concomitantemente à elaboração dos trabalhos desenvolvidos no Rio de Janeiro e em São Paulo, a SAGMACS atuava em Belo Horizonte, realizando a pesquisa da estrutura urbana da cidade, que, mais tarde, resultou na entrega do relatório com a minuta para a lei do Plano Diretor da capital mineira.

Este trabalho foi contratado pela Prefeitura de Belo Horizonte em agosto de 1958, pelo prefeito Celso Melo Azevedo, quando a SAGMACS finalizava o contrato com a Prefeitura de São Paulo. O objetivo do trabalho era repetir em Belo Horizonte a pesquisa realizada para São Paulo, porém, dando maior ênfase para a compreensão da estrutura urbana da cidade, "para um conhecimento ordenado e científico dos problemas enfrentados pela população belo-horizontina" (SAGMACS, 1963, p. 10).

O trabalho foi finalizado em fevereiro de 1959, já na gestão do prefeito Amintas de Barros, e resultou em "uma série de conclusões e recomendações, que integraram um relatório de cerca de 300 páginas, acompanhado de 60 mapas." (ibid., ibidem). Ao contrário do estudo da "Estrutura Urbana da Aglomeração Paulistana", que não foi concluído e sequer publicado pela Prefeitura, em Belo Horizonte o estudo rendeu à SAGMACS uma nova contratação no início dos anos 1960, quando a equipe retornou à capital mineira para a elaboração de um Plano Diretor para a cidade.

Apesar do "Relatório do Plano Diretor de Belo Horizonte" ter sido elaborado como desdobramento da pesquisa da "Estrutura Urbana" da cidade, que seguiu a mesma metodologia do trabalho desenvolvido para a Prefeitura de São Paulo, colocamos este trabalho dentro do que chamamos de terceira e última fase de atuação da equipe de Lebret no Brasil, tanto, devido à cronologia de épocas, visto que a elaboração do Plano Diretor foi finalizada em 1963, quanto pelas diferenças existentes na própria estrutura da SAGMACS. Neste momento, a instituição já havia sido transformada numa cooperativa de técnicos e, além disso, as questões metodológicas passavam por aperfeiçoamentos que distanciavam a equipe brasileira do Centre d'Économie et Humanisme na França, passando assim a atuar com mais autonomia, inclusive em relação ao religioso dominicano.

A alteração nos procedimentos metodológicos pode ser notada quando Benevenuto aponta que (ibid., p. 15) "a conceituação de Plano Diretor no trabalho realizado por SAGMACS corresponde àquela definida no Seminário de Técnicos em Planejamento Urbano da América Latina". Este Seminário foi realizado em Bogotá, em outubro de 1958, 
e contou com a participação dos engenheiros Antônio Bezerra Baltar e Mario Laranjeira de Mendonça, membros da SAGMACS, que representavam entidades brasileiras.

Assim, o "Relatório do Plano Diretor" dividiu o trabalho em duas partes. Na primeira, "o Plano Urbano", documento básico de orientação do crescimento físico da cidade, deveria ser integrado numa perspectiva de longo prazo e apresentar as normas e diretrizes para regulamentação das atividades e ocupação do solo urbano, "através de uma distribuição correta de ocupação e usos e da implantação de um sistema viário adequado" (ibid., ibidem). A segunda parte referia-se à minuta para o projeto de lei apresentado para disciplinar o plano urbano da cidade, apontando que,

O Plano Diretor é um documento essencialmente dinâmico. Sem perder a sua característica de diretriz, é um documento a ser continuamente revisto e adaptado às novas realidades. Nunca corresponderá, portanto, ao traçado final de uma cidade, a ser obtido num futuro definido. [...] $\mathrm{O}$ Plano Diretor perderá sua utilidade e eficiência na medida em que for estático e definitivo. (ibid., p. 16).

Deve, ainda que evitando visualizar um traçado final da cidade, ter suas bases num modelo desejável de equilíbrio urbano, correspondente a uma situação ótima de distribuição de usos e funções. [...] Não será um retrato estático da cidade futura, mas um conjunto de sistemas e relações, adotadas por uma adequação às necessidades e às possibilidades econômicas e humanas, correspondendo à organicidade e à economicidade mais objetivas. (ibid., p. 17).

No período de elaboração do Relatório, a cidade de Belo Horizonte possuía cerca de 683.908 habitantes. Havia sofrido crescimento populacional intenso na década anterior, tendo a população de 1950 , estimada em 360.000 pessoas, dobrado em 1960. O crescimento intenso era, segundo Singer (1968), reflexo da expansão industrial sofrida em todo o país e especialmente em São Paulo e no Rio de Janeiro.

A exemplo das diretrizes apontadas na parte final do estudo da "Aglomeração Paulistana", a SAGMACS critica a concentração e "monopolarização crescente", propondo, como forma de contrabalançar tais problemas, "a definição de sub-centros comerciais, localizados estrategicamente de forma a possibilitar a formação de unidades auto-suficientes na cidade." Assim, "descongestiona-se o centro principal e diminuem-se os problemas de transporte, encurtando as distâncias a serem percorridas para o 
atendimento de um certo número de necessidades." (SAGMACS, ibid., p. 22).

Deste modo, sugere-se que a cidade de Belo Horizonte passe a ser organizada "em unidades quase auto-suficientes, que em conjunto serão polarizadas pelo centro principal, contendo em acréscimo aquelas funções das quais somente a dimensão total da cidade tem necessidade." (op. Cit., ibidem). Para tanto,

O tecido urbano das unidades seria por sua vez diferenciado, numa forma diversa: os equipamentos comerciais e de serviços do escalão imediatamente inferior não estariam concentrados em novos núcleos, mas sim linearmente, ao longo das chamadas ruas "comerciais", cuja definição obedeceu também aos dados fornecidos pela pesquisa, no que se refere às ruas comerciais existentes. Com esta política, será admitida uma malha de ruas comerciais, definindo o que poderíamos chamar de subunidades.

\section{$[\ldots]$}

A lei proposta utilizou como sistema, no que se refere à ocupação e à utilização dos lotes, a definição de índices numéricos que relacionam a área do lote com a área a ser ocupada com construções e com a área total construída. Não estabeleceu, portanto, gabaritos de altura, mas sim relações, que darão a necessária variedade à paisagem urbana e a possibilidade de adoção dos partidos arquitetônicos mais adequados a cada situação. (ibid., ibidem, pp. 23-25).

Um ponto que chama a atenção no trabalho é a preocupação com a função social da propriedade urbana e uma sugestão para implantação do imposto progressivo, de modo "que um certo número de moradores não venha a conservar em seu poder um número maior de lotes do que lhe seria permissível manter, na perspectiva de patrimônio familiar." Assim, "procurando atender a esses problemas, a Lei proposta estabelece alguns índices de taxação, [...], visando uma maior movimentação no mercado de lotes, pelo aumento da oferta e pelo combate à especulação. (ibid., ibidem., pp. 26-27).

Abordando aspectos do planejamento regional e demonstrando preocupação com a questão, o relatório aponta que "torna-se necessário para complementar o Plano Diretor a criação de um sistema de integração efetiva dos poderes públicos dos municípios interessados." (ibidem, p. 28). Como "a recomendação mais importante que poderia ser feita no relatório", o mesmo sugere que "o poder público municipal de Belo Horizonte inicie imediatamente as gestões para complementar o seu Plano Diretor pelo entrosamento orgânico e efetivo com os demais municípios que se integrarão na área 
metropolitana da capital." (ibid., ibidem).

A fim de se legitimar a efetivação e aprovação do projeto de lei, a SAGAMACS apresenta como anexo I do "Relatório do Plano Diretor" o texto da introdução ao estudo urbanístico da pesquisa da "Estrutura Urbana de Belo Horizonte", realizado em 1958, que deu origem ao contrato para realização do estudo para o Plano Diretor. Além de parte do estudo de 1958, aponta, num segundo anexo, um roteiro para a organização do Plano Diretor, após sua aprovação junto à Câmara Municipal.

Este roteiro foi escrito por Antonio Bezerra Baltar e Celso Lamparelli, sendo que, de forma mais resumida, repete o conceito do Plano Diretor empregado pela SAGMACS e apresenta, em forma de diretrizes divididas em políticas, sociais, econômicas e físicas, os objetivos, princípios e normas do Plano. Aponta ainda que o Plano visa atingir, nas diretrizes sociais, a "solução dos problemas de habitação, educação, saúde, desenvolvimento cultural e espiritual da população regional e urbana"; e nas diretrizes econômicas, "o pleno emprego dos fatores da produção, elevação das receitas familiares, distribuição mais justa da renda regional, equilíbrio e estabilidade econômica dos organismos públicos".

A minuta do projeto de lei se apresenta dividida em cinco títulos: I) Da área de Expansão Urbana; II) Dos loteamentos, apontando quatro capítulos que definem o processo de aprovação dos mesmos, a documentação necessária, a forma de distribuição dos lotes e de nomeação dos logradouros públicos; III) Do uso, da ocupação e do aproveitamento dos edifícios e terrenos; IV) Do sistema viário e áreas verdes; V) Dos tributos e sanções e da licença de localização, parte em que a SAGMACS aponta para alíquotas progressivas do imposto territorial.

Assim, conforme já havíamos colocado neste capítulo, o "Relatório do Plano Diretor de Belo Horizonte" é um trabalho que, diferentemente dos estudos realizados para a Prefeitura de São Paulo (1958) e para o governo do Estado de São Paulo (1955), que não foram concluídos, teve destino diferente, sendo apresentado e discutido na Câmara Municipal nos anos de 1963 e 1964.

Porém, segundo Oliveira (2015, pp. 338-339), ainda que "o plano diretor sugerido pela SAGMACS constitui um dos esforços de maior monta da Prefeitura de Belo Horizonte para estabelecer um novo marco para o ordenamento urbano da cidade", o mesmo não foi aprovado pela Câmara Municipal, o que, mais uma vez, mantém o trabalho da SAGMACS dentro do campo das proposições, sem que as ideias e diretrizes defendidas pelo grupo tenham sido efetivadas e implantadas nas cidades brasileiras. 
CONCLUSÕES

A ATUAÇÃO DE LEBRET E DA SAGMACS: IDEIAS E CONTRIBUIÇÕES 

Uma tese de doutorado deve sempre propiciar um novo olhar sobre o tema pesquisado, trazendo novas contribuições em relação ao objeto estudado, de modo a possibilitar o aprimoramento do assunto a partir de novos questionamentos e, consequentemente, de novas pesquisas. Com este objetivo, nosso trabalho buscou elucidar questões dentro do quadro de formação do urbanismo no Brasil, contextualizar a historiografia do planejamento urbano e regional, mas, principalmente, estudar e esclarecer melhor sobre a atuação de Lebret e da SAGMACS no que tange a suas ideias, estudos e planos, que renderam a sua equipe aproximações e contribuições ao quadro do urbanismo e do planejamento regional no Brasil.

$\mathrm{Na}$ introdução desta tese mencionamos a visão de Bernard Lepetit (2004) quanto às atribuições do pesquisador que se propõe a investigar a história urbana e do urbanismo. Segundo o autor, realizar uma pesquisa de caráter historiográfico consiste em contribuir com o incremento do debate, a formulação de novas questões sobre o assunto e o incentivo às novas pesquisas, permitindo assim retomar o objeto em estudo. Isto porque "o objeto histórico é construído, e não dado de antemão", e, sendo assim, é "o encaminhamento da pesquisa que o dá à luz e o explicita." (op. Cit., p. 205).

Durante a realização desta pesquisa, percebemos que a hipótese colocada como ponto de partida em nosso projeto para este trabalho de doutorado serviu para nos orientar no percurso deste estudo, levando-nos a recuperar, através da análise dos documentos e reconstituição dos fatos, o trabalho de Lebret e a importância de suas vindas ao Brasil. Além disso, estudamos a atuação e o período de inserção da SAGMACS como instituição de urbanismo e assessoria técnica, durante os anos 1950 e os primeiros anos da década de 1960.

Conforme já expusemos no início desta tese, o estudo sobre o ideário de Lebret e a atuação da SAGMACS vêm ganhando maior notoriedade entre os pesquisadores da história da cidade, do urbanismo e do planejamento urbano e regional. Ao longo desta tese, buscamos elucidar este quadro e tecer apontamentos na perspectiva de oferecer 
um balanço dos trabalhos que vêm sendo realizados por estes pesquisadores. Percebemos, inclusive, que há fatos que vêm sendo reinterpretados a partir das conclusões obtidas nos primeiros trabalhos realizados sobre este assunto, ao final da década de 1990 e início de 2000.

Em meio a estas reinterpretações, cabe inserir a pesquisa realizada durante nosso mestrado, que culminou com a dissertação "Urbanismo e Humanismo: A SAGMACS e o estudo da “Estrutura Urbana da Aglomeração Paulistana'”, defendida no ano de 2009. Naquele momento, os autores e pesquisadores brasileiros sobre o tema SAGMACS ou o ideário lebretiano não somavam mais do que cinco estudiosos.

Atualmente, o tema repercute entre pesquisadores das áreas de história, sociologia e ciência política, do planejamento urbano e regional, da historiografia da cidade e do urbanismo. Desta forma, este quadro mostra que, já no mestrado, nosso trabalho buscou colaborar com a inserção da SAGMACS no campo de interesse de novas pesquisas e estudos historiográficos, que renderam novas interpretações e elucidações, bem como trouxeram à tona novas questões sobre a atuação do padre Lebret e da SAGMACS no campo do urbanismo e do planejamento urbano e regional no Brasil.

Estas novas questões e a possibilidade de melhor elucidação do ideário lebretiano nos levaram a questionar, durante o doutorado, se poderíamos atribuir a Lebret a formação de um método de trabalho no campo do urbanismo, através da atuação da SAGMACS. Lembramos, conforme já exposto, que esta hipótese serviu como um alimentador do nosso percurso de pesquisa. Este percurso revelou para nós a forma como ocorreu a inserção do urbanismo e do planejamento regional dentro das áreas de interesse de Lebret e do Centre d'Économie et Humanisme, fatos que se deram, conforme explicitado no segundo capítulo, anteriormente à chegada do Dominicano ao Brasil e à fundação da SAGMACS, em 1947.

Com isso, nos deparamos com o questionamento proposto, ou seja, se é possível o ideário de Lebret e as concepções, ideias e propostas desenvolvidas pela SAGMACS serem consideradas como pertencentes ao campo do urbanismo e do planejamento regional. Analisando o quadro de formação do campo disciplinar do urbanismo, no início do século XX, sobretudo a partir das concepções dos arquitetos, engenheiros, geógrafos e sociólogos franceses, pudemos inserir o trabalho desenvolvido por Lebret e alguns dos organismos vinculados ao Économie et Humanisme, como a SAGMACS no Brasil, como pertencente a este campo de atuação técnica e profissional, pois, no meio técnico francês, o urbanismo foi disseminado como uma ciência generalista, capaz de dialogar e unir diferentes disciplinas. 
Assim, apontamos no primeiro capítulo que as observações de urbanistas como Agache (2014), Bardet (1990) e Lavedan (1926), e os estudiosos do urbanismo Bruant (2001), Gaudin (2014) e Lacaze (1993) demonstram que a visão de mundo urbano de Lebret o aproximou dos membros do Économie et Humanisme, por compartilhar com eles da mesma visão a respeito do urbanismo, ou seja, deste campo disciplinar constituir-se a partir dos levantamentos estatísticos e da realização de diagnósticos que permitiriam o entendimento dos problemas da cidade, independentemente de resultarem em um plano ou proposta para o tratamento físico de uma área ou da cidade como um todo.

Esta elucidação relativa sobre a inserção de Lebret e da SAGMACS dentro do campo do urbanismo é, a nosso ver, uma das contribuições desta tese. Isto porque, apesar de parte significativa dos trabalhos e pesquisas realizadas sobre o tema, no Brasil, se situar na área da história do urbanismo e do planejamento urbano e regional, esses trabalhos estudaram apenas um ou outro trabalho realizado pelo grupo que atuou entre $1947 \mathrm{e}$ 1964. E, embora estes trabalhos visassem elucidar a formação do quadro do urbanismo no Brasil e a contribuição da SAGMACS a este campo de trabalho, entender se a atuação de Lebret e sua equipe poderiam ser consideradas como pertencentes ao campo do urbanismo e do planejamento urbano e regional continuava sendo uma questão em aberto.

Assim, o percurso realizado durante nossa pesquisa demonstrou que a SAGMACS atuou dentro deste campo disciplinar, técnico e profissional, e, mais do que isso, que a inserção de Lebret junto ao campo do urbanismo e do planejamento regional não se deu somente através de sua atuação junto à SAGMACS. Desde a França, inclusive fora do grupo fundado por ele em 1941, quando docente na École de cadres d'Uriage, Lebret propôs a criação de uma disciplina para estudar a cidade, através do projeto intitulado "La Cité: Projet d'un programme d'enquête et d'un programme d'action"221. Esta vinculação é também anterior à criação do CREDOC, IMSAC e da SAGMA, que se deu a partir de 1945, para responder às demandas do Ministère de la Reconstruction et Urbanisme.

Porém, analisando o plano de trabalho de Lebret junto à École d'Uriage, em que o Dominicano aponta que sua pesquisa se dividia em cinco partes, buscando apontamentos sobre 1) a importância da noção de cidade, 2) a organização do trabalho de pesquisa, 3) a formação de quadros, 4) Os meios sociais, 5) os principais problemas e 6) os elementos de solução, não é possível constatar aspectos de inovação quanto ao

\footnotetext{
${ }^{221}$ O documento foi consultado junto a Pasta AN45 AS67.
} 
que se praticava como procedimentos de investigação da cidade, dentro do campo do urbanismo na França, na primeira metade do século XX.

Encontramos, assim, um ponto que nos permitiu demonstrar que, embora Lebret tenha atuado dentro do campo do urbanismo e do planejamento regional, seu engajamento nesta área, através das instituições vinculadas ao Centre d'Économie et Humanisme, como a SAGMACS, estava ligado à adoção de procedimentos para a compreensão dos problemas da cidade e realização de diagnósticos que permitiram apontar diretrizes para o desenvolvimento econômico, social, urbanístico e regional em alguns dos trabalhos realizados por estas instituições, não havendo, portanto, a criação de um método de trabalho no campo do urbanismo e do planejamento regional, mas sim o aperfeiçoamento de alguns dos procedimentos metodológicos, conforme apontamos nos dois primeiros capítulos desta tese.

A constatação alcançada através do nosso percurso de pesquisa, que incluiu um estudo sobre a fundação, funcionamento e tentativas de criação e aperfeiçoamento dos métodos do Économie et Humanisme de Lebret, durante a primeira década de atuação do grupo, nos levou então a uma nova indagação: se Lebret e a SAGMACS não criaram um método de trabalho no campo do urbanismo e do planejamento regional, qual teria sido então a contribuição deste movimento, e o que, de fato, houve de inovador na condução dos trabalhos da equipe acerca da questão urbana no Brasil?

Temos então os apontamentos trazidos durante os dois últimos capítulos desta tese. No terceiro capítulo, apresentamos o quadro de aproximação de Lebret com o Brasil e a tentativa de angariar simpatia junto aos meios empresarial, político e intelectual brasileiros ao trabalho realizado nos cinco primeiros anos do Centre d'Économie et Humanisme, na França. Deste movimento resultou a fundação da SAGMACS, em julho de 1947, com sede na cidade de São Paulo, que nos anos 1950 se desdobrou com a criação de novas equipes no Rio de Janeiro, no Recife e em Belo Horizonte, cidades que também abrigaram escritórios do grupo de Lebret no Brasil.

Antes destes apontamentos, analisamos as formas como se deu a inserção de Lebret junto ao meio social, intelectual e empresarial, além da sua aproximação com o catolicismo progressista, em sua primeira vinda à cidade de São Paulo, pois foi a partir desta inserção que Lebret conquistou adeptos para apoiar a fundação da SAGMACS. Foi preciso, então, conhecer o conteúdo abordado pelo religioso francês no curso de pósgraduação em Economia Humana, ministrado junto à ELSP, entre os meses de abril e julho de 1947. 
No referido curso matricularam-se mais de cinquenta alunos, os quais, por quase quatro meses, puderam conviver com o Dominicano e conhecer suas impressões sobre a economia, os problemas decorrentes de um planejamento voltado estritamente para o lucro, a acumulação de capital e a ameaça do avanço do socialismo e do comunismo. Neste curso Lebret apresenta a contribuição de Marx na formulação de um método de análise da conjuntura social e econômica, o que perturba alguns dos estudantes, mas rende a outros o entendimento sobre o marxismo como um método científico, afastando assim alguns dos receios e preconceitos existentes entre políticos e empresários mais conservadores. Disto rendeu sua aliança com o engenheiro Lucas Nogueira Garcez, que, ao assumir o governo do estado em 1951, possibilitou o retorno de Lebret ao Brasil no ano de 1952, e, mais do que isso, rendeu à SAGMACS um contrato para realização de estudo para a CIBPU, entre os anos de 1952 e 1955, tendo continuidade num segundo contrato, realizado entre 1955 e 1958.

Sobre a segunda vinda de Lebret ao Brasil, em 1952, para atuar num trabalho de planejamento regional para o estado de São Paulo, há novas questões para se compreender sobre a atuação da SAGMACS. Isto porque, com o vínculo entre Lebret e Garcez, estabelecido em função de sua primeira estada no Brasil, a contratação da SAGMACS para a realização de uma pesquisa desta monta rendeu ao grupo o início do seu segundo período de atuação. Verificamos então o que mudou em relação à SAGMACS de 1947 e percebemos que os atores envolvidos nos trabalhos, a partir de 1952 , foram os que permaneceram em seus quadros por maior tempo ${ }^{222}$.

Além disso, nota-se, a partir desta segunda fase de atuação, a abertura da SAGMACS para o engajamento de jovens recém-formados e também estagiários ${ }^{223}$ dos cursos de Arquitetura e Urbanismo, Engenharia e Geografia, ampliando-se assim o quadro técnico para além de economistas, advogados e sociólogos, com a inclusão de técnicos e aprendizes junto à equipe de Lebret. Verifica-se, assim, a partir desta análise da formação dos quadros técnicos da SAGMACS, outra área de atuação de Lebret no Brasil: a formação de profissionais e quadros que atuaram no campo do urbanismo e do planejamento regional nos anos 1950 e 1960 e, após o término do órgão, deram

\footnotetext{
222 Apresentamos o quadro de técnicos e demais colaboradores da SAGMACS no capítulo 4, quando apontamos sobre os trabalhos realizados pelo grupo.

${ }^{223}$ No quarto capítulo desta tese apontamos as equipes formadas pela SAGMACS e o trabalho em que estes técnicos atuaram. Angelo (2010, p. 174) aponta alguns dos nomes de arquitetos recém-formados que para ela tinham em comum com Lebret as filiações técnicas, religiosas e políticas. Coincidentemente, são estes profissionais que mais tempo permaneceram nos quadros da equipe.
} 
continuidade a suas carreiras, tanto em outras equipes de assistência técnica, quanto em órgãos públicos e na atividade docente em universidades.

Seria esta mais uma contribuição importante dada por Lebret e pela SAGMACS à formação do quadro do urbanismo no Brasil, pois, em quantidade de pessoas engajadas nas pesquisas desenvolvidas, os trabalhos envolviam grande número de profissionais e técnicos das áreas da arquitetura, direito, economia, engenharia, geografia e sociologia. Alguns destes profissionais tiveram atuação pontual em um ou outro trabalho, outros participaram de alguns deles, enquanto que Lamparelli, Whitaker, Clementina de Ambrósis, Domingos Theodoro de Azevedo Neto, Antonio Cláudio Moreira, Luiz Carlos Costa e Mario Laranjeira de Mendonça seguiram nos quadros da equipe até o término de suas atividades.

Sobre o trabalho de Lebret na formação de quadros para a atuação no campo do urbanismo e do planejamento regional no Brasil, considerado como sendo uma de suas contribuições, há que se verificar também por que isto foi possível. No quarto capítulo desta tese apontamos para os aspectos que nortearam a estruturação do campo do urbanismo e do planejamento regional, tanto como uma atribuição privilegiada do Estado, quanto como função staff ${ }^{224}$, em que se abriu campo, desde a década de 1940, para a inserção dos órgãos de assistência técnica nos municípios, governos estaduais e também nos órgãos do governo federal. E foi dessa forma, junto aos órgãos de assistência técnica, que a SAGMACS se inseriu no quadro do urbanismo no Brasil, a partir de sua segunda fase de atuação, iniciada em 1952.

O percurso demonstrado no capítulo quatro aponta que, no Brasil, durante a segunda fase de atuação da SAGMACS, na década de 1950, ocorreu tanto a institucionalização dos órgãos de assistência técnica voltados ao planejamento urbano e regional, como também a preparação da instituição de Lebret para responder às demandas do desenvolvimento urbano, econômico e do planejamento regional no país. Verificando o escopo de trabalhos desenvolvidos e as equipes formadas em torno destes contratos, pudemos entender que os estudos dos "Problemas de Desenvolvimento. Necessidades e Possibilidades do Estado de São Paulo" (1952-1955) e da "Estrutura Urbana da Aglomeração Paulistana" (1956-1958) propiciaram a formação de uma grande equipe para atuar na SAGMACS, tendo os estudos realizados para a prefeitura de São Paulo engajado cerca de noventa pessoas, sendo os que mais demandaram profissionais. $O$ que mostra que a SAGMACS passava, entre os anos de 1952 e 1956, por um processo

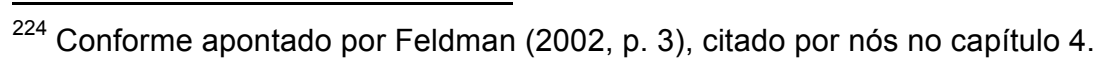


de formação de seus quadros, e, para tanto engajava seus agentes não só na realização da pesquisa, mas também na formação técnica.

Assim, o estudo que realizamos durante o quarto capítulo, recuperando o percurso realizado por Lebret no campo do urbanismo e do planejamento regional, bem como sua atuação junto às equipes da SAGMACS, seria outra contribuição desta tese. Isto porque, até então as pesquisas realizadas acerca dos temas ideário lebretiano e atuação da SAGMACS analisaram trabalhos pontuais realizados pela equipe de Lebret, como fizemos em nossa dissertação de mestrado, enquanto nesta tese analisamos a atuação da SAGMACS em todo o seu período de trabalho. Com isso, foi possível trazer um apontamento panorâmico do que foi esta instituição, no que ela atuou e como contribuiu para a formação do quadro do urbanismo no Brasil.

Foi preciso destacar ainda a atuação do personagem Louis Joseph Lebret no quadro de estrangeiros que se sobressaíram em trabalhos realizados no campo do urbanismo e do planejamento regional no Brasil, mostrando que existem distinções entre Lebret e os demais consultores estrangeiros, tanto devido ao tempo de permanência ${ }^{225}$ do religioso francês em nosso país, quanto pelo número de trabalhos realizados por ele através da SAGMACS.

Nas inúmeras vindas ao Brasil, a formação das equipes junto à SAGMACS e os trabalhos realizados para diferentes cidades, órgãos públicos estatais e empresas privadas ultrapassam, conforme demonstrado no último capítulo, os empreendimentos realizados pelos demais urbanistas e pesquisadores estrangeiros. Ainda que parte dos estudos e trabalhos realizados por Lebret e a SAGMACS não tenham sequer saído do papel e, em alguns casos, "sido engavetados" pelos administradores de plantão, o número de trabalhos realizados é maior do que os feitos por urbanistas franceses como Antoine Bouvard, Alfred Agache, Le Corbusier e pelos pesquisadores norte-americanos, destacando-se Robert Moses e Preston James, que atuaram no mesmo período em que o grupo de Économie et Humanisme iniciava seu trabalho no Brasil.

A partir desta verificação, coube a esta tese apontar a distinção entre os trabalhos realizados pela SAGMACS e o que era feito por demais técnicos e órgãos que atuavam no campo do urbanismo e do planejamento regional no período dos anos 1950 e 1960,

\footnotetext{
${ }^{225}$ É preciso expor que, embora utilizamos a palavra permanência para expor sobre as vindas e estadas de Lebret no Brasil, é preciso entender que estas não se deram de forma contínua, havendo períodos em que a estada do francês foi mais extensa do que em outros.
} 
buscando assim explicitar as principais contribuições trazidas pela atuação de Lebret e da SAGMACS dentro do quadro do urbanismo no Brasil.

O primeiro ponto a se observar quanto a estas contribuições foi o fato de que Lebret e as equipes da SAGMACS não atuaram de forma autônoma em relação ao que se realizava no Centre d'Économie et Humanisme, na França ${ }^{226}$. Ainda assim, Lebret e a SAGMACS contribuíram com a formação do urbanismo como campo técnico-profissional no Brasil, apresentando formas de atuação que aprimoraram os procedimentos de obtenção e interpretação dos dados para apresentação de um diagnóstico sobre os níveis de desenvolvimento humano e qualidade de vida, procedimentos estes que passaram a ser inseridos nas práticas de planejamento das cidades no Brasil.

Um segundo ponto que pudemos observar foi em relação às práticas que vinham sendo implementadas, principalmente no campo do urbanismo, até as décadas de 1940 e 1950, quando se apresentavam duas posições: a que colocava a urbanística e o planejamento urbano como realização de obras; e a que inseria o urbanismo como mecanismo de regulação e ordenação do espaço urbano, através da elaboração de normas, regimentos e leis. Percebemos, então, que a atuação da SAGMACS diferia de ambas, pois, nenhuma delas era capaz de enfrentar os problemas do desenvolvimento urbano a partir de uma visão de conjunto, pois tais práticas não alcançavam a compreensão da totalidade da cidade. O quadro acima somente iria se alterar a partir do aprimoramento dos procedimentos para leitura e diagnóstico do espaço urbano, realizado por Lebret e a SAGMACS, nos anos de 1950.

Neste sentido, ainda que a SAGMACS mantivesse a vinculação com o pensamento e o discurso técnico da época, de que pensar a cidade e atuar no campo do urbanismo era uma questão que cabia aos técnicos profissionais, há que se expor que a inserção da pesquisa sociológica e da pesquisa de campo, como procedimentos obrigatórios realizados nos trabalhos da equipe de Lebret, expôs maior preocupação com a questão social entre os urbanistas da época, abrindo espaço para a discussão, no campo do urbanismo e do planejamento regional, da questão do desenvolvimento econômico e dos problemas sociais encontrados nas cidades do Brasil, naquele período.

Por fim, um terceiro aspecto, de certo modo já exposto, deve-se ao fato da preocupação existente dentro da SAGMACS com a formação técnica de suas equipes, formação esta

\footnotetext{
${ }^{226}$ Importante distinguir que esta afirmação cabe até o ano de 1959, anteriormente à alteração de estatuto realizada pelos membros da SAGMACS, que, a partir da década de 1960, deixou a instituição mais autônoma em relação ao padre Lebret, que continuou sendo um supervisor dos trabalhos e da direção do Économie et Humanisme.
} 
aprimorada através da realização de cursos preparatórios na França, das Semanas Sociais realizadas pelo Économie et Humanisme, e, acentuando-se ainda mais, a partir da criação do IRFED, em 1957.

Assim, esta tese buscou trazer novos elementos para o entendimento do trabalho realizado por Lebret e pela SAGMACS. Cobrimos os quase vinte anos de atuação da equipe de Économie et Humanisme no Brasil e verificamos como foram realizados os trabalhos desenvolvidos pelo grupo; pesquisamos documentos que estavam ainda pouco evidenciados por outras pesquisas, como o curso preparado por Lebret para a ELSP, e buscamos entender as bases que permitiram à SAGMACS atuar no campo do urbanismo e contribuir com o aprimoramento do planejamento regional no Brasil. Com isso, novas questões foram suscitadas, abrindo possibilidade para a realização de novas pesquisas e estudos sobre o ideário lebretiano e as instituições vinculadas a ele, sendo assim possível reinterpretar as bases desta história.

Concluímos, por fim, conforme já explicitado, que ao realizar trabalhos de pesquisa em história urbana e social não nos tornamos autores de trabalhos finalizados, nem tão pouco de temas esgotados, mas sim, colaboradores trazendo à tona novas questões e a possibilidade de melhor reinterpretação e elucidação dos fatos que movem a história social, política, econômica e do urbanismo e planejamento urbano e regional. 



\section{REFERÊNCIAS}



ABERCROMBIE, Patrick. Planeamiento de la ciudade y del campo. Madrid: EspassaCalpe, 1936

AGACHE, Alfred Donat. La Remodélation d'une capitale: Aménagement, Extension, Embellissement. Paris: Société Coopérative des Architectes, 1932

A cidade do Rio de Janeiro: Extensão - Remodelação - Embelezamento. Paris: Foyer Brésilien, 1930

As grandes cidades modernas e seu futuro. In: GAUDIN, Jean-Pierre. O desenho e futuro das cidades - uma antologia. Rio de Janeiro: Rio Books, 2014 [63-72]

ALBERTINI, Jean Marie. L. J. Lebret. In: Revista Oikonomia. Ano 5, núm. 2, 2006 [1826]

ALEXANDER, Christopher. Une expérience d'urbanisme démocratique: I'Université d'Oregon. Paris: Les Éditions du Seuil, 1976

ALVES, André Augusto de Almeida. Arquitetura Escolar paulista: O PAGE, o IPESP e os arquitetos modernos paulistas. Tese de Doutorado. São Paulo, FAU USP, 2008

ANDRADE, Carlos Roberto Monteiro de. A peste e o plano: Urbanismo sanitarista de Saturnino Brito. Dissertação de Mestrado. São Paulo, FAU USP, 1992

ANGELO, Michelly Ramos de. Louis Joseph Lebret e a SAGMACS: a formação de um grupo de ação para o planejamento urbano no Brasil. São Paulo: Alameda, 2013

A Missão Lebret e as instituições de planejamento urbano e regional na América Latina. In: Anais do II ENANPARQ. Natal: 2012

Les Développeurs: Louis Joseph Lebret e a SAGMACS na formação de um

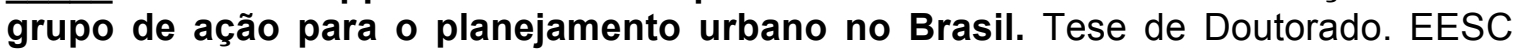
USP. São Carlos, SP: 2010

A participação no planejamento urbano nos estudos de Lebret e da SAGMACS. Anais do VII ENANPUR. Belém: 2007

AUSTIER, Isabelle. La notion de communauté dans les enquêtes sociales sur I'habitat en France. Le groupe d'Économie et Humanisme 1940-1955. In: Géneses, $5,1991[81-106]$ 
AUZELLE, Robert. Chaves do Urbanismo. Rio de Janeiro: Civilização Brasileira, 1972

BAIROCH, Paul. Revolução Industrial \& Subdesenvolvimento. São Paulo: Brasiliense, 1976

BALTAR, Antônio Bezerra. Planos Diretores para as cidades pequenas e médias do Brasil. In: IBAM - Leituras de planejamento e urbanismo. Rio de Janeiro: 1965 [161-174] Bahia, 1957

Conferência sobre Planejamento Urbano. Salvador: Escola de Belas Artes da Universidade, economia e humanismo. Conferência para aula inaugural na Universidade do Recife. Recife: 1953

BARDET, Gaston. O Urbanismo. Campinas: Papirus, 1990

A questão Urbana. Rio de Janeiro: Paz e Terra, 1983

Mission de I'Urbanisme. Paris: Editions Ouvrières, 1948

Nouvel Urbanisme. Paris: Editions Ouvrières, 1947

Problèmes d'Urbanisme. Paris: Dunod, 1941

BEGUIN, François. As maquinarias inglesas do conforto. In: Revista Espaço \& Debates, n 34. São Paulo: 1991 (pp. 39-54)

BENEVOLO, Leonardo. História da Cidade. $2^{a}$ Ed. São Paulo: Editora Perspectiva, 1993

As Origens da Urbanística Moderna. São Paulo: Livraria Martins Fontes, 1981

BERDOULAY, Vincent e CLAVAL, Paul. Aux Débuts de l'urbanisme français: Regards croisés de scientifiques et de professionels, fin de XIXe siécle et XXe siécle. Paris: L'Harmattan, 2001

BETTIN, Gianfranco. Los Sociólogos de la Ciudad. Barcelona: Gustavo Gili, 1980

BOREL, Paul. Le développement harmonisé, son originalité dans l'enseignement de l'Institut de Formation. Les Amis du Père Lebret, Paris, n. 3, maio, 1982 [21-24]

BOSI, Alfredo. Economia e Humanismo. In: Revista de Estudos Avançados. Vol. 26, n. 75. São Paulo, mai-ago., 2012

Letras, 2010

Ideologia e contraideologia: temas e variações. São Paulo: Companhia das

BRASIL. Constituição dos Estados Unidos do Brasil. De 10 de novembro de 1937

BRESICANI, Maria Stella Martins. Metrópoles: as faces do monstro urbano (as cidades no século XIX). In: Revista Brasileira de História. V. 5, n. 8-9. São Paulo: 1985 [35-68] 
. Londres e Paris no século XIX: o espetáculo da pobreza. São Paulo: Brasiliense, 1982

BREUIL, Mathilde Le Tourneur. Le Père Lebret et la construction d'une pensée chrétienne sur le développement: das le sillage de modelés politiques et intellectuelles émergents au Brésil, 1947-1966. Paris: École des Hautes Etudes en Sciences Sociales, 2006

BROWN, Radcliffe. Organização Social. In: PIERSON, Donald (org.). Estudos de Organização Social. São Paulo: Martins Fontes, 1949 [156-173]

BRUANT, Catherine. Donat Alfred Agache (1875-1959): L'Urbanisme, une sociologie appliquée. In: BERDOULAY, Vincent \& CLAVAL, Paul. "Aux Débuts de l'Urbanisme Français". L'Harmattan, 2001 [133-150]

CALABI, Donatella. História do urbanismo europeu: questões, instrumentos, casos exemplares. São Paulo: Perspectiva, 2012

Marcel Poëte: pionnier de l'urbanisme. In: LEPETIT, Bernard e TOPALOV, Christian. La Ville des Sciences Sociales. Paris: Éditions Belin [79-111]

CALVEZ, Jean Yves. A economia, o homem, a sociedade: o ensinamento social da igreja. São Paulo: Loyola, 1995

La pensée de Karl Marx. Paris: Les Éditions du Seuil, 1956

CAMPOS, Candido Malta. Os rumos da cidade: urbanismo e modernização em São Paulo. São Paulo: Editora SENAC, 2002

CARLYLE, Thomas. Signs of the times. In: Selected Writtings Harmondsworth, Penguin, 1980

CARNEIRO, Auner Pereira. O humanismo no planejamento para o desenvolvimento econômico: as influências da obra de Lebret no diagnóstico e no planejamento da intervenção estatal nas atividades sócio-econômicas do Paraná - um estudo de caso. Tese de Doutorado. São Paulo: Universidade de São Paulo, 1994

CASTEL, Robert. Les métamorphoses de la question sociale: Une chronique du salariat. Paris: Libraire Arthème Fayard, 1995

CELESTIN, Georges. Lebret et l'aménagement du territoire. In: Les Amis du Père Lebret, Paris, n. 1, mai. 1981

CERDÁ, Ildefonso. Théorie Générale de I'Urbanisation. Paris: Les Editioins du Seuil, 1979

CESTARO, Lucas R. A SAGMACS e o estudo da "Aglomeração Paulistana". In: Urbana: Revista eletrônica do Centro Interdisciplinar de Estudos sobre a cidade. Vol. 5, n. 6. Campinas, dez./2013 [6-24]

Re-conhecendo São Paulo nos anos 1950: A SAGMACS e a introdução da pesquisa urbana. In: Anais do XIII ENANPUR. Florianópolis, 2009 
Urbanismo e Humanismo: A SAGMACS e o estudo da "Estrutura Urbana da Aglomeração Paulistana". Dissertação de Mestrado. São Carlos, SP: EESC USP, 2009

CHADWICK, James. Report to her Majesty's. (Relatório apresentado ao secretario do Interior de Sua Majestade pelos delegados da lei da mendicância a respeito de uma investigação sobre as condições sanitárias da população trabalhadora da GrãBretanha). Londres, 1842

CHAMBELLAND, Collete (dir.). Le Muséé Social en son temps. Paris: Presses de l'École Normale Superiore, 1998

CHIQUITO, Elisangela de Almeida. A criação da Comissão Interestadual da Bacia Paraná-Uruguai: referencial norte-americano no planejamento regional brasileiro nos anos 1940-1950. In: Revista FAAC. Vol. 2, n. 1. Bauru, SP, abr. - set., 2012 [69-78]

A Comissão Interestadual da Bacia Paraná-Uruguai: do planejamento de vale aos polos de desenvolvimento. Tese de Doutorado. São Carlos, IAU USP, 2012

CHOMBART DE LAUWE, Paul Henry. La Fin des villes: mythes ou réalité? [s.I.]. Calmann Lévy, 1982

Aspects de la sociologie française. Paris: Editions Ouvrières, 1966

Hommes et des Villes. Paris: Payot, 1965

Famille et Habitacion. Paris: CNRS, 1959

Paris et l'agglomération parisienne. L'espace social dans une grande cité. Paris: Presses Universitaires de France, 1952

CHOMEL, André. La période 1930-1942: Des débuts du Mouvement de Saint-Malo à la fondation d'Economie et Humanisme. In Cahier Les Amis du père Lebret, n. 1, Paris, mai/1981

CLAVAL, Paul. Epistemologia da Geografia. Florianópolis: Editora da UFSC, 2011

Histoire de la géographie. Paris: PUF, 1995

COELHO, Sandro Anselmo. O Partido Democrata Cristão (1945-1965): Dilemas e inconsistências da terceira via brasileira. Dissertação de Mestrado. UFPR. Curitiba: 2002

COHEN, Jean Louis. O futuro da arquitetura desde 1889: uma história mundial. São Paulo: Cosac \& Naify, 2013

Architecture en uniforme: Projeter et construire pour la Seconde Guerre mondiale. Paris: CCA, 2011

CORDIDO, Maria Tereza Leme de Barros. Arquitetura forense do Estado de São Paulo - produção moderna, antecedentes e significados. Dissertação de Mestrado. São Carlos: EESC USP, 2007 
CORDIDO, Maria Tereza Leme de Barros, BUZZAR, Miguel e SIMONI, Lucia. O Plano de Ação do Governo Carvalho Pinto (1959-1963) em São Paulo: Moderação Política e Modernização. In: Anais do XIII ENANPUR. Florianópolis: 2009

DANGER, René. Cours d'urbanisme. Paris: Eyrolles, 1933

DESROCHE, Henri. Action sur les personnes et action sur les structures. La Tourette: Économie et Humanisme, 1947 (Documento não publicado, consultado em Fonds Lebret, na pasta AN45 AS46)

DESROCHE, Henri e LEBRET, Louis Joseph. La communauté Boimondau. L'Arbresle: Économie et Humanisme, 1944

DOUTSDAR, Neda Mohtadi. O paranismo atualizado: a Democracia Cristã e o planejamento no primeiro governo Ney Braga. Tese de Doutorado. Curitiba: UFPR, 2010

DURKHEIM, Émile. As regras do método sociológico. São Paulo: Editora Nacional, 1978

DUVERGER, Maurice. Métodos de las ciencias sociales. Barcelona: Ariel, 1962

EBENSTEIN, William. Dois estilos de vida, desafio comunista à democracia. Rio de Janeiro: Record, 1965

EI Totalitarismo: nuevas perspectivas. Buenos Aires: Paidós, 1965

Ismos políticos contemporâneos: comunismo, fascismo, capitalismo, socialismo. Caracas: Ariel, 1961

ÉCONOMIE ET HUMANISME. Rapport sur l'acitivité du Centre d'analyse economique et sociologique (1953-1954). Rhône: 1955 (Documento não publicado, consultado no Fonds Lebret, Pasta AN45 AS182)

Travaux de Sociologie entrepris par le Centre d'Économie et Humanisme (1940 à 1949). Rhône: 1949 (Documento não publicado, consultado no Fonds Lebret, Pasta AN45 AS146)

Situation du Bureau d'Etudes du Marseille. Marseille: 1948 (Documento não publicado, consultado no Fonds Lebret, Pasta AN45 AS174)

Regarde sur la Conjuncture Mondiale. [s.I.], 1945 (Documento não publicado, consultado no Fonds Lebret, Pasta AN45 AS45)

La Methode d'Économie et Humanisme. Marseille: 1944 (Documento não publicado, apresentado na Sessão de Marseille. Consultado em Fonds Lebret, na pasta AN45 AS44)

Rhône. 1941

ENGELS, Friedrich. A origem da família, da propriedade privada e do Estado. $3^{\mathrm{a}}$. Ed.

Rio de Janeiro: Expressão Popular, 2012 
A situação da classe trabalhadora na Inglaterra. São Paulo: Boitempo, 2008

Die Lage der arbeitenden Klasse in England. Leipzig, 1845

FARIA, Rodrigo de, CESAROLI, Josianne e LIRA, Flaviana (orgs.). Urbanistas e Urbanismo no Brasil: entre trajetórias e biografias. São Paulo: Alameda, 2014

FAUSTO, Boris. História do Brasil. [12ª .Ed.]. São Paulo: EdUSP, 2004

FELDMAN, Sarah. As Comissões de Planos da Cidade na Era Vargas. In: REZENDE, Vera. Urbanismo na Era Vargas: a transformação das cidades brasileiras. Niterói, RJ: Editora da UFF/Intertexto, 2012

1950: a década da crença no planejamento regional no Brasil. In: Anais do XIII ENANPUR. Florianópolis: 2009

Planejamento e Zoneamento. São Paulo: 1947-1972. São Paulo: EdUSP/FAPESP, 2005

Instituições de Urbanismo no Brasil: espaços de intermediação entre pensamento e prática. In: Anais do VII SHCU. Salvador: 2002

FERNANDES, Ana. Urbanismo como política (1930-1945): formulações e experiências. In: REZENDE, Vera. Urbanismo na Era Vargas: a transformação das cidades brasileiras. Niterói, RJ: Editora da UFF/Intertexto, 2012

FERNANDES, Florestan. Mudanças sociais no Brasil: aspectos do desenvolvimento da sociedade brasileira. $2^{a}$. Ed. São Paulo: Difel, 1974

FERREIRA, Francisco Whitaker. A atuação da SAGMACS e o trabalho de Lebret no Brasil. São Paulo: entrevista ao autor, 2007 [publicado em CESTARO, Lucas R. Urbanismo e Humanismo: A SAGMACS e o estudo da 'Estrutura Urbana da Aglomeração Paulistana'. Dissertação de Mestrado: EESC USP, 2009 [299-315]

Vargas, 1966

Condições de vida e planejamento físico. Rio de Janeiro: Fundação Getúlio

FURTADO, Celso. Teoria e Política do desenvolvimento econômico. São Paulo: Abril Cultural, 1983

FREY, Jean Pierre. Gaston Bardet. In: PAQUOT, Thierry. Les faiseurs de villes. Paris: Infolio Éditions, 2011 [101-112]

FREYRE, Gilberto de Melo. Brasil, Brasis, Brasília: sugestões em torno de problemas brasileiros de unidade e diversidade das relações de alguns deles com problemas gerais de pluralismo étnico e cultural. Lisboa: Edições Livros do Brasil, 1960

GARDIN, Cleonice. CIBPU: A Comissão Interestadual da Bacia Paraná-Uruguai no planejamento regional brasileiro (1951-1972). Dourados: UFGD, 2009

Histórico e avaliação do papel da Comissão Interestadual da Bacia ParanáUruguai no desenvolvimento regional (1951-1972). São Paulo e Mato Grosso. Tese 
de Doutorado. São Paulo: FFLCH, 2002

GARREAU, Lydie. Louis Joseph Lebret Précurseur du Vatican II: Dans la Dynamique Sociale de l'Église Auprès des marins-pêcheurs bretons et dans le développement économique mondiale. Paris: L'Harmattan, 2011

Louis Joseph Lebret (1887-1966): un homme tranqué. Itinéraire d'un combat pour la rénovation d'une Eglise ouverte au monde. [s.I.]. Editions Golias, 1997

GATHERON, Jean Marie. La Méthode d'Enquete pour la prise en charge d'un village. Économie et Humanisme. La Tourette, 1945 (Documento não publicado. Consultado em Fonds Lebret - AN45 AS45)

GAUDIN, Jean Pierre. Desenho e Futuro das cidades - uma antologia. Rio de Janeiro: Rio Books, 2014

Dessein de Villes, art urbain et urbanisme. Paris: Didier, 1991

GEDDES, Patrick. Cidades em evolução. Campinas, SP: Papyrus, 1994

GEORGE, Pierre. La Ville. Paris: Presses Univeritaires de France, 1952

GHORRA-GOBIN, Cynthia. Articuler connaissances fondamentales et action collective: $h$ 'héritage de Le Play et de Geddes. In: BERDOULAY, Vincent et CLAVAL, Paul. Aux Débuts de l'Urbanisme fançais. Paris: L'Harmattan, 2001 [229-236]

GILBERTON, Krystel. Archives Municipales de Lyon. Fonds de l'association Economie et Humanisme (1927-2007). Relatório de Pesquisa. Lyon: Université Lyon III, 2009

GINZBURG, Carlo. O queijo e os vermes: o cotidiano e as ideias de um moleiro perseguido pela Inquisição. São Paulo: Companhia das Letras, 2006

GOBLET, Yves Marie. La formation des régions-introduction à une géographie économique de la France. Paris: Libraire Générale De Droit Et De Jurisprudence, 1942

GODOY, José Henrique Artigas de. A práxis de Lebret: Economia Humana, desenvolvimentismo católico e o problema regional do Nordeste. In: Anais do IX Encontro da ABCP. Brasília, 2014

GOITIA, Ferando Chueca. Breve história do urbanismo. $3^{\mathrm{a}}$. Ed. Lisboa: Editora Presença, 1992

GONIN, Marcel. L'enquête-participation comme stratégie de changement social. In: Les Amis du Père Lebret, Paris, n. 1, mai., 1981 [11-14]

CFDT, 1969

Histoire du moviment ouvrier et des centrais syndicales en France. [s.I.].

GOVERNO DO ESTADO DO PARANÁ. Plano de Desenvolvimento do Paraná. Paraná: CODEPE e PLADEP, 1963

HARDY, Thomas. The early life. Londres, 1928 
HOBSBAWM, Eric. A era das revoluções, 1789-1848. 33a ${ }^{\mathrm{a}}$. Ed. Rio de Janeiro: Paz e Terra, 2014

A era do Capital, 1848-1875. Rio de Janeiro: Paz e Terra, 1996

HOMOBONO MARTÍNEZ, José I. Las ciudades y su evolución. Análisis del fenómeno urbano en la obra de Élisée Reclus. Bilbao: Zainak, 2009

HOUÉE, Paul. Louis Joseph Lebret: un éveilleur d'humanité. Paris: Les Editions de L'Atelier, 1997

IANNI, Octavio. Estado e planejamento econômico no Brasil. Rio de Janeiro: Civilização Brasileira, 1996

JAUSSELY, Léon. Crônica do Urbanismo. In: GAUDIN, Jean Pierre. Desenho e futuro das cidades - uma antologia. Rio de Janeiro: Rio Books, 2014 [67-72]

JOÃO XXIII. Carta Encíclica Pacem in Terris. Roma: Santa Sé, 1963

Carta Encíclica Mater et Magistra: sobre o recente desenvolvimento da questão social à luz da doutrina cristã. Roma: Santa Sé, 1961

KOWARICK, Lucio e MARQUES, Eduardo (org.). São Paulo: novos percursos e atores. Sociedade, cultura e política. São Paulo: Editora 34, 2011

LACAZE, Jean Paul. Os métodos do urbanismo. Campinas: Papirus, 1993

LACROIX, M. A. Geologie et les mines de la France d'outre mer. Paris: Segmec, 1932

LAFER, Betty Mindlin. Planejameno no Brasil. São Paulo: Editora Perspectiva, 1970

LAMAS, José Garcia. Morfologia urbana e desenho da cidade. Lisboa: Calouste Gulbenkian, 2010

LAMPARELLI, Celso Monteiro. O Padre Lebret e a atuação da SAGMACS. São Paulo: Entrevista ao autor, 2007

O ideário do urbanismo em São Paulo em meados do século XX: o padre Lebret - continuidades, rupturas, sobreposições. In: Cadernos de Pesquisa do LAP, n. 5. São Paulo: 1994

Louis Joseph Lebret e a pesquisa urbano-reginal no Brasil: crônicas tardias ou história prematura. In: Revista Espaço e Debates, n. 37. São Paulo: 1994 [90-99]

LAVEDAN, Pierre. Histoire de l'urbanisme. Vol. 3: époque contemporaine. Paris: H. Laurens, 1952

Qu'est que ce l'urbanisme? Paris: Editeur Henri Laurens, 1926

LE CORBUSIER. Planejamento Urbano. São Paulo: Perspectiva, 1971 
LE PLAY, Pierre G. Frédéric. Réforme Sociale en France. Paris: Dentu Libraire, 1874

Les ouvriers européens: étude sur les travaux, la vie domestique et la condition morale des populations ouvrières de l'Europe. Rapport du Recherché Social. [s.l.], 1855

LEÃO XIII. Carta Encíclica Rerum Novarum: sobre a condição dos operários. Roma, 1981

LEBRET, Louis Jospeh. Dynamique concrète du développement. Paris: Éditions Ouvrières, 1967

Propriedade e Socialização. Porto: Figueirinhas, 1965

Drama del siglo: miséria, inconsciência, subdesarollo, esperanza. Buenos Aires: Nueva Civilizacion, 1960

Manifeste pour une civilisation solidaire. Économie et Humanisme, 1959 (Documento consultado em Fonds Lebret, pasta AN45 AS184)

Économie et Civilization. Paris: Ouvriéres, 1958

Suicide ou survie de l'occident? Paris: Éditions Ouvrières, 1958

Guide Pratique de l'Enquête Sociale IV: L'enquête en vue de l'amenagement regional. Paris: Presses Universitaire de France, 1958

Dimenensions de la charité. Paris: Éditions Ouvrières, 1958

Guide Pratique de I'Enquête Sociale III: L'enquête urbaine - l'analyse du quartier et de la vile. Paris: Presses Universitaire de France, 1955

Guide Pratique de l'Enquête Sociale I: Manuel de l'enquêteur. Paris: Presses Universitaire de France, 1952

Guide Pratique de l'Enquête Sociale II: L'enquête rurale - l'analyse de la commune et du canton. Paris: Presses Universitaire de France, 1951

Princípios para a ação. São Paulo: Edição de Economia e Humanismo, 1950

La vision et l'engagement du Christien. Économie et Humanisme. La Tourette:

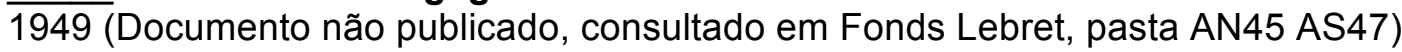

Lettre aux Americains. In: Revue Economie et Humanisme. Marseille, n. 34, nov.-dez., 1947 [561-580]

Estudos Post-Graduados de Economia Social. Escola Livre de Sociologia e Política. São Paulo, 1947, (Documento não publicado. Consultado em Fonds Lebret AN45 AS 144 e AN45 AS155)

La Méthode d'Économie et Humanisme. Économie et Humanisme. Marseille, 1944, (Documento não publicado. Consultado em Fonds Lebret AN45 AS45) 
Lignes maitresses d'une Économie Humaine. Économie et Humanisme. Marseille, 1944 (Documento não publicado. Consultado em Fonds Lebret AN45 AS44)

Exposée sur le Méthode. Économie et Humanisme. Rhône, 1943, (Documento não publicado. Consultdo em Fonds Lebret AN45 AS44)

L'Origine d'Économie et Humanisme. La Tourette, 1943, (Documento não publicado. Consultado em Fonds Lebret AN45 AS44)

La Cité. Projete d'un Programme d'Enquête et d'un Programme d'Action. École des cadres d'Uriage. 1942 (Documento consultado em Fonds Lebret, na pasta AN45 AS67)

LEME, Maria Cristina da Silva e FELDMAN, Sarah. A presença estrangeira:processo urbanos e escalas de atuação. In: Kowarick, Lucio e MARQUES, Eduardo. (Org.). São Paulo: novos percursos e atores. Sociedade, cultura e política. São Paulo: Editora 34, 2011, v. 1, [131-154]

LEME, Maria Cristina da Silva e LAMPARELLI, Celso Monteiro. A politização do urbanismo no Brasil: a vertente católica. In: Anais do IX ENANPUR. Rio de Janeiro, 2001

LEME, Maria Cristina da Silva. A formação do urbanismo como disciplina e profissão: São Paulo na primeira metade do século $\mathbf{X X}$. In: RIBEIRO, Luiz Cesar e PECHMAN, Robert (org.). Cidade, povo e nação: gênese do urbanismo moderno. Rio de Janeiro: Civilização Brasileira, 1996

A formação do urbanismo no Brasil 1895-1964. In: Anais do V Seminario História da Cidade e do Urbanismo. Campinas, 1998

Urbanismo no Brasil 1895-1995. 2ª . Ed. Salvador: EDUFBA, 2005

Formação do Urbansimo em São Paulo como campo de conhecimento e área de atuação profissional. Tese de Livre Docência. Faculdade de Arquitetura e Urbanismo da USP. São Paulo: 2000

A pesquisa pioneira de Lebret sobre as condições de habitação em São Paulo. In: Revista Espaço e Debates, v. 24, n. 45. São Paulo: 2004 [110-113]

Le pére Lebret et la politisation de la planification et de l'Urbanisme au Brésil. In: Laurent Loty, Jean Louis Perrault et Ramón Tortajada. (Org.). Vers une Economie Humaine: Desroche, Lebret, Lefebvre, Muonier Perroux.. 1 ${ }^{\mathrm{a}}$. ed. Paris: Hermann Editeurs des Sciences et des Arts depuis 1876, 2012, v. 1, [441-467]

LEPETIT, Bernard. Por uma nova história urbana. São Paulo: EdUSP, 2001

LEPETIT, Bernard e TOPALOV, Christian. La ville des sciences sociales. Paris: Éditions Belin, 2001

LOEW, Marie Reginald. Principes d'urbanisme: principes inédits d'enquête et d'analyse urbaine par Gaston Bardet. In: Revue Economie et Humanisme. Vol. 2, n. 6. Março-Abril, 1943 [263-268] 
Urbanisme e Humanisme (par S. Laine, F. Pierrefeu, Le Corbusier, André Boll, A. Gutton). In: Revue Economie et Humanisme. Vol. 1, n. 4, dezembro, 1942 [620628]

Problème d'urbanisme par Gaston Bardet. In: Revue Economie et Humanisme. Vol. 1, n. 1. Abril-Maio, 1942 [154-156]

LUKÁCS, György. Essays on Realisme. Cambridge: MIT Press, 1981

Ontologia do ser social: os princípios ontológicos fundamentais de Marx. São Paulo: Ciências Humanas, 1979

MAYHEUW, Henry. London Labor and London Poor. London: Read Books, 2012

MEURIOT, Paul. As aglomerações urbanas na Europa contemporânea. Tese de Doutorado. Paris: 1898

MORBELLI, Guido. Città e piani d'Europa: la formazione dell'urbanistica contemporanea. Bari: Dedalo, 1997

Introduzione all'urbanistica. Milão: Franco Angeli, 1989

MUMFORD, Eric. The CIAM discourse on urbanisme, 1928 - 1960. Cambridge: MIT Press, 2000

OLIVEIRA, Francisco de. Crítica à razão dualista: o ornitorrinco. São Paulo: Boitempo Editorial, 2003

OLIVEIRA, Samuel Silva Rodrigues de. A SAGMACS no Brasil e o planejamento urbano em Belo Horizonte (1958-1962). In: Revista História e Cultura. Vol. 4, n. 1. Franca, SP: mar., 2015 [338-360]

UNITED NATIONS. Measures for the Economic Development of Undersdeveloped Countries. Report by a Group of Experts appointed by the Secretary-General of the United Nations. New York: 1951

OYARZUN, Carlos. Financiamento do Desenvolvimento Econômico. Relatório de Pesquisa. Rio de Janeiro: CAPES, 1957

PAQUOT, Thierry. Les faiseurs de villes (1850-1950). Paris: Infolio éditions, 2011

PARK, Robert. The City. Chicago: The University of Chicago Bookstore, 1935

PELLETIER, Denis. Économie et Humanisme: De l'utopie communautaire au combat pour le tiers monde (1941-1966). Paris: Les Éditioins du Cerf, 1996

Engagement intellectuel catholique et médiation du social. Le enquête monographique de Le Play à Lebret. In: Mi neuf cent, n. 13, 1995 [25-45]

$\overline{8,1988}$

Le fonds Lebret: une étude critique. Cahier dus Amis du Père Lebret. Paris, $n$. 
PEREIRA, Margareth da Silva. A antologia como um gênero no campo do urbanismo. In: GAUDIN, Jean Pierre. Desenho e futuro das cidades - uma antologia. Rio de Janeiro: Rio Books, 2014 [9-16]

PEREIRA, Elson Manoel (org.). Planejamento urbano no Brasil: conceitos, diálogos e práticas. Chapecó, SC: Argos, 2008

PERROUX, François. Prèsence du Lebret. In: Tiers Monde. 1966, Tome 7, n. 27 [457460]

Economie Appliquée. Vol. II, n. 1-2, 1955

PERROUX, François, FRIEDMANN, Jonh e TINBERGEN, Jan. A planificação e os polos de desenvolvimento. Porto: Rés, 1975

PICCINATO, Giorgio. La costruzione dell'urbanistica. Germania 1871-1914. Roma: Officina Edizioni, 1977

PIERSON, Donald. Estudos de organização social: leituras de sociologia e antropologia social. São Paulo: Livraria Martins Editora S.A., 1949

PIO XI. Carta Encíclica Divini Redemptori: sobre o comunismo ateu. Roma, 1937

POËTE, Marcel. Introducción al urbanisme. La evolución de las ciudades: la lección de la Antigëdad. Barcelona: Caja de Arquitectos, 2011

PONTUAL, Virigínia. Práticas urbanísticas, deslocamentos e cruzamentos: LouisJoseph Lebret e Antônio de Bezerra Baltar no Brasil. In: FARIA, Rodrigo de, CERASOLI, Josianne e LIRA, Flaviana. Urbanistas e Urbanismo no Brasil: entre trajetórias e biografias. São Paulo: Alameda, 2014

Urbanismo, trajetórias e cruzamentos: o padre Louis-Joseph Lebret e o urbanista Gaston Bardet na América do Sul. In: Anais do XIII Seminario Historia Cidade e Urbanismo, 2014, Brasilia. Tempos e escalas da cidade e do urbanismo. Brasilia: UNB, 2014. v. 1 [114-114]

Les Reseaux Economie et Humanisme en Amerique Latine: 'la grande famille EH' et 'un reseau d'amitiés continental. In: Vers une economie humaine. Pensées critiques d'hier pour aujourd'hui, 2012, Caen. Vers une economie humaine. Pensée critiques d'hier pour aujourd'hui. Caen: ISMEA, 2012. v. 1.

Lebret in Latin America: town planning institutions in Uruguay and Brazil. In: 15th International Planning History Society, 2012, São Paulo. Cities, Nations and regions in Planning History. São Paulo: FAU USP, 2012

As redes Economia e Humanismo na América Latina: 'La grande famille E.H' e 'Un reseau d'amitiés continental'. In: XII Seminário da História da Cidade e do Urbanismo, 2012, Porto Alegre. A circulação das ideias na construção da cidade: uma via de mão dupla. Porto Alegre: PROPUR, 2012 [48-33]

O Engenheiro Antonio Bezerra Baltar: prática urbanística, CEPUR e SAGMACS. Revista Brasileira de Estudos Urbanos e Regionais (ANPUR), vol. 13, 2011 
Lebret na América Latina. In: XXVIII Congresso Internacional da Associação Latino-Americana de Sociologia, 2011, Recife. XXVIII Congresso da ALAS. Recife: Editora da UFPE, 2011

POULAT, Émile. Doctrine Sociale Catholique et Libéralisme Économique. De la Naissance du grand capitalisme à la fin du communisme sociétique. In: COLLETE, Chambelland (dir.). Le Musée Social en sons Temps. Paris: Presses de l'École Normale Superiore, 1998 [135-146]

POULAT, Émile et BOUTELOUPT, Collete. Un nouveau fonds d'archives : les Papiers du Père Lebret. Revue d'histoire ecclésiastique, vol.LXXVIII-2, 1983, p.468-472 ; Denis PELLETIER, "Le fonds Lebret : une étude critique", Cahiers des Amis du père Lebret, $n^{\circ} 8$, mai 1988 [19-48]

PRADO JUNIOR, Caio. Evolução política do Brasil. $21^{a}$ Ed. São Paulo: Brasiliense, 1994

História Econômica do Brasil. São Paulo: Brasiliense, 1988

PROST, Henri. L'Urbanisme. Archives de l'Académie d'archicture. Paris: 1901

PUEL, Hugue. Économie et Humanisme dans le mouvement de la modernité. Paris: Cerf, 2004

QUINTELLA, Ivvy Pessôa. Projeto urbano e dimensão estética no urbanismo francês da primeira metade do século $X X$ : contribuições relegadas ao ostracismo dentro da memória disciplinar. In: PEIXOTO, Elane Ribeiro; DERNTL, Maria Fernanda; PALAZZO, Pedro Paulo; TREVISAN, Ricardo (Orgs.) Tempos e escalas da cidade e do urbanismo: Anais do XIII Seminário de História da Cidade e do Urbanismo. Brasília, DF: Universidade Brasília- Faculdade de Arquitetura e Urbanismo, 2014

QUINTO JUNIOR, Luiz de Pinedo. A contribuição da cultura técnica do planejamento urbano no Brasil numa perspectiva comparada com a gênese da gestão urbana na Europa. In: PEREIRA, Elson Manoel. Planejamento Urbano no Brasil: conceitos, diálogos e práticas. Chapecó, SC: Argos, 2008

RABINOW, Paul. French Modern: norms and forms of the social environment. Chicago: University of Chicago Press, 1989

RECLUS, Elisée. The Evolution of Cities. Sydney: Jura Media, 1895

REZENDE, Vera (org.). Urbanismo na Era Vargas: a transformação das cidades brasileiras. Niterói, RJ: Editora da UFF; Intertexto, 2012

Planejamento urbano e ideologia. Rio de Janeiro: Civilização Brasileira, 1982

RIOS, José Arthur. $O$ estudo dos aspectos humanos da favela carioca e as equipes da SAGMACS. Rio de Janeiro: Entrevista ao autor, 2014

RIZZI, Fillippo. Padre Chenu e il medioevo di Tommaso. In: L'Osservatore Romano, 11 de fevereiro de 2010. Roma, 2010 
ROLDAN, Dinalva Delorenzo. Um ideário urbano em desenvolvimento. A experiência de Louis Joseph Lebret em São Paulo de 1947 a 1958. Dissertação de Mestrado. São Paulo: FAU USP, 2012

ROWNTREE, Benjamin S. A study of town life. [s.I.]. Manilon and Co., 1901

SAGMACS. Energia Elétrica no Estado de São Paulo. São Paulo: 1964 (Relatório para o governador, disponível para consulta na Biblioteca do PPG FAU USP)

Prospecto dos problemas de desenvolvimento de Urbatuba. São Paulo: 1964 (Relatório apresentado ao prefeito de Ubatuba, disponível para consulta na Biblioteca do PPG FAU USP)

Relatório sobre o problema de água e esgotos: Análise da situação dos sistemas nas sedes de municípios do interior de São Paulo. São Paulo: 1963

Estudo para uma política habitacional para a Cia. Ferro e Aço de Vitoria/ES. São Paulo: 1963

Relatório do Plano Diretor de Barretos. São Paulo: 1963

Relatório do Plano Diretor de Belo Horizonte. São Paulo: 1963

Relatório do Plano Diretor de Sorocaba. São Paulo: 1963

. Estudos para implantação de um loteamento no município de São Vicente. São Paulo: 1963

Programa de Mecanização agrícola do Estado de Mato Grosso. São Paulo: 1963 (Relatório disponível para consulta no acervo da Biblioteca do PPG FAU USP)

Revisão Agrária de São Paulo. Estudos para um assentamento na Fazenda Jacilândia. São Paulo: 1962

Saúde Pública no Paraná. São Paulo: 1962 (Relatório encomendado pela CODEPAR, parte integrante do estudo para o desenvolvimento do Estado do Paraná)

Ipatinga e seus problemas sócio-econômicos. São Paulo: 1961

Relatório do estudo "Aspectos Humanos da Favela Carioca". Rio de Janeiro: 1959 (Publicado pelo Jornal O Estado de São Paulo, fotocopia disponível para consulta na Biblioteca Central da EESC USP)

Estrutura Urbana da Aglomeração Paulistana. Estruturas Atuais e Estruturas Racionais. São Paulo: 1958

Problemas de Desenvolvimento. Necessidades e Possibilidades dos Estados do Rio Grande do Sul, Santa Catarina e Paraná. São Paulo: CIBPU/SAGMACS, 1958 (Vol. 1 e 2 - disponível para consulta em acervo da Biblioteca do PPG FAU USP)

Estrutura Urbana de Belo Horizonte. Belo Horizonte: 1958 
Problemas de desenvolvimento, necessidades e possibilidades do estado de São Paulo. São Paulo: CIBPU/SAGMACS, 1955

Estudo sobre o desenvolvimento e implantação de Indústrias no Pernambuco e no Nordeste do Brasil. CODEPE. Recife: 1955

Plano Diretor de Ourinhos. São Paulo: 1954

Paulo: 1947

Sondagem Preliminar a um estudo sobre habitação em São Paulo. São

SAMPAIO, Plínio de Arruda. O plano de ação do governo Carvalho Pinto: planejamento e política no estado de São Paulo em 1959. In: Revista Espaço \& Debates. Ano I, n. 4. São Paulo: 1981 [127-136]

SANTOS, Milton. A cidade nos países subdesenvolvidos. Rio de Janeiro: Civilização Brasileira, 1965

SARTRE, Jean Paul. O Existencialismo é um Humanismo. A imaginação: questão de método. $3^{a}$. Ed. São Paulo: Nova Cultural, 1987

SAUVY, Alfred. Trois Monde, une planète. In: L'Observateur: politique, economique et literature, 14 de agosto de 1952

SAVOYE, Antoine. Pensée leplaysienne et questions urbaines dans la reforme sociale (1881-1914): Du logement ouvrier a l'aménagement des villes. In: BERDOULAY, Vincent \& CLAVAL, Paul. "Aux Débuts de l'Urbanisme Français". L'Harmattan, 2001

SINGER, Paul. Economia Política da Urbanização. $2^{a}$ Ed. São Paulo: Editora Contexto, 2002

Desenvolvimento Econômico e evolução urbana. São Paulo: Companhia Editora Nacional, 1968

SMITH, James. Relato de Londres. Citado por BRESCIANI, Maria Stella M. Metrópolis: as faces dos monostro urbano (as cidades do século XIX). In: Revista Brasileira de História. São Paulo, n. 8 e 9, 1985 [35-68]

SUAVET, Thomas. Rapport de l'Enquête sur Saint-Etienne (1945-1946). Économie et Humanisme. La Tourette: 1948 (Documento consultado no Fonds Lebret, pasta AN45 AS46)

STEINMANN, Martin. CIAM: Doukumente, 1938-1939. Declaração dada no Congresso. Basel e Stuttgart: Birkhauser, 1979

TOPALOV, Christian. Histoires d'enquêtes. Londres, Paris, Chicago (1830-1930). Paris: Classiques Garnier, 2015

Laboratoires du Noveau Siècle. La nébuleuse réformatrice et ses réseaux en France (1880-1914). Paris: Éditions de l'École des Hautes Études en Sciences Sociales, 1999 
Naissance de l'urbanisme moderne et reforme de l'habitat populaire aux Etats Unis, 1900-1940. Paris: Centre de Sociologie Urbaine, 1988

$\overline{\text { Edicol, }} 1979$

La urbanización capitalista. Algunos elementos para su análisis. México:

TRINDADE, Isabela Teixeira. La SAGMACS en Brasil y la construcción de un nuevo método de proyetación urbana. In: Cuadernos del CLAEH. Ano 34, n. 101. Montevidéu, mar./2015 [185-194]

VALLADARES, Licia do Prado. Entrevista sobre a favela carioca. In: FREIRE, Américo e OLIVEIRA, Lúcia Lippi (orgs.). Novas memórias do urbanismo carioca. Rio de Janeiro: Editora da FGV, 2008 [157-186]

A Escola de Chicago: impacto de uma tradição no Brasil e França. Belo Horizonte: Editora da UFMG, Rio de Janeiro: IUPERJ, 2005

A invenção da favela: do mito de origem a favela.com. Rio de Janeiro: Editora FGV, 2005

72]

Qu'est-ce qu'une favela? Cahiers des Amériques Latines, n. 34. [s.I.], 2000 [61-

VELHO, Otávio Guilherme (org.). O Fenômeno Urbano. $2^{\text {a }}$ Ed. Rio de Janeiro: Zahar, 1973

VERDEIL, Eric. La limite Ville-Campagne dans les projets d'Aménagement de la Région Parisienne de 1919 à 1939. In: BERDOULAY, Vincent et CLAVAL, Paul. Aux Débuts de l'Urbanisme Français. Paris: L'Harmattan, 2001 [205-215]

VILLAÇA, Flávio. Uma contribuição para a história do urbanismo. In: DÉAK, Csaba \& SCHIFFER, Sueli. O processo de urbanização no Brasil. São Paulo: FUPAM/EdUSP, 1999

WILLIANS, Raymond. O campo e a cidade: na história e na literatura. São Paulo: Companhia das Letras, 1989

WIRTH, Louis. A Sociedade Urbana. In: PIERSON, Donald (org.) Estudos de Organização Social. São Paulo: Livraria Martins Editora S.A., 1949 [603-617]

Urbanismo como modo de vida. In: PIERSON, Donald (org.). Estudos de Organização Social. São Paulo: Livraria Martins Editora S.A., 1949 [618-644]

ZUCONI, Guido. A cidade do século XIX. São Paulo: Perspectiva, 2009 
Figura 1 - Retrato de Alfred Agache 49

Figura 2 - Retrato de Gaston Bardet 50

Figura 3 - Capa do livro "Introduction à l'Urbanisme" de Marcel Poëte 54

Figura 4 - Capa da edição núm. 17 da "Revue Économie et Humanisme" 104

Figura 5 - Diagrama de levantamento de níveis realizado pelo Économie et 111 Humanisme

Figura 6 - Capa do Manual de Pesquisa produzido pelo Économie et Humanisme: "Guide Pratique de L'Enquête Sociale - Parte II L'Enquête Rurale: L'Analyse de la commune et du canton", publicado em 1951

Figura 7 - Capa do Manual de Pesquisa produzido pelo Économie et Humanisme: "Guide Pratique de L'Enquête Sociale - Parte III L'Enquête Urbaine: L'Analyse d Quartier et de la Ville", lançado em 1955

Figura 8 - Reprodução da lista de participantes da Sessão de La Tourrete realizada em 1944 pelo Économie et Humanisme

Figura 9 - Reprodução das páginas 2, 3, 4 e 5 da lista de participantes da Sessão realizada em 1944

Figura 10 - Reprodução das páginas 6,7 e 8 da lista de participantes da Sessão realizada em 1944

Figura 11 - Fotografia de Lebret e o papa Paulo VI no Vaticano 147

Figura 12 - Capa da pasta de Lebret no Congresso Internacional de 169 Economia Humana

Figura 13 - Programação do Congresso Internacional de Economia 170 Humana, realizado em São Paulo em 1954 
Figura 14 - Fotografia com participantes do Congresso Internacional de 171 Economia Humana, realizado em São Paulo, em 1954

Figura 15 - Fotografia de Lebret, Benevenuto e o governador Garcez no Congresso Internacional de Economia Humana, realizado em São Paulo em 1954

Figura 16 - Reprodução de Prancha de apresentação do Plano Agache para o Rio de Janeiro em 1930

Figura 17 - Reprodução de croqui de Le Corbusier com proposta para a cidade do Rio de Janeiro

Figura 18 - Reprodução de imagem da proposta de Agache para a cidade de Curitiba

Figura 19 - Capa do Manual de Pesquisa produzido pela Économie et Humanisme: "Guide Pratique de L'Enquête Sociale - Parte IV L'Enquête en Vue de l'Aménagement Régional", publicado em 1958

Figura 20 - Esquema de distribuição regional para o estado de São Paulo, proposto pelo PAGE

Figura 21 - Divisão dos polos de desenvolvimento proposto pela SAGMACS para o estado do Paraná

Figura 22 - Reprodução do Gráfico 2 da "Sondagem Preliminar a um estudo sobre habitação na cidade de São Paulo" elaborado pela SAGMACS em 1947

Figura 23 - Mapa da cidade de São Paulo dividia em distritos apresentado na "Sondagem Preliminar"

Figura 24 - Reprodução do Gráfico 16 da "Sondagem Preliminar"

Figura 25 - Reprodução do Gráfico 5 da "Sondagem Preliminar"

Figura 26 - Reprodução do Gráfico 10 da "Sondagem Preliminar"

Figura 27 - Reprodução do Gráfico 12 da "Sondagem Preliminar"

Figura 28 - Mapa delimitando os municípios da Great São Paulo, conforme estudo da "Estrutura Urbana da Aglomeração Paulistana" elaborado pela SAGMACS em 1956

Figura 29 - Reprodução da Planta B9-F do estudo da "Estrutura Urbana da Aglomeração Paulistana"

Figura 30 - Reprodução da Planta B12-G do estudo da "Estrutura Urbana da Aglomeração Paulistana"

Figura 31 - Reprodução da Planta B5-F do estudo da "Estrutura Urbana da Aglomeração Paulistana" 
Figura 32 - Reprodução da Planta G7 do estudo da "Estrutura Urbana da 246 Aglomeração Paulistana"

Figura 33 - Capa do suplemento especial editado pelo Jornal O Estado de 248 São Paulo com o relatório do estudo dos "Aspectos Humanos da Favela Carioca" realizado pela SAGMACS, em 1959

Figura 34 - Reprodução de croqui inserido no suplemento especial do Jornal 249 O Estado de São Paulo

Figura 35 - Localização e identificação das favelas na cidade do Rio de Janeiro 

ANEXOS 



\section{ÍNDICE E LISTA DE DOCUMENTOS EM ANEXO}

Anexo 1 - Estatuto de fundação do Centre d'Économie et Humanisme 294

Anexo 2 - $\quad$ Projeto de pesquisa proposto por Lebret para a École d'Uriage 306 para pesquisar a cidade e desenvolver um programa de ação

Anexo 3 - $\quad$ Lista de possíveis colaboradores na América Latina 310

Anexo 4 - Carta de Bardet ao Pe. Lebret manifestando seu 312 descontentamento com a "marxisation" do Économie et Humanisme

Anexo 5 - Lista de $\mathrm{EH}$ com a relação de países que tem assinantes da 316 "Revue Économie et Humanisme

Anexo 6 - Carta de Lebret ao Ministro Claude Pétit solicitando apoio 318 financeiro para o $\mathrm{EH}$

Anexo 7 - $\quad$ Lista de Participantes da Sessão sobre Aglomerações Urbanas 320 realizada em 1953

Anexo 8 - Lista de participantes estrangeiros no I Congresso Internacional 322 de Économie et Humanisme realizado em São Paulo

Anexo 9 - Transcrição da Entrevista realizada com Celso Monteiro 324 Lamparelli

Anexo 10 - Transcrição da Entrevista realizada com José Arthur Rios

Anexo 11 - Transcrição da Entrevista realizada com Maria Adélia Aparecida 348 de Souza

Anexo 12 - Quadro de composição das equipes da SAGMACS em suas 362 diferentes fases de atuação 



\section{ECONOMIE ET HUMANISME}

(Association déclarée - Loi du ler Juillet 1901)

\section{STATUTS}

DEPOSÉS A LA PRÉFECTURE DES BOUCHES-DU-RHONE

LE 24 SEPTEMBRE 1941

(J. O. du 10 Oclobre 1941

IMPRIMERIE MAZEL

LARGENTIËRE

ARDËCHE

$1 \overline{941}$ 


\section{STATUTS}

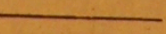

TITRE I

\section{But et composition de l'A ssociation}

Art. I. - L'Association dite " Economie et Humanisme ", constituée conformément à la loi du $1^{\text {er }}$ Juillet 1901 a pour bul:

$1^{\circ}$ - d'étudier par des enquêtes et tous autres moyens d'investigation appropriés les réalités humaines,économiques et so ciales dans leur complexité actuelle.

$2^{\circ}-$ de provoquer parmi ses membres ou en dehors d'eux des travaux scientifiques susceptibles d'aboutir à l'élaboration d'une doctrine économique, spiritualiste, remettant l'économie au service de l'ho mme.

$3^{\circ}$ - de susciter, au sein des diverses professions ou de certaines régions économiques, des techniciens et des professionnels capables de déterminer les conditions concrètes du Bicn Commun de leur profession ou de la région envisagée, et susceptibles, de ce fait, de participer aux efforts publics ou privés de réorganisation économique et protessionnelle.

La durée de l'Association est illimitée.

E!le a son siège social à Marseille.

Art. II. - Les moyens d'action de l'association sont :

$1^{\circ}$ - la création, tant en France, dans ses colonies, protectorats, pays de mandat, ainsi qu'à l'étranger, d'un ou plusieurs centres d'étude des complexes sociaux, ainsi que l'organisation de tous les services qui se révéleront nécessaires à l'élaboration et à l'utilisation des enquêtes économiques et sociales. 
$2^{\circ}$ - la création, tant en France, dans ses colonies, protectorats, pays de mandat, ainsi qu'à l'étranger, d'une ou plusieurs écoles de formation à l'action destinées aux futurs dirigeants des organisations professionnelles ou autres catégories de personnes intéressées par les travaux de l'Association.

$3^{\circ}$ - la publication d'une Revue périodique portant le nom même de l'Association "Economie et Humanisme ", de Bulletins, Documents et Collections destinés à faire connaître aux intéressés et au public les travaux et la doctrine d'économie humaine de l'Association.

$4^{\circ}$ - l'organisation dans ce même but de cours, conféren. ces, expositions, films, et de tous autres moyens similaires de propagande, enseignement et action.

Art. 3. - L'Association se compose de deux catégories distinctes de membres, les membres titulaires et les membres adhérents.

$1^{\circ}$ - les membres titulaires sont au nombre maximum de 40 , et comprennent, en proportion égale, soit des membres titulaires élus, soit des membres titulaires nommés, chacun de ces groupes ne pouvant dépasser 20 membres.

a) Les membres titulaires élus sont choisis par le Conseil de Direction de l'Association, à qui les candidatures sont adreşsées; ils sont nommés pour 3 ans. Le Conseil statue souverainement sur leur admission, sans avoir de motits à donner. Les membres titulaires peuvent être indéfiniment renommés, sous réserve de l'art. $3,4^{\circ}$.

b) Les membres titulaires nommés sont des théologiens catholiques désignés et délégués par les autorités ecclésiastiques ordinaires compétentes pour participer de façon permanente aux travaux scientifiques de l'Association.

$2^{\circ}$ - les membres adhérents sont en nombre illimité et comprennent soit des membres adhérents simples, soit des membres bienfaiteurs ou fondateurs. Leur admission est probre du Conseil délégué à cet effet.

La cotisation annuelle minimum sera fixée tous les ans avant le 31 décembre par le bureau de l'Association. 
La cotisation minimum est fixée, pour 1942, à 100 frs pcur les membres adhérents, 1.000 frs pour les membres bienfaiteurs, 5.000 frs pour les membres fondateurs, les membres titulaires élus étant libres de souscrire à l'une ou l'autre de ces cotisations. Les membres titulaires nommés sont, de par les services rendus à l'Association, dispensés de toute cotisation.

La qualité de membre de l'Association est établie par une carte délivrée ou visée annuellement ou par la quittance de la cotisation.

Les personnes morales peuvent être admises comme membre titulaires ou adhérents de l'Association, mais chacune d'elles ne peut être représentée que par un délégué.

Seuls les membres titulaires élus ou nommés participent à l'administration ou aux élections et ont seuls voix délibérative dans les assemblées.

ArT 4. - la qualité de membre de l'association se perd :

$1^{\circ}$ - par la démission

$2^{\circ}-$ par le non-paiement de la cotisation annuelle

$3^{\circ}$ - par la radiation prononcée pour motifs graves par le Conseil de Direction, le membre intéressé ayant été préalablement appelé à fournir ses explications, saut recours à l'Assemblée générale.

$4^{\circ}-$ La qualité de membre titulaire élu cesse de plein droit et sans recours possible à la fin de l'exercice trisannuel, si sa carte de titulaire n'a pas été renouvelée. Au cours de l'exercice, les membres titulaires ne perdraient leur qualité que dans les mêmes conditions que les membres adhérents.

Le membre démissionnaire ou rayé ne peut prétendre à aucun droit sur le patrimoine de l'association. Il ne peut exercer aucune réclamation sur les sommes qu'ıl aurait versées à titre de droit d'entrée, ou pour le rachat de sa cotisation, ces sommes restant définitivement acquises à l'association.

Le décès, la démission ou l'exclusion d'un associé ne peuvent jamais mettre fin à l'association.

Le patrimoine de l'association répond seul des engage. ments contractés par elle ou des condamnations queliconques qui pourraient être prononcées contre elle, sans qu'aucun des 
membres de l'association même ceux qui participent à son ad. ministration puisse en être tenu personnellement responsa. ble.

Titre II.

\section{Administration et fonctionnement}

ART. 5. - L'Association est dirigée par un Conseil de Di. rection composé de 10 membres au maximum, se répartissant comme suit :

$1^{\circ},-5$ membres élus au scrutin secret pour 5 ans par l'Assemblée Générale des membres titulaires et choisis parmi ses membres élus ou nommés.

$2^{\circ},-5$ membres nommés, désignés par les Ordinaires ecclésiastiques compétents parmi les membres titulaires nommés.

En cas de vacance de membres élus, le Conseil pourvoit provisoirement au remplacement de ses membres. Il est procédé à leur remplacement définitif par la plus prochaine Assemblée l'époque oú devait norma des membres ainsi élus prennent fin à remplacés.

cinquième, suivant des membres élus du Conseil a lieu par sort, puis d'après l'anciende déterminé d'abord par tirage au sortants sont rééligibles. Les de nomination. Les membres de ce faitleur qualité de membrembres élus au Conseil voient jusqu'à l'expiration de leurs poutitulaire prorogée de plein droit

En cas de vacance de nouvoirs quinquennaux. bres du Conseil, il est procédé á nommés, titulaires ou mem. torités écclésiastiques. Les mé à leur remplacement par les au. mis au renouvellement à membres nommés ne sont pas soumembres du Conseil. 


$$
-5-
$$

Le Conseil de Direction choisit parmi ses membres, au scru. tin secret, un Bureau composé d'un Président, d'un Vice-Prési-
dent et d'un trésorier.

Les fonctions de ral-Adjoint de l'Association Général et de Secrétaire Génémembres nommés du Conseil et choisis alues d'office à deux de Direction. Le Secrétaire Get choisis à cet effet par le Cons ei font pas partie du Bureau, mais ils et le Secrétaire-adjoint ne tive à ses délibérations et doivent assistent avec voix consulta. tés sur toutes les décisions intéressant obligatoirement consull'Association.

Le Bureau, ainsi que les secrétaires, est élu pour 3 ans, sauf les effets de renouvellement partiel du Conseil, en cas de non
réélection d'un membre.

Toutefois, le premier Conseil de Direction est composé par l'ensemble des membres fondateurs de l'Association, savoir :

$1^{\circ}$ - M. René Morecx, éditeur, Président-directeur général du Journal de la Marine marchande.

$2^{\circ}$ - M. François Perroux, professeur à la Faculté de Droit de l'Université de Paris

$3^{\circ}-$ M. Jean-Marie Gatheron, ingénieur-agricole, Professeur honoraire à la Faculté de Droit de l'Université de Lyon.

$4^{\circ}-$ M. Gustave Thibon, cultivateur, philosophe.

$5^{\circ}-$ M. Alexandre Duвors, directeur général des Forges et Aciéries de Bonpertuis,

à ítre de membres élus du Conseil, et de :

$$
\begin{aligned}
& 6^{\circ}-\text { R. P. Lebret } \\
& 7^{\circ}-\text { R. P. Serrand } \\
& 8^{\circ}-\text { R. P. Moos } \\
& 9^{\circ}-\text { R. P. Bouche } \\
& 10^{\circ}-\text { R. P. Loew }
\end{aligned}
$$

à titre de membres nommés.

Pour le premier exercice expirant le 31 décembre 1944, les fonctions des membres du Bureau seront exercées, savoir : 


\section{$-6-$}

- celles de Président, par M. René Mokeux,

- celles de Vice-Président, par M. François Perroux,

- celles de Trésorier, par M. Alexandre Dunors

et les fonctions de secrétaires, savoir :

- celles de Secrétaire Général par R. P. Lebret,

- celles de Secrétaire Adjoint par le R. P. Loew.

Art. 6. - Le Conseil de Direction se réunit sur convocation de son Président ou de la moitié de ses membres aussi souvent que l'exige l'intérêt de l'association. Les séances sont présidées par le Président ou, en cas d'absence de celui-ci par le Vice.Président.

La présence du tiers des membres du Conseil de Direction est nécessaire pour la validité des délibérations.

Il est tenu procès-verbal des séances. Les procès-verbaux sont signés par le Président de séance et le Secrétaire.

Art. 7. - Les membres du Bureau ne peuvent recevoir aucune rétribution à raison des fonctions qui leur sont conférées, sauf remboursement de leurs frais de voyage ou débours justifiés au cas où une mission spéciale leur aurait été confiée par
l'Association.

Art. 8.- L’Assemblée Générale de l'Association comprend les meinbres titulaires, élus ou nommés. Les autres membres y sont également convoqués, mais ils n'ont pas voix délibérative. L'assemblée se réunit une fois par an et chaque fois qu'elle est majorité des par le Conseil de Direction, ou sur la demande de la avis individuel pour les membres convocations ont lieu par adhérents, par une insertionbres titulaires,et pour les membres nomie et Humanisme dans le numéro de la revue "Ecopour l'assemblée.

Le Bureau de l'Assemblée générale est celui du Conseil. tion, sur la situation rapports sur la gestion du Conseil de Direc- 
approuve les comptes de l'exercice clos, vote le budget de l'exercice suivant, donne toutes autorisations et toutes décharges utiles, délibère sur les questions mises à l'ordre du jour et pourvoit, s'il y a lieu, au renouvellement des membres du Conseil de Direction.

Les délibérations sont prises à la majorité des membres prẻsents ou représentés, sauf ce qui est dit à l'article 14 concernant les modifications des statuts et la dissolution. Elles sont constatées par des procès-verbaux signés par le Président de séance et le Secrétaire ou un autre membre du Bureau.

Tout membre ayant voix délibérative peut se faire représenter à l'assemblée par un membre choisi dans la même catégorie.

Art. 9. - Le Conseil de Direction est investi des pouvoirs les plus étendus pour faire ou autoriser tous actes ou opérations permis à l'association et qui ne sont pas expressément réservés à l'assemblée généraie ou au Bureau. Notamment, il nomme ou révoque les directeurs généraux des diverses sections et activités de l'Association (centres d'études, écoles de formation, confé. rences, propagande, bulletins, revues, éditions, etc...) ; ces directeurs seront en principe obligatoirement choisis parmi les membres titulaires nommés. Dans ce cas il pourra être adjoint à l'un ou l'autre des directeurs, si le Conseil de Direction le juge nécessaire, un co-directeur choisi parmi les membres titulaires élus, le co-directeur de chaque section ayant les mêmes pouvoirs.

Au cas où pour une raison quelconque les directeurs ne pourraient être choisis parmi les membres nommés, le Conseil ne pourra désigner comme directeur qu un membre titulaire élu.

Le Conseil de Direction prend également II statue sur l'adconcernant la vie doctrinale de lex sociétaires élus ou adhémission, le maintien ou lex circonstances le rendent utile, le siège social.

Tout membre du Conseisi dans la même catégorie.

nions par un membre choisi dans la moirs en ce qui

Авт. 10. - Le Bureau a les plus larges pouve et financière de concerne l'administration intérieure, ju révoque tous employés l'Association. Notamment il nomme ou revoque tous employes 
ou gérants, fixe les traitements de ceux-ci et les allocations des directeurs, collaborateurs ainsi que les frais de voyage et de missions; il conclut les baux, fait effectuer toutes réparations aux immeubles, autorise toutes acquisitions de valeurs, meubles et objets mobiliers. Le Bureau a également les plus larges pouvoirs pour toutes ouvertures de comptes en banque, de chèques postaux et généralement toutes opérations postales ou bancaires.

Les dépenses sont ordonnancées par le Président ou, en cas d'empêchement, par le trésorier ou un membre désigné par le Président.

L'Assemblée est représentée en justice par le Président ou tout autre membre du Bureau.

Le Président peut déléguer à l'un ou l'autre des secrétaires telle de ses fonctions.

Art. 11. - Les acquisitions et aliénations d'immeubles, les emprunts et constitutions d'hypothèques pour une somme excédant le chiffre fixé chaque année par l'Assemblée générale, sont soumis à son approbation.

Jusqu'au 31 décembre 1942 , ce chiffre est fixé à 200.000 frs.

Аrт. 12 - Les membres adhérents d'Economie et Humanisme bénéficient de tous les avantages intellectuels, moraux et matériels de l'Association. Ils sont tenus au courant de ses activités, peuvent être invités à participer à ses travaux dans les diverses sections de leur compétence,et être aidés, le cas échéant, dans leurs propres travaux par l'Association, soit au point de vue scientifique, soit au point de vue matériel.

Ils reçoivent gratuitement la revue "Economie et Humanisme " et bénéficient des conditions spéciales pour l'achat des ouvrages publiés par l'Association ou sous son patronage.

Des centres locaux d'étude ou de propagande peuvent être créés entre les membres adhérents par délibérations du Conseil
de Direction. ART. 13. - Les ressources annuelles de l'Association se
composent notamment:

$1^{\prime \prime}$ - des cotisations et souscriptions de ses membres, 


$$
-9-
$$

$2^{\circ}-$ du produit des rétributions perçues pour les services exécutés,

$3^{\circ}--$ de toutes recettes autorisées par les lois.

L'Association peut constituer un fonds de réserve dont la réglementation sera faite par le Conseil de Direction.

Titre III

\section{Modifications des statuts et dissolution}

Aкт. 14. - Les statuts ne peuvent être modifiès, la transformation ou la dissolution ne peut être prononcée que par une Assemblée extraordinaire convoquée par le Conseil avec indication de cet objet. Cette Assemblée ne pourra statuer que si la moitié au moins des membres titulaires ayant voix délibérative sont présents ou représentés, et la majorité des trois-quarts des membres présents ou représentés sera nécessaire. Si cette proportion n'est pas atteinte, l'assemblée est convoquée à nouveau, mais à quinze jours au moins d'intervalle, et cette fois elle peut valablement délibérer quel que soit le nombre des membres présents ou représentés, la majorité des trois-quarts restant cependant nécessaire.

Art. 15. - En cas de dissolution pour quelque cause que ce soit, l'Assemblée générale pourvoit à la liquidation du patrimoine de l'Association. Elle pourra nommer un,ou plusieurs liquidateurs, membres ou non de l'Association, dont elle déterminera souverainement les pouvoirs. Elle statue également sur la dévulution des biens composant le patrimoine de l'Association. Cette dévolution pourra être faite au profit de telle Association, société, œuvre ou personne qu'elle déterminera. 


$$
-10-
$$

Art. 16. - Pour faire toutes déclarations, publications ou formalités prescrites par la loi, ouvrir tous comptes dans les commandé, tous poùques postaux, retirer tout pli chargé ou reou d'extraits soit des présents donnés au porteur d'expéditions tions du Conseil ou de l'Assemblée.

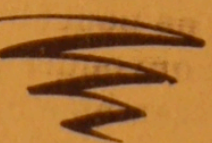



Anexo 2 - Projeto de pesquisa proposto por Lebret para a École d'Uriage para pesquisar a cidade e desenvolver um programa de ação

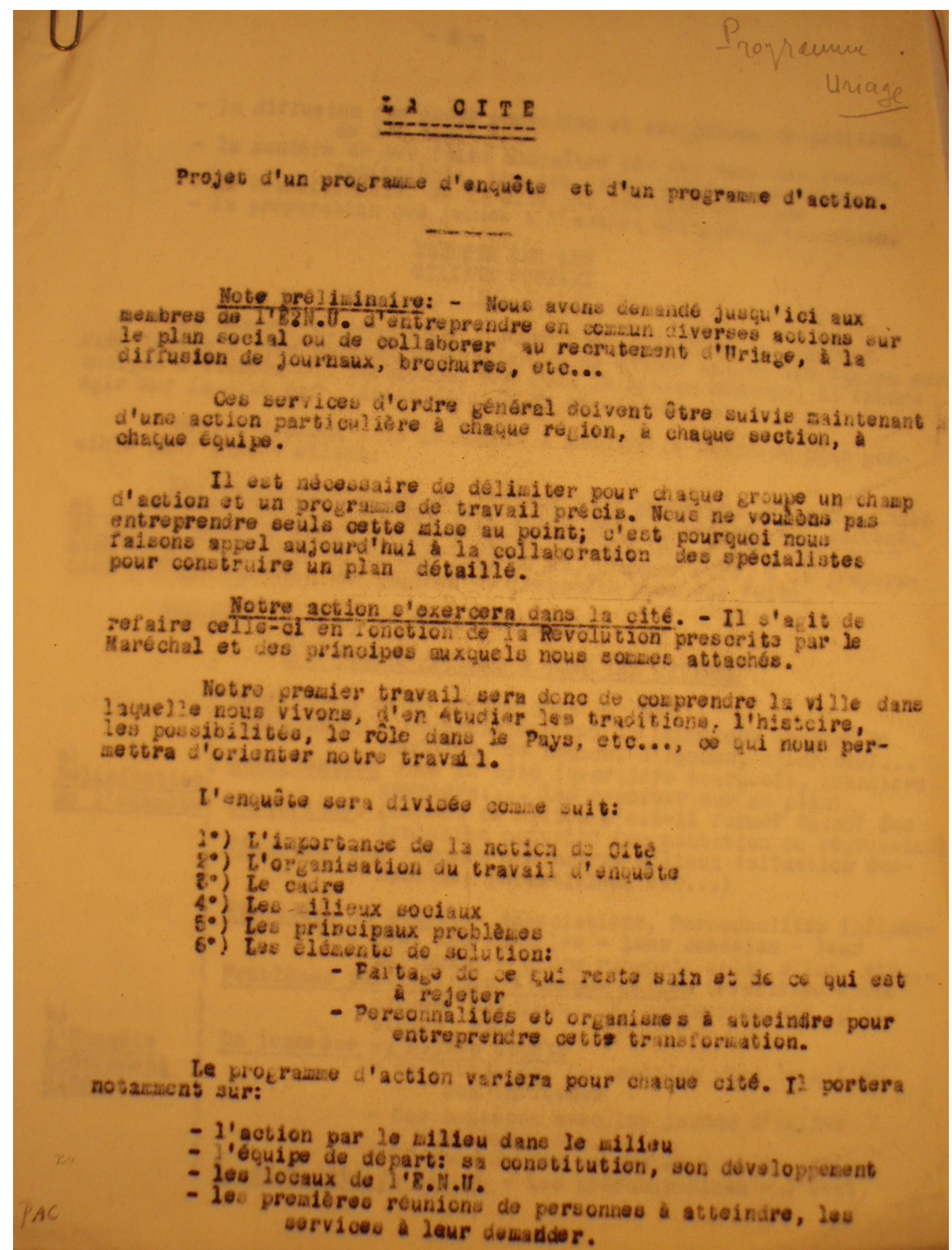




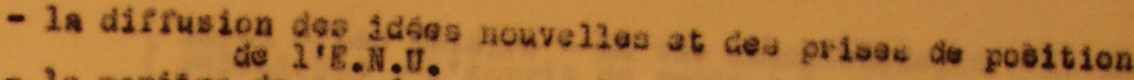

- La maniere de 2 'B. No.

de per :

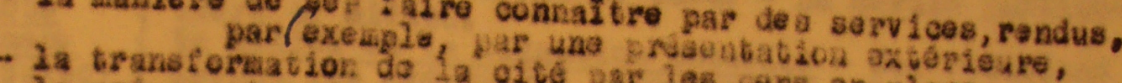

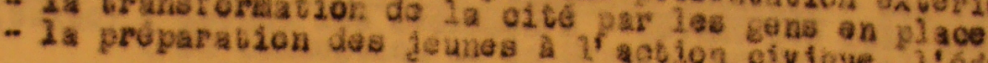

\section{BNQUETR SUR LBS \\ MITIEX socruux}

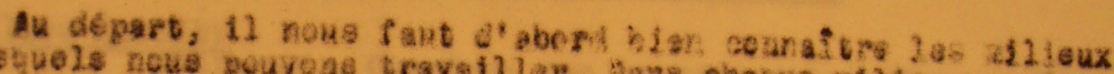
dans lastuels nous pouvene travailier. Dans chasue willou une dquipe se ohargue d'etendre son iniluence. Una fols le diliou concuis, il faudra

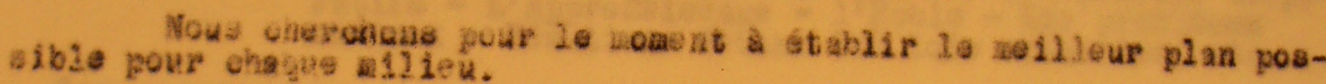

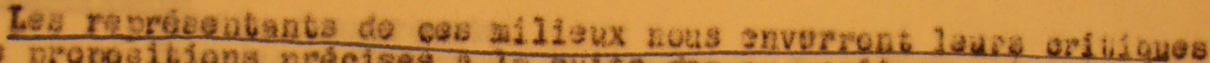

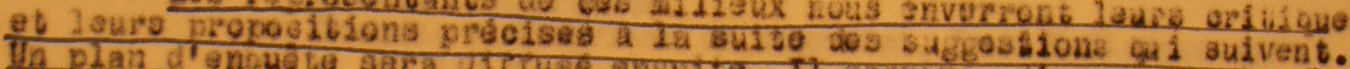

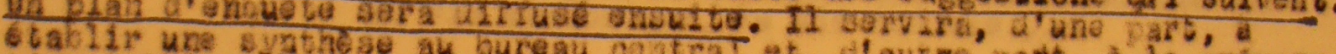

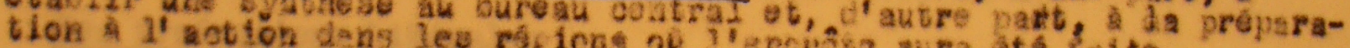

Sugeesicas pour un plan c'ençuâto:

\section{L. = PRAITS COY UNS A TOUS IRS MIIIRUX}

( Tugorbance da oe milies dizi la ciec

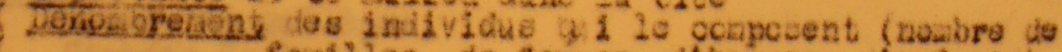

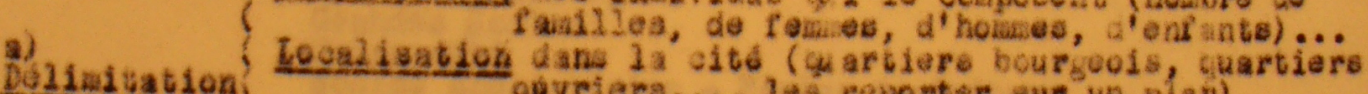

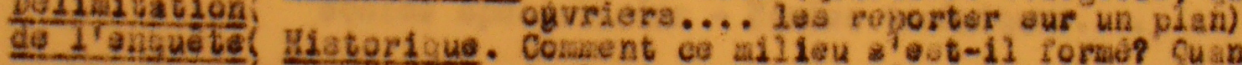

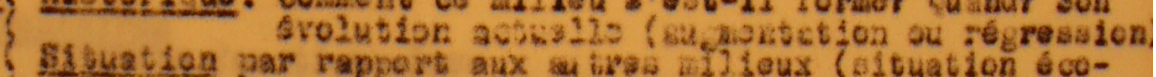

siluation par rapport anx an tiras wijieux fojtuation éconosiçue, repartition, ato...)

Structuro du bilieu - Asso olatione, Personnalitén ineluen-

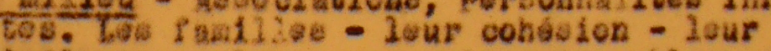
Ineluanes - le are rapports thiro ajios, eto...

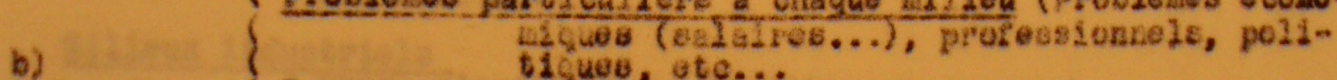

1'Snoueto to ticues, otc...

pioprotient

EL jeune soe din uilien etudis ब210:

- ขa Tormation. Sa poeitica dase le aidieu. son Iníline nce

- Ses contacos avee lea jounes d'autras

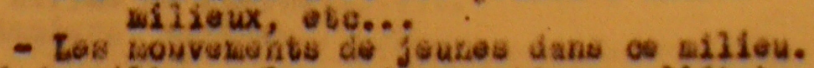

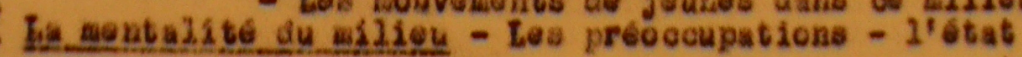




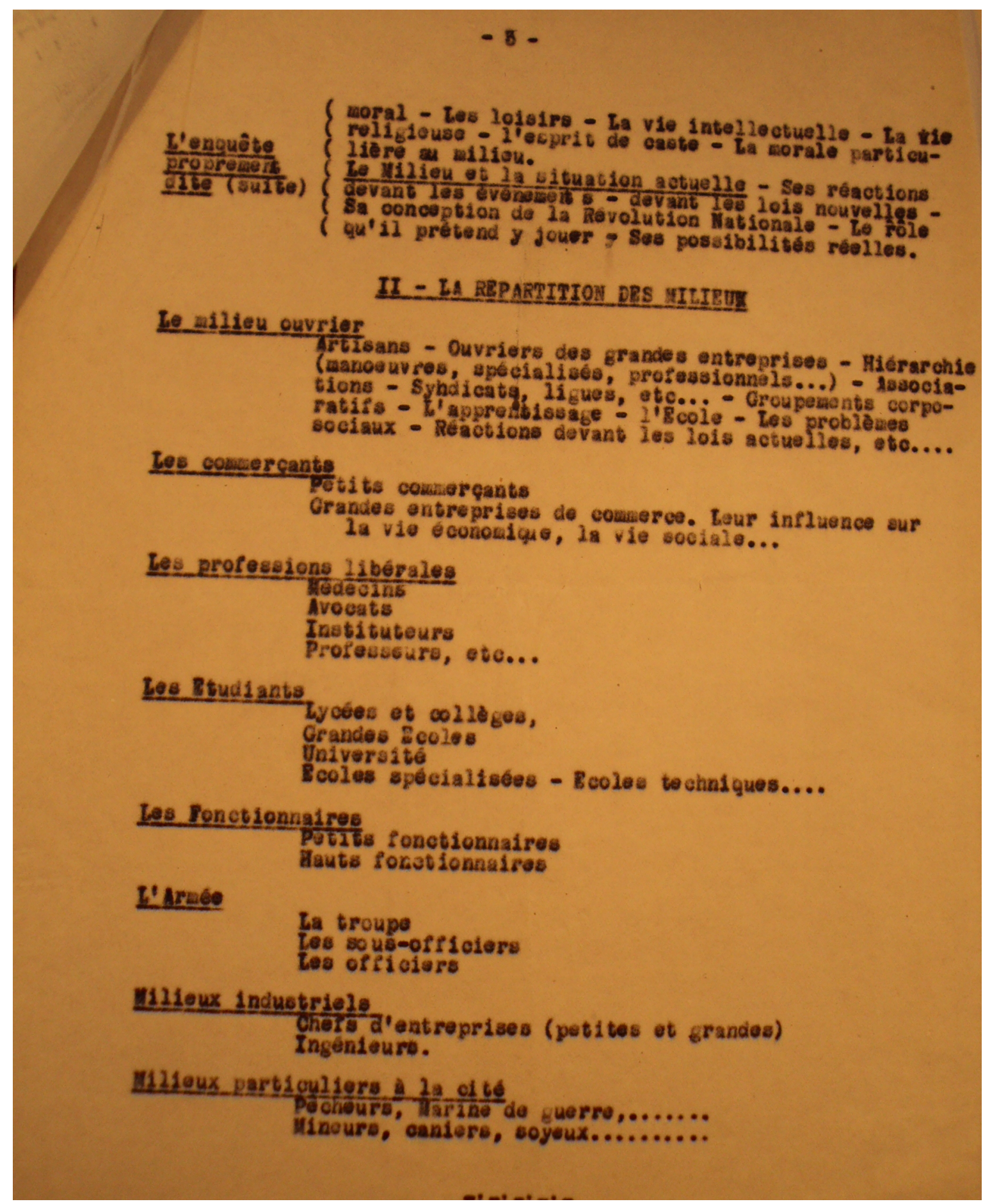





\section{Anexo 3 - Lista de possíveis colaboradores na América Latina}

Annexe II - Oxianisaes et personnes qui ont particulí̀renent contribué a je faclilter le vovace et le sésjour en Amb́rique du Sud

Bregil

- Economia e Bumanismo, (Directeur : R.P. Benevenuto de Santa Cruz) Praça de Bandeire, 40, Conj. 13 E. Sâo Pawlo

( voyage Paris Sâo Paulo A.R. et frais de afjour au Brésil)

Uruguay

- Equipos del Bien Coniun c/o Monsieur Gorge CaRuBIDIA Tarran̂sag, 4063 - Montevideo

(Nonsieur Garmendia, avocat et profossour de Droit, $\mathrm{m}^{\circ} \mathrm{a}$ logs ches lui; lui et ses amis du centre d'ótude et d'action sociale "Bquípos del

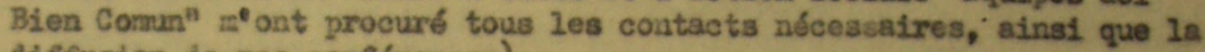
diffusion de ses conférences)

- Nonsieur Isace GANos, Professeur à la Faculté de Droit et Sciences Socialea et à la Paculté des Sciences écononiques. . Univeraidad de Uruguay Montevideo (n'a prêtó sa chairo dans ces deux Facult́́s ot a l'Institut des Professeurs)

- Monsieur coururs , Doyen de la Paculté de Droit et Solences Sociales, Univeraidsd de Uruguay

- Nonsieur le Doyen de la Faculté des Sciences Bconoriques, Univeraidad de Urugaay.

- Honsieur GROIPOIE, Directeur de 2'Institut des Professeurs.

( à ${ }^{\circ}$ obligeance desquels, je dois d'avoir pu faire mes confórences

à Universits)

\section{Chi11}

- Direccion de Pleneamiento - Mtinisterio de obrces Publicas - (directeur Monsieur AGUIRRE) aalle Korardé, Santiago du Chili.

( orgeniane qui a pris à as charge une partie de mon voyage au Chill et a mis a me disposition son avion perticuliex pour le voyage a Concepoion)

- Instituto de Urbaniame - Universidad Catbilica ( directeur : Monsieur Bmile DUHART) calle Villavicencio, 349 ou 439 Santisgo du Chili.

(a pris en charge mes frais de sójour à Santiago)

- Monsieur Juan B. ASTrCA - C. Blene Blanco, 920 Santiago du Chili

( Chef de service a la "Direceion de Planeamiento", quí s'est chargé de me piloter au courrs de mon sbjour à Santiago et d'assurer la diffuaion de mes confírences, et a pris l'initiative de la création doun groupe "Eeononie et Huananisme" au Chili)

- Instituto Chileno-francès de Cultura (Président Vonsieur Roberto WaLKRR LIFARES) Calle A Guatinas 719 Sentiago du Chill

(organisuse qui a organisé ma confórence sur Economie et llusanisme, à Santiago) 
- Monsieur Alphonse CREACH, Attaché culturel français a Santiago
(à qui je doís lor

- Monsieur Ramon VLiveas (Directeur de 1•Instituto de "Irves

Sociales") c. Huerfanos, $620-$ Santioge dutituto de "Hestigationes (min a notement

Bolivie

- Université Nationale de San Mareos, La Pas (Recteur Monsieur Gaston ARLOZ)

- Monsieur TEIssirR, Ambassadeur de France - Adeur. Camaclo 308 - La Pas ( qui m'a invité chez lui et $m^{\prime} a$ fait visiter la ville et ses environs)

Pérou

- Instituto de Urbanismo - Escrula National de Ingenieras - Lima

(Directeur : Monsieur ORTIZ de ZBVALLOS)

(organisse qui a subventionné une partie de mon voyage au Réfou) NEM

- Monsieur Nermesio CANELO, Professeur à $1 \cdot$ Institut a Urbanisme calle Califormia, 389 - Callso

- Monoieur Antonio Scrulu, Professeur à la Facul té des Sciences Beononiques et sociales - calle Paúre Jeroniso, 426-Lima

- Nonsieur Anguste DAnDERT

Apartado 1478 - Lima - Nonsieur Andr6 RUSZKOWSKI, Professeur à la Yaculté des Sciences Bconomiques
et Sociales - Apartado 1761 - Lima.

- Docteur Ernesto AJAYZA, Doyen de la Baoul té des Sojences Bconomiques et Sociales - Univeraidad Catolica - Camana , 459 - Lina

- Monsieux I'Ablé José DAnusRe' vice-recteur de I'Univeraité Catholique - Lima

- Monsieur le Recteur de l'Université Catholique - Lima

- Konsieur Brrieque de LOZADA - Directeur de la Mission des Andes - 0.I.T. hotel Bolivax - Dep - 547 - Lima

(Personnalités qui, à des titres divers, ont facilité mon séjour et mon travail à Lima) - Monaieur BIrocHE, Ambassadeur de France, et Konaieur BERYsILLER, Attachó
culturel a Lima. 
Anexo 4 - Carta de Gaston Bardet ao Pe. Lebret sinalizando com uma ruptura com o Économie et Humanisme

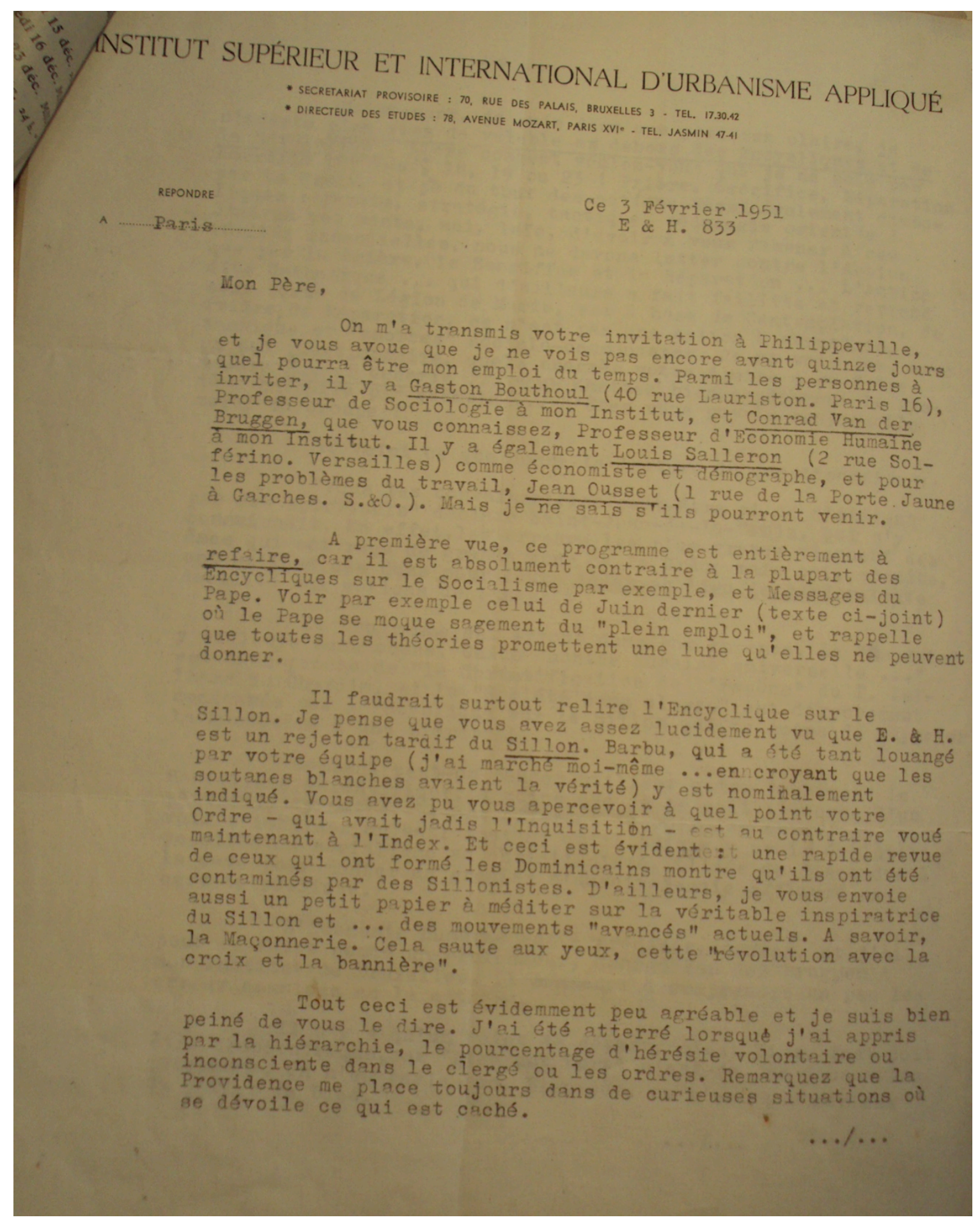




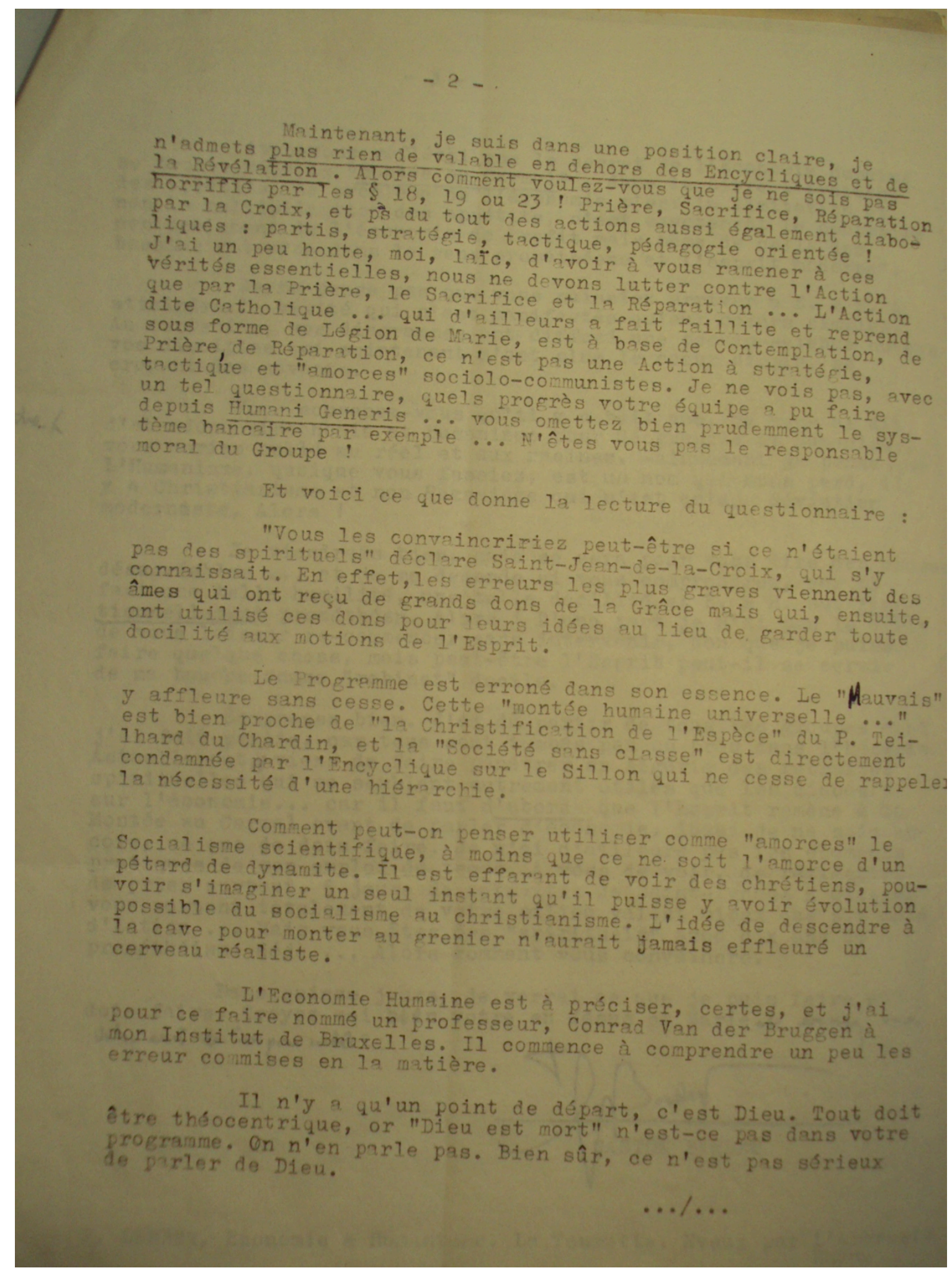




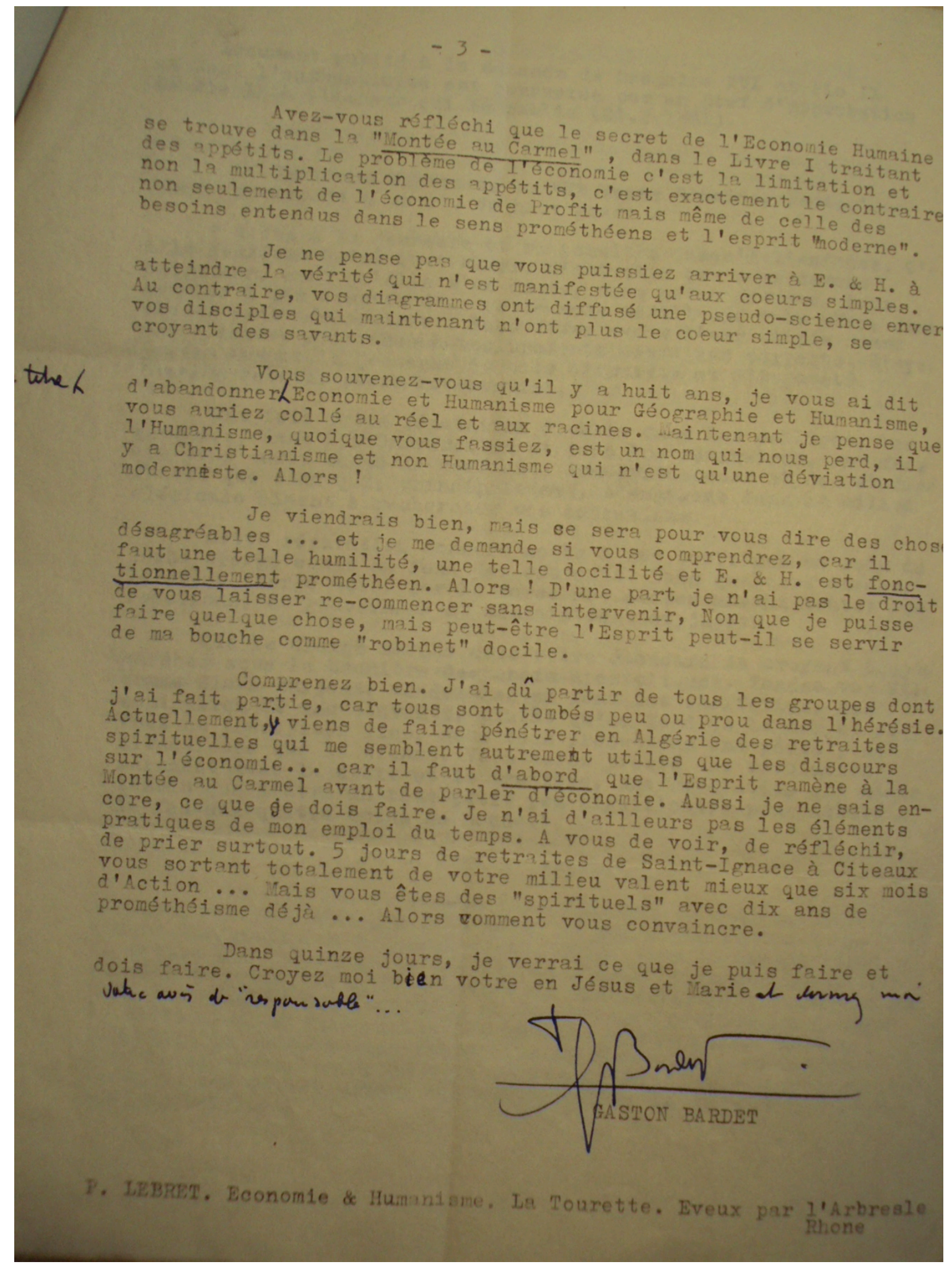



Anexo 5 - Lista de EH com a relação de países que tem assinantes da "Revue Économie et Humanisme"

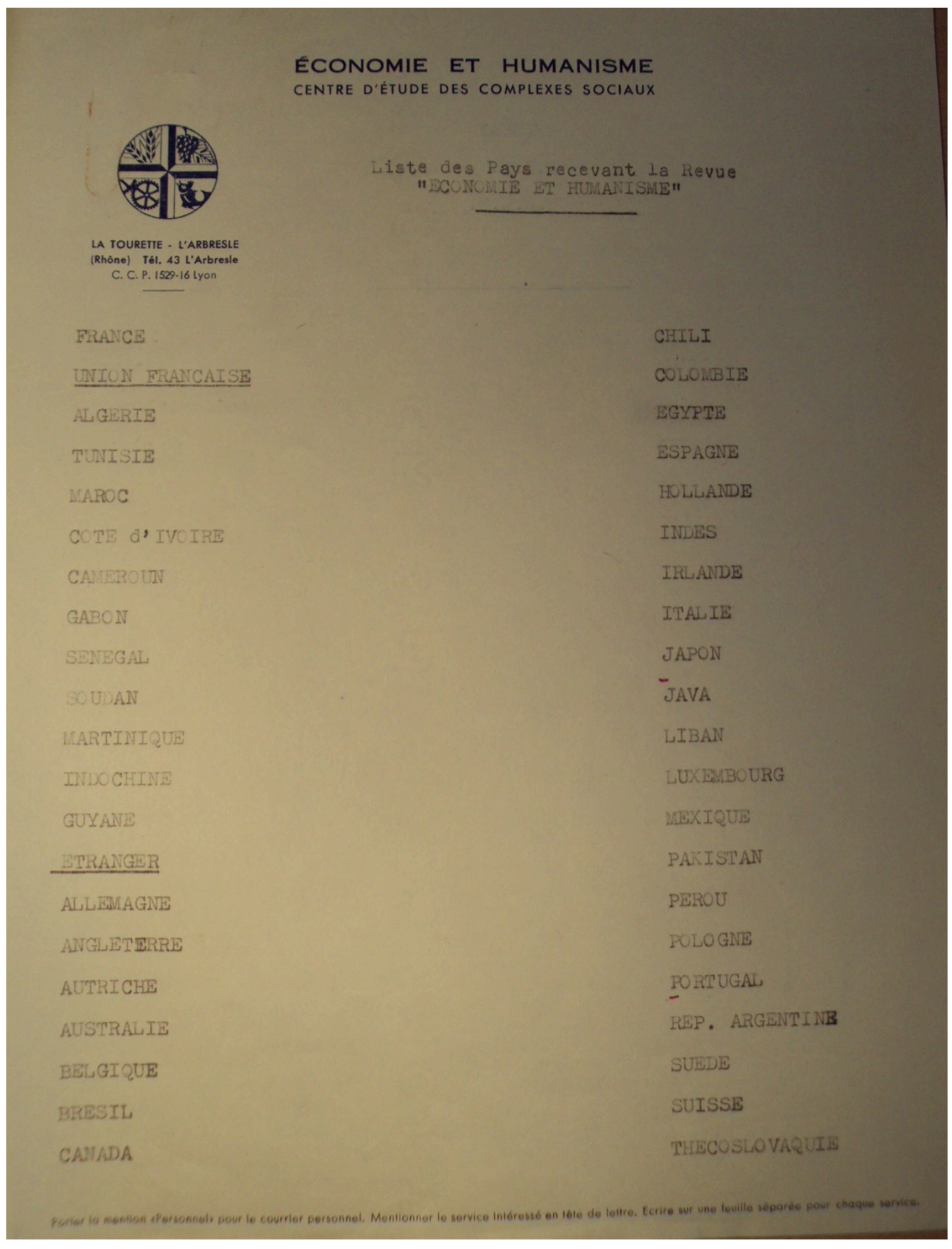



Anexo 6 - Carta de Lebret ao Ministro Claude Petit solicitando apoio financeiro ao EH

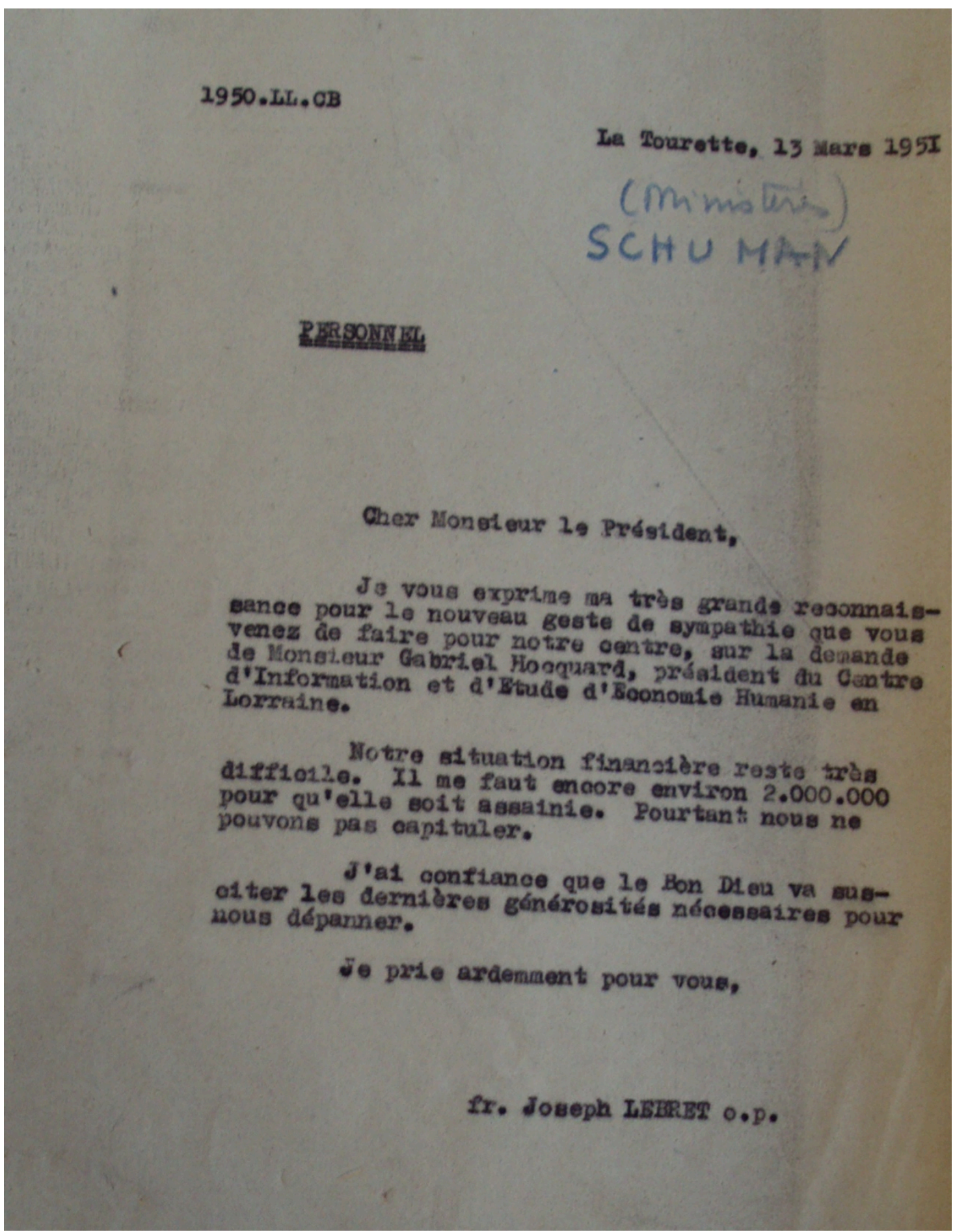



Anexo 7 - Lista de Participantes da Sessão de Análise das Aglomerações Urbanas, realizada em 1953

\begin{tabular}{|c|c|}
\hline Nome do Participante & Cidade/País \\
\hline Jacqueline Abescat & Puteaux/Siria \\
\hline Abbé Joseph Bouet & Thouers/Aube \\
\hline R. P. Brevet & Orleans \\
\hline Georges Chabnet & Le Breuil \\
\hline \multicolumn{2}{|l|}{ Abbé G. Danis } \\
\hline Jeans Besionne & Nancy \\
\hline \multicolumn{2}{|l|}{ Maurice Deuilhe } \\
\hline Marguerite Dupire & Paris \\
\hline Mms Firelin & Tunis \\
\hline R. P. Ecruient & Strasburg \\
\hline \multicolumn{2}{|l|}{ André Gane } \\
\hline \multicolumn{2}{|l|}{ Yves Goullin } \\
\hline R. P. Guilloy & Lille \\
\hline \multicolumn{2}{|l|}{ Abbé Hufschimitt } \\
\hline \multicolumn{2}{|l|}{ Abbé Hugonnard } \\
\hline \multicolumn{2}{|l|}{ R. P. Bourgin } \\
\hline Abbé Gherardini & Tunisia \\
\hline \multicolumn{2}{|l|}{ Cr. Guillanoy } \\
\hline \multicolumn{2}{|l|}{ Michel Huley } \\
\hline Yves Lery & Angers \\
\hline Abbé Lodde & Le Mars \\
\hline Gabriel Maignial & Paris \\
\hline Mms. Maquin & Reims \\
\hline Jacques Maquin & Reims \\
\hline Abbé Mateia & Rouen \\
\hline André Ohl & SAGMA \\
\hline
\end{tabular}




\begin{tabular}{|l|l|}
\hline Corentin Paillardon & \\
\hline André Pechabadens & \\
\hline Joel Perisse & \\
\hline Mme. Perrot & Grenoble \\
\hline H. Pinon & \\
\hline R. P. Poplin & Paris \\
\hline Paul Reggui & llinóis/EUA \\
\hline Th. Roddy & Grenoble \\
\hline Bernard Sarrat & Lille \\
\hline Abbé Suty & Brive \\
\hline J. P. Tixier & Paris \\
\hline P. André-Jacques Vreck & Paris \\
\hline G. Célestin & \\
\hline
\end{tabular}


Anexo 8 - Lista de participantes estrangeiros convidados para a I Conferência Internacional do Économie et Humanisme em São Paulo

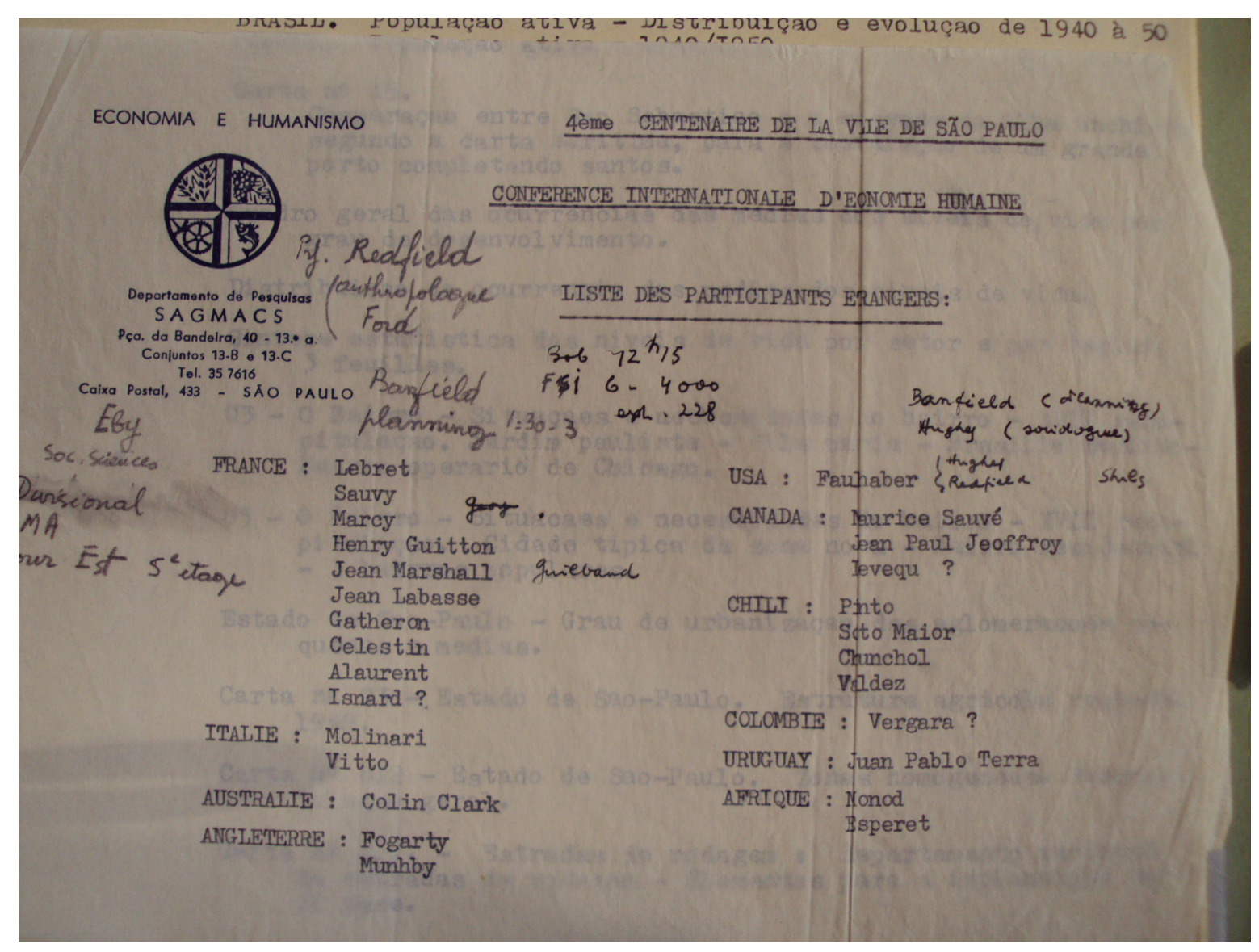





\title{
Anexo 9 - Transcrição da Entrevista realizada com Celso Monteiro Lamparelli*
}

\author{
* Entrevista realizada em 11 de junho de 2007. A transcrição foi revisada pelo depoente. \\ É vedada a reprodução total ou de partes desta entrevista sem a prévia autorização do \\ entrevistado.
}

LUCAS CESTARO - Inicialmente gostaria que o senhor colocasse sobre seu vínculo com a SAGMACS e o pe. Lebret, gostaria de entender melhor sobre a figura do pe. Lebret, e sua vinda ao Brasil em 1947, para o curso da ESLP, a formação da SAGMACS e da composição da equipe que atuou em seus quadros...

CELSO LAMPARELLI - O pe. Lebret fundou com alguns filósofos e pessoas importantes na França em 1941 um movimento de Economia e Humanismo. Mas ele já tinha uma experiência anterior, de humanizar a economia, com os pescadores da Bretanha. Isso ocorreu uma vez que ele ficou doente, e foi se tratar perto de sua família, na Bretanha, lá se deparou com uma situação de trabalho muito atrasada, buscando colaborar trocou dados com o sindicato dos pescadores do local, para poder contribuir com avanços técnicos e melhoria da qualidade de vida dos pescadores.

Com a fundação do Movimento Economia e Humanismo, ele juntamente com este grupo tinha a intenção de atualizar a doutrina social da igreja utilizando-se dos avanços das ciências sociais, da economia, da sociologia, da filosofia, buscando um quarto caminho. Pois na época a França estava parcialmente ocupada pelos alemães, fato que os franceses nunca se conformaram. Assim o Movimento Economia e Humanismo passa a atuar com o principal objetivo de atualizar a Ação Católica e dos Movimentos Sociais, enfim na formação de leigos com engajamento político e social, que viessem a assumir postos importantes após o fim da ocupação alemã. A partir daí começa a aparecer manifestações do filósofo Maritain, tanto quanto do filósofo do personalismo, e dos padres operários, buscando uma igreja mais avançada.

A ação concreta dos leigos, era a de resistência ao nazismo, tanto de resistência pacífica a ocupação, como combate direto aos alemães, mas para isso eles precisavam estudar a situação, compreender a situação. E o engajamento dos leigos precisava dessa formação, precisava de uma assessoria científica, daí entrava os grupos de estudos e formação, chamados SAGMA.

Então você tinha as SAGMAs - grupos de estudo e formação de leigos, a doutrina economia e humanismo - que buscava a integração com as ciências humanas e os avanços da técnica, e o movimento economia e humanismo - que buscava uma quarta via, que não era nem o socialismo, nem o capitalismo, nem o fascismo. E Lebret tinha seus assessores nestas 3 frentes, formando uma equipe técnica, as publicações e um centro de treinamento em Lyon.

Este grupo se ampliou muito após a guerra, ampliou-se verdadeiramente na Europa principalmente estimulados pela eficiência da democracia cristã na Alemanha com o primeiroministro Abdenauer e o Plano Marshal de reconstrução das cidades européias, enfrentaram a tarefa de reconstrução da Europa, não só de uma reconstrução material, na linha de urbanismo vamos encontrar toda uma tarefa de restauração da cidade, de construção de habitação, mas também de reconstrução sócio-política. 
Em 1947 quando o Lebret veio para o Brasil e os demais países da América Latina, ele veio para dar um curso sobre a doutrina Economia e Humanismo. É bom situarmos o contexto político do país naquele período, o presidente era o Dutra e vivíamos um período democrático em que o Partido Comunista estava legalizado. Havia uma nova constituição e se abria a perspectiva de renovação política do Brasil, Lebret de certo modo havia se entusiasmado com a democracia que se implantava após o Estado Novo, aqui no Brasil.

Os dominicanos e a ESLP organizaram um curso que foi ministrado na Escola de Sociologia e Política, que foi ministrado a uma série de jovens promissores na política, participaram o Lucas Nogueira Garcez, o André Franco Montoro, o Carvalho Pinto quase uma centena de jovens, mas não chegou a isso. Simultaneamente ele fazia palestras em apologia ao movimento e fundou a SAGMACS, fazendo uma pesquisa sobre as condições de habitação em São Paulo. Quando ele foi embora ficou responsável pela SAGMACS o prof. Luiz Cintra do Prado, que era professor da Poli. Mas o Lucas Garcez e outros profissionais ficaram ligados ao grupo de Lebret que era representado e tinha a frente o frei Benevenuto de Santa Cruz e os dominicanos.

Quando ele deixou o Brasil, foi com o mesmo intuito para a Venezuela, o México, o Uruguai e o Chile, tendo sido muito bem recebido no Chile, em função da democracia cristã, que aqui no Brasil era uma frente muito ampla, que agrupava setores da direita à esquerda e tinham interesses diversos, muito complicado de serem entendidos.

LUCAS - Mas ele foi muito bem recebido no Chile porque já tinha também a experiência que viveu aqui no Brasil, já estava calejado e sabendo em que solo estava pisando.

LAMPARELLI - De qualquer forma, depois dessa viagem ele foi proibido de voltar à América Latina toda, mesmo no Chile, tinham lá cardeais que não queriam ele por lá. Com essa proibição ele fica fazendo o movimento dele na Europa, que se amplia pra Alemanha, Espanha, Itália, e ele tem auxiliares de alto gabarito e funda a Revista de Economia e Humanismo, cuja assinatura o Anhaia Melo faz a assinatura desde a $1^{\circ}$ edição aqui para a FAU.

É importante dizer que a SAGMACS fica hibernando durante esta ausência, faz apenas um único trabalho sob a coordenação do Prof. Luiz Cintra sobre as condições de vida do trabalhador do Jóquei Clube de São Paulo, que logicamente esta pesquisa não foi tão bem vista, pois revelava algumas condições não muito dignas dos trabalhadores.

LUCAS - Em 1952/53 Lebret retorna à São Paulo com o auxílio do Garcez.

LAMPARELLI - Ele retorna em 1953, em função da eleição para governador do Lucas Garcez, que vai falar com o arcebispo de São Paulo, D. Carlos Motta movimentando a cúpula da igreja para o retorno de Lebret.

LUCAS - Enquanto no Rio já tinhamos o trabalho social de D. Hélder Câmara. 
LAMPARELLI - O D. Hélder não era arcebispo do Rio, ele era o auxiliar, mas lá havia bom transito com os dominicanos cariocas e os sociólogos. Em São Paulo tinha o pessoal da Poli que sempre o tratou muito bem. Mas, por falar em $D$. Hélder havia um vínculo com o Recife por causa do prof. Baltar, que era um engenheiro, tinha autoridade no assunto de urbanismo, era uma pessoa ativa, não só como profissional, mas como professor, alto funcionário federal, e membro do Partido Socialista, ele era uma pessoa importante, e ele será o mentor de toda a equipe e da concepção do método de trabalho urbano da SAGMACS.

Então, retorna o pe. Lebret chamado pelo Garcez para ajuda-lo a montar o Plano de Governo. Mas este Plano de Governo supunha alguma eletrificação, isto é, um aproveitamento intenso dos recursos hidráulicos, porque o prof. Lucas Nogueira Garcez era professor de hidráulica na Poli, então ele vai procurar as fontes de energia e as condições do Estado de São Paulo, através de um organismo inter-regional que se chamava Comissão Interestadual da Bacia do Paraná Uruguai, todos os Estados que pertenciam as bacias desses rios, se associaram a uma comissão e o primeiro trabalho, foi sobre as condições de desenvolvimento, isso em 1953.

Eu fiz um curso com ele aqui na FAU em 1953, sobre desenvolvimento e as necessidades das técnicas de pesquisa para identificar os obstáculos e as condições de subdesenvolvimento, nessa altura, ele rompe de certa maneira com a França, rompe no sentido de dizer "vocês não precisam de mim, eu vou ficar por aqui, pois vocês não precisam de mim aí", ele vai para a África, o Vietnã e o Libano onde ele tinha sido engenheiro supervisor do Porto de Beirute antes de se ordenar padre. Nesta passagem ele faz muitos amigos, pois ele era uma pessoa que fazia questão de conversar com todas as lideranças nos diversos níveis, e apoiava todas as iniciativas e as correntes progressistas.

Então se inicia o trabalho da pesquisa do Estado de São Paulo, que vai depois ser repetida no Paraná, Santa Catarina e Rio Grande do Sul, que a comissão interestadual pretendia fazer um plano geral.

Deste trabalho, ele conhece um médico que é o Toledo Piza, ficam amigos, ele se hóspeda na casa de praia do Toledo Piza. Há um envolvimento, vamos dizer assim, uma enorme rede com um grupo do desenvolvimento, com a equipe técnica aqui formada para fazer a pesquisa do Estado, o Baltar fazendo o trabalho de Recife, o Plano Regional, com a assessoria do Lebret, e eu era estudante aqui no $3^{\circ}$ ano da FAU e eu fui convidado para fazer os desenhos do Plano Diretor de Ourinhos. O Baltar fez o Plano e precisava de alguém para desenhar, e eu fui contratado para fazer os desenhos dos painéis para a apresentação. Então eu conheci o Lebret quando eu era membro da JUC - a Juventude Universitária Católica, que aqui neste prédio sempre vivia em disputa com a UJC - União da Juventude Comunista, dois grupos com uma intensa atividade na luta por uma influência não só da área de ensino, como também de formação de lideranças, o Artigas era um cara do partido, ele nos detestava. Taí então, este o contexto em que eu começo a fazer parte da JUC lendo o material do Lebret, pois ele dentro da Ação Católica era o que escrevia de maneira mais avançada. Tinha uma bibliografia importante que era os dois livrinhos - o Princípios para a Ação e o Guia do Militante.

Em 1954 ele orienta a direção da JUC nacional para o I Encontro Nacional dos estudantes da JUC aqui em São Paulo, a propósito do $4^{\circ}$ Centenário, então ele orientou as JUCs nos estados para se discutir, e trazer para o congresso os problemas de todos os Estados brasileiros, então no Amazonas, o problema dos seringueiros, da extração da borracha, do peão e da condição dos índios e dos fazendeiros e em cada Estado ele localizava um problema, por exemplo os peões do café no norte do Paraná, a balança do pagamento, então em cada região, em cada Estado as equipes de JUC tiveram o ano de 1953 para se preparar e trazer seus temas sobre qual era a situação. No sentido seguinte, se são universitários são capazes de formar uma equipe polivalente de sociologia, de engenheiros, comunistas, etc. 
LUCAS - Aqui no Brasil é na JUC, então que se começa o sentido de interdisciplinaridade e integração das áreas, que pautará o trabalho da SAGMACS?

LAMPARELLI - Aí começa a coisa, na própria JUC, já se tinha a interdisciplinaridade como um ponto fundamental. Antes se estudava a cultura, a arte, o Lebret veio e sugeriu "porque não estudar os problemas de seu Estado e região", então nós tivemos o Congresso durante uma semana, uns dez dias na PUC de São Paulo, em que o Lebret nem apareceu, mas ele deu toda a problemática preparada e discutida com a equipe central as equipes locais.

LUCAS - A preocupação dele sempre foi de formar lideranças autônomas, ele falava no homem integral.

LAMPARELLI - Sempre foi, aproveitamento máximo dos recursos naturais, o desenvolvimento dos homens, de todos os homens em sentido pleno, desenvolvimento integral, homem integral era uma expressão do filósofo Maritain.

Então você tem uma época em que todo o mundo está discutindo, e lá na Europa o movimento continua discutindo, mas o Lebret fica em Paris e o grupo francês vai para Lyon - La Tourette, neste local eles montam um Centro de Treinamento, que já era quase uma pós-graduação, aberta para o mundo todo. Então antes de começar a pesquisa sobre São Paulo, que aquele médico assume a Prefeitura de São Paulo por acaso, no lugar de Lino de Matos que era o Prefeito e resolveu retornar ao Senado, onde poderia ficar mais tempo. Assim deixou a Prefeitura na mão do Toledo Piza e ele imediatamente mobilizou o pe. Lebret a fazer este plano, que na verdade é uma pesquisa urbana, não é um plano, era um levantamento rápido, mas as coisas demoraram mais do que o previsto e o relatório que ele queria, que era resultado de uma associação entre o pessoal contratado pela Prefeitura e pela SAGMACS.

LUCAS - Então os contratados pela SAGMACS tiveram origem ou pertenciam há JUC.

LAMPARELLI - Eu era da JUC, e fui trabalhar com o Lebret, mas é claro que muita gente de JUC não foi, e tinha gente que era só estudante e estagiário e foi trabalhar na SAGMACS.

LUCAS - Mas eu gostaria de entender melhor, apesar de o senhor ter colocado sobre a interdisciplinaridade, como é que se deu esta integração das áreas e a preocupação do pe. Lebret sobre a cidade, o entender a cidade e sobre o pensar e planejar a cidade. Como é que isso se deu?

LAMPARELLI - Ele foi estudar profundamente a economia, ele estudou, nos livros posteriores dele ele faz análises econômicas sobre as diversas correntes, agora o que acontece aqui, é que 
ele não estava sozinho, junto com ele estava o economista Raymond Delprat. Ele vinha sempre acompanhado, a França e a Europa forneciam estes especialistas para atuarem e auxiliarem o Lebret. Em $1954 \mathrm{em}$ função do $4^{\circ}$ Centenário ocorreu também o I Congresso Internacional de Economia e Humanismo, organizado pelo movimento e a SAGMACS contando com a presença de especialistas e autoridades do mundo todo. Este congresso foi interrompido um dia antes do prazo devido ao suicídio do presidente Getúlio.

Então em 1955 ele trabalha para a bacia e faz o estudo sobre o Estado de São Paulo, em 1956 o Toledo Piza manda chama-lo para coordenar a pesquisa urbana sobre a cidade de São Paulo. Eu fui trabalhar na equipe de pesquisa urbanística, coordenando a zona leste. Você tinha 4 equipes, a equipe de base, dividida em 5 grupos (norte, sul, leste, oeste, centro), não era município era aglomeração paulistana, não era plano, era uma pesquisa urbana para entender quais eram as dificuldades e as carências da grande São Paulo.

Esta atividade foi ostensiva, cobriu todo o território, que foi dividido em 360 unidades de análise, cada unidade de análise depois era classificada de acordo com seu escalão de serviço e sua capacidade de atração. Em cada unidade se fazia uma pesquisa em duas faces, a face da população e suas necessidades e a face do equipamento e suas potencialidades internas. E cada unidade análise formava uma unidade complexa que formava a unidade completa, por exemplo a Penha era unidade completa porque era um pólo de atração, com 3 ou 4 unidades complexas, um pouco melhor servida.

Então a pesquisa, não estava querendo fazer um plano para a cidade de São Paulo, e sim para toda a aglomeração de São Paulo, que ia contra a corrente, contra a especulação, e os poderosos perceberam que não seriam beneficiados com esta pesquisa. Então quando acaba o mandato do Toledo Piza, assume o Ademar de Barros e o dr. Ademar imediatamente corta o contrato com a SAGMACS e inviabiliza a publicação deste trabalho e Lebret retorna para a França.

Em 1966 após a morte do Lebret, se formou a Associação dos Amigos do Lebret, onde se organizou e transcreveu todas as publicações e trabalhos feitos pelo Lebret, onde se formou a biografia e a listagem completa de sua bibliografia dele que está a disposição para ser consultada na França. O Peletier fez a tese de livre docência sobre isso, e tem muito a contribuir com aqueles que quiserem conhecer melhor os detalhes. E o Fundo Lebret está todo datilografado em caixas, assim como microfilmado, neste arquivo, pra eu visitar, como ainda não estava pronto eu tive que pedir autorização para o Delprat que era o presidente.

LUCAS - Mas em suas vindas, o sr. disse que ele trazia assistentes, citando o Delprat, como se dava esta vinculação desta assessoria européia e a visita do Lebret aqui no Brasil?

LAMPARELLI - Ele trazia uma equipe de lá, montava uma equipe aqui, dava o treinamento e caia fora, ia pra outro lugar, formar mais gente, tinha um método. Por exemplo, quando foi estabelecido que ia se fazer a pesquisa da Aglomeração, um engenheiro formado na Poli, chamado Mário Laranjeira vai com ele, eu não sei se ele vai sozinho, sei que inicialmente ele vai sozinho pra montar um método de pesquisa lá na França. Ele vai para o Centro de Treinamento em Lyon, mas o escritório do Lebret era em Paris, um escritório grande, de nível mundial, em Lyon ficava a escola sediando eventos, há episódios interessantíssimos de cooperação com o governo francês, por exemplo eu fui descobrir lá 5 grandes pesquisas feitos por SAGMACS, sobre habitação que era um levantamento dos 5 conjuntos do Lê Corbusier que era um desejo do Ministro que era um entusiasta do Lebret e um amigo do Lê Corbusier. Veja que a influência é do pescador ao Ministro. 
Então chegamos a 1957, em que Lebret vem para o Brasil quando o Ademar cortou o contrato, e no diário dele ele agradece ao Anhaia que foi com ele conversar com Ademar de Barros, Prefeito. Nesta altura o Anhaia já tinha de certa forma aderido e aproveitado coisas que o Lebret trazia, os dois tinham muitas afinidades, por exemplo, os dois tinham uma perspectiva regional, coisa que $o$ Prestes Maia não tinha. Prestes Maia era o homem da obra, ele sentava na prancheta e planejava como ia fazer, por exemplo a primeira gestão, foi de 1934 a 1945, pra quem foi prefeito todo esse tempo, podia fazer milhões de coisas, até fez, mas na segunda vez que ele foi prefeito, São Paulo já não cabia mais na prancheta dele, ele não tinha a menor idéia da periferia, quem mostrou o que era a periferia foi o Lebret, primeiro com o acampamento, e eu vi esse acampamento, porque fui fazer a pesquisa na Zona Leste, que eram loteamentos atrás de loteamentos, com densidade baixíssimas, com vida quase rural, com poço, fossa negra, pouco transporte, era um rio de poeira ou de lama, não tinha nada. O que é isso? Não é cidade, é um acampamento.

LUCAS - Pe. Lebret dizia isso também.

LAMPARELLI - O Lebret falou, falou com todas as letras, e é claro que a elite não gostou. Mas além desse estudo que fiz na zona Leste, eu tenho todo um texto do economista Raymond Delprat que foi o diário de campo que ele fez quando ele dirigiu a pesquisa sobre o Estado de São Paulo, e ele conta como era a vida dele na cidade de São Paulo em 1955, ele começa a pesquisa falando sobre o preço do pão, é interesantíssimo. A partir dessa pesquisa do Estado, você tem então personagens que ficaram estremamente ligados, frei Benevenuto, Mário Bastos, Eduardo Passos, Domingos Teodoro de Azevedo, que fizeram a pesquisa do Estado de São Paulo, foi a primeira pesquisa neste nível, eles percorreram todo o Estado, fizeram um estudo sobre a regionalização, sobre a potencialidade da industrialização, sobre o despropósito da concentração, tudo isso para um governo que imediatamente é substituído por um populista que joga tudo no lixo. Então toda vez você tem uma interrupção do nosso trabalho, por isso você tem 4 fases da SAGMACS.

LUCAS - E quase que todas estas interrupções estão ligadas ao Ademar...

LAMPARELLI - Mas o Ademar é o... Agora quando termina a pesquisa sobre São Paulo, SAGMACS está realizando trabalho semelhante em Belo Horizonte, eu fui pra lá colaborar com a equipe, mas quando essa pesquisa começa, o governo de São Paulo contrata o CEPEU para fazer uma série de Planos Diretores. Planos para as estâncias balneárias do Estado de São Paulo, pois estas não eram prefeituras com prefeito eleitos, a concepção era de que esses municípios eram de interesse do Estado todo, portanto quem deveria tomar conta era o governo de São Paulo. E o CEPEU, digamos assim, não sabiam bem o que teriam que fazer, não dominavam a tecnologia, e eu e o Duca (Domingos Teodoro de Azevedo Netto) viemos formar e dar o treinamento para a equipe do CEPEU. Eu fui pra Belo Horizonte no fim de 1958, então você tem em 1957 o final da pesquisa da Aglomeração em São Paulo que começou em 1956, mas com uma deficiência total, para você ter uma idéia a equipe de sociologia não terminou o trabalho, ficou quase perdido, não houve tempo, quase inviabilizou o trabalho, porque não pagaram. Então você tem a pesquisa de base, a pesquisa urbanística, que era a teoria do Baltar, e a comissão central com este material faz o relatório completo, tentando salvar esta parte da sociologia, e também para dar algumas diretrizes como direção que garantisse a concepção e salvasse a teoria que era a da cidade orgânica. E o pe. Lebret acompanha a posição da teoria orgânica polinucleada, com a 
descentralização, com um sistema de transporte coletivo de metrô extremamente simples e evidente, pois se você pegasse todas as unidades complexas, pelo menos as principais - São Miguel, Penha, Santana, Casa Verde, Lapa, Osasco, Pinheiros, Santo Amaro, que eram centros secundários estruturados ao longo do rio e das estradas de ferro. Aí estavam as áreas industriais. Então a proposta era evidente, simples, metrô de superfície acompanhando os dois rios, ligando todos os eixos secundários ao eixo principal, e depois uma proposta de junção com uma grande circular de transporte coletivo. Era simples, fácil, ele abriu o mapa, viu o que estava acontecendo e propôs. O Ademar de Barros engavetou tudo, não deixou publicar, a sorte é que uma das cópias completas foi entregue ao jornal Estado de São Paulo, 2 vieram para cá, mas os mapas desapareceram e alguns meses depois o departamento de urbanismo da Prefeitura publicou como inédito o Plano Diretor, usando todo nosso material gráfico, com as ilustrações de mapas que eu desenhei.

LUCAS - Isso eu percebi, lendo o Plano Diretor do Ademar de Barros, que havia apropriação do estudo Estrutura Urbana da Aglomeração Paulistana, estavam lá partes de texto do estudo da SAGMACS, sem sequer fazer menção ao trabalho de vocês.

LAMPARELLI - Eu vi isso, soube na hora que vi, porque os desenhos sobre a atração eram muito complexos, e eu tinha um estojo de desenho completo, era só com meu material que se faziam as linhas ou pontilhadas ou tracejadas e em diversas espessuras, então todos aqueles mapas de atração eu tive que me dispor a desenhar, porque nem todos eram capazes, e eu vi algum desses mapas lá no Plano do Ademar.

LUCAS - O senhor mencionou o jornal Estado, que fica com uma cópia do estudo. Há uma ligação da SAGMACS com o grupo Estado, não é, como é que se dá isso, pois o Estadão não era uma linha que podíamos chamar de progressista, mas eles contratam e pagam a SAGMACS para fazer um estudo sobre as favelas do Rio. Como é que era essa relação?

LAMPARELLI - Você tem aí a figura chave da SAGMACS, que era o frei dominicano Benevenuto de Santa Cruz, que era uma figura com grande transito, era um pernambucano, muito ligado as artes, ele tinha uma livraria, que era a Livraria Duas Cidades, que era uma livraria de influência da cultura francesa, freqüentada por toda a intelectualidade paulistana. O frei Benevenuto era muito amigo do pessoal do Estado, era muito amigo de alguns diretores de lá e era muito amigo do Ciccilio Matarazzo, então você tem uma elite aí, e o pe. Lebret era muito amigo de certas personalidades, por exemplo ele era amigo do pai do Severo Gomes que veio a ser senador nos anos 1980 e faleceu junto com o Uilisses Guimarães no acidente com o helicóptero. A família deles teve uma grande indústria - Cobertores Paraíba em São José dos Campos e eles queriam mudar a forma de trabalho da indústria. Por que o Lebret era o cara que pensava na reforma da empresa. A SAGMACS era uma cooperativa, eu fui procurar no diário do Lebret o dia em que ele se reuniu conosco para mudar o estatuto da SAGMACS para uma cooperativa, então os contratos eram por projetos, tinha um coordenador de projeto e a equipe. Então a cooperativa funcionava assim, você vai trabalhar neste projeto, por este período, quando acabar se você quiser continuar, ou quiser trazer outros trabalhos, pode. Então todos eram técnicos e vendedores. Quando veio o golpe de 1964 nós tínhamos 11 projetos em andamento, mas com o regime, começou a perseguição, eu fui visitado 3 vezes pelo DOPS, tivemos que deixar o escritório rapidamente, 
quando deu pra voltar ao escritório, vi os livros todos amontoados no meio da sala, tudo devassado, e o Nestor salvou parte disso comprando os volumes que restaram para a biblioteca da FAU.

LUCAS - Gostaria que falasse um pouco mais sobre o estatuto da SAGMACS enquanto cooperativa.

LAMPARELLI - Eu não sei se esse documento tem aí na biblioteca, mas basicamente era uma cooperativa de técnicos, remunerados pelo trabalho em que se vinculava, mas podia ter até trabalhos individuais, por exemplo o Lucio Kowarich, ele fez um levantamento sobre os peões do café do norte do Paraná, eu e o Costa fizemos um levantamento para uma proposta de regionalização do Estado do Paraná, então tem uma série de trabalhos que é da última fase, antes do governo do Carvalho, porque durante o governo nós técnicos estávamos em stand by, atuando no governo do Estado, só o Chico Ferreira que saiu um pouco antes para recompor a SAGMACS. Quando acabou o governo do Carvalho Pinto muitos técnicos não voltaram, foram formar a ASPLAN, então o grupo se subdividiu, evidentemente com a tensão de assumir posições técnicas e políticas num âmbito maior, usando a SAGMACS como um ponto de apoio, alguns técnicos foram trabalhar em ministérios, eu mesmo fui para o Ministério da Educação, o Chico foi para a Reforma Agrária, isso no tempo do Jango, tínhamos uma série de apoio, o Plínio Sampaio era deputado, então você percebe que aí se começou a montar a rede de aplicação mais completa das nossas idéias. Mas perceba que foram sempre períodos curtos, o maior trabalho que nós fizemos foi o governo do Carvalho Pinto, que toda a equipe mais uma série de gente competente se juntou para fazer um governo de 4 anos, totalmente planejado, uma preocupação totalmente nova.

LUCAS - Por falar no Dr. Plínio, ele não atuou diretamente na SAGMACS, mas tinha uma ligação com o pe. Lebret.

LAMPARELLI - O pai dele era muito amigo do Lebret e o jovem Plínio muitas vezes jantou com o pe. Lebret, ele era um político do Partido Democrata Cristão, com umas lideranças progressistas, e a ligação dele com a SAGMACS era muito estreita, mesmo sem fazer parte. Num certo período, ele tomava iniciativas, ele foi o chefe da campanha do Carvalho Pinto. Tem um livro de memórias dele e o Hélio Bicudo, o Hélio vai pra ASPLAN, em que eles contam a experiência do trabalho no Plano de Ação. Eu trabalhei no Plano de Ação a partir de 1959, eu deixei tudo e fui atuar no governo, então ficou hibernando a SAGMACS, em 1963 ela retorna, com a projeção não só da experiência mas com o trabalho que alguns técnicos tinham assumido, então mesmo dentro do processo, alguns ficaram no núcleo da cooperativa, inclusive sustentando algum tipo de trabalho, recuperando trabalho para política, com militância, algum tipo de articulação.

LUCAS - Isso sempre vem à tona, não é. Nas pessoas que fizeram parte, está presente o papel de militância, o engajamento da técnica com a política. 
LAMPARELLI - Exatamente, mas isso acaba em 1964. Em 1964 já não tinha mais nada pra fazer, mal deu pra eu preparar minha livre-docência, que o estatuto permitia e até 1964, era possivel prestar o concurso sendo livre-docente, pois eu não tinha nem o mestrado, nem o doutorado. E foi o fim da SAGMACS, cada um foi pra um lado, alguns preservados, eu como era muito mais gestor interno, não tinha um papel tão ativo no governo, pois meu papel mais ativo terminou um pouco antes, pois o Ministro da Educação deixou o governo antes do golpe. Então você tem a SAGMACS em 1953 trabalhando pra Bacia, depois continua em 1956 com o trabalho urbano, não falávamos em urbanismo, ou planejamento urbano, é outro tipo de trabalho, o que fazíamos era pesquisa que pudesse se subsidiar um plano de ação. Nós mesmos criticávamos o trabalho de Lebret enquanto detalhe de verificação, mas ele nos dizia "vocês conhecem intuitivamente, mas eu quero conhecer qualitativamente", nós achávamos que muita coisa era evidente, mas não importa, tínhamos que mostrar a evidência.

Depois veio o governo do Carvalho, tivemos que nos adaptar a estrutura estatal, já não era mais equipe, pois cada um era responsável por uma área. Eu era da Educação, o Hélio na Justiça, SAGMACS neste período fica parada e depois com o golpe vem o fim.

LUCAS - Antes de finalizarmos quero dizer que ainda estou intrigado com o modo em que se dá a prática urbanística do pe. Lebret, e de onde vem esse interesse sobre o trabalho urbano? Quando ele chama São Paulo em 1947 de acampamento, seus estudos ainda não falavam de cidade, mas em 1957 aí sim ele vai fazer o trabalho urbano. Como ele adquire tal interesse, como constituiu esse método.

LAMPARELLI - A pesquisa completa sobre o urbano, foi feita pelo Movimento Economia e Humanismo pela primeira vez aqui em São Paulo, porque o método tinha o interesse de captar a necessidade, tinha uma concepção religiosa, era evangélico no sentido da palavra do bom samaritano, eu me comovo e parto para a ação, a ação de suprir as carências que a sociedade sentia do processo de acumulação desordenada. Então a crítica inicialmente era uma crítica marxista, tanto que o Movimento Economia e Humanismo quando começou estabeleceu um diálogo entre os cristãos avançados e os comunistas franceses, era a política da mão estendida, mas foi proibida pelo Vaticano por uma enciclica específica de não colaboração. A partir daí você tem uma ruptura e as dificuldades do Lebret trabalhar. Após 1962 ele já não vem mais para o Brasil, ele fica dedicado no Vaticano, que é quando começa o papado de João XXIII. Aí somos nós que assumimos este trabalho urbano.

LUCAS - O senhor já falou da parceria do Anhaia com o Lebret, mas gostaria de the perguntar ainda sobre este vínculo, pensando aí numa triangulação entre o urbanismo do Brasil/França/EUA. Por exemplo, o Lebret sofreu alguma influência do urbanismo americano - o City Planning, Escola de Chicago? Pois a nosso ver o Anhaia era adepto da maneira norte americana de se planejar cidades.

LAMPARELLI - Olha sobre o seu objeto, eu acho ainda que você deveria estudar o plano de Belo Horizonte, porque lá teve continuidade, foi publicado, eu acho que você tem elementos importantes para estudar o Estrutura da Aglomeração aqui em São Paulo, mas não deveria entrar nessa discussão sobre qual era a influência, se era americana, britânica, francesa, o Lebret se influenciava pelo que o povão precisava. O que era importante no estudo era identificar nas 
unidades de análise, que se dividia em $40 \mathrm{~km}$ por $40 \mathrm{~km}$, e era entender e identificar o potencial de conectividade, era ver o isolamento e as ligações, era o estudo da estrutura, mas não estruturalismo, era estrutura de relações numa concepção organicista, não do organicista tradicional da unidade familiar, da unidade de vizinhança, era partindo da realidade, daquilo que está aí, não era sonhar com as unidades, traçar as vias, você tinha loteamento que não atrai nada, que não tinha ligação nenhuma com outro, você não tinha sistema viário, os trabalhos anteriores de urbanismo eram no máximo Consolação, 9 de julho. Agora você tinha um esquema suburbano. Então esta compreensão do que era aglomeração, foi a grande novidade, ele estava pensando um esquema de região, se pensar na cidade a partir da região. Que era também a visão do Anhaia, ele tinha uma concepção regional de plano.

LUCAS - Esta concepção do Anhaia é norte-americana a partir do Town Country Planning City de Nova York.

LAMPARELLI - Era muito mais dos ingleses, o pragmatismo dos ingleses. Pela biblioteca dele podemos ver, é tudo inglês, o Adams, o Albercomb, é tudo o pessoal inglês, o que ele tirou dos americanos foi mais a concepção democrática das comissões do Plano de Nova York. No meu artigo eu mostro que o Anhaia incorporou elementos do Economia e Humanismo, enquanto o Prestes Maia é o engenheiro da obra o Anhaia era o da ordenação, a ordenação era a legislação. o Lucio Costa era do desenho, no caso do Adams, ele escrevia que o Town Planning, era composto por três vertentes, a obra, a regulação e o desenho. Agora a vertente do Lebret e a da SAGMACS é a vertente da população, quero saber o que é que o povo está precisando, o que as pessoas estão pensando.

LUCAS - Mas não há nenhuma influência teórica sobre urbanismo? Talvez o Le Play, demais geógrafos.

LAMPARELLI - Você tem o Lê Corbusier, um dos primeiros trabalhos dele, foi um pouco a busca das necessidades. Depois eu fui ver que essa era uma tradição da sociologia do Durkheim, ele tinha uma concepção da sociedade como um organismo, e que este organismo tinha normalidade, e um esboço de um conjunto de necessidades, que quando não atendidas resultavam numa sociedade doente. Então nesta época o Durkheim tem toda uma influência, é dele não é do Conte não, é aí que o Lebret vai buscar as referências. Depois eu fui estudar em 1973 o Chombart De Lowe, da teoria das necessidades, das aspirações e descobri que ele encontrou com o Lebret nessa escola de formação de quadros, muito anterior a formação do Movimento Economia e Humanismo. 


\title{
Anexo 10 - Transcrição da Entrevista realizada com José Arthur Rios*
}

\author{
* Entrevista realizada em 25 de março de 2014. A transcrição foi enviada para revisão e \\ considerações do depoente, porém não houve retorno. É vedada a reprodução total ou \\ de partes desta entrevista sem a prévia autorização do entrevistado.
}

\begin{abstract}
LUCAS CESTARO - Iniciemos com sua exposição sobre sua formação e atuação profissional, pois, seria importante o senhor expor sua trajetória pessoal e a formação profissional, para entendermos como é que se deu sua vinculação com o Padre Lebret, o Movimento Economia e Humanismo e o trabalho na SAGMACS, onde o senhor coordenou o estudo sobre os "Aspectos Humanos da Favela Carioca" juntamente com o Hélio Modesto.
\end{abstract}

DR. JOSÉ ARTHUR RIOS- Sim, sobre minha vinculação com o Padre Lebret e minha trajetória... Bem, eu sou formado em Direito - cheguei a advogar um pouco, bastante tempo para tomar uma certa aversão ao foro - eu recebi uma bolsa para o que verdadeiramente me interessava fazer que era estudar sociologia. E então, estudando sociologia, conheci aqui no Rio de Janeiro um sociólogo norte-americano que era um dos fundadores da sociologia rural nos Estados Unidos. Era o professor Thomas Lynn Smith. Eu vim ao Rio para conhecer e tomar contato com professores e estudantes que estivessem interessados naquela época em fazer um mestrado. $\mathrm{Na}$ época não se cogitava o doutorado, era o mestrado o doutorado era muito raro, enfim, comecei a fazer uma pós-graduação com ele em sociologia na Universidade de Luisiania nos EUA. Eu fui apresentado à ele por um geógrafo que tinha sido meu contemporâneo de faculdade, na Faculdade de Filosofia, pois eu Ihe esclareço que também sou formado em Filosofia e fiz Ciências Sociais - fui da primeira turma da Faculdade de Filosofia e Letras criada pelo Ministro Gustavo Capanema no Rio de Janeiro, para fazer o andaime à Universidade de São Paulo, a USP, e o Capanema trouxe professores da França, das ciências sociais trouxe três. Três notáveis professores. Então eu fiz minha introdução acadêmica à sociologia através destes três professores: Rene Pourrier em Filosofia, Jacques Lambert, autor de "Dois Brasis", muito conhecido no Brasil e o Prof. Bie Davison Erner, economista, que depois se tornou ministro da economia no governo do De Gaulle ${ }^{227}$, digo isso para lhe dar o nível do pessoal. Mas eu não cheguei a completar o curso, porque vieram vários problemas de vida, eu fui convocado pelo Exército para a Guerra e tudo isso me tumultuou. Depois eu fiquei um pouco no espaço quando eu encontrei o Prof. Lynn Smith e eu fui para Luisiania e fiz o mestrado lá em sociologia e quando o Lynn Smith foi para a Universidade de Vanderbilt eu conheci lá o Emilio Willens, de quem me tornei amigo de forma que minha formação lá (em Vanderbilt), completou a formação francesa que eu tinha tido com o Lambert.

Minha formação em sociologia era francesa e os professores americanos ficavam muito espantados porque naquela época eles estavam descobrindo a sociologia europeia nos Estados Unidos, eles estavam descobrindo naquele período o Durkheim, Max Weber, Aneto. O Right News estava publicando a tradução dos ensaios do Max Weber e eu conhecia toda essa gente e os americanos ficavam espantadíssimos de como é que nós aqui no Brasil conhecíamos a sociologia francesa. Assim como o Prof. Eric Weberig depois se tornou uma grande figura do pensamento americano-europeu, um filósofo da política, e o Weberig ficou muito espantado quando eu o

\footnotetext{
${ }^{227}$ Esta informação sobre a participação de Bie Davison Erner ter sido ministro de economia de De Gaulle precisa ser melhor esclarecida, pois ao checarmos não encontramos este nome em referencia a equipe ministerial do presidente Gal. Charles De Gaulle na França.
} 
procurei, porque ele citava Ortega y Gasset e Unamuno e ele quis saber como é que eu aqui no Brasil sabia desses autores europeus e eu tive que explicar à ele como é que era essa história, essa comunicação nossa com o pensamento europeu. Mas enfim, para responder a tua questão, por esse tempo o Padre Lebret já tinha fundado na França o Movimento de Economia e Humanismo e foi convidado por um grupo do Partido Democrata Cristão, inclusive o Montoro que foi importante nisso, a fazer conferências na Federação das Indústrias de São Paulo. Isso é extraordinário porque era um grupo conservador, um grupo "hard core" do conservadorismo. E essas conferências do Lebret causaram grande impacto na época!

Eu já tinha ouvido falar do Padre Lebret, mas até então eu não tinha tido contato com ele. Em função desta vinda do Lebret e da criação da SAGMACS em São Paulo o Júlio Mesquita (do grupo O Estado de São Paulo) foi quem me convidou para coordenar a pesquisa sobre os "Aspectos Humanos da Favela", sabendo da minha vinculação com o Lebret.

LUCAS - Estudo há algum tempo este tema da SAGMACS. Isso começou durante o mestrado, finalizado em 2009. Meu foco ali era o trabalho desenvolvido por eles para a Prefeitura de São Paulo em 1956, quando o Toledo Piza foi prefeito e contratou o estudo "Estrutura Urbana da Aglomeração Paulistana". Assim, conheço melhor os paulistas da SAGMACS, como o Francisco Whitaker, Celso Lamparelli, Mario Laranjeira, Maria Adélia de Souza, Clementina De Ambrósis e a irmã dela Chiara, o Duca (Domingos Teodoro de Azevedo Netto), entre outros... Lá a vertente católica era muito forte, boa parte dos que tiveram posição de destaque no grupo pertenceram também ao movimento da Juventude Católica Universitária. O senhor também vem desta vertente católica? Pertenceu a JUC?

RIOS - Veja bem, aqui você me pergunta sobre essa minha ligação/vinculação com o Lebret e a igreja, se eu era católico. Que nada, eu nem era católico! Me converti depois.

Minha ligação com ele era por afinidades de ideias, as ideias que ele trazia e que na minha opinião completavam minha formação sociológica empírica que eu tinha tido nos Estados Unidos. Não era uma formação filosófica, era uma formação empírica de metodologia de pesquisa. E desde que eu voltei ao Brasil eu tinha uma ideia fixa de fazer uma pesquisa nas favelas do Rio de Janeiro. E nunca tinha havido esta oportunidade. Certa vez me apareceu um cidadão que queria que eu fizesse a pesquisa, mas era para remover a favela, disso eu não podia participar, não era meu interesse, eu não quis fazer, recusei o trabalho. E aí então apareceu o Lebret e surgiu uma oportunidade de eu ir para a França, foi para ir pra lá expor sobre educação sanitária, quando eu estava ligado ao Serviço de Saúde Pública. Eles estavam interessados em saber como é que se fazia para disseminar educação sanitária. Eu era sociólogo, já tinha trabalhado nisso, tinha uma experiência de campo, tinha coordenado a campanha de educação rural ligado ao Ministério da Educação, campanha esta que foi completamente liquidada pelos políticos da era Vargas. E então me mandaram para a Europa para eu ver como é que se fazia educação sanitária no pós-guerra e eu fui ao grupo do Lebret, ao Centro de Pesquisa do Economia e Humanismo que era perto de Lyon, que funcionava ali em La Tourette, passei ali uma semana, e o padre Lebret colocou nas minhas mão os originais do manual do pesquisador, o Manual de l'Enqueteur. Durante o dia eu assistia as palestras, conferencias e a noite eu lia os manuais.

Curioso! Porque é um enfoque prático, pragmático para o levantamento, um levantamento caracterizado de vários aspectos e aquilo ficou na minha cabeça. 
E então depois de volta aqui no Rio, eu me aventurei com o pessoal da SAGMACS em São Paulo. Nunca trabalhei com nenhuma dessas pessoas que você citou aí, conhecia todos, eu ia para São Paulo fazia reuniões com eles, mas não tive a oportunidade de trabalhar com eles. Porque naquela época, eu lembro à você que a capital federal era aqui no Rio e eles me encarregaram de criar aqui um núcleo de SAGMACS, para facilitar a busca de documentos oficiais, que tivesse alguém que estivesse perto dos ministérios e captasse os dados, então era importante ter um escritório aqui, porque era mais difícil de conseguir esse material em São Paulo. E aí eu comecei a dar uma autonomia a esse escritório, comecei a contratar pesquisas e foi aí que o Júlio de Mesquita me chamou, não por indicação da SAGMACS não, mas sim por um amigo, de uma conversa de avião, e então ele me chamou a São Paulo e teve esta conversa dizendo que queria que eu realizasse uma pesquisa sobre as favelas no Rio e eu disse que não queria que houvesse interferência política nenhuma.

LUCAS - O senhor falou a pouco em interferência política. Falemos um pouco sobre uma interferência da igreja católica e lideranças religiosas. Existia um vínculo de Lebret com D. Hélder Câmara que estava ligado a Cruzada de São Sebastião, era Arcebispo do Rio e por ocasião do Concílio Vaticano II levou o Lebret como um dos seus assessores. Como era esta ligação do pessoal da SAGMACS com a igreja Católica no Rio de Janeiro? O vínculo era tão forte quanto havia em São Paulo, ou as coisas por aí caminharam de forma diferente?

RIOS - Eu não pertenci a JUC, já disse que me converti mais tarde ao catolicismo. Mas esta pergunta aqui é importante por que é preciso esclarecer alguns pontos, vamos lá... a meu ver o clero em São Paulo recebeu mal o Padre Lebret, disseram que ele era comunista, que era um sujeito de esquerda, ele foi muito mal visto pela igreja católica de lá. E o D. Hélder ele teria tido uma intervenção favorável ao Lebret. D. Hélder era um homem muito inteligente, sabia que o Padre Lebret não tinha nada a ver com o comunismo, é explicito isso nele, num livro do Lebret fica claro o rompimento dele com um grande amigo dele, o Henri Desroches, porque ele se tornou marxista, eles eram amicíssimos e se afastaram depois disso, depois do Desroches ter virado marxista, aderido ao comunismo.

LUCAS - O Desroches era muito próximo do Economia e Humanismo também, esteve em toda a fundação, foi um dos formuladores da metodologia nos anos 1940, foi um dos difusores do método nas semanas sociais, e depois se afasta...

RIOS - Exatamente! Isso mesmo! É curioso que de certa maneira isso (esta guinada à esquerda e adesão ao Marxismo) se reproduziu no grupo de São Paulo, que foi um dos motivos do meu afastamento, alguns deles foram muito para a esquerda, não vou dizer que eram comunistas, isso seria um rótulo muito pesado, mas foram mais para a esquerda do que eu gostaria.

Então a SAGMACS já não conferia com minha visão do Brasil, da realidade brasileira, e isso foi um dos motivos do meu afastamento.

Mas aqui no Rio de Janeiro quanto ao D. Hélder e o Economia e Humanismo, ele se ressentiu da crítica que eu havia feito sobre a Cruzada São Sebastião, falando do caráter muito paternalista da cruzada. Eu não fiz nenhuma crítica, eu fiz um levantamento sobre o funcionamento da cruzada de São Sebastião, e até fui mais longe mostrando que a freira que representava o $D$. Hélder 
dentro da cruzada, era uma pessoa extremamente autoritária que se intrometia na vida das famílias querendo até controlar a natalidade das famílias... Sim, porque o apartamento não estica! E você sabe que a população de favelados tinham filhos a granel naquele período...

LUCAS - Sim, era o período de altíssima taxa de natalidade no Brasil não é? Não eram só os favelados naquele período não é? O país crescia muito...

RIOS - Sim, exatamente, mas com isso o $D$. Hélder passou a me hostilizar quando eu fazia o trabalho em favelas aqui no Rio. O problema dele não era com o Lebret não, era comigo mesmo. Não sei nem se ele leu a pesquisa, mas Espírito Santo de orelha funciona muito bem não é? E ele me convocou uma vez para uma reunião juntamente com meu chefe de gabinete o Dr. José Carlos Barbosa Moreira, onde ele me execrou. Foi uma espécie de tribunal inquisitorial, mal me deixou falar, articular e ele atribuiu isso ao governador, como se fosse uma ação do governador, uma política do governador, porque $D$. Hélder era vinculado ao Juscelino e o Lacerda hostilizava o Juscelino. Então ele achou que nesta história eu estava a serviço do governador Carlos Lacerda, que era uma manobra política para enfraquecer a Cruzada de São Sebastião e o trabalho dele aqui no Rio, e não tinha nada a ver com isso, era uma pesquisa que eu fiz. E a meu ver estudar a Cruzada era obrigatório numa pesquisa de favela, eu tinha que fazer o levantamento para fazer a comparação e ele achou que fosse uma manobra política.

Isso nem tem a ver com o Padre Lebret, mas é para seu esclarecimento que com o Lebret não houve nenhuma posição ou influência de $D$. Hélder, não havia porque o Padre Lebret não estava atuando no Rio de Janeiro, o movimento de Economia e Humanismo não trabalhava aqui, o único representante do Rio era basicamente eu.

LUCAS - Por falar nesta representação do Economia e Humanismo no Rio a SAGMACS teve quatro equipes atuantes no Brasil. Aqui no Rio com o senhor, São Paulo, Belo Horizonte e Recife não é?

RIOS - Isso, em Recife era o Baltar, uma grande figura. O único da equipe de SAGMACS com quem eu tinha um bom relacionamento. Quer dizer, eu não tinha mal com os outros, mas direto inclusive era bom de ter contato com ele.

LUCAS - Aqui no Rio o que se destaca como trabalho realizado é o "Aspectos Humanos da Favela Carioca". Desconheço outros trabalhos da SAGAMCS aqui, tem mais alguma pesquisa realizada por vocês aqui? O papel da SAGAMCS aqui se restringia a esta representação junto a capital federal? Há alguma diferença no funcionamento da equipe de SAGMACS no Rio de Janeiro em relação a São Paulo?

RIOS - É não tem mesmo outro trabalho, porque eu me tornei digamos assim, mais independente, e o escritório foi aberto pra isso, para representar o grupo no Rio de Janeiro junto aos Ministérios. 
Mas eu mantinha contato com a equipe de SAGMACS de São Paulo, com o Mário Laranjeira, com a Clementina, o Duca, tem um que você não cita aqui mas era um sujeito extraordinário o Eduardo Bastos e eu não sei o que aconteceu com ele... Ele se perdeu. A irmã da Clementina eu não me lembro bem...

Eu tinha assim essa afinidade com o Lebret, com as ideias dele e atuava na SAGMACS. Mas não tinha esta afinidade com o grupo de São Paulo. Digamos assim, que o grupo de São Paulo era mais católico, mais ligado as estruturas religiosas, era mais ligado aos Dominicanos e eu tinha afinidade com o pensamento do Lebret, as ideias dele. A minha ligação era pessoal com ele, eu passei a acompanhar quando ele vinha para o Brasil, eu o acompanhava, e sobre os trabalhos eu cheguei num dado momento quando se discutia aqui no governo Lacerda a construção do Porto de Guaratiba - veja só eu sugeri ao governador que ele chamasse o Lebret para dar uma consultoria. E ele chamou o Lebret.

Mas deixa eu te explicar melhor, em função da pesquisa da favela o Lacerda me convidou para ser Secretário de Serviços Sociais, que era uma pasta que tinha 99\% de ação em favela, o restante era asilo de menores, de idosos, algumas obras sociais, "uns cacarecos" que haviam por aí. E nesta pasta dos Serviços Sociais eu vi uma oportunidade de aplicar minhas ideias e evidentemente as ideias do Movimento na favela. Então Lebret vem ao Rio de Janeiro nesta ocasião para o estudo do Porto de Guaratiba e apresenta um relatório ao governo do Lacerda, mas eu não sei onde isso foi parar, porque não era bem um problema que me interessava, minha questão era a aproximação do Lebret com o Governador Lacerda. Mas não deu basicamente em nada, porque o Lebret ficou absorvido por aqueles problemas de criação daquela entidade internacional de combate a fome com o Josué de Castro e com o Abbe Pierre.

Então ele já estava mais fora da SAGMACS, o Lebret acompanhava as coisas aqui no Brasil por correspondências com o grupo de São Paulo. Aqui no Rio de Janeiro ele acompanhava pelas minhas cartas. Mas o grupo de São Paulo era maior, mais bem constituído e num dado momento o grupo de São Paulo ressentiu-se da minha atuação como um independente e achou que estava independente demais da equipe.

Eu não me conformei com isso, pois veja bem, se eu tenho uma afinidade ideológica, doutrinária com as ideias do Economia e Humanismo, se eu sigo o método de pesquisa deles, construí este escritório completamente independe, sem nenhum recurso disponibilizado pelo escritório de São Paulo, eu não vejo porque, o que é que eu estava errado. Então eu me desliguei da SAGMACS de São Paulo e criei um escritório de pesquisa chamado Sociedade de Pesquisa e Planejamento SPPLAN.

Eu acho até muito engraçado que na bibliografia a pesquisa sobre a favela é citado como SAGMACS, SAGMACS... SAGMACS aí é uma mera abstração, é uma sigla, a pesquisa foi feita por mim, Carlos Alberto Medina, pelo Hélio Modesto e Maria Candida Pedrosa de Campos. O Lebret só veio e assinou o contrato, tomou conhecimento, recebeu, eu informava os acontecimentos por carta é claro, mas depois disso eu me separei do grupo de São Paulo.

Mas você me pergunta aqui a diferença no funcionamento da equipe SAGMACS no Rio de Janeiro em relação a de São Paulo. Eu tinha liberdade de contratação, por isso mesmo eu contratei para a pesquisa da favela assistentes sociais, porque eu não encontrava na universidade pesquisador do jeito que eu queria. Então nós contratávamos e submetíamos a uma formação, eu e o Medina treinávamos as assistentes sociais, que foram admiráveis pesquisadoras, que nos ajudaram muito. 
Agora quanto a manutenção das equipes, elas eram mantidas pelos contratos que tínhamos. Eu ainda consegui sustentar o escritório, atravessei até a ditadura, mas neste período havia uma coisa muito curiosa: todos os escritórios de pesquisa do Rio de Janeiro tinham que ter um general que acompanhasse os trabalhos.

Tinha que ter um general, que era o homem que abria o caminho, então aí eu comecei a tirar meu time de campo, porque eu não queria fazer pesquisa eleitoral, pesquisa de opinião, fazer pesquisa de mercado, embora muito interessante, um campo lucrativo, mas não me interessava e então eu fui saindo, deixando o escritório fazendo trabalhos pessoais. Esta é a diferença de funcionamento da equipe.

Para falar um pouco mais disso, em São Paulo, eles tinham um apoio político muito forte do governador Lucas Nogueira Garcez. Quando o Garcez saiu do governo a situação ficou muito difícil. Pois foi através do Garcez que eles fizeram o planejamento da Bacia Paraná Uruguai e também de São Paulo. O Mário Laranjeira era o coordenador deles na parte técnica, e isso é o que eu me recordo. Já aqui no Rio quem conseguia os contratos era eu, eu saia em campo, eu via um trabalho que podia ser feito eu ia lá conversar e com isso eu mantive o escritório por vários anos, até essa parte que a coisa ficou na base do general e então eu fui me retirando mesmo ${ }^{228}$.

Desta mesma maneira eu deixo claro que eu nunca aceitei nenhum cargo no governo militar, embora eu tivesse amigos lá, tinha feito conferências na Escola Superior de Guerra, mas eu não podia...

Foi aí nesse período que eu voltei a vida acadêmica na PUC, cheguei a ser Chefe de Departamento na Sociologia da PUC, mas sofri muito, fui duramente combatido, aguentei dois anos, e entreguei o mandato. Foi um período difícil para mim, me retirei até da PUC e fui lecionar na Faculdade de Direito da UFRJ, era outro clima, nunca tive problema nenhum lá, dei dois cursos lá, ensinava Sociologia do Direito e Criminologia, fiquei dez anos, dialogava muito bem e em função desse trabalho é que eu fui convidado para ingressar numa Comissão da ONU de prevenção de crime e então rodei o mundo nesta condição, viajei muito, tentei trazer essa metodologia para o Brasil, não fui bem sucedido, apresentei um plano no início dos anos 1970, para uma política de prevenção de crimes e tratamento de presos ao Ministro Petronio Portela, um mês depois ele convocou os Secretários de Segurança dos Estados, o plano foi debatido, eu participei como sociólogo desta reunião, ele estava interessado nisso, mas veja bem, ele faleceu um mês depois e o sucessor dele no ministério engavetou, mandou publicar o plano porque tinha sido pago, era dinheiro público, era obrigado.

Eu lamento não poder fornecer a você as informações sobre a equipe de São Paulo que eu acho que é o que Ihe interessa mais, mas eu posso ver o que eu tenho para poder lhe ajudar e lhe esclarecer melhor este ponto. Lhe esclareço assim?

LUCAS - Bom, as questões não são no sentido de conhecer o trabalho de São Paulo, mas sim mais para esclarecer esta diferença de funcionamento em torno das equipes. $\mathrm{E}$ como o senhor esta mencionando o período da ditadura militar, citou o governador Lucas Garcez e o Carlos Lacerda, eu Ihe questiono sobre a vinculação política em torno das equipes da SAGMACS. Existe esta vinculação política das equipes não é?

Gostaria de esclarecer que não me refiro a este vinculo político com o Garcez, mas sim um mais recente ali no governo do Carvalho Pinto, Nei Braga, já nos anos $1960 \ldots$

\footnotetext{
${ }^{228}$ Após esta afirmação Rios faz uma ressalva deixando claro que nunca aceitou nenhum cargo para o qual tenha sido convidado para atuar no governo dos militares, ainda que alguns amigos estivessem trabalhando em esferas deste governo.
} 
Isso é coisa de São Paulo? O senhor disse que lá eles eram mais adeptos ao marxismo, diria que lá eles estavam mais próximos da esquerda, estou falando disso já no final do período das atividades deles, antes do golpe de 1964.

RIOS - Sim, esta questão da data é importante, mas eu preciso verificar... é ali nos anos 1960. Mas essa parte do Carvalho Pinto já foi quando eu já não tinha maior aproximação com eles. Mas aí entra uma questão de custeio do grupo, pois naturalmente haviam anos de penúria na SAGMACS, anos que não haviam nenhum contrato. A gente se virava para conseguir trabalho, nem sempre era fácil, ainda que consegui em função da pesquisa do Rio nas favelas, teve o trabalho em Alagados na Bahia, num governo de esquerda, depois teve um trabalho em zonas de mineração também ligado a gente progressista.

LUCAS - Qual a data desta separação, seu afastamento do grupo?

RIOS - Eu não me lembro bem quando foi, mas eu acho que foi em meados dos anos 1950, eu vou verificar isso... Eu também estava na Secretaria, o que era um nome muito pomposo, porque eu não tinha orçamento, eu não tinha verba própria, eu tinha verba nos órgãos coordenados, a Secretaria era uma coordenação de órgãos. Tinha a SERFA que era o Serviço de Favelas, era um órgão extremamente demagógico, infiltrado de politicagem e eu fiz o seguinte eu eliminei os intermediários do contato com os favelados, eu tinha um contato direto, eu criei comissão de moradores, verificava os que tinham uma certa liderança e chamava para conversar, explicava que eles iam criar uma comissão de moradores para conversar e que eles iam eleger os grupos eu não indicava ninguém. E eles não entendiam muito isso, vinham me perguntar se eu não tinha nenhum nome pra indicar, e eu dizia que não, mas eu entendia isso, porque haviam naquela época, no trabalho está mencionado isso os parques proletários, que não eram nem parques, nem proletários, eram currais eleitorais entregue a determinados deputados, alguns politicos que punham ali seus cabos eleitorais, eles é que alugavam barraco, vendiam, faziam o comércio, tinham as mulheres e compareciam na eleição com os votos para os seus deputados.

Eu acabei com esta brincadeira - o que você deve imaginar que me rendeu grandes inimigos - $e$ eu consegui criar mais de 100 comissões de favela. E então ficou mais fácil da gente trabalhar.

Estou the dizendo isso, para você perceber que há uma questão de método. O que eu fazia? Fazia uma urbanização de dentro para a fora e declarei que era contrário a remoção, que isso eu só faria em caso de incêndio, de catástrofe e de abertura de uma via de acesso que fosse estrutural para a favela. Isso também me granjeou mais inimigos, pois imagina ali os terrenos na zona sul, "era um filé". Mas não removi nada, só me lembro da remoção de uma favela por causa de incêndio ali na Favela da Maré que eu tive que providenciar lonas, alojamentos e eu chamei de Nova Holanda, que o governador achou que era cinismo da minha parte colocar este nome, mas ela está lá até hoje com este nome, se você entrar pelo Galeão no Rio de Janeiro, é uma favela enorme, que está lá encaixada numa parte da Maré.

Então eu apliquei a ideia do mutirão, olha aí a questão do método, que eu havia aprendido na minha experiência no mundo rural. Eu organizava mutirões com os favelados, fornecíamos o material das demolições, era uma época de muitas demolições no Rio de Janeiro, eu dava o engenheiro para orientar, e eles entravam com a mão de obra, que era a melhor mão de obra que havia, eram os melhores mestres de obras que haviam construído os prédios na Lagoa, em Copacabana e tudo o mais. 
LUCAS - Estamos falando então em um trabalho de mutirão nos anos 1950 já? Muito antes do que se noticiam as experiências que conhecemos hoje e num governo que era considerado populista, bem distante da defesa dos trabalhadores...

RIOS - Exatamente! É uma experiência participativa. Eu reunia toda essa gente, nada fazia na favela sem ouvi-los, conversávamos com a diretoria, eu tinha uma escala, um cronograma para o contato com a diretoria e assim, foram dois anos.

Bem, isso não é de seu interesse direto, mas eu estou falando isso para também lhe dar uma visão sobre este problema...

Acontece que as pressões politicas se avolumaram no fim de dois anos de uma forma brutal, já comprometendo elementos do governo. O Lacerda era um tufão ambulante, um homem de lutas, rivalizou com o Getúlio, depois com o Juscelino, de forma que ele dava pouca atenção a estes problemas que para ele eram pouco relativos. De repente o Embaixador dos Estados Unidos que eu conhecia, tinha sido meu professor de economia nos EUA, o Lincoln Gordon me chamou para conversar conhecendo meu trabalho e disse que tinha umas sobras de um fundo e o governo americano o autorizava a utilizar isso em projetos sociais e ele havia destinado isso para as favelas.

Quando os jornais noticiaram isso, eu não tive mais sossego. Mas a única verba que eu recebi em cruzeiros foi de dez milhões de uma emenda votada em Brasília pelo deputado General Mendes de Moraes, com quem eu nunca havia tido nenhum contato, de repente o (Deputado) General em Brasília votou esta verba, eu recebi isso e convoquei os escritórios de engenharia do Rio de Janeiro e solicitei que fizessem 10 projetos de urbanização para as dez maiores favelas do Rio projeto de urbanização com iluminação pública, esgoto, água, reforma urbana, cada um deles que custaria 1 milhão de cruzeiros - fizemos o contrato e o programa andou, e a pressão era tanta que dentro do governo, eu já não podia trabalhar, pressão de toda a maneira, os boatos de que eu estava demitido, os jornais noticiavam e eu fiz uma carta para o governador e não conseguia entregar. Eu estranhei isso tudo, porque eu tinha acesso direto ao governador, mas não era recebido, então depois de um tempo eu resolvi ir até o apartamento dele ali no Flamengo. Fui com meu chefe de gabinete, que era o José Carlos Barbosa Moreira - hoje um dos maiores processualistas brasileiro, foi meu chefe de gabinete, extraordinário, meu amigo até hoje, foi um colaborar de uma lealdade, de uma eficiência e fomos eu e ele ao governador entregar a carta.

O Lacerda pessoalmente era uma figura encantadora, tinha uma conversa extraordinária e me recebeu de uma forma muito cordial, disse que era um mal entendido, botou panos quentes. Eu dava dados para ele, dizia está acontecendo isso, isso e aquilo e ele negava, botou panos quentes, disse que tinha uma viagem marcada para a Europa, que ficaria fora por uns quinze dias e que quando voltasse, conversaríamos. Era um pedido razoável, eu não podia recusar ficar por mais um período, esperar este retorno do governador.

Mas na vacância do cargo assumiu o governo o vice-governador, o Rafael de Almeida Magalhães, um advogado ligado aos interesses imobiliários, era dos maiores escritórios, um grupo importante de advocacia no Rio. E com ele a pressão aumentou, então quando o Lacerda voltou eu fiz uma carta mais incisiva ainda, tive a mesma dificuldade de entregar. E coincidiu dos projetos ficarem prontos, então eu convoquei as empresas, a diretoria das favelas e a imprensa para apresentar os projetos. No dia seguinte nos jornais saiu esta notícia com destaque em uma página e na outra página saiu que eu havia pedido exoneração do cargo, coisa que eu desmenti, e disse que o 
governo tinha que assumir isso, essa responsabilidade, que eu estava sendo demitido e não que eu queria sair. Ai não deu mais para continuar e então eu fui trabalhar com uma pesquisa sobre artesanato no Ceará, fiz um levantamento lá sobre o artesanato em todo o estado do Ceará para o SESI e aí fui fazendo vários trabalhos, fiz uma pesquisa em Alagados na Bahia utilizando o método de Economia e Humanismo, enfim você pode ver que eu estava ligado ainda ao Economia e Humanismo pelo método que o Lebret havia escrito nos manuais.

LUCAS - Permita-me retornar a um ponto um pouco anterior. É sobre o paternalismo da igreja católica, o senhor comentou sobre a Cruzada de São Sebastião e falou sobre o paternalismo existente. O paternalismo é uma característica muito frequente no trabalho pastoral da igreja católica. Como o senhor se converteu mais tarde ao catolicismo talvez seja mais fácil de perceber isso, mas a questão é justamente sobre identificar um caráter paternalista nas ações da SAGMACS. O grupo de São Paulo é muito ligado ao catolicismo, era o pessoal da JUC, alguns foram até presidentes da JUC e vieram atuar na SAGMACS, ou seja como o senhor já disse, é um pessoal muito ligado a igreja católica.

Então eu lhe pergunto dentro desta linha do trabalho que a SAGMACS desenvolvia, não dizendo aqui do "Aspectos Humanos da Favela", mas eu queria que o senhor falasse sobre isso, se é possível identificar um paternalismo nos trabalhos da SAGMACS.

RIOS - Aí são duas coisas que eu queria separar um pouco.

Primeiro o paternalismo da igreja católica, era um assistencialismo de caráter paternalista, com suas exceções. Há sempre exceções, eu posso falar isso com certa autoridade sob outro angulo de minha atividade, porque eu ensinei muito, minha entrada no ensino superior no Brasil não foi nem em escola de sociologia ou nas ciências sociais, mas sim nas escolas de serviço social. Eu ensinava sociologia às assistentes sociais, e ali eu encontrava a fina flor do paternalismo. $E$ eu tinha que romper com isso, explicar que haviam duas coisas, que tinham que separar os fatos objetivamente, entender a coisa, para daí sim poder atuar sobre ele, que não dava para aplicar nenhuma receita pronta seja de um lado ou de outro. Só lamento falar isso na primeira pessoa, porque você esta interessado em Lebret e ele quebra justamente esse assistencialismo, foi isso que me atraiu ao movimento.

Agora sobre a SAGMACS eu tenho que dizer que o Lebret insistia muito nesta separação. O Lebret era um padre, não era um cientista travestido de padre. Ele converteu-se tarde, ele foi comandante de navio mercante na França, procurou os Dominicanos, fez seus estudos já adulto, se engajou em movimentos operários, ele sabia distinguir o que era comunista do que não era, distinguir o que era doutrina da igreja, o que era marxismo, ele sabia distinguir isso tudo perfeitamente, o que não era tão simples para os demais padres. E muitos não conseguiam fazer esta distinção. Então quando alguém começava a fazer a defesa do trabalhador já taxavam de comunista. Por isso, que eu acho extraordinário ele ter vindo justamente para São Paulo. Porque você sabe que ele veio para o Brasil convidado pela Federação das Indústrias, e você sabe que São Paulo é a fina flor do reacionarismo, e que quando o trouxeram certamente não conheciam exatamente a doutrina de Economia e Humanismo. Pois a doutrina deles tinha seu lado revolucionário evidentemente! O Economia e Humanismo falava em comunidade e taí a confusão, pois falar em comunidade já era ser visto como comunista.

Como eu tinha feito desenvolvimento e comunidade nos Estados Unidos que era um método, uma técnica participativa como outra qualquer, eu estava perfeitamente integrado nesta ideia, para mim 
era uma coisa efetiva, natural e foi isso que me atraiu para o movimento e essa coisa que o Lebret chamava de "la monte de la masse urbaine", esta emergência.

Agora as altas autoridades da igreja não aceitavam muito isso, achavam que era coisa do marxismo e alguns elementos (de EH) dão asas a esta confusão, por que alguns do grupo tenderam ao marxismo mesmo, tenderam e praticaram, isso é sabido!

Eu acho que é isso aí que eu poderia dizer, você entende esta situação? Nós estamos em uma época de efervescência, isso é antes de João Paulo $\|^{229}$, é uma época de elaboração doutrinaria, é anterior ao Concílio Vaticano Il que o Lebret foi consultor. Então isso tudo é anterior e havia uma grande confusão, mas para o Lebret sempre houve uma linha muito nítida de não confundir ciência com doutrina católica. Os livros dele são de um economista.

Agora, ele era um padre! E eu digo isso, porque eu presenciei alguns fatos, duas atitudes para mim marcantes, que eram atitudes de um padre, um religioso... Teve uma vez que ele estava aqui no Rio no escritório que eu tinha, que eu acabei de fechar, e este escritório tinha uma vista para a baía e caiu um avião, nós vimos o acidente. Ele parou o trabalho e foi rezar pelas vítimas, isso o comovia. Em uma outra situação eu fui leva-lo ao Convento dos Dominicanos ali no Leme e quando nós entramos no túnel nós vimos um homem estirado, vitima de um acidente, ele pediu para eu parar o carro, saltou e se aproximou, ajoelhou e rezou pelo homem. Ele fazia isso sem demagogia nenhuma, não importava se alguém estava vendo, ele fazia isso. Isso são atitudes de um padre!

Mas quando ele analisava os dados era o economista que analisava, ele conseguia dividir isso! $E$ uma diferenciação nítida. Eu mantive esta vinculação pessoal com ele mesmo depois de ter me separado da SAGMACS, quando eu ia à França eu me encontrava com ele, continuava recebendo as publicações do Economia e Humanismo.

LUCAS - Em São Paulo a SAGMACS realizou inúmeros trabalhos tendo sido contratada pelo Poder Público (governo do Estado, prefeituras, órgãos estatais), também há trabalhos assim para estatais do governo federal, no início dos anos 1960. É uma questão minha investigar as correntes ideológicas que estavam mais próximas às equipes de Lebret no Brasil. Assim, verificamos que os trabalhos empreendidos pela SAGMACS em São Paulo se deram em períodos de "alguma trégua" (digo fora dos governos de Janio Quadros e Ademar de Barros), em gestões que podemos considerar mais progressistas. Mas e o trabalho sobre a Favela Carioca? Qual era a vinculação ideológica que postulava nos bastidores?

Ele foi contratado pelo Jornal Estado de São Paulo que era apoiador do governador Carlos Lacerda e ambos faziam oposição ao presidente Juscelino Kubtischek. Isso era um aspecto considerado pela equipe ou o contrato era visto por um viés mais técnico, distante da política, como mais um trabalho a ser realizado?

RIOS - Veja bem, eu tenho que Ihe dizer que o Júlio Mesquita foi de uma correção comigo, pois diga-se de passagem, que publicou o trabalho na integra sem tirar nem por. Quando ele me

\footnotetext{
${ }^{229}$ A menção foi feita ao papa João Paulo II que reinou sobre a igreja católica, entre 1978-2005), no final do período da guerra fria e assistiu ao fim do comunismo com a queda do muro de Berlin em 1989. O papado de João Paulo II é marcado também pelo esvaziamento de grupos políticos dentro da igreja, como o fim da Teologia da Libertação - movimento que engajava leigos e criava as comunidades eclesiais de base, voltadas para uma igreja de ação e participação popular. Acreditamos que a menção de Rios seria atribuída ao Papa João XXIII, que instaurou o Concílio Vaticano II, porém, ficamos em dúvida sobre isso, ao nos depararmos com um pôster de João Paulo II na sala de sua casa.
} 
chamou para fazer a pesquisa eu disse à ele que eu não queria ingerência política sobre o trabalho, eu sabia que ele se opunha a construção de Brasília, que achava que era muito dinheiro gasto com aquilo, sendo que haviam questões mais sérias para se enfrentar e na própria capital que era o Rio de Janeiro. E ele aceitou, publicou a pesquisa toda, foi muito correto.

LUCAS - O senhor já falou um pouco da participação do Lebret no estudo sobre os "Aspectos Humanos da Favela Carioca" que foi realizado num período em que a SAGMACS já estava migrando para uma cooperativa de técnicos. Mas eu gostaria que expusesse um pouco mais sobre isso. Pois, o Padre Lebret já não se fazia tão presente entre os quadros da SAGMACS neste período.

Como foi a vinculação dele com a equipe do Rio de Janeiro durante a elaboração deste trabalho? Quais as contribuições trazidas por ele?

RIOS - Como eu já Ihe disse a atuação pessoal do Lebret nesta pesquisa foi nenhuma, ele veio a São Paulo para assinar o contrato, pois ele era a figura de proa, era de praxe ele assinar os contratos. Ele assinou o contrato e confiou o trabalho e eu fiquei então para fazer isso. Mas eu fiz a pesquisa praticamente sozinho. O que eu fiz foi aplicar o método de Economia e Humanismo, aqueles levantamentos todos, fiz os gráficos e na segunda etapa eu usei mais a pesquisa em profundidade as entrevistas que eu havia aprendido mais com os americanos. Então toda aquela segunda parte é realmente uma aplicação da metodologia de pesquisa dos americanos. Entreguei o trabalho e depois disso veio a publicação em dois encartes do Jornal O Estado de São Paulo. E veio uma segunda parte, era uma época de muita efervescência política, o Lacerda ganhou a eleição para governador em 1960 e ele era dono da Tribuna da Imprensa, ele me conhecia e tinha lido a pesquisa no Estado, e quis publicar. Obviamente que ele me conhecia, eu estava engajado na campanha de governador dele e então ele pediu licença ao Julinho para republicar a pesquisa.

Mas as proporções do jornal eram diferentes, o Tribuna da Imprensa era um jornalzinho pequeno, digamos assim o Jornal Estado era uma gorda senhora e então ele republicou isso em folhetins que tiveram uma grande repercussão no Rio, digamos assim que foi lido com grande avidez pelo público e isso repercutiu inclusive na Assembleia Legislativa. Veja que curioso e depois disso ninguém mais publica isso.

LUCAS - O senhor é Sociólogo e tem uma atuação que podemos dizer que extrapolou os ensaios e as análises teóricas, seus trabalhos são pautados pela prática, há uma ânsia em dar respostas, apontar saídas e soluções. Ousaria dizer que segue a máxima do Padre Cardin e dos "Princípios para Ação" do Lebret de: Ver, Julgar e Agir. Mas como sociólogo, gostaria que o senhor comentasse sobre a formação intelectual do padre Lebret e também do quadro de referencias sociológicas (se há) que influenciaram a metodologia de trabalho da SAGMACS.

RIOS - A sociologia era vista como uma forma de humanismo.

LUCAS - Enquanto o senhor falava em pragmatismo, de que é possível se verificar até onde é possível se chegar me ocorreu que o Lebret tinha esta leitura, ele sabia até onde era possível chegar. E sobre os Dominicanos durante o período do golpe militar, eu tenho 
a informação de que o Lebret ao tomar conhecimento e no arquivo de Fontainebleau há jornais do dia um, dois de abril narrando a derrubada do presidente João Goulart, mas o Lebret diz que era preciso se preparar para receber o pessoal deles que logo ia começar a chegar por lá, então ele já tinha clareza do que implicava um golpe também. Me fale um pouco deste pragmatismo do Lebret.

RIOS - É interessante você mencionar isso, mas eu não tenho esta informação. Eu sempre tive muita curiosidade de conhecer os arquivos do Padre Lebret lá na França, e até estive lá perto de Fontainebleau algumas vezes em viagem de visita a alguns familiares. Mas eu não tenho esta informação.

\begin{abstract}
LUCAS - Quanto a questão prática e de resultados apontados nos trabalhos empreendidos pela SAGMACS, é comum dizer que eles se restringiam a um trabalho de Diagnóstico, que conseguiam revelar as condições de vida da população, trazer a tona problemas de ordem administrativo, econômico, social e urbanístico... mas ao mesmo tempo cobra-se que eles não propunham soluções. No "Aspectos Humanos da Favela Carioca" há partes destinadas a mostrar possibilidades de urbanização de favelas, há croquis com estudos apontando "barracos" a serem removidos, equipamentos a serem construídos, etc. Não vemos isso nem em trabalhos em que a equipe foi contratada para apresentar um Plano Diretor para a cidade. O que norteou esta possibilidade da equipe carioca ir além do diagnóstico e apontar algumas soluções práticas?
\end{abstract}

RIOS - Aí é que está a diferença, talvez eu tivesse ficado mais impregnado pelo método do Economia e Humanismo do que eles lá em São Paulo! Quando eu apresentava o resultado de uma pesquisa sempre trazia proposta. Fiz isso no trabalho para o artesanato do Ceará, também em Alagados na Bahia, sempre tinha um caráter propositivo. Mas eu dizia à você que a política corrói e isso até hoje, é só olhar os casos de corrupção que estão aí. Então acho que tinha isso, talvez as equipes foram chamadas para fazer um planejamento, mas não foram cobradas sobre isso.

Eu se pudesse ia fazer pesquisa pura, gostaria de fazer isso, um estudo sobre o problema de raças no Brasil, mas quem vai me contratar para fazer isso? Ninguém ia me chamar para isso. $E$ veja só eu vivi numa época em que o Brasil era mais rural do que urbano e ninguém se preparou para esta urbanização, a SAGMACS se preocupava com isso, já percebia isso. Mas os outros não. Faziam muito pouco para se preparar.

A Escola de Sociologia de Chicago despertou para isso, ela começou trabalhando com ecologia urbana e estudando os problemas da cidade de Chicago, isso foi um marco, agora aqui em São Paulo, o Florestan vai estudar os Tupinambas, numa metrópole como aquela, cheia de problemas ele ia estudar a lua? Poxa eu não pensava assim, eu achava que tinha que trazer para o real, o Lebret também falava isso e o pessoal dá SAGMACS fazia isso, ele levava até o problema, não era para ficar sociólogo que fala da violência sem nunca ter entrado numa penitenciária. Então, o Lebret, o movimento de Economia Humana e a SAGMACS trazem isso, percebe que são fatos novos. Pois nós tínhamos clareza de que estávamos lidando com uma realidade que era urbana.

O homem é um ser imprevisível, a teoria pura não funciona na prática. Fazer o diagnóstico é importante, mas ele se esgota. E por isso o Lebret pensava na continuidade, em preparar 
quadros, abordar a realidade ao máximo, para entender isso e se preparar para o que ela exigia de nós. 



\title{
Anexo 11 - Transcrição da Entrevista realizada com Maria Adélia Aparecida de
}

\section{Souza*}

* Geógrafa 1962 pela FFLCH USP / Equipe da SAGMACS (escritório de São Paulo - 1960/1963) / Aluna do IRFED 1963/1964; Entrevista realizada em 2 de abril de 2014. A transcrição foi revisada pela depoente. É vedada a reprodução total ou de partes desta entrevista sem a prévia autorização da entrevistada.

\begin{abstract}
LUCAS CESTARO - Para iniciarmos seria importante a senhora expor sua trajetória pessoal e a formação profissional, para entendermos como é que se deu sua vinculação com o Padre Lebret, o Movimento Economia e Humanismo e sua atuação na equipe da SAGMACS. Muitos dos que tiveram posição de destaque ali eram católicos, foram da JUC. A senhora tem esta origem também?
\end{abstract}

PROFA. DRA. MARIA ADÉLIA DE SOUZA - Eu era da JUC (Juventude Universitária Católica) e foi aí que eu conheci essas pessoas do movimento Economia e Humanismo, o Francisco Whitaker Ferreira e o Pedro Calil Padis. O Calil, como o chamávamos, tinha feito Economia na USP e era meu colega. Eu o conheci ainda como estudante da graduação de Geografia e frequentávamos algumas disciplinas que eram ministradas na sede da Faculdade de Filosofia, Letras e Ciências Humanas que funcionava na rua Maria Antônia, de saudosa memória! E, a Faculdade de Economia funcionava na rua Dr. Vilanova, mas o pátio de ambas as faculdades era comum e a frequência ao Grêmio da Filosofia, também. Nesse pátio fazíamos nossas assembleias estudantis, por vezes invadidas pelos estudantes do Mackenzie!

Foi nesse contexto que conheci meu querido amigo Pedro Calil, e também em reunião de estudos da JUC, quando eu comecei a me interessar pela questão do planejamento. Calil já era da SAGMACS (Sociedade de Análises Gráficas e Mecanográficas Aplicadas aos Complexos Sociais), e me convidou para fazer um estágio lá, vendo esse meu interesse. Ele, então, me disse que como eu estava no segundo ano de Geografia seria bom tentar fazer um estágio lá com eles.

Na época eu nem sabia o que era a SAGMACS, apesar de eu ser da JUC. Então foi Pedro Calil, que já trabalhava lá na SAGMACS, quem me levou para ser estagiária, em 1960. Assim comecei a aprender a fazer tabelas, cálculos de porcentagem, com umas maquininhas engenhosas, onde a lida com uns pequenos pinos e o rodar de uma pequena manivela, nos revelava o cálculo... Aprendi também a lidar com mapa, fazer cartografia temática...

Sou eternamente devedora da SAGMACS, pois ali eu fui estagiária. Os estagiários eram carinhosamente chamados pela equipe técnica da SAGMACS de "bagrinhos".

Assim, fui "bagrinho" de Flávio Villaça e de Luiz Carlos Costa arquitetos e urbanistas de enorme competência.

Trabalhando com eles na SAGMACS eu constatei que o ensino e a Geografia praticada em São Paulo, que sempre foi considerado um curso muito bom, porém na perspectiva de uma formação tradicional, e nós aprendiamos as matérias de uma forma muito certinha, analítica, descritiva. Mas, na SAGMACS tinham os arquitetos que praticavam a Geografia a seu modo, mas que me levavam com eles a ir do presente ao futuro com muita facilidade e isso me fascinava! Eu os considerava uns malucos! Produziam mapas coloridos, lindos, mas que pouco tinham a ver com o que eu aprendia com meu professor de Cartografia, um rigoroso engenheiro cartógrafo, austríaco, 
formado para atender ao exército austro-húngaro!!!! Depois fui compreender o significado de ambas as cartografias, as normas e rigores cartográficos que nem sempre os arquitetos levam a sério... até hoje!

Agora, a relação da SAGMACS com o Movimento Economia e Humanismo se dava de uma forma muito séria, pelo fato de que a maioria dos personagens que lá trabalhavam tinham ido à Paris fazer o curso no IRFED (Institut de Recherche et Formation en vue du Développement Harmonisé). O Francisco Whitaker Ferreira - o Chico - foi, era o nosso líder, era mais velho, coordenador técnico da maioria dos trabalhos realizados pela SAGMACS. Ele o Frei Benevenuto de Santa Cruz, meu saudoso e queridíssimo amigo eram os nossos "chefões", função que exerciam com tamanho disfarce, que quem não soubesse não perceberia! Aprendi com essas pessoas que é possível fazer um trabalho rigoroso, politicamente interessado e sério, com bom humor! Tudo isso, busquei não perder na universidade que é o reino da disputa individual e do mal humor!!! Chico era o diretor técnico e o Frei Benevenuto - o "Bené" - como o chamei a vida toda, nosso diretor geral. Ambos de um humor refinado, que faziam das reuniões que pude assistir aulas maravilhosas de competência e bom humor, com todos os outros profissionais que lá trabalhavam, sobre os quais falarei mais adiante. Eles estão ai, todos, felizmente ainda vivos para testemunhar esse meu sentimento. Bené cuidou a vida toda e eu o acompanhei desde então, cuidando da Livraria Duas Cidades, uma dessas maravilhas que encantava e qualificava a vida intelectual da cidade de São Paulo...

Eu fiz o IRFED e continuei na França por mais 7 anos. Fiz parte da derradeira turma que foi aluna do Padre Lebret, no ano letivo de 1963/1964. Por isso acredito que desse grupo quem mais acompanhou o Lebret fui eu e o Chico, nos últimos dias de vida dessa ilustre figura do humanismo mundial. Para você ter uma ideia, quando ele precisava de alguém para secretaria-lo, auxiliá-lo com textos mais elaborados, ele pedia apoio para Madame Dupuy, que era bibliotecária, Editora da revista do IRFED e desempenhava o papel de secretária dele, especialmente, quando adoeceu e, para mim. Como estive perto dele e o acompanhei durante a doença, quando ficou hospitalizado no Hospital d'Alesia, perto da Cité Universitairé, próximo de onde eu morava, fui solicitada por ele, quando me ditou um primeiro rascunho de parte da "Encíclica da Vida Humana", pois o Padre Lebret foi assessor direto de papas, à época de Paulo VI. Madame Dupuy adoeceu e eu a substitui durante dias...

\footnotetext{
LUCAS - Estamos falando então de 1966 quando o Lebret faleceu. A senhora estava acompanhando de perto ele no final da vida. É um vínculo bastante forte! Da SAGMACS a senhora já seguiu para cursar o IRFED e ficou estes quase sete anos na França então?
}

MARIA ADÉLIA - Sim. Eu fui da turma de outubro de 1963 a junho de 1964, do IRFED. Fui convidada pelo próprio Padre Lebret e por Pierre Monbeig para estudar na França, quando ambos, um dia apareceram na SAGMACS, para uma visita!

Como eu fiquei mais tempo na França, eu acabei convivendo mais com o Padre Lebret em Paris e seguindo os cursos no IRFED. Eram cursos que o Padre Lebret organizava sobre vários campos do conhecimento e de professores que ele chamava para dar uma conferência, quase que semanalmente. Por exemplo, o geógrafo Jean Labasse, que era importantíssimo na geografia francesa (então professor na "Science Po" Instituto de Ciências Políticas da universidade de Paris, 
onde eu assistia a disciplina que ele ministrava). Isso por que o padre Lebret tinha um quadro de professores e disciplinas que constituíam um ano de curso no IRFED, mas ele estabelecia convênios com professores de outros institutos! Foi assim também que eu assisti no Instituto de Demografia uma conferência com o famoso professor Alfred Sauvy que nos apresentava suas recentes (e conservadoras) concepções sobre a dinâmica demográfica. Enfim, nós assistíamos também cursos no ISST - Institut des Sciences Sociales et du Travail, com todo o pessoal que estava discutindo o cooperativismo porque era visto como uma forma de chegar e atuar nas excolônias da França. Aqui tomei contato com interessantes obras sobre cooperativismo, além de ter sido aluna do marcante Professor Joffre Dumazedier, mestre da sociologia do lazer, desde os anos 60, também grande amigo do Padre Lebret.

É dessa época também, como geógrafa, meu interesse pelas reflexões sobre o Espaço, feitas pelo filósofo Paul Ricoeur em Nanterre e pelo personalismo de Emmanuel Mounier, apresentados por colegas que faziam doutorados com ou sobre esses mestres! Sempre tive muita sorte na minha vida intelectual. Minha geração teve a oportunidade e a possibilidade de assistir aulas e conferências dos maiores geógrafos e intelectuais do século $X X$, como estudantes bolsistas em Paris! Eu não perdi nenhuma dessas oportunidades! Assim fui aluna de Jean Paul Sartre, Simone de Beauvoir, Henri Lefebvre, Michel Foucault, François Perroux, em cursos e conferências que ministravam no Collège de France ou em suas Escolas e Faculdades! E dos geógrafos, todos eles: Pierre George, Michel Rochefort, Yves Lacoste (jovem e que nos dava trabalho de campo), Tricart, Bernard Kaiser, Madame Beaujeu-Garnier, Pinchemel, Jean Labasse e tantos outros...

LUCAS - Foi uma estada proveitosa então. Cursou não só o IRFED, mas também se aproximou da intelectualidade francesa. Mas no caso do Economia e Humanismo, dos adeptos do grupo de Lebret, como era esta formação dada pelo IRFED?

MARIA ADÉLIA - Era uma formação muito sólida, embora fosse um curso de especialização, ou como se diz hoje, pós-graduação lato sensu! O IRFED tinha quatro formações gerais que eram dadas em um ano de estudo, mas você tinha que fazer uma formação específica que te obrigava a se concentrar nela. As quatro formações eram: Planejamento Educacional, Planejamento Econômico, Planejamento Social e o Planejamento Territorial que era a formação para os planejadores, quem ia atuar no que aqui no Brasil era chamado de planejamento urbano e regional.

Dentro dessas formações nós tínhamos cursos de economia, curso de ética, tinha uma disciplina lindíssima que se chamava cultura e civilização que era para você conhecer a essência da sociedade que como planejador você iria intervir, estudava contabilidade, se chamava contabilidade nacional, hoje se chama finanças públicas, tínhamos estatística de alto controle, economia, economia e sociologia rural, análises econômicas e sociais "territorializadas", eu diria, ministrada pelo próprio Padre Lebret. Fomos a última turma para quem ele pessoalmente lecionou, pois depois adoeceu e veio a falecer em 1966 vítima de um câncer. E, daqui do Brasil, comigo fizeram o IRFED alguns colegas, dos quais me lembro, de Silke Weber, que sempre foi secretária de Educação em todos os governos de Miguel Arraes, em Pernambuco. Ela trabalhou junto com o Paulo Freire e fundaram, com outros pernambucanos ilustres a pedagogia do oprimido. No IRFED, Silke Weber foi aluna da formação em Planejamento Educacional.

O Planejamento Econômico era para aqueles que poderiam um dia vir a planejar a economia nacional de seus países. O IRFED formava quadros técnicos para os países subdesenvolvidos ou aqueles que acabavam suas guerras anti coloniais. O que era muito interessante naquela época, 
era o fato de que tanto o Padre Lebret quanto a própria instituição IRFED, se preocupavam em selecionar pessoas que já tinham algum engajamento nos países de terceiro mundo, expressão que surgia na época.

Refiro-me, aqui, ao ano de 1963, quando eu comecei a fazer o IRFED em outubro daquele ano. Lembro-me muito bem que naquela turma tinha muitos colegas que vinham da África, para serem preparados tecnicamente para serem os quadros técnicos e políticos qualificados para os países que tinham saído das guerras coloniais. Lembro-me, com emoção, de três colegas argelinos que tinham acabado de sair da guerra, e que estavam lá para se preparar para voltar e assumir funções de Estado em seu país recém-libertado. A característica internacional e voltada para a formação de quadros para países pobres e recém-libertos o legitimava para receber jovens que acabavam de fazer uma guerra contra a própria França! Mas nossa vivência no IRFED naqueles tempos não era tranquila, pois éramos bem mais revolucionários do que a proposta política trazida pela "ideologia" do Movimento Economia e Humanismo, de um desenvolvimento "harmonioso" e solidário. Nisso nunca acreditei ou usei esses conceitos desde então, até hoje! Tristemente vejo que esses dois conceitos-obstáculo hoje tem outros nomes que da mesma forma atrapalham a crítica a exploração humana: a maldita sustentabilidade, inclusão social ou seja lá do que for e outras detestáveis metáforas...

Havia também a formação em Planejamento Social, que tirando aquela da Educação, considerada fundamental para o avanço de qualquer sociedade do mundo pobre, era onde eram tratados os aspectos de saúde, assistência social, cultura, que o Padre Lebret colocou magistralmente no seu livro "La Dinamyque concrète du Devéloppement", um, dos melhores e, ao que eu saiba, ainda não foi publicado em português. É um livro precioso, com aspectos válidos até hoje, onde ele ensina a fazer análises cruzadas, coisa que hoje se faz usando softwares que com poucos comandos apresentam complexidades, que outrora levávamos às vezes anos, para representar... Mas o que importava era o sistema de análise, como ele nos ensinava, ou seja, a teoria que o Movimento de Economia e Humanismo oferecia. Cristã e neoliberal é bem verdade, mas coesa e muito bem ensinada... Debatíamos e discutíamos muito, especialmente os colegas recém-saídos das guerras de libertação da África.

Mas, naquela época, esses ensinamentos eram muito importantes! Havia uns famosos gráficos que denominávamos "de borboleta" que eram uma espécie de representação gráfica e iconográfica da realidade. Eu achava essa forma de representação genial não apenas pela parte gráfica, mas porque na montagem do gráfico ficava explícita, pelas variáveis consideradas, a filosofia do Movimento "Economia e Humanismo" e a sua definitiva preocupação com os aspectos políticos e sociais, ainda que a seu modo. Mas o seu humanismo era inquestionável!

A formação que fiz, era o Planejamento Territorial, que aqui no Brasil sempre foi chamado de Planejamento Urbano e Regional, mas que na sua origem não tinha esta separação, por que nós aprendíamos a ser estrategistas territoriais.

Dentro dessa imensa formação tinha uma gavetinha pequenina que era a do Plano Diretor. Este, lamentavelmente, até hoje é considerado um plano do município ou da cidade, cujo produto é uma norma politica, como sabemos, e que nem sempre tem a ver com a totalidade do uso do território do município por todos os seus habitantes. O grande produto do plano diretor, a Lei de Zoneamento, sabemos, reflete interesses poderosos e imutáveis na vida da cidade, desde sempre.

No entanto, desde que comecei a estudar esse tema no IRFED, o Plano sempre foi considerado como uma técnica, onde o difícil era exibir o que vinha antes, que eram as escolhas políticas, as diretrizes políticas, as prioridades territoriais. 
Até hoje aqui no Brasil faz-se Plano Diretor sem território, mas apenas promovendo aquilo que venho chamando de "guerra das localizações", "guerra dos valores do solo", praticadas pelos especuladores imobiliários e fundiários os quais, na verdade mandam na cidade. Acoplado a essa guerra vive o romantismo da forma e da formalidade oferecida pelo racional funcionalismo que ainda predomina, mesmo conduzindo um pretenso discurso de esquerda, de vanguarda. Tristemente, a inspiração dos planos diretores ainda está em Atenas, em Londres, em Paris, ou mais recentemente, em Barcelona!

O Plano Diretor era uma questão de técnica para o Padre Lebret, de fácil resolução. Difícil era a montagem do pacto político a ser refletido tecnicamente pelo Plano!

Naqueles tempos, o curso era em tempo integral e ficávamos um ano inteiro estudando. Se compararmos com a aprendizagem de hoje, a formação do IRFED equivaleria a três anos de um curso de pós-graduação hoje, stricto sensu, porém sem a elaboração de uma dissertação ou tese. Realizávamos provas escritas, como mecanismo de avaliação. Era linha dura!

Mas eu aprendi muito no IRFED, onde a seleção dos alunos era rigorosa, trazendo para o curso pessoas já maduras, sensiveis aos trabalhos dos movimentos sociais, pois o problema do Instituto era formar gente para melhorar as condições de vida nos países pobres, de onde vinham os alunos.

Eu me lembro de dois colegas belgas e de um padre francês, padre operário, que frequentaram o curso comigo. Eles trabalhavam na África, e assim eram meus colegas, além dos africanos, africanos negros, africanos árabes, haitianos, gente de Santo Domingo, tinha muita gente da América Central que estava fervendo por causa da revolução cubana em andamento. Do Brasil éramos: três do nordeste, eu aqui de São Paulo. O ano era 1963 (outubro, pouco antes do golpe militar...) e acreditávamos que faríamos a revolução socialista, que nos parecia em marcha... Mas logo em seguida, quando fazíamos um estágio de Economia agrícola na Bretanha, de manhã, no dia 31 de março recebemos pelo rádio a informação do Golpe Militar.

Enorme emoção, pois o que nos unia, a todos os alunos era uma problemática de fundo, libertária. O golpe militar foi um choque para toda a turma.

O fato é que eu sou de uma geração que está na transição de uma universidade que era elitista para uma universidade mais popular de classe média. Eu estou nesta transição... Eu ainda peguei esta "universidade chique"! A Faculdade de Filosofia, Ciências e Letras da USP era um reduto de "gente chique", por quê? Porque formava professores e na época ser professor, no final dos anos 1950, dos anos 1940 o professor era uma figura prestigiadíssima.

No entanto, no curso de Geografia que eu fazia na USP tenho certeza de que fui a primeira pessoa que teve a coragem de dizer: eu quero ser professora, mas eu também quero ser planejadora. Mal sabia eu o que era isso! Apenas estava sendo introduzida na SAGMACS, nessa prática, como "bagrinho",230!

Nem sabia como é que se fazia isso e por isso é que eu fui fazer o IRFED e fui uma geógrafa pioneiríssima! Sem formação específica em planejamento havia um ou dois geógrafos que se atreviam a participar das equipes multidisciplinares requeridas por essa prática. $E$ eu acho que sem dúvida alguma eu sou a primeira geógrafa paulista, com certeza e, provavelmente brasileira, com formação de planejadora que trabalhou em planejamento no Brasil. Eu tive uma outra colega contemporânea, grande geógrafa carioca, que fazia geografia urbana e que trabalhou com planejamento: a Lyzia Bernardes que foi uma grande geógrafa com um trabalho importante, sobre

230 Bagrinho, como já disse anteriormente aqui, era o nome carinhoso atribuído aos estagiários da SAGMACS. 
a região metropolitana do Rio de Janeiro. Mas a Lyzia fazia análise geográfica. Ao que eu saiba, a não ser liderando trabalhos no Governo, na área de planejamento, ela nunca elaborou uma alternativa de futuro, como fiz em várias oportunidades, definindo políticas urbanas e regionais, para o Brasil, para o Estado de São Paulo, para a região Sul do Brasil, além de dezenas de Planos Diretores. E isso tudo eu devo a este curso que eu fiz lá no IRFED e também claro a formação que eu tive aqui, na SAGMACS, mesmo sendo "bagrinho". Eu sempre sou muito atenta a qualquer processo de aprendizagem, até hoje.

\title{
LUCAS - Vamos voltar um pouquinho para situarmos melhor seu vínculo, e o curso no IRFED, pois o IRFED a senhora foi fazer já depois de ter atuado como estagiária, bagrinho do Lebret na SAGMACS não é? Já levou consigo um conhecimento sobre o método que a SAGMACS utilizava.
}

\begin{abstract}
MARIA ADÉLIA - Eu me lembro, como se fosse hoje do Padre Lebret e do professor Pierre Monbeig entrando juntos na biblioteca do escritório da SAGMACS. Era ali que eu ficava, trabalhando, sob o comando naquela época do arquiteto Luiz Carlos Costa. Foi quando eu fui convidada pelo Padre Lebret e pelo Pierre Monbeig a continuar meus estudos na França, quando terminasse minha graduação. Levei a sério esse convite! Eu era estagiária da SAGMACS e os dois foram visitar frei Benevenuto, nosso líder na SAGMACS. Foi quando o Frei, como o chamávamos, me apresentou ao Professor Monbeig dizendo que finalmente tinha na equipe uma geógrafa, ainda estagiária que estava interessada em prosseguir seus estudos sobre planejamento territorial. Foi então que o Professor Pierre Monbeig, fundador da USP foi à biblioteca me conhecer e me perguntou em que ano eu estava na Faculdade. Eu cursava o terceiro ano e então ele me disse: quando você terminar você me escreve, pois eu vou conseguir uma bolsa para você ir para Paris fazer o IRFED. Então ele chamou o Padre Lebret e me apresentou à ele dizendo que eu seria uma futura aluna do instituto. O Padre Lebret falou a mesma coisa, que quando eu terminasse para eu seguir para Paris para aperfeiçoar-me em planejamento. Levei tão a sério o convite que eu terminei o quarto ano em dezembro de 1962 e logo comecei a organizar minha viagem. E em novembro de 1963, segui de navio, o "Enrico C", para Paris, com parada em Marseille.
\end{abstract}

O Padre Lebret me ofereceu uma bolsa de um comitê católico ligado aos padres jesuítas, que acolhia exilados políticos também, naquela época, chamado Comite Catolic contre la Faim e pour le Developpement. O Professor Monbeig me conseguiu uma bolsa depois, para fazer o mestrado com Celso Furtado e o doutorado inicialmente com ele (Pierre Monbeig), terminando com Michel Rochefort. Mas a primeira bolsa que eu tive na França foi o Padre Lebret quem me arrumou. E eu me lembro de que a Silke Weber, eu e os outros colegas do nordeste tivemos esta bolsa do comitê católico. Naquela época o Brasil não oferecia ainda bolsa de estudos. Existiam esse Comitê e o próprio Governo francês, oferecendo bolsas de estudos a estrangeiros. E eu me beneficiei delas, por isso sou grata ao povo francês até hoje por ter custeado meu doutorado.

Então eu sou uma cria da SAGMACS! Acho que sou a única cria jovem da equipe, fui estagiária, fiz o IRFED. Eu comecei como estagiária e fui seguindo, trabalhei no Plano de Governo do Ney Braga para o Paraná, um projeto de loteamento para São Vicente coordenado pelo arquiteto Flávio Villaça, um projeto para a fazenda da Yolanda Penteado em Araras, o Plano Diretor de Sorocaba... mas nessa minha época não tiveram muitos trabalhos assim feitos pela SAGMACS.

Quando eu voltei de Paris a SAGMACS já não atuava mais, já tinha tido o golpe militar de 1964 e foi uma história complicada, com alguns dos nossos perseguidos pelos militares... O escritório 
estava fechado, mas alguns de nós, com a autorização do Frei usávamos o espaço. Levávamos trabalhos para desenvolver lá, utilizávamos a estrutura do espaço. O Vincenzo Bochicchio, meu colega e amigo da graduação era um cartógrafo, juntos lá fizemos o primeiro mapa da Grande São Paulo, editado pela Livraria Duas Cidades, um primor, que depois a Geomapas editou. Trabalhamos dois anos na produção dessa cartografia. O Bochicchio dava aulas, eu trabalhava na Secretaria de Planejamento durante o dia e, nas horas vagas e a noite, trabalhávamos no mapa, no escritório da SAGMACS, para segundo o Frei não deixa-lo totalmente fechado.

E esse mapa ficou lá na Livraria Duas Cidades, como um dos seus produtos à venda mas, serviu como prova para os agentes que foram prender o frei dominicano que era a conexão com o Carlos Marighela, que segundo a polícia, parece-me o contato era feito a partir da livraria! Foi uma enorme dor de cabeça, pois o nosso mapa foi usado como prova de que nós estávamos organizando a guerrilha urbana, imagine só!!!... Se não fora a amizade do Frei Benevenuto com o Alfredo Buzaid, Ministro da Justiça da ditadura, mas que era um grande intelectual, freguês da livraria, eu e meu amigo cartógrafo tínhamos sido presos, pois éramos os autores do mapa.

Guerrilha urbana, naqueles tempos sombrios!!! Na realidade, nós tínhamos feito um mapa para discutir o planejamento e a constituição da Região Metropolitana de São Paulo. Era um período que já se discutia isso, já se falava da instituição do GEGRAN, eu estava na Secretaria de Planejamento, trabalhando com o Luiz Carlos Costa, nós estávamos definindo a primeira divisão regional do estado de São Paulo, a criação do Grupo Executivo da Grande São Paulo - o GEGRAN, que deu origem a EMPLASA, tudo isso estava nascendo e tudo sendo feito a mão.

Os policiais baixaram na livraria duas Cidades em função da denuncia da conexão dos dominicanos com o Marighela. Acham um mapa, o primeiro feito para a região, cheio de informações estratégicas... Então, para ligar o mapa, com a livraria, com a Maria Adélia e o Bochicchio e guerrilha urbana foi um passo... Enorme susto levamos, todos... Inesquecivel!

Eu me lembro de que em 1968, depois do Al 5, o DOPS invadiu a SAGMACS eu fui para lá, avisada pelo Frei, para tentar salvar o que dava do nosso acervo. Eu trabalhava no palácio do Governo e o Frei Benevenuto me ligou por volta de umas dezessete horas e disse que tinha a informação de que o DOPS iria invadir o escritório. Eu convidei o Bochicchio, que também era meu colega, tinha feito estágio lá também, mais três moças, não lembro mais quem e fomos para lá em quatro carros e tudo o que deu para retirar da biblioteca a gente tirou e eu levei para uma garagem na casa de uma tia minha que morava lá no Parque São Lucas, na Zona Leste de São Paulo. Esse material ficou por um bom tempo lá até que o Frei decidiu vender esse material para o Prof. Nestor Goulart Reis, então Diretor da FAU, que comprou para a Biblioteca da pósgraduação, tudo o que pudemos salvar.

LUCAS - O Lamparelli comenta que este acervo comprado pelo Prof. Nestor não era nem um terço do acervo que tinha na SAGMACS. A senhora disse que pegou o que foi possível. Mas houve uma preocupação de retirar livros que pudessem chamar mais atenção dos agentes do regime? Priorizou-se algo para ser salvo do acervo?

MARIA ADÉLIA - Não deu tempo! O Atlas de Favelas de São Paulo tinha ficado comigo porque era uma preciosidade, depois é que eu entreguei. Mas foi o que deu para salvar, nós fomos pegando, os arquivos, os projetos, foi o que deu tempo de pegar, tinha muita coisa que estava fechada. Da biblioteca eu peguei muita coisa, de projeto não levamos quase nada e nós saímos de lá e o DOPS entrou. Acho que nós levamos para fazer isso umas três horas, eram outros 
tempos, foi uma operação com um cara lá embaixo vigiando se o DOPS chegava, nós no $13^{\circ}$ andar do prédio, aqueles elevadores que não andavam... um pesadelo... nós saímos de lá e a polícia chegou. Por pouco, pouco, não fomos pegos. Mas o Lamparelli tem razão. Ainda ficou um bocado de material que não deu para retirar. Não houve tempo...

\footnotetext{
LUCAS - Quando houve o golpe em 1964 a senhora cursava o IRFED. Alguns dos que se exilaram na França também cursaram o IRFED um tempo depois. Eu também me lembro de ter visto em Fontainebleau jornais da época, como se vocês estivessem acompanhando o que se passava por aqui.
}

MARIA ADÉLIA - Quando aconteceu o golpe em 1964 eu e a Silke Weber éramos da Ação Popular, juntamente com o Vinicius Caldeira Brant, o José Serra, a Maria do Carmos Menezes e seu marido Sergio Menezes, a Maria da Penha Vilela de Carvalho, que ficou em Paris e fez sua carreira como assistente de Paul Ricoeur e está lá até hoje...

Como disse anteriormente, e eu estava me lembrando de que em 31 de março nós todos que cursávamos o IRFED estávamos na Bretanha fazendo um estágio sobre os problemas das propriedades rurais. E eu me lembro que nós fomos nos deitar no 31 de março com a notícia do sucesso do comício da Candelária e então no meio da noite eu fui acordada por um amigo do Ceará, que depois atuou no Banco do Nordeste e ele batia na porta dizendo: Adélia, Silke acordem, acordem, acordem; e quando nós abrimos a porta ele disse: Jango caiu! Eu pensei, como assim Jango caiu? Os militares deram um golpe... Saímos todos correndo para Paris, interrompemos nosso estágio, e nos juntamos aos companheiros (da AP) que estavam já se mobilizando. Eles nos disseram alguns precisam ir para (o aeroporto de) Orly, "pois os exilados vão começar a chegar"..

Na noite no dia $1^{\circ}$ de abril eu e mais alguns companheiros já estávamos em Orly recebendo as pessoas que começavam a chegar, sobretudo, das ligas camponesas que foram os primeiros. Chegavam lá famílias de camponeses inteiras pedindo socorro. Os franceses foram de uma generosidade e o Movimento Economia e Humanismo tinha uma respeitabilidade, uma capilaridade lá que ajudou muita gente também a se alojar.

Era difícil, pois tínhamos que instalar as pessoas que chegavam, arrumar emprego, arrumar comida... Mas eram os exilados de bases políticas, gente simples, estudantes secundários e universitários... Não era o Almino Afonso que eu fui receber, era gente que começou a chegar depois em 1966, 1967, antes da coisa piorar mais aqui, gente que tinha ido para o Chile e seguiu para a França depois... Dos geógrafos o Manuel Correia de Andrade, de Pernambuco chegou em 1964, o Milton Santos chegou em 1966.

Eu me lembro do Manuel Correia porque nós íamos juntos para o curso de Mestrado, que eu comecei a fazer em 1965 sob a orientação do Prof. Celso Furtado. O Professor Monbeig tinha me indicado e o Celso Furtado me aceitou como orientanda. Eu tinha um material sobre o Paraná que eu acumulei durante o trabalho de "bagrinho" na SAGMACS, quando foi feito o Plano de Governo para o Ney Braga. Era um material muito bom e isso eu usei para o mestrado. Depois o professor Celso Furtado acabou orientando o Pedro Calil, apresentado por mim, fazendo uma bela tese sobre economia agrícola. Calil acabou ficando em Paris, fez o IRFED e acabou sendo um dos seus dirigentes, como também o Chico Whitaker. Mas já nos anos 70 se não me falha a memória.. 
LUCAS - Voltando para nosso tema e antes de avançarmos mais sobre a SAGMACS, a senhora mencionou a pouco do Lebret e o Monbeig entrarem juntos no escritório da SAGMACS. Comentou que quem fez sua indicação para o IRFED foi o Monbeig. Eu sei que há um vínculo entre ele e o Lebret, mas isso é institucional? Ele deu aulas no IRFED?

MARIA ADÉLIA - Tinham muitos professores universitários franceses que participavam do Movimento, na geografia tinha o Monbeig e o Jean La Basse que era de Lyon, vários professores da economia, o Jean Marie Albertini, professores da sociologia do trabalho, gente que trabalhava nos institutos e nas universidades de lá e que pertenciam ou eram ligados ao movimento.

Penso que no caso do Professor Monbeig pesava o conhecimento que ele tinha do Brasil, o fato dele ter estado aqui, já conhecia melhor e acredito que ele ajudou o Padre Lebret a se introduzir em alguns meios aqui no Brasil. Provavelmente pode ter sido o Professor Monbeig quem pode ter apresentado o Lebret ao pessoal do Estadão, que acabou fazendo um caderno especial do jornal sobre o estudo feito sobre as favelas de São Paulo! O Professor Monbeig ficou amigo dos Mesquitas, quando veio trabalhar na USP nos anos 1930 e foi a família que o acolheu aqui. Monbeig tem um filho que é afilhado do Julio Mesquita! Então eu acho que o fato do Monbeig ter estado aqui alguns anos antes, ele pode ter sido a pessoa que introduziu o Padre Lebret em alguns nichos da sociedade paulistana. Mas ele não deu aulas no IRFED pelo menos enquanto fui aluna. Ele estava sempre lá, contribuía, mas não dava aulas.

\begin{abstract}
LUCAS - Dentro dessa questão dos seus colegas de IRFED, pensando que eram pessoas de países pobres indo para Paris fazer o curso como é que se dava o financiamento das atividades do instituto? A senhora mencionou ter ganho uma bolsa de estudos financiada por um Comitê Católico. Estas bolsas eram para todos? Havia custos para os alunos? Como é que o Insituto se mantinha?
\end{abstract}

MARIA ADÉLIA - Parece-me que tinham organizações religiosas que financiavam, além dos trabalhos técnicos de consultoria realizados pelo próprio IRFED. O Comitê Católico dava a bolsa, como a que eu consegui, e acredito que o Padre Lebret conseguia algum dinheiro junto ao Vaticano, com a realização de trabalhos de assessoria. Mas era tudo muito simples também. 0 esquema do Padre Lebret era simples, ele conseguia as bolsas para as pessoas que iam para lá estudar de diferentes organizações, tinha formas de alojar os alunos e acho que ele conseguia algum apoio em alguns governos também.

Tinha também a Livraria que dava algum dinheiro, as edições Ouvrières eram muito comercializadas, tinham muito prestígio. Havia a Revista do movimento que também era bastante requisitada. Certamente o IRFED tinha que pagar os professores, mas era tudo muito simples, era uma sala pequena onde tínhamos aula, não tinha nada sofisticado. Mas nós, os alunos, não falávamos disso não, não dava para saber, pois cada um vinha de uma guerra de libertação, ou um lugar de extrema pobreza que era tudo muito tenso, as pessoas não conversavam muito ali.

Mas era muito interessante isso tudo, os alunos chegavam na França três meses antes do início do curso no IRFED e eram acolhidos num castelo, ficavam alojados lá, trancados por três meses só para aprender o francês. E não pagávamos nada por isso! ĺamos para lá antes para aprender o francês e assim é que nos conhecíamos. E tinha gente de todo lugar que vinham para fazer o curso: tinham aqueles quem vinham de colônias inglesas, tinha colega da Ásia. 
LUCAS - Agora poderíamos falar sobre uma questão de ideologia e posicionamento político da SAGMACS. É possível verificarmos que a SAGMACS atuou basicamente para o Poder Público e se olharmos os períodos veremos que há uma abertura em governos mais progressistas como aqui em São Paulo durante o Carvalho Pinto, o Ney Braga no Paraná, o Toledo Pizza na Prefeitura de São Paulo, em Belo Horizonte - Plano Diretor para o Amintas, o Baltar em Recife também com trabalhos bem progressistas para o desenvolvimento regional. No Rio acredito que menos... A SAGMACS não estava mesmo vinculada politicamente a esses governos? Aos partidos mais à esquerda?

\begin{abstract}
MARIA ADÉLIA - Não é que não estava vinculada politicamente. Isso não existe! O que havia era uma questão de convergências políticas, com algumas figuras ou alguns partidos, o que é diferente de hoje que há uma ligação direta de um contrato de consultoria com o partido e alguém do partido.

Naquele tempo não era assim, sendo a SAGMACS representante do Movimento Economia e Humanismo, para operacionalizar as ideologias humanistas em sua essência, combativas do problema da desigualdade, isso era uma novidade quando as discussões intelectuais no mundo se davam a partir disso e do terceiro mundo, isso vinha das reverberações da segunda guerra, a Europa ainda em reconstrução...
\end{abstract}

Então eu acho que a SAGMACS conseguiu realizar trabalhos, foi convidada a participar nos governos democrata-cristãos, onde teve, no caso do Ney Braga no Paraná. Aqui em São Paulo não tivemos esta experiência com os governos democrata-cristãos, quando eu estive lá. Aliás, nessa época, tínhamos em São Paulo pouquíssimos trabalhos. Lembro-me que, além do Plano de Governo para o Ney Braga no Paraná, trabalhei no Plano Diretor de Sorocaba, Barretos... Mas eram pouquíssimos, não foi muita coisa que a SAGMACS fez, se contar acho que não passam de vinte trabalhos! A SAGMACS deve ter durado uns quinze anos!!!

Havia também o projeto da Bacia do Tietê e antes disso tinha tido o governo Carvalho Pinto, que eu ainda era estudante, mas aí foi a mudança para o planejamento. O Governador Lucas Garcez contratou o trabalho para a bacia do Paraná-Uruguai, intitulado "Necessidades e Possibilidades para o desenvolvimento da Bacia Paraná Uruguai", ele conseguiu alguns trabalhos, viraram contratos. Mas eram pessoas, um grupo de Democrata-Cristãos mais esclarecidos que não tinham nada a ver com a esquerda não, eu acho.

LUCAS - A SAGMACS me coloca este ponto de indagação sobre a ideologia, ela começa com a vinda do Lebret em 1947 a convite da Escola de Sociologia e Política, mas há quem aponte que também foi a FIESP que bancou a vinda do Lebret para dar um curso de planejamento econômico e quando a SAGMACS é fundada ela vai trabalhar dentro do Jóquei Clube com o Lucas Nogueira Garcez e o Luiz Cintra do Prado que não eram pessoas nada progressistas.

MARIA ADÉLIA - Exatamente! Mas isso é transparente não é? Porque a Democracia Cristã não está ligada a esquerda, sempre esteve muito ligada as elites, ainda mais aqui. Mas é isso mesmo, começou com o Garcez, Jóquei Clube, depois é que começa a mudar, quando o Frei Benevenuto assume a direção e começa a trazer uma equipe bastante progressista. Não conheço bem esse início, pois já cheguei na Praça das Bandeiras. Aí, então, penso que a SAGMACS começa a se 
desvincular desses mandos, mas mesmo neste período tinha um debate interessante sobre o desenvolvimento e esta geração que eu peguei tinha o Chico Whitaker que me parecia à época o mais à esquerda, tanto que foi superintendente da SUPRA - Superintendência para a Reforma Agrária, no Governo Jango.

Mas apesar de tudo nós estávamos mais a esquerda do que qualquer outro movimento da época, tanto é que os que eram do movimento cristão e que mais se radicalizaram foram para a Ação Popular, isso foi o racha, por conta dos católicos que eram contra este conservadorismo.

Mas eu fui militar na AP lá em Paris, nem foi aqui... Mas eu fui amavelmente convidada a deixar a JUC porque eu havia participado de um comando de greve da Perus, cujo advogado era o Mario Carvalho de Jesus que participava as vezes da SAGMACS, de algumas reuniões, se não me falha a memória. Mas, na equipe tinha o médico João Yunes e o José Carlos Seixas, também médico e líder da JUC e que também eram do movimento. Nossa atuação na greve da Perus foi considerada um anarquismo inconsequente. Então deixei a JUC. Depois disso, na universidade eu fui me aproximando mais da POLOP (Organização Operária Marxista), com a Regina Toledo e o Eder Sader, que depois foi seu marido, o Fuad Saad, Mario Damato e tantos outros companheiros de politica estudantil do Grêmio da Faculdade de Filosofia, na rua Maria Antonia. Mas jamais entrei nessa organização. Era amiga de muitos dos seus militantes. A POLOP era barra mais pesada, tanto que muitos dos nossos companheiros foram mortos.

\begin{abstract}
LUCAS - Quanto ao catolicismo, isso é mais forte no grupo da SAGMACS que estava em São Paulo? É certo falarmos em equipe da SAGMACS de São Paulo, pois isso soa como se eu estivesse dizendo que houve várias vertentes dentro do grupo. Isso de fato existia? 0 que é que a diferenciava?
\end{abstract}

\begin{abstract}
MARIA ADÉLIA - Talvez sim, isso porque o Dr. Baltar que estava em Recife, o pessoal do Rio, ligado ao Arthur Rios se não me falha a memória não tinha um frei na direção de forma ali tão direta como nós tínhamos o Frei Benevenuto em São Paulo. Embora o frei fosse muito esclarecido, sabia muito bem diferenciar isso, pois era muito inteligente e um grande intelectual. Dos melhores que conheci em minha vida. E extremamente crítico e rigoroso.

Mas eu acho que você tem que ver também o contexto da igreja católica, o momento que estávamos vivendo, tudo isso tem que ser colocado, porque naquele contexto este grupo nosso era um grupo católico de extrema esquerda... naquele contexto. Era uma igreja saindo do Pio XII, de um conservadorismo e começando o Vaticano II, com o João XXIII, aquela abertura toda e com a posterior chegada de Paulo VI. Naquela época era tudo muito cioso, solene, hoje mudou, mas a igreja foi se modificando, porque o capitalismo é de uma desfaçatez que ele vai detonando com tudo e até com aquelas estruturas que pareciam intocáveis.
\end{abstract}

LUCAS - Os trabalhos feitos pelas equipes dos grupos vinculados ao Movimento Economia e Humanismo como os que a SAGMACS faziam aqui no Brasil, a SAGMA lá na França, SAGMAESCO na Colômbia, etc, tinha algum monitoramento por parte do movimento? Havia um vínculo financeiro de cooperação, como valores enviados pelo movimento da França à SAGMACS no Brasil? 
MARIA ADÉLIA - Que eu saiba não. Mas não conheço bem essa história. A SAGMACS se mantinha através dos contratos que estabelecia para realização dos trabalhos técnicos em planejamento urbano e regional e urbanismo. Eu nunca soube também de que nós tivemos que remeter nada para eles lá não. Havia um intercâmbio para fazer cursos nos diferentes países. De São Paulo foram arquitetos para a Colômbia, por exemplo fazer cursos sobre Habitação Popular!

Mas eram os contratos mesmo que mantinham as equipes. Mas na SAGMACS eu era "bagrinho". Eu não participava dessas reuniões de decisão, depois que eu fui para Paris que eu me aproximei mais do Padre Lebret.

Aqui no Brasil, nossos dirigentes, além do Frei Benevenuto era o Celso Lamparelli, o Flavio Vilaça, a Clementina Ambrósis, o Antonio Claudio Moreira, o Chico Whitaker que sabiam melhor disso. Eu me lembro de alguns intercâmbios Acho que foi o Vitold quem buscou este intercâmbio junto com outros dois arquitetos formados pela FAU o Paulão (Paulo Yazetti) e o Roberto Yazigi.

LUCAS - Por fim, gostaria que a senhora apontasse a partir de um quadro do que ocorria no campo das práticas profissionais dos urbanistas e dos órgãos que pensavam o planejamento na época em que se diferenciou o trabalho da SAGMACS e o porque conseguiu se constituir a partir desta diferença. Há alguma influência da SAGMACS nas práticas do planejamento pós década de 1960?

\begin{abstract}
MARIA ADÉLIA - Eu acho que foi um movimento importante para aquela época para dar uma conscientização sobre a questão da importância do planejamento, mostrou que o planejamento não é uma questão apenas técnica, é algo para se pensar no futuro das nações. O primeiro exercício de implantação dos princípios de planejamento, que vinga desta formação que nós tínhamos no IRFED, foi no governo Carvalho Pinto. Foram os princípios "iifedianos" que nortearam o grupo do PAGE - Plano de Ação daquele governo, um plano territorial. Se você pegar o plano do governo do Carvalho Pinto eles começam ali a instituir um instrumento que é "irfediano" que é o que eu segui pelo resto da vida e faço até hoje, onde o território não é apenas um enunciado, mas uma categoria de análise. Por isso falávamos em regionalização para descentralização e democratização de implantação de serviços, que hoje virou esta coisa de participação popular que está aí... com mais discurso do que ação.
\end{abstract}

Naquela época não! Tanto é que o Carvalho Pinto foi o primeiro governo a fazer uma divisão regional do Estado de São Paulo para efeito de planejamento. Depois, com esta experiência do PAGE, o Luiz Carlos Costa na Secretaria de Planejamento, nos anos 1960 fez o primeiro decreto de regionalização administrativa do Estado de São Paulo, que o Carvalho Pinto não tinha feito. Esse governo havia feito a regionalização dos serviços. Já o Costa, como o chamávamos, quando eu trabalhei com ele neste projeto, cuidou de uma regionalização integral dos serviços, que naquela época nós acreditávamos muito, e hoje eu me revejo nisso... Nós errávamos por falta de formação teórica e filosófica mais aprimorada... Eu não tinha sido aluna do Sartre ainda, e por isso eu acreditava na busca da intersetorialidade, como busca da prática governamental. Essa coisa faria a articulação entre os setores do governo de modo a agilizar e melhorar a prestação dos serviços. Hoje eu sei que isso não existe, o que existe é a totalidade em movimento e quem expressa essa unidade e essa dinâmica é o território usado. O território, não o setor é quem deve ser considerado pelo planejamento. Trata-se de discutir o planejamento territorial versus o planejamento setorial. 
Daquele trabalho coordenado pelo Luiz Carlos Costa na Secretaria do Planejamento do Estado de São Paulo sai a ação regional, e o primeiro decreto desta ação é de 1968, e este decreto consistia em lidar com a gestão pública de uma forma articulada, integrada, inter setorial, territorialmente falando. Depois veio a criação do GEGRAN e isso eu acho que é uma influência do Movimento Economia e Humanismo.

Mas, independentemente dos escorregões mais à direita, mais classistas, o movimento, para nós que estávamos na ativa, trabalhando nas coisas, não digo os dirigentes e os figurões, nós tínhamos uma concepção bastante avançada quanto a descentralização, participação e eu levei isso comigo para onde eu fui trabalhar pelo resto da vida.

Fui trabalhar no SERFHAU levei essas coisas, até verifiquei recentemente um Termo de Referência que eu fiz para Chapecó em 1969, que exigia reuniões populares, em Santa Catarina.

Foram das coisas que eu aprendi na SAGMACS, no IRFED, com o Padre Lebret.

Lembro-me de ter acompanhado o Padre Lebret em trabalhos de campo e reuniões no Senegal com plantadores de amendoim, para tentar ver se eles mudavam as tecnologias do plantio e poder ter maior rentabilidade. Ficamos por lá com ele três meses e não conseguimos mudar absolutamente nada na cabeça dos pequenos plantadores. Era uma tribo muito fechada, que não queria mudar nada em sua cultura de plantio, pois assim faziam há séculos...

Desde então eu passei a ser crítica das teorias desenvolvimentistas, porque tecnicamente era fácil de mudar, mas de fazer as pessoas entenderem isso não era simples. As empresas podem fazer o que bem entendem. As pessoas não!

Ou você muda a cultura ou a economia te arrasa! Claro que mais tarde esta tribo deve ter entrado num processo capitalista de cultivo do amendoim, que arrasou com tudo. Mas a que preço? Se as pessoas não conseguem entender o que é o seu modo de ser, se elas não entenderem isso para elas mesmas fazerem a crítica e querer mudar, o que vier de forma diferente, como sempre se fez com o planejamento, não é aceito e o efeito é exatamente o contrário do que se diz e discursa. Basta olhar as cidades hoje, onde as periferias são carentes de tudo. Mas os discursos dos planos, não! Neste sentido eu acho que nisso hoje, o novo conceito de lugar proposto por Milton Santos, como sendo um espaço do acontecer solidário, ajuda nessa perspectiva de lida, no planejamento com o conceito de espaço banal, proposto pelo François Perroux, que era do movimento Economia e Humanismo, embora com divergências com o Padre Lebret. Mas essa é outra conversa, com outro personagem que tenho usado na minha vida de planejadora nos tempos atuais.

Mas eu aprendi muito nessa escola da SAGMACS e do IRFED, que tenho levado adiante a vida toda, sempre renovando-a com novas aprendizagens, novas teorias, novos fazeres. Não sou nenhuma tecnocrata, pois aprendi que é preciso rigor no processo de conhecimento para ajudar as pessoas a serem melhores e que é a política quem faz isso!

Entendi que planejamento e política são irmãos siameses. 



\section{Anexo 12 - Quadro de composição das equipes da SAGMACS em suas diferentes fases de atuação}

\begin{tabular}{|c|c|c|c|c|}
\hline \multicolumn{2}{|r|}{ Nome do Técnico/Profissional } & \multirow{2}{*}{$\begin{array}{c}\begin{array}{c}\text { Período } \\
\text { de } \\
\text { Atuação }\end{array} \\
1956-1958\end{array}$} & \multirow{2}{*}{$\begin{array}{l}\text { Trabalhos em que Participou } \\
\text { Estrutura Urbana da } \\
\text { Aglomeração Paulistana }\end{array}$} & \multirow{2}{*}{$\begin{array}{c}\text { Quant. de } \\
\text { Trabalhos } \\
\text { que } \\
\text { participou }\end{array}$} \\
\hline 001 & Aderbal José Bueno & & & \\
\hline 002 & Afonso dos Santos & $1958-1959$ & $\begin{array}{llll}\begin{array}{l}\text { Estrutura } \\
\text { Horizonte }\end{array} & \text { Urbana de } & \text { Belo } \\
\end{array}$ & 1 \\
\hline 003 & Ailza Barbosa de Araújo & $1958-1960$ & $\begin{array}{l}\text { Aspectos Humanos da Favela } \\
\text { Carioca }\end{array}$ & 1 \\
\hline 004 & Alahyr Ferreira Cruz & $1956-1958$ & $\begin{array}{lll}\text { Estrutura } & \text { Urbana } & \text { da } \\
\text { Aglomeração } & \text { Paulistana } & \\
\end{array}$ & 1 \\
\hline 005 & Alain Birou & 1955-1958 & $\begin{array}{l}\text { Problemas de Desenvolvimento, } \\
\text { Necessidades e Possibilidades } \\
\text { dos Estados do Rio Grande do } \\
\text { Sul, Santa Catarina e Paraná }\end{array}$ & 1 \\
\hline 006 & Aloysio de Carvalho & $1955-1958$ & $\begin{array}{l}\text { Problemas de Desenvolvimento, } \\
\text { Necessidades e Possibilidades } \\
\text { dos Estados do Rio Grande do } \\
\text { Sul, Santa Catarina e Paraná }\end{array}$ & 1 \\
\hline 007 & Ana Maria Adamo & 1956-1958 & $\begin{array}{lcc}\text { Estrutura } & \text { Urbana } & \text { da } \\
\text { Aglomeração Paulistana } & \\
\end{array}$ & 1 \\
\hline 008 & André Franco Montoro Filho & 1963 & $\begin{array}{l}\text { Estudo para uma política } \\
\text { habitacioinal para a Cia. Ferro e } \\
\text { Aço de Vitória }\end{array}$ & 1 \\
\hline 009 & Annibal Villela & $1958-1959$ & $\begin{array}{llll}\begin{array}{l}\text { Estrutura } \\
\text { Horizonte }\end{array} & \text { Urbana de } & \text { Belo } \\
\end{array}$ & 1 \\
\hline 010 & Antonio Amilcar de Oliveira Lima & $1963-1964$ & $\begin{array}{l}\text { Relatório para o Plano de } \\
\text { Desenvolvimento do Paraná } \\
\text { Prospecção dos problemas de } \\
\text { desenvolvimento de Ubatuba }\end{array}$ & 2 \\
\hline 011 & Antonio Assimos & $1958-1960$ & $\begin{array}{l}\text { Aspectos Humanos da Favela } \\
\text { Carioca }\end{array}$ & 1 \\
\hline 012 & Antonio Bezerra Baltar & $1953-1963$ & $\begin{array}{l}\text { Problemas de Desenvolvimento: } \\
\text { Estudo das necessidades e } \\
\text { possibilidades para o Estado de } \\
\text { São Paulo } \\
\text { Plano Diretor de Ourinhos } \\
\text { Estrutura Urbana da } \\
\text { Aglomeração Paulistana } \\
\text { Estrutura Urbana de Belo } \\
\text { Horizonte } \\
\text { Plano Diretor de Belo Horizonte }\end{array}$ & 5 \\
\hline 013 & Antonio Carlos Bernardo & $1962-1963$ & $\begin{array}{l}\text { Plano Diretor de Sorocaba } \\
\text { Relatório para o Plano de } \\
\text { Desenvolvimento do Paraná }\end{array}$ & 2 \\
\hline 014 & Antonio Carlos de Macedo & 1956-1958 & $\begin{array}{lcc}\text { Estrutura } & \text { Urbana } & \text { da } \\
\text { Aglomeração Paulistana } & \\
\end{array}$ & 1 \\
\hline 015 & Antonio Carlos Queirós Guimarães & 1956-1958 & $\begin{array}{lc}\text { Estrutura } & \text { Urbana } \\
\text { Aglomeração Paulistana } & \\
\end{array}$ & 1 \\
\hline
\end{tabular}




\begin{tabular}{|c|c|c|c|c|}
\hline \multicolumn{2}{|r|}{ Nome do Técnico/Profissional } & \multirow{2}{*}{$\begin{array}{c}\begin{array}{c}\text { Período } \\
\text { de } \\
\text { Atuação }\end{array} \\
1956-1964\end{array}$} & Trabalhos em que Participou & \multirow{2}{*}{$\begin{array}{l}\text { Quant. de } \\
\text { Trabalhos } \\
\text { que } \\
\text { participou }\end{array}$} \\
\hline 016 & $\begin{array}{l}\text { Antônio Cláudio Moreira Lima e } \\
\text { Moreira }\end{array}$ & & $\begin{array}{l}\text { Estrutura Urbana da } \\
\text { Aglomeração Paulistana } \\
\text { Programa de Mecanização } \\
\text { Agrícola do Estado do Mato } \\
\text { Grosso } \\
\text { Projeto Araguaia } \\
\text { Plano Diretor de Sorocaba } \\
\text { Relatórios para o Plano de } \\
\text { Desenvolvimento do Paraná } \\
\text { Prospecção dos Problemas de } \\
\text { Desenvolvimento de Ubatuba }\end{array}$ & \\
\hline 017 & Antonio de Felice & $1962-1963$ & $\begin{array}{l}\text { Relatório sobre o problema da } \\
\text { água e esgoto: Análise da } \\
\text { situação das sedes de } \\
\text { municípios do interior de São } \\
\text { Paulo }\end{array}$ & 1 \\
\hline 018 & Antonio Delorenzo Netto & 1953-1963 & $\begin{array}{l}\text { Problemas de Desenvolvimento: } \\
\text { Estudo das necessidades e } \\
\text { possibilidades para o Estado de } \\
\text { São Paulo } \\
\text { Plano Diretor de Ourinhos } \\
\text { Estrutura Urbana da } \\
\text { Aglomeração Paulistana } \\
\text { Estrutura Urbana de Belo } \\
\text { Horizonte } \\
\text { Plano Diretor de Barretos }\end{array}$ & 5 \\
\hline 019 & Antonio Saint Pastous & $1955-1958$ & $\begin{array}{l}\text { Problemas de Desenvolvimento, } \\
\text { Necessidades e Possibilidades } \\
\text { dos Estados do Rio Grande do } \\
\text { Sul, Santa Catarina e Paraná }\end{array}$ & 1 \\
\hline 020 & Archanjo Gabriel Medeiros Cruz & 1958-1959 & $\begin{array}{|lll|}\begin{array}{l}\text { Estrutura Urbana de } \\
\text { Horizonte }\end{array} & \text { Belo } \\
\end{array}$ & 1 \\
\hline 021 & Armando Frioli & 1956-1958 & \begin{tabular}{|lcc} 
Estrutura & Urbana & da \\
Aglomeração Paulistana &
\end{tabular} & 1 \\
\hline 022 & Arnaldo Begossi & $1962-1963$ & $\begin{array}{l}\text { Relatório sobre o problema da } \\
\text { água e esgoto: Análise da } \\
\text { situação das sedes de } \\
\text { municípios do interior de São } \\
\text { Paulo }\end{array}$ & 1 \\
\hline 023 & Aryvalde Ferreira da Silva & $1958-1960$ & $\begin{array}{l}\text { Aspectos Humanos da Favela } \\
\text { Carioca }\end{array}$ & 1 \\
\hline 024 & Atsuko Haga & $1956-1958$ & \begin{tabular}{|lcc} 
Estrutura Urbana & da \\
Aglomeração Paulistana & \\
\end{tabular} & 1 \\
\hline 025 & Benevenuto de Santa Cruz & 1953-1964 & $\begin{array}{l}\text { Problemas de Desenvolvimento: } \\
\text { Estudo das necessidades e } \\
\text { possibilidades para o Estado de } \\
\text { São Paulo } \\
\text { Plano Diretor de Ourinhos } \\
\text { Problemas de Desenvolvimento, } \\
\text { Necessidades e Possibilidades } \\
\text { dos Estados do Rio Grande do } \\
\text { Sul, Santa Catarina e Paraná } \\
\text { Estrutura Urbana da } \\
\text { Aglomeração Paulistana } \\
\text { Estrutura Urbana de Belo }\end{array}$ & 11 \\
\hline
\end{tabular}




\begin{tabular}{|c|c|c|c|c|}
\hline & & & $\begin{array}{l}\text { Horizonte } \\
\text { Revisão Agrária do Estado de } \\
\text { São Paulo: Estudos para um } \\
\text { plano de loteamento da } \\
\text { Fazenda Jacilândia } \\
\text { Relatório sobre o problema da } \\
\text { água e esgoto: Análise da } \\
\text { situação das sedes de } \\
\text { muncípios do interior de São } \\
\text { Paulo } \\
\text { Plano Diretor de Belo Horizonte } \\
\text { Plano Diretor de Sorocaba } \\
\text { Relatórios para o Plano de } \\
\text { Desenvolvimento do Paraná } \\
\text { Prospecção dos Problemas de } \\
\text { Desenvolvimento de Ubatuba }\end{array}$ & \\
\hline 026 & Biro Ernesto Zeitel & $1956-1958$ & $\begin{array}{lcc}\text { Estrutura } & \text { Urbana } & \text { da } \\
\text { Aglomeração Paulistana } & \end{array}$ & 1 \\
\hline 027 & Carlos Alberto Medina & $1958-1960$ & $\begin{array}{l}\text { Aspectos Humanos da Favela } \\
\text { Carioca }\end{array}$ & 1 \\
\hline 028 & Carlos Alberto Lima de Faria & 1956-1958 & $\begin{array}{lcc}\text { Estrutura } & \text { Urbana } & \text { da } \\
\text { Aglomeração Paulistana } & \end{array}$ & 1 \\
\hline 029 & Carlos Eduardo Alves Lima & $1956-1958$ & $\begin{array}{lcc}\text { Estrutura } & \text { Urbana } & \text { da } \\
\text { Aglomeração Paulistana } & \end{array}$ & 1 \\
\hline 030 & Carlos Moraes & $1958-1960$ & $\begin{array}{l}\text { Aspectos Humanos da Favela } \\
\text { Carioca }\end{array}$ & 1 \\
\hline 031 & Casimiro dos Reis Filho & 1953-1955 & $\begin{array}{l}\text { Problemas de Desenvolvimento: } \\
\text { Estudo das necessidades e } \\
\text { possibilidades para o Estado de } \\
\text { São Paulo }\end{array}$ & 1 \\
\hline 032 & Celio Abrusio & $1962-1963$ & $\begin{array}{l}\text { Relatório sobre o problema da } \\
\text { água e esgoto: Análise da } \\
\text { situação das sedes de } \\
\text { municípios do interior de São } \\
\text { Paulo }\end{array}$ & 1 \\
\hline 033 & Celso Monteiro Lamparelli & 1956-1964 & $\begin{array}{l}\text { Estrutura Urbana da } \\
\text { Aglomeração Paulistana } \\
\text { Estrutura Urbana de Belo } \\
\text { Horizonte } \\
\text { Plano Diretor de Belo Hozionte } \\
\text { Relatórios para o Plano de } \\
\text { Desenvolvimento do Paraná } \\
\end{array}$ & 4 \\
\hline 034 & César Ubaldo Câmara & $1962-1963$ & $\begin{array}{l}\text { Relatório sobre o problema da } \\
\text { água e esgoto: Análise da } \\
\text { situação das sedes de } \\
\text { municípios do interior de São } \\
\text { Paulo }\end{array}$ & 1 \\
\hline 035 & $\begin{array}{l}\text { Chiara De Ambrósis } \text { Pinheiro } \\
\text { Machado }\end{array}$ & 1953-1958 & $\begin{array}{l}\text { Problemas de Desenvolvimento: } \\
\text { Estudo das necessidades e } \\
\text { possibilidades para o Estado de } \\
\text { São Paulo } \\
\text { Estrutura Urbana da } \\
\text { Aglomeração Paulistana }\end{array}$ & 2 \\
\hline 036 & Christa Hahlohm & $1955-1958$ & $\begin{array}{l}\text { Problemas de Desenvolvimento, } \\
\text { Necessidades e Possibilidades } \\
\text { dos Estados do Rio Grande do } \\
\text { Sul, Santa Catarina e Paraná }\end{array}$ & 1 \\
\hline
\end{tabular}




\begin{tabular}{|c|c|c|c|c|}
\hline \multicolumn{2}{|r|}{ Nome do Técnico/Profissional } & \multirow{2}{*}{$\begin{array}{c}\begin{array}{c}\text { Período } \\
\text { de } \\
\text { Atuação }\end{array} \\
1962-1963 \\
\end{array}$} & \multirow{2}{*}{$\begin{array}{l}\text { Trabalhos em que Participou } \\
\text { Plano Diretor de Belo Horizonte }\end{array}$} & \multirow{2}{*}{$\begin{array}{c}\text { Quant. de } \\
\text { Trabalhos } \\
\text { que } \\
\text { participou } \\
1\end{array}$} \\
\hline 037 & Cláudio Soares de Azevedo & & & \\
\hline 038 & Clementina De Ambrósis & $1953-1964$ & $\begin{array}{l}\text { Problemas de Desenvolvimento: } \\
\text { Estudo das necessidades e } \\
\text { possibilidades para o Estado de } \\
\text { São Paulo } \\
\text { Plano Diretor de Ourinhos } \\
\text { Problemas de Desenvolvimento, } \\
\text { Necessidades e Possibilidades } \\
\text { dos Estados do Rio Grande do } \\
\text { Sul, Santa Catarina e Paraná } \\
\text { Estrutura Urbana da } \\
\text { Aglomeração Paulistana } \\
\text { Plano Diretor de Barretos } \\
\text { Plano Diretor de Belo Horizonte } \\
\text { Estudo para implantação de um } \\
\text { loteamento em São Vicente } \\
\text { Estudo para uma política } \\
\text { habitacional para a Cia. Ferro e } \\
\text { Aço de Vitória } \\
\text { Prospecção dos Problemas de } \\
\text { Desenvolvimento de Ubatuba }\end{array}$ & 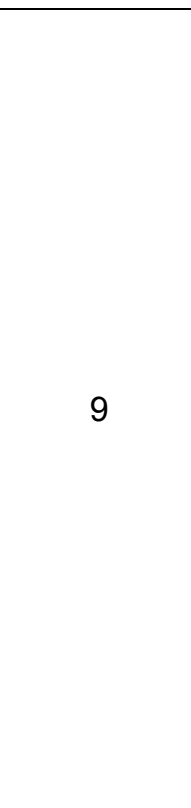 \\
\hline 039 & Clóvis Serra & $1956-1958$ & $\begin{array}{lcc}\text { Estrutura } & \text { Urbana } & \text { da } \\
\text { Aglomeração Paulistana } & \\
\end{array}$ & 1 \\
\hline 040 & Cristóvão de Andrade Franco & $1953-1958$ & $\begin{array}{l}\text { Problemas de Desenvolvimento: } \\
\text { Estudo das necessidades e } \\
\text { possibilidades para o Estado de } \\
\text { São Paulo } \\
\text { Problemas de Desenvolvimento, } \\
\text { Necessidades e Possibilidades } \\
\text { dos Estados do Rio Grande do } \\
\text { Sul, Santa Catarina e Paraná }\end{array}$ & 2 \\
\hline 041 & Darcy Passos & $1953-1955$ & $\begin{array}{l}\text { tudo das necessidades e } \\
\text { possibilidades para o Estado de } \\
\text { São Paulo }\end{array}$ & 1 \\
\hline 042 & Divo Pereira de Rezende & $1956-1958$ & $\begin{array}{lcc}\text { Estrutura } & \text { Urbana } & \text { da } \\
\text { Aglomeração Paulistana } & \\
\end{array}$ & 1 \\
\hline 043 & $\begin{array}{l}\text { Domingos Theodoro de Azevedo } \\
\text { Neto }\end{array}$ & $1953-1964$ & $\begin{array}{l}\text { Problemas de Desenvolvimento: } \\
\text { Estudo das necessidades e } \\
\text { possibilidades para o Estado de } \\
\text { São Paulo } \\
\text { Plano Diretor de Ourinhos } \\
\text { Problemas de Desenvolvimento, } \\
\text { Necessidades e Possibilidades } \\
\text { dos Estados do Rio Grande do } \\
\text { Sul, Santa Catarina e Paraná } \\
\text { Estrutura Urbana da } \\
\text { Aglomeração Paulistana } \\
\text { Relatório sobre o problema da } \\
\text { água e esgoto: Análise da } \\
\text { situação das sedes de } \\
\text { municípios do interior de São } \\
\text { Paulo } \\
\text { Plano Diretor de Belo Horizonte }\end{array}$ & 6 \\
\hline 044 & Edison Eloy de Souza & $1962-1963$ & $\begin{array}{l}\text { Relatório sobre o problema da } \\
\text { água e esgoto: Análise da }\end{array}$ & 1 \\
\hline
\end{tabular}




\begin{tabular}{|c|c|c|c|c|}
\hline & & & $\begin{array}{llr}\text { situação das sedes } & \text { de } \\
\text { municípios do interior de São } \\
\text { Paulo }\end{array}$ & \\
\hline 045 & Edison Quintana & 1955-1958 & $\begin{array}{l}\text { Problemas de Desenvolvimento, } \\
\text { Necessidades e Possibilidades } \\
\text { dos Estados do Rio Grande do } \\
\text { Sul, Santa Catarina e Paraná }\end{array}$ & 1 \\
\hline 046 & Edith Vieira & $1956-1958$ & $\begin{array}{lcc}\text { Estrutura } & \text { Urbana } & \text { da } \\
\text { Aglomeração Paulistana } & \\
\end{array}$ & 1 \\
\hline 047 & Eduardo Bastos & $1953-1958$ & $\begin{array}{l}\text { Problemas de Desenvolvimento: } \\
\text { Estudo das necessidades e } \\
\text { possibilidades para o Estado de } \\
\text { São Paulo } \\
\text { Problemas de Desenvolvimento, } \\
\text { Necessidades e Possibilidades } \\
\text { dos Estados do Rio Grande do } \\
\text { Sul, Santa Catarina e Paraná }\end{array}$ & 2 \\
\hline 048 & Eduardo Roman & $1955-1958$ & $\begin{array}{l}\text { Problemas de Desenvolvimento, } \\
\text { Necessidades e Possibilidades } \\
\text { dos Estados do Rio Grande do } \\
\text { Sul, Santa Catarina e Paraná }\end{array}$ & 1 \\
\hline 049 & Elias Pessoa de Carvalho & $1958-1960$ & $\begin{array}{l}\text { Aspectos Humanos da Favela } \\
\text { Carioca }\end{array}$ & 1 \\
\hline 050 & Estanislau Roberto Maiorano & $1947-1948$ & $\begin{array}{l}\text { Sondagem Preliminar a um } \\
\text { estudo sobre habitação } \\
\text { cidade na São Paulo }\end{array}$ & 1 \\
\hline 051 & Evanira Mendes & $1956-1958$ & $\begin{array}{lcc}\text { Estrutura } & \text { Urbana } & \text { da } \\
\text { Aglomeração Paulistana } & \end{array}$ & 1 \\
\hline 052 & Evelin Naked de Castro Sá & $1956-1958$ & $\begin{array}{lcc}\text { Estrutura } & \text { Urbana } & \text { da } \\
\text { Aglomeração Paulistana } & \\
\end{array}$ & 1 \\
\hline 053 & Fabricio Adamo & $1956-1958$ & $\begin{array}{lcc}\text { Estrutura } & \text { Urbana } & \text { da } \\
\text { Aglomeração Paulistana } & \end{array}$ & 1 \\
\hline 054 & Fernando Correia Dias & $1958-1959$ & $\begin{array}{l}\text { Estrutura Urbana de } \\
\text { Horizonte }\end{array}$ & 1 \\
\hline 055 & Flávio Villaça & $1962-1964$ & $\begin{array}{l}\text { Relatório sobre o problema da } \\
\text { água e esgoto: Análise da } \\
\text { situação das sedes de } \\
\text { municípios do interior de São } \\
\text { Paulo } \\
\text { Plano Diretor de Barretos } \\
\text { Plano Diretor de Belo Horizonte } \\
\text { Estudo para implantação de um } \\
\text { loteamento em São Vicente } \\
\text { Estudo para uma política } \\
\text { habitacional para a Cia. Ferro e } \\
\text { Aço de Vitória }\end{array}$ & 5 \\
\hline 056 & Francisco de Assis & $1955-1958$ & $\begin{array}{l}\text { Problemas de Desenvolvimento, } \\
\text { Necessidades e Possibilidades } \\
\text { dos Estados do Rio Grande do } \\
\text { Sul, Santa Catarina e Paraná }\end{array}$ & 1 \\
\hline 057 & Francisco Whitaker Ferreira & $1956-1964$ & $\begin{array}{l}\text { Estrutura Urbana } \\
\text { Aglomeração Paulistana } \\
\text { Estrutura Urbana de Belo } \\
\text { Horizonte } \\
\text { Revisão Agrária do Estado de } \\
\text { São Paulo: Estudos para um } \\
\text { plano de loteamento da } \\
\text { Fazenda Jacilândia }\end{array}$ & 10 \\
\hline
\end{tabular}




\begin{tabular}{|c|c|c|c|c|}
\hline & & & $\begin{array}{l}\text { Programa de Mecanização } \\
\text { Agrícola do Estado do Mato } \\
\text { Grosso } \\
\text { Projeto Araguaia } \\
\text { Plano Diretor de Barretos } \\
\text { Plano Diretor de Belo Horizonte } \\
\text { Plano Diretor de Sorocaba } \\
\text { Estudo para uma política } \\
\text { habitacional para a Cia. Ferro e } \\
\text { Aço de Vitória } \\
\text { Relatórios para o Plano de } \\
\text { Desenvolvimento do Paraná } \\
\end{array}$ & \\
\hline 058 & Frank Goldman & 1953-1958 & $\begin{array}{l}\text { Problemas de Desenvolvimento: } \\
\text { Estudo das necessidades e } \\
\text { possibilidades para o Estado de } \\
\text { São Paulo } \\
\text { Estrutura Urbana da } \\
\text { Aglomeração Paulistana }\end{array}$ & 2 \\
\hline 059 & Gastão Thomaz de Almeida & 1956-1958 & $\begin{array}{lll}\text { Estrutura } & \text { Urbana } & \text { da } \\
\text { Aglomeração } & \text { Paulistana } & \\
\end{array}$ & 1 \\
\hline 060 & Geraldo Semenzato & 1953-1955 & $\begin{array}{l}\text { Problemas de Desenvolvimento: } \\
\text { Estudo das necessidades e } \\
\text { possibilidades para o Estado de } \\
\text { São Paulo }\end{array}$ & 1 \\
\hline 061 & Gil Augusto Machado & 1956-1958 & $\begin{array}{lll}\text { Estrutura } & \text { Urbana } & \text { da } \\
\text { Aglomeração } & \text { Paulistana } & \end{array}$ & 1 \\
\hline 062 & Gilles Lapouge & 1963-1955 & $\begin{array}{l}\text { Problemas de Desenvolvimento: } \\
\text { Estudo das necessidades e } \\
\text { possibilidades para o Estado de } \\
\text { São Paulo }\end{array}$ & 1 \\
\hline 063 & Glauco Glacobbe & $1962-1963$ & $\begin{array}{l}\text { Plano Diretor de Barretos } \\
\text { Plano Diretor de Belo Horizonte }\end{array}$ & 2 \\
\hline 064 & Hans Alfred Rappel & 1959 & $\begin{array}{l}\text { Pesquisa Regional voltada para } \\
\text { o Desenvolvimento do Nordeste }\end{array}$ & 1 \\
\hline 065 & Haroldo Taborda Galliac & 1958-1959 & $\begin{array}{llll}\begin{array}{l}\text { Estrutura } \\
\text { Horizonte }\end{array} & \text { Urbana de } & \text { Belo } \\
\end{array}$ & 1 \\
\hline 066 & Hebe Vainier & $1958-1960$ & $\begin{array}{l}\text { Aspectos Humanos da Favela } \\
\text { Carioca }\end{array}$ & 1 \\
\hline 067 & Helena Maria Pereira de Carvalho & 1956-1958 & $\begin{array}{lcc}\text { Estrutura } & \text { Urbana } & \text { da } \\
\text { Aglomeração } & \text { Paulistana } & \\
\end{array}$ & 1 \\
\hline 068 & Hélio Hell Caiaffa & 1956-1958 & $\begin{array}{lrr}\text { Estrutura } & \text { Urbana } & \text { da } \\
\text { Aglomeração Paulistna } & \end{array}$ & 1 \\
\hline 069 & Hélio Modesto & $1958-1960$ & $\begin{array}{l}\text { Aspectos Humanos da Favela } \\
\text { Carioca }\end{array}$ & 1 \\
\hline 070 & Hélio Moulin & $1958-1960$ & $\begin{array}{l}\text { Aspectos Humanos da Favela } \\
\text { Carioca }\end{array}$ & 1 \\
\hline 071 & Hilton Prates & 1958-1959 & \begin{tabular}{|llll}
$\begin{array}{l}\text { Estrutura } \\
\text { Horizonte }\end{array}$ & & & \\
\end{tabular} & 1 \\
\hline 072 & Hiroshi Watanabe Queiroz & 1958-1959 & \begin{tabular}{|llll}
$\begin{array}{l}\text { Estrutura } \\
\text { Horizonte }\end{array}$ & Urbana de & Belo \\
\end{tabular} & 1 \\
\hline 073 & Ilka Leite & $1958-1960$ & $\begin{array}{l}\text { Aspectos Humanos da Favela } \\
\text { Carioca }\end{array}$ & 1 \\
\hline 074 & Irmã Maria Corintha & $1956-1958$ & \begin{tabular}{|lcc} 
Estrutura & Urbana & da \\
Aglomeração & Paulistana & \\
\end{tabular} & 1 \\
\hline 075 & Irmã Marta Alexandra & $1956-1958$ & $\begin{array}{lc}\text { Estrutura } & \text { Urbana } \\
\text { Aglomeração Paulistana }\end{array}$ & 1 \\
\hline 076 & Jacinto Afrânio Jairo Rossetti & $1956-1958$ & $\begin{array}{lc}\text { Estrutura } & \text { Urbana } \\
\text { Aglomeração Paulistana }\end{array}$ & 1 \\
\hline
\end{tabular}




\begin{tabular}{|c|c|c|c|c|}
\hline 077 & Jacob Elloy Runrath & $1955-1958$ & $\begin{array}{l}\text { Problemas de Desenvolvimento, } \\
\text { Necessidades e Possibilidades } \\
\text { dos Estados do Rio Grande do } \\
\text { Sul, Santa Catarina e Paraná }\end{array}$ & 1 \\
\hline 078 & Jacob Souza Filho & $1955-1958$ & $\begin{array}{l}\text { Problemas de Desenvolvimento, } \\
\text { Necessidades e Possibilidades } \\
\text { dos Estados do Rio Grande do } \\
\text { Sul, Santa Catarina e Paraná }\end{array}$ & 1 \\
\hline 079 & Jayme Hilário de Souza & 1958-1959 & $\begin{array}{l}\text { Estrutura Urbana de } \\
\text { Horizonte }\end{array}$ & 1 \\
\hline 080 & João Alfredo Alberti & $1962-1963$ & $\begin{array}{l}\text { Relatórios para o Plano de } \\
\text { Desenvolvimento do Paraná }\end{array}$ & 1 \\
\hline 081 & João B. de Arruda Sampaio & $1956-1958$ & $\begin{array}{lcc}\text { Estrutura } & \text { Urbana } & \text { da } \\
\text { Aglomeração Paulistana } & \end{array}$ & 1 \\
\hline 082 & João Carlos Seixas & $1962-1963$ & $\begin{array}{l}\text { Relatórios para o Plano de } \\
\text { Desenvolvimento do Paraná }\end{array}$ & 1 \\
\hline 083 & João Paulo Rodrigues & $1955-1958$ & $\begin{array}{l}\text { Problemas de Desenvolvimento, } \\
\text { Necessidades e Possibilidades } \\
\text { dos Estados do Rio Grande do } \\
\text { Sul, Santa Catarina e Paraná }\end{array}$ & 1 \\
\hline 084 & João Yunes & $1962-1964$ & $\begin{array}{l}\text { Relatórios para o Plano de } \\
\text { Desenvolvimento do Paraná } \\
\text { Prospecção dos Problemas de } \\
\text { Desenvolvimento de Ubatuba }\end{array}$ & 2 \\
\hline 085 & Joaquim Guedes & 1953-1955 & $\begin{array}{l}\text { Problemas de Desenvolvimento: } \\
\text { Estudo das necessidades e } \\
\text { possibilidades para o Estado de } \\
\text { São Paulo }\end{array}$ & 1 \\
\hline 086 & José Antonio Giusti Bueno & $1955-1958$ & $\begin{array}{l}\text { Problemas de Desenvolvimento, } \\
\text { Necessidades e Possibilidades } \\
\text { dos Estados do Rio Grande do } \\
\text { Sul, Santa Catarina e Paraná }\end{array}$ & 1 \\
\hline 087 & José Antonio Moraes de Oliveira & $1956-1958$ & $\begin{array}{lcc}\text { Estrutura } & \text { Urbana } & \text { da } \\
\text { Aglomeração Paulistana } & \end{array}$ & 1 \\
\hline 088 & José Arnaldo Pitton & $1956-1958$ & $\begin{array}{lcc}\text { Estrutura } & \text { Urbana } & \text { da } \\
\text { Aglomeração } & \text { Paulistana } & \end{array}$ & 1 \\
\hline 089 & José Arthur Rios & $1955-1960$ & $\begin{array}{l}\text { Problemas de Desenvolvimento, } \\
\text { Necessidades e Possibilidades } \\
\text { dos Estados do Rio Grande do } \\
\text { Sul, Santa Catarina e Paraná } \\
\text { Estrutura Urbana da } \\
\text { Aglomeração Paulistana } \\
\text { Aspectos Humanos da Favela } \\
\text { Carioca } \\
\text { Pesquisa Regional voltada para } \\
\text { o Desenvolvimento do Nordeste }\end{array}$ & 4 \\
\hline 090 & José Carlos Seixas & 1964 & $\begin{array}{l}\text { Prospecção dos problemas de } \\
\text { desenvolvimento de Ubatuba }\end{array}$ & 1 \\
\hline 091 & José Carlos Vieira & $1958-1959$ & $\begin{array}{l}\text { Estrutura Urbana de } \text { Belo } \\
\text { Horizonte }\end{array}$ & 1 \\
\hline 092 & José Crispin Noronha & $1956-1958$ & $\begin{array}{lcc}\text { Estrutura } & \text { Urbana } & \text { da } \\
\text { Aglomeração Paulistana } & \end{array}$ & 1 \\
\hline 093 & José da Silva Guedes & $1956-1958$ & $\begin{array}{lcc}\text { Estrutura } & \text { Urbana } & \text { da } \\
\text { Aglomeração Paulistana } & \end{array}$ & 1 \\
\hline 094 & José do Patrocínio Motta & $1955-1958$ & $\begin{array}{l}\text { Problemas de Desenvolvimento, } \\
\text { Necessidades e Possibilidades } \\
\text { dos Estados do Rio Grande do } \\
\text { Sul, Santa Catarina e Paraná }\end{array}$ & 1 \\
\hline
\end{tabular}




\begin{tabular}{|c|c|c|c|c|}
\hline \multicolumn{2}{|r|}{ Nome do Técnico/Profissional } & \multirow{2}{*}{$\begin{array}{c}\begin{array}{c}\text { Período } \\
\text { de } \\
\text { Atuação }\end{array} \\
1956-1958\end{array}$} & Trabalhos em que Participou & \multirow{2}{*}{$\begin{array}{c}\text { Quant. de } \\
\text { Trabalhos } \\
\text { que } \\
\text { participou }\end{array}$} \\
\hline 095 & José Gomes de Moraes Netto & & $\begin{array}{lcc}\text { Estrutura } \quad \text { Urbana } & \text { da } \\
\text { Aglomeração Paulistana } & \end{array}$ & \\
\hline 096 & José Gustavo de Arruda Botelho & $1956-1958$ & $\begin{array}{lll}\text { Estrutura } \quad \text { Urbana } & \text { da } \\
\text { Aglomeração Paulistana } & \end{array}$ & 1 \\
\hline 097 & José Joaquim Ferreira & $1956-1958$ & $\begin{array}{lll}\text { Estrutura } \quad \text { Urbana } & \text { da } \\
\text { Aglomeração Paulistana } & \end{array}$ & 1 \\
\hline 098 & José Júlio Vilela & $1955-1958$ & $\begin{array}{l}\text { Problemas de Desenvolvimento, } \\
\text { Necessidades e Possibilidades } \\
\text { dos Estados do Rio Grande do } \\
\text { Sul, Santa Catarina e Paraná }\end{array}$ & 1 \\
\hline 099 & José Maria Lopes & 1959 & $\begin{array}{l}\text { Pesquisa Regional voltada para } \\
\text { o Nordeste }\end{array}$ & 1 \\
\hline 100 & José Mirama Moreira & $1958-1960$ & $\begin{array}{l}\text { Aspectos Humanos da Favela } \\
\text { Carioca }\end{array}$ & 1 \\
\hline 101 & José Pedro Neto & 1956-1958 & $\begin{array}{lll}\text { Estrutura } & \text { Urbana } & \text { da } \\
\text { Aglomeração Paulistana } & \end{array}$ & 1 \\
\hline 102 & José Sampaio & $1958-1960$ & $\begin{array}{l}\text { Aspectos Humanos da Favela } \\
\text { Carioca }\end{array}$ & 1 \\
\hline 103 & José Sobierajski & $1955-1958$ & $\begin{array}{l}\text { Problemas de Desenvolvimento, } \\
\text { Necessidades e Possibilidades } \\
\text { dos Estados do Rio Grande do } \\
\text { Sul, Santa Catarina e Paraná }\end{array}$ & 1 \\
\hline 104 & Jurema Rosalva Vieira & 1958-1959 & $\begin{array}{l}\text { Estrutura Urbana de } \\
\text { Horizonte }\end{array}$ & 1 \\
\hline 105 & Kaoro Onaga & 1953-1955 & $\begin{array}{l}\text { Problemas de Desenvolvimento: } \\
\text { Estudo das necessidades e } \\
\text { possibilidades para o Estado de } \\
\text { São Paulo }\end{array}$ & 1 \\
\hline 106 & Laércio Rodrigues de Moraes & $1956-1958$ & 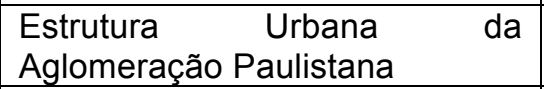 & 1 \\
\hline 107 & Laerte Marques Lima & $1958-1960$ & $\begin{array}{l}\text { Aspectos Humanos da Favela } \\
\text { Carioca }\end{array}$ & 1 \\
\hline 108 & Leodgar Jost & $1956-1958$ & $\begin{array}{lcc}\text { Estrutura } & \text { Urbana } & \text { da } \\
\text { Aglomeração Paulistana } & \end{array}$ & 1 \\
\hline 109 & Leopoldo Garcia Brandão & 1961 & $\begin{array}{l}\text { Revisão Agrária do Estado de } \\
\text { São Paulo: Estudos para um } \\
\text { plano de loteamento da } \\
\text { Fazenda Jacilândia }\end{array}$ & 1 \\
\hline 110 & Lídia Baumgartner & 1956-1958 & $\begin{array}{lcc}\text { Estrutura } & \text { Urbana } & \text { da } \\
\text { Aglomeração Paulistana } & \end{array}$ & 1 \\
\hline 111 & Liliana Marsicano Guedes & 1953-1955 & $\begin{array}{l}\text { Problemas de Desenvolvimento: } \\
\text { Estudo das necessidades e } \\
\text { possibilidades para o Estado de } \\
\text { São Paulo }\end{array}$ & 1 \\
\hline 112 & Lúcio Kowarick & 1962-1964 & $\begin{array}{l}\text { Estudo para implantação de um } \\
\text { loteamento em São Vicente } \\
\text { Estudo para uma política } \\
\text { habitacional para a Cia. Ferro e } \\
\text { Aço de Vitório } \\
\text { Relatório para o Plano de } \\
\text { Desenvolvimento do Paraná }\end{array}$ & 3 \\
\hline 113 & Luis Alcino Teixeira Leite & 1956-1958 & $\begin{array}{lcc}\text { Estrutura } & \text { Urbana } & \text { da } \\
\text { Aglomeração Paulistana } & \end{array}$ & 1 \\
\hline 114 & Luiz Alvear Palermo & $1958-1960$ & Aspectos Humanos da Favela & 1 \\
\hline
\end{tabular}




\begin{tabular}{|c|c|c|c|c|}
\hline & & & Carioca & \\
\hline 115 & Luiz Andrade & $1956-1958$ & $\begin{array}{lcc}\text { Estrutura } & \text { Urbana } & \text { da } \\
\text { Aglomeração Paulistana } & \end{array}$ & 1 \\
\hline 116 & Luiz Carlos Costa & 1956-1964 & $\begin{array}{l}\text { Estrutura Urbana da } \\
\text { Aglomeração Paulistana } \\
\text { Estudo para implantação de um } \\
\text { loteamento em São Vicente } \\
\text { Estudo para uma política } \\
\text { habitacional para a Cia. Ferro e } \\
\text { Aço de Vitória } \\
\text { Prospecção dos Problemas de } \\
\text { Desenvolvimento de Ubatuba }\end{array}$ & 4 \\
\hline 117 & Luiz Carlos M. Goelzer & $1955-1958$ & $\begin{array}{l}\text { Problemas de Desenvolvimento, } \\
\text { Necessidades e Possibilidades } \\
\text { dos Estados do Rio Grande do } \\
\text { Sul, Santa Catarina e Paraná }\end{array}$ & 1 \\
\hline 118 & Luiz Carlos Medina & $1958-1960$ & $\begin{array}{l}\text { Aspectos Humanos da Favela } \\
\text { Carioca }\end{array}$ & 1 \\
\hline 119 & Luiz Lorenzo Rivera & $1962-1963$ & $\begin{array}{l}\text { Relatórios para o Plano de } \\
\text { Desenvolvimento do Paraná }\end{array}$ & 1 \\
\hline 120 & Machado Godman & $1956-1958$ & $\begin{array}{lcc}\text { Estrutura } & \text { Urbana } & \text { da } \\
\text { Aglomeração Paulistana } & \end{array}$ & 1 \\
\hline 121 & Manoel Cabral Pinto & $1955-1958$ & $\begin{array}{l}\text { Problemas de Desenvolvimento, } \\
\text { Necessidades e Possibilidades } \\
\text { dos Estados do Rio Grande do } \\
\text { Sul, Santa Catarina e Paraná }\end{array}$ & 1 \\
\hline 122 & Manuel Valente Barbas & $1956-1958$ & $\begin{array}{lll}\text { Estrutura } & \text { Urbana } & \text { da } \\
\text { Aglomeração Paulistana } & \end{array}$ & 1 \\
\hline 123 & Marco A. França Mastrobuono & 1956-1958 & $\begin{array}{lll}\text { Estrutura } & \text { Urbana } & \text { da } \\
\text { Aglomeração Paulistana } & \end{array}$ & 1 \\
\hline 124 & Margarida Luiza Ribeiro & 1958-1961 & $\begin{array}{l}\text { Estrutura Urbana de Belo } \\
\text { Horizonte } \\
\text { Revisão Agrária do Estado de } \\
\text { São Paulo: Estudos para um } \\
\text { plano de loteamento da } \\
\text { Fazenda Jacilândia }\end{array}$ & 2 \\
\hline 125 & Maria Adélia Aparecida de Souza & $1961-1963$ & $\begin{array}{l}\text { Programa de Mecanização } \\
\text { Agrícola do Estado do Mato } \\
\text { Grosso } \\
\text { Projeto Araguaia } \\
\text { Plano Diretor de Barretos } \\
\text { Plano Diretor de Sorocaba } \\
\text { Relatórios para o Plano de } \\
\text { Desenvolvimento do Paraná }\end{array}$ & 5 \\
\hline 126 & Maria Aparecida Andrade & $1956-1958$ & $\begin{array}{lcc}\text { Estrutura } & \text { Urbana } & \text { da } \\
\text { Aglomeração Paulistana } & \end{array}$ & 1 \\
\hline 127 & Maria Aparecida F. de Aguiar & 1958-1959 & $\begin{array}{l}\begin{array}{l}\text { Estrutura Urbana de } \\
\text { Horizonte }\end{array} \\
\text { Helo }\end{array}$ & 1 \\
\hline 128 & Maria Aparecida de Queiróz & 1958-1959 & $\begin{array}{l}\begin{array}{l}\text { Estrutura Urbana de } \\
\text { Horizonte }\end{array} \\
\text { Belo }\end{array}$ & 1 \\
\hline 129 & Maria Aparecida Teani & 1953-1955 & $\begin{array}{l}\text { Problemas de Desenvolvimento: } \\
\text { Estudo das Necessidades e } \\
\text { possibildades do Estado de São } \\
\text { Paulo }\end{array}$ & 1 \\
\hline 130 & Maria Beatriz de Mello Mattos & 1953-1955 & $\begin{array}{l}\text { Problemas de Desenvolvimento: } \\
\text { Estudo das Necessidades e } \\
\text { possibildades do Estado de São } \\
\text { Paulo }\end{array}$ & 1 \\
\hline
\end{tabular}




\begin{tabular}{|c|c|c|c|c|}
\hline \multicolumn{2}{|r|}{ Nome do Técnico/Profissional } & \multirow{2}{*}{$\begin{array}{c}\begin{array}{c}\text { Período } \\
\text { de } \\
\text { Atuação }\end{array} \\
1958-1960\end{array}$} & Trabalhos em que Participou & \multirow{2}{*}{$\begin{array}{c}\text { Quant. de } \\
\text { Trabalhos } \\
\text { que } \\
\text { participou }\end{array}$} \\
\hline 131 & \begin{tabular}{|lll}
$\begin{array}{l}\text { Maria Candida Pedrosa de } \\
\text { Campos }\end{array}$ & & \\
\end{tabular} & & $\begin{array}{l}\text { Aspectos Humanos da Favela } \\
\text { Carioca }\end{array}$ & \\
\hline 132 & \begin{tabular}{|llll}
$\begin{array}{l}\text { Maria } \\
\text { Barros }\end{array}$ & do & Carmo & Guimarães \\
\end{tabular} & $1956-1958$ & 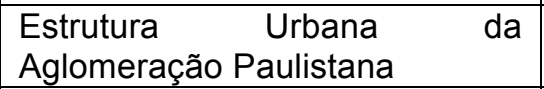 & 1 \\
\hline 133 & Maria do Carmo Pereira & $1958-1960$ & $\begin{array}{l}\text { Aspectos Humanos da Favela } \\
\text { Carioca }\end{array}$ & 1 \\
\hline 134 & Maria Edy de Andrade Ferreira & $1953-1955$ & $\begin{array}{l}\text { Problemas de Desenvolvimento: } \\
\text { Estudo das Necessidades e } \\
\text { possibildades do Estado de São } \\
\text { Paulo }\end{array}$ & 1 \\
\hline 135 & Maria Immacolata lama & $1958-1959$ & \begin{tabular}{|llll}
$\begin{array}{l}\text { Estrutura } \\
\text { Horizonte }\end{array}$ & Urbana de & Belo \\
\end{tabular} & 1 \\
\hline 136 & Maria Luiza Bresser da Silveira & 1964 & $\begin{array}{l}\text { Prospecção dos problemas de } \\
\text { desenvolvimento de Ubatuba }\end{array}$ & 1 \\
\hline 137 & Mariano H. Aranha Domingues & $1962-1963$ & $\begin{array}{l}\text { Relatório sobre o problema da } \\
\text { água e esgoto: Análise da } \\
\text { situação das sedes de } \\
\text { municípios do interior de São } \\
\text { Paulo }\end{array}$ & 1 \\
\hline 138 & Mariano Silveira Gomes & $1956-1958$ & \begin{tabular}{|lcc} 
Estrutura $\quad$ Urbana & da \\
Aglomeração Paulistana & \\
\end{tabular} & 1 \\
\hline 139 & Mario Azevedo Rison Bongonha & 1956-1958 & $\begin{array}{lll}\text { Estrutura } & \text { Urbana } & \text { da } \\
\text { Aglomeração Paulistana } & \end{array}$ & 1 \\
\hline 140 & Mario Laranjeira de Mendonça & $1956-1958$ & $\begin{array}{lll}\text { Estrutura } & \text { Urbana } & \text { da } \\
\text { Aglomeração Paulistana } & \end{array}$ & 1 \\
\hline 141 & Mario Nariotto & $1956-1958$ & $\begin{array}{lc}\text { Estrutura } & \text { Urbana } \\
\text { Aglomeração Paulistana }\end{array}$ & 1 \\
\hline 142 & Mauro Santayana & 1958-1959 & $\begin{array}{|lll|}\begin{array}{l}\text { Estrutura } \\
\text { Horizonte }\end{array} & \text { Urbana de } & \text { Belo } \\
\end{array}$ & 1 \\
\hline 143 & Maury Demange & 1956-1958 & $\begin{array}{lcc}\text { Estrutura } \quad \text { Urbana } & \text { da } \\
\text { Aglomeração Paulistana } & \\
\end{array}$ & 1 \\
\hline 144 & Michel de Planta & $1955-1958$ & $\begin{array}{l}\text { Problemas de Desenvolvimento, } \\
\text { Necessidades e Possibilidades } \\
\text { dos Estados do Rio Grande do } \\
\text { Sul, Santa Catarina e Paraná }\end{array}$ & 1 \\
\hline 145 & Miguel Zangaro & 1953-1955 & $\begin{array}{l}\text { Problemas de Desenvolvimento: } \\
\text { Estudo das Necessidades e } \\
\text { possibildades do Estado de São } \\
\text { Paulo }\end{array}$ & 1 \\
\hline 146 & Milton Antonio Moyses & 1961 & $\begin{array}{l}\text { Revisão Agrária do Estado de } \\
\text { São Paulo: Estudos para um } \\
\text { plano de loteamento da } \\
\text { Fazenda Jacilândia }\end{array}$ & 1 \\
\hline 147 & Milton Santos & $1958-1960$ & $\begin{array}{l}\text { Aspectos Humanos da Favela } \\
\text { Carioca }\end{array}$ & 1 \\
\hline 148 & Milton Teixeira & 1955-1958 & $\begin{array}{l}\text { Problemas de Desenvolvimento, } \\
\text { Necessidades e Possibilidades } \\
\text { dos Estados do Rio Grande do } \\
\text { Sul, Santa Catarina e Paraná }\end{array}$ & 1 \\
\hline 149 & Miranda M. Esmeralda Martinelli & 1956-1958 & $\begin{array}{lll}\text { Estrutura } & \text { Urbana } & \text { da } \\
\text { Aglomeração Paulistana } & \end{array}$ & 1 \\
\hline 150 & Miriam Valias de Oliveira Lima & 1962-1964 & 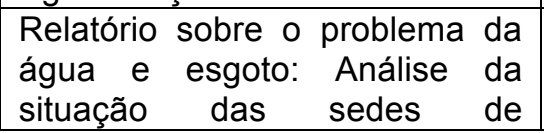 & 4 \\
\hline
\end{tabular}




\begin{tabular}{|c|c|c|c|c|}
\hline & & & $\begin{array}{l}\text { municípios do interior de São } \\
\text { Paulo } \\
\text { Estudo para implantação de um } \\
\text { loteamento em São Vicente } \\
\text { Estudo para uma política } \\
\text { habitacional para a Cia. Ferro e } \\
\text { Aço de Vitória } \\
\text { Relatórios do Plano de } \\
\text { Desenvolvimento do Paraná }\end{array}$ & \\
\hline 151 & Moyses Regman & $1956-1958$ & $\begin{array}{lcc}\text { Estrutura } & \text { Urbana } & \text { da } \\
\text { Aglomeração Paulistana } & \\
\end{array}$ & 1 \\
\hline 152 & Munir Buarraj & $1962-1963$ & $\begin{array}{l}\text { Relatório sobre o problema da } \\
\text { água e esgoto: Análise da } \\
\text { situação das sedes de } \\
\text { municípios do interior de São } \\
\text { Paulo }\end{array}$ & 1 \\
\hline 153 & Nelson Luiz Rodrigues Nucci & $1962-1964$ & $\begin{array}{l}\text { Relatório sobre o problema da } \\
\text { água e esgoto: Análise da } \\
\text { situação das sedes de } \\
\text { municípios do interior de São } \\
\text { Paulo } \\
\text { Plano Diretor de Barretos }\end{array}$ & 2 \\
\hline 154 & Nelosn Megamine & $1956-1958$ & $\begin{array}{lcc}\text { Estrutura } & \text { Urbana } & \text { da } \\
\text { Aglomeração Paulistana } & \\
\end{array}$ & 1 \\
\hline 155 & Nilda Moreira de Deus & $1958-1960$ & $\begin{array}{l}\text { Aspectos Humanos da Favela } \\
\text { Carioca }\end{array}$ & 1 \\
\hline 156 & Noemi Firmato de Almeida & 1958-1959 & $\begin{array}{llll}\begin{array}{l}\text { Estrutura } \\
\text { Horizonte }\end{array} & \text { Urbana } & \text { de } & \text { Belo } \\
\end{array}$ & 1 \\
\hline 157 & Odilon Mello Franco Filho & $1962-1963$ & $\begin{array}{l}\text { Relatório sobre o problema da } \\
\text { água e esgoto: Análise da } \\
\text { situação das sedes de } \\
\text { municípios do interior de São } \\
\text { Paulo }\end{array}$ & 1 \\
\hline 158 & Olga Maria Nogueira e Silva & $1956-1958$ & $\begin{array}{lcc}\text { Estrutura } & \text { Urbana } & \text { da } \\
\text { Aglomeração Paulistana } & \\
\end{array}$ & 1 \\
\hline 159 & Ophelina Rabelo & $1956-1958$ & $\begin{array}{lcc}\text { Estrutura } & \text { Urbana } & \text { da } \\
\text { Aglomeração Paulistana } & \\
\end{array}$ & 1 \\
\hline 160 & Orlando de Oliveira & $1956-1958$ & $\begin{array}{lcc}\text { Estrutura } & \text { Urbana } & \text { da } \\
\text { Aglomeração Paulistana } & \\
\end{array}$ & 1 \\
\hline 161 & Oscar Rezende Lima & $1947-1955$ & $\begin{array}{l}\text { Sondagem Preliminar a um } \\
\text { estudo sobre habitação em São } \\
\text { Paulo } \\
\text { Problemas de Desenvolvimento: } \\
\text { Estudo das Necessidades e } \\
\text { possibildades do Estado de São } \\
\text { Paulo }\end{array}$ & 1 \\
\hline 162 & Osmar de Paula Pinto & 1956-1958 & $\begin{array}{lcc}\text { Estrutura } & \text { Urbana } & \text { da } \\
\text { Aglomeração Paulistana } & \\
\end{array}$ & 1 \\
\hline 163 & Osmar Nascimento & 1955-1958 & $\begin{array}{l}\text { Problemas de Desenvolvimento, } \\
\text { Necessidades e Possibilidades } \\
\text { dos Estados do Rio Grande do } \\
\text { Sul, Santa Catarina e Paraná }\end{array}$ & 1 \\
\hline 164 & Otavio Escobar & $1956-1958$ & $\begin{array}{lcc}\text { Estrutura } & \text { Urbana } & \text { da } \\
\text { Aglomeração Paulistana } & \end{array}$ & 1 \\
\hline 165 & Otto Marques da Silva & $1953-1955$ & $\begin{array}{l}\text { Problemas de Desenvolvimento: } \\
\text { Estudo das Necessidades e } \\
\text { possibildades do Estado de São } \\
\text { Paulo }\end{array}$ & 1 \\
\hline
\end{tabular}




\begin{tabular}{|c|c|c|c|c|}
\hline 166 & Pajehu Maha & 1958-1959 & $\begin{array}{l}\text { Estrutura Urbana de } \\
\text { Horizonte }\end{array}$ & 1 \\
\hline 167 & Paulo Apício Macedo & $1955-1958$ & $\begin{array}{l}\text { Problemas de Desenvolvimento, } \\
\text { Necessidades e Possibilidades } \\
\text { dos Estados do Rio Grande do } \\
\text { Sul, Santa Catarina e Paraná }\end{array}$ & 1 \\
\hline 168 & Paulo Cordeiro & $1955-1958$ & $\begin{array}{l}\text { Problemas de Desenvolvimento, } \\
\text { Necessidades e Possibilidades } \\
\text { dos Estados do Rio Grande do } \\
\text { Sul, Santa Catarina e Paraná }\end{array}$ & 1 \\
\hline 169 & Paulo Faria Matos & 1956-1958 & $\begin{array}{lll}\text { Estrutura } & \text { Urbana } & \text { da } \\
\text { Aglomeração Paulistana } & \end{array}$ & 1 \\
\hline 170 & Paulo Gonçalves & $1955-1958$ & $\begin{array}{l}\text { Problemas de Desenvolvimento, } \\
\text { Necessidades e Possibilidades } \\
\text { dos Estados do Rio Grande do } \\
\text { Sul, Santa Catarina e Paraná }\end{array}$ & 1 \\
\hline 171 & Paulo lazzetti Filho & 1956-1964 & $\begin{array}{l}\text { Estrutura Urbana } \\
\text { Aglomeração Paulistana } \\
\text { Revisão Agrária do Estado de } \\
\text { São Paulo: Estudos para um } \\
\text { plano de loteamento da } \\
\text { Fazenda Jacilândia } \\
\text { Relatório sobre o problema da } \\
\text { água e esgoto: Análise da } \\
\text { situação das sedes de } \\
\text { municípios do interior de São } \\
\text { Paulo } \\
\text { Relatório sobre o problema da } \\
\text { água e esgoto: Análise da } \\
\text { situação das sedes de } \\
\text { municípios do interior de São } \\
\text { Paulo } \\
\text { Plano Diretor de Belo Horizonte }\end{array}$ & 4 \\
\hline 172 & Paulo Irineu & 1956-1958 & $\begin{array}{lll}\text { Estrutura } & \text { Urbana } & \text { da } \\
\text { Aglomeração Paulistana } & \end{array}$ & 1 \\
\hline 173 & Paulo Mendes Rodrigues & 1955-1958 & $\begin{array}{l}\text { Problemas de Desenvolvimento, } \\
\text { Necessidades e Possibilidades } \\
\text { dos Estados do Rio Grande do } \\
\text { Sul, Santa Catarina e Paraná }\end{array}$ & 1 \\
\hline 174 & Paulo Rocha Queiroz & 1961-1964 & $\begin{array}{l}\text { Relatório sobre o problema da } \\
\text { água e esgoto: Análise da } \\
\text { situação das sedes de } \\
\text { municípios do interior de São } \\
\text { Paulo } \\
\text { Estudo para uma política } \\
\text { habitaicional para a Cia. Ferro e } \\
\text { Aço de Vitória }\end{array}$ & 2 \\
\hline 175 & Pedro Calil Padiz & $1961-1964$ & $\begin{array}{l}\text { Programa de Mecanização } \\
\text { Agrícola do Mato Grosso } \\
\text { Plano Diretor de Barretos } \\
\text { Plano Diretor de Sorocaba } \\
\text { Relatórios para o Plano de } \\
\text { Desenvolvimento do Paraná }\end{array}$ & 4 \\
\hline 176 & Pedro Galery & 1958-1959 & $\begin{array}{llll}\begin{array}{l}\text { Estrutura } \\
\text { Horizonte }\end{array} & \text { Urbana de } & \text { Belo } \\
\end{array}$ & 1 \\
\hline 177 & Peter Greiner & $1962-1963$ & $\begin{array}{l}\text { Relatório sobre o problema da } \\
\text { água e esgoto: Análise da } \\
\text { situação das sedes de } \\
\text { municípios do interior de São }\end{array}$ & 1 \\
\hline
\end{tabular}




\begin{tabular}{|c|c|c|c|c|}
\hline & & & Paulo & \\
\hline 178 & Plauto Lapa Coimbra & $1956-1958$ & $\begin{array}{lcc}\text { Estrutura } & \text { Urbana } & \text { da } \\
\text { Aglomeração Paulistana } & \\
\end{array}$ & 1 \\
\hline 179 & Rafael Tancredi & 1956-1958 & $\begin{array}{lcc}\text { Estrutura } & \text { Urbana } & \text { da } \\
\text { Aglomeração Paulistana } & \end{array}$ & 1 \\
\hline 180 & Raimundo Costa Braga & $1958-1959$ & $\begin{array}{llll}\begin{array}{l}\text { Estrutura } \\
\text { Horizonte }\end{array} & & & \\
\end{array}$ & 1 \\
\hline 181 & Raymond Delprat & 1953-1958 & $\begin{array}{l}\text { Problemas de Desenvolvimento: } \\
\text { Estudo das Necessidades e } \\
\text { possibilidades do Estado de São } \\
\text { Paulo } \\
\text { Problemas de Desenvolvimento, } \\
\text { Necessidades e Possibilidades } \\
\text { dos Estados do Rio Grande do } \\
\text { Sul, Santa Catarina e Paraná } \\
\text { Estrutura Urbana da } \\
\text { Aglomeração Paulistana }\end{array}$ & 3 \\
\hline 182 & Regina Maria Novais de Almeida & $1958-1960$ & $\begin{array}{l}\text { Aspectos Humanos da Favela } \\
\text { Carioca }\end{array}$ & 1 \\
\hline 183 & Regina Zonta & 1956-1958 & $\begin{array}{lcc}\text { Estrutura } & \text { Urbana } & \text { da } \\
\text { Aglomeração Paulistana } & \\
\end{array}$ & 1 \\
\hline 184 & Reynaldo Dias de Moraes e Silva & $1962-1964$ & $\begin{array}{l}\text { Projeto Araguaia } \\
\text { Relatórios do Plano de } \\
\text { Desenvolvimento do Paraná }\end{array}$ & 2 \\
\hline 185 & Reynaldo Rudge Carlini & $1956-1958$ & $\begin{array}{lcc}\text { Estrutura } & \text { Urbana } & \text { da } \\
\text { Aglomeração Paulistana } & \\
\end{array}$ & 1 \\
\hline 186 & Ricardo Zarttini Filho & $1956-1958$ & $\begin{array}{lcc}\text { Estrutura } & \text { Urbana } & \text { da } \\
\text { Aglomeração Paulistana } & \end{array}$ & 1 \\
\hline 187 & Roberto Hamilton Salveadeu Cruz & $1962-1963$ & $\begin{array}{l}\text { Relatório sobre o problema da } \\
\text { água e esgoto: Análise da } \\
\text { situação das sedes de } \\
\text { municípios do interior de São } \\
\text { Paulo }\end{array}$ & 1 \\
\hline 188 & Roberto Yasigi & $1958-1964$ & $\begin{array}{l}\text { Estrutura Urbana de Belo } \\
\text { Horizonte } \\
\text { Revisão Agrária do Estado de } \\
\text { São Paulo: Estudos para um } \\
\text { plano de loteamento da } \\
\text { Fazenda Jacilândia } \\
\text { Relatório sobre o problema da } \\
\text { água e esgoto: Análise da } \\
\text { situação das sedes de } \\
\text { municípios do interior de São } \\
\text { Paulo } \\
\text { Plano Diretor de Belo Horizonte }\end{array}$ & 4 \\
\hline 189 & Rosie Delprat & 1956-1958 & $\begin{array}{lcc}\text { Estrutura } & \text { Urbana } & \text { da } \\
\text { Aglomeração Paulistana } & \\
\end{array}$ & 1 \\
\hline 190 & Rubens Guedes & $1956-1958$ & $\begin{array}{lcc}\text { Estrutura } & \text { Urbana } & \text { da } \\
\text { Aglomeração Paulistana } & \\
\end{array}$ & 1 \\
\hline 191 & Rui Arini & $1962-1964$ & $\begin{array}{l}\text { Relatório sobre o problema da } \\
\text { água e esgoto: Análise da } \\
\text { situação das sedes de } \\
\text { municípios do interior de São } \\
\text { Paulo } \\
\text { Estudos para uma política } \\
\text { habitacional para a Cia. Ferro e } \\
\text { Aço de Vitória }\end{array}$ & 2 \\
\hline 192 & Sarah Chucid & 1956-1958 & Estrutura Urbana & 1 \\
\hline
\end{tabular}




\begin{tabular}{|c|c|c|c|c|}
\hline & & & Aglomeração Paulistana & \\
\hline 193 & Saulo Vassimon & $1962-1964$ & $\begin{array}{l}\text { Plano Diretor de Barretos } \\
\text { Plano Diretor de Sorocaba } \\
\text { Relatórios para o Plano de } \\
\text { Desenvolvimento do Paraná }\end{array}$ & 3 \\
\hline 194 & Selda Vale da Costa & $1962-1963$ & $\begin{array}{l}\text { Relatório sobre o problema da } \\
\text { água e esgoto: Análise da } \\
\text { situação das sedes de } \\
\text { municípios do interior de São } \\
\text { Paulo }\end{array}$ & 1 \\
\hline 195 & Seno Antônio Cornely & $1955-1958$ & $\begin{array}{l}\text { Problemas de Desenvolvimento, } \\
\text { Necessidades e Possibilidades } \\
\text { dos Estados do Rio Grande do } \\
\text { Sul, Santa Catarina e Paraná }\end{array}$ & 1 \\
\hline 196 & Shigueiro Kudo & $1962-1963$ & $\begin{array}{l}\text { Relatório sobre o problema da } \\
\text { água e esgoto: Análise da } \\
\text { situação das sedes de } \\
\text { municípios do interior de São } \\
\text { Paulo }\end{array}$ & 1 \\
\hline 197 & Silviano Cançado Azevedo & $1958-1959$ & $\begin{array}{llll}\begin{array}{l}\text { Estrutura } \\
\text { Horizonte }\end{array} & \text { Urbana de } & \text { Belo } \\
\end{array}$ & 1 \\
\hline 198 & Silvina Maria Negrisolo & $1956-1958$ & $\begin{array}{lcc}\text { Estrutura } & \text { Urbana } & \text { da } \\
\text { Aglomeração Paulistana } & \end{array}$ & 1 \\
\hline 199 & Silvio Breno de Souza Santos & $1962-1964$ & $\begin{array}{l}\text { Plano Diretor de Barretos } \\
\text { Plano Diretor de Belo Horizonte } \\
\text { Estudo para uma política } \\
\text { habitacional para a Cia. Ferro e } \\
\text { Aço de Vitória } \\
\text { Estudo para implantação de um } \\
\text { loteamento em São Vicente }\end{array}$ & 4 \\
\hline 200 & Suely Virgínia de Melo Moreira & $1956-1958$ & $\begin{array}{lcc}\text { Estrutura } & \text { Urbana } & \text { da } \\
\text { Aglomeração Paulistana } & \\
\end{array}$ & 1 \\
\hline 201 & Takudy Tanaka & $1962-1963$ & $\begin{array}{l}\text { Relatório sobre o problema da } \\
\text { água e esgoto: Análise da } \\
\text { situação das sedes de } \\
\text { municípios do interior de São } \\
\text { Paulo }\end{array}$ & 1 \\
\hline 202 & Talmo Pompeu Araújo & $1958-1959$ & $\begin{array}{l}\begin{array}{l}\text { Estrutura Urbana de } \\
\text { Horizonte }\end{array} \\
\end{array}$ & 1 \\
\hline 203 & Tarcísio Wanderley & $1958-1959$ & $\begin{array}{llll}\text { Estrutura } & \text { Urbana } & \text { de } & \text { Belo } \\
\text { Horizonte } & & & \\
\end{array}$ & 1 \\
\hline 204 & Telmo Sebastião Bueno & $1955-1958$ & $\begin{array}{l}\text { Problemas de Desenvolvimento, } \\
\text { Necessidades e Possibilidades } \\
\text { dos Estados do Rio Grande do } \\
\text { Sul, Santa Catarina e Paraná }\end{array}$ & 1 \\
\hline 205 & Tetsuo Uemo & $1962-1963$ & $\begin{array}{l}\text { Relatório sobre o problema da } \\
\text { água e esgoto: Análise da } \\
\text { situação das sedes de } \\
\text { municípios do interior de São } \\
\text { Paulo }\end{array}$ & 1 \\
\hline 206 & Thekla Hartman & $1956-1958$ & $\begin{array}{lll}\text { Estrutura } & \text { Urbana } & \text { da } \\
\text { Aglomeração Paulistana } & \end{array}$ & 1 \\
\hline 207 & Tsuneo Kimate & $1962-1963$ & $\begin{array}{l}\text { Relatório sobre o problema da } \\
\text { água e esgoto: Análise da } \\
\text { situação das sedes de } \\
\text { municípios do interior de São } \\
\text { Paulo }\end{array}$ & 1 \\
\hline 208 & Tyoko Hayasi & $1956-1958$ & Estrutura & 1 \\
\hline
\end{tabular}




\begin{tabular}{|c|c|c|c|c|}
\hline & & & Aglomeração Paulistana & \\
\hline 209 & Vicente Figueiredo de Sampaio & $1958-1959$ & $\begin{array}{llll}\begin{array}{l}\text { Estrutura } \\
\text { Horizonte }\end{array} & \text { Urbana de } & \text { Belo } \\
\end{array}$ & 1 \\
\hline 210 & Vicenzo Bochicchio & $1962-1964$ & $\begin{array}{l}\text { Estudos para uma política } \\
\text { habitacional para a Cia. Ferro e } \\
\text { Aço de Vitória } \\
\text { Relatórios do Plano de } \\
\text { Desenvolvimento do Paraná }\end{array}$ & 2 \\
\hline 211 & Walter Sérgio de Salvo Brito & $1956-1958$ & $\begin{array}{lcc}\text { Estrutura } & \text { Urbana } & \text { da } \\
\text { Aglomeração Paulistana } & \\
\end{array}$ & 1 \\
\hline 212 & Welber da Silva Braga & $1958-1959$ & $\begin{array}{llll}\text { Estrutura } & \text { Urbana } & \text { de } & \text { Belo } \\
\text { Horizonte } & & & \\
\end{array}$ & 1 \\
\hline 213 & Witold Zmitrowicz & $1962-1963$ & Plano Diretor de Belo Horizonte & 1 \\
\hline 214 & Yoneco Tako & $1962-1963$ & Plano Diretor de Belo Horizonte & 1 \\
\hline 215 & Zillah Branco & $1956-1958$ & $\begin{array}{lll}\text { Estrutura } & \text { Urbana } & \text { da } \\
\text { Aglomeração Paulistana }\end{array}$ & 1 \\
\hline
\end{tabular}

